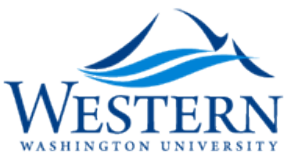

Western Washington University

Western CEDAR

East Asian Studies Press

Books and Monographs

1978

\title{
Wu Tse-T'ien and the Politics of Legitimation in T'ang China
}

R. W. L. Guisso

Follow this and additional works at: https://cedar.wwu.edu/easpress

Part of the Asian History Commons

\section{Recommended Citation}

Guisso, R. W. L., "Wu Tse-T'ien and the Politics of Legitimation in T'ang China" (1978). East Asian Studies Press. 29.

https://cedar.wwu.edu/easpress/29

This Book is brought to you for free and open access by the Books and Monographs at Western CEDAR. It has been accepted for inclusion in East Asian Studies Press by an authorized administrator of Western CEDAR. For more information, please contact westerncedar@wwu.edu. 


\title{
WU TSE-T'IEN AND THE POLITICS OF LEGITIMATION IN TANG CHINA
}

\author{
R. W. L. GUISSO
}

\author{
Preface by
}

E. G. Pulleyblank

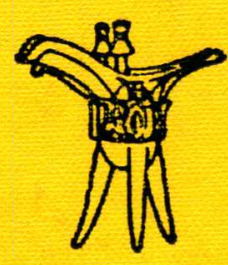

WESIERN WASHINGTON 


\section{WITH THE COMPLIMENTS OF THE}

Program in East Asian Studies

Western Washington University

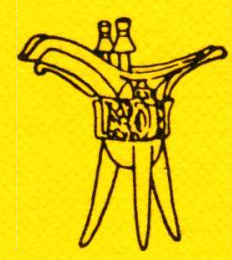

Bellingham, Washington 98225

Publishers of scholarly books on China, Japan, Korea, and Mongolia.

General Editor

Professor Henry G. Schwarz

$\rightarrow$ 


\section{WU TSE-T'IEN AND THE POLITICS OF LEGITIMATION IN TAANG CHINA}


Program in East Asian Studies, Western Washington University

Occasional Papers, Volume Eleven:

WU TSE-T'IEN AND THE POLITICS OF LEGITIMATION IN T'ANG CHINA by R. W. L. GuisSO

The Program in East Asian Studies publishes scholarly works on topics relating to China, Japan, Korea, and Mongolia.

Editor:

Professor Henry G. Schwarz 
披屠

神宗

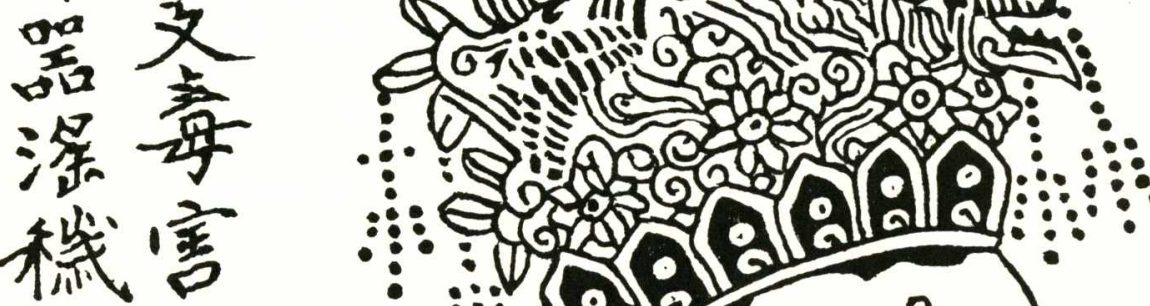

絓虫

常良: :

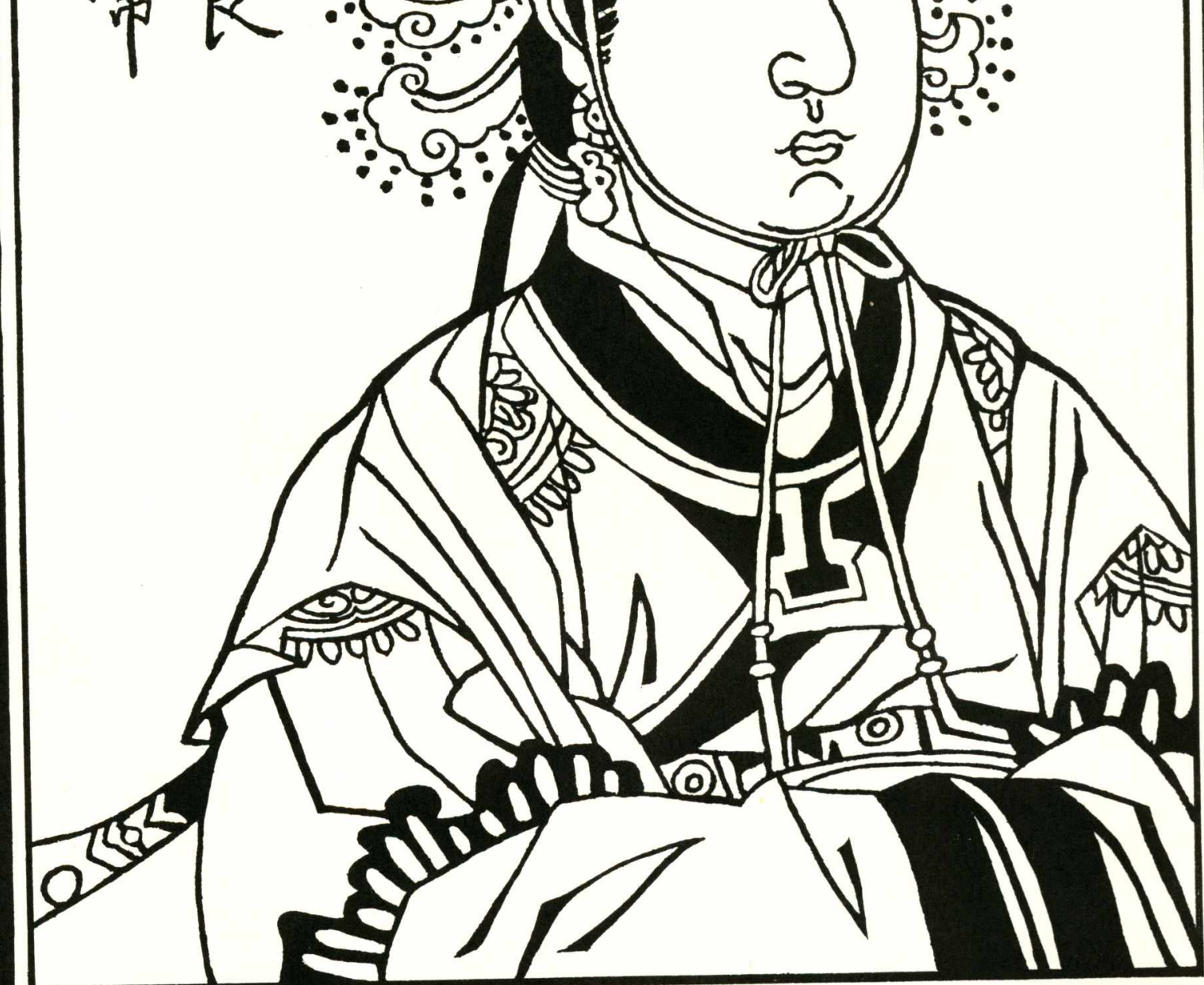




\title{
WU TSE-T'IEN AND THE POLITICS OF LEGITIMATION IN TANG CHINA
}

\author{
R. W. L. GUISSO
}

Preface by

E. G. Pulleyblank

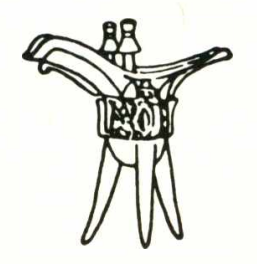


Copyright 1978

by

PROGRAM IN EAST ASIAN STUDIES
Western Washington University
Bellingham, Washington 98225

All rights reserved. No part of this publication may be reproduced or transmitted in any form or by any means, electronic or mechanical, including photocopy, recording, or any information storage or retrieval system, without permission in writing from the publisher.

Library of Congress Cataloging in Publication Data

Guisso, R. W. L.

Wu Tse-T'ien and the politics of legitimation in T'ang China.

(Occasional papers - Program in East Asian Studies, Western Washington University ; v. 11)

Bibliography: $p$.

Includes index.

1. T'ang Wu-hou, Empress of China, 625?-705.

2. China--History--T'ang dynasty, 618-907.

3. China--Empresses--Biography. I. Title.

11. Series: Western Washington University. Program

in East Asian Studies. Occasional papers - Program in

East Asian Studies, Western Washington University ;

v. 11 .

DS749.42.T36G84

$951^{\prime} .01^{\prime} 0924$

$78-4840$

ISBN 0-914584-11-1 
For Joseph and Phyllis Guisso

and for Marion Hulet, a most remarkable teacher. 


\section{ACKNOWLEDGMENTS}

The writing of acknowledgments, although a pleasant task, is also a difficult one. To mention simply the names of the numerous mentors, colleagues and friends who contributed to the present work is surely inadequate compensation for the time, the advice and the encouragement they so generously gave. I can only assure them here that my gratitude is deep and that 1 do not carry lightly the debt which I owe them.

First of all I must mention my undergraduate teachers at the University of Toronto. W. G. G. Saywell, A. H. C. Ward, W. A. C. H. Dobson, J. J. Gerson, J. L. Cranmer-Byng and R. MacDonald communicated to me an enthusiasm for East Asian history which has grown over the years and who remain today as valued colleagues. At Oxford, where my initial research on Wu Tse-t'ien took place, Raymond Dawson offered valuable guidance in the early stages and $P$. van der Loon at the end. D. C. Twitcheet drew upon his encyclopedic knowledge of medieval China to provide frequent and incisive comment without which this project would not have come to fruition. In Kyoto, Tonami Mamoru and Kikuchi Hideo made available to me the fruits of their own fine research and led me to sources I would hardly have discovered without their aid. Without scholars like them, T'ang studies would be much the poorer.

A special word of thanks is due to my colleagues in the History Department at the University of Waterloo who provided a congenial yet stimulating atmosphere in which to work and who, with humor and unfailing good nature offered constant encouragement, especially when work on the manuscript led to the shirking of other duties. John F. H. New, with his gift for the provocative insight, was especially helpful as were, indeed, the various participants in an ACLS Conference at Asilomar, California in June of 1975. Organized by the late Arthur F. Wright and by Jack Dull, the conference took as its theme "The Legitimation of Regimes in Traditional China." In ten days of free-ranging discussion, however, we also touched upon most other aspects of Chinese political thought and practice. If legitimation is successfully defined as a major theme in the following study, the conference participants deserve most of the credit for it, and it goes without saying that other ideas which originated with one or the other of them are incorporated into my work.

To a variety of other persons I am equally grateful. Julian C. Y. Ch'en, Mary C. C. Wang and Monica M. J. Lim checked the translations while Madeline Grant labored with patience and fortitude to eliminate stylistic inconsistencies and logical non sequiturs from the manuscript. Lin S. Keung often enlightened me about particular points and Reta Lienhardt typed the first draft with precision, dispatch, and the occasional stern remonstrance on the subject of sloppy punctuation. The final draft was the capable work of Nancy Stade. At various times in the course of writing and research 1 received financial support from the Rhodes Trust, the Canada Council and the Japanese Department of Education. 
Finally, I wish to make special acknowledgment of the editorial work of Professor Henry G. Schwarz. Though we were separated by a great distance in the course of readying the manuscript for publication, he worked with speed, competence and creativity and made suggestions and criticisms both of style and substance which have greatly improved the manuscript. Thanks are also due to Professor Edward H. Kaplan of Western Washington University for compiling the index. To Professor E. G. Pulleyblank I am grateful for his thoughtful preface.

There undoubtedly remain errors both of fact and logic. These, along with the more eccentric interpretations, are entirely my own responsibility. 


\section{PREFACE}

After an interlude in which interest seemed to have shifted to later periods, there are signs that T'ang studies are once more attracting the attention of a number of younger western sinologists. Without depreciating the importance of studying other parts of the seamless web that makes up the history of Chinese civilization, one can only welcome this renewed attention to the seventh, eighth and ninth centuries. T'ang was, after all, a great formative period in which the political institutions of the Chinese imperial system were renewed after the decline and division that followed the end of Han and in which new beginnings in economic and cultural life came to rapid fruition in what was ever afterwards looked back on as a golden age. Celebrating past glories should not, of course, be the main aim of historical scholarship, but to investigate the interplay of forces which led to the triumphs and disasters of an age like T'ang, so full of both lasting achievements and creative innovations with fateful longterm consequences, must be of perennial interest.

Dr. Guisso's study of the Empress Wu takes a subject which has not lacked attention of a kind in the past even in English. The sensational aspects of female rule, exaggerated and distorted by popular legend, and Confucian moralizing, in a society where male dominance was as deeply entrenched as it was in traditional China have, however, often been the main focus of such interest. The more serious historical questions raised by her reign have been little explored. Dr. Guisso has opened the debate on several issues, as well as contributing to the discussion of problems concerning the role of the Empress Wu in major societal and political changes of the T'ang period that have been raised by other scholars in the past.

One of the themes that Dr. Guisso has chosen to discuss is that of legitimacy. How could a woman establish a claim to supreme authority in the Chinese state in her own name? Other women before and after Wu Tse-t'ien exercised power as empresses dowager, ruling in the name of child emperors, but she was the only one in the whole recorded length of Chinese history who went beyond this and openly assumed the style and prerogatives of the imperial dignity for herself. In spite of the affront to Confucian political theory and tradition, this claim was accepted de facto by her contemporaries and by historians of the T'ang period. It was left to the Sung historians, especially the Confucian theorist Chu $\mathrm{Hsi}$, to undertake the "rectification of names."

Dr. Guisso attributes the empress's success in holding the allegiance of her subjects mainly to "personal and instrumental claims." This seems correct. Having shared power with her husband for nearly three decades, she still had the reins of authority firmly in her grasp when he died and was unwilling to give them up. At the same time her proved competence in government made her acceptable to the majority of her subjects, whose support enabled her to dispose of such challenges as did arise. Where the issue becomes more debatable is in regard to her ultimate aims. Dr. Guisso goes so far as to suggest that her primary loyalty was to the T'ang house and that her refusal to relinquish 
power was motivated by a desire to consolidate the achievements of the three previous T'ang reigns in freeing the monarchy from "the constraints of selfseeking aristocrats and.. . factious bureaucrats, " seeing in the untrammeled power of the monarchy the source of the peace and prosperity which had come to China since the accession of T'ang.

Such a conclusion will hardly go unchallenged, as Dr. Guisso himself suggests. It seems to credit the Empress wu with altogether too much altruism and longterm political vision. The opposite view, which treats her as simply an unprincipled usurper, is as difficult to maintain, however. One of the remarkable things about the picture we get of her from contemporary sources is the respect in which she was held by Confucian ministers who served under her, even when they disapproved in principle of her unorthodox occupancy of a position reserved for a member of the male sex.

At the heart of the problem is her intention in changing the dynastic name from T'ang to Chou in 690. In the light of earlier precedents this should have meant a transfer of the Mandate of Heaven from the Li family to the Wu family, and this is clearly what her Wu relatives expected. There is no clear evidence, however, that this was ever her intention. Instead of making the titular emperor, her son Jui-tsung, go through a ritual abdication and so leaving the way clear for a change of dynastic line, she merely demoted him to Imperial Successor (huang-ssu), making him in addition change his surname from Li to Wu. Was this, as Dr. Guisso suggests, merely an audacious way of testing her success in consolidating the strength of the imperial institution, while subtly indicating to T'ang loyalists that she really had no intention of changing the succession? Or was it just a first cautious step that was never followed up because she perceived that the opposition to a permanent change of dynasty was too great?

A factor that should not be overlooked is Wu Tse-t'ien's feminism, perhaps not consciously articulated but obvious enough in some of her actions. Her reign was unprecedented not only in the position which she herself occupied but also in the roles played by her female advisers and daughters, particularly the youngest, the T'ai-p'ing Princess, of whom she was particularly fond. Dr. Guisso has little to say about this but it is surely not without significance when we try to understand her vacillating indecision with regard to the succession. It is evident that she had as poor an opinion of the male members of her own clan as she had of her sons and the thought of handing over the continuation of her work to the former rather than the latter, who were after all the offspring of her own body, held no attraction for her. What she wanted, one may guess, was to find a way of perpetuating her own 1 ine as a dynastic founder; but the Chinese patriarchal political and family system provided no means of achieving such a goal. To make her son reign as her successor, using her surname rather than her husband's, would have been a partial victory. Even better would have been to pass the succession to a daughter. Though there is no evidence that the Empress Wu herself ever contemplated such a step, her granddaughter, the An-lo Princess, did actually ask her father, Chung-tsung, to make her heir to the throne. To Confucian minds female succession was unthinkable but in the atmosphere of female advancement started by the Empress Wu there were women who were beginning to think the unthinkable.

If this suggests that in offering these prefatory remarks to Dr. Guisso's book I do not think he has said the last word on the subject, I hope he will forgive me. What his book has done is to stimulate me to think again about 
these and other questions relating to an important epoch in T'ang history. 1 trust that it will do the same for others and provide a basis for further studies in the same depth by himself and others in future.

E. G. Pulleyblank 
Wu Tse-t'ien and the Polities of Legitimation in T'ang China is an attempt to examine and to describe the career of China's only female "emperor" and an attempt also, by using a particular frame of reference, to place in perspective her very controversial regime. I have not set out consciously to write a biography but could not avoid, of course, the inclusion of a good deal of biographical detail. In general, the life of the Empress Wu has been subordinated to larger themes, and it is for this reason that we can see her remarkable force of character and virtuosity of mind only through the darkest of glasses.

This study has three emphases. The first is the question of legitimation, the nature of the Empress Wu's position and power. How did she win recognition as the legitimate sovereign of a state and a culture which had never before permitted a woman to be Son of Heaven? And why, after this unique achievement, did she fail to preserve her position until her death? What influence did her unorthodox rise and her anomalous position have upon her times, and what does her career tell us of the process of legitimation in T'ang China?

These considerations lead to the second emphasis, that of the tension between Confucian state theory and the contradiction of a female ruler. In the resulting clash 1 attempt to show that the tradition proved to be of greater flexibility than is generally recognized but at the same time proved to be so durable and resilient that in the Chou, the empress found herself increasingly frustrated and finally defeated by it. This study suggests that while husband or son occupied the throne she was able to borrow their legitimacy and make genuine strides toward the accomplishment of her chief goals, namely the creation of a viable centralization and of an imperial institution which would be free, secure and supreme in its relationship with a new bureaucracy. In the Chou, when the empress ruled alone, the contemporary power structure came increasingly to resist innovation and with growing success. As a result, I suggest, the dynasty is best regarded as it was at Chung-tsung's restoration, as a caretaker regime, a period of consolidation and of the continuation of policies initiated in the preceding quarter century. In all probability Empress Wu seized the throne to preserve rather than to innovate.

This is not to suggest, however, that the Confucian tradition and the value system it represented survived unchanged. Certain of its components were less durable than its whole. The traditional hierarchy, for instance, was forced into a process of gradual change, with the aloof and self-sufficient aristocracy whose political and societal role had shaped the character of the age of disunion, beginning its transformation into a quite different sort of ruling class in response to creation of state status registers and the growth of the examination system. Thus the centralizing and absolutistic thrusts of the empress' regime helped to modify the customary stratification of early T'ang society and the perception of status it supported. Certain institutions, such as the fuping system, were forced into decline because the empress saw the state, its environment and its priorities in rather different terms than did the first 
T'ang rulers. In a positive vein, other institutions were fostered. The Buddhist church and the examination system are the most prominent of these, and their rapid development is to be seen partly in terms in the empress' need for support, but also in terms of her inclinations and temperament and in the close identification she developed with her people and their aspirations. The tension between orthodoxy and the rule of a usurping woman was, therefore, an important force for change and it is to be hoped that I have given it due stress.

The third emphasis is historiographical. Few figures in the history of China's middle period have been the object of so much discussion, and one result of this has been the creation of durable stereotypes and recurrent misconceptions. Many of these are referred to and examined in the following study, and largely through the introduction of new evidence such as the P'an-Zung-t'ai pei, the commentary on the Great Cloud Sutra, and the Samguk Sagi account of the Korean war. I paint rather a different picture of the empress and her policies than that which emerges in traditional historiography.

Finally, we may do well to note that the scope of the study is a wide one. Because it seeks to portray the spectrum of change over a large area both in temporal and geographical terms, depth has sometimes been sacrificed to breadth of treatment. The balance between biography and history, description and analysis has been difficult to strike, and some aspects of the period, such as economic policy, have been treated too lightly. In choosing what to omit, selection has been based on the quality of other secondary literature available and, whereever possible, an attempt has been made to identify this literature.

The effort of producing a full study of the reign of the Empress Wu Tse- $t$ 'ien has been a worthwhile one. It is to be hoped that this study will weaken the tenacity of outworn paradigms like that of the political rivalry between the Northwest and the Northeast and the "lewdness" of Empress Wu, and that it will provide insights into new ones such as the force of Buddhist legitimation. Its deficiencies will perhaps identify those many areas in which additional research would be fruitful.

R. W. L. Guisso 


\section{TERMINOLOGY AND ABBREVIATIONS}

The romanization of terms in Chinese, Japanese, and Korean follows the recommendations of the Joumal of Asian Studies Style Sheet, while Sanskrit transliterations are based upon the Dictionary of Chinese Buddhist Terms by W. E. Soothill and L. Hodous. T'ang place names are hyphenated, while the familiar, unhyphenated form is used for names describing present locations. Dates containing the name of a month have been converted to the Western calendar on the basis of Tódai no koyomi by Hiraoka Takeo. A distinction is made between the regime and the reign of the Empress Wu, the latter used only to refer to the period from 690 to 705 .

The following abbreviations have been used in this work:

\begin{tabular}{|c|c|}
\hline $\begin{array}{l}B S O A S \\
C T S\end{array}$ & Bulletin of the School of Oriental and African Studies \\
\hline $\begin{array}{l}\text { CTS } \\
\text { CTShih }\end{array}$ & $\begin{array}{l}\text { Chiu T'ang Shu } \\
\text { Ch'̈̈an T'ang-shih }\end{array}$ \\
\hline $\begin{array}{l}\text { CTShih } \\
\text { CTW }\end{array}$ & 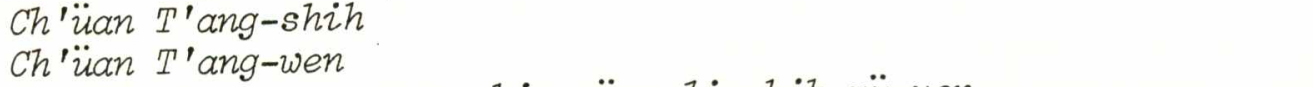 \\
\hline CYYY & $\begin{array}{l}\text { Ch'uan T'ang-wen } \\
\text { Kuo-zi chung-yang yen-chiu ÿ̈an } z_{i} \text {-shih yü-yen } \\
\text { yen-chiu-so chi-k'an }\end{array}$ \\
\hline $\begin{array}{l}\text { HJAS } \\
H T S\end{array}$ & Harvard Journal of Asiatic Studies \\
\hline $\begin{array}{l}H T S \\
\text { JAOS }\end{array}$ & Hsin T'ang-shu \\
\hline $\begin{array}{l}J A O S \\
J A S\end{array}$ & $\begin{array}{l}\text { Joumal of the American Oriental Society } \\
\text { Joumal of Asian Studies }\end{array}$ \\
\hline MSOS & $\begin{array}{l}\text { Journal of Asian Studies } \\
\text { Mitteilungen des Seminars für Orientalische Sprachen zu Berlin }\end{array}$ \\
\hline PSTS & Chi sha-men pu-ying pai-su teng-shih \\
\hline SKSC & Sung kao-seng-chuan \\
\hline$S P P Y$ & Ssu-pu pei-yao \\
\hline$S S$ & Samguk sagi \\
\hline TCTC & Tzu-chih t'ung-chien \\
\hline$T D$ & Taishō daizō kyō. \\
\hline TFYK & Ts'e-fu yüan-kuei \\
\hline THY & T'ang hui-yao. \\
\hline ILSI & $T^{\prime} a n g-z \ddot{u}$ shu-i \\
\hline$R S I$ & Töryō shūi \\
\hline$\pi T$ & T'ung-tien \\
\hline TCLC & T'ang ta chao-ling chi \\
\hline TLT & Ta-T'ang liu-tien \\
\hline$T K$ & Wen-hsien t'ung-k'ao \\
\hline YH & Wen-ÿ̈an ying-hua \\
\hline
\end{tabular}


CONTENTS

Acknowledgments . . . . . . . . . . . . . . . . . . . v

Preface by E. G. Pulleyblank. . . . . . . . . . . . . . . . . . . vii

Author's Preface. . . . . . . . . . . . . . . . . . . . . . $x$

Terminology and Abbreviations . . . . . . . . . . . . . . . . xii

Chapter 1: Introduction . . . . . . . . . . . . . . . . . . . 1

Chapter 2: Sources for the Life and Career of Wu Tse-t'ien . . . . . . 8

Chapter 3: The Origins and Rise of Wu Tse-t'ien . . . . . . . . . . . . 11

Chapter 4: The Empress Wu and the Creation of State Ideology. . . . . . 26

Chapter 5: The Road to Usurpation . . . . . . . . . . . . . . 51

Chapter 6: Imperial Power and the Ruling Class. . . . . . . . . . . . . 70

Chapter 7: The Examination System and the Bureaucracy . . . . . . . . . 87

Chapter 8: Chinese Arms and Foreign Policy to 684 . . . . . . . . . . . 107

Chapter 9: The Chou Dynasty . . . . . . . . . . . . . . . . 126

Chapter 10: Retrospect . . . . . . . . . . . . . . . 155

Appendix A: Historiography of the Empress Wu . . . . . . . . . . . . . . 160

Appendix B: The tsai-hsiang, 618-705. . . . . . . . . . . . . . 165

Notes . . . . . . . . . . . . . . . . . . . . . 199

Selected Bibliography . . . . . . . . . . . . . . . . . . 291

Glossary. . . . . . . . . . . . . . . . . . . . 301

Index . . . . . . . . . . . . . . . . . . . . . 325

About the Author. . . . . . . . . . . . . . . . . . . 335

Maps

The Distribution of the Great Clans During T'ang. . . . . . . . . . . . . 83

The T'ang Empire at its Height in the Mid-Seventh Century . . . . . . . 108

The Korean Peninsula in the Seventh Century . . . . . . . . . . . . . . . 113

The Northwest in the Chou Dynasty . . . . . . . . . . . . . . . . . . 139

The Northeast in the Chou Dynasty . . . . . . . . . . . . . . . . . . 140 


\title{
Chapter 1
}

\author{
INTRODUCTION
}

In the history of imperial China, the T'ang empress Wu Tse-t'ien occupies a unique place. For almost half a century she enjoyed supreme power: first in partnership with T'ang Kao-tsung, a ruler usually considered weak and ineffectual, later as de facto regent for her youngest son and finally, from 690 to 705 A.D., as China's sole female emperor. 1 Her rise from the obscurity of T'ai-tsung's harem was dramatic and her pursuit of power ruthless. Her political policies were controversial and her lifestyle flamboyant. For these reasons novelists and playwrights have found in her career a frequent source of inspiration. 2

For historians, too, she has been a popular subject, and few figures of her era have been so often or so passionately discussed. Judgments of her place in history, both by traditional and modern historians, have been diverse, and to the present day scholars in China continue to debate her merits. 3 It is somewhat surprising, in view of their volume, that traditional studies of the empress debate a rather narrow range of issues and, reduced to their basics, restrict themselves generally to two questions. Was the Empress Wu a legitimate emperor and, in personal terms, was she a good or a bad ruler? The controversy is framed in this manner, of course, because of the moralistic and didactic bias of Confucian historiography, ${ }^{4}$ and before turning to my own examination of her career, I might offer a short survey of the earlier views to isolate the grounds of controversy and identify some of the problems with which I shall deal later.

Turning first to the question of the empress' legitimacy, we should note that theoretical analyses of the nature of legitimate authority are of relatively recent vintage, and that while social scientists like David Easton have made useful contributions to our conceptual understanding, the original formulations of Max Weber have stood up remarkably well.5 Weber's suggestion that there exist three pure types of legitimate authority--the traditional, legalrational, and charismatic6-- is one 1 shall discuss later in some detail, and I shall remark here only that it was the first type which constituted the great barrier to the empress' legitimation. Second, we must bear in mind the distinction between claims to legitimacy and their acceptance--the belief of subjects that a particular individual or social order is legitimate. 7 For the historian this distinction is never an easy one, since sources are seldom of such psychological depth that he can pass judgment on something so elusive as the reality of belief, and for the seventh century when the vast majority of the Empress Wu's constituency was wholly inarticulate, definitive statements are best avoided. What we can say with some certainty, however, is that in her lifetime the articulate among her subjects acted as if her legitimation were valid and that after her death, attempts made to deprive her of that status in official historiography met with only limited success. 
For both these statements evidence is so full that only a few examples need to be raised. From the very beginning of the Chou, for instance, officials at all levels accorded the empress the proper forms of address and homage and, in contrast to their counterparts under Wang Mang, seem to have carried out her orders without question. There was no protest, as far as we can tell, when she performed such hallowed imperial ceremonies as the feng-shan, 8 and even those anxious for a T'ang restoration seem to have recognized the present legitimacy of the empress. In 702, for instance, we find a scholar of this persuasion memorializing: "I have heard that the empire is the empire of [T'ang] Kao-tsu and T'ai-tsung. Although Your Majesty (pi-hsia) occupies [the position of] rightful ruler (cheng-t'ung), certainly you depend on the old foundations of the T'ang clan."'9

In view of the coercive power at the empress' command, we might be inclined to suggest an element of dissimulation in this choice of terminology, but arguing against it is the attitude of her successor, her son Chung-tsung. At the T'ang restoration in early 705, he not only accorded her the honorific "emperor" (Tse-t'ien ta-sheng huang-ti), 10 but in his edict of accession said:

The emperor Tse-t'ien ta-sheng is of real intelligence, perfect virtue and deep wisdom. In response to the needs of the time, her excellent plans of 0ctober 16, 69011 initiated the grand design of perfect unity. Moving the jade seal, she destroyed the avaricious and conferring the golden halberd, she killed the immoderate. She received the sign of the Lo River [on which was] written she must [follow] the calendar of Hao $\mathrm{Hsi} .12$ She cared tenderly for those of virtue among the people and together they obtained humanity and long life. Finally, she embraced closely the search for the Tao and fixed her thoughts on wu-wei, enduring a life of toil for the sake of the imperial throne (ta-pao). Then she "restored it respectfully to the intelligent prince.". . . She made offering at the ancestral temple of Kao-tsu and respected the altars of T'ai-tsung, not disregarding the old things.13

In this way Chung-tsung set the "official line" on the usurpation, not only justifying his mother's legitimation but offering imperial recognition of the fact that a woman had been de facto and de jure emperor. His description of her legitimation process is most instructive, and we would do well to bear it in mind in the course of our own analysis.

At the restoration, of course, an element of coercion remained in that Wu Tse-t'ien was still alive and political control was vested firmly in the hands of her nephew San-ssu and the Empress Wei. Similarly, the next ruler, her last son Jui-tsung, was much under the influence of his sister T'ai-p'ing, so that the attitude of Hsüan-tsung is therefore a much better indicator of how history would view the legitimation of his grandmother. While he seems to have made no statement on the matter, the fact that in 716 he accepted her Veritable Records (shih-lu) along with those of Chung-tsung and Jui-tsung 14 suggests that he was willing to see her as emperor even though she had herself renounced the title on her deathbed. 15 Because the Veritable Records formed the principal source for the National History (kuo-shih), it seemed her legitimacy was secure.

In 780, however, the first voice to raise officially the question of Tset'ien's usurpation was heard when Shen Chi-ch'i, an official of the History office, complained in a lengthy memorial that the account of Wu Ching's era had been cast in the form of an annal (pen-chi) in the National History. 16 Basing 
his argument on the Confucian principle of the rectification of names (chengming), he contended that she was a usurper and her position false (chia 假) rather than legal (cheng). Since the Mandate of Heaven had not changed ( $t$ 'ienming wei-kai) with the deposition of Chung-tsung in 684 , the acts of the empress dowager should be placed in his annals, and even though he did not himself participate in government, his whereabouts should head each yearly entry. Te-tsung rejected his advice but, according to the T'ang hui-yao, historians of the time praised it. 17

This seems to have ended the debate in the T'ang and when the official dynastic history was completed in 945, the Empress Wu was duly given annals and in them referred to as shang or emperor. 18 There exists a certain ambiguity, however, in that the annals are still called those of an empress (huang-hou), a phenomenon duly noted by the compilers of the New T'ang History (HTS) in 1060.19 Their attitude is one we can judge with certainty not only in the finished work but also in a separate volume by Lü Hsia-ch'ing, the T'ang-shu chihpi,20 which outlines the principles on which the revision of the old T'ang History (CTS) was based. In it we find direct criticism of the practice of according annals to empresses and even of including their actions in those of husbands or sons.21 The Chih-pi does not list Tse-t'ien among the twenty T'ang emperors, but in the very next passage, which lists the number of chief ministers in each reign, we find that the empress had sixty-eight tsai-hsiang. 22 The Chih-pi was impaled upon a dilemma: if Tse-t'ien were not a legitimate ruler, how could the events of her period of actual power be recounted consistently in the chronicle style of history which was the set form of official historiography? Ouyang Hsiu in the New T'ang History, makes the uneasy compromise of according her both annals and a biography (Zieh-chuan), remarking in the latter that she "styled herself" emperor. 23 Only with Ssu-ma Kuang's Comprehensive Mirror for Aid in Government (TCTC) and the several influential if less "official" works based upon it do we find a clear position. To Ssu-ma, Wu Tse-t'ien was never emperor but empress-dowager ( $t$ 'ai-hou) from 683 until her death. 24

In the general perception it was ultimately this latter view which prevailed, and particularly as Chu Hsi's Tzu-chih t'ung-chien kang-mu because the most widely used of historical textbooks, Wu Tse-t'ien became simply a usurping empress presiding over an illegitimate regime. 25 By this time historians were also turning their attention to other facets of the empress and her rule, and once again because of the didactic function of history, the central question was that of "praise-and-blame." The striking feature of the Chou usurpation, and what made it wholly unprecedented, was of course the fact that it had been effected by a woman, and in order to understand better the common tendency of Confucian scholarship to darken the empress' reputation, we shall survey briefly the evolution of the traditional prohibition of female influence in government.

The origins of China's unwritten Salic principle are obscure but of great age. In spite of the impressive body of evidence which suggests that China's earliest society was matrilinear and perhaps matrilocal, and in spite of the fact that in its mythological tradition one of the Three Rulers (san-huang) was female, 26 the bias against women being active outside the home appears in the earliest works of what was to become the canonical tradition. "The hen does not announce the morning," says the Book of History (Shu-ching), "the crowing of a hen in the morning indicates the subversion of the family." 27 The Book of 
Odes (Shih-ching) contains several songs, suggestive of similar attitudes, like the following:

A clever man builds strong ramparts,

A clever woman overthrows them.

Beautiful is the clever wife,

But her heart as cruel as that of the owl.

Women with long tongues

Are harbingers of evil,

Disasters are not sent down from Heaven--

They originate in wives.

These two can neither be taught nor led,

Wives and eunuchs.

When they start slandering people,

At first the ruler does not hide them.

He even says? "They can go nowhere,

What evil could they do?"

But they are like merchants selling at triple profit.

All those wiles are known to the wise.

They do not let wives meddle in public affairs,

And keep them to their spinning and weaving. 28

It was, of course, because these writings were associated with Confucius, who himself declined to associate with "women and inferior persons,"29 that the bias gained increasing strength, and until the early Han informal prohibition seemed sufficient to keep women out of politics. The virtual usurpation of the Empress Lü from about 187 B.C., therefore, confronted commentators with an unprecedented situation, and the Han historians had to invent the phrase "appear in court and pronounce decrees" ( $2 i n-c h ' a o$ ch'eng-chih) to deal with it. 30 The phrase was to be used of at least eight dowagers in the Han, 31 and so pronounced and deplorable was female influence in the period that later commentators found it a principal cause of the dynasty's fall.32 In 222 A.D. Wei Wen-ti issued a formal decree that women were forbidden to involve themselves in politics. 33

The subsequent period of disunion saw no repetition of formal prohibitions, but the growth rather of customary recognition that in certain closely defined "emergency" situations, empresses or empress dowagers might exercise a temporary regency, though in all cases they were duty-bound to "restore the throne to the intelligent prince" (fu-t'ien yü ming-p'i).34 Both in North and South, however, we find instances of women who exceeded the definition of their role, and from the Sui-T'ang reunification we can trace a determination that such breaches of Confucian tradition not recur. The T'ang attitude is well expressed by Wei Cheng and his colleagues in a Sui-shu passage which also comments on the disharmony in the family lives of the Sui rulers:

In the Chin and Sung, a great number [of women] all gained their position by [imperial] favor and their rise was not due to virtue. Soon after, [their] conduct became corrupt and none observed $Z_{i}$ and $i$. By [women who were $1 \mathrm{ike}$ ] birds which devour their parents, [dynasties] were destroyed and did not return. Later examples are numerous. . . Thus, we record the biographies of empresses to hand down a warning to the future. 35

Even from this briefest of surveys it should be apparent that by the T'ang the conviction that female non-interference in politics as a desirable feature of the natural order was a well-established one. The first T'ang empresses, 
although of "barbarian" extraction and therefore accustomed to a relatively active $1 \mathrm{ife}, 36$ were models of compliance and restraint, and in the context of Confucian historiography, Wu Tse-t'ien was bound to suffer in comparison. The old T'ang History therefore praises the virtues of T'ai-tsung's empress while comparing the evil of Wu to that of a viper,37 and the New T'ang History though admitting that Wu was far superior to her successor, the Empress Wei, still insists that both women serve as a warning to future rulers. 38

It is difficult to say, as we read the traditional commentators, whether their hostility to Wu Tse-t'ien derives more from the fact that she was a usurper or a woman, and perhaps the question is too academic to merit discussion. What we must realize is that her sins were seen as offenses against a tradition, an order, an entire way of life, to which her critics remained loyal. Even during the lifetime of the empress, the first condemnation, an eloquent indictment written as a manifesto for the rebellion of 684 , took this 1 ine. In it Lo Pinwang 39 charges:

The woman Wu, who has falsely usurped the throne, is by nature obdurate and unyielding, by origin truly obscure. Formerly, she was among the lower ranks of T'ai-tsung's servants and served him by changing his clothes. When she reached maturity, she brought disorder to the palace of the crown prince. . . she usurped the pheasant regalia of empress and entrapped our ruler in incest.

Then, with a heart like a serpent and a nature like that of a wolf, she favored evil sycophants and destroyed good and loyal officials. She killed her sister, butchered her elder brothers, murdered the ruler, poisoned her mother. She is hated by gods and men alike. 40

As we shall see, some of these allegations were to find their way into later accounts, but what should be noted here is the reaction of the Confucian mind against a woman who had not only betrayed such cardinal virtues as humanity and wifely submission, but in so doing had challenged an ancient tradition which guaranteed wordly harmony and gave both livelihood and self-respect to the Confucian scholar-official. This class, with its monopoly on the writing of history, was almost bound to emphasize the ruthless and unconventional aspects of the empress' success, her "heart like a serpent and nature like a wolf," in order to defend the integrity of the state system.

This is the most basic explanation for the form taken by historical criticism, and it is consistently applicable down to the present century. In many works, of course, the "blame" is balanced by some degree of praise, and in the two T'ang Histories and the Comprehensive Mirror we find the historian looking favorably upon the empress for her decisiveness and ability to accept remonstrance, her veneration of upright men, her final settlement of the succession on the Li clan, and the control she exercised over her family, her favorites, and her "evil" officials. 41 The overall judgment, however, remains negative and many scholars representative of their age--Yüan Shu and $\mathrm{Chu} \mathrm{Hsi}$, Wang Fu-chih and Fang Hsiao$\mathrm{ju}$, as well as such prolific and perceptive Ch'ing essayists as Chao I and Wang Ming-sheng--have ensured that unfavorable opinion prevailed. 42 The rise of the Empress Dowager $\mathrm{Tz}^{\prime} \mathrm{u} \mathrm{Hsi}$ in the latter part of the nineteenth century brought inevitable comparison with Wu Tse-t'ien, and the latter's inability to arrest dynastic decline must have validated in some minds, at least, the old strictures against women in power. 
Prior to 1911 the Empress Wu thus found few admirers, and although we can identify among them at least one scholar of stature in most periods, 43 it was not until the new intellectual climate of the twentieth century that revisionist views began to appear. Marxist historians have been most active in her rehabilitation, but well before 1949 the notable studies of Ch'en Yin-k'o were finding new social significance in the regime of the Empress Wu. In one article, in particular, he attacked several of the old stereotypes, including that of her lewdness by suggesting that as a female emperor she was perfectly entitled to a male harem! 44

For Marxist historians, at least prior to the Cultural Revolution, the Empress Wu was a heroine, champion of the masses in the historic class struggle against the aristocracy and great landlords. Two important authors, Ts'en Chungmien and Lü Ssu-mien, are not persuaded that her achievements outweigh her brutality and other "feudal" characteristics, 45 but theirs is the minority view. The authors of three of the most important textbook surveys of Chinese history all portray her in a favorable light, seeing her as being ahead of her time in attacking the privileged classes, elevating the position of women, and fostering the examination system and the culture of her people. 46 0ther academic and cultural leaders in China have echoed these views, and because names like Kuo Mo-jo, Yang Chih-chiu and Wu Han were found among them, 47 the rehabilitation of Wu Tse-t'ien was rapid.

At the end of the 1950s, however, a wide-ranging debate on the empress broke out. Arising principally out of an article by Wu Tse, 48 it was to last for several years and was to develop the interpretation considered standard until the Cultural Revolution. Professor Wu's basic point at the time was that several previous works had failed to stress adequately the class struggle of their period, and to show that the masses, not the ruling classes, are the driving force of history. At the same time, there was failure to recognize that the influence of an individual is not incompatible with historical materialism, and the Empress $W u$ is a case in point. The lü-ling system of the Sui and T'ang, he goes on to suggest, was essentially a control mechanism designed to ensure the continuing power of members of the aristocratic-landlord class. T'ai-tsung began to weaken their power, but it was only with the advent of the Empress Wu, whose background had made her more class-conscious than her predecessor, that an alliance was effected among merchant, small landlord and bureaucrat to challenge them. By fostering their rise and simultaneously attacking the old ruling class in other ways, she broke their power even before the declaration of the chou at which time conflict became internalized within the ruling class. During Chou the empress remained representative of the class she had fostered, but as the dynasty became increasingly corrupt, the remnants of the T'ang family were able to ally themselves with small and middle landlords to bring about a restoration. Throughout the process the Empress Wu carried out many policies to benefit the peasant, but did so not out of altruism but because of the exigencies of class struggle. She was a great ruler but, nonetheless, a "feudal" emperor.

This very interesting analysis was the last detailed study of the empress prior to the Cultural Revolution, and in the present climate of ideological uncertainty, the debate has yet to be resumed. It is interesting to note that only in the present century have historians begun to transcend the questions raised in Confucian historiography, and as the reevaluation progresses, especially in social history, the regime of the Empress wu is coming to be seen as 
a period of rather marked transition. The process of reappraisal, however, is a lengthy one, and as three fairly recent non-Marxist book-length studies 49 of her period show, the old stereotypes of the empress are durable, and her life is by itself so fascinating that historical change is still rather poorly documented in comparison. I hope that my study does not neglect the old questions but also sheds some light on the position of the Empress Wu, on how she gained it and how she used it. In addition, I hope to examine her policies, particularly those which relate to social change, politics and the examination system, Buddhism, and China's external affairs in the seventh century. Finally, 1 shall attempt to show more clearly the origins of the Empress Wu's historical reputation and, in so doing, draw a more accurate picture of one of China's most controversial rulers. 


\section{Chapter 2}

\section{SOURCES FOR THE LIFE AND CAREER OF WU TSE-T'IEN}

The chief primary sources for the life of the Empress Wu are her annals in the two dynastic histories of the T'ang, her biography in the New T'ang History, and the numerous references to her in Ssu-ma Kuang's Comprehensive Mirror. I In some of the large official compilations of later ages, like the Ts'e-fu yüankuei, 2 there are to be found several allusions and fragments of documents not elsewhere preserved, and material of this sort is also to be found in some of the private essays and anecdotes of the T'ang. 3 The sizable corpus of writings attributed to the empress herself consists mainly of edicts and other official documents, but some of her poetry and ceremonial verses are extant, and even though commentators are reluctant to acknowledge her direct authorship, some seem fairly personal in tone. 4 In addition, the biographical sections of the dynastic histories record many incidents concerning her and conversations with her, so that we are able to assemble a fuller sketch of her character and her life than is possible in the case of most of her contemporaries.

If the sources are relatively extensive, there are compensating drawbacks. Wu did not become empress until she reached her late twenties and records of her life to that time are extremely scarce. More importantly in the present context, the sources which tell of her rise and outline her subsequent career are "official" in nature, and thus their reliability is open to question. This problem arises from two causes, one of which I mentioned earlier. The Confucian literatus, even in his role as objective historian, was bound by his duty to provide lessons for the future, and his treatment of a woman ruler who was also a usurper inevitably reflected a certain disapproval. A second cause is the fact that the Empress Wu shared with other rulers, like her predecessor T'ai-tsung, a concern with historical reputation and, like him, was not above deliberate falsification of the record. 5 In her case, we might point to the dubious assertions of the edict which raised her to the rank of Kao-tsung's empress $^{6}$ and later to the appointment of "tame" historians to oversee the writing of history in her own time.7

In order to understand the degree to which these influences occur in our major sources, the dynastic histories and the Comprehensive Mirror, we might begin by trying to discover the origin of their information. Appendix $A$, which follows a methodology developed by E. G. Pulleyblank, 8 compares their accounts of five incidents and reveals not only their consistent, if small, difference of attitude toward the empress, but also establishes that the few incidents recorded about her early life can be traced in most cases to the Veritable Records of herself and her husband.

The question of the circumstances of the composition of these records during early T'ang is a complicated one because of the disagreements in bibliographic sources, 9 and although we are certain that Ssu-ma Kuang used the thirty-chüan version of the Veritable Records of Wu Tse-t'ien presented to the throne by Liu 
Chih-chi and Wu Ching in 716, 10 we find two earlier versions mentioned in other sources. The first of these was by Tsung Ch'in-k'o who, as a relative of the empress and a supporter of her usurpation, 11 might be expected to produce a work favorable to her. Of course, we know nothing of the scope and content of Tsung's work and whether or not it treated the controversial events of 684-690, but we might reasonably assume that it formed the basis of the slightly expanded version presented to the throne in 706.12 The supervisor of this compilation was Wu San-ssu, cadet nephew of the empress. Although the position of supervisor was often a nominal one, he seems to have taken an active part in the work since Liu Chih-chi and Wu Ching, who worked under him on an earlier national history, both had occasion to complain of his interference. 13 In the production of his aunt's records he may well have exercised a good deal of editorial discretion, and it was perhaps for this reason that Hsüan-tsung had them revised. Neither Liu Chih-chi nor Wu Ching were admirers of the empress but, judging from the fragments of their Veritable Records preserved in Ssu-ma Kuang's $k^{\prime} a o-i$, they treated her with objectivity. 14

In 716 the Veritable Records of Wu Tse-t'ien were presented together with those of Jui-tsung and Chung-tsung and it is clear, therefore, that Liu and Wu were responsible for the final version of the Veritable Records for the period from 684 to 713 . The role of Empress Wu in government during that period was, of course, an overt one, but prior to 684 contemporaries were less certain of her role and the degree of actual influence she had over her husband. Moreover, as we shall see, there were certain aspects of her background and rise that she might logically wish to conceal, among them her relatively obscure lineage, her concubinage to T'ai-tsung, the beginnings of her liaison with Kao-tsung, and the machinations by which she helped ruin her rival, the Empress Wang. Information on these matters would be found in the Veritable Records of T'ai-tsung and Kaotsung, and it is natural that she would attempt to exercise some control over their content, just as she tried to influence the historiography of the later period. Indications are that she was successful.

There is some disagreement about the compilation of T'ai-tsung's Veritable Records, but an impressive body of evidence suggests that Hsü Ching-tsung 15 was a major, if not the principal contributor to them. 16 ssu-ma Kuang, for instance, refers to the version he used as the Hs⿱艹̈ Ching-tsung T'ai-tsung shih-Zu. 17 Hsü's name appears again in 659 as the compiler of a twenty-chüan Veritable Record covering the period from T'ai-tsung's death to 658 , and he may have supplemented this before his death in 672 since the old T'ang History mentions a Veritable Record in thirty chüan. 18 It seems unusual that a young emperor 1 ike Kao-tsung would have his own Veritable Record begun so early in his reign without some special reason, and the conjecture that the Empress Wu was the instigator is strengthened by two facts. Her open concern with how history would treat her rise and her role in her husband's reign was shown in the fact that the final version of Kao-tsung's Veritable Record, in a hundred chüan, was issued under her name. 19 Besides, Hsü Ching-tsung was the most important of her close supporters.

Hsü, born in 592, was of southern origins, the son of a high Sui official killed by Yü-wen Hua-chi. He was a precocious scholar, one of the handful of men who passed the difficult hsiu-ts'ai examination in the Sui, under which he first held office. After serving the rebel $\mathrm{Li} M \mathrm{Mi}$, he switched his allegiance to the T'ang and joined the staff of T'ai-tsung who seems to have heard of his literary abilities. His career thenceforth was a distinguished one. After a 
succession of promotions which ended in the presidency of the Board of Rites, he began to work in 634 on the compilation of the national history and then on the Veritable Records. He twice suffered mild disgrace, once for a breach of propriety and once for his avarice when he married his daughter to a "barbarian" chieftain. It was just as he emerged from the second demotion that the issue arose of Wu's elevation to empress and by immediately espousing her cause, he won the gratitude of Kao-tsung and assured himself of a successful future. His relationship to the new empress was a close one, and it was he who undertook for her such delicate tasks as persuading Kao-tsung to elevate her son to crown prince and to exile or execute the chief ministers who had opposed her rise. After their fill he became the paramount civil official of the realm, a status he did not relinquish until his retirement, and at his death in 672 Kao-tsung paid him the great honor of himself donning mourning clothes. Needless to say, his reputation in Confucian historiography is an infamous one.

As an historian he was an entrepreneur, and the opportunism and lack of scruple suggested by other aspects of his career are confirmed by reliable sources which accuse him of falsifying the record on more than one occasion. 20 In 673 Kao-tsung found several blatant falsehoods in his account of T'ai-tsung and ordered them corrected, 21 but how far these corrections went we can only guess. It is interesting to note that Ssu-ma Kuang is unable to date Wu's entrance into T'ai-tsung's harem since the event goes unrecorded in any source he considers reliable.22 For the same reason confusion has long existed in such matters as the date of her birth, her supposed entry into a convent on T'ai-tsung's death, and the birthdates of her two eldest sons, one of whom may have been born to her elder sister. The existence of rumors about these things even in her own $1 \mathrm{ife}$ time suggests how carefully they were obscured.

Later historians, from Liu Chih-chi onward, have expressed scorn or puzzlement on the reliability of the primary sources for the early T'ang, 23 and there is little doubt that their attitude is justified. Particularly in the case of the Empress Wu, and because of her relationship with Hsü Ching-tsung, later official historians, like the authors of the old T'ang History found it necessary to openly reject certain details of her father's career because of their conviction that Hsü exaggerated or falsified his achievements. 24

The task of the modern historian is, therefore, not an easy one, and he must attempt to distinguish the truth which lies between the operation of two opposing principles. The following chapter, which deals with the most controversial period of the empress' life, seeks to identify the specific areas of historical uncertainty and to offer at least some conjecture on what the truth might have been in these matters. 
Chapter 3

THE ORIGINS AND RISE OF WU TSE-T'IEN

The first problem to confront a biographer of the Empress Wu is the difficulty of determining the details of her family background and her early life. I have earlier alluded to the unreliability of the Veritable Records for the reigns of T'ai-tsung and Kao-tsung, and have suggested that the national historians of the T'ang as well as the later dynastic historians were suspicious of their sources and so tended to omit from their accounts any detail they regarded as flattering to the empress and her family. As a result, primary source references are fewer than might otherwise be the case.

I have also admitted the justice of these historians' scepticism in view of the likelihood of falsification, but we should be aware at the same time of the possibility of overcompensation on their part. For example, it is generally acknowledged that in order to bolster her legitimacy in the aristocratic climate of the early T'ang, Tse-t'ien took the not unusual step of falsifying her genealogy. 1 Several of her contemporaries succeeded in having their dubious lineages incorporated into the dynastic histories, but in her case the biography of her father Shih-huo mentions not a single one of his ancestors even though, as will be shown, his father's official career in the sui is attested by reliable sources.

The biography of Wu Shih-huo is, of course, our standard account of the Empress Wu's background and is also an instructive example of the historiographical processes we have been discussing. This is particularly clear when we compare it with a little-known source called the $P^{\prime}$ an-Zung-t'ai pei, a commemorative inscription the empress commissioned for her father in 699.2

The biography reads:

Wu Shih-huo was a man from Wen-shui in Ping-chou. $3 \mathrm{His}$ household was a wealthy one and he was rather fond of social intercourse. When Kao-tsu first brought troops to Fen-chin, he stopped at his home and [Shih-huo] was thus privileged to make his acquaintance. 4 When Kao-tsu became T'aiyüan Ziu-shou, he recruited [Shih-huo] as hsing-chün ssu-k'ai.5 At the time, bandits and rebels rose as [numerous as] hornets and Shih-huo would secretly urge Kao-tsu to raise troops [and rebel against the Sui]. He [also] presented him with a book [of his own composition?] on military matters, together with a fu-jui. ${ }^{6}$ Kao-tsu said to him, "Please say no more. Military books are forbidden articles, yet you still give one to me, [so] I well understand your meaning. Together we must certainly prosper."

When he was about to raise his righteous rebellion, Kao-tsu levied troops and sent Liu Hung-chi and Ch'ang-sun Shun-te 7 to share the leadership [in this task]. Wang Wei and Kao Chün-ya 8 spoke secretly to Shihhuo saying, "Hung-chi and his men are all traitors to the Imperial Guard. This is a capital crime, [so] how can they lead troops? We want to 
imprison and investigate them." Shih-huo replied, "They are all representatives $\left(k^{\prime} O\right)$ of the Duke of $T^{\prime}$ 'ang. If you do so, great confusion will follow." Wei and his group therefore hesitated and did not act. The Ziu-shou ssu-ping T'ien Te-p'ing 9 also wanted to encourage Wei and the others to make a judicial inquiry into the situation of the levy. Shih-hou said to him, "The troops they are recruiting will all be attached to the Duke of T'ang. Wang Wei, Kao Chün-ya and their group have no power of their own, [so] how can they do this?" Thus Te-p'ing desisted.

When the [T'ang] uprising began, Shih-huo was made ta-chiang-chün fu$k^{\prime} a i-t s^{\prime} a c .10$ He participated in taking the capital and for his merit [was rewarded with the titles] kuang-zu ta-fu and T'ai-ÿ̈an chün-kung. 11 Previously, when the rebellion was about to begin, Shih-huo was unable to predict the outcome. When the capital was taken, he claimed he had dreamed that Kao-tsu had entered the Western capital and [then] risen to be emperor. Kao-tsu [on hearing this] smiled at him saying, "You were connected with Wang Wei and [still] were able to remonstrate and prevent [him from seizing] Hung-chi and the others. Your sincerity is worthy of record and so I rewarded your devotion. Now you see that the matter is concluded and so say this absurd thing to flatter me."

In the Wu-te period, [Shih-huo] was promoted successively to the post of kung-pu shang-shu, and his enfiefment was raised to Duke of Yingkuo. 12 He also served as tu-tu of Li-chou and Ching-chou. 13 in the ninth year of chen-kuan [635], he died in office and was posthumously entitled $2 i-p u$ shang-shul4 with the temple name of Ting, Constant."15

To the casual reader this account appears straightforward and relatively unbiased. The Empress Wu came from a wealthy clan and was the daughter of a man who rose to prominence by early supporting Kao-tsu in his rebellion against the Sui. Seen within the context of T'ang biographical writing, however, the narrative is characterized by a certain implicit deprecation. Not a single one of Shih-huo's ancestors is mentioned, so that his lineage, it is implied, was undistinguished. He was wealthy. Was the source of his wealth the despised profession of commerce or is mention of the fact made because his clan had no other claim to renown? He participated in the events connected with the fall of the Sui capital. Did he play no more substantial part than this in the T'ang foundation? He held posts up to the level of president of the Board of Works (kungpu shang-shu), but did he do nothing worthy of record in them? Was he really the rather timid opportunist who seems to emerge from the anecdotes chosen to give flesh to the details of his career progress?

These are but some of the questions which might occur to one familiar with the official biographies of the period, and if their answers indicate an implied hostility, the reasons are not hard to understand. T'ang beliefs about heredity were such that by distorting the origins and minimizing the achievements of Wu Shih-huo, the historian could indirectly cast aspersions on the character and career of his daughter, the Empress Wu. 16

This seems indeed to have been the case when we compare the above account with that given in the $P^{\prime} a n-$ lung-t'ai pei. In doing so we must bear in mind that the inscription, too, is not a wholly reliable source for it is typical of its genre in the hagiography of its tone and in the dubious nature of some details. Its author, Li Chiao, was a noted official and littérateur of the Chou, and though not strictly speaking a sycophant, he was closely identified with 
the Wu interests. 17 The Pei is clearly tendentious, if only because the empress commissioned it, but by using it carefully and referring frequently to other sources for verification, we can find in it the most comprehensive account of the empress' immediate background. At over six hundred lines, it is too lengthy for complete citation, but in the following discussion, I hope to cover the salient details.

The Pei begins with an outline of the Wu clan's genealogy, a subject to which I shall later return, but in speaking of Shih-huo's parentage it differs from the official accounts by omitting all reference to his family's wealth. The omission may well be an attempt to dispel the persistent rumor that Shihhuo's background was mercantile, a response to the frequent charge by contemporary enemies that Wu Tse-t'ien was of low or "unsuitable" birth. 18 The truth of this matter is difficult to ascertain, but most relatively recent scholarship reproduces the view that Shih-huo's family dealt in timber, a detail recorded in a ninth-century local history and repeated in the T'ai-p'ing kuang-chi.19 The relevant passage, "in his youth [Shih-huo] dealt in timber together with a man called Hsü Wen-pao of the [same] city," is not conclusive and seems rather to suggest that Shih-huo's business was personal, not familial. It would not be unusual for a younger son, even of landholding or official family, to engage in a pursuit of this sort, and Lo Pin-wang's charge that the empress' origins were "truly obscure" might thus be greatly exaggerated. The point is raised here to illustrate the manner in which the Pei diverges from the official accounts and encourages an alternate explanation. We will pass on now to the concrete facts it relates.

According to the Pei, Shih-huo was born in 577, the fourth son of Wu Hua who held the position of cheng of Loyang in the reign of Sui Wen-ti.20 The distinguished lineage provided for him goes back to the Chou, and while the earliest ancestors mentioned are probably spurious, there is good reason to believe that the genealogy from the T'o-pa Wei onward is genuine.21 If so, the Wu clan was closely connected with the T'aiyüan area for several generations, and if it was not numbered in the national aristocracy as the empress tried to pretend, 22 it was almost certainly a clan of local prominence with some renown based upon past nobility and upon present membership in the minor official and perhaps military class. 23

The next point in the Pei, that it was Shih-huo who raised his clan to empire-wide prominence, is in agreement with official accounts. The manner in which this was achieved, however, is described differently. According to the Pei, Shih-huo was no mere opportunist who rose through a fortuitous connection with Kao-tsu, but rather was a man who gained fame for his filial actions on his parents' death and so received several $p^{\prime} i$-chao summons to office from Sui Wen-ti.24 On the advice of a yin-yang diviner, and because he had no confidence in the Sui, Shih-huo initially refused, accepting only on the intervention of the governor of T'aiyüan. 25 There is, however, no confirmation in Sui records that Shih-huo ever held office in the period, much less that he aroused the jealousy of the powerful Yang Su whom the Pei has remarking, "I have noticed that Wu's talents and appearance (feng-ku) are certainly of heroic degree. Now we enjoy an era of peace, so why use this man?"26

Whatever the truth of the matter, the Pei goes on to relate that when Wenti died, Shih-huo feared this jealousy and so retired to private life. He 
then devoted himself to a study of military matters. He was able to predict to his brothers the failure of Yang-ti's Korean expedition of 611 and also to produce a thirty-chüan work on strategy and tactics, called the Ku-chin pingyao. 27 This is probably the work he is said later to have presented to Kaotsu. In 613 he had an opportunity to test his knowledge, for he happened to be in Loyang when the city was besieged by the rebel Yang Hsüan-kan. According to the Pei, it was his advice which prevented surrender.28 Again we find no confirmation of the incident, but the Pei offers an explanation, saying that Shih-huo feared the envy of Yang-ti and so insisted that his participation go un reported! 29

When Yang-ti fled to the South in 616, Shih-huo is reported to have told his brothers, "This is a journey from which he will not return!" but when they encouraged him to rebel himself, he refused. 30 similarly, he realized that the prominent rebel Li Mi would not succeed, and he declined an invitation to join him. 31 Only when Kao-tsu came to T'aiyüan did he recognize greatness: "How brave and heroic, yet how plain and easy [of manner?]; how intelligent, and marvelously courageous! This is a man with whom one can devote oneself [to founding a dynasty]!"32 Shih-huo soon paid a courtesy call with the result that "Kao-tsu.. . took his hand and placed his confidence in him. [It was like the way] Duke Wen of Chou obtained [the services of] Chiang Ya."133 The partnership was strengthened when he accompanied the emperor-to-be in the suppression of brigands in Kao-yang 34 and when, afterwards, Kao-tsu became a guest at his home.

The Pei inserts in the narrative here the dream referred to in the old T'ang History account and, as if in anticipation of its criticism, claims that Shihhuo revealed immediately not only the dream but also some mysterious voices he had heard predicting Kao-tsu's success. 35 In addition, the Pei account of the dream differs from that of the old T'ang History in relating that Shih-huo also ascended to the heavens and touched the sun and the moon--an interpolation clearly designed to show that his offspring would also found a dynasty.

With the exception of conventional references to dreams and portents, the Pei to this point need not strain credulity; indeed, the notion that Shih-huo took the initiative in meeting Kao-tsu seems most reasonable. After this section, however, exaggerations about his achievements and honors become more pronounced. The reason lies perhaps in the general confusion of the T'ang foundation; falsification here would not easily be detected.

The Pei tells, for instance, of how Kao-tsu was "greatly pleased" about the dream and the military textbook and how Shih-huo advanced rapidly to the reception both of high honorific rank and of a ducal title. 36 On more than one occasion his military expertise is supposed to have "saved the day" in the course of the T'ang conquest, and when the capital fell, he is said to have been rewarded with a mansion, promotions, 5,000 tuan of silk and 3,000,000 cash. 37 This seems dubious since there is no official record that men even more prominent than he in the campaign received rewards of such magnitude. The subsequent honors mentioned in the Pei go similarly unrecorded elsewhere, and we might well be suspicious of such claims, for instance, that Shih-huo declined the two highest posts in the administration during the first year of the new dynasty. 38 Instead, says the Pei, he accepted a position without fixed duties but with rank equal to the chief ministers ( $t$ 'ung chung-shu men-hsia san$\left.p^{\prime} i n\right), 39$ a designation, according to the New T'ang History treatise on officials, 
which was not created until late $634 !^{40}$ Details of this sort we must reject.

The next major incident recounted, Shih-huo's appointment as president of the Board of Works (Kung-pu) in 620, is well documented in other sources, and we can find confirmation in the Ts'e-fu yüan-kuei that at about the same time, Kao-tsu praised his integrity and honored his brothers with appointments as a sign of his regard for Shih-huo. 41 Even more striking is the allegation in the Pei that Kao-tsu himself served as broker (hun-chu) in arranging Shih-huo's second marriage into the eminent Yang clan, to a cousin of the last Sui emperor. 42 Because of the inequality in clan status, historians have long been puzzled about how this marriage was effected, but here again the Pei is confirmed by a Ts'e-fu ÿüan-kuei notice which differs in detail but which shows that the emperor himself suggested both the marriage and the bride. 43 This union, concluded probably in 620, produced three daughters of whom the second was to become the Empress Wu.

It is interesting to note here the skill with which Li Chiao intersperses these verifiable facts with assertions of a more dubious nature. We find no confirmation, for instance, that Shih-huo's brothers were awarded the rank of chün-kung nor, indeed, for the statement that "afterwards, when Kao-tsu made a trip, he often ordered Shih-huo to manage the affairs of the tribunal [of censors?], to be at the same time in charge of the troops and horses of the [Palace] Guard of North and South, and to judge $\left(p^{\prime} \alpha n\right)$ the presidents of the $\mathrm{Six}$ Boards."144 Although unlikely to be true, these notices gain an air of verisimilitude by their placement among otherwise documented facts.

In 624 Shih-huo received a temporary assignment to pacify the Yang-chou area following the rebellion of Fu Kung-shih, 45 and after an administration so successful that he received imperial commendation, 46 he returned to the capital in late 626 at the accession of T'ai-tsung. The following year saw the abortive rising of Li Hsiao-ch'ang in Shan-nan, 47 and the Pei reports that when T'aitsung asked his ministers for a suitable candidate to quell the remnants, "all considered that unless Shih-huo [were put in charge], it could not be done. 148 He was duly appointed governor-general of Li-chou and seems to have remained here until 631 when he was transferred to an equivalent post in Ching-chou. 49 Some evidence recently come to light suggests that the Empress Wu may have been born during her father's posting in Li-chou, and if so, she is three years younger than has traditionally been believed. 50

The Pei relates 1 ittle else of interest to us here, giving few details of Shih-huo's administration in Ching-chou, but mentioning how his prayers before a statue of Aśoka at the Ch'ang-sha temple miraculously ended a long drought in the area.51 It is also the only source to offer details on his death in 635 at age 59, attributing his final illness to sorrow at Kao-tsu's death. T'aitsung is said to have sent him capital physicians, and his funeral arrangements were charged to $\mathrm{Li} \mathrm{Chi}$, the governor-general of his home prefecture where he was buried. 52 The last detail is significant since it was Li Chi's voice, two decades later, which was decisive in the establishment of Shih-huo's daughter as empress. Finally, the Pei gives details of Shih-huo's posthumous honors.

There are numerous aspects of the Pei upon which 1 might comment, such as its relationship to the ideology of legitimation, but since my sole purpose here is to ascertain the facts of the Empress Wu's immediate background, let me point 
out only that it provides enough reliable information to supplement and occasionally to revise the official account. The most important of the new perceptions it provides are that the Wu clan was not wholly undistinguished, and that the empress' father was a valued friend of Kao-tsu and a man who enjoyed the trust of T'ai-tsung. Beyond this, it is a source which encourages certain speculations about the early life of the empress herself. Of these we might list the possibility that she was born outside the capital in the Szechuan area, and probably in 627. Her earliest years were spent in the provinces, in a wealthy family with close ties by marriage to the imperial clan and high ministers of the T'ang. Her home was one in which Buddhism had a certain influence. From other sources we learn of the visit of a noted fortuneteller to the Wu home, 53 so it may be that popular religion generally was strong there. By offering even this much information, the Pei becomes our major, if still meager source on the first seven or eight years of the Empress Wu's life.

There exists also a corresponding inscription for the empress' mother, 54 but it unfortunately offers no information on the movements of the family over the next years. We are forced, therefore, to return to official sources and to resume the narrative with the entrance of the future empress into T'aitsung's harem at the age of fourteen. Dating of this event is problematic because of source conflicts regarding her birthdate, and Ssu-ma Kuang, discussing the matter in the $k^{\prime} \alpha o-i$, concludes that it was in 637 that T'ai-tsung 'heard of her beauty" and summoned her. 55 There is, however, reason to question this.

First of all, T'ai-tsung had only buried his beloved Wen-te Empress in the eleventh month of 63656 and is recorded to have mourned her "for a long time."157 It seems unlikely he would so soon add to his harem even if Wu had been of outstanding beauty. We find no confirmation in other sources that this was the case, and the fact that she neither advanced from her initial rank of $t s^{\prime} \alpha i-$ jen 58 nor bore T'ai-tsung any children might suggest he was not greatly attracted to her. An alternative explanation for her summons to the harem is provided in the fact that in the late 630 s one of her cousins became T'ai-tsung's favorite concubine and used her good offices to have wu selected. 59 If this suggestion is valid and if we accept the evidence of a later birthdate, we might place Wu's entry into the palace in 640 and attribute it to nepotism rather than her personal qualities. She seems to have had little to do with the emperor, for she totally escaped his notice in 648 , when he acted upon a current prophesy that a "martial prince" (wu-wang) who was female would overturn the T'ang. 60

Her duties in the imperial wardrobe, however, did bring her into contact with the future Kao-tsung who had been declared crown prince in 643 . Contrary to T'ang custom, he seems to have occupied the same palace as his father, and in T'ai-tsung's final illness is said to have been present constantly at his bedside. 61 Some sources give the impression that an incestuous 1 iaison was formed at this time, 62 and while we cannot be certain that this was so, it does seem possible in light of subsequent events.

The career of the Empress Wu should have come to an end with T'ai-tsung's death if, in fact, she retired with his other concubines to a convent. The principal sources agree that she did so, 63 and they go on to record that she was resummoned to the palace at the urging of Kao-tsung's childless Empress Wang who hoped thereby to detach his affections from a rival concubine called 
Hsiao Liang-ti. 64 The story is a curious one, with numerous source contradictions and a lack of essential details, so that it may be well to reject altogether the convent story, or to suggest that she entered under different circumstances and for a shorter period of time than is usually assumed. 65 Kaotsung may well have planned to make her his concubine from the time of their first meetings!

From her return to the palace, Wu Chao-i, as she was now known, is said to have mounted a surreptitious and skillful campaign to discredit both Empress Wang and the concubine Hsiao Liang-ti. She bribed servants to spy on them, slandered them to the emperor, and perhaps even smothered her new-born daughter in order to find some crime to blame upon the empress. 66 The usual source difficulties are, of course, magnified here since events of this sort, occurring within the palace, cannot have been made known through regular channels to the historians. The infant's death, for example, might have been accidental, and it is perhaps significant that the incident goes unrecorded in the old T'ang Histomy biographies of Wu and Wang. In any event, Wu Chao-i came rapidly to monopolize Kao-tsung's love, bearing him one or perhaps two sons in $653-4$ and emerging in early 654 as his open favorite. 67 Later that year Kao-tsung began to seek ministerial approval for her elevation to empress.

This search for approval met initially with almost universal opposition among the tsai-hsiang, a group composed at the time of six men. 68 As one of the significant political crises of the period it is well documented in primary sources and much studied by modern historians, 69 so that its full details need not concern us here. Certain points of broad importance might be made, however, and the first is that Kao-tsung showed throughout a resolution and ingenuity not often associated with his character. We must recall that his chief opponents, $\mathrm{Ch}^{\prime}$ ang-sun Wu-chi and $\mathrm{Ch}^{\prime} u$ Sui-liang, were men of great prestige and, indeed, had been entrusted by the dying T'ai-tsung with the care of his son. 70 Like their colleagues, they assumed that all matters affecting the empire fell within their purview, and this attitude had been encouraged by their recent experience in the collegial-style government of T'ai-tsung. 71 They had in his reign played a role in all important decisions including Kao-tsung's selection as crown prince, and when the latter argued that the choice of an empress was a domestic matter, their resort to this precedent was not unnatural. Kao-tsung seems to have accepted this limited view of his prerogative at first, and so turned to every avenue from cajolery to outright bribery and intimidation in order to gain agreement. Only when this failed did he simply overrule them, and in so doing he changed the balance of power and the style of rule which had characterized the dynasty up to that time.

In the debate itself, he stressed continually that Empress Wang had failed to bear him a son while Wu Chao-i had done so. This was sufficient ground for divorce under T'ang law, and nowhere is there recorded a reference in the debate either to the murder of Wu's daughter or to the charge of sorcery later cited to justify the Empress Wang's deposition.72 The arguments of his opponents therefore seem the more cogent since they could speak of the blamelessness of Empress Wang and could even point out the unfilial nature of removing an empress personally selected for her virtue by Kao-tsung's father. Moreover, they claimed, bonds of marriage were sacred, especially in the imperial household where they were an example to all. The sincerity of this argument might be questioned, however, since they admitted that compromise was possible. If 
Kao-tsung were determined to change empresses, why did he not choose a lady of distinguished 1 ineage? Wu Chao-i was not only of relatively low birth, but as a former concubine of T'ai-tsung the possibility of having an accusation of incest could only blacken the emperor's historical reputation. 73 In this suggested compromise we see perhaps the real basis of the tsai-hsiang position. They were not opposed to a new empress provided it were not Wu Chao-i; that is, they would agree to a change if they could guide the emperor's choice. Kaotsung was probably aware of this, for he made no effort to refute their specific charges against Wu until the edict on the occasion of her accession in November of 656.74

On one level, therefore, the conflict may be regarded as a struggle over the definition of imperial prerogative, and modern scholars have extended its scope even more widely than this. Ch'en Yin-k'o, for instance, saw it as a regional struggle between rival aristocratic blocs from the Northeast and the Northwest. 75 Japanese commentators like Yokota Shigeru and Matsui Shüichi view it rather as intra-bureaucratic competition between entrenched aristocrats and newly rising officials like Li I-fu 76 who allied themselves with Kao-tsung for opportunistic reasons or to compensate for the lack of a genealogy which would open to them the highest state posts.77 Maoist historians, like Chang Ch'ün, incline to the latter view, though they emphasize a different sort of class struggle and use a different vocabulary. 78 More recently, Lo Lung-chih has taken a revisionist position which sees opportunism as the chief motive of both camps. 79 All these approaches provide a certain insight, but the nature of our sources is such that a high degree of speculation is necessarily present in each. Perhaps it would be best to take both emperor and tsai-hsiang at their own valuations, for on both sides we can find such elements as genuine idealism, Confucian loyalty, and class as well as self interest. The issue of whether or not the Son of Heaven could choose his empress independently is the fundamental one, and by finding a single tsai-hsiang, Li Chi, who agreed that he could, Kaotsung won an important victory. Li's view, "This is a household affair of Your Majesty. Why [do you need to] inquire further from outsiders?" would be invoked often in support of imperial claims in the T'ang. 80 In late 656, after two years of uncertainty, the matter was settled.

The Empress Wu seems instinctively to have grasped that the manner of her elevation put the tsai-hsiang group on the defensive, and she lost no time in pressing her advantage. Taking the initiative and overriding Kao-tsung's resistance, she had newly-promoted officials like Li I-fu and Hsü Ching-tsung bring criminal charges of dubious validity against all five of her former opponents so that by late 659 all had been driven to disgrace and death. 81 In the same period, she personally effected the destruction of the former Empress Wang and Hsiao Liang-ti and with needless brutality. 82 Both of these acts appalled the Confucian historians, but it was the first which had the greatest historical significance. Not only was the social and regional configuration of power changed at the highest level of government, a change of great importance in the context of the revision of the national clan list in 659 , but the entire political climate at the same level was also altered. Ssu-ma Kuang says with only minimal exaggeration that "from the death of Ch'u Sui-liang and Han Yüan, inside and outside [the court, frank] speech was avoided. No one dared oppose the [imperial] will or strongly remonstrate. For almost twenty years [it was like this]. 1183 
We might ask at this point what role Kao-tsung played in these years. The standard sources give the impression that as his wife's vengeance unfolded, he became more and more debilitated in spirit and morale, weeping openly, for instance, at the fate of his former empress and his uncle Wu-chi.84 Though such remarks as "My family is unlucky, and there is constant trouble with my relatives, 185 indicate a belief in the need for severity, the strain of the punishments was great and may have been related to the $i l l$ ness he suffered in 660 and which resulted in the temporary delegation of his duties to the empress. 86

In this same period, on the other hand, he was proving with real achievements to be a competent and even an energetic ruler. His armies, for instance, conquered the Western Turks in 658 and incorporated into the empire the vast area of the An-hsi protectorate-general. 87 He showed his administrative ability in measures for governing the new territory and by the institution of a biennial census within the Wall, and he did not hesitate to send troops to rescue the tributary state of Paekche from an aggressive Koguryo. 88 In 659 , as we shall see, he demonstrated his centralizing talents with important measures to weaken aristocratic regionalism and to confer prestige upon the examination system. With similar purpose he took steps to strengthen the ideology of the state, and recognizing the force of Confucian, Buddhist and Taoist loyalties among the various groups of his subjects, he took steps to patronize them all. Thus he commissioned a new ritual and new versions of the dynastic histories from Liang to Sui, creating shortly thereafter the post of ch'i-chu she-jen "diarist of activity and repose" in order to facilitate the production of true dynastic records. 89 As early as 655 he showed his respect for Buddhism by publicly greeting the famed pilgrim Hsüan-tsang at the city gates and installing him in the Tz'u-en Temple.90 Two years later he freed both Buddhist and Taoist clergy from their duty of obeisance to their parents. 91 In the same year, 657 , and principally for purposes of centralization and consolidation, he completed an extensive program of building and restoration at Loyang, and he designated it the Eastern Capital.92

This final measure presents an opportunity to raise a central question. Traditionally, the explanation for the virtual shift of the court to Loyang from this period has been the antipathy of the Empress Wu to the Ch'ang-an palaces where she was haunted by the apparitions of her early victims.93 Did she therefore inspire the shift, and was she similarly the moving force behind her husband's other actions? The evidence suggests not. First of all, there existed both precedents and valid economic and political considerations for the establishment of a second capital, and these were enunciated at the time.94 Second, Kao-tsung rapidly recovered his strength after 660 , fathering two more children and making extended tours, most notably to T'ai-shan in 665.95 Third, in late 664 he forcibly reminded the empress of her technically subordinate position by threatening to depose her.96 This last event is subject to frequent misinterpretation, and so we might examine it more closely.

The Empress Wu, it seems, had been seeing at this time a Taoist priest known to be skilled in the occult (yen-sheng). These activities could easily be construed as sorcery, the crime to which Empress Wang's fall had been attributed, and it was as such that a eunuch reported it to Kao-tsung. In anger he sought advice from one of his chief ministers, Shang-kuan 1, a man who had been closely connected with the former Crown Prince Chung and also with the fallen elder statesmen.97 Warned that the empress' unrestrained influence was detrimental 
to the empire, he had Shang-kuan draft a decree of deposition. What happened next is not recorded in our earliest source, the old T'ang History, and so may be suspect, at least in detail. The New T'ang Histomy says the empress heard what was happening, hastened to her husband to confess, and "the emperor therefore repented. He also feared her anger and so said it was done on the advice of Shang-kuan 1."198 Shang-kuan and his eunuch accomplice were executed on charges of conspiracy with the former crown prince, and the Comprehensive Mirror, following the New T'ang History, says,

from this [event], whenever the emperor attended to business, the empress then hung a curtain [and listened] behind. There was no matter of government, great or small, which she did not hear. The whole power of the empire passed into her hands; reward and punishment, life and death, she decided. The emperor folded his hands and that is all. In court and country, they were called the Two Sages.99

This passage, although dubious in origin and extravagant in expression, has been extraordinarily influential in creating the quite common perception that from 664 Kao-tsung was no more than a puppet ruler. The old T'ang History, in the parallel section, offers a different view: "From this, the empress for several decades aided (nei-fu) in government with power and authority no different from that of the emperor. They were designated at that time as the Two Sages."'100

Whichever interpretation we choose to accept, it is clear that only in 664 did contemporaries begin to regard the empress even as an equal partner in government, using a phrase, incidentally, which had been similarly applied to Sui Wen-ti and his wife. 101 Until 664 Kao-tsung was almost certainly the senior partner, and it was possibly only when he began to lose ground after 660 that he considered deposition. We might even speculate from the rapidity of his "repentance" that deposition was never a serious alternative in his mind, for he had the evidence, the power and the support necessary to do it had he been determined to do so. It seems more reasonable to suggest that essentially Kaotsung ruled just as his father had, co-operatively; only in his case, the Empress Wu played the supportive role traditionally assigned to the ministerial body. Kao-tsung apparently recognized the unusual talents of his wife and, sharing with her a concurrence of purpose, used the events of 664 simply as a warning, never thereafter withdrawing his trust. There is no sign that the relationship between the "Two Sages" became antagonistic after 664 , and indeed Kao-tsung's first reaction on the return of his illness in 675 was to offer his wife the regency. 102

Kao-tsung was to live for another two decades, presiding with the Empress Wu over a largely successful administration and a prosperous state. The policies of these years are examined in subsequent chapters, but before we pass on to them, we might outline here some of the more intimate events of court life as they touched the empress' career and, to a degree, were determinants of her public actions.

The year 665 was notable for the celebration of the feng-shan sacrifice, the most important of state rituals whose function it was to announce to Heaven the successful achievement of a ruler's tasks and to beg continued blessings. 103 Both Kao-tsu and T'ai-tsung, feeling unworthy to perform this most solemn of rites, had refused ministerial requests to do so, the latter on five different 
occasions. 104 In 665 the initiative seems to have been the rulers', and while certainly related to domestic prosperity and the success of Chinese arms abroad, may incidentally have been symbolic of the restored harmony of Kao-tsung's family life. As we shall note, this represents the unique instance in Chinese history of female participation in this ceremonial, and though this later came to be considered a sacrilege, it seems at the time to have done nothing to dim the luster of the occasion.

The aftermath of the ceremony was not, however, so happy. Because of Confucian sensitivity to her own unusually great role in politics, the Empress Wu had always been careful to avoid the charge that her family, the wai-ch'i, benefited too greatly from her position. In 656 she had, therefore, presented a public "instruction" to her clan which resulted in the transfer of her half-brothers and their families to provincial postings. 105 Most sources suggest that the real reason for the transfer was the empress' long-standing dislike of them occasioned by their disrespect for her mother. 106 Both brothers had died at their posts, but the sons of the elder, Wei-liang and Huai-yün, were invited to the feng-shan celebration and returned afterwards to the capital with the imperial party. Also in the capital was the empress' niece Ho-lan Kuo-ch'u, daughter of her elder sister and, the histories allege, recipient of Kao-tsung's favors as her mother had been before her. 107 Though their vocabulary here is deliberately vague, Kao-tsung seems to have made it known that he wished the girl as a concubine, so that the allegations may have been true. The empress was in any case jealous of her, and in the eighth month of 666 at a banquet in the home of her mother, Madame Yang, the girl died in convulsions. The empress' nephews were executed as poisoners, but suspicion was naturally directed toward the empress herself. This is the first of a series of deaths within her family circle for which she is implicitly blamed in the histories.

It is impossible, so long after the fact, to pass judgment on the empress' guilt or innocence, but on the basis of what evidence we have, an alternative explanation is possible. We know that Madame Yang greatly disliked her stepfamily and at the same time she was naturally anxious that her daughter retain the emperor's favor. Her banquet may therefore have been given to rid herself of the stepfamily which seemed to be regaining favor and simultaneously to destroy her daughter's rival. This interpretation is supported by the fact that when Wei-liang's execution left Wu Shih-huo without a descendant in the male line to carry on the ancestral sacrifices, he was replaced not by a surviving member of the Wu clan but rather by Ho-lan Min-chih, Madame Yang's real grandson. 108 As her rival's brother, he is not likely to have risen to this honor and been granted the Wu surname by the empress if she had been jealous enough to murder his sister!

Min-chih, in the event, proved an unworthy candidate, soon discrediting himself in various ways. Not only is he said to have seduced the palace ladies who attended the T'ai-p'ing Princess but also to have raped the bethrothed of the crown prince. In 670 he callously ignored the mourning regulations for Madame Yang, who had been his constant protector, and in punishment was exiled to the provinces. He committed suicide on the road, thus opening the way for the return to court of the last survivors of the Wu clan, Ch'eng-ssu and Sanssu, 109 men who would have great prominence during their aunt's usurpation.

There is perhaps little to be gained in speculating upon the guilt or 
innocence of the empress in matters like these except insofar as they relate to her character and to the progress of her career. Domestic tragedy seems to have had little effect on her role in government though it may be possible that it contributed to a weakening of her self-confidence. We see signs of this in 670 , the year of her mother's death, and also a year of calamity both in domestic and foreign affairs. At the same time, a number of $i 11$ omens were observed, 110 and the empress seems to have blamed herself, for in the [intercalary] ninth month she offered to resign her position (pi-wei). The New T'ang History suggests that her request was a false one, 111 but even Ssu-ma Kuang, who is usually ready to believe the worst of her, does not question her sincerity. 112 Kao-tsung, as we might expect, declined the offer, reaffirming his confidence in her and demonstrating it even more clearly four years later when, at her suggestion, he appropriated to both of them the unprecedented title "Celestial" ( $t$ 'ien-huang, t'ien-hou). 113

This measure is well known and is usually attributed simply to a whim of the empress: her desire to avoid the style of all former rulers. 114 As we shall see, this motive was present but in all likelihood was not the sole one. The titles were taken in a mood of celebration, part of a general measure to correct and standardize the posthumous honorifics of the imperial clan, so that Kaotsung and the Empress Wu made themselves, while still alive, part of a recognized tradition of good government. This aspect of motivation became clearer within a few months when the empress presented her husband with a twelve-part memorial on the subject of governmental improvement. 115 In it she proposed a comprehensive program which envisaged in a state of peace and plenty, low taxes, light corvée and only a small army so that transformation could be carried out by virtue not force. The administration was to be more frugal, opening reserved lands to cultivation and economizing on public works and donations to monasteries and temples. The government was also to be more open, prohibiting all slander but welcoming free representation on any matter from all subjects. The servants of the state were to be better rewarded, with salary raises in the capital and promotions for those in low ranks who had no one to recommend them. Two measures were new: the first extended the mourning period for a dead mother to the full three years hitherto reserved for a father, and the second encouraged the study by all, of Lao Tzu's Tao-te ching. I shall comment on these later.

Although one source says that to some degree all the suggestions were implemented, 116 practical considerations would seem to have made impossible, for instance, any large-scale demobilization of troops. 117 At the same time, however, the symbolic nature of the act was perhaps most important and its basic principle--concern for the people's welfare generally and for the lower orders of society and bureaucracy in particular--must have been a popular one. Hostile historians have tended thus to see the memorial as a transparent device to win popular support and pave the empress' way to usurpation, but on examinination we must reject this view. The encouragement of Taoist studies, for instance, could only strengthen the T'ang, and of greater importance, in the years 684-690 when the empress was preparing her usurpation and was most in need of public support, her policies diverged widely from the suggestions of the memorial, encompassing corvée-built public works, the lavish patronage of Buddhism, and the dependence on ruthless and slanderous officials. Administration in the Chou, conversely, was based closely enough on the principles of 674 that we might instead accept the program as a sincere one. 
One of the reasons that historians see the memorial in the context of usurpation is that in 674-5 the succession question was becoming central. Kao-tsung's old illness was returning, and in the third month of 675 he suffered so serious a relapse that he suggested his wife become regent, desisting only when Hao Ch'u-chün, vice-president of the Secretariat, protested that "the Son of Heaven manages the external and the empress the internal. This is the way of Heaven."118 A second reason was that less than two months later the Crown Prince Hung died in mysterious circumstances and, as Ssu-ma Kuang puts it, "people of the time considered that the Celestial Empress [Wu] poisoned him."119

Evidence for the crime, as Ssu-ma admits in the $k^{\prime} a 0-i$, is of the most tenuous sort, arising from a court rumor in the time of su-tsung (756-62), 120 but the accounts agree at least on the details of the story. Hung was a popular prince, rapidly gaining reputation as a humane, filial and serious man and, as his independence grew, he came occasionally into conflict with his mother on policy matters. The most recent of those occasions was his persuading of Kaotsung that the two daughters of Hsiao Liang-ti, confined at the empress' wish since 656, should be released and allowed to marry. The empress showed her resentment by finding them husbands of low degree. Shortly after this Hung accompanied his parents to the Ho-pi palace near Loyang where he died.

The New T'ang History is the only one of the primary sources to suggest he was poisoned, 121 and other evidence exists which points rather to a natural death. In the first place, it seems unlikely that the empress was planning a usurpation that early, and even if she did, to poison her son in the very presence of a father who loved him, seems an extreme and foolhardy tactic. Also arguing against murder is the fact that Prince Hsien, the next in line, was possibly not the Empress Wu's son at al1122 and, therefore, was not a man she would have been anxious to have succeed. Finally, there are indications that the dead heir was not of a healthy constitution. 123

Hsien, who became crown prince in the sixth month of 675 , was a man interested in scholarship and Buddhism; he was open, lively and fond, we are told, of wine and women. 124 The rumor of his illegitimate birth, so soon to surface, must have been known in certain circles at his accession, but there is reason to believe that even so, the empress was willing to see his succession to the throne. She took a personal hand in his education, writing him letters of instruction and reprimand, and permitting the appointment as his counsellors ( ${ }^{2} n_{-} k^{\prime} O$ ) of four men not known to be friendly to her, among them Hao Ch'u-chün. 125 Hsien seems to have begun well, and he won praise from his father in 676 , the same year he presented to the throne his Hou Han-shu commentary. 126 Soon after that, however, his reputation began to deteriorate. He was told that his mother had been advised by one of her intimates, a man holding regular office and also skilled in fortunetelling, that he had not the look of a future emperor and was less noble than his younger brothers. His response, according to a palace servant with whom he had an improper liaison, was to procure the fortuneteller's murder, 127 and although proof of this was lacking, the empress was naturally suspicious.

Shortly after this, when Hsien rejected the advice of one of his secretaries to end his liaison, the empress seized the chance to have a formal inquiry made into his affairs. In searching his residence, the investigators found in his stables several hundred suits of armor which they reported as evidence of treason. 
Kao-tsung, although he had also had earlier reservations about Hsien's suitability, 128 was willing to pardon him, but on the empress' insistence, the armor was publicly destroyed and Hsien demoted to the status of commoner.129 He was soon exiled to the provinces where he committed suicide in 684, with suspicion falling on the empress as the instigator of his death. $130 \mathrm{His}$ position as crown prince was taken by his younger brother, the future chung-tsung.

Was Hsien, like his elder brother, a victim of Empress Wu's ambition? Once again, the nature of our sources makes certainty impossible. The evidence of the armor seems damning enough for the penalty of degradation and, given the circumstances, the empress had little to gain from the heir's removal. Two sons remained and would always stand between her and the throne and, besides, Chung-tsung was not only allowed to succeed but was later to comment specifically on the kind treatment he received from his mother.131 In 682 Kao-tsung, presumably with his wife's agreement, took the unusual step of establishing Chung-tsung's son as huang t'ai-sun "Heir Apparent Grandson,"1132 a measure which might be regarded as an expression of his fear that Empress Wu would deprive the $\mathrm{Li}$ clan of the throne. Yet this interpretation is also dubious in view of the long partnership of the "Two Sages," and especially in view of the great power Kao-tsung was to leave the empress in his last testament. More likely, the measure was designed to quiet the fear and suspicions inspired at the court by the unaccustomed influence of an empress and the disappearance of two heirs to the throne. When Kao-tsung died at the end of 683 it seems to have been in the belief that the succession was assured and that his heir would benefit from the expertise of the Empress Wu.

Kao-tsung's death presents us with a suitable opportunity to summarize some conclusions. From the discussion thus far one of the strongest impressions to emerge is that of the weight of historical bias against the empress. I have cited a number of instances where unprecedented or discreditable acts are ascribed to her without convincing evidence, and have shown that on occasion the historian prefaces his allegation with the phrase, "people at the time believed . . ". This is important, for the "people" to whom the historian refers were principally the bureaucratic element at the court, a group consistently ready to believe the worst of the empress. I have suggested that their attitude arose from loyalty to the Confucian tradition which was highly resistant to female influence in government even if the woman exercising it was highly competent.

The existence of this attitude had two principal effects. First, it helped to delineate the empress' constituency and to define the form taken by her search for legitimation. As 1 shall point out, the prejudice against female rule was not so strong among the masses. Second, the overt presence of the empress in her husband's administration meant that his reign was a period of exceptional tension in the highest circles of government. It was a tension which hastened historical change, and perhaps the most notable aspect of this was the relative decline of ministerial power. Since very powerful ministers had been a chief cause of dynastic change in the period of disunion, it could be argued that this development contributed to the longevity of the T'ang.

Dynastic consolidation, as I shall shortly suggest, was the central policy of Kao-tsung's reign, and in view of her eventual usurpation, the loyalty of the Empress Wu to this aim is striking. Historians who see her plotting to 
seize the throne in Kao-tsung's lifetime neglect to consider, for instance, that she and her entire clan owed their rise to the T'ang. As we shall see, policies of the period in which her hand is obvious, the celebration of the feng-shan, the extension of Buddhist patronage, and the emphasis placed on examinations, literature and the polite arts, were all elaborate and effective means of expressing dynastic self-confidence and convincing the empire that the T'ang was essentially different from its short-lived predecessors.

It is in this light that I have taken my position on the succession question. If we accept the possibility that Hung's death was accidental, then Hsien's degradation could hardly have advanced a putative usurpation by his mother, and he is most plausibly viewed as simply one more example of the overambitious crown prince seen in every reign of the T'ang up until that time. If, indeed, he was the son of the Empress Wu's sister, we could even construe his fall as the result of Empress Wu's extreme concern for legitimate succession and thereby strengthen our conjecture that at Kao-tsung's death, the Empress Wu had not yet conceived any intention of establishing a dynasty of her own.

I have devoted so much attention to the succession question not only for the light it sheds on the empress' career but also because of its great importance in 683. From the late 670 s the prosperity of the dynasty was beginning to appear jeopardized as successive years of natural disaster and meager harvest brought about regional scarcity and general economic uncertainty. By 681 these conditions had brought about something of a crisis as grain prices fluctuated wildly and the government was forced to take the unusual step of permitting the starving households of Ho-nan and Ho-pei to change their registration by settling farther south.133 The next year, 683, the fu-ping units of Kuan-nei were set to the work of cultivation in the Southwest, 134 a good indication of the severity of the situation since the government was at the same time attempting to constitute expeditionary forces to meet the resurgent Turks. A strong ruler, therefore, seemed to be an absolute necessity.

Before turning to the question of why Wu Tse-t'ien should have been thrust into that role instead of her mature sons, it is necessary to raise a theoretical matter of central importance, how an ideological basis for exercising sovereignty can be created. 


\section{Chapter 4}

\section{THE EMPRESS WU AND THE CREATION \\ OF STATE IDEOLOGY}

Since the collapse of the Han Empire in the late second century, the reunification of China had become a constant though increasingly elusive ideal. Successive dynasties in North and South had frequently exhausted their strength in the search for ways of conquest, control and practical administration which might weld a pluralistic culture of strong and persistent regional loyalties into a coherent whole. In this process, certain military, economic and organizational mechanisms had been developed which constitute in some recent scholarship the principal explanation for the restoration of the empire in the sixth century. 1 There is much that is appealing in such analyses, but at the same time, they have in common a tendency to ignore the role of what Arthur Wright calls the "suasive accompaniment to the exercise of power,"2 and what I call the state ideology, i.e., that which justifies the legitimation of the powerholder and disposes the people to accept and support his policies. Ideology was a basic concern of all Sui-T'ang rulers and a first priority of the Empress Wu. Without making significant changes in its traditional form, she could not have become emperor.

Before we proceed, some further clarification of terminology is required, for even among social scientists there is much debate about the definition of ideology and its relation both to comparable terms like political theory, culture and value structure as well as to its various components such as national myths and the religious and intellectual life of those it seeks to influence. 3 I shall give the term wide connotations in the following discussion, using it to refer to the totality of words, symbols, rituals, ideas and principles used to legitimize particular individuals, institutions and procedures. We shall also see that it is a concept subject to redefinition, for to be successful an ideology must be a process not a stasis and remain responsive to the shifts of values and constituencies. This is something seen clearly in the most successful ideology before the Sui-T'ang period, the so-called Han Confucianism which during its lengthy development in the second half of the second century B.C. came to include several of the ideas and rituals associated originally with such schools as Taoism, Legalism and yin-yang.

In the Later Han, however, this ideology became first outmoded then impotent, as rapid social change and the spread of Buddhism created new values and as increasingly weak rulers succeeded each other, each less responsive to these new values than the last. In spite of this, one feature of the syncretic Han ideology which survived even in the "barbarization" of North China was its perception of the imperial institution. The emperor continued to be seen as a "cosmic pivot," the harmonizer of Heaven, Earth and Man, and for this reason the formulation of state ideology became more and more an imperial responsibility. Thus in the Sui reunification of China, Wen-ti's greatest achievement lay perhaps in 
his ability to turn to the purposes of centralization and the consolidiation of dynastic power, the values and symbols of Confucianism, Taoism, and especially Buddhism, the faith of the vast majority of his subjects. 4

The first rulers of the T'ang, facing a hierarchy of problems very similar to those of the sui, were able to adopt similar solutions and, at least in broad outline, to espouse an ideology whose only major variation was its use of Taoist messianism. 5 The mid-dynasty usurpation of the Empress Wu, however, was a very different case. Because of its unprecedented nature, the Chou dynasty required different justifications for legitimation and different estimates of societal response. It is principally for this reason that traditional historiography has dwelt on the anomalies of the period, with most sources depicting the era as one of brilliant, extravagant and vulgar ceremonials, of constant omens and of a ceaseless attempt to influence both domestic and foreign affairs by the manipulation of the supernatural. Seen in contrast to the more rationalistic attitude of T'ai-tsung, this emphasis has a certain justification, but we must recall that $T^{\prime}$ ai-tsung was more firmly established in legitimate dynastic succession than was the empress and was, in any case, of a vastly different temperament.

This final point is of some importance. Because the formation of state ideology was so intimately connected with imperial prerogative, the character, background and training of the ruler were significant factors in its creation and form. We have earlier seen that the background of the Empress Wu differed in several respects from the rulers of the Sui and the early T'ang: her clan was of a lower social stratum, northeastern rather than northwestern, and she herself spent her formative years outside the capital where she must have been exposed widely to what Maoist historians term the "people's culture." 6 And because her ministerial body was so aristocratic and metropolitan, clashes with it were bound to be frequent. Of even greater significance, the empress was raised in a strongly religious atmosphere, and as 1 shall attempt to show, this particular aspect of her background was evident in each of the several stages which ultimately gave Buddhism a brief precedence over both Confucianism and Taoism as components of the ideology of the Chou.

The roots of the Empress Wu's deep religious feeling can probably be traced to the influence of her mother, Madame Yang. The Yang clan as a whole was known in Sui times for its particular generosity toward the Buddhist T'ien-t'ai or Lotus Sect, and both emperors had been lavish in their patronage of Buddhism in general.7 Several scholars have commented upon Madame Yang's own piety and upon her generous support for the work of translation and the erection of votive images, 8 and one goes so far as to suggest that she placed her daughter, the future empress, in a convent at an early age.9 Evidence for this is dubious, but it is generally acknowledged that from the mid-650s, as mother of the reigning empress, she was one of the most influential patrons of Buddhism in the land. In the Chi sha-men pu-ying pai-su teng-shih (PSTS), our fullest account of the obeisance controversy of 662 , she is depicted as the staunchest and most steadfast of the church's allies at the court and is credited with a share in its victory. 10

At the same time, however, Madame Yang was typical of her times in the syncretism of her beliefs. She had once welcomed to her home the soothsayer Yüan T'ien-kang to prophesy about her children, 11 and it was perhaps she who introduced 
to her daughter the Taoist priest (tao-shih) whose skill in the black arts (yensheng) almost caused her deposition in 664.12 It is little wonder, therefore, that the Empress Wu was herself inclined to belief in the mystical and the supernatural, and we may note the earliest manifestation of this tendency in her attempt to exorcise from the palace the bloody apparitions of the murdered Empress Wang and Hsiao Liang-ti. Failure to do so, according to traditional historiography, led her to desert Ch'ang-an for Loyang. 13

These few illustrations raise an interesting point. Prophecy, divination, exorcism and practices of the sort were not since Han times the exclusive property of any of the three principal philosophical traditions. As I shall later show, there were numerous contemporary examples of avowed Confucians engaging in such activities as the interpretation of omens and dreams, and there were many miracle workers among the Buddhists. The following discussion is, therefore, restricted to those aspects of state ideology which were directed toward the several definable and discrete groupings and beliefs. It should become evident that the empress propounded no novel system but rather "juggled" or reassembled in her ideology existing elements of Confucianism, Taoism and Buddhism in response to the needs of the time. We shall also see three distinct stages of her ideological development.

Both the early Sui and the reign of T'ang T'ai-tsung are regarded in the standard histories as eras of flourishing Confucianism, 14 and it is to be expected that the empress would have seen the advantages of a continued appeal to the educated classes, the aristocrats and officials, on the basis of Confucian ritual and values. Especially in the period following her controversial and unorthodox elevation, she was the very model of the humble, supportive, and ostensibly noninterfering Confucian empress. Her relatives were not raised to high posts, and she publicly praised the devotion to duty of those ministers who had opposed her, remaining detached at least in the public eye from their destruction. 15 Even the hostile Ssu-ma Kuang remarks on her initial modesty! 16 In this same period much attention was devoted to Confucian ethical values: a new ritual was promulgated and the rules of filial piety extended. 17 A new college, the Ch'ung-hsien-kuan, was founded, 18 and an otherwise severe critic in 657 praised the standard of education both in the capital and the countryside. 19 Education was, of course, a priority of Confucians, and to win the loyalty of a still developing ruling group, both Kao-tsung and his wife consistently patronize the schools and more especially the examinations, a matter I shall later discuss in detail. It may have been that in this period the Empress Wu devoted some attention also to her own studies, for she was soon to demonstrate an intimate knowledge of Confucian symbolism, nomenclature and ritual tradition which could be used both for state and personal purposes.

The first and most striking instance of her ability in this regard came in 665 when Kao-tsung decided to celebrate the most awesome of state sacrifices, the feng-shan on Mount T'ai, reporting to Heaven the fulfillment of harmony and acknowledging the continuing responsibilities of his mandate. 20 Given that rulers of the caliber of Sui Wen-ti and T'ai-tsung had felt themselves unworthy to perform the ritual, its celebration at this time was an expression of unusual personal self-confidence and dynastic congratulations, and even more unusual was the fact that the Empress Wu was able to persuade the officials of ritual that 
she be allowed to participate in it. Edouard Chavannes, who has made the most thorough study of the sacrifice, translates from her request:

d'après ce qu'expose la doctrine des livres classiques, le cérémonial

féminin et le cérémonial masculin sont donc distincts: lorsqu'il

s'agissait de constituer des associés pour l'autel féminin, on s'est con-

formé au sexe de al divinité de la Terre;... d'ailleurs, puisqu'on in-

vite les augustes impératrices défuntes à venir en personne participer au

précieux festin, pourquoi ordonne-t-on à de hauts fonctionnaires de sexe masculin de s' immiscer à des sacrifices parfaits offerts à des femmes?

$\mathrm{Si}$ on raisonne en bonne logique, il y a guelque chose qui jette le

désordre dans une excéllente ordonnance. 21

With Kao-tsung's consent the empress thus became the first woman to participate in the shan sacrifice, and it is noteworthy that there was no overt protest at the time. In 725 the great savant Chang Yüeh was to cite this sacrilege as the cause of the T'ang overthrow and the success of the Chou usurpation, 22 but at the time of the sacrifice the whole court joined in congratulating the emperor and accepted the lavish rewards he offered. 23

It is useful to speculate here upon the motives of the empress in requesting to participate. There is no direct evidence for the usual assumption that she herself inspired the sacrifice, but once it was decided she undoubtedly desired correctness of form. More than this, however, her request was an assertion of the imperial prerogative to define that correctness, and this was probably a more important motive than, for example, any concern she may have had to advance the position of women. More specifically, and within the context of Confucian ideology, she sought the best of both worlds, preserving the broad basis of the ancient rite while making real change in the name of the spirit of the regulations. "Why," she asked her husband, "should you conform to outmoded rules and not institute a perfect regulation?", 24 and with this the emperor transcended precedent and became the interpreter of a tradition which had so often tied the hands of former rulers. Chang Yüeh's later protest was essentially an attempt to repudiate this view.

Lest this interpretation seem too political, I adduce a few further examples to show the consistency with which the "Two Sages" performed resolutely Confucian actions with a subtle originality which kept them ever from becoming imprisoned by $f \circ \mathrm{Fm}^{\mathrm{m}}$. Confucius, for instance, was awarded the honorific title $t^{\prime} a i$-shih in 666,25 a term once used for the most honored of the Three Dukes (san-kung) of antiquity and a title held by the Duke of Chou, but one which had never before been awarded to Confucius. Similarly, the title "Celestial" which the monarchs appropriated for themselves in 674,26 had classical connotations of high antiquity but had never been used for living rulers. On two occasions, in 662 and in 684, new names were created for the posts and titles at every level of the bureaucracy. 27 other rulers like Wang Mang, concerned ostensibly with the very Confucian principle of the "rectification of names" (cheng-ming), had also made similar extensive revisions, 28 but there was no parallel for such thorough reform in mid-dynasty. Perhaps of greater interest is the fact that most of the names chosen in 662, such as those for the Three Departments and Six Boards, were wholly new while those of 684 , for reasons I shall discuss later, were largely an echo of the Rites of Chou (Chou- $z i$ ).

From the above summary we may conclude that in Kao-tsung's lifetime two aspects 
of the Confucian tradition, its social-ethical and its ritual-symbolic values, were espoused to bolster the state. In both areas there were well-worn examples to follow and even where ritual innovations were made, protest was absent, a phenomenon to be contrasted with the response to similar measures undertaken by the empress after her husband's death. The lack of protest may be attributed perhaps to the skillful form into which the innovations were cast, to the simultaneous and welcome grant of patronage to schools and the examination system, and the resulting social progress made by the lesser aristocracy, and finally to the intimidation of the upper levels of the bureaucracy and the great clans. Another factor, and one to which we shall now turn, was the fact that the developing state ideology was coming in the same period to embrace Taoism and Buddhism, philosophies which had their supporters among the ruling group, but which were far more important among the lower orders and so could be crucial components in the maintenance of social order.

Taoism had occupied a special position in the T'ang since T'ai-tsung's declaration in 637 that Lao Tzu was the direct ancestor of the imperial family.29 Such a claim was not unusual in the aristocratic climate of the times and was made chiefly for the purposes of dynastic consolidation--to dissociate the T'ang from the Sui with its highly Buddhistic ideology and to strengthen the royal lineage against the pretensions of the great northeastern clans. The success of Kao-tsu's rebellion against the Sui had been attributable in part to the potency of the "Saviour Li" myth of Taoist messianism, 30 and T'ai-tsung thus hoped to use the awe of inherited charisma to further his centralizing aims. In the same edict in which he declared his descent, he also decreed the precedence of Taoist over Buddhist representatives in all court ceremonials, and though the Empress Wu was to reverse the order in 691,31 she saw the value of the myth and while Kao-tsung lived she encouraged and supported him in his patronage of Taoism. A good example of this occurred immediately. after the feng-shan sacrifices when one Taoist and one Buddhist temple were founded in every prefecture of the empire and twenty-seven monks ordained and attached to each site, all expenses being borne by the state. 32 Returning from Mount T'ai, the imperial party also visited the reputed birthplace of Lao Tzu in Hao-chou and there conferred upon the sage the honorific t'ai-shang hsüan-yüan huang-ti, a mark of great respect.33 Four years later the empress took the initiative by ordaining her only daughter, the Princess T'ai-p'ing, as a Taoist nun (nü-kuan), and though her motive was probably the circumvention of Tibetan requests for a marriage alliance, 34 the act retained symbolic value and must have pleased the Taoists.

These measures were calculated to win the support of religious Taoists whose communities had grown increasingly numerous since the fall of the Han and who, largely through a virtual monopoly of calendar-making functions at court during the period of division, had come to wield a good deal of political influence. 35 There existed also, however, a large number of educated men who might be termed philosophical Taoists, men interested in the wisdom or scientific writing of that tradition. In 675 the empress appealed directly to them when she formally memorialized in praise of the sagacity and relevance of Lao Tzu and requested that "all those below the rank of prince or duke, officials both inside and outside [the capital], and all the people study the Tao-te ching.1136 As a result, the Taoist classic became part of the examination curriculum and shortly thereafter was declared the equal of the Classic of Filial Piety (Hsiao-ching) as the most important object of study for all scholars. 37 Taoist philosophy received, 
therefore, significant patronage.

It is difficult to know whether or not the empress had any sincere attachment to Taoism. As a philosophy of rule it was unlikely to hold much attraction for her but, on the other hand, she must have been aware of the deleterious effects on the Northern Chou of its proscription of Taoism and Buddhism between 574 and 578.38 On quite another level, I have noted earlier that the empress was much attracted to the supernatural, and after the Han Lao Tzu had not only been adopted and deified by religious Taoism, but had become associated in the popular mind with numerous culture heroes, folk deities and, indeed, the cult of immortality (shen-hsien). 39 Taoist adepts were the most active practitioners of the occult--exorcism (chang-chiao), amulets $\left(f u-Z_{u}\right)$ and conjurations (chang-fu)--and had moreover produced or interpreted prognostications used both by the Sui and the T'ang in taking power. 40 Finally, Taoism, with its rich and exotic pantheon, had created a realm of opulent imagination which might be expected to appeal to a romantic mind like that of the empress. In any case and whatever its attractions, Taoism appears in the traditional sources as a prominent feature of court life of the Chou dynasty, even though imperial patronage toward the organized religion was largely withdrawn: Traditional historjography, as we shall see, remarks that the empress was "fond of auspicious omens"141 and portrays her dynasty as a time when charlatans abounded. It points, for example, to her support of a notorious brothel in the belief that it was a convent whose abbess survived on a single grain of rice per day, and to the Taoist priest associated with the abbess who became a tsai-hsiang because of his supposed magical powers. 42 Above all, it documents her relations with the Chang brothers, one of whom she believed to be the reincarnation of a Taoist divinity and for whom she created a fairyland-like setting where frequent and unseemly celebrations became something of a scandal in her last years. 43 It seems reasonable to conclude on the basis of evidence like this that the empress had a personal interest in Taoism which was divorced from state purposes.

The same is true, though to an infinitely greater degree, with Buddhism. It is perhaps here that we encounter the core of the empress' spiritual 1 ife, and her short dynasty was to be, in the words of a modern Buddhist historian, "a turning point, a time of rapid advance"144 in the fortunes of the church. Interestingly, the empire saw little evidence of her preference before Kao-tsung's death, though this is not surprising in view of the T'ang commitment to the rival Taoist ideology. There exist several references to her private devotion in this period--the support of votive sculpture at Lung-men and the reception of a series of eminent monks 45--but she eschewed the adoption of any public policy on church-state relations. Dynastic consolidation and embellishment of the imperial lineage called for the subordination of religious to state interests, and the clearest indication of her willingness to do this is found in the great obeisance (pai) controversy of 662 .

The issue, whether or not monks and nuns of the Taoist and Buddhist churches should do obeisance to ruler and parents, was not a new one. From the Eastern Chou onward, it had arisen in almost every dynasty and while the practice had varied from one to the other, clerics in the South had been consistently free of the obligation until Sui Yang-ti's edict of 607.46 it represented the most basic of clashes: the other-worldly nature of clerical vocation against the Chinese way of $Z_{i}$ and $i$. Moreover, should clerics be freed of the obligation to bow to the ruler, they would in effect enjoy "extraterritorial" rights, and for anyone 
to refuse obeisance to parents was clearly subversive to filial piety. The T'ang, as a dynasty of doubtful pedigree, had increasingly emphasized the hierarchical relationships of Confucianism and its ethic of authority and obedience as the center of the Chinese Way. 47

T'ai-tsung had opened the debate during T'ang by complaining that clerics "falsely respect themselves. Seated, they accept homage from father and mother, damaging [our] customs, perverting the Ritual (Zi-ching).1148 If this is an accurate depiction of the situation, it seems that Yang-ti's edict had had no lasting effect, and as far as we can determine, T'ai-tsung had no better luck. 49 In 657 Kao-tsung was forced to decree that the clergy receive no homage from parents and seniors, 50 and either because this was ignored or because he wished to reverse the situation, he called for a full discussion of the matter in 662 .

In the edict, his own position was clear:

We wish now to order Taoist and Buddhist monks and nuns to do obeisance before emperor, empress and crown prince, as well as their [own] parents. [Since] sometimes we fear the loss of deeply-rooted feelings, it is proper to have the officials concerned discuss the matter critically and memorialize. 51

The effect of this decreee on the Buddhist community in the capital seems to have been electrifying. Within the week, over two hundred monks appeared at the gates of the P'eng-lai Palace bearing a brief of opposition prepared by the eminent cleric Wei-hsiu of the Ta-chuang-yen Temple.52 In rapid succession similar petitions were carried to influential patrons: to Li Hsien, second son of the empress and still a boy, to her mother, Madame Yang, and to the several tsaihsiang. 53 When the debate began two weeks later, more than a thousand officials were in attendance, including many from the provinces, as were more than 300 monks led by the famous Tao-hsüan who had prepared earlier briefs. Perhaps in fear of undue pressure, the chairman ruled that of the clerics, only those with civil rank (su-kuan) should be allowed to remain. 54

The meeting rapidly polarized into two groups, and several sources preserve the positions of each, though not in a very comprehensive or systematic fashion. 55 The range of debate was wide and since as a whole it constitutes a summary of earlier debates on the subject, we might do well to look briefly at the opposing positions.

Those who advocated the duty of obeisance maintained that because of the relationship established between Heaven, Earth and Man (san-i), homage to ruler and parent was essential, a gauge of civilization among all peoples, and clerical exemption thus undermined the entire Way. The power (te) of the Son of Heaven was, moreover, absolute and unique, spanning present and future worlds, and both the unity of the empire and the order of the universe depended on it. Even if clerics were removed by ordination from the secular world, they still lived in the empire and owed to the ruler a debt of gratitude for his protection and transmission of the religion. In a slightly different vein, proponents of the obligation argued that Confucianism, Taoism and Buddhism were at the most basic level the same. It was wrong, therefore, for the two churches to withhold the sign of their respect from the Confucian relationships. They pointed out that the Tao-te ching, for example, numbered the ruler among the Four Greats $(s s u-t a)$, and that no less than four Buddhist sutras also supported the obligation. 56 other tenets of Buddhism--humility, respect and discipline-- 
were cited as reasons for the pai, and several of the briefs which pursued this line of argument contained veiled threats by referring to the arrogance of the clergy and to the "excessive" numbers of monks and nuns.

A total of twenty-nine briefs putting this side of the case are found in the Ch'üan T'ang-wen, and it is interesting to note that in them the question of obeisance to parents receives a good deal less attention. Here the argument can be distilled to the simple proposition that human life is a gift of one's parents. Is it not both natural and seemly that all men should wish tangibly to show their gratitude? Because this was the first ethical objection faced by Buddhist proselytism in China, answers to it had been developed centuries before, 57 and there may have been a feeling that since new arguments were unlikely to be adduced, this aspect of the question need not be emphasized.

The fundamental position of the clerical party was that ordination constituted an effective withdrawal from the world and was a casting aside of state, society and family to enter a transcendental sphere of existence where Confucian Zi had no place. As Tao-hsüan put it,

In his manner of living, the monk has no regard for wealth and sensuous beauty. . . Therefore, he is proclaimed as one who has left the household life. One who has done so no longer embraces the rites of one who remains in the family, one who has forsaken the world is no longer immersed in the practices of the world. 58

Though this premise was constantly repeated in the debate, the clerical party had several other propositions to advance. They contended that the sangha (congregation of monks and nuns) was subject to its own discipline, the Vinaya, and thus had no need to acknowledge secular authority. Several sutras specifically forbade the practice of pai and one warned that he who accepts homage from a monk does himself harm. 59 They argued further that historical tradition freed clerics from the obligation and, cleverly turning back upon their opponents their own arguments, pointed out that a ruler who reinstated the practice would be betraying his own ancestors and committing a breach of filial piety! Still on the attack, they reminded the emperor of his duty to respect the spirits and, since the Buddha was a spirit, the emperor should perhaps pay homage to his representatives rather than vice versa. Moreover, they said, it is the emperor who permits a monk to leave the secular world by ordination. Was it not a denial of his own imperial action to subject a monk once more to worldly obligations? As effective as this point may have been in the debate, it was also a bald admission that the ruler had the right to control ordination and, as such, was ultimately destructive to the independence of the church.

In a more conciliatory view, several members of the clerical group suggested that obeisance was simply an external sign, and that the clerical vocation was by nature filial and respectful. They explained the merits of a monk's ordination and prayerful life extended to three generations of his family, and they further emphasized the filial piety of the funeral rites and memorial services held after a relative's death. Finally, they objected to the manner in which their opponents had interpreted the sutras and offered counterarguments.

On neither side was there much novelty in the arguments and it is unlikely that many minds were changed. The final vote, however, must have been unexpected in view of Kao-tsung's instructions. The clerical party under Ling-hu Tefen 60 mustered 539 votes against the pai obligation while their opponents under 
Yen Li-pen ${ }^{61}$ could gather only 354 . The emperor compromised the next month with a decree that homage to the ruler was unnecessary but that parents were entitled to receive it.62 This solution seems to have been unsatisfactory to the sangha who continued to petition their patrons, including Madame Yang, and possibly with success. The Confucian sources are silent on the matter, but the Sung kaoseng chuan relates that even the pai to parents was ended.63 When the issue next arose in 714, Hsuian-tsung is found to be ordering obeisance both to ruler and parents. 64

There are numerous facets of the incident which might profitably be explored, but what concerns us here is the position of the Empress Wu. She seems to have made no public expression of her view, and the clerical party, perhaps in deference to Kao-tsung, made no direct representation to her. There is evidence, however, that she was active behind the scenes, for of the extant briefs which advocate the pai obligation, almost one-third were produced by her blood-relatives or by men closely tied to her in other ways. 65 . Among them was Ho-lan Min-chih, her nephew and the future heir to her father. 66 The outcome was, therefore, unsatisfactory to her and it was not characteristic that she bow to defeat. Why did she do so?

The answer lies perhaps in her adaptability and far-sightedness. It is significant, first of all, that she and her husband sought to settle the question by consensus rather than by fiat, and when the outcome revealed the strength of the church in the highest circles of government, it was clear that Buddhism must play an important role in the ideology of the state. To antagonize its supporters could prejudice both present and future freedom of action. Beyond this, we might recall that the inclinations of the empress were Buddhistic and she saw little threat, political or economic, from a church recently weakened by the relatively unfavorable attitude of Tiai-tsung. 67 In the debate a blow had been struck at imperial prerogative, but at the same time the Buddhists had acknowledged the right of the throne to control ordination and, what is more, Taoism with its T'ang associations had a share in the victory. The fact that South China, the winning of the loyalty of which was a priority of centralization policy, had traditionally rejected the pai obligation may have played a part in the decision, as indeed may have been the perception that if Confucian piety were weakened, so too would be its constricted view of women. In short, the empress seems to have reflected, then changed her position to one which was probably more congenial to her, and certainly offered greater long-term advantages. Kao-tsung, who was much more friendly to Buddhism than is generally recognized, 68 was perhaps persuaded to let the matter rest.

State patronage of religion during the next two decades was, as suggested earlier, both balanced and generous. This is best illustrated by the foundation of the Kuo-fen temples in 666, valuable to both churches in a symbolic as well as an economic sense. 69 Buddhist sources offer other examples. Throughout these years the Buddhists in particular made great strides in theology, conversion and translation so that they were well prepared for the new role to be thrust upon them by the regime of the Empress Wu. Though in retrospect we must acknowledge that the church was driven to unprecedented depths of sycophancy during Chou, we must also admit that it reached heights of prosperity unseen since Liang Wu-ti or Empress Dowager Ling of the Wei, and we must turn our attention now to the reasons for this development. 
In the latter part of the fourth century and largely through the work of the eminent monk Tao-an, there had developed in China a special devotion to the future Buddha, Maitreya. 70 From a private, clerical spiritual exercise, it had developed into a cult of statewide proportions whose most prominent feature was the belief that in the last period of the Law (dharma), Maitreya would return as a universal monarch to cleanse a corrupt and confused world and to inaugurate a new golden age. This belief was not the exclusive property of any single sect and there was much variation among them in dating the apocalypse, 71 but judging from such evidence as the votive sculpture at Lungmen, Maitreya was the most popular object of devotion by the early sixth century.72 Although the cult was potentially subversive and by the T'ang had a history of involvement with popular uprisings and consequent proscription, 73 it was not easy to suppress, and as late as 664 we find Hsüan-tsang, the famed pilgrim and an imperial favorite, exhorting the multitudes to pray to Maitreya in his last sermon. 74

There is little evidence in subsequent years of any growth in devotion to Maitreya, and indeed there seems to have been a decline among the societal elite, but several events are recorded which kept alive the belief that the last stage of the Law was at hand and the coming of the future Buddha imminent. Among these two were of sufficient importance to find a place in official historiography. The first was a mysterious aura which appeared over a site in the capital in 677, and when a great cache of Buddhist relics was found buried beneath this site, the Kuang-chai Temple was founded on the spot.75 Knowledge of the event was disseminated through the empire in 684 when the reign title was changed to kuang-chai. At about the same time as these relics were being discovered, Sui-chou in Shensi was becoming a popular and lucrative center of pilgrimage because of the excavation there of a buried image whose whereabouts had been revealed by a Buddha 1 ight above it. In 683 the perpetrator of what the court then regarded as a hoax declared himself the Kuang-ming sheng Emperor and rose in rebellion, seizing two hsien before he was suppressed.76 Though his title was more closely connected with Amitäbha or Candraprabha than with Maitreya,77 his rebellion demonstrated the force of Buddhist legitimation and must have reinforced among the people the belief that the last period of the Law was at hand.

Only a few months after the rebellion Kao-tsung died and, as will be suggested in the next chapter, the Empress. Wu became almost immediately the de facto ruler of the state. The precise timing of her decision to usurp power must remain surmise but between 684 and 690 she turned first to the Confucian supports for legitimation. Prominent among the symbolic measures of the period was the renaming of all posts and offices in 684 using the Rites of Chou as the major inspiration, 78 the choice of ch'ui-kung, a phrase from the Book of History, which was of course one of the Confucian classics, 79 and the erection in 688 of a mingt'ang (cosmic hall), a typical Han institution but one based on the Book of Rites (Li-chi) and one which former Sui and T'ang rulers had feared to emulate. 80 There are several other examples, such as the creation of new forms for several Chinese characters, 81 but in the face of growing opposition which was kept in check largely by a system of terrorism, it must have been apparent to the empress that Confucian strictures against a woman ruler retained their force. She was forced, therefore, to seek a new ideology, and to legitimize her power found in Buddhism a source of support which would make her the sole female emperor in Chinese history.

The man chiefly responsible for this development is known to history as Hsüeh 
Huai-i, a virile, unlettered seller of sedge and other herbs who appeared at Loyang in the mid-680s and there formed a liaison with a maid servant of the Princess $\mathrm{Ch}^{\prime}$ ien-chin. 82 When the princess reported to the empress that he was a man of "unusual ability" (fei-ch'ang ts'ai-yung), he was summoned to an imperial audience and before long given unrestricted entry to the palace. His official biography scrupulously avoids the suggestion that he became the empress' lover, and though this is broadly hinted in later Chinese sources and generally accepted by modern historians, the evidence which exists is wholly deductive. Perhaps one source of the belief is her refusal to have him castrated, and to avoid the scandal this entailed, her choice of the alternative of Buddhist ordination. While serving with certain bhadanta like Fa-ming in the palace chapel (nei-tao-ch'ang), 83 Huai-i became a familiar figure in the capital--an arrogant, eccentric man and a chauvinistic Buddhist referred to by the people as "Master Hsüeh." By late 685 he had been installed as abbot of the reconstructed White Horse Monastery west of the capital, a site traditionally regarded as the most ancient repository of the Law in China. Though the official sources are reluctant to accord him either piety or learning, he may have acquired at least the latter in subsequent years, for when omens of dynastic change began to appear in 688-89, he was quick to offer his services. With Fa-ming and seven other monks, he seized upon the Mahomegha or Great Cloud Sutra (Ta-yün ching), and seeking justification for female rule outside the Confucian tradition, provided a commentary to demonstrate that when Maitreya was reborn as a woman, the long-awaited reincarnation would be the Empress Wu. 84

There is a good deal of contradiction among primary sources about the nature of thesutra, and the most persistent belief is that it was quite simply a forgery. 85 Japanese scholarship, however, has demonstrated the authenticity of the work and shown that it was translated five times prior to the T'ang, and from Tunhuang findings we know that it was the Northern Ljang version of Dharmarakșa that was most commonly used in the seventh century. 86 Ironically in view of the use to which it was put, the sutra had been a favorite of T'ai-tsung. 87 The New T'ang Histomy is alone among the standard sources in suggesting that the Empress Wu commissioned the commentary, 88 and given her demonstrated piety, the assumption seems a dubious one. She was, in any case, gratified when the work was presented and lost no time in promulgating the sutra and its commentary throughout the land. In 690, immediately after the dynastic change, Great Cloud temples were founded as repositories in every prefecture, and over a thousand monks were specially ordained to go forth and chant the sutra, explaining to the faithful its real meaning. 89

The effect of these two measures was incalculable. Not only did they constitute an act of patronage to Buddhism staggering in scope but, as symbols of the end of equal support for Taoism, served notice that the new regime would base itself upon a different ideology.90 More importantly, they were part of one of the most ambitious attempts in medieval China to mold men's minds, to use religious feeling to justify the very existence of a regime and even to rationalize its most unpopular acts.

Until the discovery of the Tunhuang manuscripts, a statement such as the preceding would have been difficult to justify. Fortunately, however, some of these valuable fragments are connected with the Great Cloud Sutra, and two of them-Stein 2658 and $6502--$ can almost certainly be identified as the commentary presented to the throne in mid-August 690. A fair reconstruction can be made on 
the basis of these documents, 91 and although the document is worthy of fulllength study, 92 i have chosen to translate below only the shorter of the two manuscripts, Stein 2658, in the hope that it will be sufficient to illustrate my view.

As noted above, the Sutra and its commentary have been surrounded by confusion for many centuries and it is not my intention to comment here on the debate. I shall, however, make the following observations which emerge from the document itself and which are relevant to the historical circumstances of the Sutra's presentation.

First, the commentary offers sufficient quotation from the extant version of the Great Cloud Sutra to make clear that we are not dealing with a forgery of the sutra or even with a version filled with interpolation. Second, the work must have been carried out by sophisticated exegetes, monks who were perhaps unscrupulous in their ambitions for the church but certainly more knowledgeable than Hsüeh Huai-i. The latter probably did no more than serve as a stimulus. Third, and contrary to most scholarly opinion, the identification of Wu Tset'ien with Maitreya constitutes only a minor part of the commentary and its authors seem far more interested in depicting the empress as a cakravartin and as a Bodhisattva-savior. Moreover, the document makes abundantly clear that as a legitimizing tradition, Buddhism was still immature. Indigenous prognostic texts and omenology drawn from Confucianism and Taoism play a role as great as or greater than the prophecies of the Sutra and although synthesis of tradition is a constant goal of the authors, the result often seems contrived and artificial. In spite of this, only the most foolhardy of historians would deny that the device was an amazingly effective piece of propaganda.

Stein 6502, the longer of the commentary fragments, begins with about thirty lines describing the nature of the Sutra and the meaning of its title, and then reproduces the prophecy about a female ruler who would govern a quarter of the realm of a ćakravartin and, while eliminating heterodoxy, would bring about utopia.93 At this point the two versions converge.

\section{Commentary on the Great Cloud Sutra 94}

The Buddha then praised the goodness of [the queen] Ching-kuang who had been ashamed, and went on to manifest the prophecy of the devi ( $\left.t^{\prime} i e n-n \ddot{u}\right)$. [He said that] she should rule over the land in the body of a woman. This woman is she who is called Sheng-mu shen-huang [Empress Wu]. How do we prove it? We prove it by the omen of the Cheng-ming ching 95 which says: "The Venerable One has said to Maitreya that when the Bhagavat is reborn he shall eliminate all evil. If there are arrogant and recalcitrant men, I will send the young devi with rods of gold to punish them... East of the river one meets the Luminous Head (ming-chu) and the King of the Brilliant Law (ming-fa-wang). . . The Venerable One wanted Maitreya to build for him a City of Transformation (hua-ch'eng) with a pillar of white silver above and an inscription for the myriad generations below. The devi will don heavenly robes, hang golden bells on the pillar, and summon [Buddha's] disciples to enter all at once the City."

Thus we say that Maitreya corresponds to the empress. She must be the one and the meaning agrees.96

[Examining the text above, we find that] the elimination of evil and the 
dispatch of the devi to punish the recalcitrant clearly means the destruction of violent men and the purging of the world. [The reference to the] Luminous Head and the King of the Brilliant Law east of the river is from the Book of Changes (I-ching) where it says, "The emperor comes from Chen. Chen is in the East."197 This is clear [for] the empress comes from Chen and rules the empire. She also lives in the Sanctified Capital [Loyang] which is "east of the river." The City of Transformation is the ming-t'ang98 and the silver pillar is its central column. The inscription for the myriad generations is the Kuang-wu ming. 99 [The phrase about] the devi donning heavenly robes is a clear reference to the dragon robes (kun-lung) worn by the empress [at the great ceremonial of January 689]. The golden bells hung on the pillar refer to the sage teaching of the four seasons at the ming-t'ang. The summoning of the disciples is the myriad states, like rivers returning to the sea, [to make submission] at the ming-t'ang.

[The same text] also says:

"The Luminous King and the Sage Lord will both be in the City of Transformation and on top of the tower will beat the golden drum to proclaim to all disciples [this message?]. It will immediately reach to all

those who believe this law [even if they are] ten thousand miles away, [but] for those unconnected with this Law, they will hear nothing even if they are in the adjoining room."

[In this passage] the golden drum is the great ceremonial $(t a-i)$ of the mingt'ang, and the "ten-thousand-mile hearing" means that those who are far away and seek transformation and offer loyalty will see the ming-t'ang and hear the great ceremonial. The "deafness of the adjoining room" means that if among those of the myriad regions whom the empress rears as a mother rears her children, there are some who cause disorder, they will surely be destroyed, and the cunning and vicious will ruin themselves. The Ho-t'u says: "All those who are evil become good [for] if they rebel they destroy themselves."1100

Because the ming-t'ang was raised and sacrifice was to be offered to the Three Sages, 101 [the empress] summoned provincial and frontier officials 102 as well as the [imperial] relatives to gather at the Sanctified Capital for the grand ceremony. Then all the members of the Hui clan 103 rebelled and reaped defeat and destruction. Those who survived were pardoned and exiled to distant areas where they did not hear the grand ceremony. This is proof for [the statement about] the deafness of the adjoining room.

[The same text] also says: "I shall send the Raksāsavira King, 104 and on his head shall be the K'un-lun Mountains, and from the earth shall come streams and springs." This refers to the [new] Hsin-feng Ch'ing Mountain from which issues the Sacred Pool. 105

It also says, "To the east will be the Po-shan Palace." This is the Flying Cloud Chamber of the great White Horse Monastery. 106 "To the west will be the P'an-lung Court." This means the ming-t'ang. 107 "Spiritual pearls and shining moonbeams will be above the side of the city." This means that above the mingt'ang, sun, moon and stars show in the chen [early morning] configuration.108 Because of these meanings the reference is to the Empress Wu.

The [Great Cloud] Sutra says: "[She] will obtain one quarter of the realm of the cakravartin."109 Now the empress has united the empire [i.e., China] and 
rules south to Jambudvipa. This is really one-quarter of the domain of the cakravartin.

The Sutra [also] says: "The people will flourish, secure from desolation, illness, worry, fear and disaster. All that is auspicious will be achieved at a stroke. All the lands of Jambudvipa will come under her sway and there will be no opposition in far-off places."110 This shows that right now the great ministers and the people are wholly loyal. They will have many sons and grandsons; the years will be without scarcity and all will be happy without sickness or other misfortunes. All these happy things happen at once. And because of the great wisdom, prestige and virtuous transformation [of the empress] which extends everywhere, the "four foreign people" will all come to submit. If their allegiance is wholehearted and eternal, all will receive these same blessings. If they waver and rebel, even if they escape punishment from our state, Great Heaven (shang-t'ien) will chastise them and they will destroy themselves. Thus the I-t'ung-shih chi says: "Wherever in the world there is sedition, it will come to naught. 1111 This proves it.

The Sutra [also] says: "[She] will obtain the great [sovereignty?] and be self-existent" (te-ta tzu-tsai).112 [This means] the empress has brought all states to submission and her power is without equal.

According to the Kuang-ure ming: "It is an inferior man (hsiao-jen) who will discover this inscription" and this refers to the [unknown?] man who found it. [But she who] reads this inscription will be the Sage Ruler." This refers to the empress who has read it with her own eyes.

The [Kuang-ur] ming says: "[She who is] unlike the leopard or the wolf is called Wu, and as king is in Loyang." This corresponds to the kingship of the empress in the Sanctified Capital. [In the phrase] "the great king, three [plus?] two [years?], then the inscription will appear," the word "great" means her sage virtue spreads far and encompasses all things. From the wen-ming era [i.e. 684] five years in all have passed since [we who] wanted to see but did not see [were rewarded] in the wu-tzu year [i.e. 688]. [The reason the ming says] "the superior man (chün-tzu) in yellow robes is called 'long life"" is that when augural gifts are given, "long life" is always written. "One with the virtue of earth ( $t^{\prime} u$-te) 113 will rule with the greatest prosperity," means the empress. "None of the common folk will go mad," means that the people of the empire will serve the state wholeheartedly and not lose their senses and rebel. [The phrase] "a bright cat far away shall be your guard in the four directions" refers to the Book of Changes 114 which says that "far away" (离隹 Zi) means "bright" (明 ming) and the position is in the South. Moreover, it says "middle daughter." This refers to the empress who faces south and rules the empire.115 And again we have a reference to the wen-ming period. The cat is the representation (hsiang) of the Wu [surname] and Wu belongs to the [category of?] sage clans (sheng-shih).

[In the ming, the phrase occurs] "three times six youths will sing [a ballad called] T'ang-t'ang." Three times six is eighteen and the eighteen sons are the Li [clan] 116 of the T'ang dynasty. "Later they changed the ballad to that of Wu Mei-niang."117 This clearly means that the empress will rule the empire after the Three Sages [of the T'ang]. [In the phrase] "not to travel too far nor fly too high, remaining motionless in the center," the word "center"' means that the Sanctified Capital is at the center of the Earth (t'u-chung) 118 and shows that the empress rules majestically in Loyang. "The Sage Way extends far 
to those who accept the light in all directions," means that the sage transformation of the empress reaches everywhere, to all and without limit.

"A Buddha transformed, come down from on high, will stroke her head [as when preaching] and prophesy [to her]." This corresponds to the Great Cloud Sutra. "She will enlighten and reside (kuang-chai) in the four continents and [her power] will reach the eight extremities all at once." [In this phrase], "enlighten and reside" means the empress rules and enlightens the world and favors wholly the myriad states. "Four continents" means all within the four seas and "eight extremities all at once" means the states of the eight farthest corners will receive together the sage transformation and will come [to court] to submit. "The people are all peaceful and happy; civil and military officers will develop," means that civil and military officials will grow [in number?].119 "For a thousand years the ancestral temple remains unmoved," means that the time of the sage will last forever.120 [The phrase] "eighteen forms the emperor" means the reigning emperor [Jui-tsung].

A ballad says: "not old, not new." This means that the empress is not [too] old to rule 121 and that she had already nourished [people] as a mother. Thus she is not new [i.e., inexperienced in rule], and these words are used. "Crossed sevens become a body" means the word for "woman" (nï), 122 and [the phrase] "along the base of a mountain, invert the exit, appears a Sage" means that the characters for "mountain," "exit" and "sage" make up that of "woman" (fu). Twice, therefore, is the sage virtue of the empress in evidence.

The Sutra says: "Relics [sariras] cannot be obtained. If the leg of a mosquito could be used to make a bridge [strong enough for] all beings to cross at once, relics could be obtained. If leeches in the water could grow white teeth the size of an elephant's tusk, relics could be obtained. If rabbits could grow horns which could be used as ladders to the sky, relics could be obtained. If a small boat could carry the Hsü-mi Mountain across the great sea, relics could be obtained."123

These metaphors are very numerous and show that the relics of the tathägata (ju-Zai) cannot be obtained. In the Sutra, however, we are told that the ruler of Jambudvipa would become the Guardian of the True Law and would obtain many relics, [and also that she] would desire to venerate them and [so would] build stupas of the Seven Treasures everywhere.124 [It also says that she] will venerate and respect [the Law] and when she sees those who keep to the Law and observe their pure rules, she will venerate and respect them. When she sees those who break the Law and disregard their rule, she will rebuke and destroy them. 125 Now the empress rules the empire and has obtained more and more relics. First of all, omens began to appear in the kuang-chai era [684]126 and now appear [again] in the tsai-ch'u era [689]. Thus [the passage in] the Kuang-wu ming, "kuang-chai.. . i-shih chih," makes clear that the empress has vowed to build 840,000 stupas for the relics 127 and to distribute them throughaut the world. They are distributed not by the power of mere men but by the spiritual achievements of all the eight cords ( $p a-p i a o)$ [which bring order to the eight extremities]. This is proof that [the empress] protects the True Law and has obtained many relics.

The Sutra says: "[She] will teach and convert all the places she rules, and men and women, young and old will observe the Pañcaveramāni."128 We believe that because the empress embraces the precepts of the bodhisattva ( $\left.p^{\prime} u-s \alpha\right)$, 
transforms the people and keeps them from crime, good spirits protect their persons. 129 This proves that she teaches and converts mankind and has accepted and embraced the Pañcaveramāni.

The Sutra says: "[She] will destroy the heterodox and the various perverse doctrines." The Holy Mother Empress teaches and transforms all beings. Thus she makes Deva Māra130 sigh and look up in respect and makes heretics return to the truth. This is the conversion of the yellow-capped [Taoists] by the White Horse [of Buddhism].

The Sutra says: "In another kalpa she will truly be a bodhisattva and will receive a female body to transform all beings."'l31 According to the $K^{\prime} u n g-t z u$ ch'an: 132 "[When] Heaven gives birth to a Sage, [the Sage] emerges from the grass." It does not refer to a male and in this cryptic saying is a prophecy that the empress will rule the empire. Also, as the Yüan-sung ch'anl33 says:

"A unicorn is born with two horns and for generations the people (shih$\min ) 134$ do not know it. When it is grown, full in majesty, its sponsors receive offices and posts. Virtuous and loyal ministers are found at court and the unworthy expelled from the ruler's sight. [This ruler] is capable and able to discriminate, bringing everlasting prosperity (yunglung) 135 and security to the state."

Now the family of the empress' mother is called Yang 木易 and the sheep (yang 羊) has two horns. "Shih-min" is the given name of T'ai-tsung. [the passage about] the reception of posts when the unicorn is grown in majesty means that during the years of the empress great majesty is achieved and that those of wholehearted loyalty have received offices and enjoy honor and emoluments. This corresponds. [The phrase] "virtuous and loyal ministers are found at court" means that right now all at court are wise and good. "The unworthy are expelled" means that the empress in her sagehood examines good and bad, sends away the evil [persons] and purifies the conduct of the court. Thus it is said, "the unworthy are expelled." [The phrase beginning] "is capable and well able to discriminate" [refers to] the rebellion of the commoner [and former crown Prince] Hsien at the beginning of the yung-Zung era [680]. The empress in governing for the greatest public good did not show partiality [even] to her own son. Able to discriminate, she exiled him to Pa-chou. Thus we say that she brought everlasting prosperity and security to the land.

The parahita of the bodhisattva is without set form and varies [to aid human beings] according to circumstances. This is why the present form is female.

[There may be] a question: "The prophecy of the Buddhal36 is unclear and does not explain [the details of] family and clan. On examination, there are several rulers who were female so how do we know that she who presently rules is the right one?" The answer lies in the fact that in the prophecy, the king of the country is in the fifth place of the six [in the hexagram].137 From the Han period to that of the Empress [Wu] there have been various female rulers who were served and accepted, but they were called empress dowagers ( $t$ 'ai-hou) and did not conform to the Sutra's prophecy. Our Holy Mother Empress fits the prophecy exactly and this is why the Sutra says that the female ruler of Jambudvipa will erect precious stupas everywhere and will benefit the work of the Buddha.

We also find it said in the T'ien-shou sheng-t'ul38 that "a Holy Mother shall rule mankind and her imperium shall bring eternal prosperity." This means that 
the empress governs the world and makes prosper forever the foundations laid by the [first] three [T'ang] emperors. 139

An auspicious stone (jui-shih) says: "stop, one woman, everywhere, blessings." [In this augury] "stop" means "end war,"140 and the "one woman" is the empress. It also says, "one person, sage, eighteen thousand," and "woman ruler, thousands and thousands," and "one woman, one person, thousands of years." In these [phrases] Heaven-on-high has given signs that the years of the empress will be long.

The Diagram of the Dragon's Disclosure (Lung-t'u t'u)141 says: "In the wutzu year [688] a mother-sage emperor will lay thousand-year foundations and make bright the T'ang. Uniting the minds of Heaven and Earth, she, the one, will maintain the Li [clan], and will endure long."1142 We believe that the [building of a] ming $t$ 'ang has been neglected for a thousand years. The empress began the Yang-kuan (i.e., ming t'ang) in the ch'ui-kung era [685-89] and completed it in wu-tzu. [Thus] when it says "mother-sage emperor. . .," it means that she knows the True Way in her rule, and this is why it is said that she "will lay thousand-year foundations... ." [The phrase], "uniting the minds of Heaven and Earth, she is the one.. . " means that Heaven needs the one to be pure, Earth needs the one for tranquillity, the spirits for holiness, the valleys to be filled, all beings to be born, and the nobility to rectify the empire. This shows clearly that the empress, reaching the highest Tao, transforms men and unites [them with] the minds of Heaven and Earth. [The phrase] "maintain the $L i$ and endure long" means that the $L i$ are the imperial clan and that the empress will restore peace to the land and cause the dynasty to endure long. Thus the manifest and the obscure come together and the omens, ancient and modern, agree. This makes clear that the sage rule of the empress is without 1 imit and her years will long endure.

The Sutra says:

"The Bodhisattva Ta-yün-mi-tsang asked the Buddha: 'I simply beg the jathagata to tell mankind about the future [coming] of this devi.' The Buddha replied: 'From the time I have shown the way to instrumental nirvāna, after 700 years there will be a small state in southern India called Without-Thought (Wu-hsiang). In this state is the Black River and on its banks is the city called Bountiful Harvest. In the city is a king called Teng-ch'eng and his wife will give birth to a daughter called Seng-ch'ang."1143

[There may be] a question [on this passage]: "If we draw our evidence from the Sutra, [we do not know whether] this country is the same as ours or not." The answer is that the teachings of the jathāgata are of both clear and obscure [types]. The fourth chapter [of the Sutra] is clear, and [this] of the sixth is obscure. If we calculate the time from the Buddha's nirvana to the present, it is 1,700 years. The fact that the Sutra says 700 , not mentioning the thousand, is obscure [teaching]. Other sutras and sastras tell us that after the Buddha's nirvāna the periods of the True Law and the Semblance Law last each a thousand years. In the period of the True Law many men will be pure and faithful and in the Semblance Law, the work of [the evil] Måra will gradually spread and a sage ruler of power and majesty must appear to protect and spread [the Law]. Now the [Great Cloud] Sutra speaks only of the 700 years of Semblance Law, not of the 1,000 of True Law. It is like the [words of the] Nirvana Sutra: 
"Seven hundred years hence will come the time of demons and Māra will destroy and confuse my True Law."174 We know, in fact, that evil gradually arises in the era of the Semblance Law. [The phrase in the Sutra] "southern India" means that since our land [China] lies within Jambudvipa which is the southern [continent], it is referred to as "southern." Also to explain, [we say that] in the Mahāuibhāsa-s̄astra, the Four Noble Truths correspond to the four directions. 145 The South is the truth of the Way [to extinction]. The Way is the eightfold path which destroys the eightfold perversities, and it is thus shown that the empress is a ruler of the Way and converts the South. [The passage] only mentions "South" and nothing else. [The word] "I ndia" is Sanskrit and means "moon." When the moon comes out it has two powers--one to cool and one to warm. Since the empress' rule of the empire can show equally these powers, the word "India" is used.

[The Sutra] says: "There will be a small country," and earlier, "she shall obtain one-quarter of the domain of the cakravartin." [Now] the cakravartin guides and transforms [all] the four worlds and the empire of Great T'ang which rules Jambudvipa is small in comparison. [The Sutra] says, "called Wu-hsiang," and earlier had spoken of the devi Ching-kuang who had practiced the samadhi of Wu-hsiang [i.e., the meditation of no-thought or no-form]. This is why the country is called Wu-hsiang. Now the empress in her activities cultivates no thought that is selfish, thinking [of the welfare?] of all beings and the name of the country is [thus] Wu-hsiang.

The Sutra says: "In the state will be a river called the Black River." Generally, we see birth and death as a river and passions and worries as black. Thus the empress is born by metamorphosis of the goodness and mercy of a todhisattva, and she transforms all life in the great river, banishing passions and cares. Moreover, we know that Wu is one of the Yü surnames found in the North and that the color of the North is black. Yü is also used for water. Thus it says "Black River." And the surname formed from "black water" (heishui) indicates the black robe $(h e i-i)$ which corresponds to the black river (heiho) of the K'ung-tzu ch'an. We know that the empress already wore black robes as a child 146 and this is certainly the meaning of the term.

Also, in Ping-chou by the tomb of her ancestor ( $t^{\prime}$ ai-huang) 147 there was of old a well called by the people the Well of Wu. At first there was water but afterwards it dried up. From the end of the Sui, water began to reappear, and [the well] filled with the T'ang foundation. Now it overflows, forming a wide stream which flows into the Fen River. Thus in the Sui there was a popular ballad which ran: "The river of 当犬 148 dries up but the well of Wu fills. From it a Sage must emerge." Thus it means that the flowing water refers to the empress who is not of Kuan[-chung] nor of the Liu surname. Liu Wu-chou heard the popular saying: "If it overflows, the water will flow (Ziu) [and Liu will succeed], but if it fills to the top ( $2 i$ 李) [the Li will succeed]." Wu-chou was not perceptive and did not understand the saying. Thinking it meant the Liu surname, he rose in rebellion, was killed and his line destroyed. What a mistake! But how could he know that the Black River meant the Well of Wu?"

[When] the Sutra speaks of the City of Bountiful Harvests on the south bank and later says that because of the birth of the king's daughter, there will be limitless joy, it is for this reason that the city is called Bountiful Harvests. The explanation is that our Yellow River corresponds to the Black River and the 
city on the south bank is the Sanctified Capital. Here the harvests are bountiful.

According to the T'ui-pei t'u, 149 "great accumulation in the eighth month, wisdom and brilliance reach everywhere, stop war, prosperity. Female ruler, stand straight, raise high the T'ang. Evil men, driven from court, a dragon comes as guard, purify [all within] four seas, standardize eight directions." [In this text], "great accumulation in the eighth month" means that in the eighth (yu) month, the empress' regency will be completed [and she should be emperor]. Both "spread of wisdom" and "stopping of war" refer to Wu. "Prosperity" is a proof that the throne will flourish. The "female ruler standing straight and raising the T'ang" refers to the name of the state and shows that the empress establishes the straight and revitalizes the task of the imperial clan. "Evil men driven from court and a dragon as guard" shows that the empress expels flatterers and $\mathrm{K}^{\prime} \mathrm{uei}$ and Lung [the legendary good ministers of Shun] stand guard. This is another proof that divine dragons (shen-lung) 150 protect the sage-body [of the empress]. "Purify [all within] the four seas and standardize the eight directions" makes clear that even now the sage transformation is extending throughout the universe, purifying the eight directions and putting in order and bringing harmony to the people.

[Another] prophecy says: "In this year, on k'uei-yu day, the powerful bandits are all thwarted. The empire is at peace and no one sad or anxious. Everywhere the five grains flourish with carts and oxen for sowing." Accordingly [we point out] that the first day of the first (cheng) month of the coming year is $k^{\prime} u e i-y u, 151$ and this coincides. The rebels P'ei Chien, Li Ch'ang and others planned to rebel and seize the Western Capital. 152 Now they have incriminated each other and have suffered the penalty. In court and countryside there is perfect peace. That is why it is said that the strong bandits are all thwarted.

In this year the harvest is an especially rich one. From ancient times whenever harvests were abundant, they were regional. There was famine in the East and plenty in the West, or a meager harvest in the North and a rich one in the South. Never was it like this! There is now a surplus everywhere and under the heavens, all the grains ripen. How can it fail to show that next year, $k$ 'ueiyu, will accord exactly with the omen? All that is evil will disappear and it is for this reason that it is said that the world will find peace. . . 153

Within the context of state ideology of the seventh century, the commentary on the Great Cloud Sutra holds a unique place. It was, first of all, the basic justification for the Chou usurpation and the principal source of legitimation for China's only woman emperor. It is unquestionably the strongest of several appeals to Buddhist legitimation made in the middle period of Chinese history, 154 and marks the beginning of a brief primacy of Buddhism over all other doctrines in the formulation of state ideology.

The commentary is noteworthy for this reason alone, but its implications go far beyond a simple assertion of the transformation of Maitreya and his incarnation in the person of the Empress Wu. Invocation of the myth of the mo-fa, the last period of the Law, enabled her to stigmatize her enemies, foremost among them the imperial Li clan, as devadatta or demons who had to be destroyed to purify the world. On similar grounds, specific unpopular acts like the murders of $\mathrm{P}^{\prime} \mathrm{e} i \mathrm{Y}$ Yen and of former Crown Prince Hsien were rationalized and, by extension, 
other acts of bloodshed, past and future, could find justification. Even the infamy of the terror was made more comprehensible. It is somewhat ironic that the cult of Maitreya, so long a subversive movement, should thus be turned into a bolster for the exercise of secular power, and doubly ironic when we consider that the commentary makes clear the wish of Maitreya incarnate that the Buddhist church confine itself to spiritual matters. The parable of the king of Jambudvipa who destroyed the errant clergy was a clear warning that the state would regulate the church. And this final point illustrates a feature of the commentary we must not ignore. Widely disseminated through the empire, it was virtually a blueprint for rule. Its omens and prophecies referred not only to past and present but also to the future. Forming a network of mutual reinforcement, they served initially to strengthen the position of the empress but later locked her into a pattern of economic and foreign policy decisions whose results were not always beneficial to the state.

The center of this problem lies in the resumption in the commentary of the Sutra's chiliastic vision:

Harvests will be bountiful, joy without limit. The people will flourish,

free of desolation and illness, of worry, fear, and disaster. . . The

rulers of neighboring lands will all come to offer submission. . . . At

that time all her subjects will give allegiance to this woman as the suc-

cessor to the imperial throne. Once she has taken the Right Way, the

world will be awed into submission. 155

With these words the empress promised that her dynasty would be one of material prosperity, of domestic peace, and of domination of foreign lands.

The vision itself, to return to the question of Buddhism in state ideology, had an additional significance. It constituted the first dynastic espousal of an alternative to the Confucian utopia described in the Book of Rites 156 as well as a transformation of the Chinese world view. No longer was China to be the center of a hierarchical, familial universe but rather one part of a universal Buddhist empire presided over by "Maitreya the Peerless, Golden Wheel, Sage and Holy Emperor," titles the empress appropriated in stages over the next few years. 157

The title was itself a unique one and, to a degree, anomalous, since it combined the realms of Maitreya and Ćakravartin who in classical Buddhist doctrine do not appear in the same kalpa.158 Not until the $k^{\prime}$ ai-yüan period (713-742), however, is there any recorded protest. Although at that time the claims of the empress to be Maitreya reborn were classified by Chih-sheng as one of the "three evil treasures (hsieh-san-pao) of the t'ien-shou period,"159 the church seems generally to have acquiesced in the use to which its teachings were put in the Chou dynasty. And this marks an important stage in its development, for with the reversal of the Taoist precedence over Buddhism in $691^{160}$ and with the attachment of the church to the $t z^{\prime} u-p u$ in 694,161 it was embraced by the secular power as a virtual state religion and thrust, therefore, into an unexpected and unsuitable role. The rewards of this collusion started the church upon the road to the persecutions of 841-45, and of greater importance, the Buddhist idea was twisted, expanded, and intensified to the point of exhaustion. It seems no coincidence that with the Hua-yen systematization of the Chou period, the doctrinal creativity of philosophical Buddhism in China came to an end. Once Buddhism was espoused as a state doctrine by a dynasty which ruled the entire empire, its earlier spirit of evangelism and proselytism disappeared. 162 
This development, however, was hardly apparent at the time, for in an atmosphere of lavish patronage, both official and private, the church must have seemed more prosperous than ever before. There is as yet no detailed accounting of state expenditure on Buddhism in the Chou dynasty but it must have been enormous. The continuous expense of maintaining the Great Cloud temples was of course great, and the sources speak in some awe of the numerous new foundations at the time, of the erection of images at Lungmen and in the capital and, above all, of the ming-t'ang complex which was soon characterized by gold and jewels, by the "Seven Treasures" and by a gilded statue so large that several tens of men could stand on its outstretched finger. 163 The classical ming-t'ang was to have been a simple thatched hut, but we must recall that the commentary on the Great Cloud Sutra saw it as the City of Transformation or of Temporary Nirvanna 164 and, as time went on, it was modified to accord with the omens. It was also here that Hsüeh Huai-i staged his "no-barrier" rites (wu-che-hui), a form of ritual dating back to Liang Wu-ti and deriving its name probably from the free mingling of social classes. 165 Each of these rites, according to one source, "cost 10,000 strings of cash ( $\min$ 緍) . Men and women gathered 1ike clouds and ten cartloads of money were scattered [to them], causing them to fight to gather it, with some [trampled to] death in the scramble."166 Orthodox officials made frequent protest about these expenditures, and though the empress occasionally enjoined others to religious frugality, 167 she only belatedly became aware of the financial drain on state resources caused by her own generosity. The first example is not found until the year 700 when she proposed a special tax on monks and nuns for a great statue, and dropped the entire plan when the most trusted of all her ministers memorialized on the parasitical nature of the church and pointed out that "the temples and monasteries of today [already] surpass [in splendor] the imperial palaces.11768

There were other ways, however, in which the empress could demonstrate her love for Buddhism. She is, for instance, unique in history for the frequency and duration of her bans on the butchery of animals and the taking of fish. From the time of Liang Wu-ti, various dynasties had recognized this first commandment of the Pañcaveramani, usually with three-day prohibitions. Incredible though it may seem, the Empress Wu forbade her subjects to take life to eat for the entire period between 692 and 700!169 As another sign of favor, the penalties for crimes against temples and monasteries were in 694 made equivalent to those for crimes against state property. 170 Measures of this sort aptly illustrate the expanding and mutually beneficial relationship between church and state in the period. The frequent signs of imperial favor could not but "bring benefit to the shrines of the Buddha," but each one had also its ideological content and, for example, used the religion for centralizing purposes, as a vehicle to carry civil enactments everywhere. In brief, the relationship was becoming symbiotic, and its chief symbol was the existence in every prefecture of the empire of the Great Cloud monks, many of whom wore the insignia of hsienkung, a civil position of the fourth rank. 171

The relationship, however, was not an equal one, and those scholars who characterize the Chou as a "golden age". or a "high point" of Buddhism" partly correct. As mentioned earlier, Buddhist affairs were attached in 694 to the Bureau of National Sacrifice $\left(t z^{\prime} \cdot u-p u\right)$, and if this measure gave the religion state sanction, it also rationalized state control. In the k'ai-ÿ̈an (713-42) period this organ came to exercise wide functions: the preparation of a clerical 
registry, the limitation and review of the legality of ordination, the appointment of monastery leaders (san-kang), and the determination of prayers and services for state occasions. 173 It is extremely doubtful, however, that the first three functions were exercised with any consistency during the Chou, and we know, for example, that clerical registration was not regularized until 729 and that in 714 private ordination was still a matter of concern. 174 in these matters, the empress was content, it seems, with the symbol of control and while she did reassert the throne's right to "ordain by grace" (en-tu) in 701,175 she relied largely upon the morale and responsibility of the church to prevent abuse.

The same may be said about clerical discipline, a vexing question since the church had long resisted the application of secular law in the belief that the Vināya was sufficient. The T'ang had failed to accept this argument, issuing in about 637 a code of governance called the Tao-seng ko, 176 and incorporating into the Code presented in 653 numerous provisions to deal with secular offenses by clerics. 177 Civil officials had also for some time had a duty to "admonish publicly and privately" misbehaving clergy, but since the pai controversy in 662, it seems reasonable to assume a certain reluctance to do so. Except where a specific secular offense was committed, the scope of discipline was ill-defined. In the Chou the difficulties of those ministers who wished to subject Huai-i and his followers to secular law is a good case in point. The Empress Wu, as far as we can tell, issued only three disciplinary edicts in the period--two designed to reduce friction between Buddhists and Taoists and the third forbidding monks to burv relics and show improper emotion at the death of one of their community. 178 Because these edicts threaten the penalty of laicization and empower civil officials to enforce them, they may be seen as a continuation of the erosion of the sangha's independent status, but the fact remains that the empress resorted only rarely to state intervention.

In sum, we might conclude that while she insisted on state supremacy and encouraged integration of the religious communities into the body politic, her relations with the church were singularly harmonious because she never lost sight of the mutual advantages of their cooperation. The worst that can be said of her patronage of Buddhism is that she created the climate which fostered the selling of ordinations, false registration of clerics and large-scale land dealings which blighted the next two reigns. 179 In the Chou orthodox officials were quick to attack any Buddhist abuse, but it is significant that beyond the standard complaints against the wealth and non-productivity of the church, the only charge leveled prior to 705 was that it neglected its obligation of charity to the poor. 180

These remarks seem to suggest that the Buddhism of the Empress Wu was cynical, insincere, and subordinate to state interests, but there is much evidence to the contrary. The biographies of eminent monks of her period, collected principally in the Sung kao-seng chuan, 181 are filled with references to her support for their translation projects and to the lectures they gave before her. There can be no doubt that her relations with the church were good primarily because her piety and doctrinal understanding won lively clerical respect for her. Prior to the Chou dynasty, she had already shown a desire for knowledge and probably listened to Hsüan-tsang and Tzu-en explain the tenets of the Fa-hsiang school.182 Perhaps because this school was in the process of eclipsing the T'ien-t'ai which was so closely associated with her maternal clan, she seems to have shown it no 
particular favor, but in 670 she took a great interest in Fa-tsang, the brilliant young disciple of Chih-yen and the systematizer and real founder of the Hua-yen sect. 183 What first attracted her to this most recondite and sophisticated of Chinese sects is difficult to say, but when Fa-tsang was summoned to the capital and placed at the head of the T'ai-yüan Temple founded to commemorate the empress' mother, 184 he was only twenty-seven and was to retain a close association with her until her death. It was the empress who in 674 gave him the name "Sage Head" (hsien-shou) by which he is best known, and who had ten of the most honored of capital bhadanta confer on him the holiest form of ordination (man-fen-chieh) in 680.185 In the same year she installed the famed translator Divākaral86 in the T'ai-yüan Temple with him, and together they decided upon the need for a new translation of the huge Hua-yen (Avatamsaka, Gandavyūha) Sutra. The empress cooperated by summoning from Khotan an even more eminent scholar, siksānanda, who brought his own copy of the work to Loyang and, taking charge of the project, completed a new translation in eighty fascicles in 699.187 The empress herself is said to have participated in the work, editing and assisting at lectures; and she wrote a preface for the final version taking note, as might be expected, of the Great cloud omens. 188 Another well-known participant in the project was the pilgrim and prolific translator l-ching who also received from the empress support for his work and respect as a master. 189

While there can be no doubt that the Empress Wu reserved her highest interest for the Hua-yen sect, and her inspiration of one of its most famous texts, the Treatise on the Golden Iion (Chin-shih-tzu chang), is a good example, she was not exclusivistic in her desire for instruction. Among the famous monks she received are names like Chih-hsien of the Pure Land sect, Heng-ching of T'ient'ai and many others.190 She was especially interested also in Ch'an or Zen, and if Hui-neng, the patriarch of the southern school refused her summons to the capital, 191' the northern Ch'an patriarch, Shen-hsiu, was one of her favorites. His biography relates that on his arrival at the palace, the empress knelt before him and by the admiration she showed, made him an object of lionization in the capital.192 This is undoubtedly one of the reasons Buddhist sources serve as a counterweight to Confucian works, almost invariably seeing the empress in a favorable light. In the new catalog of the Tripitaka she had compiled in 695, the editor Ming-ch'üan speaks of her as the long-awaited Universal Ruler who would bring salvation to all. 193

The preponderance of Buddhism in the state ideology of the Chou seems, on the basis of the foregoing discussion, to have served well the empress' purposes. Before we look more closely at this question, however, we might briefly raise another matter, the effect upon Buddhist doctrine and sectarian balance of imperial patronage. Historians in recent years have begun to take note of social and political influences in the sixth and seventh centuries as determinants of the doctrinal form of the eight schools which arose at that time. What seems to emerge from this research is the notion that imperial patronage of a leading monk was based first of all on the needs of a particular ruler and this, in turn, not only determined which sect would be paramount in his reign but also played a role in shaping the sect's characteristics. 194 In this way the Sui dynasty, as unifier, supported Chih-i and T'ien-t'ai the genius of which lay in the synthesis and unification of doctrine and scripture from preceding exegetical traditions. 195 The T'ang rejected T'ien-t'ai because of its Sui associations and turned to Hsüan-tsang and the Fa-hsiang school, a regressive Indian 
form of Buddhism which accorded with the dynasty's cosmopolitanism. I might add that it was also a school less congenial to the Chinese mind and so less likely to challenge the Taoist bias of the dynasty.

If the above argument holds, the Empress Wu chose Hua-yen to set off her dynasty from the T'ang, and because the central concept of the school, the doctrine of totality or the complete and harmonious interfusion of the worlds of phenomena and ultimate principle converging on the single point of the Buddha, served her centralizing, totalitarian ends. The paradigm is a persuasive one, but in the case of the empress, can constitute only a partial explanation. Her favoring of Hua-yen, we must recal1, was demonstrated as early as 670 when she could have had a T'ien-t'ai foundation commemorate her mother and when she was probably considering abdication rather than usurpation. Her patronage, moreover, was not exclusive and, as we have noted, Ch'an was not far behind Hua-yen as a recipient of her patronage. Though the basic doctrines of this school ranked high in Fa-hsiang's fivefold hierarchy of Buddhist doctrine, 196 its basic and profound egoism can hardly be considered useful to centralizing, totalitarian ends.

It is perhaps more accurate to see the empress' special fondness for Hua-yen as the product of sincere faith and of a metaphysical sophistication which found few parallels among T'ang rulers. Hua-yen is quite simply the most demanding in intellectual terms of all the sects, and is even today regarded by many as the "perfect teaching" of the Buddha. 197 It is also a school with a strongly altruistic bias: the bodhisattva reaches enlightenment in ten stages and along the way gains the power to perform miracles, to unite the universe and to deliver sentient beings from pain and desire. 198 since the commentary on the Great Cloud Sutra had also cast the empress into the role of a bodhisattva, she could only find this a most congenial doctrine.

In assessing the relationship of the Empress Wu to state ideology over the half century in which she played a role in its formulation, I would like to make the following suggestions. In the first place, her ideology was developed in stages and was characterized by an acute perception of the needs of each period and an ability to respond to them. For this reason, Taoism and Confucianism were given precedence during her husband's lifetime and continued to rank above Buddhism, though not necessarily in the same order, prior to the composition of the commentary on the Great Cloud Sutra. For the usurpation itself, legitimation was sought principally in the symbols of Buddhism and Confucianism, but Taoism was permitted to retain its court precedence over Buddhism and the Tao-te ching remained a part of the examination curriculum. The Chou dynasty saw Buddhism paramount but, as we shall see in subsequent chapters, there was occasional resort to Confucian symbolism and, more importantly, the constant presence of a substantive Confucianism in the attitudes of the empress toward the bureaucracy, education, examinations, literature and music, and war. Taoism, because of its special significance to the T'ang, necessarily lost ground, but with the coming of the Chang brothers to court, its symbols began once more to appear, and by the end of the chou the three traditions were more in balance than had been the case at the beginning of the dynasty. The grand compilation of 1,300 volumes called the San-chico chu-ying, produced early in the eighth century by the institute of which the Chang brothers had charge, 199 symbolized as well as anything else the awareness of the empress that balance was the key to a successful ideology. 
To the question of whether or not her ideology was successful, my answer is a qualified yes. In the largest sense, I base this conclusion upon the successes of the regime based on this ideology: the domestic peace, briefly interrupted only twice during her period of activity, upon the trend to cohesion and consolidation which permitted both usurpation and restoration to be effected with relative peace, and upon the factious but brilliant galaxy of ministers who consistently emerged to offer their services to the state. A second measure of success is the simple fact that her ideological manipulation, supplemented of course by intimidation and the exercise of raw power, overturned centuries of tradition and enabled a woman to ascend the throne. The fifteen years of power she enjoyed were characterized by the gradual relaxation of force and coercion, and by the growth of confidence and affection on the part of her subjects. The palace coup which deposed her was the reluctant work of a small minority of her ministers.

We shall never know whether the Empress Wu ever overcame wholly, even for a short time, the Confucian prejudice against female rule. The fact of her deposition argues against it, and the judgment of traditional historiography, as we have seen, would indicate that the effect of her reign was to strengthen this very prejudice. For this reason, her ideology was but a qualified success-qualified because in the Chou, at least, it was so highly personal that there was never any real chance that her dynasty would survive her. The people of China would support her but not her nephews and not any other woman, as the cases of the Princesses An-lo and T'ai-p'ing would show in the next reigns.

But in these remarks we anticipate ourselves too greatly. It is time now to return to our narrative from which we departed on the occasion of Kao-tsung's death. 


\section{Chapter 5}

\section{THE ROAD TO USURPATION}

Little is known of the Emperor Chung-tsung who came to the throne in January of 684. As the seventh son of Kao-tsung, the second or third born to Empress Wu, his chances of succession had seemed remote, and quite naturally his early education and training had been designed less to prepare him as future emperor than to prepare him as one who would constitute no threat to the ruler. ${ }^{1} \mathrm{His}$ career was to be an unfortunate one, and the sources depict his character as an unhappy combination of qualities: a weak will and sensuous nature but stubborn and quick to anger. He had been crown prince for only three years prior to his succession, and Kao-tsung may have had some reservations about his experience and general fitness, for his last testament provided for the continuation of his widow's influence in government: "When important matters of defense and administration (chün-kuo ta-shih) cannot be decided, the course of action [decided by] the Celestial Empress shall be adopted in both [types of problem]."2

This kind of provision was not unprecedented 3 but, strictly speaking, it differed from earlier female regencies in that the power of the Empress Wu was subject to specifically defined limitations. Her interpretation of the clause, however, seems to have been free, and she immediately contravened another provision of the will, that Chung-tsung should succeed "before the coffin," by delaying his coronation a full week. 4 We are given no explanation for the delay and might regard it, therefore, as a symbolic gesture. The Empress Dowager Wu did not yet seek the usual honored but impotent retirement and was making clear to her son that his actions would not go unobserved.

If warning it was, Chung-tsung paid little attention, and he had ruled less than a month when he committed the act which was to cost him his throne. Like his father, he was married to a formidable woman, but one very different from Empress Wu. The possessor of a proud lineage and a woman lacking in political sensitivity, 5 the new empress persuaded her husband to elevate her father, Wei Hsüan-chen, to the post of president of the Chancellery, a violation of the customary limitation on posts granted to the consort family. 6

The appointment created a crisis. It was unwelcome to the Empress Wu, who had been extremely careful to exclude her family from any meaningful political role and who clearly resented the rivalry of her daughter-in-law. In the higher circles of the bureaucracy, where a revival of ministerial power had been anticipated, it met an even more hostile reception. The spokesman for this group was P'ei Yen, an ambitious man who had risen through the examination system from the minor gentry of Shansi and was now paramount among the chief ministers as president of the Department of State Affairs.7 He had been closely associated with Chung-tsung before his elevation, and when his own prestige was enhanced still further by becoming the sole receptor of Kao-tsung's testament, he had immediately asserted his leadership over the tsai-hsiang members by transferring 
their meeting place from the Chancellery to his own department. 8 To him the entrance into politics of another empress and especially one who represented an extensive and powerful Kuan-chung clan was an unhappy development and he lodged a forceful protest. Chung-tsung replied with ill-considered temper, "What is to stop me from handing over the empire to Wei Hsüan-chen? So why should I be sparing with the post of Chancellery president?"'9 Yen was angered and astounded at so strong a rebuke and reported it at once to the Empress Wu. Choosing, to take her son's statement as one of literal intent, she summoned the full court, charged her son with treasonable intent, and had him forcibly removed from the throne by members of the Yü-lin Guard (yï-Zin chün), a group which played a key role in virtually all the coups of the early T'ang. 10 Demoted to princely rank Chung-tsung was soon exiled with his pregnant wife to Fang-chou in Hu-pei and was not to return to the capital until 698.11

He was succeeded by his twenty-two-year-old brother Jui-tsung who was wholly unprepared for his new role, and if we may judge from his actions after the restoration, he was a reluctant ruler even at this time. ${ }^{12}$ Wu Tse-t'ien, claiming he had a speech impediment and could not talk, 13 "appeared in court and pronounced decrees." There is no record of Jui-tsung ever asserting his prerogatives, and as the Comprehensive Mirror puts it: "Political affairs were decided by the empress dowager. She installed Jui-tsung in a detached palace and he had no chance to participate. 1114

The legality of these acts, as we have seen, was disputed even in the T'ang, with one school of thought maintaining that Chung-tsung never lost the Mandate, and we must ask whence derived the power of an empress dowager to depose a mature emperor. Although there was at least one Han precedent for the replacement of an emperor on a dowager's authority, 15 this does not seem to have been a normative act and went unmentioned in 684. Of greater importance, therefore, was the ability of the Empress Wu to draw on the authority of Kao-tsung's will and define the situation as an emergency, one in which the dynasty faced the familiar threat of an ambitious consort family. By convincing P'ei Yen and other high officials that this was the case, or perhaps by playing on their ambition, she in effect borrowed the legitimacy of their position to supplement her own and so win the support of the Yü-lin Guard who added a second essential element, that of coercion. The presence of force makes it difficult to know how sincerely to take the claim of the empress to legitimate authority was accepted, but perhaps by examining briefly the nature of legitimacy we can offer some explanation.

Since Roman times historians, theologians and politicians have speculated on the sources and nature of legitimate authority, and even in very modern times the debate continues. 16 present-day social scientists usually take as their starting point the formulations of Max Weber, 17 and several convincing advances have been made by such scholars as Easton and Etzioni. 18 Empirical evidence, however, which provided the basis of many of these studies, is unavailable to us. We must instead examine the Empress Wu's claims to legitimacy and, in the absence of contrary evidence, assume that their validity was accepted at least by her politically active contemporaries.

A recent manuscript ${ }^{19}$ posits the existence of five types of claim which we might use for analytical purposes: the cultural, ideological, structural, personal and instrumental. A claim to cultural legitimacy, corresponding to Weber's 
"traditional" legitimation, posits a congruence between societal values and the operative form of government and political elite within it. In the context of seventh-century China, this claim would encompass such concepts as the Mandate of Heaven, the traditional role of the Son of Heaven and his bureaucracy, and the relationship of this elite to the commoners, especially as it was defined by the theorists of Han Confucianism. Wu Tse-t'ien, as a woman, could never claim complete cultural legitimacy. Her later ideological claims, on the other hand, suggest that an alternative to the existing system might derive its authority from the fact that new procedures and power holders are better than the old. In 684 the empress might well be seen as "better" than Chung-tsung or his brother, but not until the usurpation did she posit a new set of principles. As suggested in the preceding chapter, the new regime drew more force from the Buddhist world view than the Confucian.

Structural claims argue that particular power holders ought to be considered legitimate because they legally occupy positions within a structure already considered legitimate on cultural or ideological grounds. Because an empress dowager had no formal, legally defined prerogatives in traditional China, Wu was forced to rely on teai-hsiang support to depose chung-tsung and immediately to assume the position of regent. In no source do we find the regency formally conferred, and she seems, therefore, to have taken advantage of the lack of defined legal procedure to assume the position on her own authority. 20 Undoubtedly Jui-tsung gave tacit consent, and from 684 to 690 the empress possessed the structural legitimacy of a regent's status.

Finally the empress won acceptance in 684 through personal and instrumental claims, categories closely related to Weber's "charismatic" legitimacy and the real key to her successful usurpation in 690. Personal legitimation is that type derived from superior qualities and capabilities, and is closely related to the instrumental type in that these particular qualities are seen by subjects to be necessary for or beneficial to the attainment of specific values or benefits. The special feature of these types of legitimation is that power holders who possess them can usually defy at least some of the cultural-traditional requisities of legitimacy, thus presenting their constituents with a choice of legitimized objects: either the integrity of a traditional system or the benefits which might accrue from the rule of superior or charismatic personalities.

This dichotomy presents us with an interesting perspective on the period prior to the usurpation. It may be recalled that my discussion of state ideology suggested that while the Confucian tradition was extensively patronized by Kao-tsung and Wu Tse-t'ien, it was also the tradition upon which they most often imposed their innovations. The form of the feng-shan sacrifices, the new titles appropriated by the rulers and bestowed on official posts, new mourning regulations for mothers, and the innovations in the examination system are examples of this process. I suggested that one of the reasons behind it was the unwillingness of the "Two Sages" to become prisoners of tradition and, in the context of legitimation, I might posit that Confucianism was singled out for attack because of its prohibition on female influence in government. If this was the case, we are witnessing a dual process. Confucianism was patronized sufficiently to enable it to remain primary among the three philosophies as a legitimizing ideology, but at the same time it was subtly weakened by acquiescence in innovation or modification, and the net result was that by 690 personality overshadowed tradition and a woman could become huang-ti. 
It is difficult to know whether or not the Empress Wu was consciously seeking personal legitimation in this manner prior to 684 , but her actions as regent suggest that she was. Within the first month of the new regime she began to cast aside the former conventions of female rule, for instance appearing in imperial regalia and disdaining to "hang the curtain" in the audience hall.21 She ignored the protests of her elder statesmen, P'ei Yen and Liu Jen-kuei, who suggested that she was beginning to conduct herself like the Han Empress Lü,22 and uncharacteristically not only appointed her senior nephew to tsaihsiang rank but created for him the new title huang-ssu which seems to have had the sense of "emperor-expectant."23 This was an ominous sign since Jui-tsung had produced an heir five years earlier, and it must have appeared even more suspicious when word reached the capital that the former Crown Prince Hsien had committed suicide in exile on the arrival of an envoy from his mother. 24

The possibility of usurpation seems now for the first time to have occurred to the empress and shortly after, she sent up two trial baloons. The first of these was an Act of Grace (ta-she) in the ninth month of 684, and the second the decision to establish at Loyang seven ancestral temples (miao) for the Wu clan, a number customarily reserved for the imperial family. 25 Both these decisions met with protest, the temples causing $\mathrm{P}^{\prime}$ ei Yen to compare her once more with Empress Lü, 26 and the Act sparking the armed rebellion of Li Ching-yeh.

Before passing on to the rebellion, we might pause here to examine some features of this Act not only because of its particular historical role, but because it was typical of many in the T'ang. The original purpose of the Act of Grace was the reward of merit and the pardon of convicted felons on auspicious occasions, but at the same time, they were often used to promulgate important administrative measures. While only a small number have survived in their entirety, 27 those which have are of wide scope and are useful sources for the general policy lines of their period.

The first portion of the Act 28 of 684 was the one which confirmed suspicions of approaching usurpation by transforming the external symbolism of the regime. Banners henceforth would be gold with violet trim, and certain officials would wear different robes and insignia. Loyang was to be renamed "Sanctified Capital" $(s h e n-t u)$ and its palaces called the "Great Beginning" ( $t$ 'ai-ch'u). The deep concern of the empress with symbolism and nomenclature and their relation to state ideology were reflected in her claim that official titles and posts were defective, and for the second time since she came to power, all were to be renamed. This time most of the new names harked back to the first Chou dynasty-a demonstration of Confucian reverence bearing a close resemblance to the use of Chou- $i i$ symbolism by other successful usurpers 1 ike Wang Mang. 29 Some of the new names were also drawn from a mythology principally Taoist, and several of these, like Phoenix Court (feng-ko) and Luan Terrace (Zuan-t'ai) have remained unique in Chinese history. 30 Since the Act of Grace was itself issued to commemorate the discovery of Buddhist relics, 31 we might see in the symbolic manipulation here the balance common to the empress' entire ideological policy. Finally, she pointed out that her mother's posthumous title was not of sufficient dignity and so raised it to empress dowager (hsien-t'ien t'ai-hou), a measure whose clear implication was that she was herself of imperial birth.

Though many in the empire were convinced that these measures were open indications of an intention to seize the throne, there is in the Act of Grace no 
mention of the signs of heavenly approval necessary for a successful transfer of the Mandate, and when we examine the rest of the document an alternative explanation becomes possible. Chung-tsung in 705 was to remark on the desperate situation in 684,32 and while he probably had in mind the rebellion itself, we can see from the Act that the problems of the early 680 s required a strong and experienced ruler.

In the next section of the Act of Grace, and in measures reminiscent of her lengthy memorial a decade earlier, the empress demonstrated by her concern for the people's welfare that this is precisely what she was. Here were expressed her benevolence, humanity and frugality as she pardoned criminals, made gifts to the aged and filial, offered relief to the poor and sick, and went on to restore lost ranks, grant temporary tax holidays to some areas, seek improvement in the distribution of military rewards and release a number of serving women from the palace. 33 None of these measures were unique to the empress' Acts of Grace, and though some contemporaries regarded her as overgenerous in her awards, 34 there is little evidence that she differed in any appreciable degree from her predecessors. These were not tactics to "win the hearts of the people," as some historians allege, but rather were representative of the spirit of the Acts and were designed to maintain rather than to enhance her position.

The final section of the Act of Grace deals with current problems, and here the empress began with the most basic of these, namely the rapid expansion of population, with a consequential decline in the standards of provincial administration. This was revealed in false registration, tax evasion and other forms of corruption. To combat it, a new branch of the Censorate was to be formed to closely supervise the provinces and make frequent inspection tours, while at the same time counties and prefectures were to be standardized to contain populations of 10,000 and 30,000 households respectively. New ones were to be created where necessary. 35 Because the census was closely related to the tax, equal-field and military systems, 36 household registration was a continuing and thorny problem for the government. The empress was later to approve a rather radical suggestion from $L i$ Chiao to divide the empire into twenty provinces for the purposes of closer supervision, but was thwarted in this by hostile bureaucratic opinion. 37

Another problem of the period was the growth of military abuses, principally the decline of morale which resulted from careless and excessive conferral of rewards (hsin) and their purchase by wealthy persons who had never served. 38 Because of the nature of the fu-pina militia (which will be discussed later) this was extremely serious, particularly since it dated at least from the Korean expeditions of the 660s. The Act of Grace called for investigation and punishment of offenses but had no new solutions to offer and, judging from later observations, the deterioration was not arrested. Some scholars during the T'ang and later were to blame the empress for the destruction of the fu-ping. 39

If this was the case, there is no sign that it was intentional, for the empress was genuinely concerned with administrative improvement and in the Act put forward again the Confucian panacea for all governmental problems, the recruitment of "men of virtue" (hsien). On this occasion she decreed that virtually each high official was to recommend for office one man of either civil or military ability. ${ }^{40}$ While it is difficult to know whether she used this 
form of recruitment more than earlier rulers, there is doubt she used it often, and under her almost every form of recommendation was used at least once.41 Historians often tend to comment on the growth of the bureaucracy which was partly a result of this. They seldom notice, however, that the empress also thereby created a highly qualified bureaucracy, largely loyal to her, which in turn would have the heavy responsibility of recommendation. Penalty for errors in this duty could be heavy and, as will be shown later, officials were often intimidated and, therefore, anxious to conform to the ruler's definition of "virtue."

In summary, it might be remarked that the Act of Grace of 684 provides a useful starting point for any assessment of the Empress Wu's political concerns over the next two decades and, in addition, reveals her priorities in the context of the restless political climate of Chung-tsung's deposition. It shows that she was concerned first with the viability of the T'ang and secondly with her own place in it. It was only within this framework that usurpation could be considered.

As already mentioned, by 684 the institutions of the early T'ang were showing signs of strain. The long internal peace and the acquisition of empire had spurred population increase, commercial development and demographic mobility. In turn, these placed pressure on the mechanism for registration of population and the various systems of taxation, equal-field distribution and fu-ping service which depended upon it. The rapid expansion of civil and military bureaucracy found some justification in this but, at the same time, the emoluments of officialdom and the costs of defense were becoming the largest items of state expenditure. Furthermore, the widening opportunities for bureaucratic employment, principally by means other than the examination system, were creating something akin to a "revolution of expectations" among men whose lack of a suitable genealogy had prevented their advancement to high office earlier in the dynasty. All these developments are explored in detail in later chapters.

The point here, however, is that in 684 a turning point, albeit an artificial one, arrived with the deposition of Chung-tsung. Officials were beginning to call for reform, and some, like the important critic Ch'en Tzu-ang, wanted it to be thorough: "Those who would rectify the end must first correct the beginning, and those who purify a stream must first cleanse its source. . . The abuses in the empire have existed already for a long time.1142

As we shall see, however, there is little evidence of thorough reform by the empress during the next few years, and the reason for this is the basic concern of this chapter. We must remember, first of all, that the administrative problems we have been discussing were the result of policies initiated by the first T'ang emperors and brought to fruition by those the empress and Kao-tsung had pursued. Together the Two Sages had not hesitated to innovate in areas like state ideology and in their treatment of the upper bureaucracy and the old aristocracy, but they had been wholly loyal to the lï-ling system of codified law upon which the dynasty was based. A clear sign of this was their regular issue of regulations ( $\left.k_{0}\right)$ which amended and supplemented the penal code ( $Z \dot{u}$ ) and administrative statutes ( $(i n g)$. The last set of regulations had been issued in 677 and the empress was to promulgate a shorter one in 685 , but from that time until the restoration there were to be no more. 43 Institutional reform seems therefore to have had low priority. Now in some cases like that of the fu-ping, 
rejuvenation may have been impracticable, while in others, like the tsu-yungtiao taxation system, the problem was not yet serious. For still other problems, like registration and vagrant households, solutions were sought but only in a piecemeal and ineffective fashion. I suggest, therefore, that the nature of the problem may have determined the approach to its solution. A second possibility is that the empress never really intended to deprive the T'ang permanently of the empire, and so eschewed radical change lest it be identified with her usurpation and nullified at the restoration. In this view she saw her role as that of a caretaker.

A further possibility, and the most likely of the three, lies in the evolution of the imperial institution or, at least, in the empress' perception of it. During the preceding thirty years, she and Kao-tsung had progressively diminished the prerogatives of the upper bureaucracy with the result that both the spectrum of opinion and the scope for administrative innovation had narrowed. Increasingly rule by fiat had been replacing cooperative decision-making and the ruler became, therefore, more and more the pivot of statecraft. We need not make too much of this, for the empress was following some well-worn precedents, and her political style marked a turning point only within the context of her examination policy and her success in putting the great aristocracy on the defensive.

My point here is different. The empress truly saw herself as the pivot or, to switch metaphors, as the mortar which held together the state structure. It was, therefore, her greatest priority to win for the imperial institution the confidence and support of the people, rather than to undertake reforms which would inevitably alienate certain segments of the population. If she could win this type of support for the ruler, she could afford to leave the task of institutional and economic reform to a strong emperor in the restored $T$ 'ang who would know how to use the new bureaucracy she would continue to build. If so, it is in the legislation of the reign of Hsüan-tsung that we must measure her success.

I have made this lengthy digression in the hope of providing an alternative to the usual view that the empress' policies in the years 684-690 were basically little more than preparatory steps on the road to usurpation. 1 am suggesting instead that she perceived a dynastic crisis with which legitimate succession could not cope, a challenge from the new emperor's consort family and from powerful ministers like $\mathrm{P}^{\prime}$ ei Yen, and she took extreme steps to meet it. Her usurpation must then be viewed as the result of necessity and not ambition.

These steps, however, compounded the crisis in the short run, for it was largely in response to the Act of Grace of 684 that the rebellion of Li Chingyeh broke out. Ching-yeh was the grandson of $\mathrm{Li} C h \mathrm{i}$, conqueror of Korea and one of the early supporters of the Empress Wu. 44 When he died in 669 , reportedly foreseeing his grandson's disgrace, 45 his accumulated honors had assured his descendants of privileged entry $(y i n)$ into the civil service and Ching-yeh had begun a career in the bureaucracy. Dismissed from his post for a misdemeanor, he had taken up residence in Yang-chou at the junction of the Yangtze and the Grand Canal. 46 In the brash yet indolent atmosphere of this commercial center, his closest companions were disgraced officials of good family, 47 anxious to restore their lost fortunes. By the end of 684 the empress' actions had created what seemed an ideal climate for rebellion, and in November the insurrection broke out. 
Its aims were ambiguous. Although the rebels claimed to be partisans of the deposed Chung-tsung, they soon placed nominally at their head a "look-alike" of Prince Hsien who had committed suicide earlier in the year. 48 In view of this duplicity on the part of Ching-yeh, we might be justified in thinking he planned no restoration but rather had dynastic ambitions of his own. This conjecture gains force when we examine the rebel manifesto, a brilliant polemic by Lo Pinwang, 49 which stridently blackens the reputation of Empress Wu while remaining noncommittal about Ching-yeh's ultimate aims. It runs as follows:

The woman $\mathrm{Wu}$, who has falsely usurped the throne, is by nature obdurate and unyielding, by origin truly obscure. Formerly, she was among the lower ranks of T'ai-tsung's servants and served him by changing his clothes.50 When she reached mature age, she brought disorder to the palace of the crown prince, concealing her private [relationship] with the former emperor. She then plotted covertly to gain favor in the Inner Chambers . . . and concealing her mouth behind her sleeve, she skillfully slandered the other women. With cunning flattery and perverse artfulness she deluded the ruler. She then usurped the pheasant regalia of empress and entrapped our ruler in incest.

Then, with a heart like a serpent and a nature like a wolf, she favored evil flatterers while destroying her good and loyal officials. She has killed her elder sister, butchered her elder brothers, murdered the ruler, poisoned her mother!51 She is hated by gods and men alike; neither heaven nor earth can bear her. Still, she harbors calamitous intentions and plans [to steal] the sacred regalia [of the ruler]. The beloved son of the ruler she keeps in a separate palace, and she has given the most important offices [of state] to her own group of bandits. $52^{2}$

The statement continues with a series of historical allusions to the evil effects of female political dominance in earlier times and concludes:

I, Ching-yeh, am a former minister of the great T'ang, the eldest son of

a noble family. I received the testament of our former emperor and 1 owe gratitude for the liberal graciousness of our ruling house.53. . . My spirit rises in anger like the wind and the clouds; my will is determined to restore tranquility to the altars of soil and grain. The whole world has lost hope and the people of the empire have placed their trust in me. I therefore raise the standard of righteous rebellion in order to purify the empire of the baleful omens of disaster. . . .

You my lords!. . . Some of you have been entrusted by weighty charges by the words [of the late emperor], and others have received his dying commands in the audience chamber. His words are still in your ears. How can loyalty have gone from your hearts? The earth on his tomb is not yet dry and where are his young orphan princes? We may yet change bad fortune to good, show homage to the dead emperor and serve his living successor. 54 May you one and all arise and devote yourself to the cause of the ruler. Do not permit our former emperor's orders to be brought to nothing. . . . I ask you to look at the world today. Which house possesses the empire? $\dot{5} 5$

Though many of the allegations made against the empress are false, they must at least reflect some contemporary beliefs, and as the tract became more and more familiar as a model of T'ang literary style, various of its details were adopted by hostile historians. We cannot fail to notice, however, the absence from the list of murders that of the empress' infant daughter and of her son 
Hung, the very crimes to which historians most frequently allude. We might, therefore, conjecture either that she was innocent or that she had successfully concealed these events in her own time. She herself showed a sardonic appreciation of the polemic when a copy came into her hands, blaming her tsai-hsiang for their incompetence in leaving a man of such literary talent as its author to languish in provincial obscurity. 56

In retrospect, the rebellion of Li Ching-yeh seems hardly to have constituted a serious threat to the empress, lasting only three months and affecting only three prefectures. Part of the reason for its failure undoubtedly lay in the rapidity and skill of imperial response, 57 but Ching-yeh's failings as a commander may have been even more important. In the first days of the rising 100,000 men are said to have joined him, and perhaps encouraged by this, he refused to move from his Kiangsu base in spite of the advice of lieutenants who urged a march north into Hopei where, they claimed, were to be found the finest fighting men and the greatest resentment and disappointment at the empress' "dictatorship" (ch'uan-chih). 58 Some recent scholarship has tended to confirm the soundness of this strategy, 59 and in rejecting it, Ching-yeh revealed once more his own ambitions. Instead he sent a part of his forces to take Nanking (Chin-1ing), the old southern capital, which he believed still to have an "imperial air" (wang$\left.c h^{\prime} i\right)$. 60 This seems to have been a serious error, for a month of siege warfare yielded only the eastern garrison town of the city, and by that time imperial forces comprising over 300,000 men were advancing in a pincer movement. Despite the ineptitude of the T'ang prince who led the northern army, the issue was not long in doubt, and in the eleventh month of 684 the rebels were destroyed and their leaders slain.61

Had this been the extent of the rebellion, it seems likely that its consequences would have been less serious. From the empress' point of view, however, a greater danger was present in rebel connections at the court, and shortly after the rising began the capital was shocked to learn that P'ei Yen had been arrested and charged with treason.

This was the event which led directly to a virtual reign of terror during the next few years, and for that reason the guilt or innocence of $P^{\prime} e i$ Yen has been the subject of much debate. Only in his biography in the New T'ang History do we find the direct charge that he was planning to seize the empress during a projected journey to the Cave Buddhas of Lungmen and was thwarted when rain canceled the trip, 62 but at the same time we must recall his earlier signs of ambition and the presence of his nephew as a prominent rebel.63 We are told, moreover, that he early advised the empress that her retirement would end the rebellion without fighting, 64 and at that time a number of ministers seem to have regarded his motives as suspect. To his several defenders the empress claimed to have proof of guilt, 65 but since we have no record of its presentation, we might assume that her consistent fear of the growth of ministerial power played at least some part in her decision to bring the matter to trial. She seems to have acted, after all, only when a censor pointed out that "P'ei Yen served in the court of the late emperor for over twenty years. He received the testament of guardianship [of the state] and [already] enjoys great power. If he had no disloyal design $\left(i-t^{\prime} u\right)$, why would he ask you to return political control [to Jui-tsung]?" 66 After a tribunal found P'ei guilty, he suffered the degradation of public execution, and the most prominent of his defenders, General Ch'eng Wu-t'ing, met a similar fate in the very midst of his unprotesting 
troops. 67 The empress, therefore, had found herself betrayed not only by the scion of an eminent clan but also by men in highest of civil and military positions and, according to one source, she assembled her entire court to confront them with this fact. Raising in turn the example of her three slain enemies, she warned:

These three men were looked up to [with respect, but] they were harmful to me and I was able to destroy them. If [any of] you have abilities [which] surpass these three men, then you must act accordingly. If not, you should change your hearts and serve me, not making [of yourselves an object of] ridicule for the empire. 68

Ssu-ma Kuang, who relates this anecdote, doubts that the empress would speak in such a fashion to her ministers, 69 but perhaps only because he fails to perceive the depth of her anger and shock. The rebellion itself, and what she seems clearly to have seen as a betrayal by ungrateful and overambitious officials, came as a profound disillusionment. Convinced of her own indispensability and regarding herself as the legitimate representative of the throne, she determined never again to be threatened in such a way. To this end she initiated what is termed, not inappropriately, a reign of terror which was to claim thousands of victims over the next six years and become a feature of her reign which is almost universally condemned.

In some respects this system of delation was simply an extension of the empress' earlier policies: the frequent demotions and shifting of posts through which she had long attempted to ensure that loyal men surrounded the throne.70 Ssu-ma Kuang, however, sees its origins in an incident of 684 when a privately expressed protest at Chung-tsung's deposition brought summary execution to the protester and generous reward to the informant.71 There is justification in this view but, at the same time, we have no indication that it would have been repeated had the rebellion not occurred. It was not until early 685 that there began to appear in the Censorate and the Board of Punishments the agents of the terror--men of obscure origin whose biographies are grouped in the old T'ang Histomy under the special category "cruel" $\left(k^{\prime} u\right) .72$ Most prominent among them were Chou Hsing and Lai Chün-ch'en who soon set in operation a network of spies and informers, ostensibly to eliminate the remnants of the rebellion. Before long, however, their victims included the patently innocent. In a new prison they extracted "confessions" by forgery, torture and other methods later described by Lai in a handbook called the Classic of Entrapment (Lo-chih ching), 73 and the empress seems to have been convinced of the existence of plots everywhere. In early 686 she established a great bronze urn (kuei) which in modified form was to endure as an institution until the end of the dynasty. 74 At the beginning the urn was constructed of four compartments, each for the reception of a particular sort of report: self-recommendation, criticism of the government, grievances and wrongs, and finally, omens, calamities and secret plans. Soon it was little more than a repository for a growing number of denunciations and, ironically, claimed its inventor among the first of its victims.75

Because the terror stretched on until the usurpation was secure, the climate it created in court and countryside may well be imagined. Protests poured in, and in frankness and eloquence that of $\mathrm{Ch}^{\prime}$ en Tzu-ang in 689 is representative:

From [the start of] this year, your servant has seen secret denunciations

in every corner [of the empire]. We imprison hundreds and thousands of men, and the majority are [still] denounced in connection with [the] 
Yang-chou [rebellion]. When we examine carefuly [the charges], not one in a hundred is true.

Your Majesty is humane and merciful. . . [but] you have appointed a deceitful and evil group [of officials], reckless and in rivalry with each other. With angry looks of suspicion, they then report the existence of secret [plots]. One man is accused and a hundred fill the prisons. . . Some say that for every man Your Majesty loves, there are a hundred you harm. The empire gasps and no one knows a place of rest. 76

Seen in these terms, the terror is indefensible. On the other hand, however, centuries of Confucian historiography may have gone too far in unremitting condemnation, so that a more balanced view might be appropriate here. The terror was born of well-grounded fear--the response of a woman ruler to a tradition which did not accept her because of the biological accident of her sex. She permitted the terror to continue even after seeing its evils, because she saw in it values beyond the elimination of disloyalty, and because she also knew that the phenomenon itself enhanced her power and hence her ability to control its excesses.

This view seems the more tenable when we isolate certain ramifications of the terror. The most obvious, as suggested earlier, was the further transformation of the political climate. Almost all of the victims were officials above the fifth rank, a pattern consistently maintained both before and after the usurpation. 77 The result of this was fear and uncertainty in the upper bureaucracy, and no minister could gain over the empress the degree of influence which ministers like Wei Cheng had exercised over T'ai-tsung. In 630 Tai-tsung had even gone so far as to encourage officials not to follow his edicts blindly and on several occasions withdrew them in deference to ministerial opinion.78 In 687 when the paramount minister, Liu Wei-chih, refused an edict not ratified by his own department of the Secretariat, the empress was so angered by the ingratitude of one "to whom We have given employment" that she ordered his immediate suicide.79 Traditional historians have found here a vivid contrast to the "good government of chen-kuan," but we might note instead the consistency of the empress' determination to reduce the power of high officials relative to that of the throne.

A second set of implications seldom noticed concerns the social effects of the terror. As will be shortly pointed out, several steps were taken early in the T'ang to put on the defensive the great aristocratic clans which had dominated political life in the period of disunion. Since mid-century these clans had been increasingly bureaucratized and, profiting from cohesion among themselves, their court connections, their wealth and education, they had become the predominant element in the upper bureaucracy. Less suited by temperament and training than officials of lower social origin for coexistence with a female ruler, they became easy targets for the trumped-up allegations of Lai Chün-ch'en. Since the charges brought against them were usually those of treason, the penalties extended to their families who were exiled or enslaved, and to their property which was confiscated by the state. 80 A good illustration is the final purge, that of 697, which followed the conspiracy of Liu Ssu-1i. Of its thirtysix chief victims, the Comprehensive Mirror says that "all of them were renowned [members of the] shih 士 of the land," and goes on to say that over a thousand of their relatives and friends suffered the secondary punishment of exile.81 
As far as we can judge, this incident was not atypical, and particularly because the Ling-nan exiles were more than once massacred by self-seeking inspectors from the capital, 82 we cannot estimate how many families were wholly extinguished. Those who survived were able only gradually to regain Ziang or free status with its attendant rights of examination and officeholding, so that in spite of amnesties before and after the restoration they were weakened in the competition for office and often took generations to recover. The roots of some of the factional strife under Hsüan-tsung can be traced to this time.

Less tangible but no less important were a series of decrees in 686 which empowered informers of any social class to travel at public expense to the capital to make denunciations and to receive the provisions of fifth-rank officials along the way. ${ }^{3}$ In $628 \mathrm{~T}$ 'ai-tsung had decreed death for any slave attempting to bring charges against his master, 84 but now incidents of this sort became frequent, and there were several examples of illiterate commoners rewarded with high official posts for informing. 85 The Comprehensive Mirror speaks of a wave of fear so great that "people all marked time and held their breath," 186 and there was a stream of protest against excessive punishments throughout the $680 \mathrm{~s}$. These critics were undoubtedly also aware of the social disruption which accompanied the imperial commissioners who combed the provinces in search of disloyal elements and the sad processions of once-mighty families plodding the long road to exile in Ling-nan.

For most of her reign, even in the 690s when from our perspective her position seemed relatively secure, the empress ignored the protests. In this there may have been a certain paranoia but, at the same time, she could hardly have been unaware that whatever its drawbacks, the terror always served as a tangible, nationwide reminder of the power of the central government and of its head, herself.

Finally, we must acknowledge that in the terror the T'ang judicial system survived a most severe test. Injustice was too often the rule, but a review of the trials of the period shows that it was found mainly where the secret police acted upon confessions extracted by torture or by promises of clemency toward the family of the victim.87 When these were presented to the empress she had little alternative but punishment. Often, however, she presided personally at important proceedings, and several sources offer evidence that when courageous censors like Hsü Yu-kung pointed out miscarriages of justice, she acted immediately to rectify them.88 After 697 when she destroyed the last of her evil officials and was puzzled that denunciations ceased, she replied to an explanation by Yao Yüan-ch'ung by saying, "Recently the tsai-hsiang followed their own interests and deceived me into acting as a ruler [too fond] of excessive punishments." 89 This avoidance of responsibility somehow lacks the ring of sincerity, but it is a fact that from this time the executions stopped and prominent victims of the terror $1 \mathrm{ike}$ Wei Yüan-chung were rapidly restored to office.

The initiation of the terror is often taken as the definitive sign that wu had made up her mind to usurp sovereignty. Indications are equally strong, however, that she made no firm decision to do so until the discovery of the Pao-t' $u$ in 688. One sign that she was becoming less single-minded in her political pursuits was the intimate relationship she formed in 685 with Hsüeh Huai-i, whose origins and early career were discussed above. We have noted the ambiguous suggestion of a sexual relationship, but whatever the truth of the matter, the 
empress seems to have fallen into a state of unaccustomed infatuation. His visits to the palace were frequent, and despite his arrogance and impropriety which she had to excuse to irate ministers, 90 she refused to dissociate herself from him. She began the year 686 with a decree restoring power to Jui-tsung but, says the Comprehensive Mirror, he "knew the empress dowager was not truehearted'191 and so refused. The offer was perhaps insincere, but it is at least possible that the empress was considering for herself a less exhausting role in government since she was about sixty at the time. Her association with Huai-i continued for the next decade, and he was to serve her in several capacities: unsuccessfully as a general against the Turks, and more notably in 688 as chief architect of the ming-t'ang.

The years immediately prior to the usurpation are depicted in the Confucian sources as years dominated by the terror, by the rise of such favorites as Huai$i$ and the Wu nephews, and by the advancement of the empress' usurping aims. This last perception is certainly a valid one, but it could also be suggested that the end of the policies she pursued at this time was not necessarily the overthrow of the T'ang. Jui-tsung had just indicated his unwillingness to assume power, and if we bear in mind that legitimation is not a static but a continuing process, the repairs the empress now made in the administrative structure become not simply devices to win support but rather the continued application of the political expertise she had demonstrated for so long.

The new regulations were promulgated in 685 and that same year special censors were set up to oversee the activities of Buddhist monks in the capital. Migration to the South cont inued throughout the post -684 period, and new administrative units were set up each year in Chiang-nan to accommodate the shift. In response to the increasing number of border raids by Turks and Tibetans, several large expeditions were dispatched and the An-pei protectorate reorganized 92 though without lasting success. Informed officials, appalled by the state of tu-hu-fu administration, were beginning to predict the loss of the entire Ho-hsi region unless decisive steps were taken but, as we shall see, this was not a priority of the empress and the garrisons were not augmented.

Emphasis during these years was clearly on domestic affaris, and symptomatic was the rapid growth of the bureaucracy. Though statistical evidence is lacking, the trend to expansion is seen in such developments as the encouragement of self-recommendation, al ready extensive since the foundation of the Urn, the increase of chin-shih degrees, especially at Loyang, 93 and the creation of new posts like market commissioners (shih-ling), registrajs ( $u$ u-shih), and correctors of the imperial oversights (shih-i, pu-ch'üeh). 94 Commissioners made frequent tours of the provinces, and among their duties was the recruitment of personnel for the new positions.95 Appointment of auxiliary (yüan-wai) officials became more frequent, and especially in the Six Boards the number of such positions was increased.96 In some cases, like that of the Board of Civil office, the increase was probably justified by the simple need to classify and place new officials. In others, for instance at the level of provincial administration, the proportion of bureaucrats to the general population had typically been very low. Here the increase might well have brought about a tighter administration and a government of improved quality.

It is, of course, impossible to know whether administrative improvement was as important to the empress as her more obvious need for bureaucratic support but, as mentioned earlier, she knew the importance of performance in overcoming 
prejudice against female rule. It was probably for this reason that, even as she expanded the bureaucracy, she began to turn her attention to the economic problems which had surfaced in the last years of her husband's reign.

As early as 666 and especially with the failure of the new hsien-feng coinage, counterfeiting and inflation were beginning to receive official notice, and by the death of Kao-tsung the cost of rice was said to be a hundred times that of the prosperous 630s.97 Sumptuary regulations were issued, but with 1 ittle effect, and the problems were exacerbated by a series of bad harvests and the growing costs of defense. In the early 680 s the first instances occurred of tax evasion by households fleeing their registration, and while the problem was still very much localized in the border areas, 98 it increased the financial strain on the government. None of these problems were unprecedented, and solutions were proposed by several ministers, though invariably they fell into the time-worn categories of reduction of military activity and bureaucratic recruitment and the end of the building schemes and religious patronage which were so costly in man-hours and money. This would rejuvenate agriculture and strengthen the state's revenue base.

Unfortunately, political expediency seems to have precluded any sustained effort in these directions. If the empress were to maintain confidence in the dynasty and in herself, the borders must remain secure and the bureaucracy active, smooth-running and receptive to new recruits. If she were to increase confidence, the "sanctified capital" of Loyang must be a worthy center for the dynasty. Economic reform consisted, therefore, of palliatives, extra slaves instead of a raise in salary for the lower bureaucracy and rapid suppression of the rare instances of resistance to taxation, 99 but no coherent reform program. In fairness we must also acknowledge that measures like these seem to have been considered sufficient by the majority of the empress' constituency as they were soon to make clear in the so-called Princes' Rebellion.

In this sense also, the economic measures of the period were closely related to the question of legitimation. Since out-of-work officials had been the guiding force of Li Ching-yeh's rebellion, the cost of bureaucratic expansion might be justified. Similarly, since the very existence of female rule was a source of opposition to the existing regime, the temples, palaces and monuments which made Loyang as brilliant a city as Ch'ang-an were expressions of imperial self-confidence and, moreover, the buildings themselves were of ten designed to win Heaven's sanction. The same was true of the court itself, as ceremonials became more frequent and more magnificant and more often evoked the ritual of the first Chou dynasty.

This last tactic is a most interesting one, for ever since Wang Mang the Rites of Chou had had a particular attraction for usurpers. Why this was the case is not altogether clear, but it seems to be related to recognition of the excellence of the institutions begun by the Duke of Chou and Confucius' admiration of them. 100 The Chou, moreover, had held the Mandate longer than any other of the historical dynasties and so must have been exceptionally pleasing to Heaven. Finally, for a usurper the greatest source of opposition was the Confucian loyalty of existing officialdom, and thus if a new dynasty could clothe itself in the purest and most exalted form of this tradition, it could dilute some of this natural hostility.

Though it was not until the summer of 688 that the empress decided 
on usurpation, the event which occasioned her decision was one closely related to the omen tradition of Han Confucianism and one which exactly paralleled a portent of Wang Mang's usurpation, 101 the discovery in the Lo River of what came to be called the Pao-t'u.

The Pao-t' $u$ was a white stone bearing the eight-character legend, "A Sage Mother shall come to [rule] mankind and eternally prosperous shall be her imperium" (sheng-mu lin-jen yung-ch'ang ti-yeh). 102 Beyond this we know $1 \mathrm{ittle}$ of the omen, 103 but all sources agree that it was fabricated by Wu Ch'eng-ssu who still held the title of huang-ssu and whose motives are, therefore, obvious. No source implies collusion on the part of the empress and it seems certain that she was convinced of its validity, for in the next two months she made the prophecy known everywhere. An Act of Grace was issued and a public ceremony held to give thanks. The Lo River was made sacred and fishing banned there, and the empress took a new title, "Sage Mother, Sovereign Divine" (sheng-mu shenhuang). 104 At the same time she announced a magnificent festival to formally venerate the omen and to change the reign title to yung-ch'ang to accord with it. The festival would also celebrate the opening of the ming-t'ang, an achievement of note since, although T'ai-tsung had proposed its construction as early as 631, the dynasty had thus far failed to act on it. 105 It was decreed that every single notable in the empire should assemble for the celebration--prefects, governors-general, and of course the numerous princes of the T'ang clan most of whom held provincial posts at the time.

For them the invitation was not a welcome one. Since 684 when two scions of the clan, sons of Kao-tsu, had fallen under suspicion as potentially subversive, 106 ' they had been progressively excluded from any meaningful role in politics or ceremonial, "orphaned outside [the capital] without a place to lodge their feet."107 The empress, of course, had consistently claimed that Jui-tsung's interests demanded such exclusion, and Li Ching-yeh's claim that he would restore chung-tsung by rebellion gave it some validity, but from the perspective of the princes it must have seemed she was now committed to usurpation. The opening of a ming-t'ang, so often used in the past as a legitimizing device, $108^{\circ}$ added to their suspicions, and the princes began to fear they were being assembled in the capital to be massacred. 109 At the same time they realized that refusal en masse to attend would also condemn them and, faced with this dilemma, they chose to rebel in the cause of "saving the state" ( $k^{\prime} u a n g-f u$ ).

The moving spirit in their rising was Li Chuan, an uncle of Jui-tsung and at that time prefect of T'ung-chou 通州 in Shan-nan. Forging edicts and sending out messengers to his relatives in every direction, he worked against time and poor communications to coordinate the insurrection. His plans were ruined, however, and the secrecy of the enterprise destroyed by a premature levy of troops in Po-chou, Ho-pei, where the prefect was Li Ch'ung, a grandson of T'ai-tsung. This area, where there was a strong militarist tradition as well as separatist tendencies, would seem to have been fertile ground for rebellion, yet Li Ch'ung could raise no more than 5,000 men. Even these were not enthusiastic and melted away before engaging the imperial troops, killing their leader to avoid punishment. In Yü-chou near Loyang, Li Ch'ung's father, Li Chen 李筫, was prefect. He, realizing that his son's actions had doomed him, rebelled in turn. His small force also fled as imperial troops approached and with his defeat and suicide, the so-called Princes' Rebellion came to an end. 110 
Though this rebellion, lasting only a few weeks, scarcely constituted a threat to the empress' position, she permitted her judicial officers to implicate in it the entire Li clan so that horrifyingly disproportionate punishment fell on innocent and guilty alike. In this she far exceeded earlier usurpers like Wang Mang, and it seems fair to conclude that after the initial reprisals the executions wre carried out chiefly to facilitate the usurpation. By mid-690 several hundred households had probably been extirpated, and only a few children survived as exiles in the remote South. 111

This particular aspect of the rising, of course, receives a good deal of attention in traditional historiography but, at the present time, the historians admit that neither the prestige of the T'ang name nor the (forged) edicts bearing the seal of Jui-tsung used by the rebels had evoked any significant support. The Comprehensive Mirror, while attributing the princes' failure to their lack of coordinated action and daring, admits that of the 500 members of Li Chen's group who bore official rank, all but one had been coerced into joining! 112 The empress' legitimacy seems, therefore, to have been accorded recognition at least by the provincial bureaucracy.

No force now stood between the empress and the throne, but still she was reluctant to move without further ideological legitimation. Signaling the end of the T'ang by divesting Lao Tzu of the honorific bestowed in 666,113 she presided over her delayed ceremonials in early 689. At the Lo River, what the sources call the most magnificent ceremonial since the T'ang began gave publicity to the omen of Heaven's favor, and at the ming-t'ang the empress preceded Jui-tsung in the offering, while sacrifices to her father followed those to the T'ang emperors. She herself carried the regalia (ta-kuei, chen-kuei) of the ancient chou and later that year decreed the implementation of its calendar. 114

In the same act which proclaimed the new calendar 115 she promulgated an unusual piece of propaganda, one which not only reflected the common concern of usurpers for the rectification of names but showed the same flair for subtle modification which had characterized her earlier measures of ideological patronage of Confucianism. Suggesting that in the development of the writing system anomalies and corruptions which made understanding difficult had crept in, she created a dozen new characters for such common words as "day" and "month" as well as a new name for herself, using forms which would illustrate the foundation of the words and still preserve their meaning.116 In this measure she may have intended an implicit comparison of herself with the legendary inventor of Chinese script, 117 but from another perspective it suggests a certain desperation. As the foundation of the palace examination a month laterlil shows, she was still uncertain of the support of officialdom at the capital and so must have been particularly gratified when, in the seventh month of 690 , Hsüeh Huai-i presented his commentary on the Great Cloud Sutra. Recalling the strength of Buddhist loyalty within the bureaucracy from the pai controversy of 662 , she must have known that the commentary could be as effective among them as among the Buddhist commoners.

In the preceding chapter I alluded to the key role played by the Buddhist tradition in facilitating the usurpation, and it is time not to place this judgment in context. First, we must recognize that the use of Buddhist legitimation was not new in medieval China and had, for instance, played an important role in the ideology of the Sui.119 Nor was it unknown for rulers to adopt Buddhist 
titles, though usually in an informal fashion. Liang Wu-ti had been called Huangti $p^{\prime} u-s a$ and $P^{\prime} u-s a t^{\prime} i e n-t z u$ and certain of the T'o-pa Wei rulers were referred to by the sangha as tathägata (ju-lai).120 Conversely, the persecution or proscription of Buddhism seems to have been detrimental to dynastic survival.121 Antagonistic Confucians always maintained that excessive Buddhist patronage weakened a dynasty, but the point is that by the T'ang there was wide recognition that Buddhism could not be neglected in the formation of a state ideology. The case of the Empress Wu was distinctive in that, unlike earlier rulers, she was not simply a model of Buddhist kingly behavior but insisted upon the titles both of Ćakravartin and Maitreya. Her claim to be the Buddha incarnate was an attempt not only to disarm a potentially subversive cult, but also to inaugurate a new era in Buddhistic world history.

Second, we must ask whether the Great Cloud Sutra and its commentary were of equal or greater importance than the various symbols of the Confucian tradition used in legitimizing Wu Tse-t'ien as emperor. To answer this question, we might first note that the Sutra itself was not by its nature an effective legitimizing device. T'ai-tsung had seen nothing subversive in it and, aside from its chiliastic vision, it did no more than tell that when Maitreya was reborn it would be in female form. The commentary is therefore crucial, for it not only identifies the empress as the tathāgata of the Sutra but supports the identification with $a l 1$ the weight of native prognostic tradition, both Confucian and Taoist. I commented previously on the ideological value of the commentary as a legitimizing force and here might expand these observations to clarify its relationship with other aspects of legitimation.

The invocation of the mo-fa is extremely important, for it permitted the stigmatization of all the empress' enemies, including the T'ang princes, as devadatta whose purge was righteous and necessary for the purification of the world. On similar grounds, acts like the murders of Li Ching-yeh and the former Crown Prince Hsien were specifically rationalized and by extension, other acts of punishment, past and future, could be justified. The infamy of the terror became more comprehensible and legitimation, once obtained, could be preserved by force. It is significant that immediately prior to her usurpation, the empress substantially augmented the Yü-lin Guard. 122

At least half the commentary deals with the omens of dynastic change proper to the tradition of Han Confucianism, and so is just as interested in depicting Wu Tse-t'ien as a culturally legitimate secular ruler as in showing her as a parahita. These signs of Heaven's favor seem to have been of more interest to the Chinese than claims of divinity, and it is interesting to note that when a skilled diviner enumerated for Chung-tsung the signs of usurpation and restoration, he made no mention at all of the Sutra. 123 In some senses, moreover, the Buddhist prognostications of the commentary were the least convincing of all and in.693, when Huai-i presented a new translation of the Precious Rain Sutra (Pao-yü ching), the interpolations attempted to clarify the time sequence of Maitreya's rebirth, to portray the empress even more strongly as a ćakravartin, and also to supplement the conventional omens of the commentary with others, like the appearance of a five-colored cloud. 124

What seems to emerge here is that Buddhism alone was deficient as a legitimizing force. Stated in positive terms, it might be suggested that although the commentary provides a classic example of charismatic legitimation, it 
emphasizes traditional or cultural legitimation to an equal degree. This is clear not only in its frequent resort to Confucian tradition, but in the very nature of the Sutra's prophecy: "You must know, therefore, that this is an instrumental (fang-pien) body and not a real woman's body. 125 If Chinese tradition outlawed female rule, a male deity in "instrumental" female form might win acceptance. The transformation, therefore, gave Wu what I have called structural legitimation.

Finally, to show that Buddhism played a subordinate role in the success of the usurpation, we must recall that the Sutra appeared only two months prior to the Chou foundation and at a time when the symbolism of the first Chou was already well established. Knowledge of its contents and their meaning could not have been widespread until at least a month after the usurpation when the temples were founded and the interpreters of the Sutra ordained. We see, moreover, no signs of Maitreya symbolism in the early days of the new regime: the color white was never used, and the empress did not assume the first of her Buddhist titles, "Golden Wheel," until the autumn of 693. She added "Maitreya" only in early 695 and divested herself of it less than a year later, after the mingt'ang was burned. 126 Finally, I cannot overemphasize the fact that the Sutra was itself interpreted within the context of the native legitimizing tradition-classical works like the Book of Changes and the Rites of Chou, oracular texts like the Ho-t' $u$, and "Taoistic" devices like popular songs.

The influence of Buddhism in Wu's legitimation was, therefore, not negligible but neither was it predominant. Two months after the presentation of the Sutra, in September of 690 , petitions which requested the empress to found the Chou dynasty began to appear. 127 One of them bore 60,000 names, representing officials, monks of both churches, commoners and foreigners. At the same time Jui-tsung requested that he be granted the Wu surname. The empress followed the custom of modest demurral until she was informed of the sighting of a phoe$n i x$, a sign since ancient times of the impending appearance of a sage-king. 128 A second omen, a flock of red birds in the audience hall, reminiscent of the red bird of the first Chou, 129 made it clear that Heaven could no longer be denied. Jui-tsung abdicated, becoming "emperor-expectant," and Wu Tse-t'ien ascended the throne as "holy and divine emperor" (shen-sheng huang-ti), choosing as her first reign title "Heaven-bestowed" ( $t$ 'ien-shou), a reference to the omen of the Lo River whose confirmation she seemd to consider to be the key element in her successful usurpation. 130

In summation, it might be argued that the legitimation of Wu Tse-t'ien was the result of a long and, on her part, a partially unconscious process. Her outstanding administrative ability, her lengthy devotion to the aims of the T'ang, and her instinctive concern for the people made her in the course of thirty years a familiar, respected, and almost indispensable part of T'ang government. In the context of her achievements, the fact of her sex diminished in importance and to the vast majority of her subjects, those who supported her against the princes and against the rebels of 684, narrow and legalistic considerations of legitimacy became largely irrelevant. To the guardians of tradition, who were found mostly in the upper bureaucracy and whose opposition might have been directed as much against a forceful and absolutist temperament as against a woman ruler, she remained unacceptable well into the $680 \mathrm{~s}$. In the years immediately prior to the usurpation her dual policy of delation and manipulation of Confucian and Buddhist legitimation rendered them amenable to her 
dynasty, but because of the central role of coercion, we cannot judge how sincerely they accepted her claim. I shall return in later chapters to this question.

Events in the Chou, particularly the manipulation of the succession, would demonstrate the need constantly to renew her legitimation, and this was to be a principal motif of the next fifteen years. As we will see, it was principally through the continuation of T'ang policies that the empress maintained her position, and it is time now to examine those policies in order to establish the lines of continuity. 


\section{Chapter 6}

IMPERIAL POWER AND THE RULING CLASS

The single most intriguing theme discernible in the Empress Wu's regime, at least by modern historians, has been that of social change. Though the debate continues, Maoist historians seem to have reached a broad consensus that her opposition to the aristocracy and to the large-landlord class intensified class struggle both inside and outside the ruling group, and so constituted an important stage in the dialectical process. 1 Western scholars who are interested in the problem have usually taken as their starting point the work of two major scholars. From Naitō Torajiro has come the idea that the late T'ang saw social changes which made it the transitional period between medieval-aristocratic and modern-bureaucratic China, 2 and from Ch'en $\mathrm{Y} i n-\mathrm{k}^{\prime} \mathrm{O}$ the perception of $\mathrm{T}^{\prime}$ ang history prior to the An Lu-shan rebellion as a struggle between two blocs--an entrenched aristocracy and a newly-rising group of examination bureaucrats. 3 Professor Ch'en elaborated his thesis by the division of the aristocracy into contending northeastern and northwestern groups, and by suggesting that the Empress Wu was responsible for the most significant change:

From the establishment of the T'ang by Kao-tsu and T'ai-tsung until just prior to the accession of Kao-tsung, those who held the most important civil and military posts in the state were mostly the successors of the Sui, Northern Chou, and Western Wei. This is to say that they were the descendants of the bloc assembled under the banner of Yü-wen T'ai's "Kuan-chung first" policy. From the time the Empress Wu seized power, she destroyed this traditional policy step by step and, because of her ambition to found her own dynasty, she began the destruction of the fuping system which was the traditional prop of the Kuan-chung bloc. [So] in this period social classes were in a state of flux, rising and falling.

As for the chin-shih and other examinations, although established in the Sui, they were unnecessary for the attainment of civil office. Under the Empress Wu, great emphasis was placed upon selecting officials for their literary abilities, and [because] she broke the old rules of selection, the chin-shih degree became the object of great competition everywhere. At that time there existed many persons in Shan-tung and Chiangtso who had devoted themselves to literary pursuits, but lack of membership in the Kuan-chung bloc had disqualified them from rising to official positions. The political revolution of the Empress Wu brought them to court. After this the high positions formerly monopolized by the old [elite] of Wei, Chou, and Sui were necessarily taken and occupied by this newly rising class. The replacement of Li-T'ang by Wu-Chou was thus not merely a political change. It was a social revolution and, seen in this light, was a more significant change than the dynastic succession from Sui to T'ang. ${ }^{4}$...

Both these hypotheses are persuasive ones, though the former has proven to be 
somewhat more durable than the latter. InCh'en's work certain weaknesses in premise and definition, as well as internal contradictions, have led to the successful challenge of some of his conclusions, 5 but several of his insights remain valuable, and the emphasis he places upon regionalism, examinations, and imperial policy as a determinant of change seem still to be warranted. Moreover his work raises some questions which might profitably be examined in the present context. Did the Empress Wu, for instance, consciously foment a "social revolution" even in the narrow sense in which Professor Ch'en uses the term? Did her reign see the rise of any new "class"? What role was played by the examination system and the decline of the fu-ping in societal change? And finally, what was the nature of the T'ang ruling class and, within it, the relationship between status and office? While the nature of our sources for the early T'ang is such that all statements regarding social mobility contain a certain degree of speculation, 6 partial or interim answers to all these questions are possible.

of the several contemporary observations on the subject ot the T'ang ruling class and its development, that of the genealogist-historian Liu Fang is perhaps the most comprehensive.7 In his Discussion of Sumames and Lineages (Hsing-hsi Zun), 8 dating from about 719, he wrote that clans and lineages had been a state concern from the most ancient times:

There existed a work called the Shih-pen which recorded the names, titles, and lineages of the feudal lords and great officers from the [time of the] Yellow Emperor down to the Spring and Autumn period. . . . After the Han arose Ssu-ma Ch'ien and his father edited the Shih-pen [for inclusion in] their work, the Shih-chi. They clarified the [origins of the] hereditary houses, following the Chou genealogies, and so came to know the origins of their surnames and clan names. . .

[Now] when Han Kao-t $i$ had risen and, on foot, had gained control of the empire, he appointed his officials because of their wisdom, and conferred noble rank for merit. . . He employed [only] those descendants of former princes, dukes and great ministers who were talented, and he rejected those without ability. He made no distinction between shih and shu, 9 and so for the first time office [rather than 1 ineage] was much esteemed. Still, however, the northeastern hao-chieh 10 were transported to fill the capital city. At this time the Chu and $\mathrm{T}^{\prime}$ ien of $\mathrm{Ch}^{\prime} \mathrm{i}$ and the Ch' $\ddot{\mathrm{u}}$ and Ching of Ch'u were all [considered to be] the preeminent surnames (yu-hsing)...11

The Wei [dynasty] set up the 'nine rank' system and established [officials called] the 'impartial and upright' (chung-cheng) to recommend [potential officials], and they esteemed men of noble descent (shihchou) and looked down upon those scholars of low birth (han-shih). Power reverted again to the preeminent surnames. . . .

The Chin and Sung followed this method and so for the first time, surnames (hsing) reached the pinnacle of importance. Therefore, the shih and the shu, the noble (kuei) and base (chien 其 $)^{12}$ were clearly separated once and for all. At that time when officials came to select men for promotion, they were certain to examine their genealogy ( $p^{\prime} u$ ) and registration $(c h i)$ and check to see that there was no fraud. Thus every official possessed his genealogical table (shih-chou $p^{\prime} u$ ) and it listed the offices [of family members] for generations. . . .

South of the Yangtse [the greatest clans] were [called] the 
ch'iao-hsing and the greatest were the Wang, Hsieh, Yüan and Hsiao. In the Southeast were the wu-hsing, and the greatest were the Chu, Chang, $\mathrm{Ku}$ and Lu. East of the mountains (shan-tung) were the chün-hsing, and the greatest were the Wang, Ts'ui, Lu, Li and Cheng. In Kuan-chung, they were also [called] the chün-hsing, and the greatest were Wei, P'ei, Liu, Hsüeh, Yang and Tu. In northern Shansi (Tai-pei) were the Zo-hsing, and the greatest were the Yüan, Ch'ang-sun, Yü-wen, Yü, Lu, Yüan and Tou. These Zo-hsing were the 'eight clans and ten surnames' and the 'eightysix lineages and ninety-two surnames' of the time when [the Northern] Wei [emperor] Hsiao Wen-ti moved his capital to Loyang [in 494]. . . . and they called themselves men of Loyang in Ho-nan... .13 [Liu goes on here at some length to explain how the chün-hsing were ranked according to the offices held by family members into four groups, and how this was the true origin of the term 'four surnames' (ssu-hsing) later appropriated by the northeastern clans alone. He points out that the Northern $\mathrm{Ch}^{\prime} \mathrm{i}$ restricted office to those numbered in the ssu-hsing.]

Formerly [during] the Southern Dynasties (Chiang-tso), their system of status for $\mathrm{clans}$ and $\mathrm{l}$ ineages was to consider the first of the ranking surnames in each commandery the 'preeminent surnames.' During the $t$ 'aiho period [477-500] of the Wei, all the 'four surnames' of each commandery were considered 'preeminent surnames.' The same term ['preeminent surnames'] was used for those classified as chia-men in the Lei- $i i$ of the monk T'an-kang 14 of the Northern $\mathrm{Ch}$ 'i; for the 'clans respected by all' (ssu-hai t'ung-wang) in the chien-te [572-78] compilation of the Northern Chou; 15 for those called the mao-hsing in the Sui compilation of $k^{\prime} a i-h u a n g$ [581-601]; ${ }^{16}$ and [finally] when the Shih-tsu chih was compiled in the chen-kuan period of the T'ang, the same term was used for those there classified as the first-rank families. Those whom Lu [Ching-ch'un] calls the sheng-men in his Chu-hsing lüehl7 were also considered as 'preeminent surnames.'

Any [classification] which fails to accord with these practices of successive dynasties should not be called 'genealogy' with them. The present-day custom of referring to the Ts'ui, Lu, Li and Cheng as the 'four surnames'. . certainly does not follow this standard rule.

When culture (wen) is in decay, honor is given to false [genealogies]. The Sui was heir to this sort of decay but did not understand why there was corruption and so went against the way of antiquity. [The Sui] abolished the way of local recommendation (hsiang-chü) and did not consider persons [for selection] in reference to their place of origin (ti-chu). It valued officials only for their administration. The shih thus had no locality or village of their own; villages had no officials, and the people lost integrity and their sense of shame. The shih 1 ineages were thrown into disarray and the shu-jen went beyond their appointed station. . . .

When the people have nothing left to preserve, the shih lineages will be destroyed. And when the shih lineages are destroyed, the state perishes as a result. 18

Liu Fang's analysis, impressive in its detail and in its familiarity with a full range of status terminology, is important in several respects. In the first place, it identifies a stratum of local shih, a minor aristocracy which was recognized by the state to exist "in every commandery" during post-Han 
times and which was, in Liu's view, a crucial factor in the maintenance of social order at a local level. Without them the state would perish and, as a result, they had been an object of concern to the throne since Han times. He points out that although rulers like Han Kao-tsu had successfully asserted their right to define the criteria of status, the practice of respect for lineages distinguished either by nobility or by a tradition of state service was a very ancient one and that as time went on, the growing contiguity between title and office produced a class with a virtually hereditary charisma which was highly impervious to imperial control. The gradual establishment of the ethic of Han Confucianism made such qualities as superior humanity and refinement, scholarship and service to inferiors the hallmark of prestige, and the means of distinction between shih and shu. There is ample evidence in the period of division that conferral of shih status stood beyond the imperial prerogative, and that heredity was an essential element in its attainment. 19 When a high minister of the Sung (420-477) remarked that "between shih and shu there is a gulf ordained by Heaven," 20 he was affirming not only the validity and necessity of distinction, but also an hereditary source of charisma beyond definition by man.

Liu Fang refers secondly to state recognition of shih status, most notably through the bureaucratic and legal privileges it granted in the nine-rank chungcheng system. Although much could be said about this system and the aristocratic monopoly of power it produced, the important result for present purposes is that it helped to make distinctions within the aristocracy: Liu's elite of "preeminent surnames" and the "blocs" identified by Ch'en Yin-k'o. Genealogical compilation became common practice both for individual clans and for the state, 21 but the motives were different and, as Liu suggests, there arose a parallel divergence between the public and private criteria of status. To him this was a serious matter and, as we shall see, the first T'ang emperors shared his concern.

In specific terms, Liu saw the ideal state as one characterized by wen, a word of wide connotation referring both to civil virtue and high culture. Honor, both from above and below, should be bestowed on the basis of wen, and its twin foundations were officeholding (kuan) and lineage (hsing). Moreover, as he suggests in the same essay, the clans of certain areas preserved through the generations different types of virtue:

The people east of the mountains are unsophisticated and honest (chih

筫 ), and so they esteem marriage connections. Their sincerity (hsin)

is worthy of praise. Those of Chiang-tso [the Yangtze valley] are highly cultured (wen) and so esteem individual worth. Their wisdom (chih 智) is admirable. In Kuan-chung, the people are brave and manly (hsiung) and so esteem officeholding. Their perception $(t a)$ is admirable. The people of Tai-pei Inorthern Shensi] are martial (wu) and so esteem noble relationships (kuez-ch'i). Their breadth [of mind] ( $\left.t^{\prime} a i\right)$ is admirable.22

In this statement lies the problem. While great clans could base their claim to status on regional values, genuine centralization was illusory. In other words, a dynasty seeking to consolidate its rule had first to unify the definition of wen since this was the acknowledged basis of respect. Ideally, it should itself personify the highest wen and enforce conformity upon rival claimants. It seems clear from Liu's statement, however, that intangible and long-standing clan tradition was relatively immune from imperial control, and that the successive attempts by ambitious dynasties to compile state genealogical lists had 
failed to achieve their aims. Only by revising this triadic relationship, by emphasizing kuan over hsing as a component of wen and as a claim to the status and perquisites of the shih class could a dynasty triumph over regionalism and incipient rivalry. And for the T'ang, the political history of post-Han China and the disintegration which accompanied the fall of the Sui made priorities clear. The following discussion is largely the story of how the dynasty sought to deal with the centrifugal tendencies of the aristocratic elite, and how under Kao-tsung and the Empress Wu a solution was found which ultimately effected a change in the nature of the ruling class in China and so hastened the end of the aristocratic government which had been perhaps the outstanding feature of "medieval" China.

The climate of the court in the early days of the T'ang was highly aristocratic and was seen in that light by others than Liu Fang. Su Mien, in his important encyclopedia (Hui-yao) of 803 wrote:

of the great officials who were founders of the present dynasty, all were of aristocratic clan (kuei-tsu). Since the Three Dynasties of antiquity, has there ever been a dynasty [so aristocratic] as ours? ${ }^{23}$

The imperial house, of course, was aware of this phenomenon, but between the first two emperors, Kao-tsu and T'ai-tsung, there was a great difference in attitude. The former, judging by remarks attributed to him, was both confident and proud in his lineage. Speaking once to the scion of a great northwestern clan, he said:

Our clan, the Li, was in antiquity wealthy and influential in Lung-hsi and in my grandfather's time [even] married into the imperial family. When 1 raised my righteous troops, the whole empire joined me and in a few days, I rose to become Son of Heaven. Looking at the rulers of former times, many rose from humble origins, toiling in the ranks and scarcely able to sustain their lives. You, sir, are also from an eminent clan (shih-chou ming-chia) which has successively held pure and illustrious (ch'ing-hsien) [posts]. . . After a thousand years, only the descendants of you and me will be unashamed of their antecedents! 24

Kao-tsu in this speech makes clear the degree to which a proud genealogy had become the source of pride, satisfaction and even self-respect by the seventh century. In his claim of relationship to the Lung-hsi Li clan--a claim almost certainly false 25 -he also betrays a certain anxiety. For although the wealth, the regional influence, and the status of a former consort clan with its implied concomitant of title and office which he claimed would seem an impressive enough background even for an imperial house, in the early T'ang it was not. The reason for this is the existence of a regional aristocracy whose prestige and pride was much greater. In 632, only a dozen years after his father's boast, T'aitsung defined the rivalry as follows:

At the time, the court discussed how the shih of the Northeast liked to boast of themselves. Although in successive generations they had declined, they still relied upon their former status $(t i)$ and when their daughters married into other clans, they had [to be paid] a bride gift ( $p^{\prime}$ in-ts' $\alpha i$ ). 26 T'ai-tsung disliked this, considering it very detrimental to the teachings of rectitude (chiao-i).

As a result, he decreed that [Kao] Shih-lien, . . Wei T'ing, . . Ts'en Wen-pen . . . and Ling-hu Te-fen 27 should revise and correct the [state list of] clans. Thereupon the genealogies ( $p^{\prime} u$-tieh) of the whole 
empire were investigated and checked against historical records to verify their truth. The loyal and virtuous were commended and advanced, while the disloyal and recalcitrant were censured and demoted. The compilation was called the Shih-tsu chih and Shih-lien then grouped the clans in ranks and categories (teng-ti) and submitted [the work].

T'ai-tsung said, 'For a long time, I have borne no resentment against the Ts'ui, Lu, Li and Cheng [clans] of the Northeast. I consider that over the generations they have declined to insignificance and have wholly failed to produce officials. Yet still they call themselves shih-ta-fu, and in their marriages they demand huge sums in money and silk. In ability and knowlege they are deficient, but [still] they esteem themselves. They [are forced to] sell the trees from ancestral graves and rely upon [marriage to] the rich and noble. I cannot understand why the people respect them [so greatly].

Previously, the $\mathrm{Ch}^{1} \mathrm{i}$ dynasty was restricted only to Ho-pei while the Liang and $\mathrm{Ch}^{\prime}$ en possessed no more than Chiang-nan. At that time, though they had talented men, they were minor insignificant states and not worthy of respect. Yet today the Ts'ui and the Lu, the Wang and the Hsieh are admired.28 I have pacified the [entire] empire and made one family of all the world. The shih of my court are all renowned for their achievements and the loyalty and piety of some is praiseworthy while the learning and talent of others is wide. [For this] they were chosen and employed. [Yet even] those who occupy positions above the third rank seek to become the relatives [by marriage] of those decayed, ancient families, sending them lavish [gifts of] money and silk, paying them homage. 29

Now when I specially decreed the settlement of clan [rankings], I desired to honor the officials of this court. Why then has Ts'ui [Min-] Kan still been placed in the first rank? . . 36 Do you gentlemen not respect the offices and titles of my court? You were not instructed to discuss former generations but simply to choose present offices and titles for your ranking.

Subsequently Ts'ui [Min-] Kan was placed in the third rank. The [revised] work [completed in 638] was made up of one hundred chüan and was promulgated by decree to the empire.31

This important incident, which permits great insight into T'ai-tsung's vision of a united China, has wide implications. He and his father had indeed united the empire into a single family, and he was determined that status should derive from himself as head of that family and should be earned in service to the $T$ 'ang. As emperor he could hardly have been unaware of the existence of the four regional super-elites identified by Liu Fang, but he directed his attack only against the clans of the Northeast. His ostensible reasons were their pretensions, their exclusivistic posture which failed to produce central officials, and marriage customs he regarded as detrimental to established morality. It seems unlikely, however, that these exhaust his reasons and, his disclaimer notwithstanding, he was probably aware of the northeastern clans' source of prestige and felt both inferior and insecure before it.

In the seventh century the northeastern ssu-hsing quite simply represented the longest, purest, and most uncompromsing strain of the Confucian tradition. Centered around the historical birthplace of the sage, they had made $Z_{i} x^{\prime}$, a respect for the Way, the core of their pride, and when North China fell into 
foreign hands they had refused both to flee south and leave their ancestral graves untended and, in most cases, to sully their bloodlines by marrying with the conquerors. 32 When Hsiao Wen-ti, for instance, accepted a consort from the Lung-hsi Li clan in 496, he had to compel the same four clans mentioned by T'ai-tsung to provide inmates for his harem and wives for his sons. 33

For reasons like these, the elite of the Northeast had distinguished themselves from their counterparts in other regions of North China and had added to their prestige by the traditional severity of their clan rules and the value they placed on the maintenance of morality and ceremonial within their families. 34 Their prestige arose, therefore, more from social than bureaucratic causes, and their general unwillingness to enter state service under the foreign regimes which preceded the Sui provided them with the appearance and sometimes the actuality of martyrdom. 35 Reluctance to hold offices in the capital accentuated their regional characteristics, intensified their cohesiveness and exclusivity, and dissociated them both from the exploitative nature of the foreign regimes and from the parasitical character of the collaborating Chinese elite. 36

We might note, finally, that it was in the Northeast that the T'ang had found the greatest resistance to its dynastic foundation and, as we will see, had reason to suspect the area of separatist tendencies for many years to come.37 Although Liu Fang had associated the military arts with the clans of Tai-pei, there is ample contemporary evidence to suggest that, as a whole, the Northeast possessed the finest fighting men and that the term hao-chieh or hao-tsu, which seems to have been a wide generic classification for the great clans in Han times, came to connote such characteristics as self-sufficiency and martial skill, and was reserved increasingly for the people of the Northeast. 38 Both in economic and strategic terms, the area was a key one in the survival of the dynasty and so could not be permitted to remain aloof from the centralizing policies which T'ai-tsung considered so important.

His special treatment of the area sprang therefore from two causes. The greatest clans of the Northeast enjoyed a status in the popular view which was beyond imperial control, and with their superior prestige, marriage revenues and court connections as well as their traditional military power, could threaten not only national unity but the very life of the dynasty. Status fixing by the state was an old solution but, in the newly united T'ang Empire, one with a new importance.

The revised versions of the Shih-tsu chih, according to the old T'ang History, was greeted with general approval, 39 but there are indications that in its stated aim of equating status with present success in the service of the central government, its effects were minimal. There was no rush of northeastern aristocrats to the capital, and in 642 the emperor was forced once more to attack the same clans, charging that they had abandoned the profession of official. He struck at a key source of their economic viability with a decree forbidding the sale of marriages (mai-hun).40 In the same edict he again commented on the pretensions of the group, and complained that new officials and wealthy families still contended to marry with them, a custom which was now well-established. Perhaps in order to justify what must have seemed a harsh order, he claimed that marriages of this sort degraded the great clans, led to friction among inlaws because of status differences and even caused the "buyers" of marriage to adopt the pretensions of the northeasterners. His deeper motives were perhaps punitive, reflecting both his frustration that the northeastern clans still 
remained aloof, and his determination to force them into acquiescence. If this is the case, his tactics were wrong, for as Ssu-ma Kuang remarks of a later ban, Since [these] great clans (tsu-wang) were the object of contemporary respect, in the end the prohibition could not succeed. Some [of the clans] secretly sent their daughters to the [intended] groom's house, and others [permitted their] daughters to grow old as spinsters. 41

In short, these two measures of T'ai-tsung must have struck the northeastern elite as expressions of regional discrimination on the part of a dynasty whose own origins were northwestern and, as a result, can hardly have persuaded them to contribute their services to it for reasons other than economic necessity. Secure in their social prestige and realizing that if status were dependent on office, the northwestern clans already had a thirty-year head start over them, they seem for the most part to have continued their policy of non-cooperation. of the northeastern representatives among T'ai-tsung's chief ministers not a single one was of the group of families he identified as objects of his centralizing concern. 42

I mentioned earlier that Kao-tsung inherited his father's bureaucracy and that the preponderance of northwestern influence in its highest levels has led some scholars to interpret the political struggle over Empress Wu's evaluation as a conflict between regional aristocracies. While I have attempted to show the deficiencies of this view, I must also concede that it contains some measure of validity. The fact that it has been so widely discussed indicates at least that the problem of regional jealousy within the ruling class had not wholly been solved. The events following Wu's elevation, most particularly her destruction of the principal northwestern tsai-hsiang and the declaration of Loyang as the eastern capital, created a favorable climate for another attempt to conciliate the northeastern elite, and in 659, with a new clan list and marriage ban, the at tempt was made.

The immediate inspiration for the revision of the national clan 1 ist in 659 was, we are told, the fact that Empress Wu's clan was unranked or "not clearly" ranked in the Shih-tsu chih. 43 While this may be true, it seems from such facts as the comparatively low rank of the compilers of the new 1 ist 44 and from the extant descriptions of the completed work that the motives for the revision paralleled those of T'ai-tsung two decades earlier. The chief differences between the two works is to be found in their size and scope, in the exact correlation of official and treatise rank in 659 and in the omission in the later work of all but the immediate family of the individual ranked. These differences are presented in tabular form as follows: 45

\begin{tabular}{ccc}
\hline $\begin{array}{c}\text { Title of } \\
\text { Work }\end{array}$ & Shih-tsu chih & Hsing-shih Zu \\
(final form 638) & (completed 659)
\end{tabular}

No. of

chüan

Contents

293 surnames 姓 1,651 lineages 家

Features (a) Arranged by rank 等

(b) Imperial clan placed

first, followed by the consort families. The Ts'ui
200

245 surnames 姓

2,287 I ineages 家

(a) Same.

(b) Ranking reputedly decided by the emperor, who also wrote a preface. [The imperial clan probably occupied 


$\begin{array}{ccc}\begin{array}{c}\text { Title of } \\ \text { Work }\end{array} & \text { Shih-tsu chih } & \text { Hsing-shih 2u } \\ \text { (final form 638) } & \text { (completed 659) }\end{array}$

clan, which had originally ranked first, was placed third.

(c) A total of 9 ranks.

(d) Aim to distinguish shih \pm from shu 庶.

(e) Greeted generally with approval.

Notes (1) An observation found in the Comprehensive Mirror, and in the old T'ang History, 189, 3578:1, biography of Liu Ch'ung. a special rank at the top.] In the first rank were placed the four consort famjlies (Tu-ku, Tou, Ch'ang-sun, and $\mathrm{Wu})$, the imperial clans of Sui and Chou (Yang, Y $\mathrm{ü}$-wen), 2 the clans of those who had [in the T'ang] held the posts of san-kung, 3 of $t^{\prime} a i-s s u, 4$ of t'ai-tzu san-shih, 5 of $k^{\prime} a i-f u-i-t^{\prime} u n g$ san-ssu, 6 of p'u-she. 7

Civil and military officials of the second grade (二品) and [active] civil officials of the third grade (chihcheng-shih che san-p'in) were placed in the second rank. Every [other] official was ranked according to his grade.

(c) Same.

(d) Inclusion of all who had reached at least the fifth grade in the T'ang period. No relatives of the man ranked, except his brothers, his sons and grandsons, were included.

(e) Since all who had achieved the fifth grade were elevated to shih $I$ status, even soldiers, the gentlefolk (chin-shen shih ta-fu) were all ashamed to be ranked. They called the work the Rule of Meritorious Service to the State (Hsün-ko).

(1) The respective empresses of $\mathrm{Li}$ Ping, Kao-tsu, T'ai-tsung, and Kaotsung.

(2) Referred to as hsi-kung and chiehkung.

(3). The posts of $t^{\prime} a i-w e i, s s u-t^{\prime} u$ and ssu-k'ung. In addition to the Imperial clan, members of the $\mathrm{P}^{\prime} \mathrm{ei}, \mathrm{Ch}^{\prime}$ ang-sun, Fang and $\mathrm{Li}$ clans had held one of the posts.

(4) The heads of the Chancellery, Secretariat and Department of State which were second and third grade posts. (5) The Three Preceptors of the Crown Prince, who were all first-grade officials. Four men had held the post. 


\begin{tabular}{ccc}
\hline Title of & Shih-tsu chih & Hsing-shih Zu \\
Work & (final form 638) & (completed 659
\end{tabular}

(6) An honorary official title of the first class.

(7) The two vice-presidents of the Department of State Affairs. Six men not included elsewhere in the first rank would be found here.

The substantive differences between the Shih-tsu chih and the Hsing-shih Zu reflect as much as anything else a different tactical approach to an identical problem. As we have seen, the first work is said to have been greeted with aristocratic approval and, moreover, to have had as one aim the separation of shih and shu. Both of these attest to its traditional character, and the necessity for a marriage ban four years later suggests that perceptions of status were little changed by it. T'ai-tsung clearly was not anti-àristocratic, nor did he seek by the treatise to weaken or destroy the northeastern clans. He sought rather to woo them into direct service to the T'ang, but his openly indiscreet and hostile attitude and his arbitrary reduction of the Ts'ui clan's ranking could only have had the effect of polarizing the two sides. Moreover, since he decreed that the list was to be a permanent ordinance (yung-shih), 46 the proud clans of the Northeast would be forever inferior in the eyes of the state to those whom they regarded as the upstart clans of the Northwest.

The Hsing-shih $Z u$ was at once more conciliatory and more firm. Like its predecessor, it emphasized state service over family as a determinant of status but even more greatly stressed the individual over the clan. The truly important change lay in the fact, therefore, that heredity was no longer a factor in obtaining shih status and that any individual who reached fifth-rank officialdom needed no other qualification to be accounted a shih. At a stroke officeholding became more desirable and more necessary, and marriage into one of the great northeastern clans no longer held the same attraction for those who sought rapidly to raise their status.

At the same time, however, the olive branch of conciliation was held out to the Northeast with the collection and burning of all available copies of the Shihtsu chih 47 and the elimination thereby of the clan superiority of the Northwest. Probably for the same reasons, the new work recognized the validity of marriage as status in the high ranking of consort families and removed the imperial clan from competition with the Northeast by creating a special rank for it. The Northeast, moreover, had produced its share of regional officials above the fifth rank 48 and, by providing most of the manpower for T'ai-tsung's Korean campaigns, had probably come to hold most honorific ranks. On these two grounds, its representation in the second work was, in relative terms, likely to have been better than in the first. Although the new list took even less account of genealogy than the old, on balance it was probably more palatable to the northeastern clans.

The same was true of the marriage ban issued four months later. This document forbade the intermarriage of seven surnames (hsing) and specified limitations on the bride gift. 49 Pragmatic and free of moralizing, it listed first 
the Lung-hsi Li clan, thereby implicitly bonding the imperial family to the six greatest clans of the Northeast who made up the remainder of the list. It tied the bride gift to present official rank, thus providing additional incentive for the aloof clans to seek high capital office. In this way the ban was directed not so much against their economic base as against their exclusive marriage circle and the cohesion which fostered their sense of regional independence.

If this is the correct interpretation of the ban's purpose, and if it succeeded in drawing more of the northeastern elite to the capital, it would seem logical to conclude that there was no real need for enforcement of its specific prohibitions. As we have seen, traditional historians record that the response of the great clans was to marry secretly or to keep their daughters unwed, and recent scholarship has empirically demonstrated that this was indeed the case. 50 In spite of this, there is no evidence until after the Chou dynasty that the throne insisted on enforcement, 51 and the principal reason seems to have been that there was no need to do so.

From all we can gather, the two status measures of 659 seem to have succeeded in wiping clean the slate. By permitting a limited bride gift rather than outlawing the practice as T'ai-tsung had done, Kao-tsung and the Empress Wu were recognizing that the northeastern clans had at least a social claim to superior status. The Hsing-shih $Z u$ at the same time served notice that status would henceforth be tied principally and definitively to office in the T'ang. In comparison to the Shih-tsu chih, it was more in the nature of a Who's Who than an Almanach de Gotha and so acted as an invitation to the northeastern clans to diversify their claims and compete for status on the same terms as the other regional elites. The fact that the empress, considered by contemporaries to be an easterner and known to favor Loyang over Ch'ang-an, 52 was by 659 being seen almost as an equal partner in Kao-tsung's government, must have served as an additional attraction to the Northeast. It seems more than coincidence, therefore, that before Kao-tsung's death, all but one of the lineages specified in the marriage ban of 659 had provided the T'ang with a chief minister; and in the Chou dynasty the high proportion of these same surnames in tsai-hsiang ranks further attests to the success of her reconciliation. 53

Finally, we might note in this regard the form of what seems to have been the last major attempt by the T'ang at status fixing on a nationwide scale, the Hsingtsu-hsi $2 u$ of 714.54 Though details of the work are scarce, it was altogether a more "professional" compilation than its predecessors 55 and, as much as anything else, reflects a general acknowledgment that the state had won the right to set the criteria of status. The proposal for its composition in 707 remarked, first of all, that "official families (kuan-mien chih chia) have changed, rising and falling. ${ }^{\circ}$. Judgments of former times can hardly be used as a rule for the present." 56 Chung-tsung concurred, decreeing that a treatise of eminent clans (yu-hsing) be compiled to include "men of high repute and great virtue, of pure occupation and good breeding; [men] whose titles are inherited, of the standard of well-known scholars, whose bravery has been often demonstrated, who have received honorific rank, who are of supreme distinction at this court, and who are honored in court and countryside, their fame united with general admiration. . . Barbarian chieftains of notable official service should be placed in a separate category."157 The work was to be based on the Shih-tsu chih which seems, therefore, to have escaped total destruction and was completed in 200 chïan. 58 
Although it is sometimes suggested that this compilation reflects the "aristocratic revival" said to follow the deposition of Empress Wu, these surviving details seem to indicate that it resembed the Hsing-shih Zu rather more than the Shih-tsu chih. Once again, for instance, the emphasis was placed on the individual rather than the clan, and once again it listed recipients of honorific rank and foreign chieftains--the groups whose inclusion in the compilation of 659 had led to widespread criticism. On this occasion we hear of no such protest and, as a result, might be justified in assuming that in the intervening seventy years, a principle had been successfully established. The Hsing-tsu-hsi Zu was designed not so much to create as to identify present membership in the shih class.

In 714 success and reputation in the service of the T'ang were accepted as the sole criteria of eminence, and scholars, soldiers and "barbarians" were all eligible seemingly without reference to their antecedents. The fact that during the two generations which had passed since the Shih-tsu chih, status had come to depend more on office than on clan, on achievement rather than birth, represents a social change of truly grand significance.

It is perhaps the most important historical change for which Kao-tsung and the Empress Wu were responsible. They had done no less than redefine the ruling group, the shih class, changing its principal characteristic from "aristocratic" to "bureaucratic," and winning popular acceptance for the new view of societal stratification. One of Kao-tsung's chief ministers summed up the change when he retired from office in 683, reportedly remarking on the three disappointments he had suffered in his life: his failure to win the chin-shih degree, to marry a daughter of the northeastern wu-hsing, and to be a compiler of the National History. 59 The fact that he was the scion of one of the preeminent clans makes his preferences the more meaningful.

The means by which the change was wrought, most particularly the growth of the examination system, belong properly to the next chapter, but two other aspects of it should be noted here. In the first place, the changes which occurred in the ruling class were as much qualitative as quantitative. Second, and in a directly related process, the new, more highly bureaucratized shih began to show signs of melding with its former antithesis, the shu, to form a single class of subject in a more "modern" societal configuration. Under Hsüan-tsung the change was embodied formally in law.

To understand these two developments, it is necessary to return to the state registers of status. From the descriptions provided of the two works of the seventh century, it seems abundantly clear that the clans counted in the nationwide elite comprised only a miniscule proportion of the population and indeed as early as the Sung, traditional scholars had pointed out that they were really the elite of an elite, existing above a generalized, locally prominent shih class who were also exclusive in their marriages and able to claim both social and bureeaucratic preferment. 60 As 1 already suggested, this situation is reflected only slightly in the state registers, with the clans listed in the Shih-tsu chih, for instance, comprising no more than .05 percent of the entire population. 61 Although the Hsing-shih $Z_{u}$ increased its coverage to $245 \mathrm{clans}$ and 2,287 lineages, the proportion was probably not much greater, and since status ranking was to correspond to official rank and there were over 16,000 Ziu-nei officials at the time, 62 this seems a situation difficult to explain. Even considering the nepotistic nature of the early T'ang bureaucracy, the majority of officials must have 
gone unlisted, and from this indirect evidence, it seems reasonable to assume the existence of a much larger shih stratum whose lineage made them desirable as prospective officials, but whose social standing was still too low for the national standard of registration.

Until the discovery of the Tunhuang manuscripts, further development of this hypothesis was difficult. Several documents in various collections, however, have recently thrown light on the problem, though there remains a certain controversy over their exact interpretation. 63 These conflicts aside, they constitute an extremely valuable source.

The documents in question, four or possibly five in number, ${ }^{64}$ date from the middle of the eighth century and offer detailed information on those clans considered to possess social prominence in the various chou and chün of the empire. Collation of them with later geographies and rhyme dictionaries 65 reveals the existence of a second level of shih lineages which was perhaps five times the size of the super elite of the Shih-tsu chih. 66 This configuration is the chief explanation for the form taken by social development in the second half of the seventh century.

Let me explain further. In the early T'ang, prestige, influence, and the perquisites of rule belonged to the shih class, but an inordinate share of social status was monopolized by a tiny, nationally renowned super elite concentrated east of the T'ai-hang Mountains. The following map, based on manuscript wei 79 in the Peking National Library, illustrates the regional disparity and shows the distribution of the aristocratic groupings identified by Liu Fang. As I suggested earlier, the northeastern clans were exclusivistic, proud and, largely through marriage practices, self-sufficient. Their concern with genealogy, clan solidarity and Confucian ritual was at least partly an attempt to remain distinct not only from the other regional super elites, but also from a wider stratum of local shih which aspired to the same heights. Provided the criteria of status remained unchanged, their security was assured.

The attempt begun by T'ai-tsung to equate status with present office, essentially a measure designed to balance rather than weaken the great clans, changed the situation. Whatever the failings of his policy, the emperor had at least recognized the use to which the local shih could be put, recognized their aspirations and their adaptability and thus, it will be recalled, had canvassed the genealogies of the entire empire rather than simply concentrating on the areas where the super elites were concentrated. Kao-tsung and Empress Wu had extended this principle in 659, attempting further to blur distinctions within the aristocracy while at the same time conciliating the alienated Northeast. For them the second part of the policy was of greater immediate importance, and until the 670s it reflected the need for unity, for acceptance on the part of an upstart dynasty, and for a cooperative Northeast to support the Korean campaigns. Imperial success in these aims was not total, but a good deal of evidence can be adduced to show that by Kao-tsung's death representation of the national elites was more balanced in the chief ministerial ranks than had been the case in the 650 s and, as will be shown later, that they came to dominate such governmental organs as the Chancellery and the Board of Civil office. 67

During this same period, however, the bureaucracy was expanding rapidly, 68 and if the regional distinctions within the super elite were being diluted by their common bureaucratization, the group as a whole found itself pressured from 


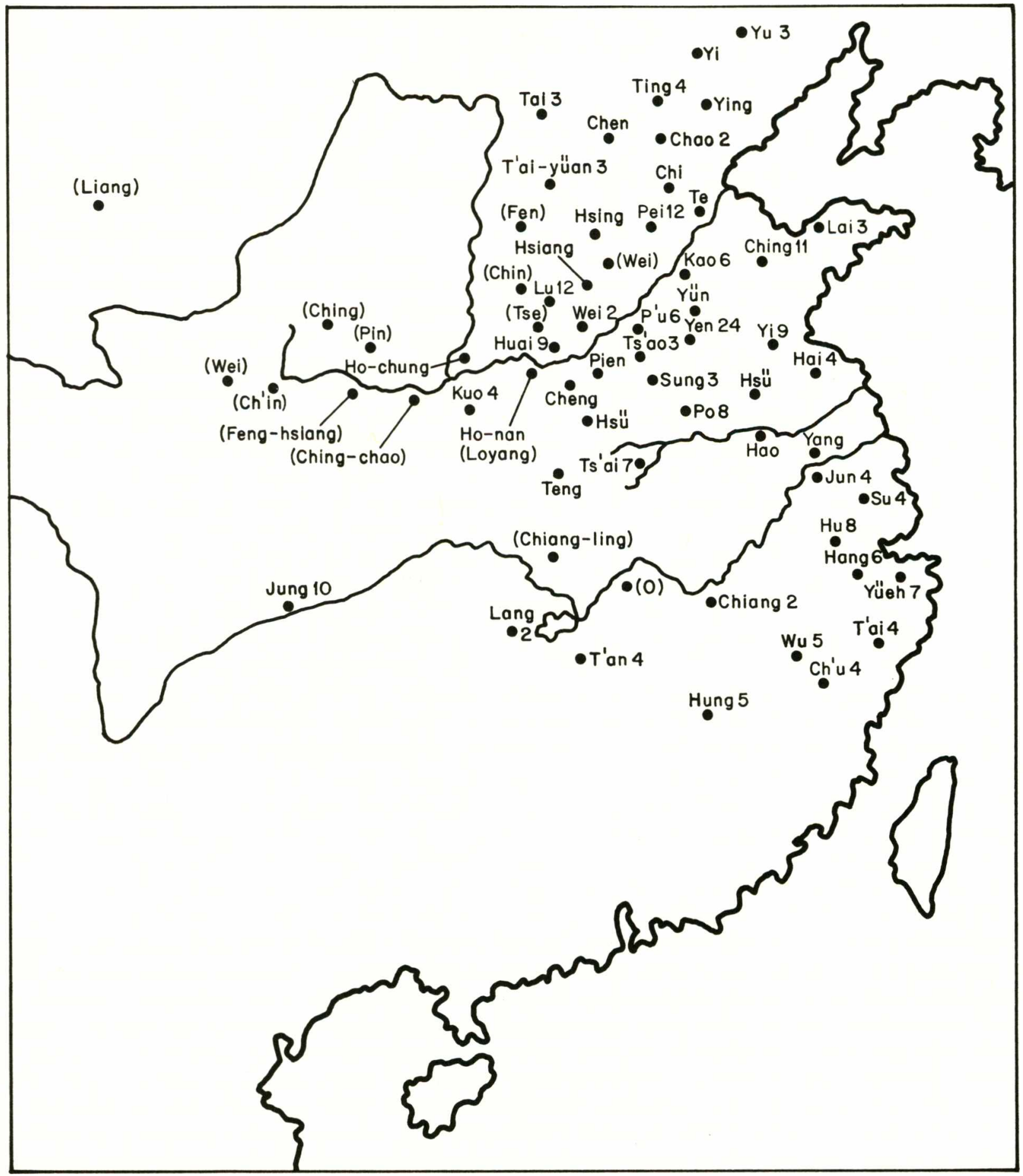

Distribution of Great Clans During T'ang

Locations of chou with one or more great clans from Peking wei 79; locations in parentheses from Ikeda On's reconstruction from T'aip'ing huan-ÿ̈ chi. 
below by the inferior layer of shih lineages who were rising in the bureaucracy through examination and the decreasing imperial emphasis on genealogy. Having committed themselves to court politics and become vulnerable to their vicissitudes, the great clans found themselves on the defensive in the maintenance of the prestige they had so long monopolized. To compensate for their surrender to one form of definition of status in terms of state service, they seem to have responded by intensifying what they still monopolized, the purity of their Confucian tradition. 69

When Kao-tsung died and the Empress Wu seized control of the government, they found themselves, therefore, in an impossible position. As representatives of the Confucian opposition to a woman ruler and as possessor of great political influence, they became the primary objects of the terror, and over the next decade hundreds of families suffered extinction or eclipse, in many cases taking generations to recover. 70 Though monographic studies on the subject are lacking, it seems safe to assume that the great aristocracy suffered a severe blow under the empress' regime and that had they clung more tenaciously to their regional bases, they might have attained a much higher rate of survival.

This, of course, lies in the realm of speculation and, in any case, it is difficult to see continued aloofness as a viable alternative for them. The message of the state registers and marriage bans was difficult to ignore and, as we will shortly see, from about the time of the examination reforms of 669 , imperial recruitment policies were directed largely toward the provincial elite whose selfinterest, traditions, and competence made them natural alternatives to the great aristocrats in the highest ranks of officialdom. Lest this group displace them by default, the latter were forced to respond to bureaucratization and, judging from extant lists of high officials, this was as true of the other regional super elites as of the northeastern wu-hsing. As we shall see, even the scions of great clans applied with increasing frequency for the state examinations.

These developments served, therefore, not only to initiate change within the aristocracy but also within the bureaucracy. By the chou and thereafter, officialdom was not only growing but, in the lower ranks at least, its highly aristocratic character was becoming progressively diluted. The super elites, still well entrenched in high office, found themselves pressured from below by the lesser shih and at the same time subject to the systematic policies by which the empress attacked the upper ranks of the bureaucracy. There was no need for status registers and marriage bans between 659 and the end of the Chou principally because the great clans had been enticed into a larger and more "egalitarian" bureaucracy and so had ceased to threaten the state from a position of independence. Representative of the emerging pattern is Li Ching-hsüan who was a member of the eminent Chao-chün Li clan, entered the bureaucracy through recommendation, recruited "myriads" each year, mostly from the Northeast, as president of the Board of Civil office married three times into the northeastern aristocracy, and was disgraced in 680. His whole family was later exterminated.71

The second major social change which occurred in the last half of the seventh century, the blurring of the distinction between shih and shu, was closely related to the policies discussed above and was equally the result of conscious imperial aim. Although the change was not completed until the $k^{\prime} a i-y \ddot{u} a n$ period (713-42) and, although it is difficult to say whether T'ang policy generally or the special situation of the Empress Wu was a more important factor in the change, the end of the distinction may be viewed as an event which truly marked the end 
to the "aristocratic" epoch.

Until the Sui dynasty it seems clear that the shih-shu division had had at least a quasi-legal basis 72 and, as we noticed earlier, T'ai-tsung's Shih-tsu chih had as one of its aims the preservation of the distinction. The Hsing-shih Zu, however, embodied a major departure from this principle and had included in its rankings such groups as the recipients of honorific rank and foreign chieftains who were, in most cases, not of the shih class. And from 659 the policy of the throne seems to have sought further to erode the distinction. The principal tactic, as we shall shortly see, was the extension of the examination principle and the wooing of Ziu-wai officials, but after 684 we find a much wider range of specific measures designed to achieve the same end. Several edicts, for instance, called specifically for the recommendation of virtuous men, "whether shih or shu" to fill official positions, and in 685 talented commoners (pai-hsing) were given the right to recommend themselves for posts. 73 During the terror servants and even slaves were given the right to denounce their masters and to travel at state expense to the capital to make their reports, while in the great Khitan rebellion, slaves and convicts were permitted for the first time to enlist in the army and to be eligible, therefore, for the various military rewards. 74 These measures were of the sort responsible for what Professor Ch'en has termed the "social flux" of the empress' period but, generally, were measures of expediency and need not be seen as any more than the most striking examples of an evolving new perception of status dating at least from 659. A systematic analysis of the edicts of the Chou period shows that the term shih is almost invariably used in its bureaucratic sense, the connotation shifting from social class to official function. 75 Conversely, the term shu, which appears in edicts much less frequently than such terms as min or pai-hsing, is used for any person who held no rank in the official hierarchy.

The effect of this practice, which included the substitution of a distinction between "free" (kuei or liang) and "unfree" (chien 貝戔), was soon to be recognized in law and embodied in the Code of the T'ang (T'ang-lü shu-i) by 737.76 It seems fair to say, therefore, that the regime of Wu Tse-t'ien marks a definite stage in the evolution of status perceptions in medieval China. In specific terms, it was the state status register she inspired, and her own edicts ( ing) which were largely responsible for the creation of the simplified, two-level model of stratification upon which the $2 \ddot{u}$ - Zing system of the T'ang was thenceforth to be based.77

In summarizing the role of the Empress Wu in the social change which occurred in her era, we must take care not to give her too much credit for acting consciously to achieve this end. While her unorthodox governmental role was clearly a catalyst, she remained in many respects typical of her times. In her regime we find the customary sumptuary regulations directed against merchants and artisans and at least one measure designed to limit the official advancement of such groups as astronomers, musicians, physicians and diviners. $78^{\circ}$ We have seen how in 683 she took great pains to embellish her own genealogy, and on other occasions she was not above crude snobbery. Objecting once to the family into which her daughter planned to marry, she asked. "How can my daughter become the sister-in-law to farm girls ( $t$ 'ien-she nü) ?'179 On several occasions she affirmed her belief in the hereditary nature of good and evil character and the effect of geography upon it. 80 Nonetheless she was a pragmatist before all else and because of her background, her Buddhism and her evolving dynastic aims, she was less inflexible than her predecessors in promoting the rise of worthy and talented men. 
Finally, the direction of social change and status perception must be related to the most basic of the empress' aims, her attempt to establish first the T'ang, then the Chou in an age when regional and clan-centered traditions were paramount and when dynasties originated in the great clans. This meant that the status claims and the prestige of the super elites not only in the Northeast but everywhere had to be subordinated to those of the state. She and Kao-tsung together took the first step, following T'ai-tsung's lead, but the development of the policy, particularly the patronage of the examination system and the lower stratum of shih whose rise it fostered, seems to have been more her own policy than her husband's. This theme we shall discuss in the following chapter.

Once officeholding had become the sine qua non for achieved status and the road to high office had been opened more widely, the greatest clans found themselves on the defensive. They possessed, after all, no monopoly on talent. When they finally acknowledged state control of status by their rush to gain office, their invulnerability was ended. As already mentioned, from 684 onward so many suffered execution or the penalty of "eradication of name" (ch'u-ming) that entire clans were suddenly plunged into economic hardship and social obscurity. 81

In spite of this, the empress' policies were not intrinsically anti-aristocratic. She was opposed only to those characteristics of the great clans which she saw as detrimental to state unity and to the full achievement of imperial power and administrative efficiency. In this opposition, however, lay the seeds of the conflict within the ruling class which would be so pronounced a feature of her own dynasty, and which would help to cement the changing perceptions of status which had evolved in the preceding decades. There is little evidence that her regime fostered the rise of any new class, but it did facilitate the advancement of an already defined secondary shih class and, perhaps of greater importance, it hastened the decline of the proud oligarchy whose monopoly of political power was the outstanding characteristic of post-Han China. 


\section{Chapter 7}

\section{THE EXAMINATION SYSTEM AND THE BUREAUCRACY}

Political developments in the seventh century, although far more richly documented than their social equivalents, present the historian with numerous problems. The first of these, the bias of traditional historiography, has earlier been discussed in some detail but it is in the political realm that it takes on its greatest significance. In the Confucian mind, questions of rule were uppermost, and by the seventh century the values of the historian were set. A good ruler was one who conformed to traditionalism and decorum, who achieved harmony in the hierarchical relationships of Heaven, Earth and Man, as well as between ruler and subject, and who brought peace and prosperity to the empire. Motivation and causation, objective assessment of success and failure except in the moral realm, are largely absent from the traditional accounts. There is a sameness in all their appraisals of the Empress Wu in her political role. She was unorthodox and undignified, ruthless and pragmatic, cruel and skillfully unscrupulous. The description of her which terms her "licentious but orderly [in administration]" (yin erh pu-Zuan) in juxtaposition to the Han Empress Lü has become proverbial.

A second difficulty lies in the fact that extant sources are concerned almost exclusively with the events and conflicts at court and usually deal only with the ruler and the highest echelons of the bureaucracy. The lower levels of officialdom, provincial administration and the extremely important class of officeholders termed those "outside the current" ( $i$ iu-wai) are dealt with only indirectly, and the historian must rely on surmise, later sources, and occasionally the evidence of Tunhuang. 1 On the other hand, the high degree of centralization in the early T'ang makes the problem less severe than is the case after An Lushan's rebellion; moreover, the first century or so of the dynasty was characterized by a phenomenon known as "value the center and esteem lightly the provinces" (chung-nei ch'ing-wai).2 This meant that most ambitious men were active at the capital, and it was there that important political events occurred. Let us now turn to some of them.

Within the governing class of pre-modern China the conventional conflict perceived by historians has been that between the "inner" (nei) and the "outer" (wai): that is, between the imperial and consort clans, their eunuchs and favorites on the one hand, and the bureaucracy on the other. Throughout history the ascendancy of a woman had almost always been accompanied by the rise of her family, the wai-ch'i, and by eunuch power. But under the Empress Wu, this type of analysis is of little use, for she succeeded in breaking the pattern. Never did a eunch exercise any discernible political influence, and never did any member of the Wu clan advance much beyond the status of a tool in carrying out such specific policies as the suppression of the upper bureaucracy or the confusion of the succession. 3 Even the military power held by male clan members was minimal, 4 especially in comparison with the Han Empress Lü who had set the pattern, 
and with the early eighth-century Empress Wei who prepared for her attempted coup by first placing as much military force as possible in wai-ch'i hands.

It is, therefore, one of the most remarkable aspects of Empress Wu's career that what she did, she did with only minimal aid from her family. There are a number of reasons for this, some of which we have looked at in our discussion of her legitimation. Even more basic than those we have already discussed, however, is the dislike she conceived for her half-brothers after her father's death with the result that she had them disgraced or destroyed between 666 and 670 . Of the survivors, her nephews Wu Ch'eng-ssu and Wu San-ssu, the sons of Wu Yüan-shuang and Wu Yüan-ch'ing respectively, were summoned to the capital in 674 but were kept out of politics until after Chung-tsung's deposition. As we shall see, both of them eventually reached tsai-hsiang status but held it for a relatively short period of time and principally as a counterweight to such competent and assertive ministers as Ti Jen-chieh.5 Even the fiefs of maintenance (shih-shih feng) awarded to the Wu clan during Chou, although a source of criticism by historians, were not excessive in the context of the times, and the real abuse of the privilege belongs to the next reigns. 6 The empress is said once to have remarked that she desired to have one member of her clan as chief minister at all times, 7 but it is significant that she was speaking at the time to a maternal relative, and that the Yangs and other relatives-by-marriage were as prominent in her period of power as were the Wus. Neither, however, became dominant either in the political or military spheres, and of no male ruler in the T'ang prior to An Lu-shan's rebellion could the same be said. Her predecessor T'ai-tsung had had his Ch'ang-sun Wu-chi, and her successor Hsüan-tsung would have his Li Lin-fu. To Wu Tse-t'ien all her servants, including her own family, were equal beneath the throne.

The Empress Wu did, however, have a series of favorites whom she used for specific purposes. The best known of these were Chou Hsing and Lai Chün-ch'en who presided over the terror, Hsüeh Huai-i who was responsible not only for the architecture of the ming-t'ang and the commentary on the Great Cloud Sutra but served also as a general, and finally the Chang brothers whose role seems to have been that of the empress' friends and confidants and whose political interventions were the immediate cause of her deposition. 8 In each case these men were given enormous power, but intrinsically it was chiefly the power of invulnerability, to be answerable to the empress alone, and not the power to venture into the realm of administrative policy-making. Their effects were felt chiefly in the determined absolutism of the empress as she used them to counterbalance and dilute the influence of more talented officials. As a result, they shared in the empress' political success.

Was the empress a success? As mentioned earlier, most traditional historians have said "no" and have cited her massacres along with the decline of Confucian "virtue," the demoralization of a bureaucracy marked by excessive appointments and poor quality, and China's weakness against its neighbors during Chou, as indexes of her failure. The fact remains, however, that she became emperor in a China where it was impossible for a woman to do so, and even traditional historiography praises her ability as ruler "to accept remonstrance and know men."9 Moreover, the internal peace and prosperity which marked her reign, and her contribution to the bureaucratization of the great clans, to the development of Buddhism and, as we shall see, to the examination system, are matters of historical record. For the modern scholar, however, these facts are not enough and must be seen in the context of teleological questions. What precisely were the 
motivations and the political aims of the empress, and to what extent and why were they achieved?

The tasks she set for herself were, I suggest, simple yet visionary. First of all, I suggest that she wanted to see her husband's dynasty consolidated and, in a more general sense, to make a harmonious state, permanently united under a strong central power whose sole, free, and acknowledged head was the emperor. Second, and closely related to this, she sought to change the relationship between ruler and minister or, perhaps more accurately, to create a new type of official who would interact in a specific way with an imperial institution for which she already had a clear definition. If not unique to her, it was at least contrastable with that of T'ai-tsung, and making it a reality was the goal of much of her political policy. Without the support of Kao-tsung, who seems early to have been persuaded to her view, she could have achieved little, and the policy of reducing the tsai-hsiang prerogatives perhaps owes as much to him as to her. Judging from the form taken both by the curriculum and the examination process itself the empress' hand is more easily discernible than that of her husband in the development of the examination system. I shall, therefore, speak of the examination policies as hers, bearing in mind, of course, that Kao-tsung offered both his acquiescence in and the legitimation for enforcement of her policies, if not the initiative in creating them.

The preceding chapter attempted to show the success of Kao-tsung's early policies to make status dependent on service to the T'ang, and to bureaucratize the great clans, especially the exclusivistic northeastern aristocracy. It further suggested the new problem which arose partially from the solution to the old. This is to say that the new bureaucracy, especially in its highest echelons, was infused with ambition, competence and the kind of self-confidence which arose from knowledge that its members possessed not only high birth but talent demonstrated either by examination or service. These officials had demands to make on the ruler and ways to abridge his prerogatives, and the representatives of their claims were the tsai-hsiang, officials above the third rank and of designated status. 10 Since the reign of T'ai-tsung, this group had been growing in strength until by the 650 s its members could justify the ancient claim that "no matter of state lay beyond their scope."1ll lt had, of course, been the tsaihsiang acting as a group who had almost succeeded in blocking the elevation of the Empress Wu, and we have seen how, with her husband's collusion, she rapidly succeeded in destroying the men involved. This had resulted in the intimidation of the group and the replacement of its members with more amenable officials like Hsü Ching-tsung and $L i ~ I-f u$, but the early opposition of the tsai-hsiang and the attempt in 664 by another of them, Shang-kuan 1, to bring about her deposition were things the rulers seem never to have forgotten.

In politics a major concern, therefore, became the definition of relations between emperor and minister, and with her customary thoroughness the empress turned first to the examination system. For the next few decades, the imperial view of the institution seems to have been that it was more a tool to achieve certain political and social ends than a method of choosing the best men to govern the state.

The first indication of concern with selection appeared in 657 . In that year the vice-president of the Chancellery, Liu Hsiang-tao, submitted a comprehensive, seven-part critique of the appointment process, 12 perhaps inspired by the 
fact that the notoriously corrupt Li $1-f u$ had recently been given charge of the Board of Civil office 13 and was already selling posts on a large scale. At the same time, Liu identified some more general faults in the system, and because his criticisms were to be echoed throughout the next decades, it is useful to present them here in a fairly full way.

His first concern was a dual one: that too many appointments were being made and that too many men were insufficiently qualified. Elaborating on this, he pointed out that less than a third of present appointees were examination graduates while the rest were recruited from among minor governmental servants, clerical employees or guards, whom he referred to as the tsa-se-jen or hsü-t'u. 14 There was no reason, he thought, to assume that these men were of virtuous character, and one of the reasons that punishments still existed in the state was that they were so numerous in the administration. His solution was the division of the qualified tsa-se-jen into four groups on the basis of their talents and character, with the best being attached to the Board of Civil office, the next to the Board of War, and so on. Those who had once committed either a private or public crime should be reexamined and, unless amnestied, should receive no appointment. . These measures, he believed, would purify the bureaucracy and inspire the $h s \ddot{u}-t^{\prime} u$ to a realization that competence and character were the criteria for appointment.

His second point was closely related to the first. Suggesting that the former practice whereby men "entered the current" of regular bureaucratic appointment only when vacant positions occurred was now disregarded, he pointed out that there existed at the time 13,465 officials "within the current."15 Considering that the average bureaucratic career was about thirty years in length, he calculated that the appointment of 500 persons per year would be more than sufficient to keep the bureaucracy at a constant level. Yet the Board of Civil office at the time was making over 1,400 new appointments a year, and as officials returned from the frontier to find positions in the capital, the numbers were further swollen. This policy, he believed, was short-sighted and dangerous.

Liu's next three points concerned education and examination. Requesting first of all that two-thirds of all appointments within the current be allotted to holders of the ming-ching or chin-shih degrees, he asked also that greater consideration in appointment and promotion be given to students in the three state schools. His point here seems to have been that while the great expansion of Confucian education was highly beneficial to the state, students should have at least equal opportunities for advancement with lower-ranking officials who currently received promotion even beyond the statutory limitations as a reward for such relatively small achievements as the suggestion of administrative improvements. He recommended further that the hsiu-ts'ai examination be reinstated. 16

Finally, Liu criticized the $k^{\prime}$ ao system of promotion, suggesting that officials rose too rapidly, with the result that many of them kept one eye constantly on their promotions instead of their present duties and that the common people were less inclined to obey them, knowing that their tenure was likely to be short. He concluded by returning in more specific terms to his first point, criticizing the three departments and the twenty-four offices for selecting and promoting their personnel from "outside the current." Officials of demonstrated classical and literary abilities found it shameful to serve in the same office with these inferior men, and the obvious result was that administrative efficiency was decreased. Liu requested that Kao-tsung have these matters fully discussed 
and issue a decree to clarify the situation. According to one source, the emperor was willing to act, but "the great ministers (ta-ch'en) shrank from reform, "17 so that nothing was done.

As we shall see, Liu's views came increasingly to characterize the upper bureaucracy, particularly from the 680s when the sole ascendancy of the Empress Wu and her search for support in the lower bureaucracy brought her to attack the exclusivism and Confucian virtue which Liu so strongly advocated as necessary attributes of officialdom. Bureaucratic opposition in 657 is more difficult to account for, though the fact that only a small proportion of existing ministers possessed an examination degree may have been a factor in their reluctance to see the implementation of Liu's proposals.18 Rapid promotions were popular at all levels of officialdom except the very top, and an even more important factor working against change was the existence in the present system of opportunities for influential ministers to build a clientele by appointing friends and relatives from "outside the current." For rulers who aspired to a greater absolutism this privilege was a dangerous one, and its possible abuse was undoubtedly one of the reasons Kao-tsung and the empress turned increasingly to examination as a means of bureaucratic appointment.

To understand this development we must realize, first of all, that the T'ang offered technically five means of entry into the nine ranks of the regular bureaucracy. Of these, the three which accounted for the overwhelming majority of officeholders were promotion from "outside the current," possession of hereditary privilege $(y i n)$, and success in one of the examinations. 19. Although examination graduates probably accounted for no more than a tenth of T'ang officialdom, they became increasingly prominent in the highest ranks of government, and we find that by the Chou dynasty, for instance, almost forty percent of the tsai-hsiang were graduates of the system, compared with only one of Kao-tsu's fourteen chief ministers and four of T'ai-tsung's twenty-one. 20 it is difficult to avoid the conclusion that in the period under discussion examination was becoming an increasingly favored path to high office.21 Because I wish to demonstrate that this was the result of imperial encouragement and that examination was the single method of recruitment which claimed the special attention of the Empress Wu, I shall now explore in detail the changes introduced into the system during early T'ang.

The mechanics of T'ang examinations are already well-known through the translations of Robert des Rotours 22 but, unfortunately, the primary source of his research, the examination treatise of the New T'ang History, omits many of the empress' contributions to the development of the system. 23 As it existed from 622,24 the T'ang system consisted of examinations held only at the capital and divided into three stages. The first of these was the ch $\ddot{u}^{25}$ which by 657 had come to consist of two main examinations, the literary chin-shih and the classical ming-ching, as well as more specialized and less highly esteemed examinations in mathematics, law, history and calligraphy. These were held on a regular basis and were supplemented by irregular "decree examinations" (chih-chü) on specific

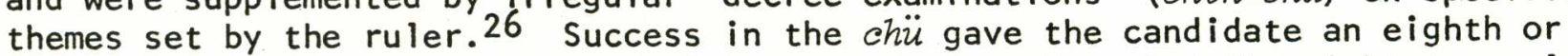
ninth rank "within the current," with no post nor salary but the right to apply for the second stage, the hsüan.

The hsüan or selection for a specific post was mandatory for those whose basic rank (san-kuan) was lower than five 27 and consisted of examination by the Three Selectors (san-ch'̈̈an), usually the president and two vice-presidents of 
the Board of Civil office. ${ }^{28}$ Under the procedure completed in 669 , the candidate presented a curriculum (hs̈̈an-chieh) and was then tested on his calligraphy (shu 書), his judgment of a hypothetical case ( $p^{\prime}$ an), his physical appearance (shen), and his manner of speech (yen).29 If he was successful, there were three further criteria (san-lei): virtuous conduct (te-hsing), [administrative] ability $\left(t s^{\prime} a i\right)$, and diligence ( $\left.Z_{a}\right)$. In this process it might be noted that the selectors enjoyed wide powers of discretion. A provisional nomination (ch'ang) was then posted with the candidate having the option of up to three refusals, and a final list (chia甲) was then submitted to the Chancellery for verification, approval and submission to the emperor. When the appointments were announced, the new official received a tally ( $f u$ ) and a patent of appointment (kao-shen). 30

The third stage of the system, the $k^{\prime}$ ao, ${ }^{31}$ was an evaluation of performance for the purposes of promotion. Details of its workings are scarce, but it seems that a report on the administration of each official was submitted annually to the Board of Civil office which in turn distributed it to the office concerned. All officials were ranked in one of nine categories, and the rankings technically were to be discussed and revised by a committee with representatives from the three departments before they were recorded, conveyed to the emperor, and made public. The ranking was made on a complicated system of "good qualities" (shan) and "perfections" (tsui), and a high score meant an increase of rank or salary or both. A low score meant fine or demotion. It was a complicated and timeconsuming process, and since the major responsibility rested with a handful of men within the Board of Civil office, 32 it could never have been too effectively administered. Two of the few extant descriptions of actual cases in the period suggest laxity of enforcement. 33

From the preceding summary two points of great importance emerge. First, the chü and hsüan were different in nature. The chü at its most basic level may be seen as an expression of the pristine purpose of the examinations, the recruitment of the ablest men into the ruling group. The hsüan, which only appeared in 628,34 served as a control, increasingly becoming a means to ensure that unsuitable or socially undesirable men did not hold high posts. Second, as office came more and more to be the determinant of status, the desirability of a degree made the examinations an ideal mechanism through which to exercise state control. The curriculum of the chï, for instance, could determine the values and attitudes of much of the bureaucracy while the criteria for success in the hsüan could control its size and composition and predict its internal tensions.

As we have seen, the Empress Wu came to power when the system was still in a formative stage. No major modification had occurred since 628 , and neither hsüan nor chü would take their final forms until the years 669 and 681 respectively. Several issues, some of them raised by Liu Hsiang-tao, remained unresolved. How could ability best be measured, and should it take precedence over "suitability"? If the hsüan in particular were to be seen as a means of state control, who represented the state, the ruler or his ministers? And who defined suitability? The empress had answers to these questions and though she unfolded them in stages, they might have been inferred from her opening move. In 659 a ceremony was held at the palace to honor 900 men successful in the chü and, after a quiz on current affairs, the top five were assigned to prestigious special positions. 35 The examination system thus became, at a stroke, the approved form 
of entry into the civil service.

The year 659, it will be recalled, was also the year of the Hsing-shih $2 u$ and the second of the T'ang marriage bans. Bureaucratization of the great clans, especially those in the Northeast, was the political priority, and it is to this end that initial recruitment policies were directed. Thus in the same month as the ceremony held for examination graduates, control of the Board of Civil office was taken from the hands of Kuan-chung aristocrats like T'ang Lin and Liu Hsiangtao, 36 and the presidency was granted to Li I-fu who claimed membership in the northeastern aristocracy. For the next three years, he exercised control over the hsüan, and his extraordinarily close identification with the empress is additional confirmation that she was more concerned with bureaucratic appointment than was her husband.

Although Li l-fu was more noted for corruption than for competence, his appointment was necessary from the rulers' point of view since the Board of Civil office had been in the hands of northwestern aristocrats since the beginning of the dynasty. Of the five holders of the top offices under Kao-tsu, for instance, all were from this group. 37 From the beginning their influence was great since at the time there were too few officials to fill the posts, and appointments were made on the basis of tallies ( $f u$ ) sent directly to the prefectures designating those who should come to the capital for appointment.38 With the creation of the hsüan in 628, this practice ended but by that time entrenchment had occurred within the Board. Under T'ai-tsung the only important officeholder not born into the group was Ma Chou, and his appointment came in 645 after he had formed a close relationship with it both through his career and his marriage. 39 The other incumbents of the Board during the period included representatives of such celebrated clans as the Ch'ang-sun, Liu, Tai, and Wei whose surnames were all preeminent in the Northwest. 40 Their monopoly, as we have seen, continued into Kao-tsung's reign.

As a group they had more in common than their regional and social origins. In the years prior to 659 , and counting only the twenty-five men who served as president or vice-president, more than half were related to each other either by blood or by marriage. 41 They seem, moreover, to have shared a certain exclusivist consciousness, with Wei T'ing, for example, scornfully incredulous that Ma Chou had reached such high posts in spite of his mean birth. 42 An interest or expertise in status and genealogy may also have been common since the two men chosen by T'ai-tsung to head the compilation of the Shih-tsu chih were plucked directly from their positions in the Board of Civil office. 43 The collective influence of Board members on the government must also have been great since over forty percent enjoyed tsai-hsiang status concurrent with their selection duties, and of these most were connected with the Chancellery whose role in the selection process was greater than that of the other Departments. 44 Their biographies suggest that some were responsible for the recruitment of thousands to the civil service and that the opportunities for the building of personal bases of support were not neglected. It was probably these men who aborted the reforms suggested by Liu Hsiang-tao in 657. It is worth noting, finally, that only three men who held the top positions in the Board prior to 659 had themselves taken examinations. 45

When Li I-fu became president in 659, he was already notorious for the selling of posts and, although his tenure seems to have served the purpose of bringing 
more northeasterners to the capital, 46 his conduct in office did not change. In 663 he was tried for gross peculation with many members of his family and sentenced to distant exile (ch'ang-Ziu) from which he never returned. 47 Liu Hsiangtao, who had been Li I-fu's judge, replaced him as president of the Board, and of the six presidents and vice-presidents between that time and 669, three were from the Northeast, two of them representatives of the great aristocracy. 48

In the decade following 659, it seems likely that the empress believed she had succeeded in achieving the social and regional balance which had been her first priority in the reform of the recruitment system, because in 669 she moved to the second stage. This consisted of systematizing the hsüan, and the man placed in charge was P'ei Hsing-chien. 49 A scion of one of the eminent Shansi clans, $P^{\prime}$ ei had qualified by $y i n$ to enter the state university, had passed the mingching examination, and had seemed assured of a brilliant career until his opposition to the elevation of Empress Wu sent him to the borders in disfavor. His administration in the An-hsi Protectorate had shown that he was a man of unusual talent, and he was recalled to the capital where he became vice-president of the Board of Civil Office, probably in 669. Only one source gives a reason for the reform, suggesting that "since Zung-shuo [661-664] a great number of unworthy officials had been appointed,"50 and the reference is probably to the difficulty of stemming the corruption begun by $L i \quad 1-f u$. Since the number of candidates was increasing each year, even with honest officials in charge of the hsüan, methods of deception were being found, and the New T'ang History tells of forged tallies, false identities, and various sorts of cheating during the examinations. 51 Since, however, similar criticisms were to continue for some time, a more basic purpose of the reform of 669 was probably to mold officials to the empress' purpose. Certainly it is this aim which is reflected in the new regulations.

$\mathrm{P}^{\prime} \mathrm{ei}$ and his colleague in the reform, Li Ching-hsüan, ${ }^{52}$ proposed not only the form of the hsüan as outlined earlier but were also responsible for the "long list" (ch'ang-ming pang or ch'ang-ming hsing-li pang). 53 The nature of the list has long been a puzzle to scholars who generally conclude that it was simply a list of the candidates eligible for posts and was designed to combat fraud and bias. 54 The earliest sources, however, invariably use the term hsing- $Z_{i}$ in referring to it, and this coupled with other evidence suggests that the list was related to the bureaucratic career of other members of the candidate's clan. 55 It was also an admission that anonymity was undesirable, and when it was suppressed in 683, the reason given was that it had become an instrument of preselection and bias: "When the long list was posted, all knew who would be chosen."156 Family background was, therefore, almost certainly a formal consideration in the hsüan, and this is wholly consistent with the evolution of the institution and with the spirit of the other provisions of the reform.

The reorganization of 669 was in many respects an affirmation of the status quo, in no sense designed to open the road to advancement to the lower orders. It seems designed rather to bar from office all but those with some prior bureaucratic connection, and it is important to note that the early prohibition against the candidacy of merchants, artisans, and other despised professions as well as relatives of felons, remained in force. 57 The existing elite, consisting of relatives of the imperial clan, possessors of the yin privilege, some holders of honorific rank (hsün-kuan) and members of their immediate family, as well as graduates of the state universities remained eligible for the hsüan 
without prior examination. 58 At the same time, all candidates needed an introduction from a local official and the signatures of five capital officials as guarantors $(p a o)$. One of these was to have personal knowledge of the candidate. 59 In the interview only those "tall and handsome" and whose speech was "judicious and precise" were to be chosen, 60 so that a man of rustic background would have little chance. And finally, the categories of "virtuous conduct," "talent," and "diligence" were nebulous enough to give the Three Selectors virtual veto power. The Board of Civil Office thus retained control of appointment to officialdom.

The Empress Wu must have approved of these measures, for not only did Kaotsung ratify them, but he left their authors in command of the Board for the next seven years.61 This is an inconvenient fact for those many scholars who wish to see the empress fostering a "new class" through the examination system.. Their view, of course, gains validity from the 680 s onward, but the provisions of 669 should be seen in the context of their time and as measures consistent with her aims and methods. As noted earlier, she worked in stages, and the immediate task was to confer prestige upon bureaucratic service and examination as a means of entry into it. After the ad hoc recruitment methods by which the early T'ang had tried to cope with the shortage of officials and which by 657 had produced a bureaucracy of very mixed origins, this was crucial. There is ample evidence throughout the century to show that those with social pretensions were reluctant to serve in office with their inferiors. 62 The empress was conscious of this. As pointed out earlier, she held no enlightened egalitarian views and, what is even more important, she had at her disposal a large pool of prospective officials with respectable shih lineages. Only one source mentions a decree from the end of 669 which also facilitated the entry to regular officialdom of clerks and minor functionaries in certain Boards. 63

The immediate effect of the reform, according to the New T'ang History, was that "from that time those who sought official posts became extremely numerous." 64 The immediate addition of a second vice-president charged specifically with the examination function is one reflection of this and the board membership was to be repeatedly increased through the rest of the century. 65 The settling of the hsüan also enabled the empress to turn her attention to the chü, and from 669 her efforts were devoted to fastening the examination habit on the country. In the next few years, for instance, the centers and opportunities for examination were extended even to the most distant prefectures of the South, special honors like the ta-ch'eng were granted to top graduates, and in 670 a decree was issued to restore the schools and Confucian temples in the countryside.66 Decree examinations began to occur with greater frequency than before.67

Literary evidence will shortly be introduced to show the rapid response to the growing imperial patronage of the chü, but it is useful here to introduce the sole source of statistical information on successful examination candidates in the T'ang. This is Hsü Sung's Teng-k'o chi $k^{\prime} a o$, a Ch'ing work based upon a listing in the Wen-hsien t'ung- $k^{\prime} a 0.68$ it has been shown to be unreliable in some respects, but there seems to be general agreement that the figures given for chin-shih graduates are accurate.69 If so, the year 669 appears to have been something of a dividing line. From 664 to 668 an average of nine men passed each year. In the years 670-674, when the examinations were held only three times, the average was thirty-eight! Likewise, if Kao-tsung's reign is divided at 669 , we find that prior to that year, the average annual number of successful candidates was fourteen, while after 669 the corresponding figure was forty-eight.70 
From these figures it seems safe to conclude that during the 670 s examination was gradually becoming the preferred form of entrance into the civil service, at least for those who aspired to the highest ranks. Needless to say, there was resistance. In 674 a memorial complained of the increasing reliance upon literary ability in selection and the frequency of cheating among candidates, going on to say:

When the Board of Rites [sic] chooses officials, it relies solely upon literary ability in ranking [the candidates], and thus the shih of the empire all disregard virtuous conduct and hasten to [practice] the literary arts. There are those who pass an examination in the morning and at night face criminal charges. Although they recite 10,000 words in a [single] day, what relation does this have to governing the state?71

In 678 Wei Yüan-chung, a student at one of the state universities, commented on the reasons for recent defeats by the Tibetans, suggesting that

the important [things] in governing a state are both civil and military. Now those who speak of civil [virtue] consider elegant expression to be first [in importance] and do not attain to moral principles (ching-Zun). Those who speak of the military emphasize horsemanship and archery, not strategy and tactics. 72

Even within the Board of Civil office there seems to have been some dissatisfaction and, two years later, an auxiliary secretary, Liu Ssu-li,73 submitted an extremely important memorial which provided the immediate impulse for change. In it he stated that

most [examination candidates] in the ming-ching do no more than copy out fragments on the general meaning [of the classics], and chin-shih candidates only reproduce by rote former dissertations in answer to the questions ( $t s^{\prime} e$ 皮). They are without real talent, and the officials concerned [with marking them] accept them without taking into account anything but the number [of candidates] to accept. 74

These different perspectives of the critics must have represented a wider spectrum of discontent, for the New T'ang Histom speaks in graphic terms of numerous

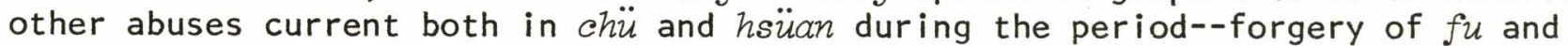
kao-shen, impersonation, and rustic unknowns finding guarantors at the capital. It tells how on the examination day some candidates were aided by others inside or outside the halls, and how they often paid someone else to write the examination for them.75 Partly as a result of corruption, men became qualified for positions which simply were not available and sometimes waited months or even years for an assignment. 76

To what extent this situation reflects any conscious policy on the part of the empress is difficult to say. P'ei Hsing-chien and Li Ching-hsüan, who were in charge of recruitment through most of the period, were both noted for their enthusiasm in recruiting. 77 The empress herself, ever since Kao-tsung had attempted to abdicate in her favor in 675, was bearing an ever greater burden within government, beginning what was virtually a regency in 675 under the cloud of whispered accusations that she had poisoned Crown Prince Hung. The failure of the ch'ien-feng coinage was obvious by the 670s, and to the embryonic economic difficulties this caused were added the foreign policy reverses which, as we shall see, began late in the decade. For these reasons the examination system could not claim her whole attention. On the other hand, since she was anxious 
to promote the desirability of examinations, she may have seen laxity of selection as an advantage and so permitted its continuation. By 681 , however, it appears that the effects of corruption were destroying respect for the system, and this she could not permit. Thus in that year, and principally in response to Liu Ssu-li's memorial, the form of the major examinations was settled, and there was to be no substantial change until 737.

Since there is some contradiction among the sources, I present the facts describing the reform in tabular form, with the new features of 681 underlined.

Source Ming-ching Chin-shih

TTCLC 106:

18ab (dated 681, eighth month)

HTS 44:

3737:2.

[des Rotours,

Excomens, pp.

152 and 167.]

THY 75,

pp. 1375-6.

(a) Same.

(b) Same.

(c) Same.

TT 15, p.

$83 a$.

T'ang Chih-yen

I, p. 9. (a) Successfully respond to 6 out of 10 citations or $t^{\prime} i e h$ from the classics.

(b) [Respond orally to 10 questions on the general meaning of the prepared classics. Probably two classics were chosen.]

(c) Afterwards, give [3] dissertations in answer to questions on current affairs. TTLT 4:4b indicates that this may have been oral.
(a) Same.
(b) Same.
(c) Same.

(a) [Answer citations on one major classic and perhaps others.]

(b) Write two compositions of different literary forms or tsa-wen. [These could be, for instance, remonstrances, inscriptions, memorials or, later, poetry.]

(c) Afterwards, write [8] dissertations in answer to questions on current affairs and on the Tao-teching.

(a) Same.

(b) Same.

(c) Only those showing thorough knowledge of literary principles (wen- $z \ddot{u}$ ) would advance to this stage.

(a) Same.

(b) Same.

(c) Must have knowledge of literary principles before proceeding.

(a) Same.

(b) Same.

(c) Same as in THY.

(a) Reform incorrectly dated and Liu Ssu-li incorrectly identified. 
Chin-shih

CTS 190

chung: 3582 :

2.

$(\mathrm{i} i \mathrm{i})$

Notes: (i) For the classics on the curriculum for each examination and the

(a) Reports that Liu Ssu-1i was responsible for adding to the number of citations.

(b) Those of great literary talent should proceed. Suggests that the candidate needed to write only one dissertation until 685 , when three were required.

(a) Reports that Liu's request added tsa-wen to the chin-shih examination. categories into which they were divided, see des Rotours, Excomens, pp. 136-38; 142, n. 3 ; and 147, n. 1 .

The exact number of citations and dissertations varies widely in the different texts, and none of the above are specific as to the number in 681 . The number of citations differed as to the number and length of the classics chosen for presentation by the candidate, and in the chin-shih no source offers a clue to the number at this time. After 737 it was necessary to answer 4 out of 10 . In the matter of dissertations, the chin-shih had 5 at the beginning of the dynasty, and in 675, 3 more were added on Lao Tzu. In 737 the Tao-te ching was moved to the t'ieh section. TTLT 4: $4 b-5 b$, is the most complete description of this aspect of the system prior to 737 for both ming-ching and chin-shih. The HTS reproduction of it is faulty.

In 634 the chin-shin also required a memorized oral recitation (or reading?) ( $t u(\bar{v}$ ) from the classics or histories and, judging by Liu Hsiao's memorial of 674 (note 80 ), this may still have been in force.

The reforms of 681 are best regarded as a response both to the growing popularity of and confusion about the chï and to the ease with which a degree was won. They are, moreover, not entirely a response to criticism for, if anything, literary ability became even more necessary. Rather they express what seems to be an imperial awareness that the time was now ripe to use the examinations to create a particular type of official. The addition of the Tao-te ching to the curriculum in 675, a measure noted earlier, was an obvious first step, and the form given the two major examinations in 681 was the second.

Specifically, the chin-shih now became the most prestigious and desirable of degrees. Hu San-hsing, remarking on the situation in the ninth century, was to say: "In the T'ang the chin-shih was highly valued while the ming-ching was scorned. A proverb said that while the fragrance of incense celebrated the chin-shih, a screen was erected for the ming-ching. ${ }^{1178}$

$\mathrm{His}$ view is borne out by numerous anecdotes and contemporary observations after the 680s, 79 and it must, therefore, be understood that the renown which the chin-shih came to enjoy was the creation of the Empress Wu. In the early part of the dynasty it was the hsiu-ts'ai whose difficulty led to its abolition 
in 651,80 and after 658 the "decree" examination, which seem to have monopolized prestige, and even the ming-ching was considered by the throne to be a more formidable achievement. 81 Judging by the number of tsai-hsiang who had chosen the ming-ching over the chin-shih prior to 705, the former seems early to have been as important a qualification for high office as the latter. ${ }^{2}$ By the reign of Hsüan-tsung, however, only three of his twenty-six tsai-hsiang had opted for the ming-ching, and since almost all of them made their choice of examination after 681 , the change in preference was a rapid one. 83

Several factors account for the comparative popularity of the chin-shih, most of them stemming from the reform of 681 . The examination was now the more difficult of the two, requiring both classical knowledge and literary skill, and we are told that the success rate was soon only one-tenth of that in the mingching. 84 The difficulty of the chin-shih was certainly real, but it was a particular sort of difficulty. Although it placed less reliance on pure memory, it also required a less rigorous, lengthy and costly training in the classics. It tended to appeal, therefore, to the most intelligent members of a somewhat lower stratum of the shih class than did the ming-ching, and its popularity in this stratum was enhanced by the fact that in it the scope for corruption and favoritism was narrower. As we have seen, the Board of Civil office was largely the preserve of the great aristocracy, and in the second or oral stage of the ming-ching subjective judgments were all-important. 85 Finally, the role of imperial patronage was crucial.

The Empress Wu, as we know, was deeply and sincerely devoted to literature. From the appearance of the North Gate Scholars around 666, her closest associates if not particularly distinguished for political talent, all had literary ability, and in the course of her career she was to turn her hand to most literary genres. 86 Many of her extant edicts reflect the contemporary belief that "the ancient dynasties chose officials for their literary ability (wen), since the origin of [good] literature is conduct (hsing 行), and conduct is known through words."187 Thus in the tsa-wen section of the chin-shih, she held out the promise of due and lavish reward for those of literary talent, and since the ming-ghing required only a "rough command of literary principles" (ts'u yu wen2i), 88 it became much less attractive in comparison.

A more cynical interpretation of the empress' motivation is also possible given the fact that the two examinations produced different types of officials. Since both her present role and that which she was destined to play shattered precedent, the deemphasis of the Confucian classics in the chin-shih could only be of advantage to her. For a would-be absolute ruler any division within the upper bureaucracy was to be exploited, and increasingly the prestige of the chinshih relative to other degrees could be useful for that end. 89

Finally, we might note that in 681 the chin-shih examination became preeminently a test of literary ability 90 and, as many contempories noted, it produced an official who was articulate and facile, elegant and competent in language, versatile but somehow superficial and lacking in the self-confidence which might arise from a sense of personal worthiness. The old values of virtue, integrity and right conduct, which theoretically gave the chün-tzu the right to participate in the process of rule, were passing or rather were being surrendered, thereby a tacit admission was being made that it was the ruler who set the standards by which he would judge his aides. Under the Empress Wu office, status, and 
self-image came to depend upon an institution which existed through imperial patronage and sufferance and as a result, the relationship between ruler and minister began a transformation which would end in what some scholars term the "Sung despotism." When the empress wrote her two-volume "Model for a Minister" ( $C h^{\prime}$ en-kuei) and in 693 made it part of the examination curriculum, 91 she was only making explicit the ruler's new power to set the standards for judging aides.

There were, as I have said, some officials who recognized what was happening and had the courage to speak up against it. Among them was Wei Hsüan-t'ung, a chin-shih graduate and in 685 vice-president of the Board of Civil Office.92 His memorial that year was basically a criticism of the Board of Civil Office and its selection practices, and in providing documentary evidence of the results of recent examination policy, he also isolated the root causes of what he saw as the problems. His critique began with a short history of the recruitment policies of early dynasties, recognizing the novelty of the examinations and characterizing their literary emphasis as "the modern way of power [politics]" (chintai chih ch'üan-tao). He then turned to the inadequacies of the Board of Civil office, pointing particularly to the small number of officials who had sole charge of a task of great magnitude and importance, and to the ease with which the Board was intimidated by men of influence to appoint their protégés so that, in effect, the state was "buying stolen goods from thieves." He went on to speak of the desirability of holding office and the plethora of candidates so that even though 1,000 chu-se "entered the current" each year, the shortage of vacancies meant that only one in ten actually received an appointment. So confused was the system that "stones were not divided from jewels," meaning that those who did gain office were not always chosen for the right reasons.

His solution to the problem was to return to some degree to earlier practices whereby the task of selection was shared widely among high-ranking officials who knew the characters and talents of their subordinates, while only the top officials were appointed by imperial order (wang-ming). Although Wei avoided the use of the term, he was actually advocating the restoration of the $p^{\prime} i$-chao system referred to earlier.93

Broadening his argument, he spoke of the necessity of learning (hsüeh) for one who would be an official. The ancient practice whereby young men were schooled in the "six proprieties" and "seven teachings"g4 before entering officialdom was superior to the present way whereby the sons of the wealthy and influential received posts even before reaching the age of twenty and in most cases were unprepared by education or character training for their responsibilities. The whole system of education suffered from the fact that these appointments were so lightly made. Moreover, said Wei, appointments from "outside the current," and particularly from the holders of honorific rank (hsün-kuan) and the Guards (sanwei), were not made by their local superiors but by a test of their calligraphy and judgments (shu-p'an).95 Again this meant that virtue and conduct were denigrated. Even the process of recommendation was badly handled since it was not only officials above the third rank who were so frequently given the privilege but all officials "within the current," and since the ruler showed little concern with the process, the recommendations were made randomly and excessively. Wei concluded by calling for a division of the selection powers of the Board of Civil office and a return to the recruitment system of the Chou and the Han.96 
This memorial, whose sentiments were soon to be echoed by those of other critics like Ch'en Tzu-ang, 97 is interesting on several grounds. We find, for instance, that several of the problems isolated thirty years earlier by Liu Hsiangtao had remained unsolved and, at the same time, that the reforms of 669 and 681 had not been wholly successful in producing the ends for which they were designed. This memorial, moreover, is one of the clearest statements we have which argues against use of the examinations as a mechanism of social mobility for the lower orders. The wealthy and influential continued to manipulate the selection process for their own advantage, and birth, Wei indicates, was still of greater importance than talent in gaining office. His perceptions, however, go even deeper than this, for he makes the crucial connection between the form of the examinations and the "modern way of power politics." In this statement lies a recognition that when literary ability was emphasized over virtue and conduct, the self-image and self-respect of the official were under attack, that he was regarded as an instrument or tool of the ruler rather than as a rightful and deserving aide in government.

His memorial, however, was not well-timed and it elicited no response. The Empress Wu had just deposed Chung-tsung and was ruling through the ineffectual Jui-tsung, attempting at the same time, of course, to bolster her own legitimation. She was not interested, therefore, in placing barriers on the road to office, and was even less desirous of producing officials of strong character whose "virtue" might lead them to oppose her unorthodox role in government. As we have seen, after 684 she was moving in fact to facilitate entry into and accelerate promotion within the bureaucracy and, moreover, she continued to patronize examination as the favored path to high office. In 689 she demonstrated publicly what the role of examination was to be in the dynasty she was soon to declare when "she examined the candidates [herself] at the Loyang palace and after [questioning them] several days, she dismissed them [since none met her standards]." 98 In this event are to be found the origins of the famous Palace Examinations ( $t i e n-s h i h$ ) of later centuries, though for the empress it was simply the logical last step in the evolution of her policy of conferring prestige upon the system. 99

The Chou dynasty was to see continued rapid rise in the popularity of examination, and in 691 a memorial, which again complained of the emphasis on literary ability in selection, graphically told of how at examination time the candidates swarm to the [gates of the] offices [in charge]. They request to visit the fowerful and wealthy to display their poems, memorials and [other] writings, seeking the benefits of [being able to use] fine words. Packed together they hope for the favor of support. Therefore, people commonly speak of the candidates as mi-chü. The term 'mi' means 'self-seeking' (tzu-ch'iu).100

The author went on to request a greater measure of practicality in the examinations, the replacement of "fancy and empty verbiage" by the discussion of practical policies. He recommended further that before permanent appointments were made, candidates hold provisional office for a period so that the selection officials would have time to assess their performance.

The empress is said specifically to have rejected these suggestions but, as we have seen, she was then much concerned to bolster her personal support and if, as seems to be the case, the examinations were still being manipulated by "the powerful and wealthy," her attempts to win popularity among the lower 
stratum of the shih, who were the chief beneficiaries of her examination poli$c y, 101$ would be frustrated. It was for this reason that she made another historic innovation, the introduction of the principle of anonymity (hu-ming) into the examinations. 102 Although she was forced to abolish the usage in 695,103 the precedent had been set for later rulers.

The Chou dynasty saw other measures designed to rationalize and extend the examination principle, the most notable of which was the inauguration of the military examination ( $w u-h s \ddot{u} a n$ ) in 702.104 Criticism continued but it is of great significance that its form now was changed. No longer was the principle itself questioned. Instead, men attacked the failures in administering the system, focusing most often on the various irregular forms of appointment and promotion which the empress used to supplement it and which resulted in the wellknown abuse of the "supernumerary officials" (Zan-kuan). Typical of this sort of criticism was a memorial in 695 from Wei Ssu-li105 in which he lamented the decline of classical education caused, he believed, by the fact that appointment to office had come to be based upon carelessness and corruption within the system, upon what he termed "lucky chance" (chico-hsing). It was still those of the great houses (kuei-men) who obtained positions, and often without examination or even prior study, so that officials, particularly at the local levels, were not only becoming increasingly mediocre but harsh and self-seeking. He advocated a thoroughgoing reform in education along with a tightening of recruitment procedures.

Implicit in his memorial, of course, is a lingering feeling that character and virtue were too little regarded in appointment, but the greater issue was what was happening to the bureaucracy itself. In a subsequent remonstrance, 106 he made this clear, pointing out that both entry into and promotion within the bureaucracy were carried out in a most careless fashion with the natural result that officials and would-be officials competed against each other and curried favor in a most unseemly fashion. There were no longer enough posts to absorb

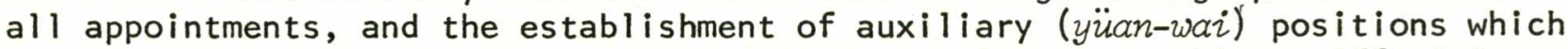
far outnumbered the regular ones had failed to solve the problem. Officials were in an uproar as they waited for lengthy periods to receive their appointments, and state revenues were being exhausted for their upkeep. Although Wei Ssu-li was in this case speaking of the situation in 709, he was also describing the outcome of the policies of Wu Tse-t'ien.

In short, the Empress Wu had in the space of only a few decades brought about a significant change in officialdom. On the surface, the change appears circular rather than linear, for Wei's fears--careless selection and too many officials-seem exactly to parallel those of Liu Hsiang-tao in 657 . There was, however, a crucial difference. The form taken by the empress' patronage of examinations had now concentrated in the highest ranks men who had qualified for office both by examination and by birth, so that in the year of Wei's first memorial, for instance, only four of the twelve tsai-hsiang were exceptions to this rule. 107 This meant that the old division of the bureaucracy at the fifth rank 108 had in fact hardened under the empress, and that below it was to be found what we might term in highly qualified usage the "newly rising class"109 of the late seventh century.

This configuration explains the principal tensions within the Chou bureaucracy. The upper ranks felt threatened, almost overwhelmed by the sheer numbers of those 
pressing from below, "unqualified" and "unsuitable" men eager to seize their positions and emoluments. I shall later show that the empress only belatedly realized the existence of this fear, that her attempts to deal with it were ineffective, and that her failure was an important factor in the seeming paradox of 705: the fact that her deposition was the work of officials who owed their own rise to the expanded opportunities she had offered through the examination system.

A complete description of the composition of the lower bureaucracy in this period is very difficult because our sources tend either to be vague or deprecatory in character. Liu Hsiang-tao, it will be recalled, listed a number of posts in the departments and the courts which seemed to have become the preserve of men appointed from "outside the current,"110 and the critics thus far mentioned confirm that men of Ziu-wai origins consistently entered the bureaucracy in great numbers and perhaps in increasing proportions. Who were these men?

The Ziu-wai officials, who were often referred to along with an even larger

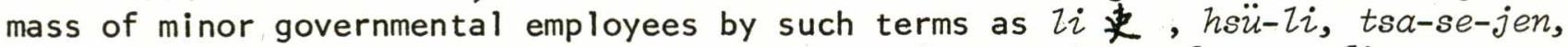
etc., outnumbered officials "inside the current" by at least four or five to one and were employed both inside and outside the capital in fairly routine clerical or guard positions.111 At the local level, many of them were appointed directly by the prefect 112 so that the central government had very little control over their quality. Certain categories whose responsibilities were greater, as well as those who wished to serve in the capital or possess formal Ziu-wai status, were compelled after a certain term of office to undergo an examination called the hsiao-hsüan.113 This examination was administered by a superior secretary (Zang-chung) in the Board of Civil Office and seems not to have been very demanding. After a successful transfer into the "current," advancement was possible on the basis of annual merit assessments, though men who began their career in this way were barred specifically from the "pure" offices114 and so were seldom able to reach the fifth rank without special consideration.

It is difficult to find clues to the social origins of the $h s \ddot{u}-l_{i}$, though one source suggests that under T'ai-tsung they were often chosen from the superior category of household (shang-hu) in each prefecture.115 Whether or not this remained a consistent policy we cannot be sure, but it seems certain that they were of lower status than most of the central officials in the early T'ang, and this would account for the reluctance of the latter to be associated in office with them. We know also that certain offices were reserved for them and that in the Chou an attempt was made to take away some of these posts and grant them to examination graduates.116 For some posts the possession of honorific rank (hsünkuan) seems to have been a requisite, 117 and this compounded the problem since this privilege was progressively devalued by the Empress Wu through its too frequent bestowal.

Honorific office, which was itself considered Ziu-wai, had originally been granted as a reward for outstanding military service, was limited to 900 men, and was considered nominally equivalent to regular offices of high rank. It carried with it certain privileges like tax and corvée exemption, the right to acquire land, and the right of sons to enter officialdom by hereditary privilege. 118 Its recipients, at least in the early years of the system, were from that stratum of society which entered the military, and perhaps the fact that the Hsing-shih $Z u$ was christened the Hsün-ko by the aristocracy suggests a contempt for awards of this sort as early as 659. Although it is difficult to 
document the process, evidence from the eighth century would seem to indicate that a fairly rapid devaluation of the awards had occurred in the late seventh, with lavish conferrals made not only as military activity accelerated, but also for non-military merit and even in return for money payments. 119 By the $k^{\prime} a i$ -

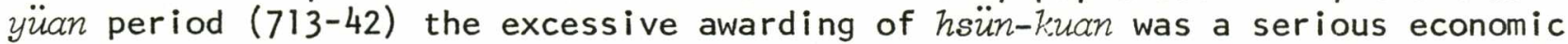
problem for the state, but in the seventh century its significance seems to have lain more in the additional pressures it placed upon the regular bureaucracy, as its recipients or their sons converted the rank to substantive office. One scholar estimates the awards in the seventh century at over 10,000,120 and since the liu-nei bureaucracy, counting only regular appointments, numbered less than 20,000 even in the eighth century, this pressure was not negligible.

As I have attempted to show, the role of the Empress Wu was a critical one in this particular trend. The nature of her search for legitimation was such that she was forced to seek additional bases of support outside the constituency of the higher-level bureaucracy which continued to be highly aristocratic and Confucian in tone even as examination became more common as a means of entry. Men who began their official careers in the $Z i u$-wai bureaucracy which continued to be highly aristocratic and Confucian in tone even as examination became more common as a means of entry. Men who began their official careers in the liu-wai bureaucracy presumably tended to be less well-educated and less committed to Confucian strictures against female rule. Particularly because the existing system slowed down their careers, 121 these men were also natural targets in the empress' search for popularity. We find, therefore, that after the 680 s several new $2 i u-$ wai positions were established 122 and, more importantly, that promotion "within the current" seems to have been accelerated. According to Ssu-ma Kuang, with the feng-shan sacrifice in 666 the empress began to advance officials rapidly "within the current" on numerous auspicious occasions:

Prior to this, rank (chieh) was not excessively increased but awarded by examination of merit $\left(k^{\prime} a O\right)$. [For] advancement to the fifth and to the third rank, [a special procedure of] tsou-ch' $\ddot{u}$ chin-chih [was followed]. At this time began the practice of excessive award, and in later years the court was thronged with those wearing the purple robes [of high officials]. 123

Su Mien was to comment in the early ninth century on the "excessive promotions of [imperial] favor" (fan-chieh chih en) 124 in this period and, as we will see, the historian Liu Chih-chi was to remonstrate frankly about it in the middle of the Chou.

We must bear in mind, however, that complaints of this sort were often exaggerated and represent more accurately a fear of upper-level bureaucrats than an actual situation. Of all officials who reached the fifth rank, a group of about 4,000 men, only a few could have done so through transfer from Ziu-wai status, and the "pure" offices seem to have always remained untainted.125 The effects of the process seem rather to have been, first of all, the growth of widespread support for the empress in the lower bureaucracy and, secondly, a strengthening of imperial prerogative as each "promotion of favor" weakened the concept of merit and earned status within officialdom. Within the lower bureaucracy, a good deal of evidence can be adduced to show a certain deterioration of quality and of the idealism of its members. 126 As these men became increasingly defensive, jealous of their perquisites and ambitious, officials in the "clear stream" struggled to enforce obstacles to their further rise. The case of Chou Hsing whose early 
career was hampered because his origins were not of the "clear stream" is a good example. 127

His case was not unique. Within the bureaucracy of the Chou and succeeding periods, intra-bureaucratic strife accelerated and began rapidly to take on characteristics of a different nature from the factionalism of the early $T$ 'ang. From the later part of Kao-tsung's reign onward, cohesive groupings among high officials, especially among tsai-hsiang, were often directed against the lower bureaucracy, and there are numerous examples of action taken against colleagues whose origins and rise the tsai-hsiang regarded as unconventional.128 The tsai-hsiang who had united in 654 against Kao-tsung's choice of the Empress Wu represented perhaps the final assertion in the seventh century by the ministers of their right to set the limits of imperial prerogative. When a parallel situation arose in the Chou over the empress' designation of a successor, she was able simply to declare it a household matter and to go unchallenged until 698. Even then, the objection was raised by a single minister, and one whose position in the empress' trust was unique.129 As Chapter 9 will show, her view of selection had been determined consistently by her wider political aims, and in the Chou her attention was to be focused upon the upper bureaucracy as the key to her achievement of legitimacy. Her attempts to mold it to her purposes, often using men from the lower bureaucracy as her aides, account for much of the political strife in the period. And the fact remains that by the Chou, the position and the aspirations of the upper bureaucracy had been changed.

To understand this more fully, let us recapitulate our findings on the evolution of the selection system and their political ramifications.

The political policy of the empress unfolded in stages, with the years 654 to 660 devoted chiefly to working out the nuances of her partnership with Kao-tsung, to the elimination of her ministerial enemies and to the weakening of the exclusivistic political control of the remnants of the Six Garrisons bloc whose dominance had been so marked both in the Sui and the early T'ang. In 659 she and Kao-tsung put into effect a series of measures designed to complete T'ai-tsung's policy of bringing social status into line with service to the T'ang and were more successful than he in enticing the aloof aristocracy of the Northeast to accept office in the capital. The fact that the Empress Wu was by that time almost an equal partner in government and was not a member of the Kuan-chung bloc undoubtedly facilitated the achievement of this aim, and an examination of the backgrounds of the tsai-hsiang listed in Appendix B offers empirical evidence that a high degree of success was in fact achieved.

The next decade was devoted to consolidation. A genuine centralization began to take hold, and the rulers felt confident enough of their primary goal, the continuance of the dynasty, to celebrate the great feng-shan sacrifice, to launch their all-out attack on Korea, and to permit the empress' emergence from behind the screen to an active and open role in politics. In 669 she took the important step of reforming and rationalizing the hsüan, a measure designed not only to fasten the "examination habit" more closely upon the country, but also to create within the existing power structure a greater feeling of security, to reassure its members that no flood of low-born shih would threaten their prerogatives. This does not mean that she failed to anticipate that applications for examination would increase rapidly and would come largely from a stratum of society not altogether acceptable to the existing elite in the upper bureaucracy. Once that process was under way, she undertook the reform of the chü in 681 , justifying 
the measure on the ground that it combated this trend. By incorporating a greater degree of difficulty into the examinations, it purported to bring the number of appointments more closely in line with the number of bureaucratic vacancies. Her real motive, however, was to turn the examinations into a bureaucratic control mechanism, and the absence of serious opposition in 681 is something of a tribute to the skill of the empress' policical timing.

The death of Kao-tsung and the prospect of a weak successor precipitated a crisis. The empress saw her work as incomplete or at least realized that it could easily be undone, and so launched the two most notable political events of the 680s: the influx into the bureaucracy's lower ranks of officials whose social status was low but whose advancement was rapid, and the terror which all but eliminated officials above the fifth rank. The decade was, therefore, much more than a preparation for usurpation. It was also the period which saw the severe weakening of the tsai-hsiang and the entire one-tenth of the bureaucracy which made up the "clear stream." Positioned squarely between two pressures, one above and one below, they opted first to defend themselves against those who would replace them, and so mounted no collective action against the terror. As a consequence they were unable to protest in concert against the one female usurpation in Chinese history. 


\title{
Chapter 8
}

\author{
CHINESE ARMS AND FOREIGN POLICY TO 684
}

The middle decades of the seventh century marked the zenith of the Chinese empire. Never before and never again would the Son of Heaven lay claim to so great an area outside the Wall and exact from it at least a nominal allegiance. Seldom would the arms of a purely Chinese dynasty venture so far afield to win the impressive if ephemeral victories that were so frequent during that period. It was a time of confidence and expansionism, a time when uncounted "barbarians" were incorporated into the Middle Kingdom and when tribute reached $\mathrm{Ch}^{\prime}$ ang-an from as far away as India and Indochina, from Persia and the oasis states of Central Asia, from Japan and the Korean peninsula. And with the tribute came requests for state marriages and alliances, for instruction in classical learning, Confucian statecraft and Buddhist theology. Life in Ch'ang-an and Loyang reflected what seems to have been a more generalized cosmopolitanism. Selfconfidence in the visual arts, in music and manners, and even in styles of clothing, 1 and the vigor and richness of foreign influence was seldom to be recaptured in later ages. It was also a time of great generals, men like Su Tingfang, Li Chi, and P'ei Hsing-chien, whose proud armies covered distances and endured hardships which stagger the imagination, and whose triumphal processions were regular events in the capital during the $660 \mathrm{~s}$ and $670 \mathrm{~s}$. It is not surprising that the Empress Wu was able to boast in 684 of how Kao-tsung, and by implication herself, had expanded the empire ( $\left.c h^{\prime} a n-y \ddot{u}\right)$ and had brought to submission areas beyond the reach even of the legendary $Y \ddot{u}$ and $T$ 'ang. ${ }^{2}$

These achievements did not necessarily belong to the Two Sages alone. Obviously they were erected upon the foundations laid by T'ai-tsung. There was also a less attractive side to the picture. From the time Empress Wu came to power scarcely a year went by without military action in some sector of the empire, and for the peasantry military corvée and troop levies were an unpleasant and unavoidable fact of life. When in the last decades of the century the state proved unable to sustain the costs of empire, the raids of rebellious former "subjects" took an enormous toll in lives and property, and agriculture was seriiously disrupted as more and more men were taken from the land to serve with expeditionary or with garrison forces. The last half of the seventh century, therefore, represents the downward slope of a cycle, a progression from expansive ambition to defensive insecurity. The chou saw the beginnings not only of an explicit and coherent isolationist sentiment at court, but of a more generalized contempt for the military arts and a distaste for government service among the people--phenomena reflected, for instance, in the establishment of military examinations in 702 and in the growing incidence of vagrancy during the period.3

This seeming paradox is not difficult to explain and rests chiefly upon weaknesses inherent in the T'ang system of military recruitment and colonial administration. What generally goes unrecognized, however, is that the foreign policy of Kao-tsung and the Empress Wu was not by choice an expansionist one. This 


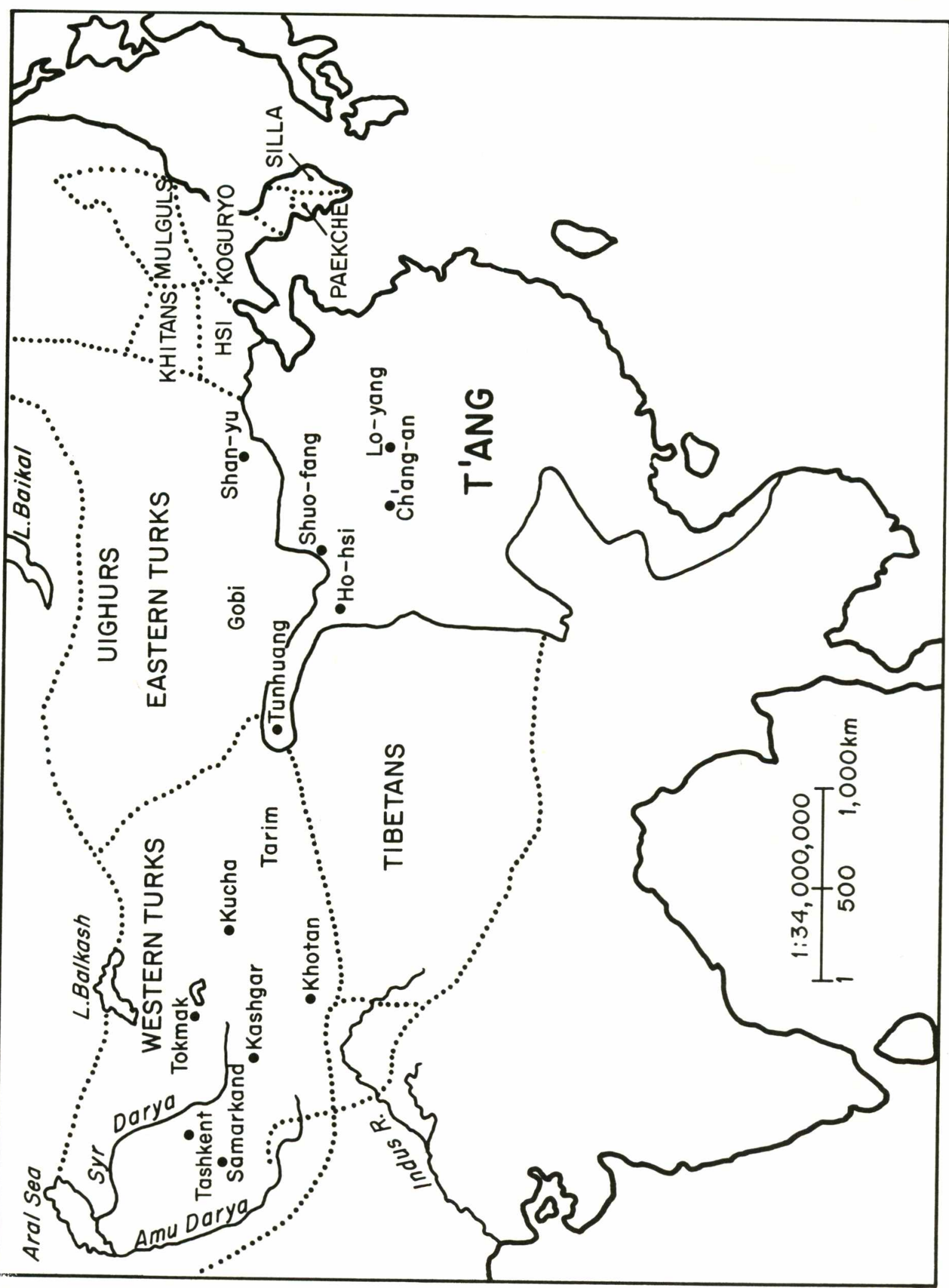

年 
chapter will attempt to show that the policy was in fact a response to both internal and external challenges, and because it was carried out not to validate any grand "imperialistic" vision, but rather on an ad hoc basis it was clumsy and shortsighted in its execution.

T'ang imperialism was the creation of T'ai-tsung. The reasons for several of his policies, including the great swing to the West, still await full explanation, but scholars tend to agree that T'ai-tsung was a ruler conscious of, if not obsessed by, the glories of the Han Empire, and a man who realized that one of the surest ways to validate the T'ang possession of the Mandate after so long a period of disunion was to replicate Han achievements. 4 He thus became one of the great conquerors of Chinese history, and from him Kao-tsung inherited not only the glories but the burdens of empire. In mid-century these latter consisted chiefly of a tradition of intervention in a restive, tripartite Korean peninsula, and on the northern and western frontiers the nascent threat of a dissatisfied Tibetan tributary and a belligerent and rebellious Turkish confederation. 5 As the thirdgeneration ruler of the T'ang, Kao-tsung's principal task was that of dynastic consolidation, the demonstration that the $T^{\prime}$ ang would endure beyond the point where so many of its recent predecessors had fallen. He could not afford, therefore, to relinquish what his father had won.

A second factor in the formulation of his foreign policy was his own character. As a child of rather delicate health and the youngest of T'ai-tsung's legitimate sons, he had become crown prince only at the age of fifteen and in the five years prior to his accession had received, as far as we can tell, little or no military training. His father's exploits, of course, were already legendary and this seems to have produced in him a certain envy and insecurity, a need to prove himself. He is recorded, for instance, to have wept when refused permission to

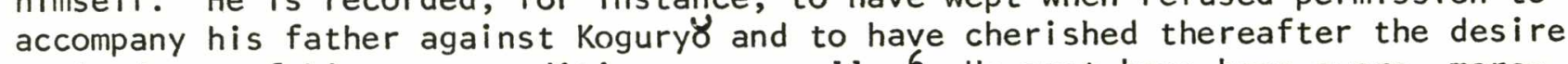
to lead one of his own expeditions personally. 6 He must have been aware, moreover, that he would always be subject to comparison with his father, and one of the first communications he received from a foreign state was a warning and a reminder from the btsan-po of Tibet: "If, when a Son of Heaven first comes to the throne, there exist disloyal subjects, he must raise troops, go to that state and punish and exterminate them."17 The commentator adds here that because the Tibetans knew that T'ai-tsung was dead, they adopted a contemptuous attitude toward China. 8

A more tangible and more dangerous reaction to T'ai-tsung's death was the rebellion of A-shih-na Ho-lu, who proclaimed himself Sha-po-lo khan, reunited the Western Turks, and set out on a series of raids which soon gave him control of the entire Tarim Basin.9 By mid-year he had crossed into China and invaded T'ing-chou with a force of 100,000 . Faced with this external threat, Kao-tsung had little choice but to respond and sent against him an army of 30,000 , supplemented by 50,000 Uighur cavalry. Fortunately it seems that even the illfated Korean expeditions of his father had not too seriously depleted China's military resources, for he had no need to call up special levies and was able to rely solely on fu-ping troops drawn from the Ch'ang-an region. 10

The Chinese achieved a rapid though temporary victory 11 and, as far as we can tell, made no effort to press their advantage. Kao-tsung seems at this stage to have had no intention of enlarging on T'ai-tsung's conquests, but it is clear that he had no intention of abdicating from the position the $T$ 'ang had come to enjoy in East Asia. In late 651 he expressed this view in a reprimand sent to 
the king of Paekche in which he referred to himself as "lord of all the world" (wan-kuo chih chu) and demanded that Paekche cease fomenting trouble with its neighboring states of Silla and Koguryð lest it face punishment from China. It is difficult to know whether or not he could have carried out this threat, for his father's last testament had explicitly called for the end of Korean intervention and his own tsai-hsiang seem to have been universally opposed to any more activity in the peninsula. ${ }^{12}$ What is important, however, is that Kao-tsung had shown himself ready to act in an area where both Sui Yang-ti and T'ai-tsung had been unsuccessful, and he thus prepared the way for the later assaults on Paekche and Kogury 8 which were to be the central feature of his foreign policy.

The first expedition to the Korean peninsula was dispatched in early 655 , in the very midst of the crisis which arose over the elevation of Empress Wu. 13 it is tempting to see her hand in the decision not only because the renewed involvement in Korea provided a convenient distraction from events at court and enabled Kao-tsung to assert his will over that of his chief ministers, but also because the empress was herself no stranger to military matters. We have seen that the foundation of her father's career was military and she might even have been familiar with his work on strategy and tactics. Her association with T'ai-tsung probably made her conscious of how much his fame rested on military prowess and how necessary it was for Kao-tsung to prove himself in this respect. She was later to point out that what T'ai-tsung had failed to do, she and her husband had accomplished! 14 Finally, we might recall that certain aspects of her character and aspirations might help to explain the upsurge of expansionist military activity which coincided with her rise. She was determined, as we have seen, to make her reign unique. She possessed an exalted view of the position of Son of Heaven and a cosmopolitan world view demonstrated, for instance, in her inclusion of foreigners in the Hsing-shih Zu. Above all, she was a woman whose political role was soon to exceed the accepted norm, and as a result she could display to her court enemies no sign of weakness, allow to them no opening for attack on the basis of her "womanly" qualities. By force of circumstance, the Empress Wu had to adopt a strong policy toward those whom the Chinese regarded as "barbarians" both while Kao-tsung 1 ived and also during her own dynasty.

These attitudes of the two rulers are of great importance since, as we have seen, their first two decades were marked by minimal opposition to their policies on the part of weakened and intimidated ministers. In contrast to T'ai-tsung whose foreign policy was highly collegial in nature until his last years, theirs was individual and, in fact, there is no recorded opposition to their foreign policy decisions until the year 678 ! 15 By that time China was too deeply involved to withdraw with impunity from "pacified" areas, and the approaching usurpation crisis was about to trigger a new upsurge of activity among the surrounding peoples which would be all the more serious since two decades of close Chinese contact had allowed Turks, Tibetans, and Koreans to borrow the sophisticated military and administrative techniques, and so to constitute a greater threat than before.

The punitive expedition sent against Koguryð in 655 achieved its objective, Kogury ''s promise to end its raids on Silla, even before reaching the Yalu River and was immediately halted. 16 it is unlikely that the emperor had any illusions about the continued quiescence of Koguryŏ, 17 but he did have a sense of priorities and the wisdom to avoid simultaneous action on two fronts. A last-ditch effort to solve the problem of the Western Turks by diplomacy had just failed, 18 and the presence of Su Ting-fang, 19 the leader of the Korean expedition, was required to 
deal with their mounting threat. The sources record no specific instructions to Su from the court, but we are told that by early 657 he had completed a reoranization of the northwestern army and substantially augmented it with Uighurs, Sogdians and other foreign troops.20 This and the fact that the original force was constituted partially of mu-ping, special levies or conscripts, suggest that Kaotsung was determined to settle the issue and perhaps envisaged a long campaign. 21 During the year 657 Su engaged in a series of battles with the Sha-po-lo khan and, though sometimes outnumbered ten to one, inflicted one defeat after another, driving him back to the $11 \mathrm{i}$ River where the power of the Turks was finally broken. The khan barely escaped with his life to Tashkent (Shih-kuo) where he was betrayed to the Chinese, and with his capture two decades of peace began along China's northwestern borders. 22

Some aspects of the campaign were typical of warfare of the period and illustrate the problems such a campaign can give rise to. After naming a field commander (tsung-kuan) of an expeditionary force (hsing-chün) the court left the entire operation in his hands. In this case the court subsequently intervened only to thwart an attempt by some of Su's subordinates to undermine him and to grant him permission to use surrendered Turks in his army. A court censor was attached to the army to report on the campaign, but with the distances and communication difficulties being as great as they were, he was not to interfere in its conduct. 23 The difficulty here, of course, was that the court might easily be confronted with a fait accompli, a punitive expedition turned by an ambitious or too successful general into an imperialist venture.

From this time on most armies seem to have been composed of a combination of fu-ping, mu-ping or mu-shih, and i-cheng ("volunteers"). 24 This combination is a significant one since the original character of the fu-ping was defensive and, for reasons adequately dealt with elsewhere, 25 it was an institution unsuited for long campaigns outside the Wall. About the method of mu-ping conscription, we have little detailed information though we do know that service was compulsory for those conscripted by a central government official called the ping-mu, and that these conscripts were supplied and equipped by their home prefecture.26 it was, therefore, far more expensive than a levy of the self-supplied fu-ping and, as Japanese scholarship has shown, conscripts came to make up an increasing proportion of the armies. 27 Moreover, there is at least one contemporary report which states that as early as 664 the length of foreign campaigns and the lack of rewards and recognition had sapped the morale both of conscripts and volunteers and that the recruitment system had already been corrupted by the rich and influential who bribed officials to escape service. As will be shown, other evidence supports the conclusion that the quality of T'ang soldiery declined through the second half of the century and, as a result, the acquisition of empire was easier than its maintenance. Finally, I might note the extensive use of foreigners in the expeditionary armies. Very often even high command positions were held by foreigners.29 There can be no doubt that foreigners played an important role in the victories in the West and in Korea, but because their contribution was so difficult to gauge, the effect of their participation may well have been to give the court a false sense of the strength and range of Chinese arms.

I cannot prove that such misapprehensions existed but, judging from the administrative arrangements made following Su Ting-fang's victory, it is plausible to surmise their presence. The conquered territory was first organized into the two protectorates of Meng-ch'ih and $K^{\prime}$ un-ling with native khans as protectorsgeneral $(t u-h u)$, and the scion of one of the great northeastern clans, Lu 
Ch'eng-ch'ing, 30 was sent out to rank and organize the tribes and to appoint prefects and other subordinate officials over them. 31 In the fifth month of the next year, the capital of the An-hsi protectorate was moved from Hsi-chou (Kao-ch'ang) west to Kucha (Kuei-tzu) where it administered sixteen tu-tu-fu or governmentsgeneral and 106 prefectures.32 As control was extended over the various peoples of what is today Sinkiang and Russian Turkestan, the Chinese empire reached the very borders of Persia, controlling more of Central Asia than had ever before been the case. 33

In view of these moves, which one scholar terms the expression of "an excess of power, 1134 it seems reasonable to conclude that in a few short years the cautious realism of T'ai-tsung had been replaced by unfettered ambition. If further proof were needed, it was provided within a month of the An-hsi foundation when Kao-tsung sent a force against Koguryð which had taken advantage of Chinese involvement in the West to escalate its raids upon silla.35 For the first time since the chen-kuan period [627-650], Chinese troops were now active in peninsular affairs and over the next year clashed with Kogury 8 on more than one occasion in the Liaotung area, while Paekche took advantage of the situation to carry out a number of largely successful raids against Silla to the South. In 660, faced with anxious Sillan calls for aid, Kao-tsung decided to settle the issues and dispatched Su Ting-fang and a force of 100,000 by sea to attack Paekche from the West. 36

For the next two decades the Korean question formed the focal point of China's external affairs. Because it was either the greatest folly or the greatest triumph of the two rulers, and because its internal ramifications were so great, it deserves special attention.

Since the first Chinese conquest of the peninsula in 108 B.C. a special relationship had been created. For almost 400 years thereafter, most of the North of the peninsula had been under direct Chinese administration, but with the gradual development of the kingdoms of Koguryð, Paekche and Silla, a desire for independence had begun to appear. The disastrous Sui campaigns were basically an attempt to reassert control over an area with a long history of chinese rule, and the T'ang seems to have regarded the territory in the same light. Kao-tsu, on one occasion, refused to receive an envoy from Kogury $\gamma$ on the grounds that the state had betrayed its allegiance as a subject (ch'en) of the Sui and was likely to cause him trouble. He relented, however, when two of his ministers pointed out that from Chou through $\mathrm{Han}$, Wei and Chin, the state had been a tributary (feng$n e i$ ) and so could not now be degraded from that status (pu-k'o $i$ chiang). 37 The patents ( $t s^{\prime} e$ 册) he conferred on the rulers of all three states in 62.4 seemed to confirm recognition of a special relationship. 38

Although subsequent years saw a good deal of internecine strife in the area, the T'ang refrained from intervention until 643 when the throne of Kogury $\gamma$ was usurped with great brutality by Y⿱艹̈n'gae Somun. 39 Not only did this act cut off the valuable annual tribute from all three states but threatened the basis of the imperial system since, as T'ai-tsung declared, the act of murdering one's sovereign to seize the throne could not be tolerated. 40 Whether or not this was simply a convenient excuse for his costly and unfortunate expeditions against Kogury $\gamma$ is difficult to know, but the fact remains that neither his failure nor his deathbed injunctions could erase the traditional Chinese view of the peninsula. Kaotsung was to point out in 668 that "the people (pai-hsing) of Koguryo are also my 

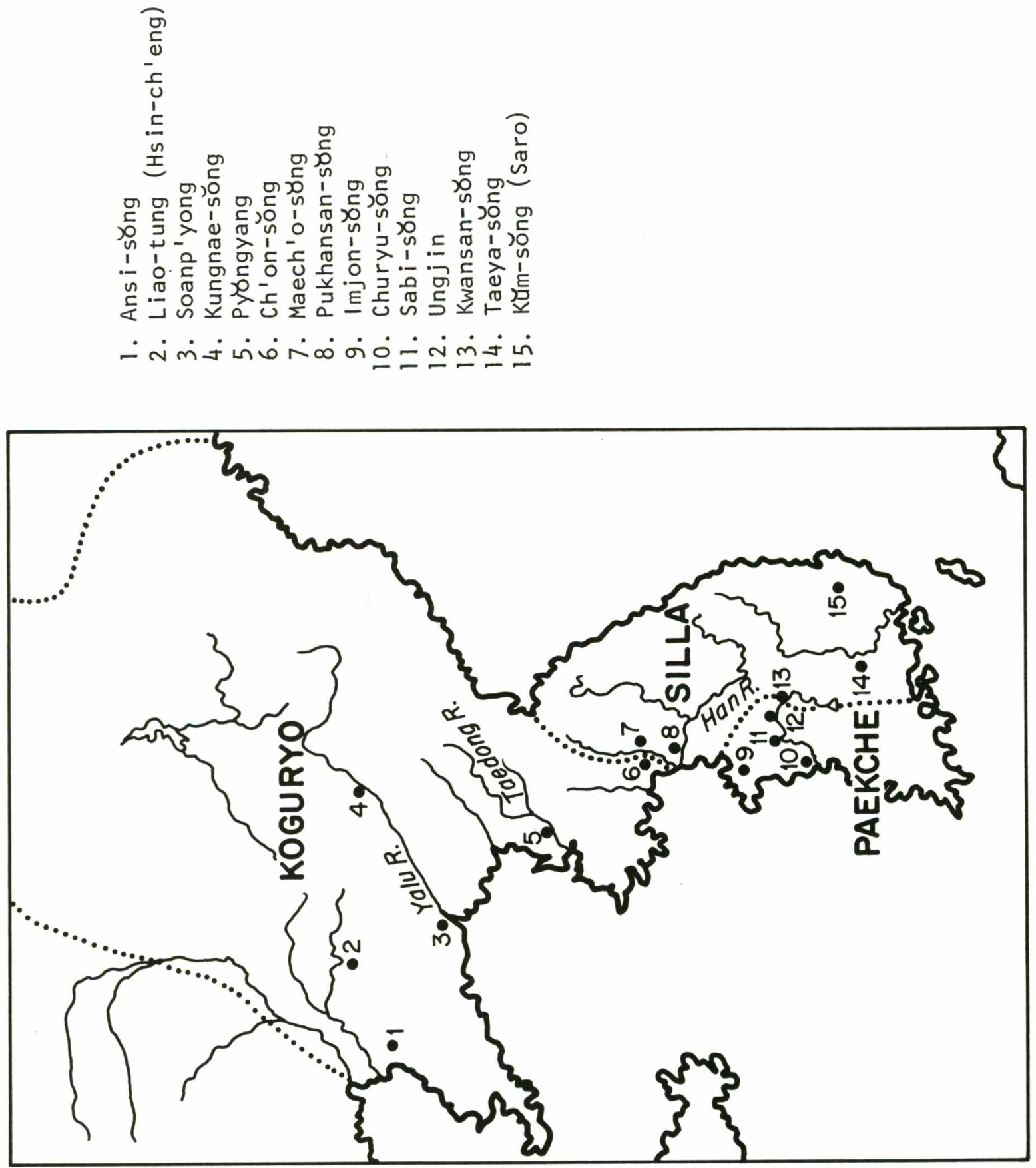

年 
people, 141 and this conviction, expressed after the conquest, was unable to prevent the loss of the peninsula to Sillan domination before the century was out.

The attempt by Kao-tsung and the Empress Wu to achieve what Yang-ti and T'aitsung had failed to do was, therefore, a result both of tradition and of their own particular ambitions. In formulating their strategy, they took full advantage of the existing strife in the peninsula, choosing Silla, the least populous and most distant of the three states, as their ally. This choice, however, was a natural one since Silla had become the most Sinicized of the states and, especially after the formalization of the peace treaty of 650 with China, had rapidly turned itself into a miniature T'ang. The best source for the period, the Somguk Sagi, tells how closely the structure of both central and provincial government of tax and corvée systems, and even of court robes resembled the Chinese model. 42 Silla had its own national academy, and the ode to Peace (T'ae-p'yong song) in which Queen Chindðk framed her appeal for Chinese aid in 649 is said to show a mastery of classical style. 43 Institutionally silla seems to have been ahead of its neighbors and had succeeded in combining its borrowed sophistication with native institutions like the hwabaek and the hwarang-to 44 which, as expressions of the national spirit, served to equip it for later hegemony in the peninsula. The Chinese, in choosing to ally themselves with Silla, showed no sign that they were aware of any ambitions Silla might itself have.

In retrospect, Sillan ambitions seem clear enough, becoming overt by 654 when the new king, Muyol, seized from Paekche the entire Han River valley, an area which had been held by Paekche for thirty years but was claimed by all three states. 45 It is not surprising that the Chinese misread the situation, for conflicting reports had been reaching the court for a long time, and since Yon'gae Somun's usurpation, the Chinese had tended to accept the Sillan version of events. There is even some evidence that the strategy of the expedition of 660 was planned as much by King Muyol as by Kao-tsung and his advisors. 46 In the course of the ensuing war, the Sillans played a much greater part than Chinese sources indicate and, as we shall see, Chinese policies ultimately served the interests of Silla better than their own.

In late 660 the great fleet of Su Ting-fang reached the mouth of the Kum River and began to move on the Paekchean capital of Ungjin. Even before his arrival, however, the flower of Paekche's resistance, an army of 50,000 volunteers, had been utterly routed by the famed Sillan general Kim Yu-sin and his hwarang vanguard. 47 Meanwhile, Su defeated another force led by King Ưija, and with "over $10,000^{\prime \prime}$ of his men slain, the king fled north with his eldest son. Shortly thereafter the capital was betrayed to the invaders, 48 and in a campaign which lasted only a week, the kingdom of Paekche with a history it traced back 700 years, was extinguished. At its fall it was a state of 200 cities and with a population of 760,000 households. 49

The Chinese accounts make no mention of the Sillan contribution to the victory, and the sources of neither side record, except obliquely, the rift which must have occurred at this juncture. From all we can gather, Silla received no reward for her efforts, and all of Paekche, including even the Han River valley which Silla had so recently regained, was organized into five tu-tu-fu--a precise reconstruction of the Han colonial administration! The posts of governor-general and prefect went to local leaders of the defeated state.50 since this organization was meant to be temporary, no protectorate was created and Su Ting-fang returned to 
Loyang to receive congratulations and instructions for the projected assault on the now isolated Koguryo. He took along most of the Paekchean royalty and over 12,000 other captives, presumably of the upper classes, in order to forestall any nationalistic restoration movement which might arise against the relatively small garrison of 10,000 which he left behind.51 This wholesale deportation is a strong indication that China planned to incorporate as much of the peninsula as possible into the empire.

By the end of 660 preparations for the expedition against Koguryo were well underway. Four of China's most distinguished and experienced generals were given charge of an army of 44,000, levied from sixty-seven prefectures in Ho-pei and Ho-nan, the same hard-pressed areas which had supported the Korean expeditions since the Sui.52 There is reason to assume that the campaign was not a popular one in the Northeast, 53 but its dispatch seems to have represented a calculated risk for the rulers, who balanced the dissatisfaction of the area against their hope for a rapid and definitive success. By the time it set out in the fourth month of 661 , it had been supplemented by Uighurs, Sogdians and Hsi to form an impressive force of thirty-five armies. The plan was to squeeze Kogury between this force's advance from the North and an assault by the Sillans and Chinese garrison troops from the South. Kao-tsung was dissuaded from assuming personal command of the northern force only by the empress' last-minute intervention. 54

From the outset, however, the two-pronged strategy went awry. A Chinese fleet carrying supplies and reinforcements for the Ungjin garrison was wrecked at sea and, inspired by this piece of luck, a fierce restoration movement led by a General Poks in broke out in Paekche.55 Before long he had rallied his whole people and won support from Japan. When the Sillans, already disaffected by their treatment a year earlier and by the high-handed actions of the garrison commander, Liu Jen-yüan, conveniently ran out of supplies and retired, the Chinese garrison found itself in an impossible position. 56 In the North, the two major armies of Su Ting-fang and $\mathrm{Ch}$ 'i-pi Ho-li were unable to effect a junction even by the fall of 662 , and Su's troops, who had already endured one winter at the walls of Pyongyang, were restive. 57 At the court Kao-tsung had suffered a relapse of what was becoming a chronic illness, had just been forced to send more troops to put down a Uighur rebellion, and was so conscious of the exhaustion of the Northeast from supplying the needs of the forces in Korea that he had to cancel the fengshan sacrifices already announced for 662.58 There seemed no alternative to retreat, and Ch'i-pi was ordered home while Liu Jen-kuei, who had assumed charge of the Paekche garrison, was ordered to withdraw into Silla and, if unwelcome there, to embark for China.59 It is of interest to note that the court was by now aware of Sillan dissatisfaction but was unable to make any positive response to it and seems to have been still unwilling to abandon its plans to rule the entire peninsula. In mid-66l Munmu, Silla's finest king of the century and a man with firsthand experience of China, had come to the throne; yet in the third month of 662 China had unilaterally decreased his status by declaring him governor-general $(t a-t u-t u)$ of Kyerim, the old name for his state.60

Direct assumption of the conduct of the war by the poorly informed court in the fall of 662 almost proved disastrous. Fortunately for China, however, Liu Jen-Kuei disregarded his instructions, broke out of the siege, regained several lost positions and managed to coax from the reluctant court an additional 7,000 troops hastily levied in Ho-pei.61 But this was as far as Kao-tsung would go. The next year he issued a remarkable decree apologizing for the hardship and 
deaths the high taxes and onerous shipbuilding corvées inflicted on Chinese by the Korean war, and he sent commissioners to ten provinces to assess the effects of the war, correct the administration and offer relief to the people. 62

In the meantime, however, the resistance movement of Paekche had exhausted itself in internal strife and Liu Jen-kuei was quick to take advantage of the situation. Only days after Kao-tsung's decree, he won one of China's greatest victories near the mouth of the Kum River, destroying not only the Paekchean army but also a supporting armada from Japan under Azumi no Hirabu no Muraji.63 As the 400 ships burned, "the heavens dark with smoke and the sea red with blood," Chinese arms were felt to have been vindicated. The court rejoiced but took no immediate steps to complete the conquest of Korea.

The major reasons for hesitation were undoubtedly the sad domestic results of the campaign and the reception of a detailed report from Liu Jen-kuei which outlined his deficiencies in weapons and supplies, the extremely low morale of his troops, and their desire to return home. 64 The year 664 , moreover, was a tense year in the capital, with Liu's report arriving in the midst of Shang-kuan l's attempt to depose the empress and amid accusations that Liu was himself planning to use his peninsular troops to engineer a coup. 65 It was decided, therefore, to hold the line in Korea. The former crown prince of Paekche was sent back to his state as governor-general and Silla was forced the next year to conclude with him a pact of everlasting friendship. 66

This last action proved to be grossly inept. Silla had once again been deprived of the fruits of victory, and Munmu objected strongly to a treaty drafted wholly by the Chinese and to the pressure exerted by Liu Jen-kuei, a mere tu-tu, to compel him to sign.67 Munmu's protest may have been responsible for the immediate recall of Liu Jen-kuei from the peninsula, 68 but this could hardly have satisfied the sillan king who nonetheless sent his representatives along with Liu to assist at the feng-shan sacrifices at which the only notable foreign absence was Koguryŏ's.

Only a month after the sacrifice, Kao-tsung announced what was to prove China's seventh and final expedition against Koguryo during the seventh century. Its ostensible purpose was the settlement of the disputed succession which followed Yon'gae Somun's death, 69 but the preparations made clear that China's aim was much greater, and that this time it would be satisfied only with the destruction of the troublesome state. The experienced general Ch'i-pi Ho-li was dispatched to Liaotung with an advance force, and the prestigious veteran Li Chi, probably about eighty at the time, was recalled from semi-retirement as supreme commander. He was seconded by Hsüeh Jen-kuei who had yet to be defeated in battle, and the revenues (tsu-fu) of every prefecture in Ho-pei were directed to Liaotung for the support of the troops.70

In the autumn of $667 \mathrm{Li}$ Chi crossed the Liao River and in the course of the following year engaged in a series of bloody but inconclusive battles. Not until the ninth lunar month of 668, and after a month-long siege did Pyongyang fall to the combined Chinese forces. 71 They burned the city to the ground, destroying all the records of the 705-year-old kingdom, and with the incorporation of its population of perhaps 4,000,000 persons into direct rule by China,72 the T'ang empire reached its greatest extent.

The burning of the capital, which seems to have been an unnecessary action, 73 proved also to be a blunder. Although reconstruction began almost immediately 
and the new city became the center of the An-tung protectorate, 74 the possibility of reconciliation, of the salving of national pride, was substantially diminished by the initial holocaust. To the inhabitants of the peninsula it must have appeared as one more instance of Chinese insensitivity, a feeling intensified by the post-conquest administration. The country was divided in the old manner into tu-tu-fu, chou, and hsien 影系, with a dual administration of Chinese and Koreans; purely Chinese rank was awarded to the pretender to the Korean throne, and the defender of Pyongyang, a national hero, was exiled to the remote South of China. 75 These provisions, the natural culmination of Chinese plans for the peninsula, were soon to prove of great benefit to Silla.

The accounts of the peninsular war as they appear in Chinese and Sillan sources differ in several respects. Even in this final campaign, the Chinese see their allies as dilatory and unreliable, pointing out that General Kim Yu-sin's army of 30,000 men arrived at Pyongyang only in time to share in its fall.76 The preceding account of events is drawn in general from Chinese sources, and it is time now to introduce the Sillan perspective. This is best done perhaps by reproducing a document addressed by King Munmu to the Chinese general Hsüeh Jenkue $i$ in 671, at a time when the estrangement of the two states was almost complete. The text is preserved only in the Samguk Sagi and represents Munmu's response to an ultimatum that within two days he either signify repentance for "crimes" against China, or suffer the condign punishment of the two Chinese armies poised to strike at him.77 In his reply, the king recants but not without listing fully his grievances and calling for their redress. His letter throws much light on Chinese policy in the peninsula and is important for the understanding of subsequent events. It is quoted in detail below.

In the twenty-second year of chen-kuan [648], my late father went to the court of China and received from the Emperor T'ai-tsung a gracious decree [which said]: "We now attack Koguryo for no other reason than our compassion for Silla, harassed by the two states [of Paekche and Koguryou]. Yearly you are invaded, enjoying no time without trouble. We have no desire for land nor for treasure or men and women [as subjects]. When we pacify the two states, [all] the land south of Pyongyang and the territory of Paekche shall both be granted to Silza, and peace shall reign forever." . . . 78

Before the great task was completed, T'ai-tsung died and the present emperor succeeded him, continuing to show us the kindness of before. [Munmu here praises Kao-tsung elaborately and protests his loyalty to him. ]

In the fifth year of hsien-ch'ing [660], the emperor saw that his father's wish had not been carried out . . . and sent a great fleet and troops. My father was old and weak and he could not take the field... [so] he ordered me to take command. . . Even before the [Chinese] fleet entered the river mouth, we had already defeated the great Paekchean force and the two armies advanced together to the capital. Together we pacified one [opposing] state, and afterwards my father agreed with Su [Ting-fang] that a Chinese garrison of 10,000 be left, and we sent my younger brother with 7,000 troops to join the Ungjin garrison.

After the great [Chinese] army had returned, the bandit Poksin rebelled west of the river [in Paekche] . . . [He besieged the garrison, totally cutting it off from aid and] I personally led a relief force 
there.. . and saved 10,000 Chinese troops from the tiger's jaws. . . 79

In the sixth year of hsien-ch'ing Poksin's followers increased and invaded [us] seizing land east of the river. A thousand Chinese from Ungjin were sent against them but were defeated with not a single man escaping. 80 After this defeat the Ungjin garrison begged us day and night for reinforcements, [but] in Silla there were many epidemics and we could not raise troops and horses. The sad requests were difficult to refuse and we did send many troops who surrounded the city of Churyu. 81 The bandits knew our forces were small and attacked us, killing many and forcing a retreat. The cities of the South then all rose together and joined the rebellion of Poksin who again surrounded the garrison. The road was cut off [but Silla managed to get supplies to the garrison]...

In the sixth month my father died and my mourning duties prevented me from taking the field [to resuce the garrison]. China ordered me to lead troops to the North . . . and also to send supplies to [the Chinese forces at] Pyŏngyang. At this time, the Ungjin garrison sent a man to advise that the garrison was isolated and in danger. . . [Here follows a long explanation of why Silla gave priority to Pyongyang, and a report of how those finally sent to the aid of Ungjin were destroyed].

In the first month of the second year of Zung-shuo [662], the Chinese commander Liu [Te-min] 82 together with our commander Kim Yu-sin and others set out to provision the Pyongyang troops. At that time, rain, wind, snow and the most extreme cold made men and horses freeze to death, and the men and provisions could not get through. The great army at Pyongyang then wanted to go back, and the Sillan troops with their provisions also came back suffering from hunger and cold, their hands and feet frozen, and countless dead littering the roadway. [Here follows a description of how they were attacked en route by the Koguryons]... In less than a month [after the disaster] the Ungjin garrison demanded still more grain. We had in total already sent tens of thousands of bushels in the South to them and in the North to Pyongyang, so that the strength of the people in our small state was exhausted and our livestock had died [of starvation]. Agriculture was disrupted and the year's harvest gone... [so that] the people could not find grass and roots sufficient to keep themselves alive. But the Ungjin garrison had an excess . . . [Here the king explains how clothing was next sent to the garrison]...

When your protector-general Liu Jen-yüan 83 was thus defending his distant and isolated city, surrounded by bandits and constantly attacked by Paekche, it is Silla who rescued him. For four years we fed and clothed 10,000 Chinese troops. . . Our loyalty and toil is great and worthy of commiseration.

In the third year of Zung-shuo [663] the commander Sun Jen-shih84 brought troops to relieve the garrison and we sent troops along [to help him]. They reached Churyu and at this time the Japanese fleet was there to help Paekche with 1,000 warships and their position was guarded by Paekchean cavalry on the shore. It was cavalry acting as the Chinese vanguard which first defeated the troops on the shore. Churyu fell and then after its submission the South was pacified. [Here follows an explanation of why Silla did not agree to sign a treaty with Paekche at this time]...

In the first year of lin-te [664] we received a decree from China blaming us for failure to conclude a treaty [with Paekche] and we sent men to Ungnyðng to swear the oath at an altar built there.85 The place we swore 
the oath became the border between our two states. Although the contents of the treaty were not what we wanted, we dared not disobey an imperial decree. [The treaty was formalized and the borders permanently fixed]...

In the second year of ch'ien-feng [667] we were told that the supreme commander $\mathrm{Li}$ Chi had invaded Liaotung and I went to Hansŏng, assembling my troops at the border. [An explanation of how Silla finally advanced toward Pyŏngyang at Li Chi's instruction but was left in a bad position by his withdrawal and retreated] 86 . . . The next year we sent an envoy by sea to discover $\mathrm{Li} C h i$ 's movements and he received instructions that we should advance and assemble at Pyongyang. In the fifth month the Minister of the Right Liu [Jen-yüan] arrived, dispatched the Sillan troops, and we advanced to Pyongyang. I went to Hansŏng to take [temporary] charge of our troops and when the combined forces were at Chi-su87 [the Koguryon king] Namgon sent out troops for a decisive battle. Our troops alone formed the vanguard and we defeated his great force, destroying the morale of the Pyŏngyang defenders. Afterwards $\mathrm{Li}$ Chi chose 500 of our cavalry to spearhead the assault on the city gates. Then Pyongyang fell.88

- . Our troops all complained then that for nine years they had been in the field and finally had pacified the two states [but] the people were totally exhausted. . . [They felt that] the people [of Silla] should be rewarded for their effort, but $\mathrm{Li} C \mathrm{Chi}$ let it be known [that he felt] that Silla had failed to come when it was most needed and that this must be considered. 89 When our troops heard this, their uneasiness grew. Also, our meritorious generals, whose names are all recorded at our court, had already reached the capital and said that silla had been deprived of honor. When the troops returned [and were demobilized?] the common people also found their fear and uneasiness increased.

Also, the cities which once were ours but were seized over thirty years ago by Koguryo, we regained in this campaign and we moved people into them, setting up officials to guard them. And [the Chinese] took these cities and gave them back to Koguryo. From the time Paekche was pacified... Silla has been wholly loyal and has exerted great effort. We know not what is our crime. . .

In the first year of tsung-chang [688], Paekche moved the boundary markers from where they had been fixed by the treaty. They seized our land and stole our slaves. [Some of] our people they deceived, hiding them in their land and they came often with false demands, refusing to leave. Also, their envoy told us they were rebuilding their fleet [only] in order to attack Japan, but really [we know] they want to attack us. When the people heard of it they were alarmed.90 [Here an abortive plot initiated by the Paekchean wife of a sillan tu-tu is described]. .

In the sixth month of the first year of hsien-heng [670], Koguryo plotted rebellion and sought to kill the Chinese officials. We wanted to send troops then, and first we sent to Ungjin saying that since Koguryo had rebelled, we had to send troops, and since both of us are imperial subjects, we should cooperate in suppressing the rebels. . . They sent their ssu$m a$ to sign a treaty with us saying that lest we suspect each other after the campaign, hostages should be exchanged. . . Although Paekche agreed to the exchange, it assembled troops in the city [where it was to be carried out] and at night launched a [surprise] attack on us. 91

In the seventh month we sent envoys to China to settle the border 
question, and after examining the maps, we were ordered to restore all of Paekche's old territory. Before long, over the next three or four years, one [state] gave and one took [even more land]. Our people have all lost their original hope, and they say that for generations Silla and Paekche have been bitter enemies. Now they see that Paekche is being restored and will again become an independent state. In a hundred years our sons and grandsons will be swallowed up. Silla is a prefecture of the empire (kuochia chih chou) 92 and it cannot be divided into two states. We want to be one family, enduring without later calamity.

In the ninth month of last year we sent envoys to explain [this situation] but they were shipwrecked and their replacements also failed to reach China. Afterwards the wind, cold, and waves made it impossible to report. [But] Paekche sent messengers who reported that we were planning to rebel. . . Afterwards, because of Paekche's slander, advance or retreat was seen as a fault and we have not yet been heard.

When your messenger brought your letter, I was astounded that Your Excellency [Hsüeh Jen-kuei] should have braved the storms and come so far from across the sea. I should have met you with proper protocol and offerings of wine and cattle at the border. Living so far in a different city, I failed to carry out the ceremonial and there was no time to welcome you. I request that you do not blame me.

I have read the message you sent which considers that silla has already rebelled but this is not our intent. . .

Now I have explained my grievances, recording them all without rebelliousness. China has not sent an envoy nor heard my reasons [for my actions]. [Instead] it sent an army of several tens of thousands... . and towering ships which fill the sea and anchor at the mouth of the [Kŭm] river. You reprimand Paekche but attack Silla. Alas! when the two states [of Paekche and Koguryö] were not yet pacified, we were ordered to attack them. Now that the game has been slaughtered, it is we who are thrown into the cooking pot!...

I write to protest our innocence, to ask you to consider the matter and report it. 93

Although a number of Munmu's allegations, for lack of collaborating evidence, must remain just that, certain of his grievances seem to be well founded. If T'ai-tsung had indeed promised to increase Sillan territory, the promise had not been honored, and twenty years of Chinese intervention had brought little but hardship to the area. The king seems to acknowledge, moreover, that China's initial concern lay with the internecine strife in the peninsula. Yet in the administrative dispositions it made after each major victory, a clear progression in Chinese ambition is discernible. After 663 Silla was recognized by China only as the tu-tu-fu of Kyerim, 94 and after the fall of Koguryo, the establishment of the An-tung protectorate put Hsüeh Jen-kuei and his garrison of 20,000 in overall charge of peninsular affairs.95

On the other hand, Munmu's letter reveals the ambition of his own state, and it is difficult to avoid the impression that Silla's alliance with the T'ang was from the beginning merely an expedient. From the time of the Sui expeditions against Koguryŏ, the evidence shows that Silla had initiated a good deal of the unrest on the peninsula, 96 and some of Munmu's protestations about Sillan participation in the campaign ring hollow. He makes no mention of the "illness" of Kim Yu-sin which prevented the troops of the great general from reaching Pyongyang 
until immediately before its fall, 97 and Chinese sources have nothing to say of Sillan contributions to the taking of the city. It is possible to see an element of duplicity in the king's policy. While he awaited his moment. the Chinese were to exhaust themselves in the fighting and be cast more and more in the role of imperialists, allowing the Koreans to see the advantages of Sillan rather than Chinese hegemony. The standard interpretations which see the emergence of Sillan ambition only with the fall of Koguryo 98 are perhaps therefore misleading.

Whatever the case, it is clear that within a few short years of its triumph, China had significantly advanced the Sillan cause. Hsüeh Jen-kuei proved to be a stern administrator, and instead of attempting to reduce anti-Chinese feeling with leniency, he had rigidly enforced the sometimes ill-advised policies of the distant court. The most damaging of these was a decree in the summer of 669 issued, according to the Comprehensive Mirror, because rebellious feeling remained strong among the Koreans.

A decree ordered that 38,200 [Korean] households be transported to the underpopulated areas south of the Yangtze and Huai rivers as well as to prefectures in Shan-nan and Ching-hsi. The impoverished and weak were to remain to support the An-tung protectorate.99

Thus almost four percent of the Korean population, representing probably the entire ruling class, was forcibly removed from the country. 100

Among those who escaped, however, was a close relative of the deposed king, a man called An Sung, who immediately made himself a symbol of resistance and raised the standard of rebellion in 670. With great perspicacity, Munmu used his position as the only remaining king in the peninsula, to give An Sung a patent of kingship and grant him with his 20,000 followers asylum in Silla.101 The T'ang considered both these Sillan actions to be rebellious, and it was when Munmu was charged with 'betraying the Mandate of Heaven and repudiating your father's instructions"102 that he wrote the letter quoted extensively above. Though his apology was accepted in 671, he was by no means sincere, and from 671 to 675 he initiated several forays into Paekche and engaged in numerous battles with the Chinese who found allies only among the unreliable Mulguls. In this period the Sillan source grows increasingly boastful, and even though the king once more made a formal apology in 675 , China was almost certainly on the defensive. 103 Evidence is abundant of disaffected "nationalist" elements from Paekche and Koguryo deserting to Silla in these years. 104

By 677 Sillan power was entrenched all along the Taedong River, and Hsüeh Jenkuei, who had suffered serious defeats in 676 was in despair. 105 since accepting Munmu's apology and reconfirming his position in 675, the court had sent no reinforcements and it was clear that none would be forthcoming. As mentioned earlier, the year 675 offered the first hints of Empress Wu's usurpation and domestic politics took precedence. The entire Northeast was exhausted by drought and by the constant drain on its manpower, and in 670 the rising power of the Tibetans had driven so deeply into China that a projected feng-shan sacrifice for that year had to be canceled.106 When two years later the Tibetans annihilated one of the greatest armies China had yet raised, the court was plunged into turmoil and the immediate imperative became the prevention of a Turco-Tibetan alliance. 107 For these reasons, China's last intervention in the peninsula was no more than a facesaving attempt at compromise.

In 677 the deposed king of Koguryo and the son of the last king of Paekche, along with many of their exiled countrymen were sent back to their country in the 
hope that they could rally their people and check the sillans. ${ }^{108}$ Both received a curious combination of titles--Chinese court rank, a governor-generalship, and a patent making them kings of two chün called Ch'ao-hsien and Tai-fang.109 This seems to have been an innovation in colonial administration, an attempt to assuage nationalist feelings with kingly titles while the kings were subordinated to the Chinese protector with the title governors-general. Predictably, it

failed. King Pojang of Kogury $\gamma$ was engaged in a conspiracy with the Mulguls from the moment he crossed the Liao and, when he was recalled to China, died on the way. Puyorung of Paekche was too frightened both of Silla and of his own people ever to take up residence in his own state. The next year silla set up a northern capital on the Taedong, and the seat of the T'ang protectorate abandoned its advance back to Pyongyang and remained at Hsin-ch'eng in Manchuria.110 The entire peninsula south of the thirty-ninth parallel became the preserve of Silla.

On his death in 681 King Munmu could well express both his satisfaction that the borders were settled and his confident wish that "weapons be melted down for agricultural implements."111 His successors, Sinmun (681-91), Hyoso (692-701) and Sŏngdŏk (702-36) regularly sent tribute to China, received confirmation in return, and only during the great Khitan rebellion of 696-98 were there any signs of strained relations. 112

In retrospect, the Korean policy of Kao-tsung and the Empress Wu is best seen as a progression from necessity to ambition to realism. The theoretical basis of traditional Chinese foreign policy was the creation and maintenance of an external order which mirrored the same relationship between ruler and subject as that which existed inside the Wall. Harmonious interdependence of "inner" and "outer" was especially important in the case of a new emperor, and the early recalcitrance of Koguryo could therefore not remain unchallenged. It was principally the special position of the Empress Wu in government which created the ambition to succeed where T!ai-tsung had failed. For this the conquest of Kogury $\gamma$ was sufficient, but the attempt to incorporate the entire peninsula was too much. Realization of this fact was belated but it came in time to prevent further bloodshed, and the strategic withdrawal of 677 salvaged at least some of China's prestige. It was too late, however, to prevent the virtual destruction of the fu-ping system in the Northeast and the economic depression which characterized the area during succeeding decades. 113 For a time, however, the court refused to admit the futility of attempting to impose the tu-hu-fu system upon a people with administrative sophistication and national aspirations of their own. In 678 the empress as de facto regent was dissuaded from a further attack upon silla only by the dramatic deathbed plea of Chang Wen-kuan: "Now the Tibetans have invaded and we are about to send troops to the West to punish them. Silla, although it claims it will not be coerced (pu-shun), has yet to violate our borders."114 The empress apparently agreed that so long as Silla observed the forms of its tributary relationship, it could be permitted to exist in peace.

After 678 China's foreign policy turned exclusively to the West and to the North and became increasingly a reaction to foreign initiatives.

The Tibetans, a people whose first recorded tribute mission reached China in 634, had been rapidly extending their power in Central Asia since about 650, and in 670 initiated a series of large-scale and generally successful raids on the Chinese border. 115 In the autumn of 678, having enticed an incompetent Chinese commander and his force of 180,000 men to Kokonor ( $\mathrm{Ch}^{\prime}$ ing-hai), the Tibetans inflicted upon him a crushing defeat which seems to have had the effect of 
substantially reducing the military resources of the Northwest. ${ }^{116}$ It also made the Tibetans an extremely formidable and confident foe, with Ssu-ma Kuang remarking, "Of all the barbarians who have flourished, no others could compare to them."117 The court, which seems to have suffered some difficulty in raising such a large force, was dismayed, and Kao-tsung convened his first recorded policy debate, a meeting which produced only the timeworn alternatives:

Some wished to conclude a peace and give rest to the people. 0thers wished to strengthen [the borders] to prepare [for a great attack]. - . Still others favored an invincible army to destroy them. 118 The emperor, probably disappointed that no decision was reached, rewarded and dismissed the participants.

A slightly more original point of view, though one which still illustrates the impoverishment of policy, came from a student at the state university, Wei Yüan-chung, who was later to become a controversial chief minister. Perceiving that the military was becoming less and less capable of victory, he enumerated its faults--its amateurism, its hereditary ranks, its unattractiveness as a career. He pointed out the mediocre quality of leadership, charging that generals were chosen for "daring and strength" or simply because they were descendants of generals or military families, rather than for intelligence or knowledge of strategy and tactics. He spoke of the sinking level of morale among the soldiery because "since Su Ting-fang fought in Liaotung and Li Chi destroyed Pyongyang rewards have not been distributed at all," and because the officials responsible for this and the generals responsible for recent humiliating defeats had gone unpunished. $119 \mathrm{His}$ solutions were not novel since Liu Jen-kuei had suggested the same things in 664--that the quality of military leadership be raised and the system of rewards and discipline be properly administered. His memorial does, however, show that Liu's proposals had been ignored and, in enumerating the basic causes of military weakness, it points up the most serious flaw in T'ang "imperialism."

The T'ang empire was founded upon an essentially defensive military organization whose training was less than professional and which was essentially selfsupporting and self-equipped. 120 The burden of fu-ping service thus imposed upon the peasantry resident in the more than 600 chün-fu was onerous, and a large part of the vagrancy problem which arose during Chou can be traced to fugitives from the areas where the system was enforced.121 Recent research has shown that the supplies a soldier was expected to provide for himself exceeded in value the tax remission he received, and the land allotted to him was less than he could expect to receive in the normal course of equal-field distribution. 122 The crucial importance of special rewards is, therefore, clear and, as we have seen, generals and officials became increasingly lax and corrupt in this regard as time went on. Moreover, as campaigns became more frequent and of longer duration, the resources of the fu-ping became inadequate, and since the Korean campaigns an ever greater proportion of the hsing-chün or expeditionary armies came to be made up of special levies. 123 Because these forces were only supposed to be constituted technically for the duration of a given campaign but often found themselves used as garrisons, it was crucial to provide them with incentives. Thus when Wei Yuan-chung criticized the failure to bestow honorific rank and other rewards on meritorious troops, he was condemning the shortsightedness of a court which had yet to realize that it was rendering the fu-ping obsolete. Nor did the court understand that the hsing-chün represented 
not an expedient but a transition to the future form of military organization. During the Chou dynasty, other developments would bring about that realization and pave the way for the later creation of a more "professional" military organization under Hsüan-tsung.

In the last years of Kao-tsung the failings of the old system became painfully obvious. The Tibetan victory of 678 enabled them not only to effect an alliance with the Western Turks, 124 but also to consolidate their control over the scattered tribes of the West who had been steadily defecting to them since their seizure of the Four Garrisons in 670.125 Although by this time real power was in the hands of the mGar clan, ${ }^{126}$ the accession of an eight-year-old btsan-po in 679 seems to have given the T'ang a temporary respite from Tibetan attack. The empress wished to exploit this situation with a massive expedition, but $P^{\prime} e i$ Hsing-chien spoke convincingly enough of the exhaustion of China's western provinces to dissuade her. His subsequent diplomatic maneuvers broke the TurcoTibetan alliance and restored Chinese control to much of the lost territory. 127

P'ei's intervention was well-timed, for in the tenth lunar month of 679 yet another threat loomed in the great rebellion of the Northern Turks. Under Ashih-na $\mathrm{Ni}$-shu-fu and A-shih-te Wen-fu, they rapidly seized all the twenty-four prefectures established in the Shan-yü protectorate in 650 , and persuaded both the Khitans and $\mathrm{Hsi}$ to join them. 128 Once again the troop levies began, and P'ei Hsing-chien led a force of 180,000 to the North. His inspired leadership won a resounding if temporary victory, and by Kao-tsung's death the Turks had regained control of much of the Shan-yü area and the Tibetans had resumed their raids.129 Sadly for China, the succession crisis and the internal rebellions of the next few years left it with little opportunity to confront the border question, and during the Chou the Empress Wu was never able fully to repair the damages caused by the neglect of 683-690. The halcyon days of the T'ang empire were already past.

As we shall see, historians in general tend not to approve of the foreign policy of the Empress Wu, regarding her as responsible for the decline of Chinese prestige in Central Asia and for the deterioration of China's own border defenses. In this judgment and particularly as it applies to the Chou period, there is a certain validity, but the judgment is nonetheless superficial. It is true that the empress' deepest concerns, even in Kao-tsung's lifetime, were political and dynastic and that her greatest care was domestic stability. Foreign affairs never received the same priority and were always subordinated to the above concerns, with the result that the creativity and vigilance so prominent inside the Wall were less conspicuous outside it. And, of course, neither Kao-tsung nor his wife had any firsthand military experience.

At the same time, foreign policy failures must be placed within the peculiar context of the time. The constraints both of tradition and of circumstance imposed upon the empress operated with their greatest force in the realm of military and foreign affairs. She knew that to be accounted great, conquest or, in Chinese terms, "pacification of the barbarians" was necessary, but as a woman she could have no clear perception of the soldier's life nor could she take the field at the head of her troops. This may help to account for the decline of the fu-ping.

It may also be the case that a concept of empire radically different from that of T'ai-tsung shaped the foreign policy of the period. As I have pointed 
out, she and her husband were not responsible for the great swing to the West nor for the intervention in Korea which marked the reign of their predecessor and, as we shall see, during Chou Chinese troops were active outside the Wall only once. Kao-tsung and the empress came to power, however, at a time when the commitment to empire had already been made and when any sign of weakness would have been detrimental to dynastic interests, and possibly also to the empress' own position and political policies. We must bear in mind that it is unlikely she ever saw military endeavor in any terms other than as an extension of domestic policy. To her, results on the home front were what mattered, and these demanded that T'ai-tsung's achievements be equaled or surpassed.

The Korean experience was, I suggest, the key to the empress' later foreign policy. It revealed not only the rewards of success but also its cost. After the peninsula was lost to direct control, foreign policy became increasingly a matter of reaction to foreigners' initiatives. The empress seems to have decided to hold if possible what China already possessed but to acquire no more. It was chiefly for this reason that to meet the invasions which occurred during the Chou dynasty, she was able year after year to call upon truly amazing reserves of manpower and raise armies which sometimes reached half a million. While her people enjoyed domestic peace, they would fight more readily to preserve that peace than to extend the glory and prestige of the empire.

What Korea failed to teach, or rather what the empress failed to learn, was that the two bases of T'ang foreign policy, the fu-ping and tu-hu-fu systems, were incompatible. The latter aimed to "transform the barbarians" and succeeded usually only in bettering their administrative skills and technical sophistication. But while providing for a good deal of self-government, China insisted on deference and subordination with the result that it fueled ambitions of a protonationalistic sort. Neither the fu-ping nor the hsing-chün made provision for the establishment of garrisons on foreign soil, and so could not provide the requisite force in place for semi-colonial rule. During the Chou, the empress was often forced to rely on undignified expedients in dealing with the barbarians, and while these were successful in the short run, they left her successors with problems greater than she had herself to face.

By $684 \mathrm{it}$ was the shortcomings rather than the successes of the foreign policy of the previous two decades which were most obvious, and their recognition promised a greater realism in foreign affairs during the Chou period. 


\section{Chapter 9}

\section{THE CHOU DYNASTY}

The Chou dynasty, which lasted from October 690 to February 705, was one of the shortest in Chinese history. The restoration of the T'ang, moreover, occurred not with the death of the Empress Wu but with her deposition. Why, after capping so long and successful a political career with China's only female usurpation, did Wu Tse-tien end her career in failure? But, one may ask, was this denouement actually a failure?

Was the empress, first of all, attempting to establish a dynasty which would endure for the conventional "myriad generations"? In all likelihood, it seems not. I stated earlier that her loyalty to the T'ang, or at least to its aims and achievements, was genuine, and that her regency and possibly her usurpation were undertaken in response to perceived crises. Beyond this she seems to have given signs at the dynastic changeover that the T'ang was not to be deprived permanently of the empire, and that her aim was to legitimate her own reign rather than to found a dynasty which the Wu clan would continue. These signs were both symbolic and substantive, and the first of them appeared at the very moment of the founding since there is no evidence that Jui-tsung formally abdicated. Since the third century A.D. dynastic founders had invariably used ritual abdication as a formal preface to the transfer of power, 1 and thus from the beginning the source of the Chou mandate was questionable. In substantive terms, it is important to note further that Jui-tsung was immediately declared his mother's successor, and although his title was huang-ssu rather than $t^{\prime} a i-t z u, 2$ and although he had adopted the Wu surname, he held his position until 698, and then it was his elder brother Chung-tsung who replaced him.3 Although the latter also accepted the Wu surname, contemporaries must have seen this as simple expediency, and the important fact is that throughout the Chou the succession never left the hands of the $\mathrm{Li}$. The ambitions of certain members of the Wu clan were to make the succession question the most acrimonious and bloody of the period but, as I shall show, the empress only briefly considered the possibility of a Wu successor. She may in fact have anticipated both the struggle and its form, since even prior to the restoration she began to construct a close web of familial relationships between the $W u$ and $L i$ clans, 4 and was to continue to do so in subsequent years. In 699 she formalized this policy by having the leading members of both clans swear an oath of concord at the ming-t'ang. 5

A second important sign which pointed throughout the dynasty to the likelihood of a T'ang restoration was the lack of genuine instructional-symbolic innovation by the empress. In this she broke the well-defined pattern both of conquering dynastic founders like Han Kao-tsu and usurpers who planned an enduring dynasty like Sui Wen-ti. We find, for instance, no new law code, the foundation of no institutions of lasting importance, and no attempt at widespread social reform. With few exceptions, even the ritual coloration of the Chou varied little from the T'ang, and though red banners replaced the yellow of T'ang, 6 
and "Wu" replaced "T'ang" in place names throughout the empire, court dress and ceremonial, official titles and office names remained largely unchanged after 690. In view of the empress' demonstrated concern with ritual and nomenclature, it is particularly striking that she seems never to have chosen a "virtue and element" (te-yün) for the Chou.7 Chung-tsung, as we have noted, could remark at the restoration that the empress "did not disregard the old things," and on grounds like these it seems difficult to avoid the conclusion that the chou is best seen as a caretaker regime and, indeed, was regarded in this way by the Empress Wu herself.

I am not saying, of course, that this constitutes a full explanation for what seems the relative inactivity of the empress during the Chou in comparison with the decades prior to 690. Other factors were certainly present, the most important being the growing inflexibility of the central government as the T'ang gained greater security, and also the relative success of its gradualist approach to the paramount state concerns of consolidation of imperial authority at the expense of the aristocracy. I have earlier attempted to show how closely the empress identified herself with these policies.

In addition, we must recognize that throughout the chou the empress' position remained rather tenuous. She must have known that the acceptance of her claim to be emperor was based chiefly on personal or charismatic factors, but that at the same time a female Son of Heaven was a semantic and cultural violation of the Confucian tradition to which the elite among her subjects, the group through whom she had to work, gave perhaps their deepest loyalty. For this reason, her freedom of action was restricted, and she found herself more subject to the wishes of the bureaucracy than might have been the case with a male ruler of similarly absolutist temperament. Her political defeats, which ranged from matters like a failure to effect a planned reorganization of the provinces in the mid-690s to her inability to protect her favorites, were more numerous than is generally recognized, and although she was able to continue the trend toward dilution of ministerial power, it is of great importance to recognize that without the presence of her husband or son on the throne, she was less effective in government than she had been prior to 690 .

These considerations, although suggestive, still do not throw much light on our earlier question of how the empress was able to endure even for fifteen years in her anomalous position, and how eventually she invalidated her claim. As will be pointed out, her sensitivity to bureaucratic loyalties and her skillful manipulation of the succession were factors in the maintenance of her position, but for a wider explanation we might turn to a traditional source. The New T'ang History, comparing her success to the failure of Empress Wei, says "reward and punishment came from her alone and she did not borrow [the authority of] minis-

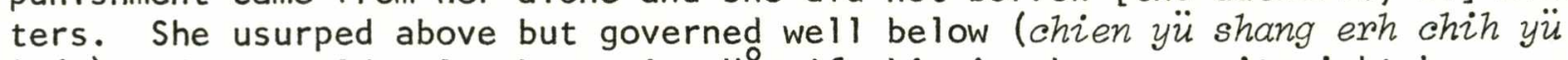
hsia) and so could rule the empire."18 If this is the case, it might be argued that the empress used the same combination of political acumen and popular support to which she owed her rise as the basis of rule during most of the Chou. It was only in her last years, after she had delegated authority to unworthy favorites, permitted corruption, and neglected the state, that she was forced to retire.

It is difficult to tell if her deposition occurred because she had lost popular support, though what evidence there is would suggest this was not the case.9 
It is equally difficult to judge with certainty whether any but the very small number of ministers actually involved in the coup of 705 would have participated in it had they been offered the chance. The possibility exists, therefore, of a very simple explanation for the deposition--superior planning on the part of a small number of alienated bureaucrats. Still the absence of identifiable support for the empress at the end would seem to indicate that one of my earlier suggestions remains valid. The source of her legitimacy was personal, not normative, and her occupancy of the throne was an aberration accepted partially because it was seen to be temporary. The level of her performance was, therefore, subject to a scrutiny more rigorous than might be the case early in more conventional dynasties, and only while she continued to fulfill successfully the well-defined role of emperor 10 were her claims actually to be emperor accepted.

In sum, Wu Tse-t'ien was emperor by sufferance, her authority deriving not from ritual abdication and, therefore, not in the fullest sense from Heaven. Undoubtedly certain of her ministers continued to regard her as a usurper or, at best, as a self-proclaimed regent. In these circumstances she needed to constantly demonstrate that the "young prince" was not ready for rule, or that she was more capable than he and was preserving rather than changing his heritage, or both. In these circumstances there also existed ample precedent for ministers, or for the young prince himself, to decide that the regency should be brought to an end. What the de facto ruler in this situation might consider treason, could be regarded from the opposite perspective as an act of Confucian loyalty and, indeed, of ministerial duty.

The history of the Chou may perhaps be more readily understood against this background.

In spite of its short duration, the Chou might be divided for analytical purposes into four stages which seem to conform, admittedly with some artificiality, to the traditional rhythm of the dynastic cycle. The division between these periods is not always clearcut, but certain turning points may be identified and, using this form of analysis, we might posit that the first five years made up the great days of the dynasty. In this period the state was prosperous, expansive and confident, and the court was characterized by administrative efficiency. In 696, however, a downturn began, and from China's massive defeat by the Tibetans early that year, serious problems of a financial and military nature arose and were not arrested until late 697 with the gradual suppression of the foreign threat and the rise to ministerial hegemony of $\mathrm{Ti}$ Jen-chieh. This "dynastic revival" gave the Chou a second period of at least superficial prosperity, but after $\mathrm{Ti}$ 's death in 700 and the rise to unbridled supremacy of the Chang faction, corruption began to run rife and a rapid decline set in which even the removal of the empress in 705 was unable to stem. Throughout the period, and as counterpoints to this rhythm, there were also to be seen the general continuation of T'ang policies upon which 1 have already commented, and the gradual decline of the empress' health and capabilities, especially in the final period as she approached her eightieth birthday.

The Chou began, as might be expected, with several new ceremonial arrangements designed to emphasize the transfer of the Mandate. These consisted chiefly of such symbolic measures as the rearrangement of ancestral temples and sacrifices, 11 the changing of the banners to red, the substitution of "Wu" for "T'ang" in place names and, most importantly, the transfer of the seat of government to Loyang which had become the "Sanctified Capital" in 684. The declaration of a 
new capital was, of course, an act redolent with the traditional symbolism of imperial prerogative, and we have seen earlier how in economic terms Loyang was a logical capital site.12 At this time practical motives of a different sort were also present, for it is likely that the empress was attempting to dissociate herself from the T'ang capital and from the loyalist clans who had been drawn by official posts to settle there. As an extra measure of insurance, at least 100,000 households from seven chou surrounding Ch'ang-an were resettled near Loyang to strengthen the new center, and it is probably more than coincidence that they were chosen from areas where the concentration of fu-ping units was highest.13 Ch'ang-an remained the western capital and was placed in the immediate charge of one of the Wu princes. 14

It is tempting also to see in this eastward shift of the capital a replication of the pattern of the Han restoration or even to suggest that Loyang's Buddhist associations and the prophecy of the commentary on the Great Cloud Sutra played a part. Whatever her motives, however, the empress rapidly set about turning Loyang into a worthy rival to Ch'ang-an, beginning the huge task of walling the city in 692,15 and continuing her earlier program of building temples, monuments and public works. The ming-t'ang complex became larger and more elaborate, and in early 695 she completed the "Pivot of Heaven" ( $t^{\prime} i e n-s h u$ ), a pillar of iron and bronze over a hundred feet high erected at the South Gate of the Forbidden City to commemorate the "ten thousand virtues of the Great Chou."16 These constructions were enormously expensive--the cost of the pillar, for instance, was said to be beyond estimation17--but, at the same time, their symbolic value was great. They constituted a demonstration of self-confidence by the empress, contributed to the "imperial air" (wang-ch'i) of her capital and, in a more concrete sense, were often measures of patronage of the type we have seen to be so important in the creation of state ideology.

I showed earlier that this was true particularly in the case of Buddhism, and fine examples of financial patronage are found not only in the expansion of the ming-t'ang complex, but also in the fabrication of the "seven treasures" ( $c h$ ' $i$ pao, Sansk. sapta ratna) in 693 after Hsüeh Huai-i presented a second sutra, that of the "Precious Rain" (Pao-ÿü ching), which reemphasized the empress' identity as a ćakravartin. 18 The Buddhist church was to benefit in numerous other ways during early Chou--by gaining precedence over Taoism, encouraging the long ban on the butchering of animals, and the stiffening of penalties for crimes against church property--but it is a measure of the empress' experience and skill that she did not forget Confucian sensitivities during this early period. As we shall soon see, her substantive concern with the linked issues of education, examinations and official appointments continued to grow at least superficially, and at the same time she distributed symbolic favors even-handedly. It is interesting to note, for example, that in the same ten-day period in which she founded the Great cloud temples, she conferred a new honorific on Confucius, and later in the dynasty was similarly to honor his favorite disciples. 19 She modestly refused early requests to magnify her own titles and hesitated when it was suggested in 691 that she perform the feng-shan sacrifices at Mount Sung in Honan. 20 When she eventually performed the rite in early 695, it was immediately after carrying out the great sacrifices to Heaven and Earth at the southern suburb, and it was followed by the declaration of a year's freedom from the tsu tax for the entire empire! 21

A second major way in which the empress appealed to Confucian sentiment was 
in her treatment of the few surviving members of the T'ang clan. There were well-established precedents, though too often honored in the breach, whereby a former imperial house was permitted by its successor to exist in dignity, though usually under surveillance. In the early Chou Jui-tsung and his immediate family seem to have lived under virtual house arrest, 22 but as early as 691 the empress began to confer princely rank on her grandsons, beginning with the sons of the former Crown Prince Hsien and later extending the privilege to the five sons of Jui-tsung. 23 Because various members of the Wu clan also bore princely rank, this created a situation unprecedented at least since the sui reunification but, considering the strength of T'ang loyalism, it was clearly a politic move to permit the coexistence of two "imperial" clans.

In measures like these it seems clear that the empress was concerned early in the new reign principally to reinforce her credentials to rule, and that she not only made provision for her own support and security, but was careful simultaneously to balance measures which emphasized dynastic change with others which could be construed as indications that the change was not necessarily permanent. Her purpose, of course, was to broaden her appeal to those literati who might be willing to serve the Chou in the belief that they were protecting the $T^{\prime}$ 'ang heritage. As a further enticement, she moved very quickly to alleviate the terror which had been the greatest source of bureaucratic alienation since its initiation in 684 .

The Chou, for instance, was scarcely six months old when Chou Hsing, the leader of the so-called evil officials, was charged with treason, found guilty and murdered on the road to exile. 24 According to one source, he had been responsible for several thousand deaths, 25 and though we might expect a certain exaggeration in the figure, it does not seem unreasonable when we consider that an upright censor, permitted to investigate in mid-692, found him responsible for no fewer than 850 miscarriages of justice.26 The empress, of course, had been long aware of this danger, but prior to the usurpation had shown little scruple about using it to her advantage. Now, however, while she permitted Lai Chün-ch'en to take over Chou Hsing's apparatus of denunciation and punishment, she responded to criticism of her harshness by the appointment of good and courageous judicial officers to balance the bad, and by herself taking a personal interest in important cases.

Most famous of the good censors was Hsü Yu-kung, a man she appointed in spite of his fearful refusals of office immediately after the dynastic change, 27 and she soon added to the censorate men like Yen Shan-ssu, Chu Ching-tse, and Chou Chï 28 who spoke with such conviction against the system of delation that after mid-691, the Comprehensive Mirror reports, punishments began to diminish. 29 In that same year, when Lai accused seven high officials of rebellious conspiracy and managed to extract false confessions from them, the empress listened to the plea of a ten-year-old boy and then released them from prison to conduct their defense before her and prove themselves innocent. 30

The question which must be asked here is why the empress permitted Lai Chünch'en to remain in office and continue his activities after his dishonesty had been exposed. Several conjectures were earlier offered about the reasons for her initiation of and support for the terror in general, and so long as a woman occupied the throne most of these remained valid. At this time, however, a more concrete reason existed in the appearance in late 691 of a campaign advocating 
the establishment of Wu Ch'eng-ssu as crown prince. 31 Initially the empress was cool to the proposal, but seems at the same time to have flirted briefly with the idea, since she permitted open representations in its favor to be made, and when the expected storm of ministerial opposition arose, Ch'eng-ssu allied himself with Lai to eliminate the most inflexible of his opponents. In subsequent months several "plots" were discovered, and numerous officials were exiled or executed. It is all too likely that the empress was not really deceived and permitted the destruction of so many persons principally to reduce the influence of T'ang loyalism and to see whether the court could be intimidated into the support of Wu claims. She was conscious, however, that she could not go too far, and so balanced the influence of the Lai-Wu faction by conferring virtual invulnerability on their most prominent enemy, Li Chao-te.

Chao-te was a ming-ching graduate from a family of officeholders who was vice president of the Secretariat in 691. An uncompromising and outspoken Confucian even when in office and hence unpopular with his colleagues, he nevertheless survived as paramount minister for two years from the time of his elevation to tsai-hsiang status in mid-692.32 He was strongly opposed to a Wu succession, and shortly after the matter arose he told the empress that "from ancient times I have never heard that a nephew became Son of Heaven and [then] set up ancestral temples for his aunt. Your Majesty, moreover, received the guardianship (ku$\left.t^{\prime} o\right)$ [of the empire] from Kao-tsung and if you give it to Ch'eng-ssu, then he will be without ancestral sacrifices!"33 A few months later the empress accepted his argument that Ch'eng-ssu was a threat to her own power, and she abruptly dismissed her nephew along with his relatives and supporters from their high posts, necessitating the governmental reorganization which left $L i$ Chao-te and his adherents supreme. 34 Wu Ch'eng-ssu was never again to hold tsai-hsiang status except for one month in 697. His fall illustrates one of the most remarkable of the differences between Wu Tse-t'ien and other female powerholders in China. Although she frequently appointed Wu princes to positions of command in expeditionary armies and the $Y \ddot{u}-1$ in Guard, she cannot be said to have used male relatives in other ways to underwrite her political power. 35

The career of $\mathrm{Li}$ Chao-te served the empress' purposes even with its unhappy end. During early Chou Li served as a vigilant counteracting force to Lai Chünch'en, curbing Lai's excesses and even frustrating his attempts to marry into the great northeastern aristocracy, 36 but the empress also clearly saw that Li's role could last no longer than Lai's. When Lai was exiled for corruption in late 694, she acted simultaneously on complaints about Li's excessive power and arbitrary nature to also send him from the capital, 37 and in 697 she had both men executed on the same day even though $\mathrm{Li}$ was probably innocent of any capital crime. 38 Because $\mathrm{Li}$ Chao-te was also the most prominent defender of T'ang interests during the succession dispute, his fate shows how the empress could manipulate the court factions to simultaneously keep both her own and the T'ang restorationist partisans from dominance over the throne.

Li Chao-te's victory in expelling the Wu clan from their powerful positions in 692 was a real one, and there are indications that the empress feared that it would lead the court to regard the succession as settled and so deprive her of a valuable political weapon. Thus she began the year 693 with a magnificent ceremonial which was remarkable not so much because she personally composed the music for the 900 dancers, but because she chose her two nephews to make the secondary offerings, excluding Jui-tsung from the proceedings. 39 Shortly thereafter she secretly had Jui-tsung's two favorite consorts executed on charges of 
sorcery laid by a slave girl. Jui-tsung was either too cowardly or too diplomatic even to raise the matter, but since one of the consorts was the mother of the future emperor Hsüan-tsung, the incident undoubtedly had its effect on his later attitude toward his grandmother. 40 As heir apparent, Jui-tsung was in the delicate position of being the most likely focus of any restoration plot, and the empress seems to have deliberately emphasized the insecurity of his position two months later when she first changed the princely titles of his five sons, and then publicly executed two officials who had paid him a secret visit. 41 on this occasion he himself was denounced as a traitor, and for a brief period the T'ang family's prospects hung by a very thin thread. He was saved, however, when one of his retainers, while being interrogated by Lai Chün-ch'en, attempted to cut out his own heart to show his master's loyalty. The empress is said to have sighed at her inability to know her own son when she heard of it and halted the proceedings so that, as the Comprehensive Mirror remarks, "Jui-tsung, from this [time] was safe (te-mien).1142 The empress seems at this time to have de-1 cided definitively in favor of a Li succession, and she did not allow any further discussion of the matter until 698 when Chung-tsung's appointment was being considered.

I suggested earlier an element of artificiality in the succession dispute, contending that the empress' attitude was determined not by any serious intent to have a nephew succeed her, but rather by her desire to attain certain political ends. Among these the most important was undoubtedly the continued expansion of imperial prerogatives at the expense of those of the tsai-hsiang group. This becomes abundantly clear when we place the succession dispute within the context of other measures more overtly directed toward the same purpose.

Scholars have for some time recognized that during Sui and early T'ang a key problem for the imperial house was the reduction of the pretensions and the actual power of the great houses whose members had not only monopolized governmental authority but had also so often usurped the throne during the period of disunion. An earlier chapter discussed at length some of the ramifications of this problem and showed that the T'ang solution lay essentially in the dilution of the power of the great clans through the "bureaucratization" of status.

T'ai-tsung, as we have seen, attempted to establish the principle that status was dependent upon service to the T'ang, and as a result he could attract to the highest posts in his bureaucracy men of aristocratic or at least officeholding background. Particularly in the case of his tsai-hsiang, men of proud genealogy were predominant, but because of his unique talents, the collegial-style government which marked most of his reign was highly successful. T'ai-tsung was a big enough man to coopt the best of the well-born of his generation. Inevitably, however, the chief ministers developed a sense of initiative and group consciousness which T'ai-tsung's successors, Kao-tsung and Empress Wu, seem to have regarded as highly dangerous and, as suggested earlier, the united opposition of the tsai-hsiang to her rise led to the destruction of their leadership and a period of over two decades when they were regarded by the throne as rivals rather than partners in government. Only in the last years of Kao-tsung, and under P'ei Yen's competent leadership, 43 did signs of collegiality begin to reappear. It seems possible that had Chung-tsung supported the aspirations of this group and allied himself with it against his mother, he might have avoided deposition. Instead he alienated $\mathrm{P}^{\prime} \mathrm{ei}$ Yen by threatening to continue, in the persons of himself and his wife, the pattern of emperor-consort family government, 
and thus threw the tsai-hsiang into the arms of the empress during her seizure of power in 684. P'ei's role in Chung-tsung's deposition was viewed by the empress as having the unwelcome effect of reinforcing the prestige and ambitions of the chief ministers and, as already suggested, this may have played a role in P'ei's downfall. His successor as paramount minister, Liu Wei-chih, perished in 687 largely because he fought the empress' assertion of imperial over ministerial prerogatives. 44 Until the rise of Li Chao-te in the early $690 \mathrm{~s}$ and $\mathrm{Ti}$ Jen-chieh in the late 690s, no dominant personality rose from among the tsaihsiang. The tenuous nature of the empress' legitimacy required that this be the case.

The manner in which the empress weakened ministerial power was not original nor, indeed, did it create an irreversible trend, for Hsüan-tsung's government, at least in its early years, bore greater resemblance to that of T'ai-tsung than to that of the empress. 45 This is just one more example of the general lack of innovation during Chou mentioned earlier. The insecurity of the empress' legitimacy dictated that she work as closely as possible within the traditional framework. Despite occasional appearances of fundamental reform, she changed only the de facto balance of power at the top, and when her two immediate successors proved unable to fill her shoes, the status quo ante of T'aitsung's time reappeared. The New T'ang History "judgment" quoted earlier demonstrates that her methods did not go unnoticed by the dynastic historians.

Her chief tactic was the manner in which she used her unquestioned right of appointment and dismissal. To begin with, she expanded the number of ministers holding tsai-hsiang status while at the same time shortening their tenure. Thus we find that in the late 690 s as many as sixteen men held the rank, compared to a previous high of ten 45 and a much lower average. The highest estimate for T'ai-tsung's reign is twenty-nine tsai-hsiang in twenty-one years while the corresponding figure for the years $684-705$ is sixty-six. 46 Under T'ai-tsung, the average tenure was seven years and under the empress, just over two. This contrast is suggestive, of course, of two highly different political styles, and it seems no accident that factionalism was a much more pronounced phenomenon in the Chou.

During the Chou only a tiny proportion of ministers reached tsai-hsiang rank before the age of sixty and that even then ministers were shifted with such frequency that consolidation and entrenchment were impossible. Lou Shih-te, whose career was otherwise remarkable for lengthy tenure in high posts without demotion, 47 held four different positions and was four times sent away from the capital on military duty during his six years as tsai-hsiang. Even Ti Jen-chieh, who enjoyed the fullest trust of the empress, held no fewer than seven different positions during his three years as tsai-hsiang! Furthermore, a fairly large number of such appointments were preceded by such terms as "provisional" or "acting" (chien-chiao, shih 試) 48 so that appointees were openly made conscious of a certain instability in regard to their tenure or qualifications. An astounding eighty percent of the Chou tsai-hsiang suffered dismissal, some to exile or death and others simply to a lower post. For the reign of T'aitsung, the corresponding figure is thirty-three percent. 49 it is interesting to note that among the early writings of the perspicacious historian Liu Chihchi is a fu of 695 which warns of the dangers of aspiring to high office. He entitled it, "Think Carefully" (Ssu-chen fu). 50

The overlap of function and responsibility inherent in the role of the 
tsai-hsiang could be exploited by the empress to foster dissension and rivalry. She did this by simultaneous, and sometimes also parallel, appointment of political enemies. Ti Jen-chieh, for instance, was the first elevated to tsaihsiang on the same day as Wu Yu-ning, and when $\mathrm{Ti}$ became Chancellery president in mid-698, Wu San-ssu was made his opposite number in the Secretariat. Imperial relatives, sycophants, and the occasional mystic expert only in Taoist magical practices 51 were seldom to have lengthy tenure, but they were often appointed simply to balance the opinions of their better qualified colleagues. Their very appointment tended to devalue tsai-hsiang status and, by contrast, to elevate the imperial institution.

Other traditional control methods were directed to the same end. Special rewards, usually in the form of personal commendations, silks or official rank for the recipient's sons were conferred in ways that would remind ministers that distinction was earned not merely by passing an examination or gaining high office, but by pleasing the ruler while in office. The empress used ministerial remonstrance, something for which she is often praised, 52 to encourage criticism directed against her as a person, and discourage attempts to limit the scope of imperial power. She permitted ministers to openly ridicule her fondness for auspicious omens or her penchant for making excessive numbers of appointments, 53 but at the same time she discouraged the use of arguments based on precedent in memorials to her, lest such precedents limit her prerogatives. She also punished participants in unseemly quarrels which occurred in the imperial presence. 54 Certain questions, like the succession or the role of her favorites, she regarded as "household matters" and throughout the Chou refused to permit ministers to raise them, often on pain of death. 55 This, of course, made nonsense of the ancient tsai-hsiang claim of omnicompetence, but skillfully preserved the appearance of free discussion in the court and undoubtedly enhanced the empress' popularity among those too far removed to perceive the reality.

Finally, there were times during Chou when the empress simply excluded the tsai-hsiang from her counsel, preferring to seek advice from outside their circle. Early in the dynasty her chief alternative seems to have been a group of non-official advisers, popularly called the "North Gate Scholars" (pei-men hsüeh-shih). Often considered the predecessors of the Hanlin Academy, 56 these men are first mentioned as a group in the year 674, when Ssu-ma Kuang tells us that they began not only to compile the literary works later ascribed to the empress but were "secretly ordered to participate in decisions in order to divide the power of the tsai-hsiang."157 It is difficult to know how extensively their services were used, though the empress did turn to them, for instance, when her regular ministers balked at the grandiose nature of her ming-t'ang plans, and she had the group's leader, Liu Wei-chih, second P'ei Yen in recommending Chung-tsung's deposition.58 The standard sources make little mention of them during the Chou, and perhaps because many entered the regular bureaucracy, their coherence as a group was destroyed by then. It is also possible that the empress found less use for them as she turned more to her own family and favorites, some of whom she realized were not without talent. Wu San-ssu, for instance, came almost to monopolize capital architectural projects, and the Princess T'ai-p'ing and Shang-kuan Wan-erh seem to have served as confidantes and secret advisers.59 In the last years of the dynasty the Chang brothers and their many hangers-on played a similar role, enjoying privileged access to the empress and sometimes refusing access to her even to the tsai-hsiang! 
It is important, as we view this process, to recognize two things. First, the empress enjoyed only a partial success in reducing the prerogatives of her ministers and was forced on occasion to accept defeat in matters as trivial as the curbing of her extravagance and as fundamental as her ultimate admission that the succession concerned not just her household but the entire empire.60 Second, although the bureaucracy was progressively weakened and restricted at the top, it continued to expand and develop in the lower levels as both entry into and promotion within it were facilitated. As a consequence, an ever-larger sphere of bureaucratic activity tended to slip out from under imperial control.

Early in 692, for instance, when the empress appointed to lower capital positions a large number of provincials recommended by special commissioners and did so "without inquiring [whether they were] worthy or stupid," there was a common saying to the effect that even sawyers and pottery menders had become officials.61 In 695 Liu Chih-chi pointed out in a much admired memorial that the empress' yearly Acts of Grace conferred so many promotions and honorific ranks that official robes and insignia were encountered everywhere. He compared her "excessive" appointments to gravel in need of sifting. 62

Without exact figures it is difficult to estimate, except in this impressionistic sense, how greatly the bureaucracy expanded during the Chou, and the task is made even more difficult by the fact that the new men seem to have been absorbed either into nominally menial jobs or through auxiliary appointments, rather than through the creation of new positions.63 But for our present purpose it is perhaps sufficient to demonstrate the existence of the trend. The Chou bureaucracy may not have been characterized by quality below the fifth rank, but it was opening a way to genuine social mobility. Its lower ranks constituted a huge pool from which those who showed ability might be drawn out and elevated to the charmed circle of fifth-rank officialdom. For approximately one-fifth of the Empress Wu's tsai-hsiang, we have no information whatever on their antecedents or previous careers, a fact which suggests that men of obscure origin were at last reaching the highest posts and that at least some succeeded in doing so even without formal examination.

The pressure from below which this phenomenon brought to bear upon those already occupying high posts helps to explain, for instance, why the coup which deposed the empress was the work exclusively of high officials, and it also helps to explain why the Chou saw no further attack on the great aristocracy in the form of clan lists or marriage bans. Such measures were no longer needed. If the tsai-hsiang group in the Chou constituted a representative sample, it seems clear that the scions of the great clans were coming to define their status in bureaucratized terms by writing examinations and accepting capital positions but, at the same time, were able to control only a small proportion of the most pivotal offices.64 In other words, even if they continued to fight for their own interests, they now did so on a field chosen by the throne and which undermined their old regional power bases. Little attempt seems to have been made to balance appointments on a regional basis, and this would suggest that the great aristocracy was coalescing into a more coherent, less divided interest group. Subject to pressures both from above and below in their bureaucratic role, the great clans were clearly on the defensive during the Chou and sought more to maintain than to advance their positions. They were by no means impotent and revived under Hsüan-tsung, 65 but by the eighth century power struggles had become more internalized than before, and the throne now played 
a more powerful role thanks to the work of the Empress Wu.

One more consequence of the widening of the road to office was the extremely high quality of those officials who reached the top. The traditional historians who so frequently criticize the empress are also consistent in their admission that her abilities were great enough to attract into her service men like $\mathrm{Ti}$ Jen-chieh, Li Chao-te, Hsü Yu-kung, Wei Yüan-chung, and many others whose talents were hardly inferior to the ministers who had surrounded T'ai-tsung. Ssuma Kuang, summarizing earlier views found in the dynastic histories, says that although the empress made too many appointments, she rapidly dismissed or executed the incompetents, and that because of her decisiveness and her abilities to use reward and punishment and to recognize talent, "the brilliant and worthy of the time were all in rivalry to be employed by her."166 This is undoubtedly true, but surely it was also the case that these talented men recognized the validity and the value of many of her wider aims and desired to contribute to their achievement.

Perhaps the strongest indication that this was so is that the political uncertainty, factionalism, and the continued existence of the terror of early Chou could not undermine its efficient if unambitious administration. The sharpest contemporary criticism of the government, as we have seen, centered upon excessive number of punishments and appointments. There were no signs of unrest outside the capital. Corruption, even when it involved the empress' closest supporters, was dealt with swiftly.67 For reasons to be mentioned shortly, a demographic shift was beginning to come to the notice of the court, and in this period attempts were made to tighten the census procedure and to create new administrative units to deal with the growth of population in the Yangtze valley. 68 Both the Boards of Civil office and of War were expanded, presumably to keep pace with their work load, and decree examinations were held, sometimes at the rate of two a year.69 We find little evidence anywhere of maladministration but rather that "the minds of the people were made up [in the empress' favor]. 170 Another sign of her self-confidence was the creation of the Record of Current Politics (Shih-cheng chi) which recorded her every pronouncement and sent it monthly to the History office. 71

The Chou suffered no setback in foreign affairs until 696 and, indeed, China's prestige among its neighbors seemed to rival its mid-century height. Tribute missions appeared from Central Asia, India and Indochina, a new king was invested in Silla in 693,72 and by 696 over 1,000,000 foreigners had sought and been granted permission to settle within the empire. The largest group to enter were 670,000 Western Turks of the Shih-hsing tribe, and large numbers of $\mathrm{Ch}^{\prime} \mathrm{iang}$ and Man tribesmen were also incorporated.73 In December of 692 two of the finest generals of their age, Wang Hsiao-chieh and T'ang Hsiu-ching, 74 who had earlier persuaded the empress that the time was ripe for the recovery of the Four Ciarrisons, inflicted heavy defeats on the Tibetans and reestablished the An-hsi protectorate at Kucha for the first time in twenty-two years. It is interesting to note that the empress seems not to have regarded this as expansionism, for on being informed of the victory, she remarked that the old borders of the chen-kuan era [627-650] had been restored completely and now were quiet.75 The frontier remained peaceful until early 694 when the Eastern Turks found themselves a brilliant if erratic leader in the new khan, Mo-ch'o (Qapagan), who soon dominated much of Central Asia and became the most formidable enemy of the Chou. 76 He wasted no time in testing China's border defenses but Chinese 
arms, even when led by Hsüeh Huai-i or one of the Wu princes, were still formidable. These early raids were sporadic and brought Mo-ch'o so little profit that he soon asked to submit, and in the winter of 695 he was permitted to do so with a generalship and a ducal title. 77

Mo-ch'o's submission was in a sense the high-water mark of the Chou. It was the last foreign policy success the dynasty was to enjoy for quite some time and, moreover, was symbolic of the success of the policy of buying acceptance through growth of rewards which had characterized domestic administration and, with the single exception of the Four Garrisons, foreign affairs also. In the widest sense, the aim of this policy for the empress was to secure her legitimation, permitting prosperity and inertia to do their work of reconciling bureaucrat and commoner to the unprecedented rule of a female emperor. This policy was, however, costly. Bureaucratic expansion, public works and patronage of Buddhism accounted for much of the budgetary increase, but defense costs also mounted rapidly as some of China's neighbors began to take advantage of internal dissension. The empress had been successful in augmenting the fu-ping system and in the establishment of some new garrisons, especially in the South, 78 but it rapidly became evident that the demands on the state treasury were simply too great. Thus as early as mid-694 the empress had tried to assess her officials the equivalent of two months' salary to support the military, but had been forced to withdraw the assessment in the face of general opposition.79 In the same month, the growing shortage of metal was demonstrated when farm implements had to be melted down for the construction of the t'ien-shu. 80

At about the same time, officials began to identify still other causes of the financial problem, foremost among them the failure of earlier attempts to tighten census registration. In $695 \mathrm{Li}$ Chiao, a censor of distinguished lineage, a chinshih graduate and a man of recognized literary talent, drew attention to the growing number of vagrant households, a problem which he asserted had existed for some years. 81 He did not directly blame the central government for the phenomenon but rather the indifference of local officials who were lax about identity cards (chien-ch'a), and he pointed out the futility of recent attempts to have local officials reform the situation. He offered four solutions. First, the present law should be clarified and the government should show a tolerant attitude to present offenders. Second, a time limit of 100 days should be set, during which the squatters could give themselves up and opt either to remain where they were or return to their original homes. Third, in either case they were to receive amnesty and financial aid to get a new start. Fourth, the whole reform should be supervised by special censors sent out from the capital.

The empress is said to have approved this plan and actually to have appointed the censors before she was forced to shelve it because of ministerial objections whose grounds we are not given.82 There is evidence from Tunhuang that a similar plan was implemented about $702-3$, but its effect could not have been great since Hsüan-tsung faced the problem in greatly magnified form early in his reign. 83 It seems likely rather that the Chou continued to suffer from the problems $\mathrm{Li}$ Chiao connected with the vagrants--tax evasion, local conflicts, and the toorapid growth of urban population--but that they were not viewed as serious enough to require a concerted effort at reform.

These first signs of economic strain, followed by two successive political defeats, coincided for the empress with the severe personal disappointment and 
weakening of prestige caused by Hsüeh Huai-i's burning of the ming-t'ang complex in early 695. We have already noted how this event led to a shift in her ideological priorities from Buddhism to Confucianism, particularly in symbolic terms. 84 Moreover, it seems to have fostered an atmosphere of freer speech at the court. Frank criticism of her plans to rebuild the ming-t'ang 85 were voiced as well as complaints, already noted, about excessive appointments and rewards and lax provincial administration.

The empress' response varied: she agreed to build a smaller version of the ming-t:ang, rid herself of Hsüeh Huai-i and other favorites 86 and, toward the end of the year, abolished the principle of anonymity (hu-ming) she had herself introduced into the examinations, probably in 690.87 While her reasons for this are not altogether clear, it seems likely that such a measure would have appealed to those already in office who would now find it easier to help their friends and relatives gain entry into the bureaucracy. Although her response to the problem of vagrancy was a positive one, it seems that in these other areas she continued to rely on palliatives rather than take the positive steps which might have jeopardized her popularity. As we have seen, and in spite of the fiscal problems so evident in 695 when she offered the feng-shan sacrifice at Mount Sung, at the end of that year she declared an empire-wide holiday from that year's tsu tax! 88

What impact this might have had we are not told, for domestic problems were soon overshadowed by the renewal of the foreign threat with the massive defeat sustained by the hitherto invincible Wang Hsiao-chieh and his deputy, Lou Shihte, at the hands of the Tibetans in April 696.89 The underlying causes of this defeat are hard to identify since the sources provide no more than the briefest outline of events among the Tibetans since the accession of the young btsan-po in 679. From what we can gather, the young ruler had initially lacked the strength to wrest state control from the mGar clan who had been in power since his grandfather's time. It was a member of this clan, Lun Ch'in-ling, who was responsible for the victory. 90 Shocked by her first defeat during the Chou, and with the Tibetans only a hundred miles from Ch'ang-an, the empress had no time for retaliation before a new threat arose on her northern flank. This was the great Khitan rebellion which broke out in early summer.

This event seems to have been totally unexpected. The Khitans had been quiescent since 648 when T'ai-tsung had incorporated them into the Ying-chou tu-tu-fu 91 under which they had come to enjoy a good deal of self-government. The two rebel leaders Li Chin-chung and Sun Wan-jung had risen to high administrative posts there but, as was sometimes the case, the Khitans had not been fortunate in the Chinese officials placed over them, and the current governorgeneral seems to have been a hard and self-willed man who not only treated the chieftains like slaves but had refused relief during a recent famine.92 This is usually given as the immediate cause of the rebellion, but the dissatisfaction with Chinese rule may have run deeper, since within a week $\mathrm{Li}$ and Sun had thousands of rebels under arms. Since the Khitans were a relatively sophisticated enemy and already lived inside the Wall, official response was both swift and in earnest. Twenty-eight generals at the head of an unspecified force were sent against them, but in the first major battle, near present-day Peking, the imperial troops were almost annihilated. The disaster was compounded when the Khitans used captured Chinese seals to forge orders which led the relief force into an ambush.93 


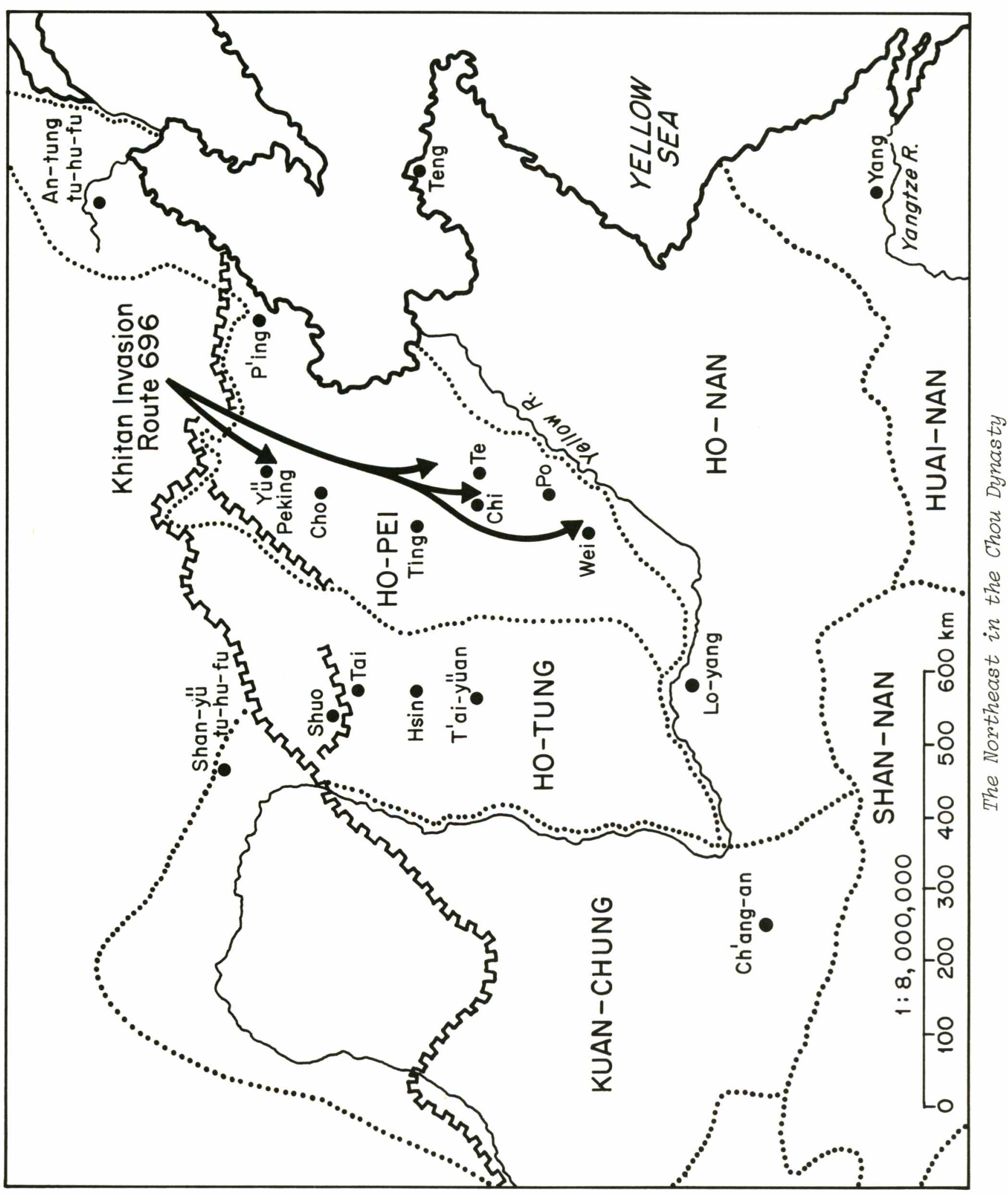


In what was admittedly a desperate situation the empress initially overreacted. She made an unprecedented offer of official rewards to criminals and private slaves who would enroll in the army, 94 she quickly began to transfer all the troops from the Northwest as well as from Huai-nan and Shan-nan to Yü-chou, and ordered the latter to make the 4,000- $2 i$ march in a hundred days! Even the grain transport ships from the Yangtze valley were to be diverted and continue with their present crews to the front.95 Critics at court objected to all of this, and it is difficult to tell how many of these measures could be carried out, for in the same month, June 696, Mo-ch'o's Turks drove into Liang-chou, and the Tibetans, still in Lung-hsi, threatened to advance unless Chinese forces were withdrawn from the Four Garrisons.96 Though now beset on three sides, the empress recovered from her initial panic, and decided to rely upon the calm expertise of officials like Kuo Yüan-chen and Ch'en Tzu-ang who had firsthand experience of the frontiers.97 These men rapidly evolved a series of policies which were ultimately to prove successful.

Turning first to the Tibetans, and acting on Kuo's perception of serious rivalry between the ruler and Lun $\mathrm{Ch}^{\prime} \mathrm{in}-\mathrm{ling}$, the empress immediately sent envoys to parley about a marriage alliance and an exchange of territory, but with secret instructions to exploit the factional rivalry.98 Ch'en Tzu-ang had considered the Turks and Tibetans to be a greater threat than the Khitans and, acting on his advice, the empress turned next to Mo-ch'o. Fortunately for her, the Turk had already revealed the nature of his ambitions, requesting not only that the Turks settled inside the Wall be returned to him, but also that the empress adopt him as a son and arrange an imperial marriage for his daughter.99 Knowing, therefore, tht he had designs on the Chinese throne, the empress was able to temporize while still encouraging his hopes, and to this end she promised to consider his requests while meanwhile confirming him as khan and appointing him an imperial general.

These marks of favor coincided with the death of the Khitan leader Li Chinchung, and Mo-ch'o seized the opportunity to attack the unprotected Khitan base and capture the families of the absent leaders, as a result of which he was granted still more distinctions from the empress.100 it may be that the Turk had his own interests at heart in this attack on a rival foreign power but, whatever his motives, he substantially weakened the Khitans who now had no option but to advance further south, and they rapidly reached Wei-chou, less than two hundred miles from Loyang. Here they halted for the winter, providing the empress with a breathing space but ominous news soon arrived that the Khitans were seeking local support for her deposition and the restoration of Chungtsung. 101

The year 697 opened gloomily. Mo-ch'o had become impatient, and he began once more to plunder the border prefectures. At the same time, a well-connected prefect named Liu Ssu-li was persuaded by a fortuneteller that he possessed signs of greatness, and he rapidly began to form a party at court to help him seize the throne. The conspiracy seems to have been well advanced by the time it came to the ears of Lai Chün-ch'en who saw in it a chance to regain his lost favor and reported it immediately by the special (shang-pien) procedure to the empress. Not fully trusting Lai, she put the investigation in the hands of a grandnephew, Wu 1 -tsung, but he soon proved to be fully as unscrupulous as Liu, forcing the guilty Liu to implicate many innocents, in all probability those 
most opposed to the Wu interests. In all, we are told, thirty-six families, "all distinguished shih of the empire," and over a thousand of their adherents and relatives suffered the penalties of exile or death in this final purge. 102 It also brought Lai back to power, and although the empress used her typical ploy and elevated his enemy Chi Hsü at the same time, 103 Lai's power was great enough to again create a climate of fear and dread in the court, and once again to raise questions about the succession.

The atmosphere of the court was becoming even more confused just then because of the meteoric rise of two unknowns, the half-brothers Chang, I-chih and Ch'angtsung. 104 These young men, probably only in their twenties at the time, were the grandsons of a distinguished minister, Chang Hsing-ch'eng, and the elder of them had used the yin privilege to take up an official career. He was also "white of complexion, of great beauty and skilled in music and song," qualities seemingly shared by his younger brother Ch'ang-tsung who attracted the attention of Princess T'ai-p'ing and won her recommendation. Taking advantage of his access to the palace to speak to the empress of his brother, he secured an introduction for him, and before long both were awarded high rank and showered with brocades, horses, slaves and other gifts. In the popular literature of later times and, indeed, even at the time, the rise of the brothers was attributed to a sexual liaison with the empress, 105 yet the standard sources not only portray them as somewhat effeminate but specifically state that they were castrated (ch'eng p'i-yang chih ch'ung). Moreover, the empress was seventy at the time and, although she was "skilled with cosmetics" and so able to conceal her age, 106 it seems more likely that she favored the youths because they were diverting company and, more particularly, because she believed that Ch'ang-tsung was the reincarnation of the Taoist immortal Wang Tzu-chin. 107 The empress had apparently begun to show the interest in personal immortality which characterized so many rulers late in their lives. 108

Whatever the reasons for their rise, the Changs were soon the dominant personalities at court, with even the various members of the Wu clan waiting at their mansion gate and contending for the privilege of holding their bridles! 109 The Changs' relatives were also awarded gifts and honors seemingly without limit, and life at court began to take on an almost frivolous cast. The empress was pondering whether to gild her nine recently cast tripods 110 even as the Khitans smashed an army of 170,000, killed Wang Hsiao-chieh, and occupied Yü-chou with great carnage. 111

As if this were not enough, Mo-ch'o at the same time presented what was virtually an ultimatum threatening rebellion unless he were awarded the entire Shanyü protectorate and unless all the Turks who had previously settled in six prefectures inside the Wall were returned to him. 112 The ensuing debate seems to have jolted the court back to reality, and the empress inclined first to the "hard line" of Li Chiao and T'ien Kuei-tao,113 but was finally forced to the side of the appeasers by the magnitude of the Khitan threat. Thus she returned to Mo-ch'o several thousand tents of settled Turks, along with huge bribes of textiles, seed grain, farm implements and iron, as well as the promise of an imperial marriage, 114 hoping this would temporarily satisfy him. As summer approached, she sent two more huge armies, one 200,000 strong, against the Khitans. The source of these troops is unknown, but considering the enormous levies of the past two years, these armies might be seen as one last great effort at national salvation. The overall commander was Wu l-tsung, a grandnephew of the 
empress whose military career was not a distinguished one. ${ }^{115}$ His appointment suggests that the troops might not have been wholly reliable and that the empress was now more concerned with keeping close rein on the military than with a frontier army's efficiency.

Fortunately for her, the tide now turned. The Khitans seemed to have no appreciable success in winning over the Chinese in occupied areas and so sought an alliance with Mo-ch'o, intending later to betray him. The Turk, however, anticipated their bad faith by seizing their newly built storehouse and base in Manchuria, taking all the booty they had hitherto gained. It seems unlikely that he planned any direct attack on the Khitans but news of his raid reached them while they were engaged in battle with the Chinese and, fearing attack from the rear, their Hsi allies mutinied and the rest of the army scattered. Sun Wan-jung was killed by his subordinates while in flight and the remnants of the rebellious tribes joined Mo-ch'o.116 Thus at an enormous cost in men and money and after the devastation of much of the Northeast, the Khitan rebellion came to an end.

As was often the case with the empress, success brought a relaxation of the harsher aspects of her rule. Even as this final campaign against the Khitans was in train, she had moved, albeit unwillingly, against Lai Chün-ch'en and had destroyed him before the final victory. His fall was of his own making, for since his return to favor he had, in open disregard of the law, denounced several high officials in order to seize their wives, concubines and possessions, and had become ever more arrogant and unrestrained. Either because he sought supreme power for himself or because he was by now demented, he accused the Wu princes and Princess T'ai-p'ing of engaging in a conspiracy with Chung-tsung and Jui-tsung. The princess, whose shrewdness seems almost to have matched her mother's, responded by leading the accused in a countersuit. Lai's rise had been based, of course, on the fact that among his many false denunciations, he had identified the occasional genuine plot, and on the basis of this service to the state, the empress thought to pardon him. Ironically, it was Chi Hsü who had once been accused by Lai, who persuaded her otherwise and she permitted his execution though, as we have seen, she sent his chief enemy Li Chao-te to the same block.117 She also made her peace with Lai's faction. The decree outlining Lai's crimes also pardoned the many officials whom he had intimidated into making false appointments. 118 Later that year she called together her ministers and, explaining why she had placed such trust in Lai and in Chou Hsing before him, acknowledged that she had been deceived and promised henceforth to eschew such methods. 119

It is impossible to gauge the sincerity of the empress' repentance, but it is a fact that in mid-697 the terror finally came to an end. Moreover, contemporaries seem to have sensed the change of climate, for when Wu Ch'eng-ssu and San-ssu renewed their succession claims early the next year, the ministers united in opposition, showed no fear of remonstration, and in fact were able to speak frankly with impunity. Led by $\mathrm{Ti}$ Jen-chieh, who was henceforth to enjoy the complete trust of the empress, 120 several went so far as to suggest the regularization of the succession by the elevation of Chung-tsung, and $\mathrm{Ti}$ disposed of the old argument that the question was a "household matter" by pointing out that for a ruler, all within the empire constituted his household.121. The empress took time over her decision and, although in Ssu-ma Kuang's judgment it was $\mathrm{Ti}$ who persuaded her definitively against a Wu succession, 122 ironically 
enough, it was the Chang brothers who successfully urged Chung-tsung upon her. 123 It is unlikely that the initiative for this lay with them, but although they are seldom credited with any political acumen at all, they could well have at least recognized that their survival would depend on others once their protector died. In the third month of 698 , ostensibly for medical reasons Chung-tsung was brought back to the capital. 124

These events raise interesting questions about the nature of Wu Tse-t'ien's power, foremost among them perhaps the question of how important coercion was in its maintenance. The answer seems to be that until the bureaucracy was satisfied that the will of Kao-tsung was to be carried out and Chung-tsung was assured succession to the throne, punishments were an integral part of the Wu regime, as important to its survival as its state ideology or the winning of popular support. If this is so, my earlier suggestions on the highly personal nature of the empress' legitimation are strengthened for, at the risk of repetition, it must be pointed out that her rule had to produce divided loyalties within officialdom. Though most high officials recognized that her ability exceeded that of the rightful heir and therefore deferred to her claims, they also saw themselves as guardians of the well-defined tradition requiring the Son of Heaven to be a male. Thus the empress, whose whole career was in violation of this tradition, could never be certain whether loyalty to her ability would remain uppermost in her officials' minds. Perhaps more than anything else, it is a measure of the flexibility of T'ang Confucianism that compromise was possible but, since this compromise came about only with the second decade of the empress' de facto rule and since the compromise was essentially a Confucian victory, it too was a measure of the strength of tradition. With the succession now regularized, the empress would be permitted to remain in power but only so long as she continued successfully to fulfill the obligations of ruler.

This is not to say, however, that she became a "lame duck," a prisoner of the upper bureaucracy, in the last years of her reign. For instance, when Ti Jenchieh became paramount minister, she took care, as always, to balance his appointment this time with a new position for Wu San-ssu. 125 She also stopped short of proclaiming Chung-tsung as crown prince immediately and, as we shall see, she insisted on the invulnerability of the Changs in spite of their increasingly flagrant corruption. To increase her base of support in the lower bureaucracy, she put Li Chiao in charge of the selection system in late 697 where he "began

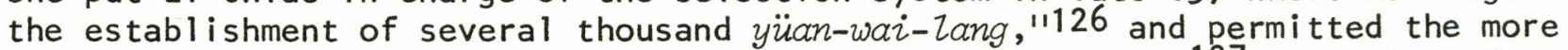
rapid advancement of lower officials within the bureaucracy.127 In spite of these measures, however, the effect of the terror's end and the return of Chungtsung was still enough to produce a greater spirit of cooperation between the empress and her ministers and one which led to happy results, particularly in foreign policy.

The defeat of the Khitans, and the necessity of placating Turks and Tibetans to achieve it, seems to have led to the rise of a strong and articulate pacifist party at court, and one which advocated for the first time the abandonment of some previously gained territory. In the winter of $697 \mathrm{Ti}$ Jen-chieh put the case for this into an erudite memorial 128 which first outlined China's natural barriers against the foreigners, and pointed out that the wise rulers of ancient times had recognized that conquest beyond these borders was the use of national wealth to acquire worthless and unproductive land which would yield no revenue. Ambitious rulers like Ch'in Shih-huang-ti and Han Wu-ti had impoverished the 
state with their expeditions. Recently, he pointed out, successive campaigns had eaten up huge sums of money and still continued to do so, in spite of the fact that "in Kuan-tung there is famine, in Shu and Han [households] flee their registration, and south of the Chiang and Huai the levies never cease, [so that] people cannot return to their livelihood and one after another turn to banditry." He recommended that the empress abandon her present policy and return to that of T'ai-tsung. For the North and West, 129 this would mean utilizing largely native administrations, eschewing far-off garrisons and attacking foreigners only if they rebelled. A-shih-na Hu-se-lo130 should be made khan and placed in charge of the Four Garrisons, while a scion of the old ruling family of Kogury should be given An-tung to hold. Chinese troops should store up supplies and guard the borders against attack while spying on potential enemies. If the Turks and Tibetans attacked in force they would risk defeat, and mere raids would reap little profit.

According to the Comprehensive Mirror, those conversant with foreign affairs agreed with $\mathrm{Ti} .131$ Although the empress did not implement $\mathrm{Ti}^{\prime}$ 's specific recommendations, she tended during the remainder of the Chou to follow the general policy lines he had set down. Judging from memorials which Ch'en Tzu-ang submitted that year, the empress began to economize as early as 698. She abolished the T'ung-ch'ang army and the huge annual corvée which transported supplies to the northwestern garrisons, and ended the levies and corvee in Chien-nan. 132 Even with Mo-ch'o, whose presence had made $\mathrm{Ti}^{\prime} \mathrm{s}$ specific proposals impossible to grant, the empress attempted conciliation. Obviously seeing him as a greater threat than the Tibetans whose invasion route she was content to garrison, 133 she abruptly agreed to a marriage alliance in the sixth month of 698 , sending Wu Yen-hsiu, the second son of Ch'eng-ssu, to marry Mo-ch'o's daughter. 134 The dispatch of a prince of the blood to marry a foreign woman (rather than a Chinese princess to marry a foreignmale) was wholly unprecedented, a fact quickly pointed out by orthodox officials. The empress quickly stilled her critics by demoting one of them, Chang Chien-chih, to a remote southern prefecture. 135 He would return in 704 as tsai-hsiang and then take charge of the restoration coup.

The sending of a male "bride" to the Turks turned out to be a serious miscalculation, for Mo-ch'o saw immediately that the empress had no intention of granting his major demands and by this time he must also have realized that the succession was to be the $\mathrm{Li}$ and not the Wu. Thus he pointed out to the envoy who had accompanied Wu Yen-hsiu that he had wanted his daughter to marry into the $\mathrm{Li}$ clan who had always treated his people well, and he threatened to restore the T'ang. In the eighth month of 698 he sent forth troops for that purpose and achieved several rapid successes, with one of the three frontier armies upon which he made a surprise attack submitting voluntarily and without a fight. At the same time, he sent angry missives to the court, listing five grievances against the empress and threatening to seize Ho-pei for himself. 136

Her response was to rouse the empire for yet another great effort, recruiting four armies said to total 450,000 men and drawn in all probability from throughout the country. 137 Even a force of this size, however, proved unable to pin down the mobile foreigners, and she was forced to call for even more troops. This time the people balked. In over a month, we are told, no more than 1,000 men responded to the call to arms, 138 and she was finally forced to play her trump card. In form acceding to a request from Jui-tsung, she declared Chungtsung heir apparent and two days later made him supreme commander (yüan-shuai) 
of the Ho-pei armies, supplanting her grandnephew Wu Chung-kuei. 139 The appointment of Chung-tsung was, in fact, a nominal one with $\mathrm{Ti}$ Jen-chieh actually filling the post, but its propaganda value seems to have been great since the sources tell us that before long 50,000 men joined the army.140 $\mathrm{Ti}$ was able to lead an additional 100,000 men into the field, and this seems to have convinced Mo-ch'o that the combined Chinese forces were too strong to fight and so he withdrew to the steppes, leaving behind a death toll estimated by one source at 80,000 to 90,000 persons. $141 \mathrm{His}$ own army had swollen to 400,000 and as the various tribes north of the Wall submitted to him, he briefly became the greatest power in Central Asia, almost reconstituting the great T'u-chüeh empire of the mid-sixth century and exhibiting "a highly contemptuous attitude toward China."142

The empress' failure to complete the subduing of Mo-ch'o is the principal reason traditional historiography tends to regard the Chou as a weak dynasty, but in retrospect this seems unfair. The Turks, after all, were driven from China and, although Mo-ch'o was to return once more, his last raid was in no sense so serious a threat as the invasion of 698. It is unlikely, moreover, that the empress had either the ability or the inclination to go onto the offensive. As mentioned earlier, she faced a strong peace party at court, and she also had some doubts about the reliability of her troops when those she did send in pursuit of Mo-ch'o "did not dare to press [him]."143 She undoubtedly interpreted the reluctance of the people to enroll in the army in 698 as a sign of their desire for rest and, always sensitive to the popular mood, when Mo-ch'o withdrew she seems to have decided that she would henceforth play a waiting game and use diplomacy rather than war to deal with her enemies.

She was fortunate, therefore, when her Tibetan policy of fomenting internal dissension at last bore fruit in the summer of 699 . While Lun Ch'in-ling was out of his capital, the young btsan-po used subterfuge to escape confinement and struck hard at his enemy, seizing and executing 2,000 of Lun's supporters in the capital. He then attacked and routed Lun himself. Lun committed suicide and his followers, including over 7,000 tents of T'u-yü-hun, sought refuge in China.144 Perhaps in an attempt to consolidate his position, the btsan-po invaded China the next year but was driven back when the experienced general T'ang Hsiuching bested him in six successive battles. 145 Rather than follow up these victories, the empress chose to consolidate, putting Kuo Yüan-chen in charge of strategic Liang-chou. During the next decade his capable administration is said to have secured the borders, brought prosperity to the area, and won the respect of the Tibetans. 146 In 703 after yet another defeat, they resumed tribute payments to China and requested a marriage alliance. 147 The sources do not record whether or not this was granted, but the accession of a seven-year-old ruler in the following year (704) ensured that the Tibetans would pose no threat for the remainder of the Chou.

of Mo-ch'o little was heard in China until he again invaded early in 702 . He swept deep into Shensi and reached the empress' home prefecture of Ping-chou before halting. Chinese countermeasures were swift. The "Shan-tung Defense Army," made up entirely of northeastern troops had earlier been established for just such an eventuality 148 and, shortly thereafter, a still larger force was levied, and nominally headed by Jui-tsung who received the title of supreme commander. Although the Turks could not be pinned down, the rapidity of the Chinese response seems to have impressed Mo-ch'o, and he retired without engaging in a major battle. In the sixth month of 703 he sent an envoy to request that his daughter be 
married to a son of Chung-tsung. ${ }^{149}$ The sources are not specific on whether or not his request was granted, but a marriage of some sort was certainly arranged since Mo-ch'o sent a message of gratitude at the end of the year. 150 That he remained active outside the Wall is evidenced by certain administrative changes on the frontier, 151 but after one more great victory at Ming-sha near Tunhuang in 706, he caused no further trouble in China. He was assassinated by a rival in 716.152

In view of these facts, the later stages of the Empress Wu's foreign policy should be seen neither as unrealistic, overambitious, nor as a failure.

The diminution of foreign threats after 699 should perhaps have made possible an attempt to solve some of the longstanding internal problems, but this was not the case. Part of the reason lies, of course, in the empress' age. Although early in 699 she is said to have grown new eyebrows, shortly afterwards she suffered her first recorded illness while visiting Mount Sung, in Taoist legend the site of a miraculous ascent to the land of the immortals by Wang Tzu-chin in the sixth century B.C. 153 Although she recovered slightly, she suffered a relapse the next year. She improved again when she took an elixir of long life fabricated by a Buddhist monk. 154 Her health seems gradually to have declined thereafter and with it her extraordinary administrative abilities seemed to diminish. She may also have felt that the time for relaxation had come, that she was at last secure in her legitimation. Indicative of this is the fact that immediately after her second illness she divested herself of the last of her grandiose titles. 155

A second reason for the administrative decline which characterized the last years of the Chou is the death of $\mathrm{Ti}$ Jen-chieh in the autumn of 700 . As the empress put it, his death left the court empty 156 and, though she lamented his absence each time an important decision was called for, she was to find no one to replace him. It was partially for this reason that she made perhaps the worst decision of her career, turning more and more to the Chang brothers for company and for stimulation.

At the beginning of 699 , and probably in response to complaints that the Changs did nothing to deserve their favor, she had established for them a new institution, the k'ung-hao fu or Office of the Crane. The crane, of course, was a symbol of longevity and the means by which Taoist immortals were conveyed to Heaven, 157 and the purpose of the office was ostensibly that of literary compilation. Not only were a number of competent scholars appointed to it, but in 701 its members produced at least one large and important work. 158 In mid-700 its name was changed to the feng-ch'en fu or the office of Imperial Attendants, but by that time it had already acquired a rather unsavory reputation as the site of evenings of drinking, gambling, and other unseemly and undignified activities in which the empress herself and high officials who wished to curry favor with the Changs often participated. Needless to say, this gave rise to scandalous rumors and, the old T'ang History tells us, the empress went so far as to order that handsome youths be recruited as attendants, an act which caused one official to remonstrate:

Your Majesty has already granted intimate favor (nei-ch'ung) to Hsüeh

Huai-i and to Chang $\mathrm{I}-\mathrm{chih}$ and Ch'ang-tsung. Surely this should be enough. Recently I heard that a head of the Servants of the Imperial Apartments, called Liu Mu, himself claimed that his son Liang-pin was white and pure, beautiful in beard and eyebrow. The chief administrator 
of the Gate Guard of the Left, Hou Hsiang, said that his virility (yangtao) and robustness surpassed that of Hsüeh Huai-i, and unassisted he wanted to recommend himself as fit for membership in the Office of Imperial Attendants. 159

It seems clear, therefore, that in the popular perception the office was viewed as something akin to a male harem, and the empress' reputation suffered. She is said to have rewarded the author of the blunt memorial quoted above and remarked that had it not been for his plain speaking, she would not have known the situation existed. 160 In all likelihood this was true, for the empress' attraction to the Changs seems to have been based more than anything else on their youth and her belief that Ch'ang-tsung, whom she dressed in feathers and mounted on a wooden crane, was the reincarnation of Wang Tzu-chin 161 and hence in possession of the secret of longevity. When we recall that even the great T'ai-tsung, who seems to have been far less superstitious than many of his contemporaries, was not immune from the lure of immortality, her infatuation becomes more comprehensible.

These activities of the Changs, aside from the fact that they distracted the empress from more important concerns and somewhat lowered her prestige, were relatively harmless, and there is no record of $\mathrm{Ti}$ Jen-chieh, for instance, offering any protest. More harmful, however, was their growing tendency to interfere in politics and to indulge in corruption on a grand scale. This latter activity became apparent almost from the beginning of their careers at court. In fairness it must be acknowledged that the two favorites were less corrupt than other members of their parvenu clan. Chang $\mathrm{Ch}^{\prime}$ ang-i, for instance, sold posts lavishly. On one occasion, when he forgot the given name of a client, he had all sixty persons of the same surname on his lists appointed to office! 162 When he and two other brothers were tried for corruption in 704, the three of them were found guilty of accepting over 4,000,000 cash in bribes, and others of the Changs' protégés were just as bad.163

None of the Changs, it seems, possessed any degree of political talent or literary ability and had been notable failures even in relatively unimportant provincial appointments. 164 The old T'ang History explicitly remarks that when Ch'ang-tsung was vice-president of the Board of Rites, he had to have documents ghost-written for him. 165 In spite of this, however, the two favorites had no qualms about intervening in state affairs, and the empress, says one source, often entrusted political matters to them. 166 As a consequence late in 701 they were responsible for an inner-court tragedy with wide ramifications when they denounced Chung-tsung's son and daughter along with her husband, a Wu prince, for criticizing the favor they enjoyed. The empress, in a burst of anger, ordered all three to commit suicide, thus leaving Chung-tsung without an heir. The existence of such an heir might have helped prevent the intrigue and bloodshed which marred the next two reigns. 167 The Changs allied themselves with the shrewd Wu San-ssu who was himself playing a double game by this time, 168 and this formidable alliance so intimidated even the Li clan that in 701 Chung-tsung, Juitsung and T'ai-p'ing joined together in the sycophantic request that $\mathrm{Ch}^{\prime}$ angtsung be granted princely rank! 169 Most of the ministers, needless to say, now feared to raise their voices against the favorites, with the single exception of We $i$ Yüan-chung, an outspoken and upright man who had four times endured disgrace at the hands of unworthy officials, but whose integrity and military ability had gradually brought him to the somewhat diminished position of paramount minister 
after the death of $\mathrm{Ti}$ Jen-chieh. ${ }^{170}$ He had twice indirectly attacked the favorites and now openly warned the empress against the "inferior men" (hsiao-jen) with whom she surrounded herself. The Changs accused him of treason and in 703 his trial involved much of the court. 171

The details of the trial have been recounted elsewhere, ${ }^{172}$ but its outcome illustrates how high the Changs had risen and the effect their rise had on the court. Although in the course of the trial it became clear that Wei Yüan-chung was innocent, and although the empress was warned that her behavior was beginning to cause good men to "slap their thighs at home" even though they had to "gag their mouths at court"173 for fear of the Changs, she knowingly overrode justice for the first time in her career, exiling Wei Yüan-chung to a low provincial assignment in the Far South. Even in the face of a concerted effort by ministers to have the verdict reversed, 174 she insisted it be carried out and by so doing she began to convince some key people that she was no longer competent to rule, and for a woman that was enough to undermine her legitimacy.

Deficiencies began to be noticed in other areas and, as problems went unsolved, the support of various constituencies began to dissipate. The upper bureaucracy, already somewhat alienated by her appointment policies and her support of unworthy favorites was the first to defect. Though the empress was highly successful in the first years of the dynasty in minimizing high official opposition by her patronage of Confucianism, by the late 690s it was becoming widely recognized that her support had been more apparent than real. In 699, for instance, one of the grand secretaries, Wei Ssu-li,175 memorialized on the state of education, inspired, according to the Comprehensive Mirror by the fact that the empress often used unscholarly ( $f e i j u-s h i \hbar$ ) members of her own clan and relatives by marriage for administrative and teaching positions in the imperial schools and supplemented them with their own poorly trained students who gained their positions as rewards for assisting her in ceremonials. 176 Largely for this reason, Wei contended, over the last two decades the youth of the empire had come to have contempt for those charged with Confucian learning and, as a result, shunned both the schools and the doctrines they taught. This made little difference to the scions of powerful clans (kuei-men) who could still easily gain appointment through favoritism, but poorer people were unable to rise and thus the bureaucracy was becoming riddled with unworthy and incompetent officials. From the time of Chung-tsung's deposition the bureaucracy had expanded rapidly, and at the same time evil officials had risen to intimidate or execute those honest officials who remained. Corruption in the selection system and the avarice of local officials had aggravated a bad situation. Wei's solution was to expand the school system and order the sons of the nobility and upper classes to enroll so as to ensure that they could use no other method to gain office. At school they should be required to obey the rules, to venerate Confucianism, and assist at the lectures of virtuous and erudite men. As a practical inducement to the adoption of this plan, Wei pointed out that it would assure a supply of highly qualified officials at all levels, and instead of the present situation where "more than half the empire's households have fled their registration, the tsu and tiao [taxes] shrink and our budget is insufficient," the state would be prosperous and happy. 17$\rangle$

There is probably an element of exaggeration in Wei's argument, but evidence from other sources tends to confirm his views on the extent of corruption in the selection system and the declining standards of provincial administration. 178 
The nature of our sources does not give us access to details of appointments to the capital schools, but Wei is probably correctly identifying a trend since, as we have seen, the literary emphasis in the examinations was regarded by some as detrimental to a more substantive Confucianism, and the several "decree" examinations of the Chou seem also to have been literary in bias.179 For these reasons the last years of the empress may have seen the beginnings of a progressive failure of the Confucian component of her state ideology, and although she made Wei Ssu-li rector of the state university, the imbalance was exacerbated as she turned more frequently to the mystical comforts of Taoism and Buddhism.

Recent scholarship has shown that quite aside from her relationship with the Changs and her visits to Mount Sung, the empress seems to have developed a greater interest both in Taoist festivals and literature in her last years, and she bestowed her patronage on both. 180 Still more conspicuous and more unpopular with Confucians, however, were the fruits of her long support of Buddhism, a patronage of whose dangers, I have tried to demonstrate, she was consistently aware. Nonetheless, by the year 700 officials could complain of how Buddhist foundations surpassed even the imperial palaces in magnificence and of how monks squeezed the people and disregarded their own Law. 181

There were signs that after 700 the empress sought to compensate for her earlier patronage by, for example, ending the ban on butchery and attempting to tax the clergy rather than the people at large for new images she wished to erect. 182 These, however, were palliatives and, as we have seen, she remained intensely Buddhistic until the end of her life. The effect of this partial withdrawal of support may, however, have further weakened her position, by raising doubts among the Buddhists about the reliability of her support without really appeasing the Confucians. Certainly the report of a miraculous appearance by the Buddha immediately after the ending of the butchery ban suggests an attempt by perhaps opportunistic Buddhists to warn the empress not to abandon her Buddhist loyalties. 183 Some dramatic act was necessary to restore this crumbling ideological hybrid.

This may be why in November 701 the court returned to Ch'ang-an for the first time in twenty years, 184 and remained there for almost exactly two years. Although it is sometimes suggested she made the move for reasons of health, it is far more likely that the empress' motives were political and ideological. Just prior to the move, she had ordered the suicide of Chung-tsung's children, and in that same month there had appeared the first open suggestion that she abdicate, in the form of a memorial from an otherwise unknown scholar, Su An-heng. Su pointed out that she had held the empire in trust for over twenty years and that since Chung-tsung had shown himself to be both respectful and mature, it was time the throne be returned to him. She had, moreover, more than twenty grandsons who should occupy the princely ranks now held by the Wu clan, thus ending the anomalous situation of having two imperial clans and avoiding trouble in the future. 185 While the empress failed to act on his suggestion, she rewarded rather than punished him, thus showing a clear recognition that his viewpoint was not an isolated one. The return to the T'ang capital, accompanied by the proclamation of the new era name of $c h^{\prime}$ ang-an, was designed, therefore, both to reduce political pressures and to show the sincerity of her Confucianism, for like the Duke of Chou she was preparing now to "hand over the throne to the intelligent prince." 
Although once back in Ch'ang-an the principal concern of the court was how to deal with Mo-ch'o, the empress was also able to make some repairs in her ideological policy and to tighten the administration somewhat. She now extended the examination principle to its logical conclusion by the establishment of the military examination, 186 and she declared an absolute moratorium on punishments concerned with the early rebellions against her while ordering a reinvestigation of Lai Chün-ch'en's cases, an action which resulted in the rehabilitation of many of his victims. 187 Several popular appointments including those of Li Chiao and Wei An-shih were made, Wei Ssu-li was put in charge of the state university (kuo-tzu chien), and a new type of censor was established.188 The order for the composition of a national history in $703^{189}$ was a Confucian act, and the placing of Wu San-ssu at the head of the compilers may indicate that the empress was about to withdraw from active life and wished to determine her place in history before doing so.

Unfortunately, any restoration of her popularity among her ministers which might have resulted from these measures and from the successful resolution of the foreign problem was dissipated by her actions in the aforementioned trial of Wei Yüan-chung, and when she returned to Loyang immediately after the trial, she deemed it prudent to leave her grandnephew Wu Yu-i in charge of ( $2 i u-s h o u$ ) Ch'ang-an. 190

Back in Loyang, and with an energy and competence surprising in a beleaguered and ailing woman nearing her eightieth birthday, the empress at last confronted some of the long-standing problems of her dynasty. Probably at the suggestion of Li Chiao, who had regained tsai-hsiang status in 703 , she sent special commissioners throughout the empire to examine the standards of provincial administration on the basis of the six categories ( $i$ iu-t'iao) used by the Han and perhaps to deal directly with the vagrancy problem. 191 Shortly afterwards she held a discussion on the problem of local administration. Li Chiao and T'ang Hsiu-ching argued that she was largely to blame for bad local government because she used demotion to the provinces as a punishment for unworthy capital officials. As a consequence, officials "all value capital posts and have contempt for provincial fosts." Her remedy was to take twenty experienced and able capital officials and concurrently appoint them as prefects. According to Ssu-ma Kuang, this experiment was a failure, 192 but it demonstrated the empress' consistent concern for the people and her willingness to attempt unusual tactics to better their lot. It was on these grounds, too, that she was dissuaded from completing a huge image of the Buddha in mid-704193' and, perhaps because of measures of this sort, we find a good deal of evidence to suggest that to the very end she retained her great popularity among the people. 194

The same cannot be said, however, of the feelings of her bureaucrats. $\mathrm{Al}-$ though her staff increase in the second university at Loyang in early 704195 and the amnesty and rehabilitation of all the earlier victims of Chou Hsing and Lai Chün-ch'en at the beginning of $705^{196}$ were undoubtedly popular, her expansion of the number of sub-fifth-rank officials within the bureaucracy still frustrated all her efforts to win the united support of the higher officials. The empress had always seen as one of her tasks the reduction of ministerial power relative to that of the throne. Her "excessive" appointments and rapid promotions within the lower bureaucracy had been a useful weapon in this conflict and one which had evoked numerous protests from high-ranking officials. With the rise of the Changs, however, and the death of $\mathrm{Ti}$ Jen-chieh who seems to have served as a 
kind of buffer, there are signs that the empress finally reversed this policy. In 701, for instance, the promotion process ( $k^{\prime} a 0$ ) was tightened. 197 Acts of Grace, of which there had been eleven in the preceding eleven years, ceased and when new posts were established, as in the case of the provincial censors, the number of officials to hold them was specified.198 At the end of 704 she abolished all the new posts established since 701.199 It is unlikely that economic motives alone were behind these decisions for she was still to suggest the erection of new Buddhist images and build new palaces. 200 Rather the policy seems to represent an attempt, belated though it was, to woo the upper bureaucracy. In so doing, of course, she risked the alienation of her allies below the fifth rank, and it is perhaps because of this policy shift that she found no support among them at the time of her deposition.

In retrospect, we may conclude that any attempt at this stage to win over her ministers became impossible for the simple reason that they could not be reconciled to the role of the Changs at court. To the empress, of course, her favorites were a solace and a diversion, not to be taken seriously. The perspective of her ministers, however, was different. To them the brothers were dangerous. They had been responsible already for more than one miscarriage of justice and for the spread of corruption and scandalous rumors which diminished the prestige both of the empress and those whose duty it was to remonstrate with her. They were, moreover, dangerous in a more direct way, for their party of hangers-on was large, their association with the shrewd and ambitious Wu San-ssu was close, and increasingly they alone determined who should have access to the empress.201 In the event of her sudden death, it was not impossible that they could yet overturn the succession. It seemed imperative to certain ministers that action be taken quickly.

In the end, it was the continuing attempt of the empress to conciliate her great ministers which brought about her downfall though short of returning to a policy of terror, it is difficult to know what other course she could have taken. In mid-704 she permitted the trial of three lesser members of the Chang clan for corruption and unwisely suggested that I-chih and Ch'ang-tsung be investigated at the same time. She was probably of the opinion that they were not directly involved in their kinsmen's bribery and that by permitting the conviction of lesser members of the clan, she would demonstrate her impartiality and thereby disarm the critics of the favorites. The tribunal found these men guilty. It also found that Chang Ch'ang-tsung had illegally occupied someone else's land and imposed upon him a light fine which the empress was happy to confirm. But when the tribunal went further and pointed out that the law demanded he be dismissed from all posts because of his brothers' proven crimes, she balked. Securing the agreement of one of her tsai-hsiang that Ch'ang-tsung "had meritorious service to the state," she immediately amnestied him, and before Wei An-shih and T'ang Hsiurching could complete their simultaneous investigation of 1 -chih she transferred them to the provinces.202 T'ang Hsiu-ching was probably speaking for all the other high officials when he secretly warned Chung-tsung before his departure that the Changs' abuse of favor was certain to cause a revolution.203

This thought must by now have occurred both to the empress and to the Changs. Her response was an unfortunate mixture of conciliation and overconfidence. She appointed T'ang loyalists like Huan Yen-fan 204 and, most notably, Chang Chien-chih to tsai-hsiang rank, and while she attempted to keep the customary balance, 205 she thus provided her enemies with a focus of leadership. The 
Changs, undoubtedly aware that in their recent crisis Wu San-ssu and his faction had offered no support, responded by abandoning their policy of using Wu against $\mathrm{Li}$ and decided instead to act on their own.

Whether or not the Changs made actual preparations to seize the throne is difficult to know, but in January of 705 wall posters accusing them of conspiracy began to appear. The empress refused to heed reports of these until on the nineteenth of the month, specific charges of treason were laid against Ch'angtsung. 206 According to his accuser, he had consulted a fortuneteller who told him he had the physiognomy of an emperor and that if he erected a Buddhist temple at Ting-chou, the empire would turn to him in support. This, of course, was a capital charge and, taking no chances, the empress appointed a tribunal of three, two of whom could be expected to vote for acquittal.207 As was also expected, the third judge, Sung Ching,208 dissented and as the court rallied around him, she used her former tactic of appointing him as a provincial commissioner in order to eliminate his opposition. His courageous response was to point out that such a commission was improper for one of his rank and when the empress, returning to her customary respect for the law, permitted him to remain in the capital, Ch'ang-tsung's case was lost.

As Sung Ching continued to press his suit, he was joined by others, most notably Huan Yen-fan, and even by a genuine supporter of the empress, Ts'ui Hsüanwei.209 Both attempted to convince her that it was in her own interest and, indeed, necessary for her survival to let the law take its course and, reluctantly, she sent Ch'ang-tsung to be tried once more by Sung Ching at the Censorate. While the trial was still in progress, however, she changed her mind and dispatched a messenger with an extraordinary pardon, freeing $\mathrm{Ch}^{\prime}$ ang-tsung and thus making him immune from further prosecution.

This act convinced the court officials that the ascendancy of the favorites was complete and, as the empress returned to seclusion in a remote section of the palace (ch'ang-sheng ÿüan) where the Changs alone were permitted to see her, they determined to act. According to most sources, Chang Chien-chih, who was now tsai-hsiang and chief imperial librarian, had determined to restore the T'ang during his provincial exile, 210 and now he set about recruiting a party to destroy the Changs by force. Easily persuading Ts'ui Hsüan-wei and Huan Yen-fan to join him, he added to his conspiracy the censor and prominent opponent of both the Chang and Wu parties, Ching Hui,211 as well as Yüan Shu-chi who had formerly served in Chung-tsung's household and was currently a member of Juitsung's staff. $212 \mathrm{His}$ presence was probably necessary to associate the princes with the conspiracy, and it was he who gave Chung-tsung what little advance warning of the coup he received.

All that remained now was to muster sufficient force, and Chang Chien-chih turned naturally to the Yü-lin Guard, suborning the General of the Right, Li To-tso, who some twenty years earlier had aided the empress in effecting Chungtsung's deposition. On both occasions he seems to have been motivated by concern for the welfare of the state. 213 Chang also insinuated Huan Yen-fan, Ching $\mathrm{Hui}$ and Li Chan, the son of $\mathrm{Li} /-f u$, into positions of command in the Yü- 1 in Guard, almost "tipping his hand" for the Changs immediately countered by having Wu Yu-i reappointed as general.214 More than anything else this move demonstrates the skill of the Wu interests. Since "several tens" of officials were later to be disgraced as their adherents, 215 the Changs might well have chosen 
another of their supporters for the post instead of a member of the Wu clan which had already demonstrated its unreliability as an ally. The appointment smacks of manipulation by Wu San-ssu, who had already assured his own future through a clandestine relationship with Chung-tsung's wife and the marriage of his nephew to the heir apparent's favorite daughter.216 In any case, Wu Yu-i seems to have remained inactive while the coup unfolded, thereby ingratiating the Wus with the conspirators.

Their preparations complete, the conspirators moved quickly. On the night of February 20, 705 they gathered a force of just over 500 men at the Hsüan-wu Gate, and sent for Chung-tsung. Although he had earlier approved the plan, Chungtsung now lost his nerve. While agreeing that the Changs should be destroyed, he did not wish to alarm his sick mother. $217 \mathrm{Li}$ Chan, one of the messengers, persuaded him that only his presence could now halt the action, and thus he agreed to accompany the conspirators to the northern gate. As soon as they caught sight of him, however, the others smashed the gate and swept into the palace grounds. Reaching the western pavilion where the empress slept, they ran into the startled Changs in the courtyard and decapitated them on the spot. Awakened by the clamor, the empress confronted the plotters, but must immediately have recognized that the coup was a success. After addressing words of scorn to her son and certain others of the plotters, 218 she returned to bed, her half century of power at an end.

The next day Chung-tsung took charge of the state and sent commissioners through the provinces to announce the restoration. On the twenty-second of the month he became emperor once more, though seemingly without a formal ceremony of abdication by his mother. He granted her the title "Follower of Heaven, Great Sage, Emperor" (Tse-t'ien ta-shen huang-ti) 219 and transferred her to the Shang-yang Palace west of the city where for the next year she remained an ill but honored political spectator receiving bi-monthly homage from the court. There is ample testimony, as mentioned earlier, that she remained popular among the people and, it seems, even with some ministers who remained at court. 220 It must have been with sardonic amusement that she saw Wu San-ssu so rapidly maneuver himself into a commanding position in government, reenact some of her old provisions, and render the five chief conspirators against her impotent.221 Nevertheless she was probably relieved to see the Li and Wu clans avoid strife and instead join in close alliance to impose their will on court and empire. On December 16,705, as she prepared to die quietly in her bed at about the age of eighty, she could afford to magnanimously renounce the title of emperor which she had held so long and finally to forgive her earliest enemies, those who had stood in her way so long ago when by becoming Kao-tsung's empress, she began the climb which would end on heights greater than any other woman in China would ever scale. 
Chapter 10

RETROSPECT

In the highly polarized historiography concerned with the reign of the Empress Wu there are only two areas of general agreement. Both Confucian critics and her modern apologists see her personal achievement as an improbable one, and the age over which she presided as one of significant historical change. Both perceptions are accurate but in their juxtaposition there is certain danger. The temptation is great to see in her impressive strength of character the chief cause for the social and political events of the late seventh century. I have tried to show, on the contrary, that Kao-tsung played a greater role than is generally recognized in the formation of imperial policy, and that it was while her husband and son formally occupied the throne that the achievements of the empress were most marked.

I have taken as a recurrent theme in this study the idea that the empress was a woman of her times. Her social, economic and judicial views could hardly be termed advanced, and her politics differed from those of her predecessors chiefly in their greater pragmatism and ruthlessness. The success of her usurpation and the longevity of her power I have attributed largely to borrowed legitimation, and have suggested that they were the result also of her ability to identify herself more closely than had the rulers of Sui and early T'ang with most of her subjects, those among whom she had been born and had spent her early life. To this degree, at least, there is validity in the Maoist interpretation which sees the masses as the driving force of history.

Indeed in many respects the Empress Wu behaved much like one of those sturdy, matriarchal T'ang widows whom we encounter in the Tunhuang manuscripts. Like them she was independent, occasionally eccentric, eager to protect her own family, and in the end, dedicated to the preservation of her husband's property and its inherritance by their son. And so, when all is said, we might best think of her as "the widow, Li," protagonist of the most spectacular romance of her epoch and also the most archetypical of the women of her time.

At a higher level we might also choose to regard the career of the Empress Wu as a story of the attainment and maintenance of power, and of the sometimes unintended results of its use. In her career we can see illustrated the tendency of power to seek its own maximization, and we see this tendency collide with a tradition of only limited flexibility. The Confucian state system denied the throne to a woman, but was willing temporarily to compromise that prohibition. It remained firm, however, in its determination that no woman should establish a dynasty. The manner with which the empress treated the succession question would seem to indicate that she was fully aware of this, and when on her deathbed she renounced her imperial title it must have been in the knowledge that history would judge her a usurper. Because she displays many signs of being concerned with her.historical reputation it seems reasonable to conclude that her seizure of the throne was not an act lightly undertaken. She was motivated perhaps not 
so much by raw ambition as by a perceived necessity.

History and historians have been reluctant to acknowledge this possibility, and it goes unremarked even in modern studies. It is for this reason that I have made much of her service and her loyalty to the T'ang. Perhaps I have given it undue emphasis, but the fact remains that it was in the course of her very successful partnership with Kao-tsung that T'ai-tsung's work of consolidation and centralization was brought to fruition. The T'ang was thereby enabled to embark upon a confident and expansive third generation which set it off from all the ephemeral followers of the Han and, indeed, even from the Sui whose rapid fall seemed to validate the preceding pattern of short dynasties. By the time of Kao-tsung's death, and in spite of the many problems which were beginning to emerge, the T'ang seemed secure or, at the very least, to have won an enduring vote of confidence from the people. The failure of Li Ching-yeh's revolt is a strong indication that this is true, and it is important to note that since Li claimed to be in rebellion on behalf of Kao-tsung's heirs, it was the Empress Wu whom the people saw as the true guardian of dynastic and national interests.

In 684, with the rebellion suppressed, the empress must have felt a certain pride. In less than three decades she and her husband had achieved a great deal. They had maintained a high level of domestic peace and prosperity and had won the allegiance or at least the acquiescence of the aloof super elite of the Northeast. They had claimed greater successes in foreign policy than any dynasty since the Han, and they had firmly established an appointment system perceived by the middle and lower ranks of the shih class as a way to enhance their status and to achieve the perquisites of high office. The "Two Sages "' state ideology had come to be accepted by most of the elite as both viable and balanced. These policies and others like them had achieved dynastic legitimation. By 684, the weakest points in legitimizing terms were at the center and at the top. An ambitious consort clan like the Wei or an overpowerful minister like P'ei Yen could still have undone the work of decades, and this the empress perceived.

It was perhaps more for this reason than as a step toward eventual usurpation that she took the regency in 684, and the terror which followed can be seen as part of a much wider policy than one designed simply to eliminate bureaucratic opposition to her rule: it can be seen as the essential component of a plan to free the imperial institution from bureaucratic domination. It was, therefore, the logical culmination of the T'ang policy of disarming potential and actual rivalry to the throne by the great aristocratic clans by inveigling them into bureaucratizing their status.

This is not to excuse the terror. By regarding it in this light, however, we can see the proclamation of the Chou with its female founding emperor as the most audacious way of all for the empress to test the success of T'ang policies rather than as a sign of the megalomania of a remarkable woman.

Numerous objections can be raised to this interpretation and just as many to my related proposition that the empress founded the Chou with every intention of restoring the T'ang. The most pertinent of these objections is also the simplest--that it is far-fetched. After all, if Wu Tse-t'ien sought simply to create a freer and more independent monarchy, why was it necessary to found a new dynasty when Jui-tsung had shown himself amenable to a regency of indefinite 
length? Several answers are possible, but the most convincing is to be found in the fact that for three decades Wu Tse-t'ien had been in reality if not in name the equal of the emperor. During that period she had come to identify the interests of the monarchy with her own and to see that as an institution evolving away from the constraints of self-seeking aristocrats (and more recently from the factiousness of bureaucratized aristocracy), the monarchy had united China and had brought to its people the greatest measure of peace and prosperity they had known since the Han. In short, in her eyes this was the achievement of an independent monarchy and it was also her achievement. Formal recognition by all of a female emperor would symbolize for all time the freedom of the imperial institution. If the emperor could be a woman, the emperor could be and do anything! Moreover, when we recall that she had always shown a deep faith in the supernatural, it seems reasonable to believe that she was convinced by the Pao-t' $u$ and the Great Cloud Sutra that Heaven itself was demanding that she accept the Mandate. Could it not have been that this was what made her decide to risk the opprobrium of history?

During the Chou, continuity was the rule and the watchword. Only in her patronage of Buddhism did the empress depart substantially from T'ang precedents, and even this departure may be seen as a measure to aid legitimation. If Taoist messianism were by no means a spent force, it was less relevant in the mid-T'ang than at the dynasty's foundation and Taoism had always been a less effective force than Buddhism for dynastic consolidation among the people. Real innovation and real conflict in the Chou were political and were restricted chiefly to the upper bureaucracy. It was here that the empress saw the new rivals to absolutism and here that both her fate and her historical reputation were determined. Chung-tsung's statement at his restoration that she had respected the heritage of the T'ang was probably more than filial convention. The battles she fought against the throne's would-be limiters helped strengthen the hands of her eighth-century T'ang successors.

There remains still the question of ultimate aim, of whether Wu Tse-t'ien at any point contemplated the foundation of a line of Wu emperors. I admit that in saying she did not, I appear to stand on shaky ground. To remark that in 698 Chung-tsung's reappointment secured a T'ang restoration proves nothing, and some might wish to read my account of the succession struggle during the Chou in quite a different light. Were not the empress' manipulations of sons and nephews designed to "test the wind," and could not the novelty of her symbolism-a new capital and a new calendar, her monuments and her palaces--be seen, as some contemporaries saw them, as signs to be associated with the beginnings of a dynasty whose aim was to endure the conventional ten thousand generations?

This view is tenable but 1 hold to my interpretation. Never during the Chou dynasty did the succession rest with the wu clan and, what is more, innovation of both a symbolic and a substantive type was more marked in the six years of the preceding regency than in the fifteen of the Chou. And, finally, it need not follow that because the empress had a reputation for excess in her punishments, her spending and her pleasures, she was similarly excessive in her desire for familial power and historical immortality as a dynastic founder. Her entire career is a testament to her acute and seasoned understanding of the nature of female legitimation, and in her own dynasty, as 1 have shown, she was always willing to listen to those ministers 1 ike $\mathrm{Ti}$ Jen-chieh who reminded her of its limitations. She owed far more to the $\mathrm{Li}$ clan than to the Wu and she knew also 
that, like any other woman of her time and place, it would be in the ancestral temple of the T'ang that her sacrifices would be made.

The most 1 can admit is that in the heady days of the Pao-t' $u$ and the Great Cloud Sutra and all the other signs that she was Heaven's chosen, she toyed with the idea of an enduring Chou, but soon faced with the realities of an immovable tradition, she quickly deferred again to its interpreters.

The Empress Wu was in power for almost half a century, and I have mentioned that her accomplishments were many. In attempting to explain her successful legitimation 1 have also suggested that in some respects she came to embody the cosmopolitanism, self-confidence and eclecticism which were characteristic of the first half of the T'ang. In other respects she embodied the flaws of her age, most particularly in the static, almost timeless, view she held of the world, and consequent failure to realize and act upon the problems engendered by the growing complexity of her society.

Chinese historians have not treated her kindly, yet her legacy was a real one. For better or worse, she modified the relationship between the imperial family and the greatest of the old clans, and that between the ruler and his ministers. In neither case did she complete the task she had set upon, but she furthered or perhaps initiated a trend, and her tactics would be used, though not acknowledged as hers, by ambitious rulers of later times. The examiniation system, at least in its literary emphasis, was as much her creation as it was that of its founders, and the results of the reforms she made in the system were to be seen not only in the superb bureaucracy she bequeathed to Hsüan-tsung but also in the poetic creativity which graced his reign and that of his successors. Her orchestration of the evolving relationship among Confucianism, Taoism and Buddhism, and of the tensions between church and state were to have consequences throughout the T'ang. Moreover, even if certain of her policies, such as the misuse of the fu-ping and the unwarranted expansion of the bureaucracy achieved only short-term goals for which the dynasty would later pay too high a price, almost to the end of her life she acted with resolution, panache, and a constant awareness of her subjects' interests. It is little wonder that in the popular imagination of later times she was monumentalized, and that in a novel like Flowers in the Mirror (Ching-hua-yüan) we find her not only instituting civil service examinations for women but successfully commanding in mid-winter that all the flowers bloom for her pleasure.

It might be well before concluding to point to a dimension of seventh-century history almost wholly neglected in this study: the condition of the country in general and that of the peasants in particular during the empress' regime. On this matter many questions could be raised but, as I said earlier, the narrow focus of contemporary sources must preclude definitive answers. At the same time, popular attitudes were a key element in the success of Wu Tse-t'ien's legitimation and since we find no primary sources which articulate these attitudes, we are perhaps justified in some careful speculation about their origins.

There is ample evidence, to begin with, that the reign of Kao-tsung was generally prosperous. Agriculture suffered little disruption except in areas affected by natural disasters or the expansiveness of his foreign policy and, with only minor problems, equal-field redistribution was successful. It is only from the time of his death that we begin to hear of economic difficulties which would affect the people at large--inflation, counterfeiting, food 
shortages and declining government services, registration abuses and the appearance of fugitive households. Complaints about these matters became more frequent throughout the Chou but, as we have seen, there was no substantive economic reform.

Such matters are relative. It must also be conceded that the Chou saw no signs of popular unrest nor any of the omens which indicated that Heaven desired a change of Mandate. The people had twice demonstrated their support for the empress by refusing to join rebel movements against her and, as far as we can tell, they remained constant to the end. The source of their loyalty is difficult to define and it may be that inertia, conservatism and love and respect all played a part. What we know for certain is that her legitimizing policy was aimed at the people as a whole. Her patronage of Buddhism and her foundation of the Great Cloud temples, her public humiliation of great ministers and proud clans during the terror, her measures to raise the status of women, the record number of her Acts of Grace with their lavish conferrals of goods and honorific rank, her twelve-point memorial and other measures of this kind were designed to benefit the people and, whether sincere or not, served as public affirmation of her concern for them and so won their support. It seems fair to suggest that the people came to see Wu Tse-t'ien as a competent, decisive and clear-sighted ruler, frank both in her virtues and in her vices. In their eyes at least, possession of these qualities made the fact of her sex irrelevant.

Kuo Mo-jo, in the final appendix to the 1963 edition of his play Wu Tset'ien, cites several instances of the popularity of the Empress Wu among the people of Kuang-yüan county in Szechwan where there has long existed the belief that this was the place of her birth. Most striking is the fact that right up to the present day the people of the area have continued to observe the twentythird day of the first month of the lunar calendar as the day they believe to be her birthday. No emperor of traditional China could ask for a finer tribute! 
Appendix A

HISTORIOGRAPHY OF THE EMPRESS WU

The following five examples, drawn from early in the career of the Empress Wu, are intended chiefly to demonstrate the process of historical selection operative in the three sources most influential in shaping subsequent historical opinion, the two dynastic histories and the TCTC. In each case, the difficulty of factual certainty is apparent and, with it, the basis of prejudice for the historian's choice of interpretation. Comparison of the three sources provides a gauge to the relative hostility of each and makes clear the overwhelming importance to each of Wu Ching's shih-lu as a primary source.

Example 1

CTS

6

3075:3. 初

HTS

76: $3867: 1$.

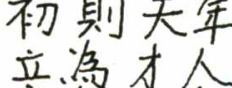

十四時・太宗閏其美・容止召入宫。 人。交管旺后。

TCTC 195, p. 6134.

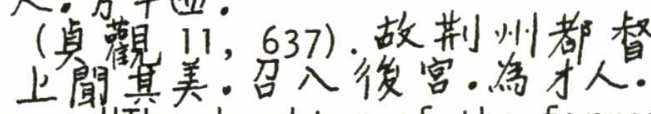

The TCTC notice says: "The daughter of the former tu-tu of Ching-chou, Wu Shih-huo, was fourteen years old. The Emperor [T'ai-tsung] heard of her beauty and summoned her into his harem where she was given the rank of ts'ai-jen." The two earlier sources are similar to the TCTC in diction and detail, although the HTS adds the information that T'ai-tsung had been a widower "for a long time." His wife had died in mid-636, so that if Ssu-ma Kuang's dating is correct he waited a year-and-a-half at the most before adding to the harem!

The degree of similarity is explained in the $k^{\prime} a o-i$ notice: "The Annals of Tse-t'ien in the CTS say she died at the age of eighty-three but the T'ang- $2 i$ 唐曆, the T'ang-ch'ao nien-tai chi 唐朝年代記 by Chiao Lu 焦璐, the T'ung-chi 出充出已, the 害ang-nien hsiao-Iu 唐年小金录

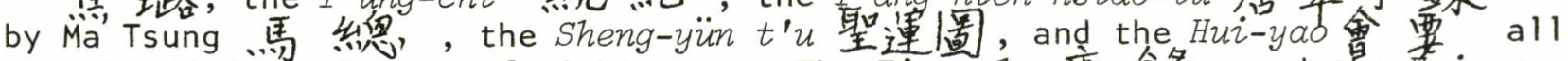
say she died “at the age of eighty-one. The T'ang-iu 唐金录 and the Hui-yao say she entered the harem in the thirteenth [not the eleventh] year of chenkuan [639-640]. [However] since she entered the harem at the age of fourteen, and because of the shih-lu of Wu Ching says she died at the age of eighty-two, I place her introduction into the harem in this [eleventh] year."

In this account two points are striking. First, Ssu-ma Kuang is willing to accept the authority of the shih-lu on the empress' age over contradictory sources which are far more numerous and, in the case of the CTS, equally authoritative since Wu Ching made a primary contribution to both. Second, it is clear that not a single one of the sources at Ssu-ma's disposal, including the shihZu, makes reference to Wu's entry into T'ai-tsung's harem. This uncomfortable fact seems, therefore, to have been expunged successfully from contemporary and official history, probably through the empress' influence. 
Her entry into the harem seems to have been dated only in two sources and both place it in chen-kuan 13,638. Neither the T'ang-Zu nor Su Mien's Hui-yao (completed in 804) is extant, but the T'ang hui-yao is of course based upon the latter and contains the following passage (chüan 3, p. 23):文德皇后崩·大宗開武士 蒋萑女有才貌.召入宫.以為才人. Since the diction is very close to the notices in CTS, HTS and TCTC, the HUi-yao probably formed the basis for all three.

It is difficult to avoid the conclusion that the Empress Wu attempted deliberately not only to conceal her incest with T'ai-tsung but also her true age. The motives for the former are obvious but unless we attribute to her a certain vanity, the latter seems puzzling.

Example 2

CTS 51：3279:3. [王]后㲘不自安。密與母枊氏求巫祝厭勝。

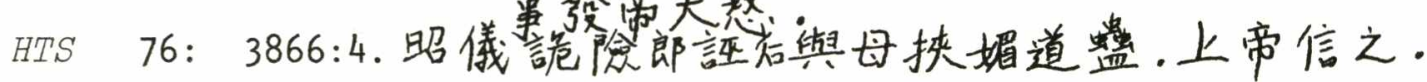

TCTC 199, p. 6288. 武昭儀㟇王后與母魏國夫人柳氏。虎厚幐。

The disparity among sources here is marked. The CTS suggests that the Empress Wang and her mother actually engaged in sorcery and, therefore, angered Kao-tsung, while the other two sources regard them as innocent, seeing the sorcery charge as a calumny fabricated by Wu Chao-i. Ssu-ma Kuang explains in the $k^{\prime} a O-i$ : "The CTS biography of the Empress Wang says she was frightened and ill at ease so that she and her mother secretly sought out a witch and engaged in black magic. When this became known she was degraded. Now I accept what is written in the shih-lu."

The CTS view is clearly dependent upon a source other than the shih-lu and one more favorable to the Empress Wu since the charge of sorcery would be sufficient grounds for Kao-tsung to depose Empress Wang. Other extant sources offer no corroboration of either interpretation, although the frequent use of the T'ang- Zi by the CTS will be demonstrated later. The TFYK 333:5a records that Liu Shih, uncle of the Empress Wang, was demoted to the provinces when his sister, the empress' mother, was "punished by being forbidden entry to the palace," and his subsequent demotion was for "revealing palace secrets" (chin chungyiu). The reference here is almost certainly to the sorcery charge, and it is to be expected that Liu Shih told his side of the story. See TCTC 199, p. 6288.

On the other hand, it may be argued that in the relatively complete account of the debate surrounding the elevation of the Empress Wu, the above incident is unmentioned. Kao-tsung, even when challenged by Ch'u Sui-liang to show that the conduct of Empress Wang was anything but blameless, seems to have remained silent. I am not convinced that this is conclusive since Kao-tsung similarly forbears mention of the alleged murder of Wu Chao-i's daughter by the Empress Wang, and the whole debate may have been severely edited to show the latter in a favorable light. The TCTC 199, pp. 6286-7 does admit that the two rivals "exchanged slanders and accusations," so that Ssu-ma Kuang's decision here to rely on the shih-Zu rather than the CTS is perhaps more a reflection of bias than of conviction.

In general, the machinations of the inner palace were never very clear to contemporary historians since there existed no mechanism for obtaining reliable information. For this reason, the T'ang-li, a work in forty chüan by Liu Fang 
is particularly valuable. His biography, CTS 149: $3479: 2$ and HTS 132: 3975:3, records that much of the information therein was based on his conversations with the famous eunuch Kao Li-shih whose sources of information for events within the harem might be more accurate than those available to the official historians. In the example above, for instance, I suspect that the CTS notice follows the $T^{\prime}$ 'ang- $Z i$ and is the proper interpretation. The Empress Wu, after all, is known to have had a network of palace spies charged with reporting on her rival and, given the prevalence of witchcraft at the time, almost certainly had grounds for her accusation. She herself had to answer the same charge in 664 .

The varying versions of the incident also demonstrate a greater hostility to the Empress Wu on the part of the HTS and the TCTC than on the part of the CTS. This is a consistent tendency.

Example 3

CTS

6: 6075:3. 進号虎宸妃

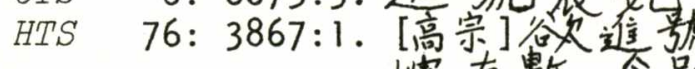
嬪有數. 令别章號不可。

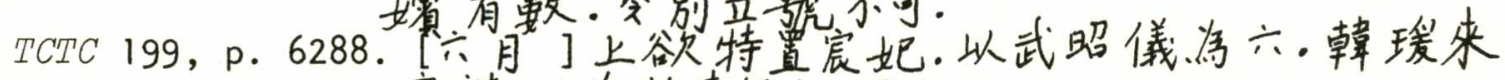

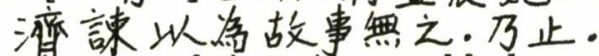

The source dispute here, although parallel to the second example, is different in that it concerns a public event about which the historian could be expected to have certain knowledge. The HTS and TCTC suggest that the remonstrance of Han Yüan and Lai Chi prevented Kao-tsung from creating a new category of concubine to be awarded to Wu Chao-i, while the CTS maintains that she was actually granted the title. The $k^{\prime} a o-i$ says: "The T'ang- $l i$ dates this event in the fourth month, but now I follow the shih-Zu. Han Yüan and Lai Chi had not reached the posts of shih-chung and chung-shu-ling [respectively] by the fourth month [of 655]. The T'ang- $Z_{i}$ also says their remonstrance was unsuccessful, but the decree which established the [new] empress refers to her as [the] Chao-i [concubine]. If this is the case, she was never granted the title of ch'en concubine. I now follow the Hui-yao."

Ssu-ma Kuang is on firm ground here. The appointment of Han and Lai in the fifth month to the posts mentioned can be verified even in the CTS annals of Kao-tsung, and no other source mentions that the ch'en-fei title was ever awarded. It is of interest that the $S h i \hbar-I_{u}$ seems to have noted the event but not the outcome, since the $k^{\prime} \alpha o-i$ cites the Hui-yao as its authority. Wu Chao-i's reception of the title must have been at least a tradition of the palace since the CTS is here clearly reproducing the T'ang- $2 i$. Several other examples could be drawn to show how highly the authors of the CTS regarded the T'ang-li as a source and how they often preferred it to the shih-Zu. Ssu-ma Kuang's view is, of course, different. See Example 4.

My own reading of the $T^{\prime}$ ang- $Z_{i}$ notices concerned with the Empress $W u$ and preserved in the $k^{\prime} \alpha o-i$ makes clear the vast difference between official and non-official history. A separate study would not be amiss.

Example 4

CTS 65: 3310:3 [biography of Wu-chi].[上]日: 武昭儀有令德。朕欲立局

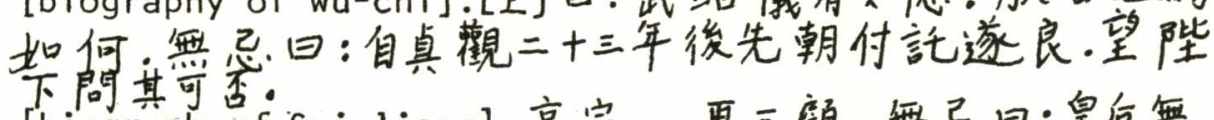

CTS 80: 3340:4 [biography of Sui-1iang]. 高宗...再三顧. 無忌湟后無 能息。昭儀有子。今欲立皇皇后。公等以婆如何。遂 良曰: 皇后出自名家... 
HTS 105: 3922:3 [biography of Wu-chi] [上] 言后無忌。照俄有子; 必 欲立之者。無忌已數諫。郎日: 先帝付託遂良。 願脿下訪之。遂良極道京可。

HTS 105: 3923:3 [biography of Sui-liang].帝昌…皇后無子。今谷立 昭俄。謂何。遂良對旦: 皇后名家

TCTC 199, pp.6289-90.上雇謂無忌日:皇后無子, 武昭儀有子。今欲立 昭儀為后, 何如。遂良對日: 皇后名家…

This episode, in which Kao-tsung solicits the support of the four most prestigious of his ministers for the plan to elevate Wu Chao- $i$ to empress, is one of the best known of the century. It will be noted that the two dynastic histories are in perfect agreement while Ssu-ma Kuang glosses the salient point. His $k^{\prime} a o-i$ notice says: "The T'ang- $l_{i}$ records that when Wu-chi and the others were about to enter [the audience hall] Sui-liang said that [Kao-tsung] was going to ask about the empress and asked whether he should remonstrate. Wu-chi told him that however strongly he did so, he would himself support him. When they went in, the emperor looked at Wu-chi and said, 'The greatest of all crimes is to be prevented from continuing one's line. Now, my empress is barren and I want to depose her and establish in her place the daughter of Wu Shih-huo. What is your opinion?' Wu-chi said, 'Ever since the twenty-third year of chenkuan [649-650], your [late] father placed his trust in Sui-liang. I would rather you asked him.' If this story is true, then Wu-chi betrayed Sui-liang.

do not accept it."

This is one of the very few instances in the $k^{\prime} \alpha o-i$ in which Ssu-ma Kuang relies solely on his own judgment and offers no supporting evidence. It may be that the shih-lu fails to mention the incident, but in view of its centrality to the crisis I find this hard to accept and reluctantly conclude that Ssu-ma Kuang suppressed it. Support for this view comes from the fact that the CTS passages above actually elaborate on the T'ang-li story and so must have had an additional source, and also from the fact of Ssu-ma Kuang's extraordinary fondness for Wu-chi. Note his remarks in TCTC 199, p. 6267, in connection with T'aitsung's dying words to Wu-chi and, more particularly, his treatment of Wu-chi's complicity in, or instigation of, the charges which brought death to the innocent Li K'o吴王李恪. See TCTC 199, p. 6280.

The historical significance of the controversy lies in the fact that if Wuchi is seen to be an opportunist, his opposition to the Empress Wu may have been less disinterested than is usually portrayed, and her later actions against him therefore justified. Even in the case of her so-called revenge, there is some room for doubt. See the next example.

Excomple 5

CTS 65: 3310:3. 許敬宗遗人上封事。稱監察御史李巢,與無忌,

HTS 105: 3922:4. 敬宗謀后指, 陰使洛陽人李奉節上無忌蘰事.

TCTC 200, p. 6312. 苟宗因㟇奏[韋]季方欲舆無忌構䧟忠臣近戚, 使權歸無忌, 何陵謀仅, 今事覺, 故自殺。

Although the details differ in each account, the sources agree that Hsü Chingtsung fabricated a charge of treason against Wu-chi by having someone send a secret denunciation to Kao-tsung. The $k^{\prime} a O-i$ notice is extremely long, quoting extensively from the shih-lu, mentioning contradictions with the CTS, and protesting Wu-chi's innocence. It then continues: "The shih- $l u$ in recording the 
incident is careless (Zu-mang 图菒), and discrepancies are found from beginning to end so that the whole truth cannot be known. Thus I abbreviate, giving the general significance, and that is all... The shih-Zu, [however], compared to the CTS biography is earlier and more detailed, and since the biography is later and more brief, it is less worthy of reliance."

In this passage we see most clearly the reason for the TCTC tendency to rely, wherever possible, on the shih-Zu and to favor its interpretation over that of the dynastic histories in spite of Ssu-ma Kuang's equation of the two in his T'ung-chien shih-li, 1:3-4a. Several additional examples of the process are adduced in Li Shu-t'ung, T'ang-shih k'ao-pien, pp. 238-9. In view of the hostile attitude of the shih-Zu, especially when compared to the T'ang-Zi, and in view of the tremendous prestige of the TCTC, it is not surprising that the Empress Wu has fared badly in traditional historiography.

While in the example above the point of dispute is a matter of detail rather than interpretation, it should be noted that the CTS is supported by the T'angZi, the Shih-t'ung and, in some areas, by the shih- $z u$ itself! And the CTS, unlike the HTS and TCTC, nowhere mentions that Hsü Ching-tsung was acting directly under the orders of the Empress Wu. His reasons for the destruction of Wu-chi were easily as strong as her own, and it is entirely possible that he acted on his own initiative. Ssu-ma Kuang (TCTC, Zoc. cit.) as much as admits the speculatory nature of his judgment with the unsupported statement, "The empress ordered ching-tsung to await his chance and entrap him [Wu-chi]," and one wonders how he knew even this much. If the $k^{\prime} a o-i$ reproduces the full shih-lu report, there is no mention there of the influence of the Empress Wu. 


\author{
Appendix B \\ THE TSAI-HSIANG, 618-705
}

The following list attempts to provide in tabular form a brief biographical sketch of every man who held tsai-hsiang, or chief ministerial status from the beginning of the T'ang to the deposition of the Empress Wu. The principal source of information is HTS 61: 3774:1, the table of chief ministers, but because of errors and omissions in it additional information is taken from the annals and biographies of the CTS and from later studies like TCTC and principally from the Nien-i-shih ssu-p'u, chüan 33, Yen Keng-wang's T'ang p'u-shang ch'eng-lang piao provides some information not found elsewhere. Where the actuality of appointment is disputed, I usually include the man in question so that the list may be as comprehensive as possible.

The names are arranged in chronological order based on the date when tsaihsiang status was first awarded, and the key to the information is as follows:

a. Dates (age given in Chinese style).

b. Native place and the T'ang province to which it belonged.

c. Ancestry.

d. Examination.

e. First official post mentioned in the biography in the dynastic history.

$f$. Recommendation (by whom).

g. Year and lunar month when tsai-hsiang status was first awarded.

h. Length of tenure of tsai-hsiang status.

i. Descendants.

j. Remarks, and Western-language sources in which more information may be found. For the latter, the three abbreviations used are: Examens - Le traité des examens by R. des Rotours. Fonctionnaires - Le traité des fonctionnaires et de I'armee, by the same author.

Eberhard - Das Toba-Reich Nordchinas by W. Eberhard.

The term "family extinguished" (chia-k'ou chi-mo) refers to the punishment elaborated in the text whereby the immediate family of a criminal is either executed, or exiled and deprived of political rights. In many cases, it will be noted, rehabilitation occurred before the deposition of the Empress Wu. "Executed by the Empress Wu' simply means that the event occurred between 684-705, and "in exile" means that the man in question had either been demoted to a provincial post or exiled to Ling-nan before his death. The length of tenure (category h) is based entirely on my own calculations. In many cases a chief minister was given a particular commission outside the capital during his tenure. Unless there is specific mention that he was at the same time deprived of tsaihsiang status, I include this period in his tenure although he could scarcely exercise his court functions. This is done chiefly to permit consistency of analysis since the actual time consumed by special assignments is invariably vague. 
The native place is in every case taken from the CTS biography, and the term "eminent clan" is used only when explicitly so stated by the same source. I chose this methodology for the sake of consistency, and because the CTS most nearly represents contemporary opinion. But caution is necessary. First, the authors of the HTS display a much more pronounced aristocratic attitude, so that many tsai-hsiang are listed in the table there as members of great clans when their connection was very tenuous and in spite of the fact that their biographies in the same work offer different pen-wang. This is the case with the Empress Wei and, for instance, with Li I-yen (no. 63). Second, there are problems of geographical terminology. Hsüeh Yüan-ch'ao (no. 61) came from Fen-yin (汾陪) in P'u-chou, a place also known as Ho-tung, and the home of the eminent Ho-tung Hsüeh clan. Is there a reason beyond historical ignorance why the authors of the CTS do not identify the affiliation? Third, there is the problem of false claims. Li I-fu (no. 39) is the most obvious example, but the list of tsai-hsiang more successful than he in establishing in history their false claims could be readily expanded.

A thorough search through epigraphical evidence would yield a substantially more accurate list, but I see little to be gained in such a line of inquiry. The connection between the tsai-hsiang and the great houses strikes me as an artificial one, for there is probably no case in the seventh century of a man rising to the rank of chief minister solely on the basis of family eminence. The aristocratic cast of high officialdom in the T'ang is a noteworthy phenomenon, but unless it is shown that (a) the consciousness of these officials was more aristocratic than bureaucratic after the attainment of high office, and (b) family background aZone could form the basis of ministerial cohesion or factionalism, this approach to the history of the period should be subordinated to others.

The chief value of presenting the information in this form is the demonstration of a trend away from personalized government. Several facts should be noted in this regard. First, the rapid decrease in the incidence of recommendation. At least after the 660 s advancement became increasingly structured, and the highest posts were filled by men with a bureaucratized mentality and an understanding of the system. Influential connections and the ability to win general notice by outstanding performance or virtue diminished in importance. Even the extension of the recommending privilege by the Empress Wu seems to have had little effect at the highest levels of government. Second, the diminution and virtual disappearance of marriage relationships with the imperial family. Third, the progressive shortening of tenure, as ministers were increasingly regarded by the ruler as instruments of policy rather than as colleagues. Demotion and the shifting of posts may be regarded in this light as well as being seen as mechanisms of imperial control or the assertion of prerogative. Fourth, the rising importance of examination as a qualification for high office, a phenomenon discussed in the text.

The information presented here shows clearly the importance of a family tradition of officeholding. I find fewer than a dozen men under the empress who achieved tsai-hsiang status after beginning with examination alone. Twice that number had no degree but came from families which, although not among the preeminent clans even at the local level, had held office earlier in the dynasty. The yin privilege must have played a part, but I suspect that intangible factors were of greater significance. It will be noted that few tsai-hsiang were without descendants in bureaucratic positions, but that few of them equaled the eminence of their forebears. This is a suggestive trend and worthy of pursuit 
in the later T'ang.

The tsai-hsiang sample, while conducive to misinterpretation, is by no means barren and, particularly if combined with other definable groupings such as high officials in the six Boards, could yield many more insights into T'ang government. The order of advancement and the relation of lower posts to the eventual attainment to tsai-hsiang rank, the role of military men, the development of specialized functions, and the relationship of the tsai-hsiang to regionalist problems could all be explored with profit.

1. Li Shih-min李世民 = T'ai-tsung 太宗.

2. P'ei Chi 裴寂. CTS 57: 3292:3, HTS 88: 3893:1.

a. ca. $571-630$.

b. P'u-chou 㜑州 in Ho-tung.

c. Father and grandfather officeholders. Lineage praised by Kao-tsu but family poor.

d. No examination.

e. Pu-chou chu-pu 補州主簿.

f. None mentioned. Early friendship with Kao-tsu.

g. 618: cheng.

h. 8 years.

i. Son marries a daughter of Kao-tsu, grandson official career under Empress Wu but executed by her.

j. The most favored of Kao-tsu's ministers.

3. Hsiao Yü 萧瑀. CTS 63: 3304:3, HTS 101: 3915:1.

a. 575-648.

b. Nan-lan-ling 南菊陵.

c. Imperial family of Liang, married to Sui family.

d. No examination.

e. Min-pu shang-shu民部尚書.

f. None.

g. 618: cheng.

h. 9 years.

i. Son marries a daughter of T'ai-tsung and has official career.

j. A prominent Buddhist. Several quarrels with T'ai-tsung and once disenrolled. Eberhard, p. 40, no. 32.

4. Liu Wen-ching 貿 文青爭. CTS 57: 3293:1, HTS 88: 3892:3.
a. C. 620 at age 52 . 京北 for generations.

c. Grandfather an officeholder, father dies in battle, and Wen-ching succeeds to his posthumous position.

d. No examination.

e. Chin-yang Zing 育陽令。

f. Close friend of P'ei Chi who introduces him to Kao-tsu.

g. $618: 6$.

h. 2 months, then disenrolled for treason.

i. When family rehabilitated, two sons have official careers and one marries princess.

j. See Eberhard, p. 54, no. 54 for clan claimed by Wen-ching. 
5. Tou Wei 竇 戎. CTS 61: 3301:1, HTS 95: 3904:3.

a. d. 618.

b. See no. 6. Tou K'ang's uncle.

c. --

d. --

e. --

f. --

g. Appointed $618: 6$ but dies same month.

h. --

i. Son has official career.

6. Tou K'ang 竇抗。 CTS 61: 3301:3, HTS 95: 3904:3.
a.d. 621.

b. Fu-feng 扶風 in Kuan-chung.

c. Eminent clan. Consort family of sui, and $K$ 'ang is son of Wen-ti's daughter Wan-an 萬安.

d. No examination.

e. High honorary positions in Sui.

$f$. Youthful friendship with Kao-tsu.

g. 618:6.

h. 2 months, then made general.

i. Two sons, primarily military careers.

j. In early $T^{\prime}$ ang this clan produced 7 officials above the third rank, 5 above the fourth, more than 10 above the fifth, and three times married princesses as well as placing several of their daughters in the harem. An unparalleled achievement according to CTS. Eberhard, p. 383, no. 69 .

7. Ch'en Shu-ta 陳叔達. CTS 61: 3301:1, HTS 100: 3912:3.

b. Wu-hsing 兴興 in Chiang-nan.

c. Imperial family of Ch'en dynasty, 16th son of Hsüan-ti 宣帝.

d. No examination.

e. Nei-shih she-jen 内史含人.

f. Early allegiance to T'ang.

g. 619: cheng.

h. 7 years, 10 months.

i. No children mentioned.

j. A poet and scholar who left works in 15 chüan.

8. Yang Kung-jen 楊菾仁. CTS 62: 3302:4, HTS 100: 3912:3.
a. d. 639 .
b. Hua-yin 萍隍 in Kuan-chung.
c. Imperial family of Sui dynasty.
d. No examination.
e. Prefect of Kan-chou 甘 $\%$.
f. Captured by Kao-tsu's troops early in rebellion and persuaded to join T'ang.
g. 619:10.
h. 6 years, 9 months.
i. Son and grandson have official careers. Brother, nephew, niece, and great-grandson marry into T'ang family. Also the clan of the Empress Wu's mother. 
j. Eberhard, p. 73, no. 87 .

9. Feng Te-i 圭德率. CTS 63: 3304:2, HTS 100: 3912:4.

a. d. 627 at age 60 .

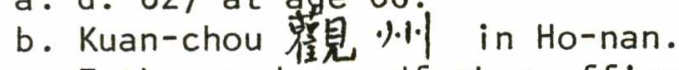

c. Father and grandfather officeholders. Marriage relation to eminent Lu clan of Fan-yang.

d. No examination.

e. Sui hsing-chün chi-shih 行軍記公in army of Yang Su.

$f$. Surrendered territory to T'ang.

g. $620: 2$.

h. 7 years, 4 months.

i. Son marries daughter of Kao-tsu. Has official career. Nephew also an official.

j. Possibly connected with Feng clan of Eberhard, p. 36, no. 21. Also known as Feng Lun 封倫.

10. P'ei Chü 裴矩. Sui-shu 67: 2507:1, Pei-shih 38: 2869:4, CTS 63: 3305:

3, HTS 100: 3913:1.

a.d. 627 at age over 80 .

b. Ho-tung 河束.

c. Eminent clan, father and grandfather officeholders.

d. No examination.

$f$. Deserts Tou Chien-te to join T'ang.

g. $624: 12$.

h. 1 year.

i. Son has official career under Kao-tsung.

j. Foreign-affairs expert and map maker of Western regions. Long experience makes him something of an elder statesman in reign of Kao-tsu.

Eberhard, p. 380, no. 61 .

11. Yü-wen Shih-chi '宇文士及 CTS 63: 3305:4, HTS 100: 3913:3.

a. d. 642. $\mathrm{E}$ '安.

c. Imperial family of Chou, marriage to Sui and T'ang families.

d. No examination.

e. Sui shang-nien feng-y花尚替奉御.

$f$. Close friend of Kao-tsu.

g. $625: 12$.

h. 1 year, 9 months.

i. Son has official career.

j. Friendship with T'ai-tsung. Eberhard, p. 76, no. 96.

12. Li Yüan-chi李元吉 CTS 64:3306:4.

a. Killed by T'ai-tsung in coup of 626 .

b. Claimed Lung-hsi 㜔西 in Kuan-chung.

c. T'ang imperial family, fourth son of Kao-tsu (b. 609).

d. No examination.

e. T'ai-ÿün-chün shou 太原郡守.

f. None.

g. $625: 12$.

h. 6 months.

i. 5 sons, all executed by T'ai-tsung. 
j. His concubine of the Yang clan, later taken by T'ai-tsung, probably introduced the Empress Wu into the harem.

13. Tu Yen 杜淹. CTS 66: 3312:2, HTS 96: 3905:4.

a. d. 628 .

b. Ching-chao 京北 [Ch'ang-an].

c. Uncle of Ju-hui (see no. 17).

d. No examination.

f. Kao Hsiao-chi 高孝基.

g. $627: 9$.

h. 11 months.

i. Son inherits title.

j. Excomens, p. 241; Eberhard, p. 68, no. 78.

14. Ch'ang-sun Wu-chi 长䋇無忌, - CTS 65: 3309:3, HTS 105: 3922:2.
a.d.659.

b. Loyang 洛晹.

c. A T'o-pa clan, offices and titles for seven generations, Wu-chi's sister married to T'ai-tsung.

d. No examination.

e. After military posts in T'ang conquest, pi-pu Zang-chung 比部郎中.

f. A close friend of T'ai-tsung from youth.

g. $627: 7$.

h. Total almost 16 years.

i. Family extinguished in 659-60.

j. See text and Eberhard, p. 33, no. 10.

15. Kao Chien 高俗. CTS 65: 3309:1, HTS 95: 3903:3.

a. d. 647 , aged 71 .

b. Po-hai㴾海 in Ho-nan.

c. Eminent clan, imperial family of $\mathrm{Ch}^{\prime} \mathrm{i}$, married into $\mathrm{Ch}^{\prime}$ ang-sun and T'ang families.

d. No examination.

e. Sui chih-li lang 治䄚郎.

f. Probably received first sul post by recommendation.

g. $626: 7$.

h. 8 years, 1 month.

i. Son marries daughter of T'ai-tsung, holds high posts, killed by Empress Wu because of relationship with Ch'ang-sun Wu-chi.

j. Also called Kao Shih-lien 高士廉. Eberhard, p. 42, no. 41.

16. Fang Hsüan-ling 房玄遴令. CTS 66: 3310:4, HTS 95: 3905:1。

a. d. 648 at age 70 .

b. Ch'i-chou 黹州 in Ho-nan; moved to capital in the Sui.

c. Ancestors held office since Wei.

d. Chin-shih at age 18 .

e. $Y \ddot{u}-c h ' i$ wei 羽...騎尉。

f. Wen Yen-po 温㖒搏 et al.
g. 626:7.

h. Total almost 30 years.

i. Two sons, one married to daughter of T'ai-tsung, have official career, conspire to rebel, family reduced to commoner status early in reign of Kao-tsung. 
j. With the exception of Wei Cheng, probably the most important of T'aitsung's ministers.

17. Tu Ju-hui 杜 如晦. CTS 66: 3311:4, HTS 96: 3905:3.

a. d. 630 at age 46 .

b. Ching-chao 京北 [Ch'ang-an].

c. Officeholders in Chou and Sui, son marries into T'ang family.

d. First to pass the hsüan in Sui.

e. Kan-yang wei 涂陽尉.

f. Kao Hsiao-chi高孝基 and Fang Hsüan-ling (no. 16).

g. 628: cheng.

h. 2 years. Resigns because of illness.

$i$. Son and grandson have official careers.

j. He was nephew of Tu Yen (see no. 13). Examens, p. 241.

18. Li Ching 李靖. CTS 67: 3312:3, HTS 93: 3900:3.

a. d. 649 at age 79 .

b. Yung-chou雥州 near Ch'ang-an.

c. Father and grandfather held office in Sui and Wei.

d. No examination.

f. Yang Su and Niu Hung 牛 34 .

g. 628: cheng.

h. 6 years, 11 months.

i. Son and younger brother have official careers.

j. Career primarily military. Fonctionnaires, p. 6.

19. Wang Kuei王珪. CTS 70: 3318:2, HTS 98: 3908:3.

a. d. 639 at age 69 .

b. T'ai-yüan 太原 in Ho-tung.

c. Ancestors held posts in Liang and $\mathrm{Ch}^{\prime} \mathrm{i}$ but had declined to impoverishment before Kuei was orphaned.

d. No examination.

e. Sui feng-Zi-Zang 奉䄈郎.

g. $628: 12$.

h. 4 years, 4 months.

$i$. Two sons have official career, and the younger marries a princess. Eberhard, P. 70, no. 81 a.

20. Wei Cheng 魏徴. Pei-shih 56: 2932:2, CTS 71: 3320:1, HTS 97: 3906:3.

a. d. 643 at age 63 .

b. Chü-lu 鉅鷹 in Ho-pei.

c. Father held low office in Ch'i. Cheng early orphaned and impoverished.

d. No examination.

e. Clerical staff of rebel Li Mi; T'ang mi-shu ch'eng 密墨承.

$f$. None mentioned.

g. 629 .

h. 13 years, 6 months.

i. Four sons have official careers, one executed by Empress Wu.

j. Excomens, p. 242. Wechsler, Mirror, pp. 33-79 and 106-166 offers a full treatment of Cheng's life and career.

21. Wen Yen-po 温彦博. CTS 61: 3300:3, HTS 100: 3912:1. 

a. d. 637 at age 64 .
b. T'ai-yüan 太原 in Ho-tung.
c. Father officeholder in $\mathrm{Ch}^{\prime} \mathrm{i}$ and Sui.
d. No examination.
e. Sui wen-Zin Zang 文. 林郎.
f. Ch'in hsiao-wang Chün 秦杽王俊.
g. $630: 2$.
h. 7 years, 4 months.
i. Son marries daughter of Kao-tsu, has official career. Many relatives hold high posts.
$j$. Considered one of the most successful families of early T'ang.

22. Tai Chou 戴昌. See no. 55.

a. d. 633.

b. Hsiang-chou 相州 in Ho-pei.

c. No ancestors mentioned, biography says family poor.

d. No examination.

e. Sui men-hsia Zu-shih 1 g 下睩事.

f. Su Wei 蘇威 and P'ei Chü. Captured by T'ai-tsung.

g. $630: 2$.

h. 3 years, 4 months.

i. No sons. Adopts nephew Chih-te (see no. 55).

j. No formal education. Noted for repression of literature while in charge of examination system.

23. Hou Chün-chi 候君集. CTS 69: 3316:2, HTS 94: 3902:2.

a. Executed for treason, 643.

b. Pin-chou 函医 赠 in Ho-pei.

c. No ancestors mentioned.

d. No examination.

e. Military posts with T'ai-tsung early in conquest.

$f$. None mentioned.

g. $630: 11$.

h. 10 years, 2 months (nominally; often out of capital).

i. Sons exiled to Ling-nan.

j. Military career.

24. Yang Shih-tao 楊師道. CTS 62: 3307:1, HTS 100: 3912:4.

a. d. 647 .

b. Hua-yin陸 in Kuan-chung.

c. Younger Brother of Kung-jen (see no. 8).

d. No examination.

e. Honorary posts in early T'ang.

f. None mentioned. T'ai-tsung impressed by his calligraphy.

g. $636: 6$.

h. 7 years, 6 months. Demoted 645 for connection with Korean failure.

$i$. Son has official career, married to T'ai-tsung's niece, executed for suppression of aristocracy while in charge of examination system.

25. Liu Po 留泊. CTS 74: 3326:4, HTS 99: 3911:4.

a. Ordered to commit suicide, 645 .

b. Ching-chou 荆师] in Shan-nan.

c. No ancestors mentioned.

d. No examination. 
e. Huang-men shih-Zang黄門侍郎 under rebel Hsiao Hsien.

$f$. None mentioned, though wide military reputation.

g. 639:11.

h. 5 years, 1 month.

i. Son has official career and has Empress Wu rehabilitate father.

26. Ts'en Wen-pen 岑 文本. CTS 70: 3319:1, HTS 102: 3916:3.

a.d. 645 at age 51 .

b. Nan-yang 南陽 in Shan-nan.

c. Father and grandfather officeholders.

d. Hsiu-tsai.

e. Chung-shu shih-lang 中書侍郎 under rebel Hsiao Hsien.

g. 642: cheng.

h. 3 years, 4 months.

i. Nephew reaches tsai-hsiang status under Empress $W u$ and is executed for opposition to Wu Ch'eng-ssu. See no. 69.

27. Li Chi李棈. CTS 67: 3313:2, HTS 93: 3901:2.

a. d. 669 at age 76 .

b. Ts'ao-chou 曹州 in Ho-nan.

c. No ancestors mentioned, poor family.

d. No examination.

e. Bandit, joins Li Mi, becomes general of Kao-tsu.

$f$. None mentioned.

g. $643: 4$.

h. 6 years, 8 months.

i. Son has official career, but family extinguished after grandson's rebellion.

j. See text and Fonctionnaires, p. 7.

28. Chang Liang 張亮. CTS 69: 3316:4, HTS 94: 3902:3.

a. Executed 646 , for treason.

b. Cheng-chou 奠州 in Ho-nan.

c. Peasant background.

d. No examination.

e. Joined $\mathrm{Li} M \mathrm{Mi}$ in rebellion, subordinate to $\mathrm{Li} C h \mathrm{C}$ who brings him to T'aitsung's force.

f. Fang Hsüan-ling (no. 16).

g. $643: 7$.

h. 2 years, 7 months (accompanies first Korean expedition).

i. Family extinguished.

j. Noted as particularly compassionate to lower orders of society. Probably innocent of treason.

29. Ma Chou焉周. CTS 74: 3327:2, HTS 98: 3909:2。

a. d. 648 at age 48 .

b. Ch'ing-ho 清河 in Ho-pei.

c. No ancestors mentioned, orphaned, impoverished.

d. No examination.

e. Prefectural clerk. f. Ghost writer of impressive memorial for General Ch'ang Ho 常何, and
this brings him to attention of T'ai-tsung. 
g. $644: 8$.

h. 3 years, 5 months.

i. Son has official career; like his father, much concerned in selection system.

j. Examens, p. 240.

30. Ch'u Sui-1iang 褚遂良 CTS 80: 3339:3, HTS 105: 3921:1.

a.d. 658 at age 63 in disgrace for opposition to Empress Wu.

b. Hang-chou 杭帅 in Chiang-nan, but lived in Lung-yu.

c. Officeholding family.

d. No examination.

e. Clerical post under rebel Hsüeh Chü 薜舞.

f. Ou-yang Hsün卧陽詢and Wei Cheng.

g. 644:9.

h. 3 years, 9 months.

i. Family exiled to South.

j. See text.

31. Kao Chi-fu 高季事甫. CTS 78: 3336:3, HTS 104: $3921: 3$.

a. d. 653 at age 58 .

b. Te-chou 德帅| in Ho-pei.

c. Officeholders in Wei and Sui.

d. No examination.

$f$. None mentioned.

g. 645:2 (disputed appointment, more likely 649:9).

h. 4 years, 3 months.

i. Son has official career but exiled to South in 664 because of connection with Shang-kuan 1.

32. Yü Chih-ning 于志蜜. CTS 77: 3335:4, HTS 104: 3920:4.

a. d. 665 at age 78 .

b. Yung-chou 䧹州 in capital area.

c. Officeholders in Chou and Sui.

d. No examination.

e. Sui kuan-shih-hsien ch'ang-shih 冠代影系企史.

$f$. None mentioned.

g. $649: 5$.

h. 8 years, 4 months. Resigns 659 because of age.

$i$. Son and grandson have official career.

$j$. Famed for erudition and for outspokenness.

33. Ts'ui Jen-shih 崔仁位. CTS 74: 3328:1, HTS 99: 3912:1.

a. d. ca. 650-1 at age over 60 .

b. Ting-chou 定帅 in Ho-pei.

c. No ancestors mentioned.

d. Decree examination at beginning of wu-te (618-627).

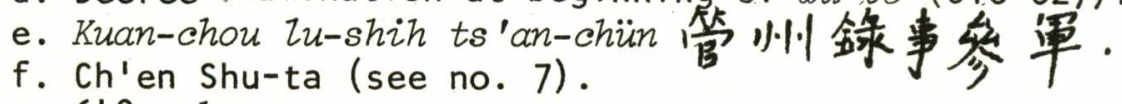

g. 648: cheng.

h. 1 month.

i. Son and grandson have official careers serving together under Chung-tsung. The latter 崔湜 reaches tsai-hsiang status. 
34. Chang Hsing-ch'eng 張行成. CTS 78: 3336:4, HTS 104: 3921:4.
a.d. 659 at age 67 .
b. Ting-chou 定归 in Ho-pei.
c. No ancestors mentioned.
d. Decree examination in early T'ang.
e. Sui yeh-che-t'ai san-ts'ung yüan-wai-Zang 謁者台散從真外郎。 f. Famous tutor recommended by a Sui ch'a-hsiao-Zien 察孝康. Possibly
also by Fang Hsüan-ling.
g. 650: cheng.
h. 2 years, 9 months.
i. Son has official career after succeeding to father's post. His col- lateral grandsons were the two notorious favorites of the Empress Wu.
$j$. Noted for close association with the young Kao-tsung, for his opposi- tion to T'ai-tsung's regional bias, and for bringing many Northeasterners into the government.

35. Liu Shih 㘭爽. CTS 77: 3334:3, HTS 112: 3938:3.
a.d. 659 in exile.
b. Piu-chou 蒲州 in Ho-tung.
c. Officeholders since the Wei, married into Tou clan, and his niece was Kao-tsung's empress.

d. No examination.

f. None mentioned. Rapid rise when niece married to Kao-tsung.

g. 651 : cheng.

h. 3 years, 6 months. Resigns as Empress Wu rises.

i. Family extinguished. Grandson holds posts in k'ai-ÿ̈an (713-742).

j. Biography stresses his innocence, is very hostile to Empress Wu. Eberhard, p. 54, no. 55.

36. Yü-wen Chieh 宇文節. No biography.
a. d. 653 at age 67 .
b. --
c. Possibly related to Yü-wen Shih-chi (no. 11).
d. --
e. --
f. --
g. 651: cheng.
h. 2 years, 3 months.
i. --
j. Possibly Eberhard, p. 76, no. 96.

37. Han Yüan 暲瑗. CTS 80: 3340:4, HTS 105: 3923:3.
a. d. 659 at age 54 in exile.
b. Yung-chou
c. Father and grandfather officeholders.
d. No examination.
e. Ping-pu shih-lang 兵 部待郎.
g. $652: 3$.
h. 3 years, 10 months. Demoted $657-8$ for opposition to Empress Wu.
i. Family extinguished.
j. Possibly Eberhard, p. 38, no. 25. 
38. Lai Chi 來緐. CTS 80: 3341:1, HTS 105: 3923:4.

a. d. 662 at age 53 in battle with Turks.

b. Yang-chou 揚怆 in Huai-nan.

c. Father a famous Sui general killed by Yü-wen Hua-chi.

d. Chin-shih.

e. T'ung-shih she-jen通士舍人.

$f$. None mentioned.

g. $652: 9$.

h. 3 years, 4 months. Demoted $657-8$ for opposition to Empress Wu.

i. No descendants mentioned.

39. Li I-fu李莪府. CTS 82: 3343:2, HTS 223 shang: 4163:3.

a. d. 667 at age 53, in exile.

b. Ying-chou漒 归 in Ho-nan, but claimed membership in the much more prestigious Chao-chün 走党君 $\mathrm{Li}$ clan.

c. Grandfather held low office.

d. No examination.

f. Li Ta-liang 李大亮 Liu Po (no. 25), and Ma Chou (no. 25).

g. $655: 7$.

h. 7 years, 9 months.

i. Son 李湛 receives many posts and honors. Assists in coup which deposes Empress Wu.

j. With Hsü Ching-tsung (no. 42) the most important of the empress' early supporters. A byword for cunning and opportunism; his biographies are a source for much historiographical hostility to the Empress Wu. Fonctionnaires, p. 158.

40. Ts'ui Tun-1i 崔敦福. CTS 81: 3341:2, HTS 106: 3925:1.

a. d. ca. 656 at over 60 .

b. Yung-chou 䧹州 near capital.

c. Grandfather president of Board of Rites in Sui. An eminent northeastern clan who moved to Kuan-chung at end of Wei.

d. No examination.

e. T'ung-shih she-jen通士舍人.

$f$. None mentioned.

g. $653: 1$.

h. 2 years, 9 months.

i. Son and grandson have careers; like their father, mostly in Board of War.

j. Eberhard, p. 65, no. 77a.

41. Tu Cheng-lun 杜正倫. CTS 70:3319:4, HTS 106: 3924:2.

a. d. in exile in 658 after disagreement with Li $1-f u$.

b. Hsiang-chou 相 $\%$ in Ho-pei.

c. No ancestors mentioned.

d. Hsiu-tsai (with his two brothers, numbered among about ten who succeeded in this examination in the Sui).

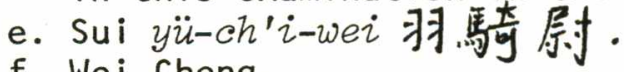

f. Wei Cheng.

g. $656: 3$.

h. 2 years, 8 months.

i. No descendants mentioned. 
42. Hsü Ching-tsung 許苟文宗. CTS 82: 3342:4, HTS 223 shang: 4163:1.

a.d. 672 at age 81 .

b. Hang-chou 杭 $\% \dot{j}$, and considered an eminent Chiang-tso family.

c. Father a Board president in Sui.

d. Hsiu-tsai.

e. Huai-yang-chün ssu-fa shu-tso 淮陽郡司法書佐.

f. Yes.

g. $657: 3$.

h. 13 years.

i. Grandson has good career. Son probably also an official.

j. Probably the single most important minister during the first decade of the empress' power. Great importance in the historiography of the century. See text. Fonctionnaires, p. 158.

43. Hsin Mao-chiang 辛茂㸹. No biography.
a.d. 659:11.
b. --
c. --
d. --
e. --
f. --
g. $658: 11$.
h. 1 year.
i. --
j. Possibly Eberhard, p. 40 , no. 35 .

44. Hsü Yü-shih 許国任币. CTS 59: 3297:2, HTS 90:3896:4.
a. d. 679 .
b. Kao-yang 高陽 in Ho-pei.
c. Remotely a southern family, officeholders since the Liang.
d. Chin-shih.
e. Huang-men shih-Zang 黄門侍郎 in 657.
$f$. None mentioned but fäther important general under Kao-tsu.
g. $659: 4$.
h. 3 years, 7 months. Demoted 662 for quarrel with Li I-fu.
i. No descendants mentioned.
j. Seven members of family active in seventh century.

45. Jen Ya-hsiang 任雅相. No biography.
a. d. $662: 2$.

b. --

c. --

d. --

e. --

f. --

g. $659: 5$.

h. 2 years, 9 months.

i. --

j. Sole mention of Jen is in the CTS biography of Turks. He was Su Tingfang's deputy in the expedition of 657 .

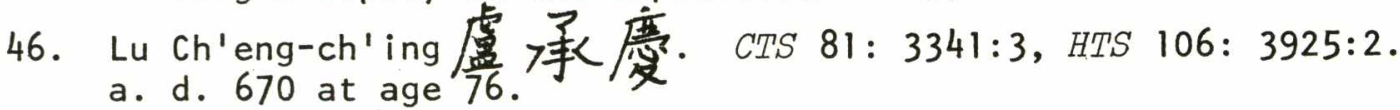


b. Fan-yang 范陽 in Ho-pei.

c. Father and grandfather officeholders, eminent northeastern clan.

d. No examination.

e. After service in military posts at beginning of chen-kuan (627-650),

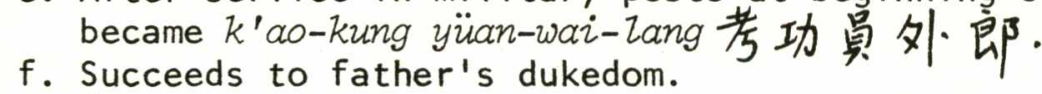

g. $659: 5$.

h. 1 year, 2 months. Dismissed for incompetence.

i. No direct descendants mentioned as active in government, but 3 brothers all have posts in seventh century.

j. Eberhard, p. 58, no. 63.

47. Shang-kuan 1上官俄. CTS 80: 3341:2, HTS 105: 3924:1.

a. Executed 664 as moving spirit in attempt to depose Empress Wu.

b. Shan-chou P夹. . . in Ho-nan near Loyang, but lived at Chiang-tu江都.
c. Father held office in Sui.

d. Chin-shih.

f. Yang Kung-jen (no. 8).

g. $662: 9$.

h. 2 years, 3 months.

i. Family extinguished. Grandaughter advances from palace slave to private secretary of Empress Wu. In reign of Chung-tsung becomes important political figure, a noted literary patron, and briefly given charge of assessing examination candidates.

j. A poet of renown who has given his name to a concise yet ornamental style of composition sometimes called "five-word"五 $\frac{1}{\overline{1}}$ poetry. Took vows of Buddhist monk.

48. Tou Te-hsüan 賽德玄. HTS 183: 3904:4.

a. d. 666 at áge 69 .

b. Ch'i-chou 岐 $\%$ in in Kuang-chung.

c. Grandfather married to Chou family, father inherited his title. Tehsüan is a grandnephew of Tou Wei (no. 5) and Tou K'ang (no. 6).

d. No examination.

e. Served on Kao-tsu's staff in conquest.

f. None mentioned.

g. $664: 8$.

h. 2 years.

i. None mentioned.

j. Biography recounts incident of 664 in which Kao-tsung personally and ceremonially appoints 10 men to tsai-hsiang status to show his reverence for the institution.

49. Yüeh Yen-wei 㟫夜璋. CTS 81: 3342:3, HTS 99: 3912:1.
a.d. 676.

b. Ch'ang-an.

c. No ancestors mentioned.

d. No examination.

$f$. None mentioned.

g. $664: 12$.

h. 4 months. 
i. Son gains high position. Executed in Chou.

50. Sun Ch'u-yao 孫處出与. CTS 81: 3342:3, HTS 106: 3926:2.

a. d. ca. 660 .

b. Ju-chou 汝 $\cdots$ in Ho-nan.

c. No ancestors mentioned.

d. No examination.

e. Ch'i-wang yu-chi 部王祐記。

f. Makes personal impression on T'ai-tsung.

g. $664: 12$.

h. 4 months. Dismissed for misdemeanor.

i. Son a general in reign of Jui-tsung. Killed by Khitans.

51. Liu Jen-kuei 劉仁鿂. CTS 84: 3346:1, HTS 108: 3928:3.

a.d. 685 at age 84 .

b. Pien-chou $\frac{1}{\top} \cdot \mu \cdot$ in Ho-nan.
c. No ancestors mentioned.

d. No examination.

f. Chang Jen-ch'üan 誩任琟.

g. $665: 10$.

h. Though some appointments disputed, probably about 19 years.

i. Son officeholder, executed in early Chou with immediate family. One grandson official under Hsüan-tsung.

$j$. One of the heroes of his age who won his reputation in Korea. Eberhard, p. 378 , no. 52 .

52. Chiang K'o 姜恪. No biography.

a. d. 672 .

b. --

c. --

d. --

e. --

f. --

g. $665: 3$.

h. 6 years, 11 months.

53. Chao Jen-pen 走逍仁本. CTS 81: 3342:3.

a. d. 670 .

b. Shan-chou 陕烟 in Ho-pei.

c. No ancestors mentioned.

d. No examination.

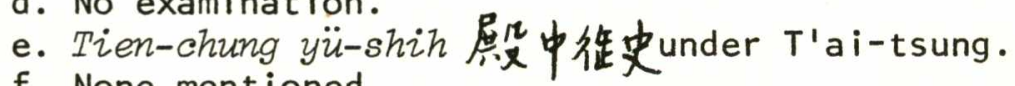

f. None mentioned.

g. $667: 6$.

h. Disputed. Probably 3 years, 4 months. Dismissed because of quarrel with Hsü Ching-tsung.

i. No descendants mentioned.

j. Once punished for making his own copy of secret edicts. Eberhard, p. 369 , no. 12 .

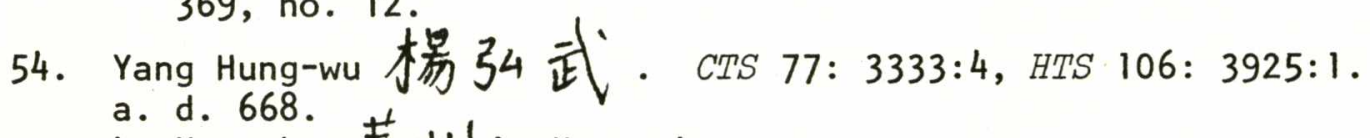

a. d. 668 . 薄归. in Kuan-chung. 
c. Officeholders. Collateral branch of Sui family (see no. 8).

d. No examination.

e. Tso-ch'ien-niu pei-shen 左千牛借身.
f. Mother of Empress Wu.

g. $667: 6$.

h. 10 months.

i. 3 sons, all have official careers before the Empress Wu bans all descendants of Yang Su楊素 from holding capital office. All sent to provinces, returning only after restoration.

j. Eberhard, p: 73, no. 89.

55. Tai Chih-te 戴至德. CTS 70: 3319:1, HTS 99: 3911:3.

a. d. 679 .

b. Hsiang-chou 相州in Ho-pei.

c. Nephew of Tai Chou and adopted by him (see no. 22).

d. No examination.

e. Hsi-t'ai shih-iang 西台侍郎.
f. None mentioned.

g. $667: 6$.

h. Disputed appointments. Probably 11 years, 7 months.

i. No descendants mentioned.

56. Li An-ch'i 李安期. CTS 72: 3323:4, HTS 102: 3917:3.

a. d. 670 .

b. Ting-chou 定 $\%$ in Ho-pei.

c. Father and grandfather high officials.

d. No examination.

e. Fu-hsi Zang 待河郎.

g. $667: 6$.

h. 3 months.

i. Grandson has career.

$j$. An-ch'i much praised for handling of selection system, and as the third generation of his family to hold high court office and draft edicts, etc.

57. Chang Wen-kuan 張文瓘. CTS 85: 3348:4, HTS 113: 3939:2.

a. d. 677 at age 73 .

b. Pei-chou 具州 in Ho-pei. Moved to Wei-chou魏州at end of Sui.

c. No ancestors mentioned. Orphaned.

d. Ming-ching.

e. Ping-chou ts'an-chün开川师厽草。

f. Li Chi (no. 27).

g. $667: 6$.

h. 13 years, 3 months.

i. No sons mentioned. Brother and uncle have official career.

j. Prevented the last attack on Silla. Uncle of Li Chiao (no. 123). Fonctionnaires, p. 10.

58. Yen Li-pen 属立本. CTS 77: 3334:2, HTS 100: $3914: 2$.

a. d. 673 .

b. Yung-chou 淮州from Sui period.

c. Father held Sui posts. A family of artisans and builders. 
d. No examination. Primarily a painter.
e. First post mentioned is chiang-tso ta-chiang 特夺作大匠.

f. None mentioned.

g. 668:12 (provisional).

h. 4 years, 11 months.

i. Sons mentioned but seem not to have entered public life.

j. Considered by contemporaries to be an incompetent administrator.

59. Li Ching-hsüan 李苟文玄. CTS 81: 3342:1, HTS 106: 3925:4.

a. d. 682 at age 68 .

b. Po-chou 毫归 in Huai-nan but claimed Chao-chün.

c. Father held office.

d. No examination.

e. Tutor of Kao-tsung.

f. Ma Chou (no. 29) and Hsü Ching-tsung (no. 42).

g. $669: 2$.

h. 10 years, 6 months. Demoted after defeat by T'u-fan.

i. Son has good career, but executed when Empress Wei falls.

j. Famed for his administration of the examination system when he reputedly recruited "over 10,000 men" each year, including many of his own clan and friends. Married three times into the most eminent northeastern clans. The great personal following he enjoyed coupled with a quarrel with Liu Jen-kuei led to his downfall. Excomens, p. 245.

60. Hao Ch'u-chün 郝處俊. CTS 84: 3347:1, HTS 115: 3942:1.

a.d. 681 at age 75 .

b. An-chou安州 in Huai-nan.

c. Father an early supporter of T'ang but dies when Ch'u-chün is 10 . Inherits title of hsien-kung.

d. Chin-shih in 628 .

e. Chu-tso tso-Zang 著作佐郎.

f. Kao Shih-lien.

g. $669: 3$.

h. About 12 years.

i. Grandson executed by Empress Wu. By publicly cursing her on the way to execution, begins custom of gagging prisoners. Family stripped of honors.

j. With Hsü Hu-shih responsible for bringing many southerners, especially from his own area, into government.

61. Hsüeh Yüan-ch'ao 薜元超. CTS 73: 3325:1, HTS 98: 3909:1.

a.d. 683 at age 62 .

b. P'u-chou 蒲州 in Ho-tung.

c. Father and grandfather held office, succeeds to title of nan 男, marries into T'ang family.

d. No examination.

e. T'ai-tzu she-jen 太子舍人.

f. T'ai-tsung personally impressed with his erudition.

g. $676: 3$.

h. 7 years, 4 months. Resigns because of illness.

i. Two sons become noted scholars and high officials.

j. Eberhard, p. 40, no. 34 . 
62. Lai Heng 来 沍. CTS 80: 3341:1, HTS 105: 3923:4.

a.d. 678 .

b. Elder brother of Lai Chi by different mother.

c. See no. 38 for father.

d. No examination.

e. No information.

f. None mentioned.

g. $676: 3$.

h. 2 years, 8 months.

i. No descendants mentioned.

63. Li 1-yen 李義琰. CTS 81: 3342:2, HTS 105: 3924:1.

a. d. 688 .

b. Wei-chou魏州, but part of eminent Lung-hsi Li clan with which T'ang family claimed connection.

c. Father and grandfather officeholders.

d. Chin-shih.

e. T'ai-ÿian wei太原尉 is first specific office mentioned.

f. Li Chi (no. 27).

g. $676: 4$.

h. 6 years, 11 months. Offends emperor and resigns in fear.

i. Younger brother and four grandsons have official careers.

64. Kao Chih-chou 高智周. CTS 185 shang: 3559:4, HTS 106: 3924:4.

a. d. 683 at age 82 .

b. Ch'ang-chou 常州 in Chiang-nan.

c. No ancestors mentioned.

d. Chin-shih.

e. Fei-hsien Zing 貫具系令.

$f$. None mentioned.

g. $676: 6$.

h. 3 years, 5 months.

i. No sons, but marries daughter to son of close friend and sponsors his career.

65. Chang Ta-an 張大安. CTS 68: 3316:1, HTS 89: 3895:1.

a. d. 684 .

b. Wei-chou 魏州 in Ho-pei。

c. Father a general and close friend of T'ai-tsung. 0lder brother high official.

d. No examination.

e. Not noted.

f. None mentioned.

g. $677: 4$.

h. 3 years. Demoted when Crown Prince Hsien falls in 680 .

i. Son has official career.

j. Associated with Hsien's commentary on Hou Han-shu.

66. Ts'ui Chih-wen 崔知温. CTS 185 shang: 3559:4, HTS 106: 3924:3.

a. d. 683 at age 57.

b. Hsü-chou 許州 in Ho-nan.

c. Father and grandfather officeholders.

d. No examination. 
e. Ling-chou tu-tu-fu ssu-ma 露州都督府司画.

$f$. None mentioned.

g. 679:4.

h. 3 years, 11 months.

i. Two sons as well as his elder brother have official careers.

67. P'ei Yen 裴炎. CTS 87: 3351:3, HTS 117: 3945:2.

a. Executed 684, supposedly conspiring to assassinate Empress Wu.

b. Chiang-chou 出草赠 in Ho-tung.

c. No ancestors mentioned, but student in Hung-wen kuan.

d. Ming-ching.

f. None mentioned.

g. $679: 4$.

h. 5 years, 6 months.

i. Two sons have official careers.

j. Biographies assume Yen's innocence of treason. Fonctionnaires, p. 12.

68. Kuo Cheng-i 率正一. CTS 190 chung: 3581:4, HTS 106: 3924:4.

a. Executed 689 at age 82 .

b. Ting-chou 定㓝 in Ho-pei.

c. No ancestors mentioned.

d. Chin-shih.

e. Chung-shu she-jen 中書舍人.

f. Hsüeh Yüan-ch'ao (no. 61).

g. $682: 4$.

h. 1 year, 8 months. Dismissed when Chung-tsung deposed.

i. No descendants mentioned.

69. Ts'en Ch'ang-ch'ien 岑声倩. CTS 70: 3319:3, HTS 102: 3917:1.

a. Executed 691 .

b. Chi-yang 棘陽 in Ho-nan.

c. Nephew of Ts'en Wen-pen who adopted him (see no. 26).

d. No examination.

e. Ping-pu shih-lang 兵部侍郎.

f. None.

g. $682: 4$.

h. 9 years, 1 month. Opposed elevation of Wu Ch'eng-ssu to crown prince.

$i$. Son has career, executed shortly after his father, and the tombs of his ancestors desecrated. A grandson is appointed to high office by Empress Wu in the ch'ang-an period [701-705], an act signaling the restoration of political rights for the descendants of many of her victims.

70. Wei Hsüan-t'ung 楾玄同. CTS 87: 3352:1, HTS 117: 3945:4.

a. Ordered to commit sulcide in 689 at age 73 .

b. Ting-chou定州 in Ho-pei.

c. No ancestors mentioned.

d. Chin-shih.

e. Ssu-lieh ta-fu司列大夫.

f. Li Shen-1i 李審福.

g. $682: 4$.

h. 7 years, 5 months. 
i. Third son an official of Hsüan-tsung.

j. Well-known memorial on examination system. Exomens, p. 247.

71. Wei Hung-min 章弘敏. No biography.

a. Dates unknown.

b. --

c. --

d. --

e. --

f. --

g. 684: cheng.

h. 10 months. Demoted because of connection with P'ei Yen.

72. Liu Wei-chih 留祽之. CTS 87: 3351:4, HTS 117: 3945:3.

a. Ordered to commit suicide in 687 at age 57 .

b. Ch'ang-chou 常) 㺫 in Chiang-nan.

c. Grandfather d Ch'en prince, father holds high office in Sui and T'ang.

d. No examination.

e. Reputation for literature, appointed to Chao-wen-kuan 昭文館.

f. Probably Liu Ku-yen 㘭顧言 and Li Po-yao 李伯菜药.

h. 3 years, 5 months.

i. No sons mentioned. Elder brother held high posts.

j. Paramount minister while he held tsai-hsiang status. North Gate scholar.

73. Wu Ch'eng-ssu武承埇. CTS 183: 3553:1, HTS 206: 4109:2.

a. d. 698 reputedly of chagrin.

b. T'ai-yüan太原. in Ho-tung.

c. Son of Wu Yuian-shuang 武元狄, half-brother of the Empress Wu.

e. Shang-i feng-yü 尚衣奉御.

f. Called from exile to be heir to Empress Wu's father.

g. $684: 5$.

h. 8 years, 9 months.

i. One son forced to commit suicide by empress after offending the Chang brothers, another active in the reign of Chung-tsung until the coup against San-ssu.

j. See text.

74. Li Ching-ch'en李景䛺. No biography.

a. --

b. --

c. --

d. --

e. --

f. --

g. $684: 10$.

h. 1 month. Transferred to lower post.

75. Shen Chün-liang 浣君諒. No biography.
a. --
b. --
c. -- 

d. --
e. --
f. --
g. $684: 10$.
h. 4 months. Transferred.

76. Ch'ien Wei-tao 寋味道. No biography.
a. Executed 688,' probably in connection with Princes' Rebellion.
b. --
c. --
d. Decree examination in 675 .
e. --
f. --
g. 684:10 (disputed; second appointment 688).
h. 9 months.

77. Ts'ui Tzu 崔些. No biography.
a. --
b. --
c. --
d. --
e. --
f. --
g. $684: 10$.
h. 5 months. Sent as commissioner to Ho-pei.

78. Wei Fang-chih 章方犋. HTS 103: 3919:4.
a. Executed in early ${ }^{C}$ Chou for opposition to Wu Ch'eng-ssu.
b. Ching-chao 京兆 [Ch'ang-an].
c. Grandfather was ming-ching and officeholder in Sui.
d. No examination.
e. Not noted.
f. None mentioned.
g. $684: 11$.
h. Disputed. Probably 5 years, 3 months.
i. Family extinguished.
j. Eberhard, p. 386, no. 84.

79. Wei Ssu-ch'ien 幸思謙. CTS 88: 3353:2, HTS 116: 3943:2.
a. d. 689 .
c. No ancestors mentioned.
d. Chin-shih.
f. Kao Chi-fu (no. 31) and Huang-fu Kung-i皇甫公秉.
g. $685: 2$.
h. 2 years, 1 month. Resigns due to age.
i. Two sons both reach tsai-hsiang status. See nos. 131 and 135 .
j. An admirable and uncompromising official. Eberhard, p. 72, no. 85.

80. P'ei Chü-tao 裴居道. CTS 86: 3350:3.
a. Dies in prison in 690 .
b. Chiang-chou 出条州 in Ho-tung.
c. Father and grahdfather officeholders, his daughter married to Crown 
Prince Hung. Eminent clan.

d. No examination.

e. Na-yen 嵌内 言.

$f$. None mentioned.

g. $685: 2$.

h. 5 years, 6 months. Slandered by evil officials.

i. No sons mentioned.

j. Eberhard, p. 380, no. 61 .

81. Su Liang-ssu 蘇良呞司. CTS 75: 3329:1, HTS 103: 3919:2.

a. d. 690 at age 85 .

b. Yung-chou 猚州 near Ch'ang-an.

c. Father and grandfather held office in Chou and Wei, and father also had successful career in Sui and T'ang.

d. No examination.

e. Chou-wang-fu ssu-ma国王府司画.

$f$. None mentioned.

g. $685: 5$.

h. 4 years, 9 months.

i. Son has career but exiled to Ling-nan in Chou, causing erasure of family honors. Grandson regains dukedom at restoration.

j. An example of an innocent man charged by evil officials and saved by intervention of the Empress Wu. Eberhard, p. 381, no. 63.

82. Wei Tai-chia 韋待價. CTS 77: 3333:3, HTS 98: 3910:2.

a.d. in exile ca. 690 .

b. Yung-chou 権州 near Ch'ang-an.

c. Grandfather high Sui office, father, Wei T'ing 考挺, high office and noble title in early T'ang. Married into T'ang family.

d. No examination.

e. Tso-ch'ien-niu 左千牛.

$f$. None mentioned. Military renown.

g. $685: 6$.

h. 3 years, 11 months. Exiled for defeat by T'u-fan.

i. Younger brother has successful career. Son awarded fifth rank because of father's early military success. Cousin to Wei An-shih (no. 125).

j. Little talent in civil realm. An object of scorn when he was placed in charge of examination system. Eberhard, p. 386, no. 84.

83. Chang Kuang-fu 張光輔. CTS 90: 3360:3.

a. Executed 689 for sorcery and possible treason.

b. Ching-chao 京北.

c. No ancestors mentioned.

d. No examination.

$f$. None mentioned. Gained merit in Princes' Rebellion.

g. $687: 5$.

h. 2 years, 3 months.

i. Family extinguished.

84. Wang Pen-1i王本立. No biography.

a. Dates unknown.

b. -- 

c. --
d. --
e. --
f. --
g. 688:9.
h. 1 year, 5 months.

85. Fan Li-ping 范履冰. CTS 190 chung: 3581:4, HTS 201: 4100:3.

a. Executed 690 for collusion in treason.

b. Huai-chou 懹州 in Ho-pei.

c. No ancestor's ment ioned.

d. No examination.

e. Chou-wang-fu hu-ts'an 周王府户厸.

g. $689: 1$.

h. 6 months.

i. No sons mentioned.

86. Hsing Wen-wei 开文偉. CTS 189 hsia: 3576:4, HTS 106: 3926:2.

a. Suicide in exile 690-1. Demotion to provinces for graft.

b. Ch'u-chou涂州 in Huai-nan.

c. No ancestors mentioned.

d. No examination.

$f$. None mentioned, but early fame as scholar.

g. 689:10.

h. 1 year. Demoted.

i. No sons mentioned.

87. Wu Yu-ning 武敒蜜. CTS 183: 3553:3, HTS 206: 4109:3. Cousin從父兄邪 of the Empress Wu. See text.

g. 690:2.

h. Disputed. Probably 3 years, 3 months.

88. Shih Wu-tzu史務湠出。 CTS 90: 3360:3, HTS 114: 3941:1.

a. Committed suicide in 691 .

b. Hsüan-chou 宣州 in Chiang-nan.

c. Father officeholder.

d. No examination.

e. No information.

$f$. None mentioned.

g. $690: 9$.

h. 4 months. Slandered by Lai Chün-ch'en.

i. No descendants mentioned.

89. Fu Yu-i 傅遊㯲. CTS 186 shang: 3564:4, HTS 223 shang: 4163:4.

a. Suicide in prison 691 .

b. Wei-chou 衛归 in Ho-pei.

c. No ancestors mentioned.

d. No examination.

e. Ho-kung chu-pu 合宫主簿.

f. Rises by flattering Empress Wu, claiming to have seen favorable omen for usurpation.

g. $690: 9$. 
h. 11 months. Probably planning treason.

i. Sons and grandsons imprisoned for some crime between 705 and 707 .

j. Called the "Minister of the Four Seasons" from the various colors of his robes when he received four promotions in one year. Responsible for the notorious massacres in Ling-nan of the exiled families of the victims of the terror.

90. Ko Fu-yüan 格輔元. CTS 70: 3319:4, HTS 102: 3917:1.

a. Executed 691:10. Opposition to Wu Ch'eng-ssu.

b. Pien-chou 沛归 in Ho-nan.

c. Uncle a Sui official.

d. Ming-ching, and famed for literary attainments.

e. Yü-shih ta-fu 御史大夫.

$f$. None mentioned. Elder brother an official of Kao-tsung.

g. $691: 6$.

h. 4 months.

i. No descendants mentioned.

91. Jen Chih-ku 任知古. No biography.

a. No dates.

b. --

c. --

d. --

e. --

f. --

g. $691: 6$.

h. 7 months. Demoted to provincial post.

92. Yüeh Ssu-hui 㓦出思晦. See no. 49.

a. Executed 691:10. Opposition to Wu Ch'eng-ssu.

b. Son of Yüeh Yen-wei (no. 49).

c. --

d. --

e. --

f. --

g. $691: 6$.

h. 4 months.

93. Ti Jen-chieh 狄仁祭. CTS 89: 3356:1, HTS 115: 3941:2.

a. 630-700.

b. Ping-chou并州 in Ho-tung. Same native place as Empress Wu.

c. Father and grandfather officeholders.

d. Ming-ching.

e. Pien-chou p'an-tso 泣州判佐.

f. Yen Li-pen (no. 58).

g. $691: 8$ for 4 months. Reappointed 697:8.

h. 2 years, 10 months.

i. Sons and grandsons officeholders. Two sons known as bad officials.

$j$. The most famed official of the Chou, and only one who enjoyed the whole trust of the Empress Wu. See text.

94. Ou-yang T'ung 區负陽通. CTS 189 shang: 3575:3, HTS 198: 4090:4.

a. Executed 691 for opposition to Wu Ch'eng-ssu.

b. T'an-chou潭州 in Chiang-nan. 
c. Three generations of officeholders from Ch'en dynasty.

d. No examination but early fame as scholar.

e. Chung-shu she-jen 中書舍人.
f. None mentioned.

g. $691: 8$.

h. 2 months.

i. No descendants mentioned.

95. P'ei Hsing-pen裴行本. No biography.

a. No dates.

b. Possibly brother of P'ei Hsing-chien.

c. --

d. --

e. --

f. --

g. $691: 9$.

h. 4 months. Exiled to Ling-nan.

96. Li Yu-tao 李游道. HTS 197: 4088: 1 .

a. No information.

b. Chao-chou趙州 in Ho-pei.

c. Grandfather and nephews officeholders.

d. No examination.

e. Not mentioned.

$f$. None mentioned.

g. $692: 1$.

h. 8 months. Exiled to Ling-nan.

i. No sons mentioned.

j. Eberhard, p. 376, no. 43.

97. Ts'ui Shen-chi 崔神基. CTS 77: 3335:3, HTS 109: 3930:2.

a. Died in reign of Chung-tsung.

b. Pei-chou 具州 in Ho-pei.

c. Father a military career and, as early partisan of Empress Wu, recipient of title to which Shen-chi succeeds.

d. No examination, though younger brother is ming-ching.

e. Ssu-pin ch'ing 司 富䐚.

f. None mentioned.

g. $692: 2$.

h. 7 months. Exiled to Ling-nan.

i. No descendants mentioned.

98. Yüan Chih-hung袁智弘. No biography.
a. No dates.
b. --
c. --
d. --
e. --
f. --
g. $692: 2$.
h. 7 months. Exiled to Ling-nan.

99. Li Chao-te李昭德. CTS 87: 3352:3, HTS 117: 3936:1. 


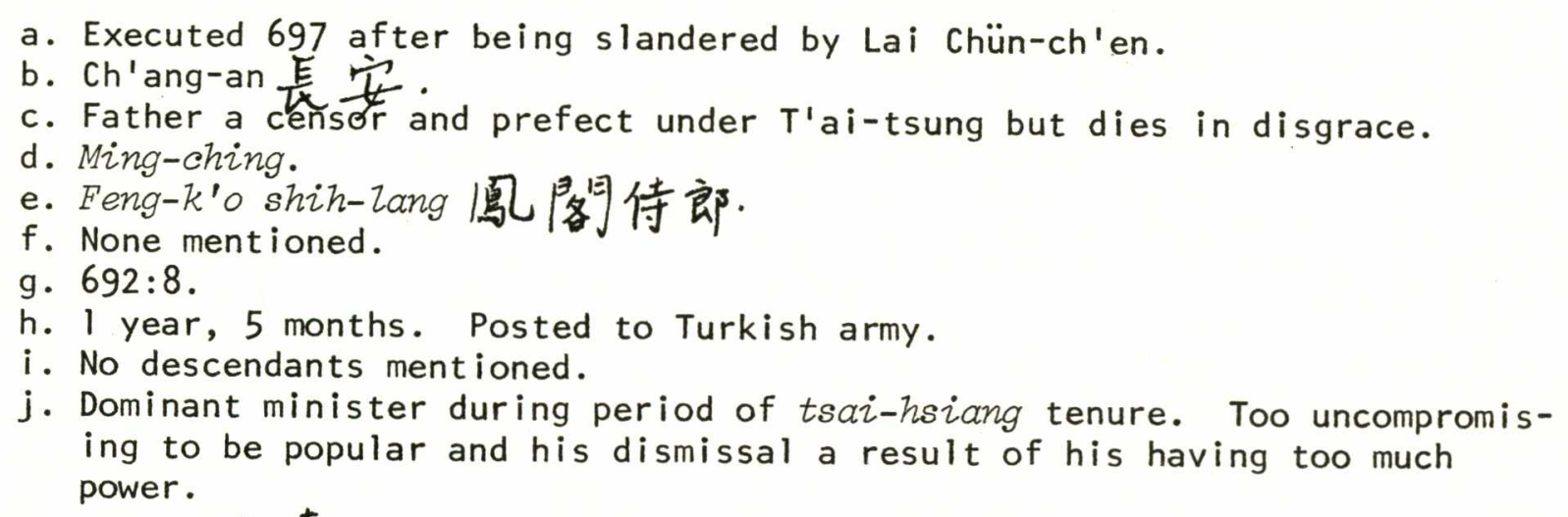

100. Yao Shou 姚璫. CTS 89: 3358:1, HTS 102: 3918:1.

a. d. 705 at age 74 .

b. Wan-nien 萬年 near Ch'ang-an.

c. Grandfather officeholder, orphaned while young.

d. Ming-ching.

e. T'ai-tzu-kung men-lang 太子容門郎.

f. None mentioned.

g. $692: 8$.

h. 3 years, 1 month. Transferred to provincial post.

i. Younger brother passes ming-ching, has rapid rise, holds many of same posts as brother.

j. A wholly good minister. Expert on ming-t'ang and ritual generally. Responsible for creation of office of shih-cheng-chi

Fonctionnaires, p. 159; Eberhard, p. 386, no. 86.

101. Li Yüan-su李元素: HTS 106: 3925:4.

a. Executed 697.

b. Younger brother of Li Ching-hsüan (no. 59).

c. See no. 59 .

d. No examination.

e. Wu-te Zing 武德令.

f. None mentioned. Probably aided by brother.

g. $692: 8$.

h. 4 years, 5 months. Charged with treason.

i. No descendants mentioned.

102. Ts'ui Yüan-tsung 崔元㬎宗. CTS 90: 3360:3, HTS 114: $3941: 1$.

a. d. age over 90 in reign of Chung-tsung.

b. Cheng-chou 鄚州 in Ho-nan.

c. Grandfather an officeholder under Kao-tsu.

d. No examination.

e. Ch'iu-kuan shih-lang 秋'官待郎.

g. $692: 8$.

h. 2 years. Exiled to Chen-chou振州because of enmity of other officials.

i. No descendants mentioned.

j. Known as a harsh official.

103. Wang Hsüan 王王搴. No biography.

a. Dates unknown. 

b. --
c. --
d. --
e. --
f. --
g. $692: 8$.
h. 1 month. Exiled to Ling-nan.

104. Lou Shih-te 要師德. CTS 93: 3366:2, HTS 108: 3929:4.

a.d. 699 at age 74 .

b. Cheng-chou船 怰 in Ho-nan.

c. No ancestors mentioned.

d. Chin-shih before the age of 20 .

e. Chiang-tu wei 江都原扵.

f. Lu Ch'eng-yeh

g. 693:2 [disputed].

h. 6 years, 2 months.

i. No descendants mentioned.

j. A rare combination of civil and military talent, serving the state in high posts for over 30 years.

105. Wei Chü-yüan 章巨源. CTS 92: 3364:4, HTS 123: 3958:4.

a. Killed 710 at age 80 in coup.

b. Third cousin of Wei An-shih (no. 125). Related to Empress Wei.

c. Three generations of officeholders.

d. No examination.

e. Ssu-pin shao-ch'ing 司㙞少卿.

g. $693: 9$.

h. Disputed. Probably 1 year, 10 months in all.

i. No descendants mentioned.

$j$. Rise due to connections but a highly competent official.

106. Lu Yüan-fang 陸元方. CTS 88: 3354:4, HTS 116: 3944:4.

a.d. 701, shortly after demotion.

b. Su-chou 蘇州 in Chiang-nan.

c. Eminent clan. Offices since Ch'en but father unmentioned.

d. Ming-ching and decreee examination 八 科.

e. Chien-ch'a yü-shih 監察卸史.

g. 693:9.

h. Disputed. Probably 2 years, 2 months. Demoted for arrogance about tsai-hsiang prerogative.

i. Son rises to tsai-hsiang under Chung-tsung.

j. Regarded as incorruptible. Consulted by Empress Wu on all promotions and demotions.

107. Tou-lu Ch'in-wang 严虚欽望 D CTS 90: 3360:2, HTS 114: 3941:1.

a. d. 709 at age over 80 .

b. Ching-chao 京兆 [Ch'ang-an].

c. Three generations of officeholders, marriage into both Sui and T'ang families.

d. No examination. 
e. Ssu-pin-ch'ing 司蜜㑡.

f. None mentioned.

g. 693:9.

h. 2 years, 4 months. Transferred (no reason given).

i. No descendants mentioned.

j. Considered an expert in political survival. Possibly Eberhard, p. 382, no. 70.

108. Su Wei-tao 蘇味道. CTS 94: 3368:1, HTS 114: 3940:4.

a. d. 706 at age 58 .

b. Chao-chou 趙州 in Ho-pei.

c. No ancestors mentioned.

d. Chin-shih before, the age of 20 .

e. Hsien-yang wei 咸陽尉.

g. $694: 3$.

h. 6 years, 7 months. Dismissed for overburdening the common people when he moved father's tomb.

i. No sons mentioned. Younger brother has career.

j. Criticized for failure to innovate in his long tenure of high posts. Known as the "fence sitter."

109. Wang Hsiao-chieh王孝僺. CTS 93: 3366:2, HTS 111: 3935:3.

a. Killed 696 in Khitan rebellion.

b. Ching-chao 京北.

c. No ancestors mentioned.

d. No examination.

e. Military career. T'u-fan expert.

f. None mentioned.

g. $694: 4$.

h. I year, 11 months. Dismissed because of defeat.

$i$. Son has career, becoming general for Hsüan-tsung.

110. Wu Shih-fang 武什方. No biography.

a. Dates unknown.

b. --

c. --

d. --

e. --

f. --

g. $694: 7$.

h. I month. Retires to search for magic elixir.

111. Yang Tsai-ssu 楊再思. CTS 90: 3360:1, HTS 109: 3930:3.

a. d. 709.

b. Cheng-chou奠州 in Ho-nan.

c. No ancestors mentioned.

d. Ming-ching.

e. Hsüan-wu wei 玄武尉.

f. None mentioned.

g. $694: 8$.

h. 5 years, 4 months. Transferred to become censor.

i. Younger brother and grandson have careers. 
j. Known as a flatterer, sycophant to Chang brothers and expert in survival.

112. Chou Yün-yüan 国允元. CTS 90:3360:4, HTS 114: $3941: 1$.

a. d. 696.

b. Yü-chou豫州 in Ho-nan.

c. No ancestors mentioned.

d. Chin-chih before age 20 .

$f$. None mentioned.

g. $694: 10$.

h. 1 year, 4 months. Dies in office.

i. No descendants mentioned.

113. Sun Yüan-heng 㐨元亨. No biography.
a. Executed 697 .

b. --

c. --

d. --

e. --

f. --

g. $696: 4$.

h. 9 months.

114. Li Tao-kuang 李道庶. No biography.

a. d. ca. 700 in hónor.

b. Remotely Hua-chou滑州 in Ho-nan; moved to Wan-nien in the Sui.

c. Father a Sui general who joined T'ang and was rewarded with dukedom and imperial surname.

d. No examination.

e. Pien-chou泫州 prefect.

$f$. None mentioned.

g. $696: 9$.

h. 1 year, 4 months. Transferred to provinces.

i. No descendants mentioned.

115. Wang Fang-ch'ing王方膺. CTS 89: 3357:3, HTS 106: 3942:4.

a. d. 702 in honor.

b. Yung-chou维州 near Ch'ang-an. Until moving north in the Chou, considered an eminent Chiang-tso clan.

c. Four generations of officeholders, but Fang-ch'ing orphaned at age 16 .

d. No examination.

e. Yüeh-wang-fu ts'an-chün越王府參筆.

g. 696:9.

h. 1 year, 11 months.

i. Son holds office under Hsüan-tsung.

j. A bibliophile and expert in ritual. Much honored by Empress Wu. Possibly Eberhard, p. 385, no. 81.

116. Wang Chi-shan王及善. CTS 90: 3359:1, HTS 116: 3944:3.

a. 617-699. Dies in semi-disgrace after criticizing Chang brothers.

b. Lo-chou 洛州 in Ho-nan.

c. Father a Sui general, joins T'ang, wins dukedom, and dies in Korea. 
d. Chi-shan succeeds to father's title. No examination.

e. Tso-feng-ÿ̈ 左奉裕.

f. None mentioned.

g. $697: 4$.

h. 2 years, 4 months. Asks for holiday and never recalled.

i. No descendants mentioned.

j. Lacked formal education, but much praised by contemporaries. Large role in ending of terror.

117. Tsung Ch'u-k'o宗梦客. CTS 92: 3365:4, HTS 109: 3930:4.

a. Executed Z10 in coup.

b. P'u-chou㜑 州 in Ho-nan.

c. No ancestors mentioned, but marriage relationship to Empress Wu.

d. No examination.

e. Fang-shao-chien 方省.

f. None mentioned. Elder brother urges usurpation.

g. $697: 6$.

h. Disputed. Probably 11 months in all.

i. Family extinguished.

j. Closely connected with Chang brothers.

118. Wu San-ssu武三思. CTS 183: 3553:2, HTS 206: 4109:4.

Son of Wu Yüan-ch'ing 武元㕍, half-brother of the Empress Wu.

g. $697: 6$.

h. Disputed. Probably 2 years, 2 months.

119. Tu Ching-ch'uan 杜景佺. HTS 116: 3944:4.

a.d. ca. 698 on the road to provincial post.

b. Chi-chou糞州 in Ho-pei.

c. No ancestors mentioned.

d. Ming-ching.

e. Tien-chung shih-yü-shih 殿中待御史.

f. None mentioned.

g. $694: 8$ for 5 months, 697:10.

h. 1 year, 2 months. Transferred.

i. No descendants mentioned.

j. An upright man, contributed to preservation of justice during the terror. Eberhard, p. 68, no. 78.

120. Chi Hsü 吉港, CTS 186 shang: 3565:3, HTS 117: 3946:2.

a. d. in exile 700 .

b. Lo-chou 洛州 in Ho-nan.

c. No ancestors mentioned.

d. Chin-chih.

e. Ming-t'ang wei 明堂层。

f. None mentioned. Rises by denouncing conspiracy.

g. 698:11.

h. I year, 3 months. Dismissed for insulting Wu 1-tsung and because his brother gains a post under false pretenses.

i. No descendants mentioned.

j. Responsible for many executions during the terror and closely connected with Chang brothers, but secretly a T'ang loyalist. Much favored by Empress Wu. 
121. Wei Yüan-chung 魏元忠. CTS 90: 3362:4, HTS 122: $3954: 4$.

a. d. ca. 710 at age over 70 .

b. Sung-chou宋州 in Ho-nan.

c. No ancestors mentioned.

d. Failed examination candidate.

e. Appointed to mi-shu sheng 密書省 on strength of unsolicited memorial in 678 .

f. None mentioned.

g. 698: intercalary last month.

h. 4 years, 1 month.

i. 2 sons have careers.

j. A principled and uncompromising official. Three times exiled from capital but much valued by Empress Wu. Helped compile her shih-Zu.

122. Yao Ch'ung 姚崇. CTS 96: 3371:1, HTS 124: 3959:1.

a. $651-721$.

b. Loyang, more remotely from Shan-chou 陈州 in Ho-nan.

c. Father an officeholder under T'ai-tsung.

d. Decree examination $下$ 筆成章.

e. P'u-chou ssu-ts'ang 潗恻司念。

f. Su Liang-ssu (no. 81).

g. $698: 1$.

h. 5 years, 7 months. Resigns to care for mother.

i. Three sons have official careers. i. Three sons have official careers.
j. Also known as Yao Yüan-ch'ung 元 崇 or Yüan-chih ${ }^{2} \dot{z}$. Wept at deposi-
tion of the Empress Wu. Excomens,

123. Li Chiao李山喬. CTS 94: 3368:1, HTS 123: 3957:4.

a. 644-713.

b. Chao-chou 趙州 in Ho-pei.

c. Three generations of officeholders. Considered eminent clan. Nephew of Chang $\mathrm{Hsi}$ 張金易.

d. Chin-shih before age of 20 .

e. Chien-ch'a yü-shih 監察御史.

$f$. None mentioned.

g. $698: 10$.

h. 3 years, 4 months. Demoted at restoration.

i. No sons mentioned.

j. A remarkable career, balancing sycophancy to Wu clan with some of the frankest remonstrance of his time. An important literary talent, leaving collected works in 50 chüan. Nephew of Chang Hsi (next entry). Exomens, p. 245; Eberhard, p. 52, no. 51.

124. Chang Hsi 張金易. CTS 85: 3349:1, HTS 113: 3939:3.

a. Died early in reign of Jui-tsung.

b. Pei-chou 具州 in Ho-pei.

c. Nephew of Chang Wen-kuan (no. 57) and uncle of Li Chiao (no. 123).

d. No examination.

e. Not mentioned.

f. None mentioned.

g. $700: 7$.

h. 6 months. Exiled for accepting bribes.

i. No descendants mentioned. 
125. Wei An-shih 章安石. CTS 92: 3364:1, HTS 122: 3955:4.

a.d. 714 at age 64 .

b. Ching-chao 京兆.

c. Three generations of officeholders. See no. 82.

d. Ming-ching.

e. Ch'ien-feng wei 乾封尉.

f. Su Liang-ssu (no. 81).

g. $700: 10$.

h. 3 years, 10 months. Demoted for opposition to Changs.

i. Two sons and several other family members have official careers. Related to Empress Wei.

j. Eberhard, p. 386, no. 84.

126. Li Huai-yüan 李懷遠. CTS 90: 3360:2, HTS 116: 3945:1.

a. d. 706 in honor.

b. Hsing-chou 邢州 in Ho-pei.

c. No ancestors mentioned. Improverished orphan.

d. $S s u-k^{\prime} 0$ 四科

e. Ssu-li shao-ch'ing 司䄚竖捩.
f. None mentioned.

g. $701: 2$.

h. 5 months. Resigns because of age.

$i$. Son and grandson have successful careers.

j. Much favored by the Empress Wu. Known for his frugal tastes and love of nature.

127. Ku Ts'ung 雇素王. HTS 102: 3918:4.

a.d. 702 in honor.

b. Su-chou 蘇州 in Chiang-nan.

c. Father and grandfather officeholders from Sui.

d. No examination.

e. Li-pu shih-Zang 吏部侍郎.
f. None mentioned.

g. $701: 5$.

h. 1 year, 5 months. Dies in office.

i. No descendants mentioned.

128. Li Chiung-hsiu李迥秀. CTS 62: 3304:1, HTS 99: 3911:2.

a. d. between 707 and 710 .

b. Eminent Lung-hsi clan.

c. Three generations of office and titles.

d. Three decree examinations英材㑏出 and chin-shih.

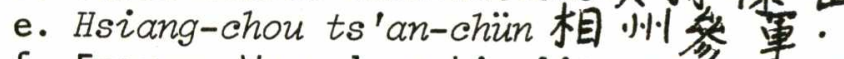

f. Empress Wu values his literary" ta fent and places him precipitately in charge of examinations.

g. $701: 6$.

h. 2 years, 8 months. Demoted when attacked by other officials for his association with Chang brothers.

i. Son has career, but family extinguished in $k^{\prime} a i-y \ddot{u} a n$ (713-742) because of his treason.

j. His mother was of low-born family, but his wife of the eminent Ts'ui clan. Eberhard, p. 48, no. 50. 
129. T'ang Hsiu-ching 唐休景. CTS 93: 3366:3, HTS 111: 3935:4.

a.d. 712 at age 86 in honor.

b. Ching-chao 京兆.

c. Grandfather and great-grandfather have military careers. Father unmentioned.

d. Ming-ching before age 20.

$f$. None mentioned.

g. $703: 7$.

h. 1 year, 5 months. In office at restoration.

i. Elder son succeeds to rank and has civil career. Second son a general.

$j$. The greatest expert of his time on western frontier affairs. Much valued by Empress Wu.

130. Chu Ching-tse 朱䔩埧. CTS 90: 3359:3, HTS 115: 3942:3.

a.d. 709 at age 75 .

b. Po-chou毫州 in Ho-nan.

c. Notable family; famed since Chou for Confucian virtue. Ancestors unmentioned.

d. No examination.

e. Po-shui wei 泊水尉.

f. Wei Yüan-chung (no. 121).

g. $703: 7$.

h. 7 months. Resigns because of age.

i. No descendants mentioned.

j. Known for frankness. An historian of note.

131. Wei Ssu-1i章嗣立. CTS 88: 3354:4, HTS 116: 3943:3.

a.d. 719 at age 66 .

b. Cheng-chou宓洲 in Ho-nan.

c. Son of Wei Ssu-ch'ien (no. 79).

d. Chin-shih.

e. Shuang-Ziu Zing 隻流充.

f. Recommended by his father.

g. 704: cheng (disputed).

h. 11 months. Transferred when his brother reaches tsai-hsiang status.

i. Three sons, all have good careers.

j. A relative of the Empress Wei. Eberhard, p. 72, no. 85.

132. Ts'ui Hsüan-wei 崔玄暲. CTS 91: 3361:4, HTS 120: 3952:3.

a. 638-706. Dies on road to provincial demotion.

b. Po-ling 博陵 in Ho-pei.

c. Eminent clah. Father held low post.

d. Ming-ching.

e. K'u-pu yüan-wai-Zang 庫部真外·郎.
f. None mentioned.

g. $704: 6$.

h. 6 months. Still in office at restoration.

i. Two sons have official careers. Younger brother a high official in own time.

j. Exemplar of the best features of the northeastern aristocracy. Eberhard, p. 65 , no. $77 a$. 
133. Chang Chien-chih 㨏束之. CTS 91: 3361:4, HTS 120: 3952:4.

a. 625-706. Deștroyed by Wu San-ssu.

b. Hsiang-chou裹州 in Shan-nan.

c. No ancestors mentioned.

d. Chin-shih, and decree examination of 689 when he was first of more than 1,000 candidates.

e. Ch'ing-ch'eng ch'eng 青城丞.

f. Ling-hu Te-fen, Yao Ch'ung (no. 122), and Ti Jen-chieh (no. 93).

g. $704: 10$.

h. 3 months. In office at restoration.

i. Son a bad official, partly responsible for father's downfall.

$j$. Leader of restoration coup. 134. Fang Jung 房谪虫. CTS 111: 3403:3, HTS 139: 3985:3 [Biography of son
Fang Kuan].

a. Exiled 705, died shortly thereafter.

b. Loyang.

c. No ancestors mentioned.

d. No information.

e. No information.

f. None mentioned.

g. $704: 10$.

h. 3 months. In office at restoration.

i. Son has biography.

135. Wei Ch'eng-ch'ing 韋承愿. CTS 88: 3354:2, HTS 116: 3943:3.
a. d. ca. 709 in hohor.

b. Son of Wei Ssu-ch'ien (no. 79).

c. Above.

d. Chin-shih.

e. Yung-wang-fu ts'an-chün 䧹王府参年.

g. $704: 11$.

h. 2 months. Demoted at restoration for connection with Chang brothers.

i. No sons mentioned.

$j$. Much praised for his work in presiding over examination system. Skilled in literature and helps compile the shih-Zu of Empress Wu as well as composing a separate work called Tse-t'ien huang-hou chi sheng-wen 則天皇后紀聖文. Eberhard, p. 72, no. 85 . 


\section{NOTES}

(Works are usually cited in abbreviated form. For full citations, see abbreviations on page xii and the bibliography.)

\section{Chapter 1}

1. According to some classifications of Chinese mythology, the sister of Fu $\mathrm{Hsi}$, called $\mathrm{Nü}$ Kua, was numbered among the san-huang of antiquity and so might be considered China's first female ruler. See Ch'en Teng-yüan, Kuo-shih chiuwen, v. 1, pp. 44-47. The chronology of the reign of the Empress Wu is subject to some dispute, but by correlating the dates of the earliest sources given in the Tzu-chih t'ung-chien $k^{\prime} a o-i$, I suggest that her elevation occurred on November 24,655 , that the Chou dynasty was proclaimed on October 16, 690, and that the T'ang restoration occurred on February 23, 705.

On the empress' titles, see THY 3, pp. 23-4, CTS 6:3077:1, HTS 76:3868:2. Citations are to the $\mathrm{K}^{\prime} \mathrm{a} \mathrm{i}-\mathrm{ming}$ edition of 1935, and references take the form of chuian: page: section, as above. References to the TCTC are from the Ku-chi ch'upan-she edition (Peking, 1957) which intersperses the $k^{\prime} a O-i$ and the Hu Sanhsing commentary in the text. Other editions noted in the bibliography have been used occasionally for textual verification.

2. One of the best-known novels is the Sui-T'ang yen-i attributed to Lo Kuanchung in the fifteenth century and revised in a hundred hui by Ch'u Jen-huo, probably about 1681. The chapters pertaining to the empress begin at hui 70 . An even more famous example is the Ch'ing work Ching-hua-yüan by Li Ju-chen.

A large erotic literature concerned with the scandals of the Chou court and the empress' "lovers" also exists, many of these works transmitted only in Japan. Professor Herbert Franke of Munich has recently called to my attention two manuscripts found in the Harvard-Yenching Library, the short novel Ju-ichün chuan (anon.) and the Seng Huai-i chapter of the Seng-ni nieh-hai, sometimes attributed to the painter T'ang Yin. A long novel called Wu-hen-t'ien (noted by Sun K'ai-ti, Chung-kuo t'ung-su hsiao-shuo shu-mu, p. 151) does not seem to be pornographic.

Several modern works are rather sensationalistic. Among these are the T'ang-kung erh-shih-ch'ao yen-i by Hsü Hsiao-t'ien and the Li-tai ti-wang hsingai mi-wen published under the pseudonym Ling-yün Ko-chu. Some Japanese have been similarly impressed by this aspect of the empress' life, and a representative product is Hayashi Fusao, Chugoku senya ichiya.

In recent drama, two well-known plays are Kuo Mo-jo's four-act Wu Tset'ien, first performed in 1959, and T'ien Han's Hsieh Yao-huan, first published in Cḧ̈-pen, 1961, no. 7-8, pp. 6-43. Like Wu Han's 'Hai Jui Dismissed from office," the latter play is an attempt to use an historical figure to criticize the Maoist regime, and it was suppressed in the Cultural Revolution. In recent days the empress' career has once again been widely discussed because of attempts to compare her with Mao's wife Chiang Ch'ing. On this question see Chung-kuo tsa-chih, July 1975, pp. 39-44.

Works in English include Lin Yü-t'ang's imaginative novel Lady Wu, and the late Robert van Gulik's successful series of Judge Dee mysteries based upon $\mathrm{Ti}$ Jen-chieh, the most famous of the great ministers of the Empress Wu.

3. For a summary of the debate in the 1950s see Albert Feuerwerker, ed., History in Communist China (Cambridge: M.1.T. Press, 1968), pp. 132-135. A more detailed discussion is Tonami, "Zui no bōetsu."

4. See Gardner, Historiography, and several studies in Beasley and Pulleyblank, Historians. 
5. On Easton's views, see A Systems Analysis of Political Life (New York, 1965), particularly pp. 286-305, and for Weber, The Theory of Social and Economic Organization (New York, 1957).

6. Weber, pp. 326-7.

7. For this and some of the following perceptions, I am indebted to an unpublished manuscript by Anne Thurston of Yale University, "Authority, legitimacy and power: A reformulation."

8. In the year 696. See THY 7, p. 104, CTS 6:3076:2, and HTS 4:3642:1.

9. TCTC 207, p. 6559.

10. CTS $6: 3077: 1$ and HTS $4: 3642: 4$.

11. I am uncertain here of my translation of the phrase ch'u-chiu chih ying-mo 初九之英言某。

12. The reference here is to the legendary Fu Hsi. The phrase runs tang haohsi chih 2 i-shu 當昊䇅之歴數.

13. TTCLC 2:3b, CTW 17:10b. At a recent ACLS conference at Asilomar, California in June of 1975 the late Professor Arthur F. Wright suggested that it was unlikely Chung-tsung himself was responsible for this decree. While I tend to agree, I believe that its very promulgation is the important point since it portrayed Tse-t'ien as a legitimate ruler rather than as a usurper.

14. THY 63, p. 1094 .

15. TCTC 208, p. 6596.

16. THY 63, pp. 1095-97.

17. Ibid.

18. CTS $6: 3075: 3$.

19. HTS $4: 3643: 3$. On the compilation of the T'ang histories see des Rotours, Examens, pp. $111-112$.

20. See des Rotours, Examens, pp. 111-112.

21. T'ang-shu chih-pi 3:6b-7a and $2: 23 a b$ respectively.

22. T'ang-shu chih-pi 4:lab.

23. HTS $76: 3867: 3$.

24. Kuang never refers to her as anything but $t^{\prime} a i-h o u$, reporting the usurpation of 690 in the following terms: "The empress dowager accepted ( $\left.k^{\prime} 0\right)$ [the title] huang-ti and the request of the ministers [to establish the Chou]." TCTC 204 , p. 6467.

25. For Chu Hsi's listing of the dynasties he considered to be legitimate, see his introduction to the Chih-ÿ̈an k'ao-ting t'ung-chien kang-mu. The kang-mu follows Shen Chi-ch'i's suggestion and, considering Chung-tsung to be the legitimate monarch, lists his whereabouts in each year of the chou before outlining the history of the period.

26. See Note 1 to this chapter and Yang, Excursions, pp. 27-44. This article, entitled "Female rulers in ancient China," appeared originally in HJAS 23 (196061), pp. 47-61.

27. From the "Speech at Mu." See Legge, Shoo King, pp. 302-303.

28. Karlgren, Book of Odes, no. 264.

29. Analects, XVII:25. Legge, in the Four Books, uses the translation "girls

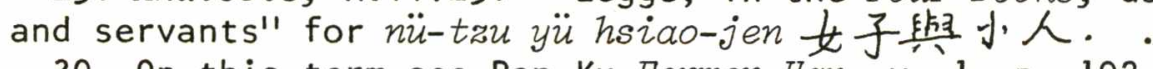

30. On this term see Pan Ku, Former Han, v. 1, p. 192, n. 1.

31. Ch'̈̈, Han Social Structure, pp. 73-74.

32. See, for instance, Nien-erh-shih cha-chi, v. 1, pp. 40 and 57.

33. San-kuo chih, Wei-chih 2:0924:2. The edict uses the term fu-cheng,"aid in government."' 
34. Yang, Excursions, pp. $50 \mathrm{ff}$. The cases in which female regency seems to have been accepted followed closely the Han precedents: the extreme youth of the heir, the illness or inability of a reigning emperor to manage government, and the issue of an edict of permission from a dying emperor.

35. Sui-shu $36: 2457: 3$.

36. Although most studies contrasting the northern and southern dynasties remark on the relative freedom of women in the North, a monograph on the subject would be most welcome. Teng, Fomily Instructions, p. 19, translates an observation of the late sixth century: "In the city of Yeh it was the custom for women to handle all family affairs, to demand justice and straighten out legal disputes, to make calls and curry favor with the powerful. They filled the streets with their carriages. . . begged official posts for their sons and made complaints about injustice done to their husbands. Were these customs handed down from the T'o-pa Wei dynasty?" The wife of Sui Wen-ti (Sui-shu 36:2457:2), née Tu-ku, was perhaps typical of this sort of woman and was considered by contemporaries to be almost a partner in her husband's government. On the first T'ang empresses, see CTS $51: 3278: 4 \mathrm{ff}$.

37. CTS $52: 3283: 2$.

38. HTS $76: 3869: 2$.

39. Biography in CTS 190 shang:3581:1 and HTS 201:4100:3.

40. The full text is found in WYYH 646:11b-12b and CTW 199:1a-2a.

41. See, for instance, CTS $6: 3077: 1$ and the examples from all three works cited in Appendix A. Several others are pointed out in the text.

42. Yüan Shu entitles chüan 30 of his T'ung-chien chi-shih pen-mo 'The Calamity of the Empresses Wu and Wei" and, as earlier noted, Chu Hsi portrays her as an ambitious and unscrupulous usurper in the kang-mu. Wang Fu-chih, in Tu t'ung-chien Zun, chüan 21, details the weakness and stupidity of Kao-tsung, impugns the motives of the Empress Wu in all her acts, expresses outrage at her executions, and even refuses to credit her with such well-knwon innovations as the palace examination. Fang Hsiao-ju, in what seems to be the prevailing view in the Ming, exhibits a similar attitude in such works as his Hsïn-chih chai-chi, chüan 5 .

Chao I seems to hold a fairly balanced view of the empress both in his Kai-yü ts'ung-k'co, chüan 41, and in his Nien-erh-shih cha-chi where chüan 19 contains two essays, one condemning her excessive punishments and the other praising her ability to accept remonstrance and to use the best possible men in her administration. In chüan 3 of the latter work, however, he compares her to the Han Empress Lü and states unequivocally that from antiquity, her evil was unparalleled. Wang Ming-sheng, in the Shih-ch'i-chih shang-chiao reflects the hostile attitude of the T'ang official histories.

43. In her own time, of course, the empress did not lack defenders, and talented literati like Li Chiao, Ch'en Tzu-ang and the poet Shen Ch'üan-ch'i turned their considerable skills to the praising of her reign. Generally, however, these were conventional, commissioned works and of little historiographical importance.

The first important defense of the empress as a ruler came from Lu Chih, one of the most important of T'ang Te-tsung's ministers. See CTS 139:3453:4 and HTS 157:4015:3. His political writings are favorable to her, admiring her skillful use of officials and her ability to hold the support of the people. See, for

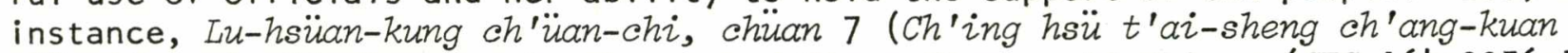
chï-chien shu-li chuang. Another noted T'ang figure, Li Chiang (CTS 164:3056:1 
and HTS 152:4007:3) holds a similar view. See Li hsiang-kuo Zun-shih chi, chüan 299 hsia.

In the Sung, the only figure of note who seems to have been favorably disposed was Hung Mai whose biography is to be found in Sung-shih 373:5460:3. His writings are of great range and make frequent reference to the Empress Wu and developments of her reign. While he censures her for the rise of supernumerary officials (Jung-ch'i san-pi, chüan 7), his wider view as stated in the Jung$c h ' i$ hs $\ddot{u}-p i$ is that as a ruler she was the equal of Han Wu-ti.

The Ming scholar Li Chih whose career is outlined in Ming-shih 221:7622: 3 , suggested that no recent ruler had measured up to her standard in the ability either to know men or to value talent. He praised the internal peace of her reign and considered her generally a model for subsequent ages. See $\mathrm{Li}$ Chih ts'ang-shu, chüan 48.

44. Ch'en Yin-k'o, "Hun-yin chi-t'uan," pp. 33-51.

45. See Ts'en, Sui T'ang shih, chapter 13; and Lü, Sui T'ang Wu-tai shih, v. 1, pp, 126-149.

46. These works are Lü Chen-yü, Chien-ming Chung-kuo t'ung-shih; Ch'ien Potsan et al., Chung-kuo Zi-shih kai-yao; and Shang Yüeh et al., Chung-kuo $Z_{i-}$ shih kang-yao, especially pp. 128-132. Both Professors Lü and Ch'ien have written separate articles on the empress.

47. See the fifty-page appendix to Kuo Mo-jo's Wu Tse-t'ien in the second edition (1963) which introduces a good deal of new information and concludes that the empress' reign was perhaps the high point of the T'ang and the keystone of the dynasty's greatness. Yang Chih-chiu, Sui-T'ang summarizes favorable comments on the empress since Chao $I$ and portrays the Chou as an era of great prosperity and rapid development in agriculture, handicrafts, textiles and water control. Wu Han, a central figure early in the Maoist cultural revolution, wrote about the empress in 1959. His paper, reproduced in his Teng-hsia chi, pp. $140 \mathrm{ff}$, is a well-argued if poorly documented apology dismissing the standard charges against her as little more than the bias of traditional historiography, and praising the use of her reign by influential scholars like Fan Wenlan to discredit the Kuomintang. The reference here is to Fan's pioneering survey Chung-kuo t'ung-shih chien-pien.

48. Wu Tse, "Kuan-yü Wu Tse-t'ien," and 'Lun T'ang-tai ch'ien-ch'i."

49. These are The Empress Wu by Fitzgerald, Wu Tse-t'ien by Li T'ang, and Sokuten Bukō by Toyama Gunji.

\section{Chapter 2}

1. CTS 6:3075:3, HTS $76: 3871: 1$ and $4: 3640: 3$. A good deal of information is also to be found in the annals of Kao-tsung, CTS 4:3070:4, and HTS 3:3638:3.

2. The principal compilations of this kind, in addition to the Ts'e-fu yüankuei, are the T'ai-p'ing kuang-chi and the T'ai-p'ing ÿu-Zan. All date from the Sung and their composition is outlined by Kuo Pai-kung in Sung ssu-ta-shu $k^{\prime} a o$.

3. The chief anecdotal sources used are:

(a) Ch'ao-yeh ch'ien-tsai by Chang Cho dating from the early eighth century.

(b) Feng-shih wen-chien chi by Feng Yen dating from about 800 .

(c) TaT'ang hsin-ÿu by Liu Su, composed 807.

(d) Liu pin-k'o hsi-hua lu by Wei Hsüan, composed 856.

(e) T'ang chih-yen by Wang Ting-pao, ca. 955.

(f) Nan-pu hsin-shu by Ch'ien I, composed between 1008 and 1016. 
(g) T'ang ÿu-Zin by Wang Tang, ca. 1100.

Details on several of these works may be found in des Rotours, Examens.

4. The empress' writings extant today constitute only a small proportion of those attributed to her in the various bibliographies. Her official writings are found in such works as the WYYH and TTCLC and are conveniently collected in CTW 95:4a ff., T'ang-wen shih-i 8:19a ff. and T'ang-wen hsü-shih 1:3b ff. A number of her surviving poems are found in Ch'üan T'ang-shih 5:51b ff.

The bibliographical sections of the HTS (chüan 57-60) list no fewer than twenty-three works issued under her name and comprising in all almost 700 chüian. Among these were such large-scale compilations as the Kao-tsung shih-Zu (Veritable Records of Kao-tsung), Ch'ui-kung chi (Collected Writings of the ch'uikung Period) and Lieh-nü chuan (Biographies of Eminent Women), each of them at least 100 chïan in length. Most commentators acknowledge that the majority of the works ascribed to the empress were in fact composed by the so-called North Gate Scholars, but their scope and range is indicative of her demonstrated literary interests and also of her use of Confucianism for legitimizing purposes.

5. On T'ai-tsung's attempts to manipulate the record, see Wechsler, Mirror, pp. $19 \mathrm{ff}$.

On several occasions Empress Wu revealed a concern with her place in history, for instance when she told $\mathrm{Ti}$ Jen-chieh that she wanted her own dynasty to enjoy a reputation equal to that of the Han. See CTS 89:3357:2. Conspicuous examples of her overt influence upon the historical process are cited throughout the text, and both Wu Ching and Liu Chih-chi had occasion to complain of the low standard of historiography in her period of power. During the Chou, in 702 and 703, memorials from Liu Yün-chi and Chu Ching-tse emphasized the great importance of true records, obliquely criticizing the bias of contemporary compilations. On these criticisms, see CTS 190 chung:3582:1 and HTS 202:4101:1 for Liu and CTS 90:3353:3 and HTS 115:3942:3 for Chu. The memorials are abstracted in THY 63, pp. 1100-1.

6. CTW 11:25b. The edict comments on the prominence of the Wu clan and the "talent and conduct" of the empress which led to her selection for the harem. Her behavior in the palace is said to have won her renown and, contrary to all other evidence, she is said to have gotten along well with the other palace women. The edict further implies by the use of the term hsien-tz'u that Wu served Kao-tsung's mother rather than his father and that it was bestowed upon him by his father (sheng-ch'ing). This was equivalent to making her empress (t'ung-cheng-chün). Needless to say, much of this was untrue.

7. Pulleyblank, in "Kaoyih," outlines the compilation of the shih-Zu and kuoshih of the seventh and early eighth century and identifies some of the figures involved.

8. In Background, pp. 3-5, and Appendix A of this work.

9. See Wechsler, Mirror, pp. 24-27, THY 63, p. 1094, and TFYK 554:11a.

10. See, for instance, Appendix A, example 1 , where the shih-lu identified is attributed to Wu Ching.

11. On Tsung, see CTS $92: 3365: 4$. He is said to be the inventor of the new characters the empress promulgated shortly before her usurpation. His work was in eighteen chüan.

12. THY 63, p. 1094, TFYK 554:17a. The HTS, the Shin-t'ung 12:30a, and the Ch'ung-wen tsung-mu chih-shih-lu all mention this work. It was in twenty chüan and a decade later was revised in thirty chüan by Wu Ching and Liu Chih-chi. 
According to the $k^{\prime} a 0-i$ 8:16a, ta-yeh 9, it was this revised version that was used by Ssu-ma Kuang.

13. See THY 63, p. 1098 and TFYK 556:17a. Liu, in his well-known letter of resignation (Shih-t'ung 20:10a-15b), complained that an official historian was for the most part compelled to follow the directions of his supervisor in what he wrote.

14. On the historiographical standards of Liu Chih-chi, see Beasley and Pulleyblank, Historians, pp. 135-36 and note, for instance, the $k^{\prime}$ co-i notice for t'ien-shou, second month in TCTC 204, p. 6463, where the shih-Zu posits a natural death for a minister said elsewhere to have been executed on the empress' order.

15. On Hsü, see CTS $82: 3342: 4$ and HTS 223 shang:4163:1.

16. Wechsler, Mirror, p. 25n. See also Pulleyblank, "Kaoyih" for some brief remarks on the composition of T'ai-tsung's shih-lu. The CTS mentions the shihZu both of Kao-tsu and T'ai-tsung in 20 chüran authored by Fang Hsüan-ling, and a second shih-Zu in 40 chüan for T'ai-tsung, authored by his brother-in-law Ch'ang-sun Wu-chi. For Kao-tsung there are two listings: one in 30 chüran by Hsü Ching-tsung and one in 100 chüan under the name of Empress Wu.

The HTS notice offers more information, listing a Kao-tsu shih-lu by Ching Po (CTS 189 shang:3576:2, H'S 198:4091:4) under Fang's supervision, and suggests that is was revised by Hsü Ching-tsung. Another work by Ching and supervised by Fang is the Chin-shang shih-Zu which clearly refers to T'ai-tsung (THY 63, p. 1092). This seems to have been supplemented in 650 by Wu-chi's additional 20 chüan, becoming the Chen-kuan shih-Zu in 40 chüan (THY, Zoc. cit.: and TFYK 554: $30 \mathrm{a}$ and $556: 12 \mathrm{a})$. The HTS is the only source to mention a 30-chüan Huang-ti shih-lu by Hsü Ching-tsung. This work seems to have been used by Ssu-ma Kuang (see next sentence in text) and, if so, it must have been used by the dynastic historians as well.

17. K'ao-i 8:10b, ta-yeh 12/12.

18. See note 16 .

19. See note 16 .

20. See, in addition to his biographies mentioned in note 15, THY 64, pp. $1103-4$, and Wechsler, Mirror, p. 25.

21. THY 63, pp. 1092-3. Interestingly, Kao-tsung refers specifically to incidents in the kuo-shih prior to 649 , strengthening my conjecture that Hsü Chingtsung was largely responsible for our knowledge of the history of this period.

22. See Appendix A.

23. See, for instance, the remarks of Shen Chi-ch'i, a compiler of the kuoshih in 780, THY 63, pp. $1095 \mathrm{ff}$.

24. CTS $58: 3296: 1$.

1. See Note 21 to this chapter.

Chapter 3

2. The text of this inscription is found in WYYH 875:1a and CTW 249:1a. See also the memorial from its author, Li Chiao, thanking the empress for the rewards he received on its completion. WYYH 592:2a and CTW 246:7b.

In 669 the empress changed the name of the bureau in charge of her father's tomb from Hao-ling shu to $P^{\prime}$ an-lung t'ai and, according to the Sung epigraphical collection Pao-k'o ts'ung-pien 7:22, the stele itself was erected in 700 . The Chin-shih $2 u$ 25:5b describes the stele and tells us that the calligraphy was that of Chung-tsung. 
Citations are from the WYYH text.

3. Just northwest of present-day Ch'eng-ku hsien in Shansi, about six miles east of the Fen river; see HTS 39:3723:1, TT 179:11b and THY 70, p. 1257. For geographical references I depend chiefly on Hiraoka Takeo, ed., Tödai no gyōsei chiri.

4. I am not certain of the sense of the phrase which runs yin meng ku-chieh 因蒙顧接. The parallel HTS passage runs yin-pei ku-chieh 因被顧接. 617, and TFYK 345:22a gives a more specific chronology, indicating that he was appointed at the time of Kao-tsu's attack on Hsi-ho chün which would mean the sixth lunar month. See also TCTC 184, p. 5739 and Nunome, Zui Töshi kenkyü, pp. $117 \mathrm{ff}$. The post of ssu-k'ai was in charge of armor, weapons, etc. See des Rotours, Fonctionnaires, v. 2, p. 511.

6. For a good discussion of fu-jui, see a paper recently presented by Anna Seidel to the ACLS conference on legitimation at Asilomar in June of 1975. The paper is called "Dynastic treasures and Taoist $Z$ u registers."

7. Biographies are found in CTS 58:3295:1 and HTS 90:3896:1 for Liu, and in CTS 194 shang:3596:3 and HTS 105:3923:1 for Ch'ang-sun.

8. Neither of them has a biography. From the description of the incident found in TCTC 183, pp. $5733 \mathrm{ff}$. We know that Wang Wei was deputy Ziu-shou at the time and inferior, therefore, only to Kao-tsu. Both he and Kao were executed in 617.

9. No biography.

10. Another name for the ssu-k'ai post mentioned in note 5 .

11. On the honorific post of kuang-lu ta-fu, see Fonctionnaires, v. 1, p. 35. Both the Pei and the HTS call the dukedom 1 -yüan, but 1 am unable to verify that such a geographical designation existed. On the rank of chün-kung, see Fonetionnaires, v. 1, pp. 45 and 451 .

12. That is, president of the Board of Public Works, a position of the third rank, second grade. The Pei adds that the real revenues (shih-shih feng) of 800 households were awarded with the fiefdom.

13. On the position of tu-tu or governor-general, see Fonctionnaires, v. 2, pp. 668 and $675 \mathrm{ff}$. Ching-chou was $1730 \mathrm{Zi}$ from the capital.

14. President of the Board of Rites. The Pei adds that T'ai-tsung expressed great sorrow at this death and suggested that he be called "loyal and filial."

15. CTS 58:3295:4. The biography is in HTS 206:4109:2 and the genealogy in HTS 74 shang:3849:3. The latter is summarized without significant alteration in Shen Ping-chen, Erh-shih-wu-shih pu-pien, n. 3, p. 7575 (K'ai-ming ed.).

16. Chapter 5 offers several observations on contemporary beliefs about heredity. We might also note in this regard the remark of Sui Yang-ti, "From the house of a general must come a general, and from the house of a minister, a minister." (TCTC 182, p. 5672). The suggestion that Wu Shih-huo was of rather obscure origin and mediocre ability was also, therefore, a comment on his offspring.

17. Li Chiao (CTS 94:3368:1 and HTS 123:3957:4) was an aristocrat from one of the great lineages of Chao-chou. At a precocious age he passed the chin-shih examination and showed a great deal both of literary and administrative talent early in his career. The collected works mentioned in his biographies are no longer extant, but a large number of his own memorials and those he wrote for members of the Wu clan still survive. See CIW 242 to 250 . He seems to have been a highly skilled politician and in spite of his close identification in the Chou with the Chang brothers, he survived their fall with only a temporary demotion to the provinces. 
His major positions were in the Chancellery, Secretariat, and History Office, and though some of his memorials are sycophantic, there are also many severe remonstrances and suggestions for administrative improvements. He was a skilled politician and the TFYK preserves a number of notices which show that his literary talents were widely recognized. See 551:5b as well as 460:3a, 671: 25a, and 327:24a.

18. The charge was made by several tsai-hsiang in the course of the controversy surrounding her elevation and was raised again during the rebellion of $\mathrm{Li}$ Ching-yeh. These instances are outlined in the text.

19. T'ai-p'ing kuang-chi 137:4b. The local history T'ai-ÿ̈an shih-chi is attributed in the HTS treatise to Li Chang (CTS 164:3506:4 and HPS 152:4008:3) and was 14 chüan in length. Li was posted in T'ai-yüan sometime between 847 and 860 to that his account is some 250 years after the fact. Because of its almost identical wording, an article on Shih-huo in Wei Hsin-tzu, Shu-pen fen-men kuchin Zei-shih, 15:10ab, seems also to be based on Li's work.

20. The post of cheng was of the seventh rank, third class, too low to confer the yin privilege of facilitated bureaucratic entry upon any of Wu Hua's sons. Since the Pei also points out that he died before Wen-ti, it seems logical to conclude that the family resided in Loyang sometime between 589 and 605 .

21. As 1 shall suggest in Chapter 5 , the Wu lineage was probably not included in the carefully researched Shih-tsu chih of T'ai-tsung's reign and was first published, though in abbreviated form, in the Hsing-shih $\tau_{u}$ of 659 . It was not until Kao-tsung's death, and in two stages, that the empress began to embellish her genealogy in an effort to win acceptance and bolster her legitimation in an age where genealogy retained a good deal of importance.

In 684, just after her seizure of the regency, she erected ancestral temples for five generations of her ancestors and bestowed posthumous honors on them (HTS 75:3867:2 and TCTC 203, p. 6422). Included at this time were:

(a) Wu K'o-chi who was said to have held the post of san-ch'i ch'ang-shih in the T'o-pa Wei. His existence is confirmed in no other source, though the HP'S treatise adds the information that he held the positions of ta-chung-cheng ssu$t^{\prime} u$ and yüeh-wang ch'ang-shih and inherited the title of shou-yang kung. His wife was of the P'ei clan, perhaps the eminent Ho-tung lineage examined by Yano Chikara, "Kizoku seiji."

(b) His son Chü-ch'ang held the position of Yin-chou ssu-ma during the Ch'i (550-577), succeeded to the ducal title, and was posthumously made t'ai-wei. The HTS adds that he was sometime chen-ÿ̈an chiang-chün, the first military post in the family. Chü-ch'ang has no biography in the dynastic history, but his existence is mentioned by Liu Tsung-yüan (773-819) in his Lung-ch'eng Zu 72:9a. Nunome, Zui Toshi, p. 142, also accepts the truth of this part of the genealogy. Chü-ch'ang's wife was of the Liu clan. It is of some importance to notice the Wu identification with the Ch'i dynasty, a fact which later contributed to the empress' acceptance by the great northeastern clans.

(c) The family fortunes in the later Chou seem to have taken a turn for the worse. Chü-ch'ang's son Chien did not succeed to his father's rank and held only the low military post of $t s^{\prime} a n-c h \ddot{u} n$. The HTS mentions a posthumous award of prefect of $\mathrm{Ch}^{\prime} \mathrm{i}$-chou. His wife's maiden name was Sung, and it is interesting to note that the Wu clan, unlike the contemporary local Chinese elite, seems to have avoided marriage with foreign surnames.

(d) Of Wu Hua the HTS says that in addition to his cheng position at Loyang, he was posthumously awarded the rank of Ping-chou prefect, further confirming the family connection with that area. His wife was of the Chao clan. 

in 684 .

(e) Wu Shih-huo, his fourth son, was entitled t'ai-shih and Prince of Wei

After a thorough search for collaborating evidence to establish the truth of the genealogy, I am inclined to believe that it was a true record. It was promulgated, after all, at a time when claims could easily have been checked and when there existed a number of potential opponents who must have been eager to prove them false. The empress was in no position to risk public ridicule at this stage of her career and the genealogy therefore does not claim too much.

In the second stage of genealogical publication, four days after the proclamation of the Chou, Wu Shih-huo was posthumously entitled emperor ( $T^{\prime} a i-t s u$ hsiao-ming kao huang-ti). At this time a sixth-generation ancestor, Wu Hsiashih, said to have been duke of Chin-yang during the Wei, was added to the genealogical list. While this award strengthens the family connection with the Wen-shui area, it seems strange that he went unmentioned in 684 even though only five ancestral temples were established, and I am reluctant to accept the claim. TCTC 204, p. 6467 and HTS $76: 3867: 4$ point out that at this time the progenitors of the clan were identified as King Wen of Chou and his son Wu. See Shih-chi $4: 13: 2$ and $4: 13: 3$. This was a perfectly conventional move paralleling the T'ang claim of descent from Lao Tzu and might also be seen as a bid for Confucian support in her new dynasty.

In sum, we have complete certainty in the Wu genealogy only to the empress' paternal grandfather but a high likelihood of truth to the fifth generation.

On the distaff side, the Yang clan of the empress' mother was divided into five branches, and hers, the Kuan-wang, was the second. It took its name from Yang Hung (Sui-shu 43:2469:1) who was tsu-tzu (son of paternal male third cousin) to Sui Wen-ti. Hung held numerous posts during the Sui until he aroused the jealousy of Yang-ti and is classified as one of the "four eminents" of the dynasty. $\mathrm{His}$ younger brother Ta (Sui-shu 43:2469:4) was the maternal grandfather of the Empress Wu and served as chief minister (na-yen) under Yang-ti. He died in a military campaign, probably in 616, leaving a son and daughter, the empress' mother. Her own background is outlined in Ta Chou wu-shang hsiao-ming kao huanghou pei-ming, CTW 239:2a, by Wu San-ssu. The inscription dates probably from 693 when she received the title. Judging by the pei-ming, which accords with TCTC 201, p. 6369 and disagrees with CTS 183:3553:2, she 1ived from 579 to 670 . There is no record of an earlier marriage, though she was in her thirties when her father died.

22. See Chapter 5 .

23. Summarizing the evidence from earlier notes, it seems that the clan held a fiefdom until the sixth century and even after that maintained its landowning character and military tradition. Numome, Zui Töshi, p. 144, concludes without citing evidence that the Wu could be numbered among the hao-tsu or magnate clans. On the matter of their local prominence, some interesting evidence has recently come to light through one of the Tunhuang manuscripts from the Peking collection. This is wei 79 (discussed further in Chapter 5) and is, in brief, a list of clans prominent in T'ang times in the various prefectures of the empire. This list has been studied by several scholars, and an excellent review. of the literature on it and related documents is found in Johnson, Medieval Chinese Oligarchy, pp. 62-88. Johnson demonstrates a connection between this list and one of similar nature found in the Sung geography $T^{\prime} a i-p$ 'ing huan-y $\ddot{u}$ chi and presented in Ikeda, "Tódai no gumbō hyō," pp. 320-323. Leaving aside the question of the validity of the relationship, an interesting concordance appears in 
the parallel sections on Ping-chou. Wei 79, which has several lacunae, runs as follows:

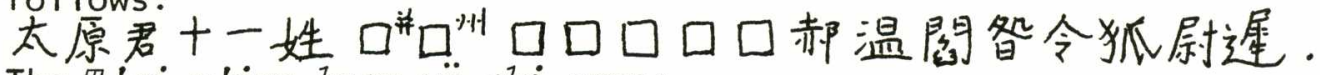

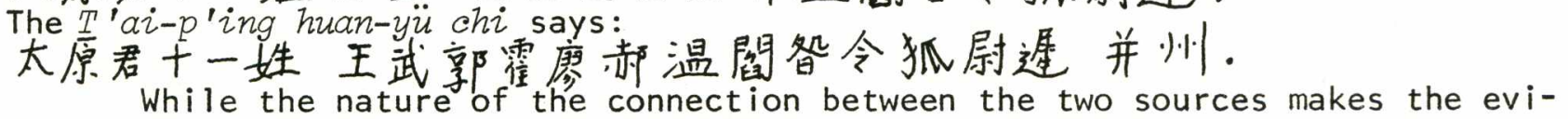
dence suggestive rather than conclusive, the similarity is striking and the same is true when other parts of the list are compared. The possibility that the empress' own prominence caused the inclusion of her clan in the list can be discounted since this did not happen in the case of great contemporaries like Ma Chou, Wei Cheng, Ti Jen-chieh and Chang Yüeh. At the very least, the concordance of the two lists strongly supports other evidence of the clan's local importance.

24. WYYH 875:36. On the T'ang $p^{\prime} i$-chao system of appointment see Tonami, "Chūsei." Tsukiyama, Tōdai, pp. $209 \mathrm{ff}$. contains several relevant but less coherent remarks. Although the three principal literary examinations were established in the Sui ( $T$ 'ang yü-Zin 8:12b and T'ang chih-yen 1:3b), all our evidence shows that only a minute proportion of officials took a degree and that appointment was based principally on the yin privilege, on recommendation and $p^{\prime} i-c h a o$.

25. Ibid. The governor was Yang Liang, and his biography (Sui-shu 45:2471:3 and Pei-shih 71:2971:2) places him in Ping-chou in 597. Nunome, Zui-Toshi, p. 128, lists Shih-huo among six early adherents of the T'ang who had held Sui office.

26. WYYH 875:4a. Yang Su's biography (Sui-shu 48:2475:2 and Pei-shih 41: 2882:2) contains no mention of the incident. The Empress Wu, at the urging of the Chang brothers, was to ban Yang Su's descendants from capital office. See TTCLC 114:7b and CTW 95:12a. This perhaps supports the truth of the Pei story.

27. WYYH 875:4b-5a which erroneously calls the book Ku-chin tien-yao. Interestingly, CIS and TCTC accept the belief that the book was given to the emperor while HIIS does not mention the incident. The Shih-ch'i-shih shang-chiao $86: 9 a b$ specifically rejects it.

28. WYYH 875:5b. The rebellion occurred in 613 and is outlined in TCTC 182, pp. $5671 \mathrm{ff}$. and in the biography of the rebel leader Yang Hsüan-kan. See Suishu 70:2510:4 and Pei-shih 41:2883:2. The best secondary treatment is Nunome, Zui Toshi,pp. 19-49.

29. WYYH $875: 5 b$.

30. WYYH $875: 6 a$.

31. Ibid. On Li Mi, see Sui-shu 70:2511:4, Pei-shih 60:2939:4, CTS 53:3283:

2 , and HPS $84: 3886: 4$. See also the numerous references in Bingham, Founding.

32. WYYH $875: 6 a$.

33. WYYH 875:6ab.

34. Kao-tsu's campaign here against the rebel Li Fei is well documented, but no source mentions the participation of Shih-huo.

35. WYYH $875: 6 \mathrm{~b}$. Omens in the form of dreams were of great importance at the time. See, for instance, the biography of Lü Ts'ai in CTS 79:3338:4 and HIS 107: 3926:4. Fu Yu-i (CTS 186 shang:3564:4 and HIS 223 shang:4163:4) committed suicide because of his dream of imperium. The TFYK account of the dream $(766: 12 \mathrm{~b})$ does not suggest that Shih-huo touched the heavens.

36. WYYH $875: 6 a-7 b$.

37. WYYH 875:7a.

38. WYYH 875:7b. The posts were nei-shih-ling and na-yen.

39. Ibid.

40. Fonctionnaires, v. 1, p. 8. 
41. TFYK 626:7b and 627:6a. According to Yen Keng-wang, T'ang p'u-shang ch'eng-lang piao, v. 1, pp. 222-3, Shih-huo held the board presidency from 620 to 624 or 625 when he was commissioned to Yang-chou.

Both edicts seem to date from early 620 since the second gives his rank as yu-hsiang su-wei and the Pei records that he held the post early in the year. The edict mentions that although Shih-huo had lost both his wife and two sons, he had not reported [and asked for a leave of absence] so that he could be $\mathrm{re}^{-}$ garded as a model.

Another index of Kao-tsu's regard is the fact that Shih-huo was among fourteen men granted the extraordinary privilege of amnesty-in-advance in 618. See HTS 88:3893:2, biography of P'ei Chi.

42. WYYH 875:10a.

43. Shih-huo's first wife was of the Hsiang-li clan, the first foreign surname to appear in the family tree. On the surname, see Dai kanwa jiten 8, p. 8315.

$\mathrm{His}$ second marriage into a clan so much more exalted than his own has always been a puzzle to historians. Ch'en Yin-k'o in "Li-T'ang," pp. 553-6, is forced to claim that Shih-huo's timber dealings brought him into contact with Yang Ta who was charged with a number of building projects in Loyang. The explanation in the Pei, confirmed in TFYK 853:16a, is much more plausible. In it Kao-tsu suggests to Shih-huo that he take a new wife and recommends Madame Yang as a virtuous and intelligent woman. He is said to have delegated the Kuei-yang princess to serve as go-between, and he offered to have the state bear the marriage expenses. The Pei, exaggerating, places Kao-tsu in the role of go-between.

The Kuei-yang princess, incidentally, was married to Yang Shih-tao, son of Yang Hsiung, and therefore first cousin of the bride. Her choice shows the difficulty of marriage between social unequals in the T'ang. Nunome, Zui-Toshi, pp. 314-69 presents a full account of the marriage connections between the imperial clans of the Sui and T'ang.

On the marriage, see also CTW 239:10ab.

44. WYYH 875:8ab.

45. WYYH 875:9a. On Yang-chou, see CTS 40:3223:1, HTS 41:3727:2, and THY 71, p. 1270, and on Fu Kung-shih, see CTS 56:3920:3 and HTS 87:3891:4. According to the dating in the TCTC 190, pp. 5970-71, the appointment would have been made just after the third month of 624 .

Kuo Mo-jo conjectures that Shih-huo was also posted to Li-chou in this year since he believes the empress was born here and accepts the traditional date of 624. See note 50. This seems unlikely since TFYK 671:24a and the Pei both place him in the capital prior to his appointment, and we know that he remained in this post for more than a year. See also TFYK 690:19a.

46. TFYK 677:21b and WYYH Zoc. cit.

47. On the rebellion, see TCTC 192, pp. 6032 and 6039. It occurred at the end of 627 .

$$
\text { Li-chou was in Shan-nan (CTS 39:3220:1, HTS 40:3725:3, THY 70, p. 1237, }
$$

and $T T$ 176:9b).

48. WYYH $875: 9 b$.

49. WYYH 875:10a. In addition to his post as governor-general of Ching-chou, he is said to have been charged with the military affairs of six additional prefectures. The Pei exaggerates the posting, calling it ta-tu-fu, but its additional assertion that it was accompanied by T'ai-tsung's commendation is confirmed by TFYK 681:17b and T'ang-wen shih-i 1:7b. 
50. The time and place of Empress Wu's birth have been a perplexing problem since primary sources give three different dates. See the first example in Appendix A. If she was born in 623,624 or 625 , then she would have been born either in Ch'ang-an or in Yang-chou where her father was posted in those years. Kuo Mo-jo suggests in the appendix to Wu Tse-t'ien, pp. 152-59 and in an article in Kuang-ming jih-pao, September 26, 1962 that her birthplace was Lichou. He bases this belief on a poem by Li I-shan, found in CIShih 20:47a and T'ang-jen pa-chia shih 2:10a, in which Li-chou is given as the birthplace of the "Golden Wheel," a title used by the empress during the chou. I have found additional confirmation for the belief in $Y \ddot{u}-c h ' i$ sheng shih chien-chu by the Ch'ing scholar Feng Hao (2:30b-3la). Feng quotes Hu Chen-hsiang, a Ming expert on T'ang literature.

Kuo Mo-jo goes on to mention a 1955 archeological expedition to the area (see $K^{\prime} a 0-k u$, July 1960, pp. 53-57) which excavated a stele identified by the leader of the expedition, Chang Ming-shan, as belonging to a temple built to commemorate the empress in her birthplace. Professor Chang cites other manifestations of the belief, among them certain place names and an annual festival on the twenty-third of the first lunar month, supposedly in celebration of her birthday.

The stele contains some 800 characters, and Kuo quite convincingly establishes its authenticity (Wu Tse-t'ien, pp. 135-39). There are several lacunae, three of them occurring in the key passage which Kuo reconstructs to form a specific statement that the empress was born in Li-chou. His case is convincing. The question of birthdate now arises. I am not persuaded by Kuo's conjecture that Shih-huo was posted to Li-chou in 624 because his movements that year are accounted for, and because the stele says the event referred to occurred when he was tu-tu. This can be no earlier than 627. Kuo also calls attention to an anecdote in which the soothsayer Yüan T'ien-kang (CTS 191:3590:2 and HTS 206:4106:1) predicts the empress' imperium while she was still an infant in the care of her nurse. Even in its most detailed form, TFYK 860:27a and T'ai-p'ing kuang-chi $224: 2 \mathrm{~b}$, the story is too vague to be dated and says only that Yüan stopped in Li-chou on his way to the capital at the request of Madame Yang. The T'ai-p'ing kuang-chi, chüan 221, does mention a trip to the capital but in 632 . I have no doubt that the incident is authentic, but I would use it rather to demonstrate that the empress was born later than 624 .

What seems to emerge here is that the empress' age was generally unknown even to contemporaries. Since I find convincing the evidence that Li-chou was her birthplace, I believe she was born either in 627 or 628, making her approximately the same age as Kao-tsung.

51. WYYH 875:10ab.

52. WYYH 875:10b ff.

53. See note 50 .

54. See note 21 .

55. See Appendix A, example 1 .

56. TCTC 194, pp. 6121-22; and see Wechsler, Mirror, p. 137.

57. HTS $76: 3867: 1$. The same source also says that the future empress was highly pleased at her summons to the harem even though the chances of advancement were slim. Interestingly, the CTS does not mention the incident.

58. T'ai-tsung had a large harem whose organization is outlined in CTS 51: 3278:3 and THY 3, pp. 32-33. There were nine ts'ai-jen, all of the fifth rank. See also TCTC 199, p. 6284. T'ai-tsung ultimately had fourteen sons, of whom his wife bore three, and twenty-one daughters. See CIS 76:3331:1 and Nunome, 
Zui-Töshi, pp. 341-57.

59. Following the lead of Ch'en, "Hun-yin chi-tuan," several scholars have demonstrated the primacy of political concerns in the choice of imperial concubines in the T'ang. See especially Nunome, Zui-Tóshi, pp. 314-67. On these grounds Wu's choice is rather puzzling since she was the orphaned daughter of a man with no enduring influence and T'ai-tsung, moreover, had already three concubines of the Yang surname. Kuo Mo-jo, Wu Tse-t'ien, pp. $117 \mathrm{ff}$., is eloquent on the subject of her beauty, but it is difficult to find contemporary collaboration that she was outstanding.

My own explanation is based on a notice in HTS 80:3877:3 "The mother of Ming, prince of Ts'ao, was originally the concubine of [T'ai-tsung's executed brother] the prince of Ch'ao. T'ai-tsung 'favored' her and wanted to make her [his] empress. Wei Cheng remonstrated. . . and he gave up the plan." CTS 62: 3303:1 identifies the lady as the niece of Yang Shih-tao. This made her a samegeneration cousin of Wu. Other evidence (T'ang-chien 6, pp. 51-2) suggests the favor of the Yang concubine dates from the late $630 \mathrm{~s}$.

If this was the case and Wu came to T'ai-tsung's attention through her cousin, her entry into the harem was unlikely to have occurred in 637 as Ssu-ma Kuang dates it. She was fourteen sui at her entry so that, if my suggested birthdate is correct, the event probably occurred in 640. While the element of speculation in this chronology is great, I believe that it is warranted by the numerous contradictions in the sources.

60. TCTC 199, pp. 6259-60. The prophecy surfaced because of an astrological configuration which presaged the rule of a woman, and because of a popular tradition that the T'ang would be overturned after three generations by a female. Although T'ai-tsung managed to have the suspected threat, a general whose nickname as a child had been "Fifth Lady," executed, he was told that he could not cheat destiny and that although the female ruler would destroy most of the T'ang clan, she would be merciful in her old age. It is interesting to note that the commentary on the Great Cloud Sutra refers to this tradition.

61. TCTC 199, p. 6267. T'ai-tsung's Yü-hua Palace seems also to have had quarters in it for the crown prince (TCTC 198, p. 6253 and HTS 3:3638:3).

62. The origin of the story may be the 684 polemic of Lo Pin-wang quoted earlier. The standard histories are silent on the matter and TCTC 199, p. 6284, simply says that she "pleased" Kao-tsung when he came to wait on his father.

63. See CTS 6:3075:3, HTS 76:3867:1, TCTC 199, p. 6284, THY 3, p. 23, and Ch'ang-an chih 9, p. 115. The major discrepancy in the sources 1 ies in the name of the convent, with HTS and Ch'ang-an chin calling it An-yeh, and the others the Kan-yeh. I am unable to verify the existence of the latter in any of the nine sources indexed by Hiraoka and Imai in Chōan to Rakuyō. Hu San-hsing in TCTC, Zoc. cit. suggests that Ssu-ma Kuang is in error. Fitzgerald, Empress Wu, pp. 17-19, gives an account of the incident, using the wrong name.

64. A story given in all the primary sources. The concubine Hsiao was one of the three highest consorts, placed directly below the empress in the first rank.

65. The question is fully treated by $L i$ Shu-t'ung, T'ang-shih $k^{\prime} a o-p i e n$, $p p$. 310-335. Professor $L i$ advances five reasons which, he believes, render invalid the traditional account. These are given below with my comments interpolated.

(a) The account has a number of inconsistencies of which the most important is the contention that Kao-tsung visited the convent on the "taboo day" $(c h i-j i h)$. This would be the third day of the fifth month in 650 , and he was not in the capital at the time.

Here Professor $\mathrm{Li}$ is assuming that it is T'ai-tsung's "taboo day" which 
is meant. There were, however, several of these days each year to commemorate both emperors and empresses. THY 23, pp. $448 \mathrm{ff}$. I am unable to verify that Kao-tsung was out of the capital at this time.

(b) HIS $76: 3867: 1$, the only source to date Wu's return to the palace, places it "at the end of chen-kuan [627-650]." If she had taken the tonsure, it would require two years for her hair to grow out to the customary length for concubines.

This seems unconvincing since the shaving of the head accompanied final vows, and I am not certain that former concubines actually became fullfledged nuns. The form of the tonsure in T'ang times may not have meant a complete shaving of the head.

(c) Kao-tsung's decree of 656 releasing a number of former concubines from the palace (CTW 12:1a) indicates that it was the older consorts who entered the convent. It is therefore unlikely that wu went.

While I agree that all concubines were not necessarily forced into a convent (see, for instance, THY 3, pp. 35-37), I read the decree differently and would interpret the phrase nien-Zao kung-jen i-ling fang-ch'u年老宫人已令 放出 as "the older palace women were already ordered to be sent away." I think the subsequent phrase that many women still remained refers to the younger concubines, since the decree was probably inspired by Wu's fear of female rivals. I agree with Professor $L i$ 's conclusion.

(d) The decree establishing Wu as empress (Chapter 2, n. 6) claims that T'ai-tsung bestowed her on his son. This is untrue and was probably inserted in the record to explain why she did not enter the convent.

I believe the claim was made to suggest that Wu had never had relations with T'ai-tsung and absolve Kao-tsung from the charge of incest which had in fact been leveled against him.

(e) There is no evidence that the Empress Wu ever favored or supported the An-yeh monastery. It was not chosen to commemorate her. The obvious explanation, of course, is that she wished to conceal any connection with the monastery which had taken in T'ai-tsung's consorts whether she had ever been there or not. In summation, I do not believe that Professor Li makes a very convincing case even though I accept his conclusion.

The issue, I think, is so confused because we have no idea of the source of the story. The confusion of detail may suggest more than one source, and the lack of any reliable chronology compounds the problem. Professor Li suggests simple fabrication by Hsü Ching-tsung to show his patrons in a favorable light by emphasizing the jealousy of Empress Wang, and that Wu later destroyed all those who knew the truth. Ching-tsung's shih-lu of Kao-tsung became the official version.

I find this an appealing explanation and would add the notion that it was an explanation concocted late, probably around 657-8 when the shih- $Z$ u was being completed. Initially, Kao-tsung hoped the fact of incest could be concealed, but when he found it was impossible, a second and more elaborate justification was developed. I believe that Wu was simply concealed after T'ai-tsung's death, possibly at the An-yeh monastery, since she and Kao-tsung had already planned to continue their liaison and sought thereby to avoid immediate scandal.

An article in Kuang-ming jih-pao, September 12, 1962 under the pseudonym Ching T'ang accepts the nunnery story but is puzzled by the chronology and tries to show that the Empress Wu returned to the palace in 651 or 652 .

66. See CIS $6: 3075: 3$ and $51: 3279: 3$. The best known incident in the rivalry 
is the allegation that Wu killed her own infant daughter in order to blame Empress Wang and give Kao-tsung an excuse to depose her. See HTS 76:3867:1 and TCTC 199, pp. 6286-7. Interestingly, the event is not recorded in the CTS and Ssu-ma Kuang concludes his account by pointing out that Wang failed to clear herself. For Fitzgerald's views on the matter, see Empress Wu, pp. 22-23.

The Empress Wang (CTS $51: 3279: 2$ and HTS 76:3866:4) was from the same prefecture as Wu, the daughter of one of T'ai-tsung's officials. The clan already had a marriage connection with the T'ang, and her great-aunt, a princess, seems to have had her married to Kao-tsung before he became crown prince. Her great misfortune was sterility, and in 652 she adopted one of her husband's sons by another consort so that an heir could be proclaimed.

Her uncle Liu Shih (CTS 77:3334:3 and HTS 112:3938:3) seems to have risen to tsai-hsiang rank because of his niece's position, and it was his resignation in the sixth month of 654 which signaled publicly that she had lost favor. See TCTC 199, p. 6285.

67. TCTC 199, pp. 6283-4. In the third month of 654 Wu persuaded Kao-tsung to elevate the posthumous titles of the thirteen ministers considered to be Kaotsu's earliest adherents, thereby enhancing her father's prestige. It seems likely that the court recognized his motives.

68. In mid-655 when the important debate, outlined in TCTC 199, pp. $6289 \mathrm{ff}$., took place, the tsai-hsiang body was composed of Ch'ang-sun Wu-chi, Ch'u Suiliang, Lai Chi, Han Yüan, Yü Chih-ning and Li Chi. Their careers are summarized in Appendix B.

69. The principal studies, in addition to Ch'en Yin-k'o's cited above, are Yokota, "Bu-Shu seiken seiritsu no zentei"; Matsui, "Sokuten Bukō no yōritsu o megutte"; Chang, "Lun T'ang K'ai-yüan ch'ien ti cheng-chih chi-t'uan"'; and Lo Lung-chih, "Lun T'ang-ch'u kung-li-ssu-hsiang yü Wu Chao tai T'ang ti kuan-hsi." 70. TCTC 199, p. 6267. T'ai-tsung also told his son that while Wu-chi and Sui-liang were alive, he need have no anxiety about the empire.

There is a good deal of evidence that Wu-chi hoped to dominate Kao-tsung. This is conveniently summarized in Sun Kuo-tung, "T'ang chen-kuan."

71. See Wechsler, Mirror, Chapter 4.

72. TCTC 200 , p.. 6293.

73. The validity of the incest argument is a moot point, and it is perhaps significant that it was raised by $\mathrm{Ch}^{\prime} \mathrm{u}$ Sui-liang, a southerner. There is a good deal of evidence that this sort of union was common in Central Asia and not unknown in North China at the time. See Ch'en Ku-yüan, Chung-kuo hun-yin shih, Chapter 3, and Lin Hui-hsiang, Wen-hua jen-lei hsüeh, pp. $214 \mathrm{ff}$. Lin T'ien-wei, Sui-T'ang shih hsin-pien, pp. 56-75, amply demonstrates the Turkic cast of the T'ang court by listing 164 great ministers whose lineage was wholly or in part "barbarian." Both levirate and sororate marriages are attested in the biography of Li O (Sui-shu 66:2503:2 and Pei-shih 77:2985:2).

In the T'ang imperial clan, the practice was not unknown, and we have earlier noted T'ai-tsung's desire to raise his brother's consort to the position of empress. Though it is not generally known, he also took the consort of a halfbrother, releasing her on Wang Kuei's objection. See HTS 78:3908:2. The T'ang marriage laws (TLSI 12-14, especially 14, pp. 123-5, and TRSI, p. $248 \mathrm{ff}$. ) seem to contain no prohibition, and Chung-tsung, Hsüan-tsung, and Shun-tsung were all involved in similar relationships.

Sui-liang's objection, therefore, seems less important than the political reasons for tsai-hsiang opposition. Kao-tsung, as earlier suggested, attempted 
to conceal Wu's relationship with his father, but he did so probably in deference to the feelings of the more purely Chinese of his ministers. It was, after all, an age marked by the reassertion of Chinese cultural values.

74. Chapter 2, n. 6.

75. For this and the following interpretations, see note 69 above.

76. On Li I-fu, see Appendix B, no. 39.

77. See note 69 above.

78. Ibid.

79. Ibid.

80. TCTC 199, pp. 6291-2, especially the commentary. For Empress Wu's view on "household matters," see Chapter 9, pp. 134 and 143 .

81. See the biographies of the victims in Appendix B, nos. 14, 30, 32, 37 and 38. Also TCTC 200, pp. 6303-4 and $6312 \mathrm{ff}$.

82. CTS $51: 3279: 3$ and TCTC 200, p. 6294. She had the hands and feet of the women cut off and drowned them in a wine barrel.

83. TCTC 203, pp. 6410-11. See also THY 30, pp. 556-7 and Ÿ̈-hai 157:29b. While there is a certain rhetorical exaggeration in the account, there seems to have been an equal degree of truth. In 665 Kao-tsung complained that his ministers never remonstrated, only to be told by $\mathrm{Li} C h i$ that this was because there was no need to do so. TCTC 201, p. 6343. The first real remonstrance is dated 682 by Ssu-ma Kuang, TCTC 203, pp. 6410-11.

84. TCIC 200, p. 6294 tells how Kao-tsung visited the prison of his ex-wife and, at her request, changed its name to Court of Recollection (Hui-hsin ÿ̈an). On his reaction to the charges against Wu-chi, see TCTC 200, p. 6313.

85. TCTC 200, p. 6313.

86. See TCTC 200, p. 6322 and CTS 6:3075:2. Ssu-ma Kuang here follows the CTS in admitting that the empress was highly intelligent and well versed in literature and history.

87. TCTC 200, pp. 6309 and 6317 where the commentary identifies the various administrative centers. See also Chapter 8.

88. THY 85, p. 1557. This census was designed to keep up-to-date the system of nine grades to which each household was assigned. See Twitchett, Financial Administration, pp. $29 \mathrm{ff}$.

89. See CTS 4:3071:4 ff. On the new office, see Fonctionnaires, v. 1, p. 187.

90. CTS $4: 3071: 4$.

91. TCTC 200, p. 6308, and Chapter 5 .

92. CTS 4:3071:4 and TCTC 200, p. 6308. See also Chapter 6.

93. TCTC 200, p. 6295 and THY 3, p. 24.

94. CTW 12:6ab. The edict begins by tracing back Loyang's history as a good capital site to the Duke of Chou and comments upon its favorable strategic and economic location. It points out that earlier dynasties had established the precedent of two capitals and that since Loyang had often been one of them, it had become a majestic city. Its central location facilitated the payment of taxes and tribute and henceforth it would be the residence of the ruler.

95. CTS 4:3072:4 and TCTC 201, pp. $6344 \mathrm{ff}$.

96. Ssu-ma Kuang, TCTC 201, pp. 6342-3, begins his account by remarking the empress' initial humility and willingness to serve Kao-tsung and suggests that for this reason he was willing to elevate her in spite of opposition. As time went on, she is said to have arrogated more and more power to herself, much to her husband's chagrin. See also HTS 105:3924:1 and Fitzgerald, Empress Wu, pp. 44-47. 
97. Appendix B, no. 47.

98. HTS 105:3924:2.

99. TCTC 201, p. 6343. "Two Sages" dates from 660 .

100. CTS 6:3075:3. The same work dates her real power from about 675 when she was offered the regency. On this question see also Chou, Han-T'ang, p. 631, and CTS 5:3074:1.

101. Sui-shu 36:2457:2. Wen-ti's wife, of course, was not nearly so prominent in government as Empress Wu, and the Sui-shu specifies that the term "Two Sages" was used within the palace.

102. CTS 5:3074:1 and TCTC 202, pp. 6375-76. The phrase is she-chih kuo-cheng 揪知成政.

03. See the exhaustive study of the ceremonial by Chavannes, T'ai Chan, and my Chapter 4.

104. See Wechsler, Mirror, especially pp. 123-25.

105. CTS 4:3071:4. On the official posts held by the empress' half-brothers, see TCTC 201 , p. 6349 which also outlines the source of discord in the family.

106. TCTC 201, p. 6349 and HTS 76:3867:1-2.

107. CTS 183:3553:1, HTS 76:3867:2, and TCTC 201, p. 6350 .

108. On Min-chih, see CTS 183:3553:1, TCTC 202, pp. 6366-7.

It is interesting to note that the HTS account of his death $(76: 3867: 2)$

portrays him as an innocent victim of Wu's suspicion that he considered her the murderer of his sister.

109. Their biographies are found in CTS 183:3553:1 ff. and HTS 206:4109:2 ff. On their arrival at court, see TCTC 202, p. 6372.

110. CTS 5:3073:4 and 3074:1.

111. HTS $76: 3867: 2$.

112. TCTC 201, p. 6365. The offer may have been connected with serious drought in Kuan-chung at the time. See CTS 5:3073:3.

113. CTS 5:3074:1, HTS 3:3640:1, and TCTC 202, p. 6372 .

114. TCTC 202, p. 6372 .

115. Submitted in the twelfth month of 674. The fullest text is in HTS 76: 3867:2; see also CTS 5:3074:1, THY 37, pp. 675-76, TFYK 564:56, and TCTC 202, p. 6374 .

116. HTS, Zoc. cit. With the exception of the provisions relating to the Taote ching and the mother's mourning period, the standard sources offer no evidence of action. Notices in TFYK $80: 10 \mathrm{~b}$ and $490: 10 \mathrm{ab}$ suggest that early in 675 various promotions were made and taxes and corvée lightened, and that on some of the other provisions no formal edict was needed.

117. See Chapter 8.

118. TCTC 201, pp. 6375-76. See also TFYK 180:7a. The remonstrance went on to suggest that Kao-tsung would be betraying his heritage should he fail to bequeath the empire to his son.

119. TCTC 202, p. 6377. See also TFYK 261:17b, THY 2, p. 20, and CTS 5:3071:1.

120. TCTC 202, p. 6377. The $k^{\prime}$ ao-i points out that neither the shin-lu nor the CTS hint at murder.

121. HTS $76: 3867: 2$.

122. See note 124 .

123. See CTS 86:3350:1 and HTS 81:3878:3. Conversely, the ill health of the crown prince may have provided the empress with a convenient explanation for his sudden death, and it may be that she made certain it was mentioned in his epitaph. For the epigraphical collections containing this, see Chin-k'o t'i-pa so-yin, $p$. 53 b. 
124. His biography is in CTS $86: 3350: 3$ and HTS $81: 3878: 3$. There is no direct evidence of illegitimate birth beyond the rumor referred to in the text and his reaction to it.

125. CTS 5:3074:1. This seems to be yet another indication that Kao-tsung retained $\mathrm{h}$ is independence.

126. CTS $86: 3350: 3$.

127. TCTC 202, p. 6397. The CTS gives no details.

128. Kao-tsung, according to Hsien's biography and THY 4, p. 42, regarded him as a most precocious and talented child and rewarded him lavishly for his Hou Han-shu commentary. At the same time, he remarked in 678 on how he loved most his youngest son who had just married a praiseworthy woman and, after Hsien's fall, expressed disapproval of his reading matter. TCTC 202, pp. 6397-98. The Empress $W u$ is said to have attempted to instruct him in his duties by sending him uplifting books and personal instruction. CTS 86:3350:3.

129. CTS 86:3350:3, THY 4, p. 42, and TCTC 202, p. 6397.

130. TCTC 203, p. 6419. Though Ssu-ma Kuang states flatly that the empress ordered her son's death, he does not identify his source. Neither of the official histories suggests openly that she did so.

131. See CTW 17:5a.

132. TCTC 203, p. 6406. There were precedents for the establishment of a t'ai-sun in the Chin and Ch'i dynasties.

133. CTS 5:3075:1.

134. CTS 5:3074:4.

\section{Chapter 4}

1. Most notably Elvin, The Pattern of the Chinese Past.

2. In "Sui ideology."

3. These questions are succinctly discussed in John B. Starr, Ideology and CuZture (Berkeley: University of California Press, 1973), Chapters 1 and 3.

4. There are, of course, no accurate estimates of the proportion of the Chinese population which gave its primary allegiance to Buddhism in the sixth and seventh centuries, but Wright, "Sui Ideology," conveys a realistic impression of its great importance in the eyes of the state, and there are a number of suggestive indications to be found in the works of Gernet, Tsukamoto and Michihata cited in later notes.

5. See the remarks in Bingham, Founding, pp. $51 \mathrm{ff}$. on the "Savior Li" myth and the much more systematic treatment by Seidel, "Image."

6. A distinction first emphasized in 1940 by Lü Chen-yü in his Chung-kuo shehui shih chu wen-t' $i$ which seems to have become standard in later works like the cooperative volume Chung-kuo wen-hsüeh shih (Peking, 1958). Note also Levenson's reflection on the paradigm in Confucian China, v. 3, pp. $56 \mathrm{ff}$.

7. See Yamasaki's "Bukkyō fukkō" and "Zui no Yōdai." Ch'en Yin-k'o, "Wu Chao" offers more specific information on the empress' mother and the Yang clan, and Ch'en, Buddhism, pp. $194 \mathrm{ff}$., presents a good summary.

8. See, for instance, TD 52:2108, PSTS 3, p. 456a.

9. Ch'en, "Wu Chao," p. 143.

10. See note 8. The author, Yen-tsung, states that Madame Yang was in fact important to the survival of the church.

11. Chapter 3, n. 52. 
12. Chapter 3, n. 96 .

13. TCTC 200, pp. 6294-95.

14. See Sui-shu 75:2520:2 and CTS 189 shang:3575:1.

15. TCTC 200, p. 6294. It was, of course, Hsü Ching-tsung who brought the formal accusations against those who had opposed Wu's elevation.

16. TCTC 201 , p. 6342.

17. CTS 4:3071:4. On the new ritual, THY 37, p. 670, and on the extension of filial piety, THY 26, p. 498.

18. THY 64, p. 1117.

19. This was Liu Hsiang-tao whose memorial is discussed in Chapter 7 . His comment is found in the abstract of this critique, TT 17, p. 93b.

20. In addition to the sources mentioned in the preceding chapter, see the succinct history of the ceremonial during the T'ang in THY 7, pp. $79 \mathrm{ff}$. Also CTS 23:3159:1.

21. Chavannes, T'ai Chan, p. 185. On the ceremony of 665 , see also TCTC 201, pp. $6344 \mathrm{ff}$, CTS 5:3073:1, TFYK 36:2a, 40:20b, 780:24a and 80:9a.

The celebration of 665 seems to have been appropriately timed, and Ssuma Kuang remarks on the general prosperity which had followed five successive bountiful harvests. Foreign representatives attended from as far away as Persia, attesting to the success of Chinese arms. The quoted passage is also found in CTW 97: lab.

22. CTS 23:3160:2. The occasion of his remark was an order to prepare a brief on the feng-shan which Hsüan-tsung was considering at the time. On Chang, see Pulleyblank, Background, p. 194. It is of interest to note that Empress Wu became the first woman ever to participate in the great sacrifice of the Southern Suburb in 669. TFYK 596:28b.

23. TCTC 201, p. 6346.

24. CTS 23:3159:4.

25. TCTC 201, p. 6347. See also TT 20, p. $114 \mathrm{~b}$.

26. CTS 5:3074:1, TFYK 30:5a, THY 1, p. 3, and TCTC 202, p. 6372. See also Tz'u-hai, pp. 262 and 266.

27. On the changes of 662, see TCTC 200, pp. 6326-27, CTS 4:3072:3, and HTS $3: 3639: 2$. The new names were given in two stages, in the second and fourth month of the year, and while it is difficult to identify a consistent source of inspiration, the new titles seem in the main to have been wholly new or else derived from those used at the height of the Han. It may be possible, therefore, to see the changes as a reassertion of Chineseness, an attempt to dissociate the T'ang from the "barbarian" regimes which immediately preceded its $r$ ise. The motive of ritual replication seems also to have been present and, if so, the reversion to the old names in 670 (TCTC 201, p. 6365 and CTS 5:3073:3) was an acknowledgment of error. The year 670, of course, was an economic low point in Kao-tsung's reign with the worst drought and famine of the period, and was marked by other ritual attempts at solution like the change of nien-hao and the empress' offer to abdicate.

The second change, as comprehensive as the first, occurred in the ninth month of 684, shortly after the accession of Jui-tsung. See TCTC 203, p. 6421, CTW 96:1la, and WYYH 463:6b. On this occasion the chief inspiration for the new names seems to have been the Chou- $Z_{i}$ so that the Six Boards, for instance, were designated by Heaven, Earth and the four seasons. As we shall later see, a few came from the Taoist pantheon and some were unprecedented, so that the purposes were probably ideological and designed to signal a new and prosperous era.

28. See Pan Ku, Former Han, v. 3, pp. $103 \mathrm{ff}$. On the close connection between 
Chou- $Z i$ symbolism and usurpers and reformers, see Tanigawa, "Keii."

29. CTW 6:6b-7a, THY 49, p. 859, Kuang hung-ming chi 25, TD 52:283c. The claim was reasserted in each subsequent reign: by Kao-tsung in 666 (CTW 12:13b) and Chung-tsung in 708 (CTW 18:8a). On T'ai-tsung's edict, the disputed date and the possibility of a second one in 641, see Michihata, Chügoku Bukkyosshi, p. 153.

30. See note 5 .

31. TCTC 204, p. 6374, THY 49, p. 859, CTW 95:4a, and TTCLC 113:4a. The edict reviews the Buddhist omens which helped bring the empress to the throne. It is of importance to note that an edict of 675 had given the clerics of both churches equal places at the court. THY 49, p. 859, TFYK 60:10a. ff.

32. CTS 5:3073:1. On these foundations, see Tsukamoto, Nishi Bukkyo, pp. 24

33. TCTC 201, p. 6347. On a similar move by Wen-ti, see Wright, "Sui ideology," p. 87.

34. HTS 83:3884:2, TFYK 303:20b, and THY 50, p. 870. In spite of her 1:ater importance, little is known of T'ai-p'ing's early life. The youngest of Kaotsung's three daughters and the only one born to the empress, she was only six when her ordination occurred. The HTS tells us that a palace was remodeled to look like a convent, but the princess seems to have found the monastic life uncongenial, and in 681 she was married in a lavish ceremony marred by the accidental burning of the trees along the processional route (TCTC 202, p. 6402 and TFYK 84:17a). Her husband died in prison at the end of 688 (TCTC 204, p. 6453), and two years later she married Wu Yu-chi, a grandson of Shih-huo. This was part of her mother's plan to unite the Li and Wu clans, and the sources say she had to arrange for the death of Yu-chi's wife to make it possible.

From this time, T'ai-p'ing became her mother's closest confidante, and a mark of her favor is the fact that she came to hold a fief of revenue (shih-shih feng) of 3,000 households, almost ten times the statutory limit for a princess. TCTC 204, p. 6466 and CTS 183:3554:2.

35. There is still no systematic study on the development of organized Taoism from Han to T'ang, but see, in addition to Seidel's works cited earlier, her Divinisation and Maspero's Taoisme. Ware's "Wei Shu and the Sui Shu on Taoism" is still useful, as are several sections of Tokiwa, Bukkyō to Jükyō Dōkyo. Several works in the $T D$ refer to the size of the canon and the activities of the church in the early T'ang. See, for instance, TD 49, Fo-tsu Zi-tai t'ung-tsai 12:581b ff.

36. WHTK 29, p. 271c. This was one of the suggestions of her twelve-point memorial. While her motive was most closely connected with Taoist ideology, it is also possible that the Tao-te ching was chosen for its mother imagery and its assertion of female superiority.

37. In 678. See THY 75, p. 1373 and TFYK 639:19a.

38. The best study is Tsukamoto's "Haibutsu."

39. Maspero, Taoisme, pp. $15 \mathrm{ff}$. and $116 \mathrm{ff}$. See also the extensive bibliography in Seidel, Divinisation.

40. Wright, "Sui ideology," pp. 86-87.

41. TCTC 205, p. 6484. Some of the most conspicuous omens, besides those mentioned in the text, are a three-legged chicken in 684 (TFYK 46:12a), a new mountain peak in 686 (THY 70, p. 1243), an unseasonal snowfall in 693 and the footprint of the Buddha in 701 (TFYK 15:15ab). These are also mentioned in the standard histories. 
Like earlier T'ang rulers, she found it necessary to prohibit magical and superstitious practices among the people and did so in 689 and 695 . See THY 44, p. 797, and CTW 96:2a.

42. TCTC 205, pp. 6494-95. See Appendix B, no. 110.

43. See Chapter 9.

44. Kamata, Chügoku, p. 120.

45. See, for instance, TD 49, Fo-tsu t'ung-chi 39:368a and 369a for reference to her votive patronage at Lungmen and the monks she received in this period. Tsukamoto, Shina, pp. $372 \mathrm{ff}$., shows that the greatest activity at Lungmen occurred in the second half of the seventh century. We might also note an edict of 673 prohibiting the cruel snaring of animals, TFYK 42:15a.

46. On the history of the conflict see Ch'en, Transformation, pp. $78 \mathrm{ff}$. and Yen Tsung's PSTS. The origins of the problem are examined in Itano, "To-Shin," and Tokiwa, Bukkyō to Jükyo Dōkyō, pp. $56 \mathrm{ff}$. contains some useful references. Yang-ti's edict is discussed also in Ch'en, Buddhism, p. 202.

47. This is suggested at a number of points in the text and by two articles in Wright and Twitchett, Perspectives, pp. 239-307. The Fo-tsu t'ung-chi, not always a reliable source because of its late date, mentions an early directive that clerical conduct should be guided by the Hsiao-ching. See 39:365b.

48. Chen-kuan cheng-yao (Ssu-pu pei-yao ed.) 7:10a-11b, quoted by Michihata, Bukkyöshi, p. 336. T'ai-tsung once remarked on the importance of Buddhist devotion among his people (THY 47, p. 836) and, as the two articles in Perspectives (see preceding note) make clear, considered it important in his state ideology.

49. Fo-tsu t'ung-chi 39, TD 49:364b suggests that the edict was rescinded two years later, while Fo-tsu li-tai t'ung-tsai 11, TD 49:569a puts the original edict in 632 and does not mention its withdrawal. Caution is necessary in the use of Buddhist sources.

50. Ch'en, Transformation, p. 81, and Michihata, Bukkyōshi, p. 339. See also THY 47, p. 836 and Fo-tsu t'ung chi 39, TD 49:367a.

51. CTW 12:4a. See also Kuang-hung ming-chi 25, TD 52:284a; PSTS 3, TD 52: 455b. The edict is dated the sixteenth day of the fourth month in Fo-tsu $Z_{i-t a i}$ t'ung-tsai 12, TD 49:580b.

52. Michihata, Bukkyōshi, p. 337 and Fo-tsu Zi-tai t'ung-tsai, Zoc. cit. On Wei-hsiu, see SKSC 17, TD 50:812b.

53. Ch'en, Transformation, pp. 79-80, and Michihata, Bukkyōshi, Zoc. cit. Prince Hsien, of course, was still a child and unless he had been in some way connected to the church as a child, it is difficult to know why he was chosen. The crown prince, of course, had been called Hung because of the force of the name in Taoist messianism, and Chung-tsung, we are told, was called Fo-kuang Wang because of a light appearing at his birth. See Fo-tsu t'ung-chi 39, TD 49: 367a. The brief to Madame Yang is found in PSTS 3, TD 52:456a.

54. Fo-tsu $Z_{i}$-tai t'ung-tsai 12, TD 49:580c. I am not sure what forms the civil rank (su-kuan) took.

55. Most particularly PSTS 3, TD 52:455b ff. and the CTW which preserves a total of thirty-six briefs connected with the debate, only seven of them advocating freedom from obeisance. Michihata, Bukkyōshi, pp. 335-57, has summarized the arguments of both sides and identified some of their sources. The discussion in the text is based largely upon his work.

56. Tao-te ching, chang 25. The ssu-ta are the Tao, Heaven, Earth, and the ruler.

57. See, for instance, Zürcher, Buddhist Conquest, v. 1, and note the early appearance of such works as the T'ai-p'ing ching (ca. 126-144) which, in their attack on Buddhism, began with its unfilial nature. See Ch'en, Buddhism, pp. 51-52. 
58. Quoted in Ch'en, Transformation, p. 79. The original is found in Kuanghung ming-chi 25, TD 52:286a.

59. For the references, see Michihata, Bukkyoshi, p. 343.

60. CTS $73: 3325: 4$ and HTS 102:3918:3. The member of a clan originally from Tunhuang and, in the T'ang, one of the most eminent of Ho-hsi, Ling-hu, Te-fen, had held high posts under the first two emperors. A very erudite man, he had worked both on dynastic histories and the Shih-tsu chih. Shortly after the pai controversy, he resigned his posts and died in 666 at the age of 84 . His biography contains no suggestion of Buddhist loyalties.

61. See Appendix B, no. 58.

62. CTW 12:7b, Fo-tsu li-tai t'ung-tsai 12, TD 49:561a. See also. Ch'en, Transformation, p. 80 .

63. SKSC 17, TD 50:812c. With no confirmation elsewhere, even in PSTS, I am inclined to doubt the statement.

64. CTS 8:3081:2.

65. Yang Ssu-hsüan (CTS 62:3303:2), who submitted a joint brief with Yang Shou-chüeh, was a maternal cousin of the empress. Yang Ssu-chien and Yang Ssucheng (HTS 71 shang:3814:4) were his brothers. Yang Ling-chieh (HTS 71 shang: 3814:2) was from a different branch of the same clan and with Ho-lan Min-chih, the empress' nephew, the Yang clan thus accounted for five briefs. Lü Ts'ai (CTS 79:3338:4) was a close associate of Hsü Ching-tsung and Li Ch'un-feng who are mentioned as advocates of the imperial party in PSTS, and both he and Li submitted briefs. Li I-fan was the brother of $\mathrm{Li} /-f u$, and $\mathrm{Ch}^{\prime} \mathrm{iu}$ Shen-chi was an adherent of the empress later used to dispose of her son Hsien.

other examples could be adduced but the role of Hsü Ching-tsung, and the stance of the Yang clan which contrasts so strongly with that of the empress' mother, are perhaps sufficient to illustrate my point.

66. Chapter 3, n. 108.

67. Perspectives, pp. 239-265. See also the short exploration of T'ai-tsung's Taoist bias in Yüki Reimon, "Shotō Bukkyō."

68. Kao-tsung was by no means an ardent supporter of Buddhism, and 1 agree substantially with the conclusions of S. Weinstein's 'Imperial patronage of T'ang Buddhism," in Perspectives, pp. 265-306. At the same time, he recognized the force of Buddhism among his subjects when he founded a temple to commemorate his mother (CTW $11: 6 \mathrm{~b})$, and when in an edict attempting to place an abbot he commented specifically that Buddhism was declining in the West but flourishing in the East, i.e., in China. (CTW 11:8a). His establishment of the Kuo-fen temples in every prefecture after the feng-shan sacrifice in 665 was the greatest act of patronage the T'ang had yet seen and led the monk Tao-shih to conclude his great encyclopedia of 668, the Fa-yüan chu-Zin, with the judgment that no former ruler was comparable to him. I commented earlier on his public stance of respect for Hsüan-tsang, and Buddhist sources comment on other concessions toward the church such as his exemption of their literature from the use of "taboo" characters. See Fo-tsu t'ung-chi 39, TD 49:369a.

69. Tsukamoto, Nishi Bukkyō, pp. $21 \mathrm{ff}$. and earlier references.

70. Zürcher, Buddhist Conquest, v. 1, pp. 194-5; T'ang Yung-t'ung, Han-Wei, pp. 217-219.

71. See, for instance, Ch'en, Buddhism, pp. $279 \mathrm{ff}$., and Wright, "Sui ideology," pp. 95-96.

72. Tsukamoto, Shina Bukkyöshi, pp. $273 \mathrm{ff}$. and $581 \mathrm{ff}$.

73. See Eberhard, Tobareich, Chapter 18, and Shigematsu, "Tö-Sö." The TFYK 921:17b notes that a man called Sung Tzu-hsien had gained some credence and a 
rebellious following in 613 by calling himself an incarnation of Maitreya. I find no formal prohibition of the sect in the T'ang until 715 .

74. Fo-tsu t'ung-chi 39, TD 49:367c. The late date of the source and the lack of confirmation elsewhere make the notice somewhat suspect.

75. THY 48, p. 846. This event, recalled in 684, accounts for the change of era name to kuang-chai. Soothill and Hodous, Dictionary of Chinese Buddhist Terms, p. 202a, gives a short history of the temple founded to commemorate the event. The incident is also mentioned in the commentary on the Great cloud sutra.

76. TCTC 203, pp. 6413-14.

77. The $k^{\prime} d o-i$ notice, $i b i d$. says that another source calls him the yüehkuang wang or ćandraprābha.

78. Note 27 above.

79. Tz'u-ÿ̈аn, p. 339c. It was the era name from 685 to 689.

80. See Wright, "Sui ideology," p. 90 , and on the history of the institution in the T'ang, THY 11 , pp. $271 \mathrm{ff}$. The best examination of the symbolism of the ming-t'ang and its origins is Granet's Pensée chinoise, especially pp. $175 \mathrm{ff}$. and 210-29. Wang Mang, of course, also used a ming-t'ang for legitimizing purposes. See Pan Ku, Former Han, v. 3, pp. 191-94.

81. In the eleventh month of 689 . See HTS 76:3867:4, TCTC 204, pp. 6462-63, and the Act of Grace which promulgated the measure, WYYH 463:1b and CTW $96: 16 \mathrm{~b}$.

In the act, the empress remarked upon how the writing system had become progressively confused and complicated so that even scholars had difficulty in understanding some of the characters. As part of a continuing reform, she was issuing twelve new characters which would preserve the foundation of the words while illustrating their meaning. The first of the new forms was the replacement of the Chao in the empress ' own given name by a new character Chao 盟 whose components symbolized the heavenly bodies illuminating the void below. We cannot, of course, eliminate the possibility that the two components of the empress' new name were chosen for their Buddhist significance. The top of the character is $v i d y \bar{a}$, the Buddha-wisdom which enlightens and destroys illusion, while the lower part is sunnya, the empty or illusory.

Some sources simply attribute the fabrication of the new characters to the empress but they were, in fact, the invention of Tsung $C h^{\prime} i n-k^{\prime} \circ$ (CTS 92: 3365:4 and HTS 109:3930:4), a close supporter and a relative by marriage.

While the new characters have been a source of fascination to scholars, especially to those interested in the epigraphy of the period, there seems to exist no consensus on their form. The only full secondary study is Tokiwa's "Bu-Shū shinji." In it, nineteen new characters are identified showing that the list was, in fact, supplemented. It is also clear that the new forms were used universally for fifteen years, and examples have been found both in Tunhuang and in Japan.

The new characters are given below:

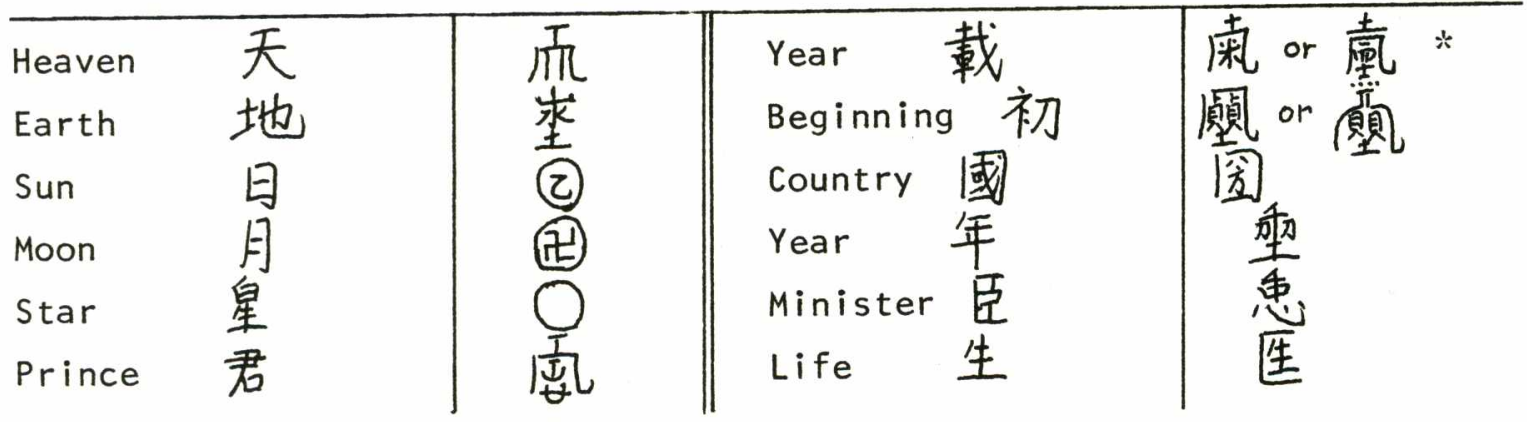




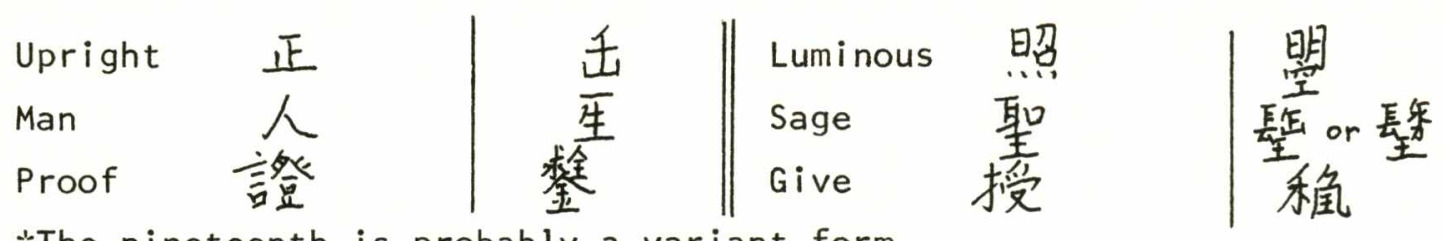

*The nineteenth is probably a variant form.

A number of these characters were used in the reign titles of the empress and so appeared in all official documents.

Tokiwa also finds $\mathbb{Z}$ used for 萬 "ten thousand" since 693, but 1 am not convinced that this was one of the empress' new characters.

As a legitimizing device, the new characters might have been intended to suggest an implicit comparison with the legendary inventor of a script or perhaps to emphasize the "new beginning" of a second Chou ruling the united empire. Alternatively, they might be seen simply as a sign of the Confucian ruler's concern with literacy and education.

82. The fullest account of this figure is in CTS 183:3554:3; see also TCTC 203, pp. 6436-37. He obtained the surname Hsüeh when the empress had him adopted into her daughter T'ai-p'ing's family, since he was not himself of the shih class.

83. Ch'en, Buddhism, p. 222, seems to suggest that while palace chapels had existed in earlier dynasties including the Sui, they date from 691 in the T'ang. It seems clear from Huai-i's biography that this was not the case though 1 have seen no earlier reference in the dynasty. On ministerial complaints about Huai-i and the request that he be castrated, see TCTC 203, p. 6441.

84. For a full examination of this event, see the sources cited in note 91 below.

85. The two T'ang histories use the term "falsely compiled" (wei-chuan or weitsao), while Ssu-ma Kuang, who says it was a four-chüan work while all extant versions are in six, simply says it was composed and presented. (TCTC 204, $p$. 6466). The Fo-tsu t'ung-chi says it was "translated by imperial order" (ch'ih-i) and the Seng-shih Züeh says it was retranslated (ch'ung-i). Similar discrepancies exist on the matter of the number of monks involved.

86. Yabuki, Sangaikyo, pp. $716 \mathrm{ff}$.

87. Ch'en, Buddhism, p. 217, and Tsukamoto, Nisshi Bukkyō, p. 27.

88. HTS $76: 3867: 4$.

89. TCTC 204, p. 6469, CTS 6:3076:1, and HTS 4:3641:3. In most cases the foundation of the Great Cloud temples involved only a name change for existing establishments, and Tsukamoto, Nisshi Bukkyō, p. 29, shows that large and powerful temples were chosen. The source of the new monks is unspecified.

90. In contrast to the equality of Buddhist and Taoist foundations in 666 . It must be noted that in 689 the empress stripped Lao Tzu of the honorific bestowed at that time. THY 50, p. 865 .

91. The first full study of the Tunhuang evidence is to be found in Yabuki, Sangaikyo, pp. 686-761. His reconstruction is based upon Stein 2658, and it is upon the text reproduced in his work that my translation is based. More recently his research has been supplemented by Shigenoi, Töai, pp. 203-37 which looks at the longer and generally superior version of the commentary, Stein 6502 . I might note here that the prophetic passages of the sutra which are to be found in the commentary occur in Chapters 4 and 6 of the Great Cloud Sutra and that my citations are to TD 12, no. 387, pp. 1097 and 1107.

92. This need has now been answered with the publication of Forte, Political Propaganda. This most useful work which examines the circumstances and problems 
of the sources, composition and meaning of the commentary reached me only when my own study was in press preventing me from incorporating the author's findings. Forte gives a full translation of Stein 6502 and though our translations differ only in minor respects, the reader is referred to his much fuller annotation of the text and his resolution of certain problems which had baffled me.

93. For an exposition of these lines see Shigenoi, Todai, pp. $205 \mathrm{ff}$.

94. In the translation which follows, I have supplemented the lacunae at the beginning and end of Stein 2658 by the use of Stein 6502 and have sometimes used the latter to correct errors in the former. Where the text uses the term shenhuang, I have translated "the empress" for purposes of clarity and, for the same reason, have occasionally turned direct quotation into indirect speech.

95. Yabuki, Sangaikyō, p. 721 promised a fuller study of this work but, as far as I can tell, never carried it out. The Cheng-ming ching seems to have been a short work, highly prophetic and popular in character which was classified as false or dubious in both the Sui and T'ang indexes. Four or perhaps five copies are to be found in the Pelliot, Stein and $0 \overline{t a n i}$ collections but a full study has yet to be undertaken. It is of interest to note that even in the Chou in$\operatorname{dex}$ ( $T$ a Chou $K^{\prime}$ an-ting chung-ching mu-Zu, 15, p. 427c) the work is classified as false though it is cited with some frequency in the commentary.

96. At this point the following note is inserted in small characters in both copies of the manuscript:

"Maitreya" (Mi-10) is a Sanskrit word which [in Chinese] is translated as the "Compassionate One" (tz'u-shih). As the Vimalakirti-sutra puts it, "the merciful and compassionate mind is that of the woman [or daughter]." The empress corresponds to this meaning.

97. Cf. Legge, I-ching, 2nd ed. (0xford, 1899), p. 425.

98. Chapter 5, n. 108.

99. I suspect that this term refers to the Pao-t'u since HTS 76:3867:4 records that in August of 688, the stream in which it was found was renamed Kuangwu, probably as a means of drawing attention to the Wu surname. There are many references to the text of the Kuang-wu ming throughout the commentary which leads one to believe that the inscription was much lengthier than previously thought or, alternatively, that the reference is to another prophetic stone altogether. See Yabuki, op. cit., pp. 229-31 where the scattered references are collected to give a rough reconstruction.

100. I am of the view that the reference here is to the classical Ho-t' $u$, a prognostic text supposedly transmitted by the Yellow Emperor to King Wen of Chou. It enjoyed great currency in the Han and was later outlawed because of its subversive potential. See Dai kanwa jiten 6:17245:182 and the remarks of A. Seidel in "Dynastic treasures." Granet's discussion in Pensée, pp. 148-74, is most enlightening. The text also allows the possibility here that Ho-t'u refers to an omen specific to Empress Wu in which case the quotation should be lengthier.

101. The first three T'ang emperors. See also TCTC 204, p. 6447.

102. Here the most ancient terms for local officials are used. I am uncertain why.

103. The name of the Li clan was changed to Hui "viper" after the Princes" Rebellion. See Chapter 5.

104. A feared figure in Buddhist mythology ruling a race of cannibalistic, black-bodied, red-haired demons in the southwestern kingdom of the heavens.

105. A reference to the new mountain peak of 686. See CTS 37:3203:4 and THY 70 , p. 1243.

106. Unless the passage is a pun on the word shan which also means monastery, 
I am not sure how the connection is made by the commentators.

107. P'an-Zung "ascending dragons" were part of the empress' décor in the ming-t'ang.

108. See THY 11, p. 277.

109. See Ta-fang teng wu-hsiang ching, in TD 12, p. 1098a. The ćakravartin was the universal monarch "whose chariot wheels roll everywhere without hindrance," and Jambudvipa, strictly speaking, was the southernmost of the four Buddhist kingdoms. Mochizuki, Bukkyo daijiten (Kyoto, 1958), v. 1, p. 317 , says that Jambudvipa was also used for eastern lands like China. See also TCTC 204 , p. 6466.

110. TD 12, p. 1107a.

111. I am unable to identify this reference though the title suggests a Buddhist prophecy. It is quoted on other occasions in the commentary.

112. TD 12, p. 1097c.

113. Wu Tse-t'ien had established at the time of the feng-shan sacrifice that as Heaven was associated with the emperor, Earth was associated with the empress.

114. See Legge, I-ching, p. 430.

115. Wu, of course, was the second of Madame Yang's three daughters.

116. By using the characters "son" (子) and eighteen (十八), the Li surname is composed (季). The reference is to the ballad tradition (t'ung-yao) of omenology upon which we earlier commented.

117. It will be recalled that Wu was named Mei 美 "beauteous" when she entered T'ai-tsung's harem.

118. The phrase t'u-chung in the Shu-ching (Legge, p. 428) refers in fact to Loyang.

119. The bureaucratic expansion in the Chou will be discussed later.

120. In this passage we see three of the empress' nien-hao used. Kuang-chai was adopted in 684, yung-ch'ang in 689, and sheng-li in 698.

121. The phrase might also be translated "has not ruled long."

122. In the fashion $x+f=t$.

123. TD 12, p. 1096c.

124. TD 12, p. 1107a.

125. Ibid. This passage shows that the commentators knew that the church might trespass on its new favor, and it also helps to explain why an emperor like T'ai-tsung had had the sutra so frequently chanted.

126. See note 74 to this chapter.

127. In imitation of the Emperor Asoka ( $r$. about 274-237 B.C.) who is said to have built 84,000 stupas. Sui Wen-ti used the same model.

128. The first five commandments against killing, stealing, adultery, lying and intoxication. They bind both laity and clergy. The passage is found in TD 12, p. 1098a.

129. The passage might also mean "good spirits protect her person."

130. Mära is the destroyer who appears in different categories like desire, falsehood, etc.

131. Since Maitreya was the Buddha and not a bodhisattva, the inclusion of this passage is a very significant one.

132. I am unable to locate any text by this name and suspect a reference to the many $c h$ 'an-wei texts associated with the Confucian Classics. Seidel, "Dynastic treasures," offers a convenient summary of the literature.

133. Wei Yüan-sung was a well-known fortuneteller of the Northern Chou and seems to have been instrumental in the Buddhist persecutions of $574-77$. He is 
described sometimes as "one who attained the Way" and, as a Taoist, may have written some of the messianic ballads current at the foundation of the T'ang. Some of his sayings, engraved on stone, were presented to Kao-tsung in 674 and locked away. Translation is extremely difficult.

134. Shih-min was also the given name of T'ang T'ai-tsung.

135. Another of Empress Wu's era names.

136. The phrase ta-sheng hsüan-chi here is unclear. I can locate no text with this title and so translate literally. It has been suggested to me that there might be a connection with the Amitayus Sutra (Wu-Ziang-shou ching).

137. I think the meaning here is that in the I-ching hexagrams, the fifth place from the bottom is that of the ruler. In this case it should be a broken or "female" line.

138. This is an alternate name for the Pao-t'u discussed in the following chapter. See HTS $76: 3867: 3$.

139. The theme of T'ang continuity is resumed at several points in the commentary, and I will later suggest that this is how the empress saw her role.

140. Probably an attempt to depict the Wu surname in the fashion

141. This is probably a contemporary augury but one which may echo the classical Ho-t'u which contained a Zung-t'u.

142. I am rather unsure of my translation here.

143. TD 12, p. 1107a.

144. TD 12, p. 643b. There are three extant versions of the sutra, and the quotation is from the most recent or "southern" text.

145. See TD 27, p. 912a for the quotation.

146. As mentioned earlier, Ch'en $\mathrm{Yin}-\mathrm{k}^{\prime} \mathrm{o}$ regards this as evidence that the empress was early placed in a Buddhist convent. I find his argument unconvincing.

147. The empress' father was posthumously entitled T'ai-huang, though the phrase might also mean "the great emperors" of the past.

148. I cannot identify this character.

149. A prognostical work in one volume compiled in the reign of T'ang T'aitsung and said initially to have contained sixty prophecies.

150. Shen-lung was the last of the empress' era names adopted just before her deposition.

151. This prophecy turned out to be wrong since the empress changed her era name before the end of the year.

152. I find no specific mention elsewhere of a plot headed by these two men although the standard sources confirm their execution. It seems that three explanations are possible: (a) that the executions were a residue of the Princes' Rebellion of 688 since Li Ch'ang was a member of the imperial clan and P'ei Chien a relative by marriage, (b) that the persons executed were involved in the plot of 689, discussed in Chapter 6, n. 70, or (c) that the charges were fabricated by the overzealous penal officials active in the terror and are thus unmentioned in the official sources. I am of the view that there was indeed a last-ditch stand against the proclamation of the Chou and the Western Capital would be a natural focus for it.

153. The numerous lacunae hereafter make coherent translation from Stein 2658 impossible. Stein 6502, as I said earlier, is much longer and my translation has covered only 284 of its 375 lines. The most interesting facet of the remaining portion is perhaps the extensive use of Taoist omenology, most particularly the inscription of the famed K'ou Ch'ien-chih of Mount Sung and Yü Hsien-chang of the Western Mountain. The last omen mentioned is the new mountain peak of 685 
which, as 1 will suggest, is identified by Confucian historiography as the first sign of the impending usurpation.

154. Wright, "Sui ideology," pp. $97 \mathrm{ff}$. , in pointing out how Wen-ti stopped short of proclaiming himself the tathägäta, suggests that this formula had been used by the rulers of the Northern Wei. This tactic and the hostile reaction of the South against it is studied by Takao, Chügoku. It is important to note, however, that the Wei precedents were neither so elaborate nor systematic as the actions of the Empress Wu who established special temples and monks and who used her imperial title, her architecture and ceremonial to establish her claim.

155. Ta-fang-teng wu-hsiang-ching 6, TD 12:1107a. The vision described was not a particularly original one and might be compared with that of another of Dharmarakșa's translations, the Fo-shuo Mi-lo hsia-sheng ching, TD 14:453.

156. Eloquently translated in de Bary, Sources, v. 1, pp. 175-76.

157. CTS 6:3076:2, HTS 4:3641:4, and TCTC 205, pp. 6492, 6494 and 6496. The empress took her full title in three stages. In the autumn of 693 and in response to a petition of 5,000 names solicited by Wu Ch'eng-ssu, she called herself "Golden Wheel," the symbol of the cakravartin. For this move the immediate inspiration was the presentation of a second sutra, that of the Precious Rain (Shigenoi, Tódai, pp. $218 \mathrm{ff}$. ), which portrayed her as a cakravartin and was followed by the erection in the ming-t'ang of the sapta-ratna--the seven treasures of the cakra. See Soothill and Hodous, p. 303a, and TCTC, Zoc. cit.

In 694 Ch'eng-ssu again sponsored a petition of 26,000 names requesting an augmentation of title, and "Peerless" was added. Ch'eng-ssu seems in this to have been flattering his aunt in hopes of gaining the succession. Only at the beginning of 695, and with no apparent reason, was "Maitreya" added to the title.

The sequence is somewhat puzzling in view of the importance the empress attached to the Maitreya omen and to which she referred on other occasions. See, for instance, CTW 97:6b-7a, her preface to the new translation of the Hua-yen Sutra. In the second month of 696, and immediately after the ming-t'ang burned, she divested herself of "Maitreya the Peerless" (TCTC 205, p. 6502), seeming therefore to connect the assumption of the title with the calamity which followed. Her initial reluctance to call herself Maitreya might perhaps be attributed to humility and reverence.

158. Yabuki, Sangaikyō, p. 726.

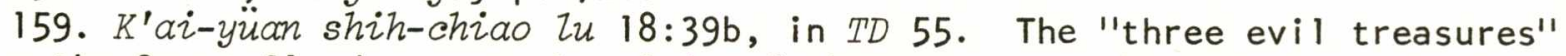
were the Great Cloud omens, the claim of the empress to be Maitreya reborn, and the Great Cloud temples erected under the auspices of the "false monk" Huai-i.

160. THY 49, p. 859 and TCTC 204, p. 6473. The edict is found in TTCLC 113: $4 a$ and $C T W$ 95:4a.

161. THY 49, p. 859. See also Fonctionnaires, v. 1, p. 412, n. 1. According to TTLT 18:13a-14b, the $t z^{\prime} u$-pu was to supervise the Buddhist and Taoist clergy and nominate their temple heads (sarigha, Ch. san-kang) as well as the bhadanta (ta-te) of the capital. It later carried out a triennial census and registration (TRSI, p. 859).

Earlier in the T'ang, the affairs of the church had been overseen by two offices attached to the Board of Rites, the Ch'ung-hsüan shu which was primarily concerned with Taoism and the Hung-lu ssu whose principal function was the management of tribute envoys. The implications of this organization are that Buddhism was seen as an extension of Taoism and as a foreign religion.

On the matter of clerical discipline and state regulation, see Moroto, "Tōsho," pp. $66 \mathrm{ff}$. 
162. The only sect to rise after the Chou was that of Ch'an, and it might be argued that its principal tenets were developed prior to the end of the Chou.

163. See TCTC 205, p. 6498. According to Ssu-ma Kuang, the expense was so great that the treasuries were emptied to pay for it. See also TCTC 205, pp. 6499-6501. On the opposition to Buddhist expenditures, see THY 49, pp. $857 \mathrm{ff}$.

164. See the commentary translated in the text. Whether or not the mingt'ang was ever so simple as the ideal would suggest is difficult to know, but those who protested the plan of 696 to reconstruct it seem to have seen it in this light. This is discussed in later notes.

165. See Mochizuki, Bukkyö daijiten, v. 8, pp. 221 shang.

166. TCTC 205, p. 6498.

167. See, for instance, CTW 95:8a and TTCLC 80:11b for a decree of 696 condemning excessively elaborate funerals and other forms of commemoration. The clan instructions of Yao Ch'ung (Appendix B, no. 122) warned his descendants against excessive patronage of Buddhism. CTW 207:5b.

168. THY 49, p. 857, TFYK 327:21b, and TCTC 207, pp. 6549-50. Ti Jen-chieh criticized not only the wealth of the church but the burdens which the clergy placed on the people by the non-productive nature of their vocation, their sale of sutras and relics, and their disregard of the law. He went on to point out that as a compassionate religion, Buddhism should not be the cause of imposing labor upon the people.

The empress apparently rescinded the call for corvée labor but continued to make collections from the clergy for five months. Li Chiao later pointed out that over $170 \mathrm{million} c c^{\prime} i e n$ had been collected and suggested that this be distributed to the poor at the rate of 1,000 ch'ien per household. The suggestion does not seem to have been followed. THY 49, pp. 857-58.

169. THY 41, p. 731, CTS 6:3076:1, and TCTC 205, p. 6482. Ssu-ma Kuang adds that the ban included fishing and, since there was drought and famine in the South, caused starvation. Human life was thus deemed less valuable than animal life.

Bans on butchery seem first to have been enacted in China under Liang Wu-ti, and there are examples in the Sui and T'ang though usually for the space of three days. It is difficult to know how severely the ban was enforced, but TCTC, Zoc. cit. mentions one high official nearly cashiered for contravening it, and the memorial of Ts'ui Yung which resulted in its lifting indicated that it had caused much suffering among the poor though the rich had of ten managed to avoid it. THY 41, p. 731. Ts'ui's biographies are in CTS 94:3368:3 and HTS 114: $3940: 1$.

See also Huang, T'ang-tai fo-chiao, pp. $107 \mathrm{ff}$.

170. THY 41, p. 746. This meant that crimes against state property entered the ta-ni category of punishment. TLSI 1, pp. $15 \mathrm{ff}$. and 19, p. 61. This enactment occurred shortly after Buddhism was attached to the $t z^{\prime} u$-pu, again emphasizing its position in the state.

171. TCTC 205, p. 6469. The notice says that only the nine men who, with Huai-i, were responsible for the commentary were awarded the red (instead of black) cope and the silver belt ornament of fourth-rank officials. Judging from Stein 2278, reproduced by Yabuki, Sangaikyo, pp. $748 \mathrm{ff}$., the award was much wider. Twenty-seven monks are given name and rank, and several who had no connection with the Sutra are hsien-kung. Since the document in question is another containing omens of the empress' imperium, its compilers are likely to have been Great Cloud monks. 
172. See, for instance, Huang, T'ang-tai fo-chiao, p. 67, and Weinstein's remarks, "Imperial patronage," in Perspectives, p. 265.

173. See Ch'en, Transformation, pp. $85 \mathrm{ff}$.

174. Ch'en, Transformation, pp. 85 and 92.

175. Ibid.

176. See Ch'en, Transformation, p. 95 and Michihata, Bukkyöshi, pp. 137-77 for a more general examination of the problem of clerical discipline. Wright, "T'ai-tsung and Buddhism," in Perspectives, pp. 261-63, has some interesting remarks on another attempt to regulate the clergy through a sutra called the Ichico ching.

177. See, for instance, TLSI 2, pp. 48-49 which outlines the punishments for such offenses as fornication (chien ), disrespect to or assault upon superiors, mistreatment or killing of slaves, theft, etc. In most cases, punishment was heavier than that imposed for the same offense upon commoners. See also Ch'en, Transformation, p. 102.

178. CTW 95:9b, 96:5b, and 95:11b respectively. The first two date from 698 and 700. I have been unable to date the third.

179. See the several references to the abuses of this period in Gernet, Aspects économiques. See also TCTC 209, p. 6624.

180. See note 168 above and see the remonstrance in 704 by Chang T'ing-kuei (CTS 101:3385:1 and HTS 118:3946:1) found in TCTC 207, p. 6571. As a result of this memorial, the empress halted her plan to erect a huge and costly image.

181. TD 50, no. 2061 .

182. Hsüan-tsang (600-664) has a full biography in TD 50, Ta-tz'u-en-ssu santsang fa-shih chuan, no. 2053 and SKSC 4:721b. Tz'u-en (632-82) was his successor and the systematizer of Fa-hsiang doctrine. SKSC 4:725b.

When Hsüan-tsang returned to China in 645, T'ai-tsung had supported his translation work and Kao-tsung continued this patronage. He seems to have had a fondness for Tz'u-en, setting him up in the temple he founded for his mother, listening to his lectures and composing a eulogy for him.

183. The best account of Fa-tsang's life and the historiographical problems surrounding it is Kamata, Chügoku, pp. $129 \mathrm{ff}$. See also SKSC 5:732b, and Ts'ui Chih-yüan's biography in TD 50:280c.

On Chih-yen, see Fa-tsang's biography of him in TD 51:163b, Hua-yen-ching ch'uan-chi 3. He lived from 602 to 668 and though he seems to have been at court, the favored position of the Fa-hsiang school meant that he received little support.

The Hua-yen or Avatamsaka school derives its name from the massive sutra first translated in 403. See the Hua-yen ching ch'uan-chi, TD 51:153a. It is often considered the most sophisticated and recondite of Chinese schools. The most useful study for the T'ang is that of Kamata, cited above, and Chang, Buddhist Teaching is an ambitious attempt at an overview of the sect.

184. THY 48, p. 848 and Hanada, Bukkyo Daijii, v. 5, p. 3149a. The THY mistakenly dates the foundation in 675 rather than 670 and, according to SKSC 2: $719 a$, there was a T'ai-yüan temple in each capital.

185. Kamata, Chügoku, p. 130. On the conferral of honorific names, see Huang, T'ang-tai fo-chiao, pp. $64 \mathrm{ff}$.

186. K'ai-ÿ̈an shih-chiao Iu 9, TD 55:564a, SKSC 2:719a. Also associated with them at the time was the monk Buddhapäla who came from Kabul in 676 (SKSC 2:717c). Divakara translated eighteen texts before his death and the $K^{\prime} a i$-ÿ̈ran shih-chiao Iu says the empress contributed a preface to his canon.

187. SKSC 2:718c. The notice here gives the impression that the empress considered the former translation inadequate and, hearing of the exixtence of an 
earlier Sanskrit version in Khotan, sent a messenger to summon Siksānanda. The origin of the belief is probably the claim she makes in her preface to the new translation. Kamata, Chügoku, p. 130 mentions some of the other collaborators. See also K'ai-yüan shih-chiao lu 9, TD 55:566a.

188. Found in CTW $97: 5 \mathrm{~b}$ and TD 10 .

189. SKSC 1:710b. After his two maritime pilgrimages to India in 671 and 685, he brought back to China over 400 texts he had collected. The empress is said to have met him at the gates of Loyang, showered him with gifts and set him to work on the Hua-yen translation. She later supported his other translations and his studies of the lands he had visited since she "respected the Law and valued the man." KYSCL 9, TD 55:968bc. Chavannes, Mémoires translates from his work.

190. See, respectively, Li-tai fa-pao chi, TD $51: 184 \mathrm{a}$, and SKSC 5:732b on Heng-ching who became Master of Precepts (shou-chieh shih), perhaps because of the Yang clan's friendship for T'ien-t'ai. Other examples are found in SKSC 19: $832 \mathrm{~b}$ on Wu-hsiang, and 20:836b on Ch'u-chi of Pure Land, as well as Pao Ssu-wei (3:720a), Bodhiruci $(3: 720 b)$, Yin-tsung $(4: 731 b)$, Tao-tsun ( $8: 758 a)$, Tao-ch'eng (14:791b), Hui-an $(14: 823 \mathrm{~b})$, etc.

191. Hui-neng (SKSC $8: 754 \mathrm{~b}$ ) was invited at the request of Shen-hsiu but, because of illness, did not attend.

192. SKSC 8:755c. The empress may have played a part, though unintentionally, in the eclipse of northern Ch'an by its southern rival. Yamasaki, Zui-Tó, pp. $197 \mathrm{ff}$., sees the success of northern Ch'an in gaining imperial support and converts among the upper classes as the cause of southern Ch'an's greater success among the commoners and hence its longevity.

Further instances of the empress' support for northern Ch'an are found in CTW 97:6b and in the fact that Shen-hsiu is one of only three monks to be given an official biography. See CTS 191:3592:2.

193. Ta-Chou k'an-ting chung-ching mu-lu, TD 55:372c.

194. Kamata, Chügoku, pp. $144 \mathrm{ff}$., and more recently, Weinstein, "Imperial patronage," in Perspectives, pp. 265-306.

195. Weinstein, op. cit.; pp. 274-91.

196. Kamata, Chügoku, pp. $134 \mathrm{ff}$. Ch'an had not yet systematized its doctrine at the time of Fa-tsang's schema, but in the second highest category of "abrupt teaching" he placed such basic Ch'an doctrines as that of sudden enlightenment and the ineffable character of all religious experience.

197. Chang, Buddhist Teaching, p. ix.

198. Chang, Buddhist Teaching, pp. $28 \mathrm{ff}$.

199. THY 36, p. 657 and CTW $78: 8 \mathrm{ab}$.

\section{Chapter 5}

1. On Chung-tsung, CTS 7:3077:2, HTS 4:3642:4, and THY 1, p. 4. He was born in late 656 and, prior to his elevation to crown prince in 680 , had held only the usual sinecure of younger imperial sons, the position of mu in the two capitals. See Fonctionnaires, v. 1, pp. 396-404 and v. 2, 884-904. There is no record either of civil or military administrative experience beyond this.

2. TCTC 203, p. 6416. The complete document is found in TTCLC $11: 3 \mathrm{~b}$ and CTW 13:20a.

3. Yang, Excursions, p. 31 .

4. TCTC 203, p. 6416. P'ei Yen, the paramount minister, memorialized to ask 
that the coronation take place without delay.

5. Empress Wei (CTS 51:3279:3 and HTS 76:3868:2) was a member either of the Yung-chou or Tu-ling branch of the Wei clan, both of them extensive and powerful and both having produced consorts and chief ministers earlier in the dynasty. Wei became Chung-tsung's consort only after the death of his first wife who had incurred the displeasure of the Empress Wu, and was to give him only a son and a daughter. The son was executed in 701. The total domination of Wei over her husband is traditionally dated from his exile in 684 when in gratitude for her support, he is said to have promised her a free hand should better days ever come. She seems to have become virtual ruler on his restoration and was responsible for much of the corruption and administrative decline which marked the period. Some sources accuse her of poisoning her husband in 610, an allegation which Ssu-ma Kuang accepts (TCTC 209, pp. 6641-2).

6. TCTC 203, p. 6417. See also CTS 87:3351:3 and HTS 117:3945:2. The empress' father had been made prefect when Chung-tsung became crown prince in 680, and this customarily was the highest post he should have held. Chung-tsung wished simultaneously to raise the son of his wet nurse, a man not of the "clear stream," to the fifth rank.

7. CTS 87:3351:3 and HTS 117:3945:2.

8. Sun Kuo-t'ung, "San-sheng-chih" sees the transfer of the Cheng-shih t'ang to the Department of State Affairs as a result of the gradual shift of departmental importance. The evidence is quite convincing and fails only to account for the timing of the move, since the Chancellery had lost its paramount position prior to 684. What is more, the Chancellery was at that time under Liu Jen-kuei (Appendix B, no. 51), a man of greater experience and prestige than $P^{\prime} e i$ Yen and the one person feared by the empress at the deposition. TCTC 203, pp. 6418-19. It seems therefore to have been an inappropriate moment for $\mathrm{P}^{\prime} \mathrm{ei}$ to assert his leadership.

I believe that to Professor Sun's analysis we must add the character and ambition of P'ei Yen. It seems clear from his biography that he was highly ambitious, once trying to cashier P'ei Hsing-chien, of whom he was jealous, and remaining as close as possible to the crown prince as Kao-tsung died. Since Jenkuei was over eighty in 684, $\mathrm{P}^{\prime}$ ei Yen found it a propitious moment to seize control of the tsai-hsiang group and was especially hostile to the plan to replace Jen-kuei with Empress Wei's father since this would obviously dilute his personal power. It was for this reason, I think, that he took the extreme step of betraying Chung-tsung to Empress Wu.

Subsequently, he became the strongest advocate of a restoration of power to Jui-tsung and his failure in this may have led him to the attempted coup of which he was accused later in the year.

9. TCTC 203, p. 6417. See also CTS $86: 3351: 3$.

10. TCTC 203, pp. 6417-18, and note the commentary. On the Yü-1 in Guard, see Fonctionnaires, pp. 555-560, and more particularly Ch'en, Cheng-chih shih, pp. $39 \mathrm{ff}$. for a demonstration of how the Yü-lin Guard determined every palace revolution in the early T'ang. At this time they numbered only about a hundred men, most of them retainers of the $\mathrm{Li}$ clan (CTS 106:3396:2), so their willingness to depose Chung-tsung is doubly interesting. Their number was to be greatly increased in 689 by the Empress Wu, and under Chung-tsung's restoration the force reached 10,000. THY 72, pp. 1291-92. See also Pulleyblank, Background, pp. 6467.

11. CTS 7:3077:1 and TCTC 203, p. 6420. Chung-tsung, demoted to Prince of 
Lu-ling, was soon transferred to Chün-chou, even farther from the capital. Empress Wei gave birth to the notorious Princess An-lo on the way.

12. On Jui-tsung, see CTS 7:3079:1, HTS 5:3643:3, and THY 1, p. 5 .

13. TCTC 203, p. 6418.

14. Ibid.

15. See Ch'̈̈, Han Social Stmeture, p. 74.

16. See the excellent short review by $D$. Sternberger in the International Encyclopedia of the Social Sciences (New York, 1968), v. 9, pp. 244-48.

17. Found chiefly in The Theory of Social and Economic Organization, A. M. Henderson and T. Parsons, trs., (New York, 1947), pp. $152 \mathrm{ff}$. Weber, of course, distinguishes three pure types of legitimacy: the traditional, charismatic, and the legal-rational.

18. See particularly D. Easton, A Systems Analysis of Political Life (New York, 1965), and A. Etzioni, The Active Society: A Theory of Societal and Political Processes (New York, 1969). These and other sociological theories are very well reviewed in an unpublished paper by Anne F. Thurston, "Authority, legitimacy and power: A reformulation," which is part of a Ph.D. thesis for Yale University. I am indebted to her for some of the ideas which follow in the text.

19. Thurston, "Authority," pp. $49 \mathrm{ff}$.

20. See, for instance, TCTC 203, p. 6418 in which she admits self-assumption of the regency.

21. TCTC 203, p. 6419. I have seen no instance of "hanging the curtain" prior to its usage by Empress Wu, and it might therefore have been her own innovation cast aside at this time.

22. See the two biographies cited in notes 7 and 8 above.

23. CTS 183:3551:1 and TCTC 203, p. 6419.

24. TCTC 203, p. 6419, and see Chapter 4.

25. TCTC 203, p. 6422 and THY 12, pp. $294 \mathrm{ff}$. and 15, pp. $325 \mathrm{ff}$. Subsequent discussions on the ancestral temples in the T'ang invariably referred to the sacrilege of Empress Wu. Arthur Wright, in a recent paper on the formal procedures by which Sui Wen-ti legitimized himself (Asilomar, 1975), emphasized the importance of ancestral temples and titles.

26. TCTC 203, p. 6422.

27. The Act of 684 is found in TTCLC 3:4b, WYYH 463:6b, and CTW 96:11a. See also TFYK 15:14b ff. For Empress Wu, this Act and that of 689 are the only ones extant in their entirety.

28. I have divided the document somewhat arbitrarily into three sections which seem to contain provisions of the same nature.

29. I do not mean to suggest here that Wu was openly and consciously following the model of Wang Mang. If anything, she avoided exact duplication of his actions. The use of Chou- $i_{i}$ symbolism, however, seems to have had a great appeal to rulers concerned about their legitimacy. On the peculiarly Confucian use of literary titles see Dubs' remarks in Pan Ku, Former Hon, v. 3, pp. 104 ff.

30. The Phoenix Court and Luan [a type of phoenix] Terrace were used respectively for the Department of State Affairs and the Chancellery. The luan, for instance, is said to have conveyed the Han Taoist adept Mei Fu to the land of the immortals. The phoenix had since ancient times been a sign of the impending appearance of a sage-king.

31. The era name was changed to kuang-chai to commemorate the discovery of relics described in the last chapter.

32. CTW 17:10a.

33. See CTW 17:8b and 14b-16a. 
34. Several examples are given in Chapter 9, and we might note the specific criticism of the frequency of the Acts by Liu Chih-chi in 695. TCTC 205, pp. 6500-01 and THY 81, pp. 1494-5.

35. CTW 96:15a. On the new branch of the Censorate, see THY 60, p. 1041 .

36. See Twitchett, Financial Administration and the succinct summary of the T'ang Z Zü-Zing system by Ikeda in "Ritsūryo." On the census itself, TRSI, pp. 242-45.

37. CTS $94: 3368: 2$.

38. CTW $96: 15 a$.

39. See Pulleyblank, Background, Chapter 5, and my remarks in Chapter 8. The usual starting point in discussing the decline of the fu-ping is the Yehhou chia-chuan (Yü-hai 138:20ab), translated by Pulleyblank, Background, p. 143. Yeh's remarks seem to have been influential in Ch'en Yin-k'o's suggestion [Chapter 6] that Empress Wu deliberately weakened the fu-ping, and the contention of $\mathrm{Ku}$, Fu-ping, p. 216, that her reign was "the decisive first step" in the decline of the institution. Hamaguchi, "Fuhei" has explored the question in detail.

Generally speaking, the aspects of the Chou blamed by modern scholarship for the fu-ping decline are:

a) The political climate of the Chou court--factionalism and disputes among tsai-hsiang and generals, as well as the empress' disgrace or execution of so many high military officials.

b) The empress' excessive use of the troops.

c) The expansion of her personal bodyguard and the use of eunuchs in it. The Y $\ddot{u}-1$ in Guard came to overshadow the fu-ping and exercise too much control over the court.

d) The overgenerous conferral of honorific rank, even to the nonmilitary, which destroyed the merit principle. Tangible rewards of land and grain were curtailed in spite of promises to the contrary so that expectations were disappointed.

e) Landlord and official classes scorned the fu-ping and hired peasants, often the poor and weak, to serve for them. Worse, they bribed the officials in charge of draft lists to exempt them so that peasants were unfairly conscripted or quotas were left unfilled. Tunhuang evidence makes clear this absolutely key factor in the decline of the system.

f) The government could not control the problem of vagrant or fugitive households. Unable to tell who was eligible for fu-ping service, it was unable to equalize the burden.

As we shall see, there is some evidence that all of these factors were present in the Chou, but because our evidence is scanty, it is difficult to judge the degree to which they affected the system's decline. It should not be too much to say, however, that the list alone reveals something of Wu's attitude toward the system, and it seems unreasonable to deny that she failed to offer it support or contribute to its viability.

Her motives are difficult to discern, and I can agree with Professor $C h$ 'en only in the widest sense. The fu-ping was at its most basic level an instrument of centralization, but because the initial distribution of units was so weighted in favor of the Northwest, contradiction was inherent from the first. If the system had to be weakened in the name of regional equalization, then Professor Ch'en is right. I am not sure, however, that this was the case. By the Chou dynasty, two ill-fated rebellions had demonstrated that a viable centralization had been achieved and that the T'ang system could 
withstand even a female ruler. As we shall see, the hard-pressed northeastern prefectures strongly resisted the invasions of Khitans and Turks and their invitations to collaborate in the deposition of the empress. In these circumstances, the fu-ping had no function that could not be better served by professional armies, and what is more, its inadequacies had become apparent as early as mid-century when it was first used as a semi-permanent garrison in Korea and when the decline in its morale came to imperial notice. By the Chou dynasty it was probably too late to arrest the decline without a full-scale reform and for reasons I shall mention later, this was impracticable.

In short, while I admit that the Empress Wu bears much of the responsibility for the decline of the fu-ping, I am not convinced that she consciously set out to destroy it.

40. CTW $96: 15 a b$.

41. The most striking use of recommendation for appointment came in 686 when the establishment of the Urn began a continuing process whereby anyone who felt himself qualified for office could recommend himself for appointment. In addition, decrees were issued after 684 whereby present officials were asked to recommend their own replacements and, in some cases, to suggest up to three names (THY 26, p. 890). Specified ranks were often ordered to recommend, sometimes the third rank and above (THY 53, p. 920) but more commonly fifth rank and above (TFYK 67:27b ff.). On occasion, the hereditary principle was served by having officials recommend "sons and nephews" (THY 53, p. 919) or, conversely, those "not of powerful or influential clan" (CTW 13:14a, Kao-tsung). Decrees calling for recommendation were issued both on auspicious occasions and calamitous ones, as in the case of the burning of the ming-t'ang (CT'W 96:2b). An edict of Kao-tsung in 677 commanded that capital officials above the third rank every year recommend all whom they knew of civil or military talent or good character (CTW 13:14a and TFYK 67:28a).

In the Chou we find commissioners sent out to seek worthy men, and prefects and tu-tu enjoined to recommend so that, as will be shown, the empress became the butt of much criticism. Monographic study of the frequency with which she used this method of recruitment relative to other T'ang rulers would be useful.

Judging from CTW 95:14b, there were legal penalties for a bad recommendation in response to these decrees, and several biographies suggest that existing officials were reluctant to recommend since their own fate was then tied to that of their protegés. Yang Tsai-ssu (Appendix B, no. 111) "never once recommended another" in the course of his successful career.

42. From a memorial of 685. See Ch'en Tzu-ang chi, p. 184.

43. Discussed in detail in Twitchett's "Note."

44. On Li Chi, see Appendix B, no. 27.

45. TCTC 201, p. 6360 .

46. A good study of the area in this period is Ch'üan Han-sheng, "Ching-chi ching-k'uang."

47. The names and former ranks of several of these figures are found in TCTC 203 , p. 6422 .

48. The rebels restored the era name of Chung-tsung and claimed to be acting on his behalf, but there is no indication that he was even cognizant of the rising. The use of a double for the deposed Prince Hsien throws suspicion on Ching-yeh's motives. See TCTC 203, pp. 6423-24.

49. On Lo Pin-wang, see CTS 190 shang:3581:3, HTS 201:4100:3 and Kuo Mo-jo's speculation on his fate in Wu Tse-t'ien, p. 147. The manifesto is found in CTW 
197: la and is abstracted in TCTC 203, pp. 6423-4.

50. A reference to the duties of a ts'ai-jen concubine in the imperial wardrobe. Fitzgerald, Empress Wu, p. 97, renders the passage, "Formerly she served T'ai Tsung with her body and then made use of an occasion when [Kao Tsung] was changing his clothes to commit fornication with him."

51. The reference here is probably to Wu's niece rather than to her sister (Chapter 3, n. 107), and there is, of course, no evidence that wu had anything to do with the death either of Kao-tsung or of her mother. It is interesting to note that Pin-wang makes no reference to the murder of her infant daughter or, indeed, to Prince Hung.

52. Here Pin-wang is referring to Jui-tsung's exclusion from politics and also perhaps to the rapid rise of the Wu nephews. It might be noted that Wang Mang was also charged with murdering the ruler and planning usurpation in Chai I's rebel manifesto in 8 A.D. Pan Ku, Former Hon, v. 3, pp. 235-36.

53. There is no evidence that Ching-yeh received Kao-tsung's testament or that he ever held a post higher than prefect.

54. The ambiguity might be deliberate here since the rebels were using the names both of Crown Prince Hsien and of Chung-tsung.

55. CTW 197:la ff.

56. TCTC 203, p. 6424.

57. The imperial force consisted of 300,000 men led by one of the T'ang princes, and amnesty was extended to all who would voluntarily submit. Fitzgerald, Empress Wu, pp. $98 \mathrm{ff}$, outlines the campaign. On the leader of the force, see CTS 60:3298:3 and HTS 78:3872:4.

58. The advice of Wei Ssu-wen, about whom nothing is known except that he was a demoted censor. See TCTC 203, pp. 6426-27.

59. See Pulleyblank, Background, pp. 75-81, and the references cited in later chapters.

60. TCTC 203, p. 6426.

61. On the end of the campaign, see TCTC 203, pp. 6430-31.

62. HTS 117:3945:2. See also TCTC 203, pp. 6425-6 where the $k^{\prime}$ ao- $i$ examines the conflict. Ssu-ma Kuang repeats a story from the Ch'ao-yeh ch'ien-tsai which also suggests that $\mathrm{P}^{\prime} \mathrm{ei}$ Yen was connected with the rebels but concludes that the allegations arose from his enemies, and so refuses to give credence to his guilt.

63. Note 8 above and TCTC 203, p. 6425.

64. TCTC, Zoc. eit. and HTS 117:3945:2.

65. TCTC 203, p. 6426. "I know that P'ei Yen was rebellious. . . ."

66. CTS 87:3551:4 and TCTC 203, p. 6425.

67. TCTC 203, p. 6432. On Ch'eng, see CTS 83:3345:2 and HTS 111:3935:2. He had been a prominent and successful commander against the Turks and had been given a command in the Yü-lin Guard just prior to Chung-tsung's deposition, in which he assisted. This perhaps indicates a very close relationship to $\mathrm{P}^{\prime} \mathrm{e} i$ Yen. Two of his friends were also prominent among the rebels, so that his defense of $\mathrm{P}^{\prime} \mathrm{e} i$ may not have been the sole reason for his execution. The Turks are said to have rejoiced at his demise.

68. TCTC 203, p. $6432, k^{\prime}$ ao- $i$ which traces the incident to the T'ang t'ungchi, a source which Ssu-ma Kuang refuses to accept. The story is also found in HTS $76: 3867: 3$.

69. TCTC, Zoc. cit.

70. Discussed in Chapter 9.

71. TCTC 203, p. 6418. Chung-tsung had apparently been generous with his hunting attendants and one of them expressed dissatisfaction at his deposition. 
On the establishment of these attendants, see TCTC 195, p. 6141.

72. CTS 186 shang:3564:1.

73. CTS, Zoc. cit. and TCTC 203, pp. 6439-40. See also Fitzgerald, Empress Wu, pp. 115-117.

74. TCTC 203, pp. 6437-38, THY 55, pp. 956-59, Fonctionnaires, v. 1, pp. 143-46, and Feng-shih wen-chien chi 4, pp. 42-44. Some sources suggest there were originally four urns, only later united into one.

75. TCTC 203, p. 6438.

76. Ch'en Tzu-ang chi, pp. 216-17. The memorial is abstracted in TCTC 203, pp. 6440-41.

77. See Chao I, "Wu-hou chih jen," in Nien-erh-shih cha-chi, 19, pp. 25758 and the lengthy discussion in Hamaguchi, To ochō. The question is explored in Chapter 6.

78. See TCTC 192, p. 6031 and 193, p. 6080. Wechsler, Mirror, notes several occasions on which T'ai-tsung withdrew edicts on the advice of Wei Cheng or others.

79. On Liu, see Appendix B, no. 72. He was an early favorite of the empress, seconded P'ei Yen at Chung-tsung's deposition, and was paramount minister from the time of P'ei's death. On this occasion, he challenged the legality of an order to have him investigated for bribery and adultery.

80. TLSI $3: 1, \mathrm{pp} .40 \mathrm{ff}$. lists three types of punishment for errant officials. The first was removal from present office, the second the stripping of all posts including honorific ones, and the third "eradication of name." The latter was the most severe and meant that the official lost all offices and titles and paid tax and corvée according to his basic status (pen-se). Once convicted, a man could hand on to his sons none of the privileges of rank and was often himself without livelihood. The penalty of eradication was often applied together with those of exile or of chi-mo (TLSI 17:3, p. 40) in which the criminal himself, his father and son(s) were executed with the sole concession that those under fifteen and over sixty could be strangled rather than beheaded. His mother, daughter(s), wife and concubines, his grandfather and grandson(s), brother(s), sister(s), and slaves all became state property while his land, dwellings and property were confiscated.

81. TCTC 206, p. 6513.

82. TCTC 205, pp. 6491-92 and Fitzgerald, Empress Wu, pp. 150-151.

83. TCTC 203, pp. 6438-39.

84. TCTC 183, p. 6061.

85. The most famous was Hou Ssu-chih, a cake seller who rose to the Censorate after convincing the empress that illiteracy was no barrier to the fulfillment of his functions. TCTC 204, p. 6464.

86. TCTC 203, p. 6439.

87. For this rather insidious principle see TLSI 1:1, pp. 26-27. In 697 the empress commented that she had always seen the confessions of those who were executed. TCTC 206, p. 6523.

88. On Hsü Yu-kung, see CTS 85:3349:1 and HTS 113:3939:3. A summmary of the trials in which he acted as defender is found in TT 169, pp. 894c ff. and TFYK 616 and 617. A case could be made to suggest that the precedents set by the cases he won contributed to making the law more lenient during the terror.

89. TCTC 206, p. 6523. On Yao, see Appendix B, no. 122. The phrase I have translated as "followed their own interests" might be rendered "took care of things without hindrance."

90. CTS 183:3554:4 and TCTC 205, p. 6498. A censor had been given permission 
to examine the monk's conduct but Huai-i rode his horse into the courtroom, dismounted briefly, then rode out again. The empress did not order a retrial but gave the censor permission to exile the many ruffians with whom Huai-i had surrounded himself.

91. TCTC 203, p. 6437.

92. Sources here are contradictory. The Turkish raids, which had become a problem in Kao-tsung's last years, had increased in intensity and in early 685 the Chinese had suffered a great defeat in Hsin-chou, losing over 5,000 men. Three months later they were able to recoup their losses, and the An-pei protectorate was moved to T'ung-ch'eng to accept the surrender of the defeated tribes. TCTC 203, p. 6435 and Hu San-hsing locate the new center. I think the date given, however, is a year too early since THY 73, p. 1309, Ÿ̈̈-hai 133:20a, Yüan-ho chün-hsien t'u-chih 4, and Ch'en Tzu-ang chi, pp. 190 ff. suggest that the move occurred in conjunction with the abolition of the Shan-yü protectorate which was put under a garrison commissioner in the fifth month of 686. See also Ts'en, T'u-chüeh, pp. 309-20 for a full examination of events.

Ch'en Tzu-ang at this time had just left a post in Kan-chou, and the long memorial cited is our best contemporary source for the state of the Turks and the Uighurs in the period. In it Ch'en suggested first of all that the court discard its arrogant refusal to receive the so-called Shih-hsing tribes who had just inflicted heavy defeats on the Uighurs without instructions from China. Second, he suggested that the new An-pei protectorate be substantially strengthened and much better supplied in order to deal with the surrendered Turks. Finally, he recommended that since Kan-chou was the key to the defense of the Northwest and was also an object of plunder both to the Tibetans and the Chiu-hsing Turks, more Chinese should be settled there. Pointing out that the 3,000 kuan-hu there supplied scarcely a hundred good troops and were unable even to bring in the annual harvest, it was entirely possible that all three prefectures of Kan, Liang and Su would soon be lost to the foreigners along with the entire Ho-hsi region.

The situation he describes was all too typical of the protectorate system in the late seventh century. The memorial is also found in Ch'en Shih-i chi, 8.

93. In 689, Loyang for the first time produced more chin-shih than Ch'angan. Teng-k'o chi-k'ao, first year of yung-ch'ang.

94. See respectively, THY 69, p. 1213 [687], THY 69, p. 1213 [685] and THY 56, pp. 965-66 [685].

95. See, for instance, TCTC 205, pp. 6477-78.

96. The precise origins and definitions of ÿüan-wai officialdom are unclear. The Hu commentary, TCTC 201, P. 6356, suggests that the first time one of these supernumeraries received equivalent rank and emoluments (yüan-wai t'ung-cheng) was 654 but implies that the practice did not become widespread until 668 . THY 58 , pp. $1003 \mathrm{ff}$. lists many of these appointments as they were regularized in the Boards, and 1 have found that in the decade following 668, yüan-wai officials were added almost every year to one or another of them.

Because this was a time when officialdom generally was expanding, the new appointments were warranted and probably beneficial, especially in the Board of Civil office. In 697, however, a massive increase occurred when Li Chiao, in charge of the selection system, "began the establishment of several thousand yüran-wai-kuan." (TCTC 206, p. 6525.) I think this meant that the practice was extended to the provinces. Ironically, Li Chiao advocated a great reduction in these positions in 706 , contending that they performed no 
service but drew salaries and extorted from the people. CTW 247:26.

97. TT 7, p. 40c. See also THY 89, pp. 1623-4, Ÿ̈-hai 80:18b. On these problems, there are several useful remarks in Twitchett, Financial Administration, especially pp. $66 \mathrm{ff}$.

98. The literature on the question of registration and vagrancy has grown very large since the Tunhuang discoveries, and a good review of the problem is Nakagawa, "Tō-sō no kakkyo." Pulleyblank's comments in Background, pp. 27-32, are stili useful and the modifications suggested by Tonami, "Tō no ritsuryō," solve many of the outstanding questions. Li Chiao's thorough memorial of 695 on the problem has been translated by Balazs in "Beiträge," pp. $27 \mathrm{ff}$. Judging from his remarks, the problem had existed for some time but the measures of 684, mentioned earlier, seem to have kept it under control.

99. See THY 91, p. 1652 and TCTC 204, p. 6445 respectively.

100. See Chpater 4, note 28 . It is difficult to account for the attraction of the Chou- $Z_{i}$ al though the Confucian doctrine of rectification of names certainly played a part. Analects $11: 23$ and $111: 14$ provide a clue, the latter reading: "Chou had the advantage of viewing the two past dynasties. How complete and elegant are its regulations. I follow Chou." (Legge, Four Books, p. 31).

101. Pan Ku, Former Han, v. 3, p. 219. Like the Pao-t'u, the stone found in 6 A.D. was white with red writing. Seidel discusses omens of this kind in "Dynastic treasures."

102. CTS 6:3075:4, HTS 76:3867:3, and TCTC 204, p. 6449. See also the commentary to the Great Cloud Sutra translated in the preceding chapter.

103. Chapter 4, n. 96. Evidence from Tunhuang suggests a longer inscription.

104. TCTC 204, p. 6449 and HTS 76:3867:3. I have found no previous instance of a ruler adopting the title shen-huang though there may be some connection with the san-huang of antiquity or perhaps to the shen-huang of Taoist mythology who possessed the secret of immortality.

105. See Chapter 4 , note 80 .

106. TCTC 203, p. 6425.

107. HTS 76:3867:4. TCTC 204, p. 6449, suggests that after the discovery of the Pao-t'u, the empress determined to usurp and decided to el iminate the imperial clan.

108. See, for instance, Pan Ku, Former Han, v. 3, pp. 191-92, and Wright, "Sui ideology," pp. 89-90.

109. TCTC 204, p. 6449, which suggests that the princes were beginning to make plans to save the state (kuang-fu). See also CTS 64:3307:4, biography of Li Yüan-chia.

110. On Li Chuan, CTS 64:3307:4, HTS 79:3875:1; on Ch'ung, CTS 76:3332:3 and HTS 80:3877:1. On the rising generally, TCTC 204, pp. 6449-53 and Fitzgerald, Empress Wu, pp. 121-23. The imperial forces were not large, consisting of two armies of about 100,000 each.

111. TCTC 204, p. 6467. Ssu-ma Kuang points out that Princess Ch'ien-chin who had introduced the empress to Hsüeh Huai-i was the only adult survivor, and TCTC 205, p. 6485 offers a rough estimate of the number of victims.

112. TCTC 204, p. 6451 .

113. THY 50 , p. 865 .

114. TCTC 204, p. 6454 and HTS 76:3867:4. CTShih 5 preserves the verses she is said to have composed for the ceremonial at the Lo River. On the calendar, see TCTC 204 , p. 6462.

115. CTW $96: 20 \mathrm{~b}$, TTCLC $4: 1 \mathrm{~b}$. 
116. Chapter 4, note 82.

117. A suggestion of Lin Yü-t'ang in the novel Lady wu which 1 do not find very convincing. It is interesting to note, however, the legend that Yü was able to compose the Hung-fan after receiving the Lo-shu which was engraved on the shell of a turtle which emerged from the Lo River. Acker, T'ang and PreT'ang Texts, v. 1, pp. 85-94, looks at some legends of this sort.

118. TCTC 204, p. 6463. See Chapter 7.

119. Wright, "Sui ideology," pp. 93-104.

120. See Ch'en, Transformation, pp. $82 \mathrm{ff}$.

121. Wright, "Sui ideology," pp. 85-86, discusses the most notable example, that of the Northern Chou.

122. CTS $6: 3075: 4$.

123. HTS 109:3931:1. The diviner was attempting to show Chung-tsung that the Chou and T'ang were the same and that the course of events could have been predicted on the basis of eight signs.

124. Shigenoi, Tödai, pp. 216-33.

125. Ta-fang teng wu-hsiang ching 6, TD 12:1107a.

126. Chapter 4, n. 157.

127. TCTC 204, p. 6467.

128. Tz'u-ÿ̈аn, p. $1688 \mathrm{~b}$.

129. See Legge, Book of History, v. 2, p. 298. The comparison may seem forced, but in view of the preceding replication of Chou symbolism and the fact that the empress was to choose red as the color of her banners, it does not strike me as unreasonable.

130. CTS 6:3076:1, HTS 76:3867:4, and TCTC 204, p. 6467.

1. See Chapter 1 , notes 46-49.

2. See Miyakawa Hisayuki, "Outline of the Naitō hypothesis," and Miyakawa Ichisada, "Four ages."

3. The thesis is presented most systematically in Parts 1 and 11 of Chengchih shih, pp. 1-94.

4. Ch'en, Cheng-chih shih, p. 14.

5. See, for instance, Wechsler, "Factionalism," in Perspectives, pp. 87120, and the several remarks in Johnson, Oligarchy, pp. 128-130. In an earlier version of his work, Johnson listed three broad categories of objection to Ch'en's thesis, and these seem worthy of mention here. In the first place, Ch'en's belief that the ruling class polarized along historico-geographical lines because of the rivalry between Chou and $\mathrm{Ch}^{\prime} \mathrm{i}$ does not give sufficient weight to the fact that the imperial clans of both originated in the so-called Four Garrisons, and that the ruling group in both was composed of precisely the same type of clan; that is to say, of Hsien-pei and collaborating Chinese who were not numbered among the preeminent surnames of the time.

This latter fact is important because while the refusal of the northeastern elite to collaborate with the $\mathrm{Ch}^{\prime} \mathrm{i}$ and the Sui is well-known, the corresponding attitude of the northwestern clans usually goes unremarked. Liu Fang, in his Hsing-hsi Zun (see note 8), identified as the preeminent of the Northwest the six clans of Wei, P'ei, Liu, Hsüeh, Yang and Tu. While they were prominent in the government of Sui and T'ang, they seemed to play hardly any role at all in the Chou central administration and so can hardly be 
identified with Yü-wen T'ai's "northwestern bloc." The imperial clans of Sui and T'ang both claimed kinship with the purely Chinese elite of this area, but it is well established that these were spurious claims and that both were of six Garrison (Wu-ch'uan) origins. For this reason there seems no cause to assume a political polarization of the T'ang ruling class on purely regional grounds. I shall later show that friction arose more from perceptions of cultural and racial purity than from geography.

The second criticims of Ch'en's formulations is one applied to his definitions. To him the T'ang "ruling class" consisted of "the [imperial] Li clan and the high civil and military officials," so that the local and semi-official power structure receives too little consideration. His use of such terms as "class" and "social revolution" are rather vague and, more seriously, his attempt to divide the so-called Shan-tung and Kuan-chung blocs by the existence of the T'ai-hang Mountains is hardly adequate. To cite only one example, the native place of the Empress Wu 1 ies to the northwest of the range yet, as I shall show, she was considered by contemporaries to be an "easterner."

Finally, Professor Ch'en seems never to resolve a basic contradiction. After depicting so clearly the regional rivalry in Part 1 of his book, he moves on in Part $\mid 1$ to the struggle between the new [post-Empress Wu] and the old elites, writing on p. 53, "Before the Empress Wu destroyed the old 'Kuan-chung First' policy, the T'ang ruling class had been made up not only of the Chinese, non-Chinese, and semi-Chinese clans of Yü-wen T'ai's northwestern bloc, but also of the great Shan-tung clans who in tradition followed that of the northern dynasties. Men of this type composed almost the whole of the upper bureaucracy. . . " [My emphasis]. A comparision of this passage with that quoted in the text shows a direct contradiction, caused by an initial failure to define closely the ruling class.

These criticisms, of course, do not invalidate Ch'en's work, but they do suggest that some modification is required.

6. Of several reasons which could be cited, the most important is that extant sources provide information on only a tiny proportion of the T'ang population, and that with the exception of the Tunhuang manuscripts, no local history has survived. Twitchett, "The composition of the T'ang ruling class," in Perspectives, pp. 47-85.

7. See CTS 149:3479:3 and HTS 132:3975:3.

8. The full text is found in CTW $372: 7 a-11 b$ and in an abbreviated form in HTS 199:4093:4. It is the only lengthy discussion of the subject remaining from T'ang times.

9. This distinction was the most crucial in medieval status terminology and was sanctioned both by law and by custom. While shu is rendered conventionally by "commoner," the term shih has yet to find a suitable English equivalent, and rather than use "scholar," "gentry" or "literati," I prefer to leave the word in its Chinese form and define the characteristics of the group.

The best studies on the term are Niida's Shina and his supplementary remarks in "Rikuchō." Miyakawa, Rikuchōshi kenkyū (Tokyo, 1956) attempts to make the distinction a precise one, and Mao, Liang-Chin demonstrates the wide range of status terminology used even within the shih class. Miyazaki's Kuhon shows that the meaning of shih varied over time and differed in North and South. Johnson, OZigarchy, Chapter 1, pp. 5-17 elaborates upon some of this research. Working from these studies, the following salient characteristics of the shih in the early T'ang might be isolated: 
(a) They were generally and by social convention recognized to constitute a class distinct from the shu.

(b) The criminal code granted them no concessions on the basis of social as opposed to occupational status (Johnson, Oligarchy, p. 8).

(c) They were exempted from corvee, and this privilege was a mark of their social status (Miyazaki, Kuhon, p. 249, and Mao, Liang-Chin, p. 283).

(d) State schools, both central and provincial, tended to admit only the shih, but Miyazaki's view ( $p$. 247) that education was reserved to the shih is an overstatement.

(e) Shih status depended principally upon the sanction of other shih and was beyond the power of the emperor to confer (Chou, Wei Chin, pp. 99-100).

(f) The hallmark of the shith was culture: morality, high standards of conduct, loyalty to discipline and tradition, a certain commitment to noblesse oblige and to the self-consciousness of class. Within these limits, it was an hereditary status.

(g) The shith were distinguished by an exclusive marriage circle and by a determination not to marry below their station (Mao, Liang-Chin, pp. 230-37).

There was no statutory ban on marriage with commoners ( $\mathrm{Ni}$ ida, "Rikuchō," p. 22).

(h) Status and officeholding were closely connected. Commoners found it exceedingly difficult to enter the bureaucracy and, although never barred de jure from officialdom, tended to rise only in unusual circumstances, chiefly through military prowess in periods of dynastic change. For the shih, state service was an important means of preserving their status, but it was not all-important, and culture and lifestyle combined with social recognition permitted some clans to eschew office while retaining prominence. See, for example, Ochi Shigeaki, "Nancho no koseki mondai," Shigaku zasshi, 69:8 (1960), pp. 940-64. Shih status could be gained by office, but office was granted generally only to those who already possessed shih status.

It is this final point which has led Japanese scholarship in this century to characterize the entire post-Han era as that of the "aristocratic society" to which Toyama's book of readings Kizoku shakai provides an excellent short introduction. Johnson, Oligarchy, pp. 5-45, is a most useful new addition to the 1 iterature on the subject.

10. A term discussed later in the chapter. I prefer the translation "magnate clans" which perhaps conveys something of the close regional ties, military prowess and "feudal" organization which seem to have been common to their tradition. Liu Fang provides a useful insight here, for by T'ang times the term seems to have included a connotation of opposition to centralization and was applied most frequently to the northeastern clans.

11. The term yu-hsing is used consistently throughout the essay as the generalized description of the most important clans on the national level.

12. These terms have received less attention than shih and shu, probably because the latter was the more common distinction until the middle T'ang. Several translations, such as "noble and base" or sometimes "free and unfree" have been used, but these are not altogether satisfactory since chien is often used for servants, slaves, artisans, merchants, prostitutes, etc., and kuei seems often to have been highly relative and to have meant simply "non-chien." It was replaced by the term liang "free" in T'ang law. There now exists a full study of the chien class in the T'ang. The opening chapter in Hamaguchi Tó ócho discusses the distinction.

13. It was members of this group who were most prominent in the high officialdom of the early T'ang and who constituted Professor Ch'en's "Kuan-chung bloc." 
On the ssu-hsing question which follows in Liu's essay, see Johnson, OZigarchy, pp. 28-30, and note TCTC 140, p. 4394, where Hu San-hsing anachronistically applies the term to the first four clans of the realm. This seems to have been T'ang usage.

14. The only mention I find is in T'ai-p'ing kuang-chi 184:4la, and the bibliographical treatises of the T'ang histories make no reference to the monk's work. The T'ung-chih, chüan 66 which is probably our most complete listing of genealogical works, mentions neither this nor the next two works listed by Liu Fang.

15. I find no other reference, though the title seems to indicate that this was a statewide compilation.

16. Again I find no details of this work, and it seems odd that it goes unmentioned at the time the Shih-tsu chih was compiled. As the first work since the Han to apply to the entire country, it should have been a primary source of reference. In this connection, we might note the growing tradition in northern dynasties of compiling national status lists, and the parallel development whereby the definition of preeminent surnames came increasingly to be divorced from local prominence. It seems clear that whereas in the Wei each prefecture had its preeminent surnames, these later compilations listed only clans of wider prominence and, therefore, some prefectures would go wholly unmentioned.

It is important to note here that the term mao-hsing seems to refer to Chinese clans of long and proud lineage and suggests that the Sui was more ambiguous than is generally thought in its "anti-aristocratic" policies.

17. On Lu, see CTS 189 hsia:3577:1 and HTS 199:4092:3. His work is attested in the CTS, HTS, TFYK, T'ung-chih and $Y \ddot{u}$-hai which also mention an earlier compilation called the I-kuan p'u. He died in prison in 696 and is considered by Liu Fang as the father of T'ang genealogical studies.

18. CTW $372: 7 a-11 b$.

19. Numerous anecdotes from the dynastic histories could be cited to demonstrate this, and some are to be found in Ikeda On's draft chapter for Volume 3 of the forthcoming Combridge History of China, "The decline of the T'ang aristocracy." We might also note, for instance, Non-shih 56:1754:4 which tells of a man who had the "bearing, [official] qualification and style" of the shih and requested the Southern $\mathrm{Ch}^{\prime} \mathrm{i}$ emperor to confer the status. After consultation with his social arbiters, the emperor had to confess that he could do nothing since "the shih-ta-fu really stand beyond my authority [in this matter]."

Chou, Wei Chin, pp. 98-99, cites this anecdote to demonstrate the snobbery and the necessity of peer recognition which were part of the shih group, but it seems equally valid to suggest that it was lack of lineage which led to the rejection of the aspiring shih.

Wei-shu 60:2035:2 contains a memorial from Han Hsien-tsung asking that shih $\amalg$ and shu 庶, have separate living quarters in Loyang rather than being assigned their places on the basis of official rank. In it, Han contends that official rank is transient, its holders rising and falling. On the other hand, if artisans were to cultivate the conduct and standards of the shih, they would not reach the status in a hundred years. He went on to say that if the sons of the shih followed the behavior of the artisans, they would become like them in a single morning.

Some scholars, for instance Johnson, OZigarchy, p. 8, see this as a denial of the hereditary principle. I believe that Han is suggesting that shih status can be lost but that "conduct and standards" are in themselves insufficient to gain the status. The emperor might bestow high office or expose 
non-shih to their superiors in the hope of raising their status but, according to Han, both tactics are futile.

These examples suggest, therefore, that while office and culture are attributes of the shih, they are not the determinants of the status. I shall later attempt to show the tenacity of the hereditary principle in relation to the early-T'ang attempts at status fixing and even in the form taken by its regulations concerning the examination system.

20. Said in relation to Wang Hung, Sung-shih 42:1550:4, an imperial favorite who sought shih status. Similar statements are found in Miyakawa, Rikucho, pp. $376 \mathrm{ff}$. and Chou, Wei Chin, pp. $99 \mathrm{ff}$.

21. The secondary literature on this subject is large, and T'ung-chih 66, pp. $783 \mathrm{c} \mathrm{ff.} \mathrm{gives} \mathrm{some} \mathrm{idea} \mathrm{of} \mathrm{the} \mathrm{volume} \mathrm{of} \mathrm{these} \mathrm{compilations,} \mathrm{1isting} 131$ works in the four categories of arrangement, those by rank, rhyme, single area and single clan. Cheng $\mathrm{Ch}^{\prime} i a o$, T'ung-chih erh-shih-Züeh $1: 1 \mathrm{~b}$, tells us that under the T'ang, "the study of lineage and clan reached its zenith." A good overview of the subject is the important article by Utsunomiya, "Tōdai kijin." A number of studies cited in later notes shows the prevalance of falsification.

22. CTW 372:10a. This passage offers an interesting insight into Ch'en's Northwest-Northeast hypothesis. The greater role of Kuan-chung in the government of the early T'ang was perhaps as much a matter of choice and regional proclivity as of dynastic policy.

23. THY 37, p. 663 .

24. CTS 57:3292:4. The minister is P'ei Chi (Appendix B, no. 2) who, though poor in his youth, considered himself a member of the eminent Ho-tung P'ei clan which is systematically studied by Yano, "Kizoku seiji." Note also Kao-tsu's conversation with Tou Wei (no. 5), CTS 61:3301:1, in which he speaks in a similar vein.

25. The lengthy debate on the origins of the T'ang clan has centered chiefly on whether their lineage was purely Chinese or Hsien-pei, and $\mathrm{Ch}^{\prime} \mathrm{en}$, Kuo-shih chiu-wen, v. 2, pp. $2 \mathrm{ff}$. collects most of the important data. Ch'en Yin-k'o has three articles on the subject in CYYY but his suggestion that they were a decayed branch of the Chao-chün Li clan seems to have been effectively rebutted by Chu Hsi-tsu, "Po Li-T'ang," and Liu P'an-sui, "Li-T'ang." Though conflicting evidence makes the problem very vexing, I am of the view that the Lung-hsi connection was false and that it should be seen in the same light as the Sui attempt to claim connection with the eminent Hung-nung Yang clan.

26. On the bride gift, see Okamoto, "Tōdai heizaikō." Okamoto shows that the gifts were often of very great value and as important as the letters of engagement in formalizing the marriage. Since the northern dynasties the state had attempted to define the gifts in terms of official rank, but social status seems to have been of greater importance. See also TRSI 9:27 and 30, pp. 245 ff. and Nien-erh shih cha-chi, chüan 15, v. 1, p. 197.

27. On the compilers, see respectively Appendix B, no. 15; CTS 77:3333:2 and HTS 98:3910:2; Appendix B, no. 26; and CTS 73:3325:4 and HTS 102:3918:3. The large literature on the subject is extremely well reviewed by Ikeda's "Tōchō." In this literature the background of the compilers is generally neglected.

The reason for their choice is difficult to know. Te-fen and Wen-pen had been the compilers of the Chou-shu in the large project of 629 and so could claim historical expertise, but neither of the other two seem to have been distinguished scholars. Both of them, however, were from relatively eminent clans, both held the highest positions in the Board of Civil office, and both had present marriage connections with the imperial clan. The Ling-hu and Wei clans 
shared the background and regional origins of the T'ang, and the grandfather of Ts'en Wen-pen had been closely identified with the Later Liang and so may have been included to represent the South in an attempt to achieve regional balance.

Kao Shih-lien was probably the key figure, not only as head of the project but as the only northeasterner in it. He claimed descent from the imperial clan of $\mathrm{Ch}^{\prime} \mathrm{i}$, and thus his Six Garrison origins and the fact that he was the uncle of T'ai-tsung's wife would effectively set him apart from the four great northeastern clans against whom the 1 ist was directed.

Therefore, although the chief compilers reflected the regional balance typical of the upper bureaucracy in the early T'ang, it is difficult to escape the conclusion that the group constituted a "packed jury." Their first verdict must have been a great surprise and attests to the overwhelming prestige of the northeastern clans and the dichotomy between office and social status which was still so strong.

28. Ikeda, "Tōdai," in perhaps the most important study to date correlates Tunhuang evidence with later sources to reconstruct the fullest list of eminent T'ang clans. Interestingly, the Wang and the Hsieh do not seem to appear in the lists. Moriya's classic study of the T'ai-yüan Wang clan, Rikuchō, identifies two branches early established in the South and remaining prominent for three to five centuries, so it may be to one of them that T'ai-tsung refers. Both of the northern Hsieh clans mentioned by Ikeda had southern branches.

29. T'ai-tsung is reported to have chosen marriage partners for the imperial clan only from the households of his meritorious ministers and to have refused even to discuss the possibility of a northeastern marriage (TCTC 200, p. 6318). $\mathrm{His}$ great ministers, however, men like Wei Cheng, Fang Hsüan-ling and Li Chi, did not hesitate to seek brides from these clans once their fortunes were made. This was an important phenomenon since it was not only the bride gift but the influence of and aid from in-laws at court which helped keep these clans solvent.

See also Nunome, Zui-Tóshi, pp. 358-9 and 362-3, which offers a complete list of the marriages of T'ang princesses, confirming the boycott of the northeastern elite.

30. This was Ts'ui Min-kan whom the dynastic histories call Ts'ui Kan since "min" was a taboo character under T'ai-tsung. The Ts'ui clan was composed of ten branches and Min-kan belonged to that of $\mathrm{Ch}^{\prime}$ ing-ho. At the time of the list, he was vice-president of the Chancellery, a post of the fourth rank, and Wei T'ing was his opposite number.

The diction of CTS 65:3309:3 creates something of a problem here, since the passage in question is usually interpreted to mean that Ts'ui was placed above the imperial clan. I am not sure this was the case. The rather sketchy descriptions of the Shih-tsu chih which remain tell us that the work contained 100 chüan and placed all the preeminent clans of the empire in nine ranks. It seems unlikely, therefore, that there would be only one clan in the first rank and T'ai-tsung was probably objecting to equality rather than superiority.

It would be well to take note here of two possible interpolations in the parallel HTS account found in 95:3903:4. In the first T'ai-tsung is said to have instructed his compilers to "rank first the imperial house and follow it with the consort families. Demote new clans and promote the old, placing the great (kao-liang) on the right and the lesser (han-chün) on the left." Second, just before pointing out that he wished to honor the officials of his own court, he is reported to have said, 'For many unbroken generations to be kung, ch'ing, or ta-fu--that is what should be defined as a great family (men-hu)."

Both these statements are somewhat suspect since they contradict the 
main criterion for inclusion, that is, present official position. Since this is confirmed in every other source, the HTS statements must be rejected. They do, however, illustrate the quandary in which the compilers found themselves and suggest the possibility that the finished work was organized in such a way that the first two ranks were monopolized by the imperial and consort families with the other clans spread through the remaining seven.

31. CTS 65:3309:2. See also TCTC 195, pp. 6135-36 and THY 36, p. 664.

32. Moriya, Rikucho, especially pp. 135-36, shows how narrow the marriage circule of the T'ai-yüan Wang, who were often grouped with the northeastern ssu-hsing, remained throughout the T'ang; and an unpublished M.A. thesis by Saito Aiko for Tokyo University has shown in meticulous detail that this was true for the other super elites of the Northeast. The contrast with the LiT'ang clan, whose first rulers had married into the Tu-ku, Tou, and Ch'ang-sun clans, should be noted.

The refusal to marry with foreigners was principally a matter of pride, but a suggestion by Ts'en, Sui-T'ang shih, v. 1, p. 117, has merit. He points out that dissociation from the central power of the foreign regimes was also dissociation from exploitation of the peasantry and so became a source of popularity among the people.

33. TCTC 143, pp. 4393-6. The passage also offers some information on the Wei perception of the ssu-hsing and their relation to the Lung-hsi Li clan. The northeastern elite was not wholly successful in preserving its daughters from the foreigners.

34. For a general exposition of the clan rules, see Liu, Clan Rules. In the T'ang the two most celebrated sets of rules were those of Mu Ning and Han Shou, both from prominent northeastern clans. See CTS 155:3487:3 and HTS 163:4026:1. Among the ssu-hsing, the Ts'ui were most famous for their life style, cohesiveness and piety. See, for instance, HTS 182:4062:2, the biography of Ts'ui Tzuyüan, and note how the qualities they instilled in members suited them for official careers and maintained them as the predominant T'ang clan. The biography of Ts'ui Hsüan-wei (Appendix B, no. 132) contains an admonition from his mother, née Lu, that as he embarked upon his official career he should not seek profit for himself or his clan but seek only honesty and integrity. Another fine example of clan rules are those of Liu Tz'u (CTS 165:3508:2) whose seat was near the capital but who had close marriage ties with the Ts'ui. See also Utsunomiya, "Tōdai kijin," pp. 493 ff. and Takeda, "Tōdai shizoku."

35. The best-known case is that of Ts'ui Hao whose execution in 450 led to the decimation of the entire northeastern aristocracy. See Wang 1-t'ung, "Ts'ui Hao."

36. Evidence could be adduced to support each of these points, and I suspect that these are what T'ai-tsung had in mind when he suggested that the people of Kuan-chung and Shan-tung were different in their way of thinking (CTS 78:3336:4). An incomplete study I have made of the data in the HTS tsai-hsiang table suggests that in the two generations from the inauguration of the Sui to the death of T'ai-tsung, the number of officials produced by the northeatern ssu-hsing was proportionately almost the same as that of six super elite clans of Kuanchung identified by Liu Fang but, as several scholars have suspected, the proportion of central officials was appreciably lower. Interestingly, a fairly high proportion of these provincial appointments was made in the Northeast in spite of the fact that since the sui attempts had been made to restore the Han practice of avoidance. The reasons, I think, are the same as those in the northern and southern dynasties recently explored by Kubozoe's "Gi-Shin." The 
long resistance of the Northeast to the T'ang and its continuing hostility meant that Kao-tsu and T'ai-tsung not only used intermediaries like Wei Cheng and Ts'ui Kan there but seem also to have permitted the region a greater degree of autonomy. See, for instance, TCTC 186, p. 5823.

A current debate in Japanese scholarship concerns the precise relationship between the aristocracy and the rural community (hsiang-t'ang). What seems clear, however, is that the peasants, even in the T'ang, were still in the habit of looking to the great clans in their area for relief in times of calamity. The early T'ang seems to have been slow to usurp these relief functions in the Northeast, and I shall show that Kao-tsung and Empress Wu were more active in this respect.

37. See Pulleyblank, Background, pp. $75 \mathrm{ff}$. and the literature reviewed there.

38. See, for instance, Ch'en Yin-k'o, "Hao-chieh," which stresses the cohesion and military prowess of the group, demonstrating that T'ai-tsung's coup depended on them. Matsui, "Tōdai," shows that the term was also used commonly for the aristocracy of the Southwest which shared many characteristics with those in the Northeast. Kikuchi, "Setsudoshi" is the best short treatment of the haochieh as a distinct group and their influence on the societal structure.

39. CTS 82:3343:4 and TCTC 200, p. 6315. I am sceptical about this in view of the forced revision, the treatment of the northeastern ssu-hsing, and the fact that the quoted passage occurs only in the biography of Li I-fu. It met approval, I think, only in relation to the Hsing-shih-Zu.

40. TTCLC 110:4a, TFYK 159:7a, and THY 83, p. 1528. The ban was issued in the sixth month of 642 and is discussed with its secondary literature in Ikeda, "Tōchō," pp. $51 \mathrm{ff}$. In it T'ai-tsung again attacks the northeastern clans saying that traditions and standards of conduct there have declined, and while the clans still enjoyed local prominence and renown, they had fallen into poverty and rejected the propriety of marriage by interesting themselves primarily in the wealth of those clans who wished to marry with them. They turned weddings into a business proposition. Although T'ai-tsung accused the clans of Shansi (Yen-Chao) of the same fault, his regional bias is clear.

41. TCTC 200, p. 6318.

42. See Appendix B. Ts'ui Jen-shih was from Ting-chou in Ho-tung, and $I$ find no relationship with the eminent Ts'ui of Ho-pei.

43. The sources disagree. CTS $82: 3343: 4$ claims that Li I-fu initiated the recompilation because his clan was unranked, and TCTC 200, p. 6315 says Hsü Ching-tsung asked for a revision because the empress' clan was unranked. HTS 95:3903:4 and THY 36, p. 665 cite both reasons. I find it hard to believe, in view of Shih-huo's career, that the Wu clan was unranked and prefer the THY wording: "was not clearly ranked." This would suggest that the empress was unsatisfied.

Li I-fu was very conscious of his inferior clan status and falsely claimed membership in that of the Chao-chün Li clan. He had to resort to intimidation to enforce the claim but when he attempted to use his false status to marry his son into the northeastern elite, he was rebuffed. His motives for desiring a new list were therefore strong, and he may also have inspired the marriage ban issued the same year that he was attempting to marry his son. See TCTC 200, p. 6318.

44. The compilation of 659 was delegated to twelve men of whom we have the names of only five. Of these, only Li I-fu and Lü Ts'ai (CTS 79:3338:4 and HTS 107:3926:4) are known in any other context. With the exception of Li 1-fu, none occupied a position above the third rank, and one even held a liu-wai post! 
Since the compilers represented neither great clans nor the upper bureaucracy, a new concept of status was reflected in their choice.

45. The table is based on information found in all the standard sources and follows that of I keda, "Tōchō," p. 48.

The chief differences lie in the size and scope of the works. In addition, the Hsing-shih-lu makes an exact correlation of official rank and rank within the treatise and deletes all but the immediate family of the man ranked. The list of 659 was much larger than its predecessor and reflects the growth in officialdom and in the number of persons rising through the military in a time of foreign expansion. The approximate number of clans and persons ranked is difficult to know because we are by no means sure that the term chia '家 is similarly used in both lists, nor indeed are we certain of the exact meaning of the term. Johnson, Oligarchy, pp. 91-92, sees chia as a subdivision of hsing 姓 which might be translated as "surname" or "descent group," and this seems justified in view of the form of the list. We must be cautious, however, about equating chia here with "family" or "household," a unit in T'ang times of five or six members, since if we did so we would find ourselves with an unbelievably small ruling class--less than $.02 \%$ of the population. In the table I have chosen to translate the term chia as lineage in full realization that the rendering is unsatisfactory, but in the hope that it will underline the fact that we are dealing with a special sort of "family." Imabori, "Tödai shizoku," convincingly establishes a difference in the size of shih and shu households, and Niida, Shina, p. 337, suggests an average figure of ten persons in what would here be termed a chia. This, of course, is about double the size of an ordinary hu. Moriya, Rikuchö, pp. $143 \mathrm{ff}$. assembles evidence of a much larger figure but, after finding that a hundred was not uncommon, is reluctant to use the figure. Judging from specific cases of clans punished by Empress Wu, I would tend to put the number of individuals in a chia at between ten and thirty in this case. See, for instance, TCTC 200, p. 6317, and 206, p. 6513.

46. CTS 82:3343:4. HTS 223 shang:4163:4 uses the term ch'ang-shih. This is rather puzzling. Since a stated aim of the compilation was to form a nexus between status and official rank, it could hardly be left unrevised and was probably intended to serve as the basis of future lists.

47. CTS 82:3343:4, HTS 223 shang:4163:3, and THY 35, p. 665. I keda and Johnson are both of the view that the burning did not serve its purpose since the list of 707 was to be based on the Shih-tsu chih. This shows, however, only that some copies survived and underestimates the symbolic importance of the act. In any case, the Hsing-shih Iu was the standard of status measurement for half a century of rapid social change and so of greater importance than T'aitsung's compilation.

48. Note 36 above.

49. CTS 82:3343:4, HTS 95:3904:1, THY 83, pp. 1528-29, TCTC 200, p. 6318, and $y \ddot{u}-h a i$ 50:25a. In the ban seven surnames and eleven chia were forbidden to intermarry, and the bride gift was limited so that chia of the third rank or above could receive $300 p^{\prime} i$ of silk [a $p^{\prime} i$ was 1.8 by $40 \mathrm{feet}$ ] and one of the eighth rank received fifty $p^{\prime} i$. It had also been the practice, if the groom's house were higher than the bride's, for his chia to accept double these gifts. This was now forbidden.

50. See the studies of Moriya and Saitō cited above, and Tsukiyama, Tödai, pp. $163 \mathrm{ff}$.

51. Chung-tsung reissued the ban, probably in 707 when the new clan list was 
compiled. The standard sources do not mention the event but, judging from WYYH 900:7a, this final prohibition specified five surnames, mentioning the Northern We $i$ head of the clan by name and numbering the sons of each, so that the decendants of a total of forty-four men were forbidden to intermarry. In the case of the Ts'ui, eight generations were represented so that the scope of the ban was wide, including perhaps 300 chia.

52. On the fondness of the empress for Loyang, see Ch'üan, T'ang-Sung and Ts'en, Sui-T'ang shih, v. 1, pp. 142-47.

Both political and economic factors were present in the lengthy sojourn of the court at Loyang from the time of the empress' rise, and while I accept the belief that there existed antipathy between her and the northwestern clans concentrated near Ch'ang-an, I also believe that she and Kao-tsung were attempting consciously to reconcile the Northeast. It is significant that immediately after the marriage ban in the intercalary tenth month of 659 , they went to Loyang where they were to stay for two years. This was, incidentally, a prosperous time in the Northwest and a period of drought in Ho-pei. In 660 there was a good deal of construction in Loyang--palaces, bridges, marketplaces, etc., and it was also from here that Su Ting-fang's great Korean expedition was launched. See THY 30, p. 560 and 86, p. 1577, and TCTC 200, p. 6320.

The growing importance of Loyang had been evident from about 656 when the first new palace in many years was built there (THY 30, pp. 551-2 and note the reasons why the first T'ang emperors did not build there), and when in early 657 the officials at Loyang were declared in all respects equal to their Ch'ang-an counterparts. THY 68, p. 1190. As noted earlier, Loyang became the Eastern Capital at the end of that year. It seems clear that the emphasis on Loyang reflected not only an appreciation of political and economic realities but, more specifically, was an attempt to reconcile the Northeast. In 660 when Kaotsung and the empress made a well-publicized trip to Ping-chou, the geographical origins of the empress were further emphasized.

53. The exception was the Cheng clan of Jung-yang, and T'ang-kuo shih-pu, shang, p. 21, tells us that even in the T'ang they were considered reluctant to move from their native place. My calculations show the following distribution of tsai-hsiang from the ssu-hsing:

$\begin{array}{lcccc}\text { Kao-tsu } & \text { T'ai-tsung } & \begin{array}{c}\text { Kao-tsung } \\ \text { (from }\end{array} & \text { 659) } & \text { Empress Wu } \\ \text { Ts'ui } & 0 & 0 & 2 & 4 \\ \text { Lu } & 0 & 0 & 1 & 0 \\ \text { Li } & 0 & 0 & 2 & 6 \\ \text { Cheng } & 0 & 0 & 0 & 0\end{array}$

54. CTS 189 hsia:3578:1, and see Utsunomiya, "Tōdai kijin," p. 59 for other sources. The work was suggested in 707 and completed seven years later. See also Ikeda, "Tōchō," pp. 48 and 56. Lü, Sui T'ang, p. 788, contends that this was the last of the state-sponsored treatises, and although there is evidence of other, much smaller works (Utsunomiya, "Todai kijin," pp. $59 \mathrm{ff}$. ), this was certainly the last large-scale manifestation of state concern with status fixing.

55. The compilers were all high officials. Headed by Wei Yüan-chung (Appendix B, no. 121) and Chang Hsi (no. 124), they included five Board vicepresidents, most of whom were concurrently appointed to the History office. Wei's death put a temporary stop to the project but Liu Ch'ung, who made the original proposal, continued to work with the historians Wu Ching and Liu 
Chih-chi and five others to complete the project. Hsüan-tsung had it corrected and brought up-to-date by Liu Ch'ung, Liu Chih-chi and Hsüeh Nan-chin. See THY $36, p .665$. The same source notes that Liu Chih-chi had recently created a stir by publishing the first honest and critical genealogy of his clan.

56. TFYK 560:20b. See also CTW 235:2a.

57. TFYK 560:21a.

58. CTS 189 hsia:3578:1. The use of the Shih-tsu chih as a model is usually explained in terms of an aristocratic revival after the chou. I doubt, however, that this was the case as early as 707 , and I suspect rather that it reflects a nostalgic wish to associate the era with "the good government of chen-kuan" and to eradicate the influence of Empress Wu in as many respects as possible.

59. The story is told of Hsüeh Yüan-ch'ao (Appendix B, no. 61) and is found in T'ang ÿu-Zin 4, pp. 140-41. Interestingly, his biography tells us that he was a compiler of the kuo-shih while attached to the Hung-wen kuan and also that he was married to a T'ang princess. The anecdote may therefore be apocryphal, but if not, his preference in wives is doubly interesting.

The T'ang-kuo shih-pu contains several anecdotes of the sort.

60. See, for instance, the essay from Shen Kua's Meng-ch'i pi-t'an translated by Twitchett, "T'ang ruling class," in Perspectives, pp. 54-56.

61. My own estimate. See note 45 above.

62. TCTC 200, p. 6308, from a memorial by Liu Hsiang-tao, discussed in the following chapter. Liu counts 13,465 Ziu-nei officials in 657 and says that 1,400 more entered the bureaucracy annually. The list of 659 was to include those who had reached the fifth rank, perhaps one-tenth of this figure. of these higher posts there were a total of about 3,000 in capital and provinces so that, considering the figures in the Hsing-shih $Z u$, it seems clear that we are dealing with a highly inbred bureaucracy.

63. There is a fairly full literature on the subject, including the studies of I keda, Takeda and Twitchett mentioned earlier. In addition, see Niida Noboru, "Stein," and Mou Jun-sun, "Tun-huang."

64. The most important are Peking wei 79 and Stein 2052. Four fragments collectively numbered Stein 5861 and Pelliot 3191 may, according to Ikeda, be part of a whole. Another Pelliot fragment, no. 3421, may be related. I had intended to discuss these documents in detail because 1 am reluctant to accept all of Ikeda's conclusions, but Johnson, Oligarchy, pp. 64-87, has recently outlined the relationship and filiation of the documents with great care. I am not sure, however, that his view of the purpose of the lists is convincingly established.

65. Principally the T'ai-p'ing huan-ÿ̈ chi, a Sung geography by Yüeh Shih, the Kuang-ÿ̈n rhyming dictionary, and the genealogical work Ku-chin hsing-shih shu pien-cheng. See Ikeda, "Tödai," pp. 314-18.

66. Because the Tunhuang documents give only hsing and not chia and are so very fragmentary, comparison is difficult. Still, they list about five hsing per prefecture, while the state lists of 638 and 659 average less than one, so that even allowing for uneven distribution, the multiple of five seems reasonable.

67. To avoid a major inconsistency of Professor Ch'en Yin-k'o, I must specify here that the term "national elite" henceforth includes the preeminent clans of the Northeast. These were, I have suggested, well represented in the Hsing-shih Iu and increasingly accepted high posts in the central government from 659 . Analysis of the T'ang tsai-hsiang, or chief ministers, has recently become conventional among scholars despite the shortcomings of the group as a 
representative sample. Johnson, OZigarchy, Appendix 1, pp. 204-206, outlines some of the problems and advantages of using the sample and on p. 138 offers the following breakdown in "chief ministerial man-years":

Period

618-626 (Kao-tsu)
$627-649$ (T'ai-tsung)
$650-659$ (Kao-tsung)
$660-683$ (Kao-tsung and Wu-hou)
$684-704$ (Wu-hou)
$705-711$ (Chung-tsung and Jui-tsung)
$712-735$ (Hsüan-tsung)
$736-755$ (regime of Li Lin-fu)

Great Clan (claimed)

$\begin{array}{lc}91.8 & (38.8) \% \\ 63.2 & (15.9) \\ 40.0 & (8.0) \\ 53.3 & (1.8) \\ 53.1 & (0.4) \\ 56.3 \quad(1.0) \\ 52.2 \quad(4.4) \\ 50.0(38.6)\end{array}$

Non-Great CZan
$8.2 \%$
36.8
60.0
46.7
41.7
40.6
47.8
50.0

Although Professor Johnson seems to recognize the existence of unusual situations in 618-626 and 736-755 which might distort his conclusions, he uses these figures as his principal evidence in refuting Ch'en Yin-k'o's notion of the rise of a new class during and after the regime of Empress Wu. I do not accept his view.

In the first place, the use of "man-years," even if combined with the very different matter of individual appointment, can be extremely misleading and is valid only when placed in the context of the evolution of tsai-hsiang policy and the differing views of the institution held, for instance, by T'aitsung and the Empress Wu. T'ai-tsung's "usurpation" and Empress Wu's destruction of the entire tsai-hsiang group who had opposed her rise were events that were perhaps atypical but nonetheless distort the percentages of such a small sample to an unacceptable degree.

Finally, and this is a more serious methodological objection, the possession of great-clan status did not prevent a man from being at the same time an "examination bureaucrat." Appendix B of the present work shows how rapidly even members of the greatest clans turned to examination as a qualification for office in the later part of the seventh century.

Professor Johnson concludes on p. 139 that "the examination system had very little effect on the social composition of the political elite in the T'ang dynasty." This is true only in the narrowest sense. Equation of the tsai-hsiang group with "political elite" is tendentious, to say the least and, moreover, ignores the changes which the examination system began to occasion even in this narrowly-defined political elite. The typical great-clan chief minister during Kao-tsu's reign was very different from his counterpart during Hsüan-tsung's reign. To obscure this fact does no service to our understanding. It seems to me that in dealing with the tsai-hsiang sample, questions of a different sort might be asked and 1 attempt to do so in subsequent sections. I deal with aristocratic domination of the Chancellery and the Board of Civil office in Chapter 7.

68. See Chapters 5 and_9.

69. See Utsunomiya, "Tödai kijin," pp. 81-95. The family codes, private genealogies, and continued exclusivity of marriage were symptoms of the phenomenon, and anecdotal collections offer many examples of the pride of clan tradition continuing to flourish. See, for example, T'ang-kuo shih-pu, shang, p. 20 , for $\mathrm{Li}$ Chen 李稹 who refused to use his official titles, always signing himself "Lung-hsi Li Chen." Several other interesting points are raised in the excellent article by Takeda, "Tödai shizoku." 
70. In order to clarify somewhat the full extent of the tragedy of so many great clans during the period of the Empress Wu, I provide below a list of those exiled and executed for real or alleged crimes. In most cases their immediate families were exiled or enslaved and their property confiscated. Sources are given only for those who do not appear in Appendix B.

(a) In 659, at the instigation of Hsü Ching-tsung, a final revenge was carried out on the former tsai-hsiang Ch'ang-sun Wu-chi, Ch'u Sui-liang, Han Yüan, and Liu Shih. In every case, their immediate families were enslaved, those of sons and grandsons exiled to the far South, and several collateral relatives, nephews and cousins, also executed (see CTS 183:3553:1 Ch'ang-sun Shang). When the empress pardoned Ch'ang-sun in 674, there remained only a single grandson to carry on his ancestral sacrifices, and the others were pardoned only in 706 , in the last will of the empress (CTS 7:3078:1). It may be noted that the Liu family, for example, was in desperate straits economically when the pardon came, and Liu Shih's grandnephew had to beg from Hsüan-tsung the money to bury properly his ancestor. In the same memorial, he pointed out that all five families punished at the time [including, I think, that of Lai Chi, who suffered only exile] were in a similar position. See CTS 77:3334:4.

In 664, the adopted son of the deposed Empress Wang, who was degraded to commoner when tied to the "treason" of Ch'ang-sun Wu-chi and the others, was executed for complicity with Shang-kuan I (TTCLC 39, and CTS 4:3072:4).

(b) In 664 Shang-kuan I, who was a poet of renown as well as scion of an eminent Shan-chou clan, was executed for his part in persuading Kao-tsung to depose the Empress Wu. His only son died with him and the rest of the family was enslaved. Shang-kuan's son had married into the Cheng clan, and it was their daughter Shang-kuan Wan-erh who, after rising from palace slave to private secretary to the Empress Wu, came to exercise such power in the reign of Chungtsung and was able then to rehabilitate her grandfather. She, of course, perished in the coup against the Wei faction.

(c) In 681 a small rebellion in Ch'ang-chou led by Li Lung-tzu was snuffed out and the leader executed (HTS $3: 3640: 2$ ). I am unable to establish his lineage.

From 659 until the rebellion of Li Ching-yeh, with the sole exception of the Shang-kuan affair, the regime of the empress was singularly bloodless and compares favorably with that of almost any other T'ang ruler. It is difficult not to notice that this was the period in which she sought, above all, consolidation and centralization, when she was wooing the elite of the Northeast to the center.

(d) In the aftermath of Li Ching-yeh's rebellion of 684, the carnage was great. The most prominent of the clans to fall were those of $\mathrm{Li}$ Chi whose own tomb was desecrated, T'ang Chih-ch'i (CTS 85:3348:4), Lo Pin-wang (CTS 190 shang: 3581:3), and Tu Ch'iu-jen (HTS 106:3924:3). Only Lo Pin-wang was of undistinguished lineage. Of capital officials the list is much greater; $P^{\prime} e i$ Yen and the general Ch'eng Wu-t'ing were largely self-made men but at the height of their influence, while Yang Shen-jang (CTS 190 shang:3581:1) and Yüan Wan-ch'ing (CTS 190 shang:3581:1) and Yüan Wan-Ch'ing (CTS 190 chung:3581:4) were of old and eminent families, the former a maternal relative of the empress. Several of the other victims (Hsüeh Chung-chang, Wei Chao, Liu Ch'i-hsien) are without biographies but bear surnames appearing in the clan lists and appear in the HTS treatise as members of great clans.

The most interesting aspect of this incident is that, with the exception of the Yang-chou ringleaders, officials above the fifth rank suffered the 
ultimate penalty, while those below that rank were either demoted or exiled with their immediate family. In Yang-chou itself, those below the sixth rank were simply disenrolled (ch'u-ming). See CTS 190 shang:3580:2, biography of Liu Yenyu.

There is no complete list of the victims of the long series of reprisals which followed the suppression, since the evil officials in charge of the investigations "forced every man indicted to implicate tens and hundreds of others. The eminent families (i-kuan) trembled in fear..." (CTS 186 shang:3565:1).

The persecutions concerned with the uprising ended with the Act of Grace

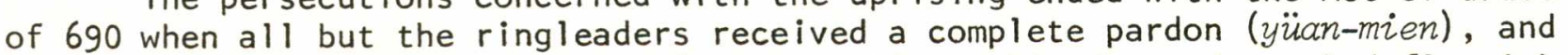
it is interesting to note that by 801 even Ching-yeh's descendants had flourished and became prominent in the semi-foreign area to which they were exiled (CTS 87: $3314: 3)$.. The major reason for the higher recovery rate of the families involved was the relatively short period before amnesty, and a legal precedent supported by the Empress Wu on a personal plea from the celebrated censor Hsü Yu-kung (CTS $85: 3349: 1$; and HTS 113:3939:3). By contending that the penalty of chi-mo which entailed confiscation and registration of household members as chien 賊, "unfree," in the census registers could not be applied to the family of a man already dead when the charge was brought, he saved over 300 families, reducing their punishment to exile. See TT 169, pp. $8940 \mathrm{ff}$. and TFYK, pp. 616-17, which both contain several other examples of how Hsü Yu-kung successfully pleaded for clemency before the empress and so set several legal precedents. Paradoxically, the law seems to have become more lenient during the terror!

(e) The week-long Princes' Rebellion of 688 ended in the wholesale destruction of the T'ang family. At least forty-four princes were executed and over one hundred chia destroyed, with many others barred from holding office (meikuan). The sources, with some exaggeration, claim that only a few children, exiled in the remote South, survived. At the same time, the evil official Ch'iu Shen-chi (CTS 186 shang:3564:1) seized the opportunity to implicate in the rising former exiles in Ling-nan and, as commissioner to the area, carried out a brutal massacre, drowning over 1,000 families.

A complete list of casualties is impossible to draw, but we are told that particularly in the two centers of the rebellion, Po-chou and Yü-chou, they were great. In the former over 1,000 families were killed, in the latter 6,700 persons were convicted of complicity which usually carried a sentence of exile, and 5,000 persons suffered the penalty of chi-mo (CTS 89:3356:2, biography of Ti Jenchieh). Several capital officials, including the empress' own son-in-law, were also executed. TT and TFYK, Zoc. cit., show that the empress presided personally over many of the trials at the time, and she appeared both competent and just:

(f) In 689 several of the highest capital officials, including the tsai-hsiang Chang Kuang-fu, were executed for conspiracy with the brother of $\mathrm{Li}$ Ching-yeh who had escaped his place of exile. Several more, including Wei Yüan-chung, were sentenced to death and amnestied only on the day of execution. There are a number of historiographical problems surrounding the event; see the $k$ 'co- $i$ notice for TCTC 204, p. 6460.

After the declaration of the Chou dynasty and the elimination of the T'ang family, there occurred a respite in the terror, and only in 697 was there another large incident.

(g) In the first month of that year, a provincial prefect, Liu Ssu-li, conspired to rebel and, when word leaked out, was executed with his closest associates. At the time, Lai Chün-ch'en, seeking to regain his lost favor, managed 
to convince the empress that numerous high officials in the capital were involved, with the result that over thirty chia were destroyed. CTS 57:3293:2 has a good account of the incident.

I count during this incident a total of thirteen high officials executed, among them members of such eminent clans as the T'ai-yüan Wang, the Lung-hsi Li, and the Yü-wen. The celebrated genealogist Lu Ching-ch'un also died. In many ways this event was a turning point in the dynasty. Ssu-ma Kuang remarks that so eminent were the victims that "the whole empire was angered," and the empress, of course, destroyed the evil officials later in the same year and almost immediately summoned Chung-tsung back to the capital.

The six incidents cited above account for most of the empress' victims, though the list is by no means complete. The years 690 and 691 saw the execution of eighteen other officials above the fifth rank, several of them tsaihsiang and many, members of great families. Most perished for opposing Wu Ch'eng-ssu's ambition to be named crown prince--a most natural cause and a fine example of the intensification of the tradition which initially had given the elite members their status. In almost every case the penalty of chi-mo was applied to the victim's family, but in several Acts of Grace before her deposition the empress specifically amnestied those who for complicity had been exiled or enslaved (ch'ang-liu chi ÿu-nu). I hope to complete soon a separate study on the recovery of these families.

71. Appendix B, no. 59. Interestingly, Li first became vice-president of the Board of Civil office in 669 when the first major reform of the period was undertaken. Just as Ch'en Shu-ta (Appendix B, no. 7) was earlier credited with bringing many southern shih to accept capital office, $\mathrm{Li}$ is credited with recruiting numerous men from the Northeast. In all, he served in the Board for eight years.

72. As, for instance, in the form of census registration. See the standard study by Masumura, "Kōhakuseki," and the studies cited in note 9 above.

73. WYYH 462:9a and CTW 95:14b. See al so TCTC 203, p. 6435.

74. On the informers, see TCTC 203, pp. 6438-39, and on slaves and convicts, TCTC 205, p. 6507 and THY 86, p. 1569. The last measure inspired a strong protest from Ch'en Tzu-ang. See Ch'en Tzu-ang chi, pp. $178 \mathrm{ff}$.

75. See, for instance, CTW 96:4b, 96:6a, and 96:11a.

76. TLSI 22:3, pp. $93 \mathrm{ff}$. The material is arranged in a very convenient chart in T'ao Hsi-sheng, Chung-kuo cheng-chih ssu-hsiang shih, v. 3, pp. 249-51.

77. The most important recent work on the system has been done by I keda On. See his fine summary, "Ritsuryo"l where on P. 289 he offers some cogent remarks on the interaction between status and $Z_{\ddot{u}}$-ling systems. See also, in the same volume, Ogata, "Ryōsensei," which offers a tabular presentation (p. 354) of the shift in usage from shu to $\min$.

78. TTCLC 100:3a, CTW 95:9b, and THY 67, p. 1183. For instances of sumptuary regulations directed at merchants and artisans, see THY 31, p. 572 and CTW 96: $19 b$.

79. TCTC 202, p. 6402.

80. For the former, see CTW 95:12a and TTCLC 114:7b, an edict of 701, forbidding the descendants of Yang Su to hold capital office, and CTShih 5, p. 57 where she speaks of the virtues of her own ancestors. The influence of geography on character was a prevalent idea of the age as we have seen in Liu Fang's essay and Lo Pin-wang's polemic. Pulleyblank, in Historians, pp. 135-66, shows that Liu Chih-chi expressed the view in his historical works. Empress Wu exhibited the same feeling on several occasions as, for instance, in her decree executing 
Lai Chün-ch'en, and sometimes when she honored other officials. See CTW 95:1la and HTS 109:3930:2.

This idea may help to account for the popularity of northeastern marriages and the propensity of so many officials to claim native places with which they had only the most remote connection.

81. Explored in earlier notes, especially note 70 above.

\section{Chapter 7}

1. The uses and limitations of Tunhuang evidence are succinctly explored by Twitchett, "Chinese social history." Saiiki bunka kenkyü contains several excellent studies on the mechanics of provincial administration, fu-ping and tu$h u-f u$ systems, etc., based on the manuscripts.

2. The problem was first brought to T'ai-tsung's attention by Ma Chou (Appendix B, no. 29) in 664 and, because no action was taken, appeared again in subsequent reigns. Chao I cites some examples in Kai-ÿ̈ ts'ung-k'do 17, pp. 328-29, and its manifestations in the Chou are discussed in Chapter 9. The Empress Wu once told a talented minister that she wished to keep him in the capital because the provinces were of lesser importance. TCTC 206, p. 6517.

After t'ien-pao (742-756) the situation began to reverse itself, as several scholars have noted. Ch'en, Kuo-shih chiu-wen, v. 2, pp. 13-15 cites the most useful sources on the question.

3. See Chapter 9. On eunuchs in the T'ang, Rideout's "Rise of eunuchs" is still useful and a more generalized view is presented by Mitamura, Chinese Eunuchs.

4. Chapter 9. As we shall see, the empress used various clan members in military positions at the capital during crises, most notably following her usurpation when four of them were given commands in the Yü-lin Guard and other capital units. Considering, however, that seventeen members of the clan were given posts and titles at the time and hence were available for military duty, the proportion was small. Furthermore, as Ching Hui was to comment in 705 , the Wu princes were usually posted outside the capital (CTS 183:3553:3) during the Chou, and it would therefore be false to suggest that the empress needed to concentrate military power in Wu hands to maintain her position. On several occasions she also gave command of expeditionary armies to relatives or favorites, but only in the case of the final expedition against Mo-ch'o's Turks does there seem to have been any feeling on her part that the loyalty of the troops might have been in doubt. Most striking of all, Wu postings in the Yü-lin Guard were so infrequent in view of this force's history and intimate connection with the T'ang that they amount almost to bravado.

5. See Chapter 9.

6. See CTS 183:3553:2, HTS 131:4109:3, and Wan Ssu-t'ung's short essay in Erh-shih-wu shih pu-pien 6, p. 7573 which suggests that the Wu relatives became wealthy but had little political power.

I am, of course, speaking here of "fiefs of maintenance," a subject upon which the fundamental study is Niida, "Tōdai no hōshaku." Chao I, in Kai-yü ts'ung-k'ao 77, pp. 336-9, was perhaps the first of modern scholars to charge that "as a result of the desire of the Empress Wu to make great her clan, she bestowed the title [and emoluments] of prince upon more than twenty [members of her family], and this was the inception of the cheapening of the title. . . " 
This theme is followed and amplified by Tonami, "Zui no bōetsu," pp. $165 \mathrm{ff}$., which is the best of recent studies and contains a most useful bibliography on the subject.

While I agree with Professor Tonami about the magnitude of a problem which was probably directing into private hands most of the revenues of the richest areas of the country by the early eighth century, I cannot accept that the Empress Wu was responsible for the development. My own research on the matter is incomplete, but the following points may be made. There was a statutory limit on the number of households assigned to each rank (TRSI, pp. 318-19 and THY 90, p. 1642) and, for present purposes, the important point is that a prince was limited to 1,000 and a princess to 350. The T'ai-p'ing Princess, the favorite of her parents, had early exceeded this limit, in the ch'ui-kung period (6859) receiving the revenues of 1,200 households, and in sheng-li (698-700) of 3,000 (TCTC 204, p. 6466). Tonami believes that the awards of the Wu clan were increased in proportion. There is, in fact, no evidence for this, and I believe that the special role of the princess as the only family member taken fully into the confidence of the Empress Wu, explains the excessive grant. In 690 when seventeen members of the clan received princely rank, only Ch'eng-ssu and Sanssu received the full 1,000 households, and the two figures mentioned for the more junior members are 300 and 400. I find no mention of an increase prior to the restoration.

My reading of the biographies of the seventh century and of the rather misleading list in THY 90, pp. 1638-42, would indicate that awards beyond the limit were made by Kao-tsu to favorite ministers, and that T'ai-tsung was an even worse offender. See, for instance, CTS 55:3292:4 and 3293:3. The destruction of the very extensive T'ang family and the confiscation of their property and revenues in the late 680 s also provided the empress with an enormous financial cushion. Considering, for example, that almost all of Kao-tsu's twenty-two sons received the full 1,000 households, these alone would cover the Wu awards, and it seems perverse to criticize the empress on these grounds. The genuine abuse arose in the next reign and should be attributed to Wu San-ssu and the Empress Wei. There remains a good deal to be said on the matter.

7. See the biography of Yang Tsai-ssu, Appendix B, no. 111.

8. See Chapters 4 and 9 on these figures.

9. Nien-erh-shih cha-chi 19, p. 258 .

10. Chou Tao-chi's massive if diffuse study Han-T'ang has left little to say on the subject. TT 20, pp. 119-21, gives a succinct evolution of the position from earliest times. See also Fonctionnaires, v. 1, pp. 4-11 for a translation with annotation of the HTS treatise.

11. HTS 46:3739:3. The claim seems first to have been made under Han Wu-ti. See TT 20, p. 1196.

12. Hsiang-tao (HTS 106:3925:2) was a native of Wei-chou, the son of Lin-fu, who had died in office in 629 after a successful career in which he served three years as vice-president of the Board of Civil Office. With his Chancellery appointment, Hsiang-tao was concurrently made vice-presieent of the Board of Civil office in charge of selection. He ended his career in honor, dying in 666 at the age of 71 .

The full memorial is found in CTW 162 and is abstracted in his biography, in TCTC 200, p. 6308 and TT 17, p. 93a. The discussion in the text follows the arrangement of the latter.

13. See Appendix B, no. 39. Li, who seems to have possessed a good deal of 
literary talent as well as an ambitious and ingratiating personality, had risen rapidly in his official career until he offended Ch'ang-sun Wu-chi who used his influence to have him demoted to the provinces. While attempting to block this order, l-fu discovered that Kao-tsung was seeking support in his campaign to depose Empress Wang and made himself the first official to urge formally that he do so. Immediately upon the empress' elevation, he was rewarded with tsaihsiang status. Fitzgerald, Empress Wu, pp. $36 \mathrm{ff}$. outlines the remainder of his career.

14. TT 17, p. 93a. Tu Yu's commentary here outlines the meaning of these terms, and we might note that they were also referred to by such terms as tsajen, $h s \ddot{u}-Z_{i}$, or chih-chang-jen and sometimes meant officials "outside the current." It is difficult to know whether Liu is specifically contrasting these men with examination graduates since he speaks of men "educated in the classics and contemporary affairs." Because of the form of the examinations, I assume that this is his meaning.

15. The term Ziu-nei referred to the nine ranks of career officials "within the current" of promotion. By the eighth century there were approximately 2,500 in the central administration and another 16,500 or so in the provinces. In the same period we find about 56,000 Ziu-wai officials and another 300,000 minor or part-time employees composed of clerks, guards, runners, etc. See Ikeda, "Ritsuryō," pp. 300-303.

16. On this examination, see des Rotours, Examens, pp. 31 and 128-30. It had been discontinued in 651, largely because of its tremendous difficulty.

17. TCTC 200 , p. 6308.

18. See Appendix B for the tsai-hsiang sample and further discussions in this chapter which suggest that bureaucratic recruitment by examination did not really gain momentum until the 670s.

19. In addition to these, one could enter on the grounds of a father's or grandfather's noble title or through a special act of imperial favor. The relative importance of examination and yin is discussed by Wittfogel, "Public office," pp. $23 \mathrm{ff}$., which gives also his calculations for the T'ang. See also the lengthy discussions in Tsukiyama, Tödai, pp. 139-63 and 195-224 which lists a number of other relevant studies.

20. See Appendix $B$ and later notes. Literary evidence, some of which is cited later in the chapter, suggests a rough figure of one-tenth, and a fairly careful calculation made in the forthcoming Cambridge History of China, Volume 3, estimates that examination graduates accounted for fifteen percent at most of the entire T'ang bureaucracy.

21. By this I mean to suggest not that examination was increasingly the sole form of bureaucratic entry, but rather that it was increasingly used in tandem with hereditary privilege. Examining only the small sample in Appendix $B$, it is clear that many chief ministers could have entered the bureaucracy on the basis of yin alone but used examination to better their chances of reaching one of the "pure" posts. The combination of yin and examination gave a man a higher initial rank at the beginning of his career and seems also to have facilitated promotion. See TRSI, pp. 297-98, Excomens, pp. 146-51 and 227-29, and TTLT 2:19b. This meant, of course, that the existing elite possessed a great institutional advantage in the competition for office.

22. See note 16 .

23. The only innovations explicitly credited to the empress are her foundation of the military examination and the ending of the principle of anonymity, 
a usage, incidentally, which she had herself initiated. HTS 44:3737:2 glosses over developments in the Chou by suggesting that "from the [time of the] disorders of Empress Wu, many of the old ways were upset but Chung-tsung set them again in order."

24. The precise beginnings of the system in the T'ang are subject to some dispute. The most detailed examination is Fukushima, Chügoku, pp. 53 ff. I follow his dating rather than the more usual 621 .

25. Summarized in Examens, pp. 26-36 and Liu T'ang-tai, pp. 128-63.

26. A full study of the decree examinations, the first of which appeared in 658 , would be most welcome. These examinations seem to have been held in the palace, sometimes under imperial supervision, and were designed to produce a particular type of official such as one who was "upright and correct" or "sage and good," qualities listed in the examination title. Many sources offer lists of these titles which numbered over seventy in the T'ang, and the Empress Wu employed them often in her reign. Between 688 and 702 they were held nine times and, although the usual practice was to respond with dissertations to a question put by the emperor, some of these seem to have required poems or rhyme-prose. A notice in WHTK 33, p. $311 \mathrm{lb}$ suggests that the emperor tested the candidates without knowing their identity, rewarded those who scored well with excellent posts (mei-kuan), and gave the others positions appropriate to their basic rank. The number who passed was usually small, though in 688 thirty candidates succeeded.

See Examens, pp. $205 \mathrm{ff}$. for the HTS description of these examinations and note the fairly full listing in Yün-Zu man-ch'ao, chüan 6, pp. 82-86. Contemporary anecdotes suggest that these examinations carried a good deal of prestige, and some scholars like Li Chiung-hsiu (Appendix B, no. 128), Liu Ssu-li, Chang Yüeh and Chang Chiu-ling sat for them several times.

27. On the hs̈̈̈n, see Examens, pp. 146-51 and 227-79, TRSI, pp. 297-98, and TTLT $2: 19 \mathrm{~b}$. This provision meant that only the sons of princes (wang) were exempted from the hsüan.

28. Examens, p. 213 and TTLT 2:5a.

29. TTLT 2:5b, Examens, p. 217, and TCTC 201, p. 6362.

30. TTLT 2:6a, and Examens, p. 217. des Rotours distinguishes the tally from the patent, but Ssu-ma Kuang, TCTC 200, p. 6293, considers them to be the same thing. It seems, incidentally, that the patent had to be rescinded before an official and his family could be punished by the law. See also Niida, Horitsu bunsho, pp. 793-806.

31. Examens, pp. 50 and $231 \mathrm{ff}$., TRSI, p. 288, TTLT 2:20b, and THY 81, pp. 1500-01.

32. TTLT 2:10a and Fonctionnaires, v. 1, pp. 59-71. The $k$ 'ao was basically the responsibility of the lang-chung assisted by an auxiliary secretary (ÿüanwai lang) in the $k^{\prime}$ ao-kung branch of the Board. They were supervised by two higher officials from the Chancellery and from State Affairs.

33. $\mathrm{Ti}$ Jen-chieh (Appendix B, no. 93) was raised from B-plus to A-minus by Liu Jen-kuei (no. 51) who was new at the task and seems to have required direction. THY 81, p. 1501. The second example, from 669, is found in TCTC 201, p. 6358. Lu Ch'eng-ch'ing (no. 46) had placed in the B-minus category an official who had lost an entire cargo of grain being transported to the capital in stormy weather. Lu is said to have been a man who thought highly of his own generosity and when the lower official appeared unaffected by his low rating, he raised him to $B$. The man now requested an even higher grade and, remarking that he had 
shown himself unaffected by favor or insult, Lu again raised him to B-plus. How typical these cases were is difficult to know. Ma Chou complained in 632 that no ratings higher than B-plus had yet been awarded (THY 81, p. 1500) so that the impression was created that the dynasty lacked good men. A rating of $B$ in four $k$ 'ao was required for advancement, and for these reasons the evaluation tended to become more generous at least until an official reached the fifth rank. To enter this charmed circle, a man needed a patent from the emperor, who received a list of eligible persons from the Board of Civil Office. TTLT 2: $5 \mathrm{~b}$ and $21 \mathrm{aff}$. Evaluation was probably taken very seriously at this level, and it is evident also that the Li-pu 吏部 and the tsai-hsiang could use this power to block "undesirables." Yang, Cheng-chih shih, pp. 173-74, documents several cases where men left the civil service after reaching this threshold of power. By the Chou, it seems that advancement to the fifth rank had been greatly accelerated by the empress' special promotions, and this was undoubtedly a source of dissatisfaction in the upper bureaucracy. In 695 she decreed that before an official could apply for the fifth rank he must have undergone at least twelve $k^{\prime}$ 'ao, have committed no crime, and have occupied one of the "pure" posts above the seventh rank. Those who applied for third-rank posts should have undergone twenty-five $k^{\prime} a 0$, though exceptional talent could be exempted from these regulations. TFYK 629:20b.

34. Excomens, PP. 239-40 and THY 75, p. 1355. HTS 45:3738:3 points out that prior to that time there were too few officials to fill the posts, and as a result the central government simply sent out tallies to designate those who should come to the capital for appointment. Once prospective officials had become more numerous, it was decided to make the selection more careful, and the hsüan was created at the suggestion of Liu Lin-fu, the father of Hsiang-tao. On conditions early in the dynasty, see Fukushima, Chügoku, pp. $71 \mathrm{ff}$.

35. THY 26, p. 507. The five successful candidates were appointed to the Hung-wen kuan to deal with imperial decrees and, in turn, to come to the palace and draft them on alternate days. This was an unprecedented honor for inexperienced men. Hsü Ching-tsung, incidentally, had earlier been attached to the same body for similar purposes, and it seems that this college, established in 626 with places for twenty students, had by now become an advisory body to the throne. It perhaps inspired the creation of the "North Gate scholars."

36. On T'ang Lin see CTS 85:3348:2 and HTS 113:3939:1 and on Hsiang-tao, note 12 above. T'ang Lin's native place is given as Ch'ang-an though the family was originally from the North and had held office since the Chou. His uncle's execution by the Sui had deprived the clan of privileged status, and Lin was largely a self-made man rising through military ability.

Although the Liu clan claimed a native place in Ho-pei, Lin-fu had been one of the earliest servants of the T'ang and T'ai-tsung's first vice-president of the Li-pu, probably residing in the capital and certainly identified with the Kuan-chung group. For contemporary evidence of capital residence by the great clans, see TT 17, p. 96c.

37. These were Li Kang (CTS 62:3303:1 and HTS 99:3910:3), Yin K'ai-shan (CTS 58:3295:2 and HTS 90:3896:2), Yang Shih-tao (Appendix B, no. 24), Yang Kung-jen (no. 8), and Feng Te-i (no. 9).

38. See note 34 above.

39. Appendix B, no. 29. He was married into the clan of Tai Chou (no. 22).

40. For their tenure in the Board of Civil Office, see Yen, T'ang $p^{\prime} u$-shang, pp. $81-90$. 
41. Those related by blood were Yang Shih-tao (Appendix B, no. 24), Yang Tsuan, and Yang Kungjen (no. 8); Tu Yen (no. 13) and Tu Ju-hui (no. 17); Liu Lin-fu and Liu Hsiang-tao; T'ang Lin and T'ang Chiao. Related by marriage were Kao Chien (no. 15), Ch'ang-sun Wu-chi (no. 14), Liu Shih (no. 35), and Ch'u Suiliang (no. 15). Several more distant marriage relationships also existed.

Taking the group as a whole from 618 to 705 , I find a total of seventyseven men, of whom $I$ am unable to find information on eight. Of the remainder, thirty-three were related in the same very close fashion described above, and the high incidence of father-son, uncle-nephew relationships gives the Board almost an hereditary cast for the entire century. In the T'ang, seven direct descendants of Liu Lin-fu held Li-pu positions (CTS 81:3342:1).

After 659 there seems to have been little dilution of the aristocratic character of the body, but the regional balance improved rapidly and even before the Chou, three of the "four surnames" of the Northeast were represented. Tsukiyama, Todai, pp. 74-84, has some rather scattered remarks on the Li-pu at this time.

42. CTS $77: 3333: 2$. Ma Chou is referred to as han-shih.

43. Chapter 6 , note 44. Kao Chien was president of the Li-pu and Wei T'ing had just been transferred to the Chancellery.

44. The tsai-hsiang connection became less pronounced after 659 , but between 618 and 705 twenty-three were concurrently tsai-hsiang and six more had held the status before their appointments to the Li-pu 吏部. It is also of note that the majority were president or vice-president of the Chancellery when awarded tsai-hsiang status, and that evidence could be adduced to show a greater concentration of aristocrats there than in the other two Departments until about the end of Kao-tsung's reign. The role of the Chancellery in the hsüan was the most important of the Departments. Examens, p. 218 and Fonctionnaires, v. 1, pp. 137 ff. Acting with the Li-pu, it could genuinely control the awarding of posts. 17) .

45. These were Yang Tsuan, Lai Chi (Appendix B, no. 38), and Tu Ju-hui (no.

46. See CTS 82:3343:2. Evidence for this is largely deductive. From his biography we learn not only that I-fu made appointments on a grand scale but also that he was anxious to identify himself with the Chao-chün Li clan, one of the greatest of the Northeast. As I suggest in Chapter 7, pp. 93-94, his appointment as president of the Li-pu was designed primarily to weaken the control of appointments by the northwestern aristocracy.

47. His fall is outlined in TCTC 201, pp. 6334-5. This category of punishment was exempted from the amnesty of 666 which followed the feng-shan sacrifice, and $L i$ is said to have been so disappointed that he took sick and died.

48. The two ssu-hsing representatives were Lu Ch'eng-ch'ing (Appendix B, no. 40) and Li An-ch'i (no. 56). Chao Jen-pen (no. 53) was also from the Northeast. The others, Hao Ch'u-chün (no. 60) and Yang Hung-wu (no. 54) represented the South and Northwest respectively.

49. Biographies in CTS 84:3347:2, HTS 108:3929:2, and Examens, p. 243. In the fourth month of 669 , and as a result of $\mathrm{P}^{\prime} \mathrm{ei}$ 's reform, a second vice-president was added to the Li-pu, and P'ei himself took the post. TFYK 629:3a. He, therefore, had no experience in the Board before drafting his reforms.

50. Feng-shih wen-chien chi 3, pp. 27-28.

51. HTS 45:3738:3. "At this time, candidates were very numerous, and [even] ignorant and mediocre men applied. Some forged their tallies ( $f u-k a o$ ) and falsely claimed to have been appointed while others used someone else's name to gain 
appointment. Some from far-off regions had no relatives but still found guarantors. On the examination day, some found others to use their name [and take the examination for them], and some cheated by using the answers of those near them or by seeking help [from friends] outside the hall. Therefore, many [appointees] had no real talent. . . ."

As early as 627 T'ai-tsung had complained that candidates were falsifying their credentials. TCTC 192, p. 6031.

52. Appendix B, no. 59.

53. Examens, P. 243, CTS 84:3347:3, HTS 108:3929:2, and THY 75, p. 1347.

54. See Exomens, p. 243. Ch'en Teng-yüan, Kuo-shih chiu-wen, v. 2, p. 116 , connects it to a list of retiring officials.

55. See CTS 84:3347:3, TT 15, p. 84c, TFYK 629:18b, and TCTC 101, p. 6362 . Both HTS 45:3738:3 and THY 75, p. 1347, use the shorter form, and Feng-shih wenchien chi 3, p. 28, suggests that this was the common abbreviation. The notices also reveal that the same year Chang Jen-wei composed a hsing-li which des Rotours calls a "catalogue des noms de famille," but this does not seem to give the connotation of $Z_{i}$. See Feng-shih wen-chien chi 5, p. 53, on the tzu- $i_{i}$. We know that in the first stage of the examinations a man had to submit documents showing his ancestry and native place (Excomens, pp. 147 and 184) and this was true also for the hsüan (note 51 above). 1 believe that these were checked against the hsing- $Z_{i}$ to be certain of a candidate'e eligibility. If so, the hsing- $l i$ was a permanent list similar to the national status registers but concerned solely with official postings. Candidates for the hsüan were checked against it and a "long list" of successful candidates with their clan's bureaucratic record was posted together with the number and nature of the expected vacancies for the coming year. When the usage was discontinued because "everyone knew who would be appointed" (see next note), it must have been because family influence was clear to see in the list. The paucity of specific information about the list renders any interpretation speculative, but this view seems consistent with the class-conscious and exclusivistic character of the other measures of 669 . The list seems to have been designed to prevent the entry of undesirables. See also Ts'ui Jung's memorial of 680 in THY 74, p. 1335.

56. Feng-shih wen-chien chi 3, p. 28. The passage goes on to say that the bias of the vice-president of the Li-pu who drew up the list resulted in such lively protest that he was demoted to the provinces.

57. HTS 45:3738:2. See also Examens, p. 180 .

58. That is to say, all those whose basic rank was above nine; listed in Examens, pp.: 227-8. On the universities, by which I mean the kuo-tau hsüeh, the t'ai-hsüeh and the ssu-men hsüeh which were administered by the kuo-tzu chien and had a total of perhaps 350 students at this time, see Liu, T'ang-tai, pp. 92-98. Only the ssu-men hs̈̈еh admitted commoners.

59. Excomens, p. 215 and TT 15, p. $84 \mathrm{~b}$.

60. TCTC, 201, p. 6362, TFYK 629:19a; and see TRSI, p. 285 for other references.

61. The presidency was left vacant from 669 to 674 and 676 to 684 perhaps since the vice-presidents had been given the whole task of selection in 670 . Li Ching-hsüan was raised from vice-president to president in 674 and remained there until raised to State Affairs in late 676. P'ei Hsing-chien remained as vice-president until mid-679.

62. This was first noted in Liu Hsiang-tao's memorial of 657 (note 12 above) and several other examples appear in later notes. See also the remarks of $\mathrm{Ch}^{\prime} \mathrm{u}$ 
Sui-liang in the biography of Wei Ssu-ch'ien (Appendix B, no. 79). This attitude was to be of importance in the dynamics of the Chou bureaucracy.

63. TFYK 629:19a. According to this decree, the chu-se from the Boards of Civil office and War who had undergone the requisite number of $k$ 'ao, needed to be examined only on one classic and one history before becoming eligible for appointment "within the stream."

64. HTS 45:3738:2. The passage adds that there were sometimes ten persons waiting for a single position.

65. See THY 58, pp. $1004 \mathrm{ff} .$, TT 23, pp. $135 \mathrm{ff}$, and TFYK 629:3a ff. The principal increases occurred in 669, 689, and 694 .

66. On the ta-ch'eng, see Examens, p. 165 and on the restoration of the schools, TFYK 550:4b and CTW 11:20b. Fukushima, Chügoku, pp. $129 \mathrm{ff}$. , examines the decline of the provincial schools showing a correlation with the numbers who presented themselves for examination. For educational policy in the reign of Kao-tsung, see Taga, Tódai kyōiku, pp. $94 \mathrm{ff}$.

67. Note 26 above.

68. WHTK 29: pp. 276-80. The list is derived from the Teng-k'o $l_{\ddot{u}}$ of the Sung scholar Yüeh Shih and is exhaustively discussed by Fukushima, Chügoku, pp. $77 \mathrm{ff}$. Lin, Sui-T'ang shih, pp. 202-264, reprints the 1 ist with some annotation. The origins of this kind of compilation are discussed in Fukushima, chügoku, pp. $159 \mathrm{ff}$, , and $Y \ddot{u}$-hai 115:19b ff. lists a number of indexes of graduates, usually compiled by a single clan. These began to outstrip genealogical compilations in the later T'ang. See Fukushima, Chügoku, pp. 194-201.

69. Fukushima, Chügoku, p. 78.

70. No examinations were held in 669. The figures are as follows:

$664-3$
$665-a 11$ failed
$666-2$
$667-5$
$668-26$

$670-54$

671 - no examinations held

672 - no examinations held

$673-79$

$674-57$

These years seem to be the high point of success for chin-shih candidates in the dynasty, and when fifty-five succeeded in 682, a reexamination, which only fifteen passed, was held. In the $k^{\prime} a i-y \ddot{u} a n$ [713-742] period, an annual upper limit of twenty-five was set, but it seems not to have been enforced since by my calculation the average for Hsüan-tsung's reign was twenty-seven. The numbers changed little after that, and Ma Tuan-lin's remark that at its most flourishing period the chin-shih never produced more than fifty graduates (WHTK 29 , p. 280) refers to this period.

Again working from chin-shih figures in the Teng-k'o $2 \ddot{u}$, discussed in note 68 above, the examination's development in the T'ang may be shown:

Kao-tsu

T'ai-tsung

Kao-tsung to 669

Kao-tsung 670-684

Empress Wu

71. TCTC 202, pp. $6374-75$.
further information exists.

$\begin{array}{ccc}\text { Graduates } & \text { Times Hezd } & \text { Average } \\ 26 & 5 & \text { per Time } \\ 205 & 20 & 5+ \\ 208 & 15 & 10+ \\ 430 & 9 & 14- \\ 532 & 21 & 48- \\ & 21+\end{array}$

The memorial came from Liu Hsiao about whom no

72. TCTC 202, pp. 6386-87.

73. Biography in CTS 190 chung:3582:2. 
74. See Examens, pp. 166-67 for the numerous sources in which the memorial is abstracted. I follow des Rotours' translation.

75. HTS 45:3738:3. I have found this passage nowhere else.

76. HTS 45:3738:4. I find few other references to this problem prior to 705 , and it seems to have become serious only in the reign of chung-tsung. See TCTC 209 , pp. 6633 and 6635 .

77. See their biographies cited earlier. Li's biography points out that while his ability and carefulness were praised and while he could remember the names of all his appointees, he brought "more than 10,000" men into the administration in one year. This figure, of course, is a conventional approximation. He was dismissed in 676 because of Kao-tsung's displeasure with the manner in which he built a large clientele in the upper bureaucracy through his appointments and his three marriages into the preeminent northeastern clans. The T'angkuo shih-pu, shang, p. 20, tells how his marriages so confused the generation order of the clans that grandfathers were grandsons and vice versa.

78. TCTC 252, p. 8167.

79. See, for instance, T'ang-kuo shih-pu, hsia, pp. 55-6, Feng-shih wen-chien chi 3, p. 22, and T'ang chih-yen 1, p. 3. Chao I gives other examples in Kaiyü ts'ung-k'ao 28 , p. 583.

80. Exomens, p. 163, TT 15, p. 83a, WHTK 29, p. 271b, and Ÿ̈-hai 115:11b. The biography of Tu Cheng-lun (CTS 70:3319:4) tells us that fewer than twenty men attained the degree in the Sui, and prior to 651 only another twenty-eight were successful. In the same period the chin-shih sometimes produced seventeen graduates in a single year! When the hsiu-tsai was reestablished in 736 , the TT tells us it was considered less difficult than the chin-shih. Ch'en, Kuoshih chiu-wen, v. 2, pp. 117-20 and 125-27, introduces some useful sources on the relative positions of the examinations.

81. Feng-shih wen-chien chi 3, pp. $24 \mathrm{ff}$., states that the chin-shih was more highly esteemed than decree examinations, but this reference, 1 think, is to the situation in the eighth century. The HTS treatise (Examens, p. 208) says that those successful in the decree examinations received the most illustrious titles, and $I$ find it suggestive that those recorded to have taken both examinations in the seventh century chose usually to take the decree examination first. The ming-ching, as we have seen, conferred a higher point of entry to the bureaucracy than did the chin-shih.

82. Taking as a sample the graduates among the tsai-hsiang from 664-705, I find that fifteen had chosen the chin-shih and thirteen the ming-ching.

It is of interest to note that Japanese scholarship seems widely to accept that the aristocracy long favored the ming-ching over the chin-shih. See, for instance, Tsukiyama, Tódai, pp. 69 and 139. This is reasonable in view of the greater need for books, tutors, orthodoxy, tradition and discipline to prepare the curriculum, and also in view of the form of the examination which from 737 and possibly from 681 included an oral interview with the aristocratic members of the Li-pu. It is difficult, however, to find statistical evidence.

In the later part of the T'ang few high officials seem to have entered the bureaucracy via the ming-ching.

83. See Pulleyblank, Background, pp. 194-204. Seven men had chosen the chinshih while six passed all the other types.

84. WHTK 29, p. 27lc and Ÿ̈-hai 115:15b. The T'ang chih-yen, 1, p. 4, comments that "the"chin-shih was founded in the Sui ta-yeh [era, 605-617] and flourished in chen-kuan [627-650] and yung-wei [650-656]. If a scholar-official reached the 
highest of state offices without passing the chin-shih, he was in the end not considered praiseworthy. The candidates before long often numbered no less than eight or nine hundred men. . . The difficulty [of the examination] was expressed [by saying] thirty is old [to pass the] ming-ching and fifty is young [to pass the] chin-shih."

Ts'en, Sui-T'ang shih, v. 1, pp. $184 \mathrm{ff}$. gives four reasons for the relative popularity of the chin-shih.

85. Examens, p. 147.

86. See Chapter 2. We cannot be certain, of course, of the actual role of the empress in the writings issued under her name, but there is ample evidence of her fondness for literature, and most sources which comment on the form taken by the chin-shih attribute the literary emphasis to her interest. In addition, we find several other examples of this. See, for instance, TFYK 110:3b which describes a poetry-composing party, and 840:16a which tells how she awarded high office to the author of a fine poem on the ming-t'ang. THY 77, p. 1405, suggests how widespread was private scholarship and literature in her reign, and we are told also that when she dispatched commissioners in 691 to inquire about the state of the provinces, the whole court submitted poems to mark the event. THY 77, p. 1414. The dynastic biographies of noted 1ittérateurs and poets like Sung Chih-wen and Shen Ch'üan-ch'i (CTS 190 chung:3581:4 and HTS 202: 4100:4) suggest the importance of her patronage. Other examples are cited by Lin, Sui-T'ang shih, pp. 199-200.

87. CTS 118:3414:1, the biography of Yang Yen. The occasion was a debate of 763 in which Yen protested the literary emphasis in the examinations, and his opponent rebutted his arguments by suggesting that the Hsia dynasty was founded upon sincerity, the Shang upon respect and the Chou on literature which governed men's conduct quite as much as sincerity and respect.

88. TTLT 4:4b.

89. There is no evidence that the empress discriminated on the basis of a man's degree, but her patronage of the chin-shih created the climate which caused high officials to have contempt for those of their colleagues without the degree. See the examples cited earlier and the anecdotes in Yin-hua Iu, 3, and T'ang-kuo shih-pu, hsia, pp. 55-56, which outline the honorific vocabulary which grew around the degree.

90. See the chart in the text and note 87 above. Yang Yen also complained that chin-shih candidates knew neither the classics nor the histories. Other evidence is cited in following notes.

91. TFYK 639:20a, THY 75, p. 1373, and see Chapter 9.

92. Appendix B, no. 70 .

93. Chapter 3, n. 24.

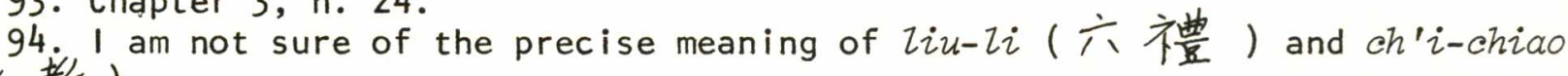
( $x$ 教).

95. Discussed on pp. 103-105. Wei might be referring here to the practice whereby sons of honorific officials of the fifth rank or above and high regular officials could enroll their sons as prefectural na-k'o p'in-tzu, "sons of ranking officials paying a tax." At the age of eighteen, these were attached nominally to the Guards and after thirteen years took what seems to have been rather an easy examination to enter the regular bureaucracy.

96. The memorial is found in full in CTW 168:2b and is abstracted in THY 74, pp. 1336-7, Excomens, p. 247, and TT 17, p. 94a. Fukushima, Chügoku, pp. 106-21, analyzes it chiefly as a catalog of abuses growing out of Wei's conviction that Confucian virtue received too little attention in selection and his belief that 
the Board of Civil office had grown too powerful.

97. THY 74, p. 1337.

98. TT 15, p. 83a. See also THY 76, p. 1390, WHTK 29, p. 2720, and TFYK 639: 20a. The latter text uses only the term $p i$, "finish," not suggesting that the candidates all failed.

99. The important steps in the process were the inauguration of decree examinations in 658 and the settlement of their basic form in 683 (THY 75, p. 1376), the ceremony of 659 , the creation of the ta-ch'eng in 675, the reforms of 681 and, of course, the continuing process of raising more and more graduates to the highest posts.

100. WHTK 29, p. 272a. The full text is found in CTW $281: 10 \mathrm{~b}$, and it was submitted by Hsüeh Ch'ien-kuang whose biography is found in CTS 101:3383:2. See also TT 17, p. $94 \mathrm{c}$.

101. Chapter 6.

102. Excomens, pp. 247-8, TT 14, p. 85b, and WHTK 37, p. 348c. The TT says that the empress believed the Li-pu often failed to select the right men and so decreed that examinations be written anonymously and that the same regulation apply to the $k^{\prime}$ ao.

No source offers a dating for this event, but $\ddot{y} \ddot{u}$-hai 115:25b suggests that she ordered a decree examination in 689 to be administered anonymously. The notice is rather puzzling because it goes on to say that Chang Yüeh, after a reexamination, was placed first. In other sources we are told that Chang Chienchih (Appendix B, no. 133) topped over 1,000 candidates, and the Yü-hai also mentions this event $(115: 24 a b)$. The Teng-k'o chi-k'ao puts Chang Yüeh's examination in the preceding year and 1 am, therefore, suspicious of the first notice. Even if it is reliable, we cannot be sure that the principle was extended to other examinations. However, since it is the earliest mention of the hu-ming, we might assume that the practice began about this time.

103. Chapter 9, note 87.

104. Excomens, pp. 209-212, TFYK 639:20b, THY 59, p. 1030, and TCTC 207, p. 6558. There was a corresponding hsüan. See Examens, p. 222, note 1 .

105. Appendix B, no. 131. The full text is in CTW 236:3b and the memorial is discussed in Chapter 9.

106. CTW 236:5a. It was submitted in 709 and is abstracted in his biography and in TCTC 209, p. 6634. The conditions described are for the reign of Chungtsung and are a good deal worse than those of the Chou.

107. These were Li Yüan-su (Appendix B, no. 101), Wei Chü-yüan (no. 105), Toulu Ch'in-wang (no. 107), and Wang Hsiao-chieh (no. 109).

108. Japanese scholarship has demonstrated the existence of this division even in the chung-cheng system. See Miyazaki, Kuhon, pp. 233-43. I pointed earlier to several of its applications in the T'ang and might recall that the fifth rank was the standard for inclusion in the Hsing-shih-Zu and that for all her innovations in recruitment, the empress never changed the rule that entry into the fifth rank was possible only by imperial decree. Fukushima, Chügoku, pp. 152 ff., collects other data on the division.

109. The term used by Ch'en Yin-k'o (see Chapter 6) and fairly standard in Japanese scholarship.

110. Note 14 above.

111. See TT 40, pp. $229 \mathrm{ff} .$, TRSI, pp. $114 \mathrm{ff}$. , and CTS 42:3253:3 which provides a full list of titles. One of the greatest lacunae in T'ang studies prior to the rebellion of 
An Lu-shan lies in the study of the Ziu-wai officialdom. Since this group was extremely important, especially in the provinces where it formed the closest link between government and people, our perception of T'ang administration remains somewhat blurred. Tsukiyama, Tödai, pp. $437 \mathrm{ff}$., looks at the hsü- $i_{i}$, who were not strictly speaking liu-wai but often grouped with them, under the five headings of function, entry "into the current," restrictions placed upon them, provincial abuses, and the various attempts made to reduce their number. His treatment is useful but not too coherent.

It is useful perhaps to have some concept of the size of the group, and Ikeda's figures in "Ritsuryo," pp. 300-303, suggest for instance that in the three Departments at the capital there were a total of 241 Ziu-nei officials and 1,498 Ziu-wai distributed as follows:

$\begin{array}{lcc} & \text { Ziu-nei } & \text { Iiu-wai } \\ \text { State Affairs } & 159 & 1,135 \\ \text { Chancellery } & 40 & 176 \\ \text { Secretariat } & 42 & 187\end{array}$

On a wider level, TCTC 214, k'ai-ÿuan 21 (733) gives a total of 17,686 Ziu-nei officials and 57,416 Ziu-wai in the whole administration. TT 40, p. 230b, speaking of a slightly later period, gives a grand total of 368,668 , so that the $h s \ddot{u}-l_{i}$ must have numbered almost 300,000 . The figure is further divided into 18,805 Ziu-nei and 349,863 Ziu-wai. In addition to these, there was a large number of minor employees recruited on a part-time basis.

As mentioned earlier, memorialists tended to group together all those who were not Ziu-nei in their complaints.

112. TTLT 30:23a.

113. TTLT 2:31a and CTS 43:3245:1. This minor examination was held annually and consisted of tests in writing, mathematics, and contemporary affairs though the last was not important. Candidates underwent an annual $k$ 'ao and had to take the minor examination after three $k^{\prime} a O$ in order to advance, al though the constant complaints suggest that enforcement of the promotion rate was lax. See also Fonctionnaires, v. 1, pp. $67 \mathrm{ff}$.

114. As Miyazaki, Kuhon makes clear, the distinction between "pure" and "muddy" posts was a very old one, and in the T'ang the key capital appointments, perhaps 500 or so, were reserved for men of good birth and scholarly attainment usually demonstrated by examination. See TTLT 2:24a ff.

115. TT 35, p. 200c. The passage notes the establishment of 7,000 hs $\ddot{u}-s h i \hbar$ chosen from the superior households.

116. THY 67, p. 1183. The full text is in TTCLC 100:3a and CTW 95:9b.

117. TTLT 2:31a and Tsukiyama, Tōdai, p. 443.

118. On the question of honorific rank, see Fonctionnaires, v. 1, pp. 50-59, THY 81, pp. 1491-92, and the useful secondary study by Matsunaga, "Tódai."

119. The sale of honorific ranks is mentioned in the Act of Grace of 684 , CTW 96:15a, and there is a good deal of Tunhuang evidence to show that the government was concerned with fraudulent claims.

According to $\mathrm{Tu} \mathrm{Yu}$ (TT 48, p. 773), the real cheapening of honorific rank occurred in the $k^{\prime} a i-y \ddot{u} a n$ period (713-742), but Professor Matsunaga's work indicates that from the mid-670s and perhaps from the rationalization of the system in 674 (THY 81, p. 1491), awards became increasingly free. Liu Jen-kuei complained in 664 (TCTC 201, pp. 6340-41) that military rewards were not being distributed, and in 688 we hear that honorific rank was being given for special corvée duty, for instance, in the construction of the ming-t'ang. See CTW 96: 
19a. Matsunaga ("Tōdai," p. 36) shows that land grants often accompanied these awards so that the economic ramifications were quite serious.

120. Fukushima, Chügoku, p. 119.

121. Note 113 above. Liu-wai officials could advance only one grade every three years, and once they entered the regular bureaucracy and became subject to the $k^{\prime}$ ao system there, every four years. Since the bottom ranks contained six grades, it would take twenty-four years to reach the seventh rank! Al-

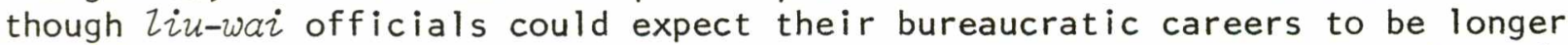
than the twenty to thirty years which seems to have been average for high officials, they could not expect to come anywhere near the fifth rank in the normal course of events.

122. Chapters 5 and 9.

123. TCTC 201, p. 6346.

124. THY 81, pp. 1493-94.

125. Tonami, "Zui no bōetsu," pp. $172 \mathrm{ff}$. and Tsukiyama, Tōdai, pp. 444-52.

126. See, for instance, the remarks of Tsukiyama, Todai, pp. 453-64.

127. TCTC 204, p. 6460. Kao-tsung, it seems, had planned to promote Chou Hsing to a "pure" post until he found out that he was ineligible. Chou is said to have gone frequently to the audience hall to await the announcement of his appointment, and this embarrassing experience may help to account for the revenge he ultimately took on the "pure" officials.

128. Chapter 9. The most striking instance is their opposition to the Chang brothers and the large faction which grew up around them. See also Tonami, "Chusei," pp. $47 \mathrm{ff}$. on the forms of factionalism after Empress Wu.

129. This was $\mathrm{Ti}$ Jen-chieh, and the question is fully discussed in Chapter 9 .

\section{Chapter 8}

1. See, for instance, Scott, Golden Age: Mahler, Westerners; and Reischauer, Ennin's Travels.

2. CTW 96:11b, from the Act of Grace changing the reign title to kuang-chai.

3. See Chapter 9.

4. See Wright, "T'ai-tsung and Buddhism," in Perspectives, pp. $250 \mathrm{ff}$. for a discussion of what the author calls T'ai-tsung's "Han Wu-ti syndrome," and Wechsler, Mirror, pp. 101-105 with the sources cited there. Other indications are found in TCTC 196, p. 6173, 198, p. 6226, and 198, p. 6247.

5. See CTS 194 shang:3596:2, 194 hsia:3599:2, 196 shang:3603:4, and 199 shang:3615:1, and the succinct summary of T'ai-tsung's reign by Wechsler in the forthcoming Cambridge History of China, Volume 3.

6. TCTC 197, p. 6218 , and 200 , p. 6323 for his intention personally to attack Korea. Other indications are found in TFYK 124:8b and 543:7a. The latter notice is an interesting memorial dissuading him from going to Korea.

7. TCTC 199, pp. 6269-70. CTS 196 shang:3604:2 points out that since the warning was accompanied with precious objects for T'ai-tsung's tomb, Kao-tsung was able to put a favorable interpretation on it, exchanging gifts and bestowing on the Tibetan ruler an additional title.

8. TCTC, Zoc. cit.

9. TCTC 199, p. 6273 and CTS 194 hsia:3600:1. The best secondary accounts are Ise, Chügoku, pp. $196 \mathrm{ff}$. and Ts'en, T'u-chüeh, pp. 269-74. I am in agreement with Professor Ise that the rising was inspired not by any Chinese action, 
but by internecine strife among the Western Turks which can be traced back to 646 and to A-shih-na'Ho-lu's rapid success which led him to believe that Chinese arms were weakened by T'ai-tsung's death.

10. TCTC 199, p. 6274. HTS 215 hsia:4134:1 says there were only 20,000 Chinese troops while CTS and TT 199 are silent on the matter.

The troops were levied in the chün-fu of $\mathrm{Ch}^{\prime} \mathrm{in}, \mathrm{Ch}$ 'eng, $\mathrm{Ch}$ 'i and Yung, all of which lie just west of Ch'ang-an and are cited in Ku, Fu-ping, p. 155. In Yung (Ching-chao) there were 131 chün-fu with an average of about 1,000 men each, so that 1 think the higher figure is the more likely one.

On the fu-ping system there have been few studies of note since Pulleyblank reviewed the literature in 1955 (Background, p. 140) aside from Ku's excellent if tendentious work cited above. Kikuchi Hideo has published some fine articles, and his "Fuhei seido" is perhaps the best available introduction to the subject. See also his "Tö sessho fu" which settles, I think several outstanding questions on the distribution of the units and their relationship to earlier military systems.

Because of the necessity to contrast it with expeditions later in the century, the form of Kao-tsung's first major army is worth a closer look. Generally speaking, the emperor, on the advice of the Board of War chose one or more generals who were designated as tsung-kuan for the area in which the expeditionary army or hsing-chün was to engage. At the time they and their deputy commanders were chosen, each was allotted a specific number of troops, called chenghsing-jen, who were usually chosen from fu-ping units in specified chün-fu. The troops, who provided their own clothing and equipment, etc., were told how long the expedition was to last (TCTC 201, pp. 6340-1) and, as far as I can tell, were to be replaced when their tour was complete, usually after one year. The government had a pool of perhaps 500,000 troops to draw upon, less about 100,000 who acted in rotation as capital guards and another 50-100,000 stationed at the borders. The establishment of these border garrisons remains something of a puzzle. See Pulleyblank, Background, pp. 147-49. Empress Wu increased the fu-ping just prior to her usurpation.

11. TCTC 199, p. 6277.

12. CTW 15:3b and TCTC 199, p. 6277. For reasons shortly to be spelled out, it is difficult to know which of the states began the hostilities which inspired Kao-tsung's rebuke. I tend to believe the sillan acount that Paekche was emboldened by T'ai-tsung's death to violate the Sillan border and seize seven fortresses, since it had been formally allied with Kogury $y$ since 643 and both had designs on Sillan territory. Silla, however, had retaliated even before sending Kim Ch'un-ch'u, the future King Muyol, to China in 649.

A second embassy arrived in 650 bearing the plea for aid from the sillan Queen Chindok, and Kao-tsung seems to have responded with a "mutual security" treaty. See Weems, Hulbert's History of Korea, v. 1, p. EDI05.

There are few satisfactory studies of Sino-Korean relations in this period, and most of my remarks on the subject are drawn from Kim Pusik's Samguk Sagi of 1145 supplemented, of course, by the Chinese sources. The best secondary study is Ikeuchi, Man-Sen shi; another useful work is Nishijima, "Tōa."

T'ai-tsung's will is found in TTCLC $11: 2 \mathrm{~b}$ and CTW 9:8b. On tsai-hsiang opposition to the attack on Korea, see Wechsler, "Factionalism," in Perspectives, p. 95. Of Kao-tsung's tsai-hsiang only $\mathrm{Li} C \mathrm{Chi}$ had been in favor, and Ch'u Sui-liang had been a most outspoken opponent.

13. TCTC 199, p. 6287. 
14. CTS 93:3366:2. After the recovery of the Four Garrisons in 692 .

15. TCTC 202, p. 6385. Discussed on pp. 122-123.

16. TCTC 199, pp. 6287-8 and CTS 199 shang:3615-2. See also Ikeuchi, ManSen shi, v. 1, pp. $308 \mathrm{ff}$. on the campaign. It might be noted that this first campaign caused great hardship in the Northeast, a fact called to Kao-tsung's attention in early 656 by Lai Chi (Appendix B, no. 38). See TCTC 200, Pp. 629697.

17. Discussed on pp. 112-117 passim.

18. TCTC 200, pp. 6295-96, which describes an attempt to set up rival khans in order to detach A-shih-na Ho-lu's followers. See also TCTC 200, pp. 6301-2 and note the lengthy review of T'ang-Turkic relations in the $k^{\prime}$ ao- $i$ notice.

19. Biographies in CTS $83: 3344: 3$ and HTS 111:3934:2. Su's background was typical of the northeastern hao-chieh. The son of a man who never held office but was able to lead thousands of men into the fray at the collapse of the Sui, he gained early experience against the Turks under T'ai-tsung and thenceforth pursued a career of uninterrupted military success. He won noble titles without ever holding significant civil offices and was praised at his death in 667 as the conqueror of three states. His biography gives an account of the ensuing campaign.

20. TCTC 200 , p. 6305.

21. On the mu-ping, see Pulleyblank, Background, pp. 146-47.

22. The best short account is in TCTC 200, pp. 6306-8; see also CTS 194 hsia: $3600: 2$.

23. This practice of attaching a censor to expeditionary forces seems to have been discontinued sometime before 687 when the empress was petitioned to reinstate it. She refused on the grounds that generals required freedom of action. THY 62, p. 1086 and TCTC 204, pp. 6446-7. On central control of the military, see Kikuchi, "Fuhei seido," pp. $421 \mathrm{ff}$.

24. On these terms see note 21 above and Kikuchi, "Tödai fubo." Under this system, a central official called the ping-mu was sent to an area usually chosen for its military reputation, large population or absence of fu-ping units, and there chose a suitable number of troops from households with several sons.

Kikuchi shows that from the beginning the wealthy and influential managed to avoid service and that troops of this sort tended to be used often as occupying forces, not being demobilized so rapidly as the fu-ping. Liu Jen-kuei's memorial of 664 , cited earlier (CTS $84: 3346: 3$ ), is a good indication of this.

25. See note 10 above.

26. Note 24 above.

27. Note 24 above and subsequent discussion in the text.

28. Note 24 above.

29. The T'ang use of foreigners is well-known, and Chao I comments on it in Kai-y $\ddot{u}$ ts'ung-k'ao 17, p. 327, following his discussion of the amazing success of T'ang arms.

30. On the early organization of the area, see 0̄tani Shöshin's study of the An-hsi protectorate in Ikeuchi Hiroshi, ed., Töyōshi ronsō, pp. 271-92. On Lu Ch'eng-ch'ing, see Appendix B, no. 46. Lu had made his reputation by compiling for T'ai-tsung a complete census of China's population from earliest times but was in mild disgrace at this time because of his close relationship to Ch'u Suiliang. He had much administrative ability and pursued a successful career in the Board of Finance until his dismissal for erroneous estimates of expenditure.

31. TCTC 200, p. 6307 and CTS 81:3341:3. 
32. TCTC 200, pp. 6307 and 6317-18. See also Lin, Sui-T'ang shih, p. 366.

33. A recent and eloquent appreciation of the T'ang empire is Miyasaki, Dai Tó teikoku, especially pp. $319 \mathrm{ff}$.

34. Ise, Chügoku, p. 204.

35. This was the sixth month of 658. The troops were mostly those of $\mathrm{Ch}^{\prime}$ eng Ming-chen (CTS 199 shang:3615:2), presumably raised in Liao-tung, though the famed general Hsüeh Jen-kuei (CTS 83:3345:1 and HTS 111:3934:4) was dispatched as his deputy. In the major battle of the campaign the Chinese were victorious against a force estimated at 30,000 , but the victory was facilitated by the rebelliion of the Koreans' Khitan allies.

36. TCTC 200, p. 6320. China later justified this attack in the treaty she forced Silla and Paekche to conclude in 665. SS 6, p. 68. Claiming that

Paekche had thrown off its allegiance to China, fomented discord with Silla and formed alliances with Kogury and Japan, the emperor had given the state a chance to recant, attacking only when it "considered its position impregnable because of the great distance and was contemptuous of Our Will.."

A caution about sources might be inserted here. Since the records of Koguryo perished in the sack of Pyongyang in 668, the SS and Samguk Yusa offer no more than an abridgment of the chinese histories in writing about the state. As a result, an unbiased view of peninsular strife in the period is almost impossible.

37. HTS 220:4147:4. See also CTS 61:3300:3, biography of Wen Yen-po (Appendix $B$, no. 21). On China's early relations with the peninsula, rapid summaries are found in Hatada, History of Korea, pp. 3-24, and Henthorn, History of Korea, pp. 18-54.

38. TCTC 190, p. 5976 and HTS 220:4194:1 and 3. The kings of the three states received patents calling them chün-wang and using the names of the Han commanderies. They also received the Chinese titles of chu-kuo or shang-chukuo (CTS 1:3065:4), the highest in the system of honorific rank. Nishijima, "Tōa," p. 255, notes the ambiguous nature of these conferrals.

Mori, "Zui-Tō," summarizes a paradigm widely used in Japanese scholarship in which China's foreign relationships are divided into several types: father-son, father-in-law-son-in-law, ruler-subject, patent and seal, direct control, and enemy state, roughly in their order of chronological evolution. The relationship with the Korean states was a highly advanced one.

39. CTS 199 shang:3615:2, TCTC 197, p. 6202, and SS 49, pp. $486 \mathrm{ff}$. for his biography. The latter source tells us that after murdering over a hundred high officials at a banquet, he killed the king and installed a puppet ruler from a cadet branch of the royal house. He was himself the real ruler and one of great cruelty and severity. "No one dared [even] to look upon his face and when he mounted or dismounted from his horse, nobles and generals prostrated themselves on the earth. . . ."

40. CTS 199 shang:3615:2.

41. TCTC 201, p. 6355. See also THY 43, p. 766. The occasion was the sighting of a comet which Hsü Ching-tsung interpreted as an omen of Koguryŏ's fall. Kao-tsung disagreed.

42. SS 4, pp. $56 \mathrm{ff}$. Although the process had been going on for some time, it became wholly conscious in 649 when Silla changed its calendar to that of the T'ang and began to use Chinese era names. See also Nishijima, "Tó," pp. $258 \mathrm{ff}$.

43. Text in CTS 199 shang:3617:1 and $S S$ 5, p. 57. It is of the five-word 
line style and combines praise for the T'ang with an appeal for aid.

44. The Hwabaek was the ancient Sillan Council of State and continued to exist above the Sinicized administration, deciding the most important state matters. The Hwarang-to which might be translated as "Company of Knights of the Flower," was inaugurated in the middle of the sixth century and aimed to develop carefully chosen young men into military and societal leaders. It rapidly built a tradition of patriotism and loyalty, high culture and leadership, and under Kim Yu-sin, the Hwarang became the flower of the Sillan army. The only English treatment of the subject is Rutt's "Flower boys of Silla."

45. $S S$ 5, pp. 58. Muyol (r. 654-661) was a nephew of Queen Chindrk, not, as the CTS suggests, her brother.

46. His son Munmu was to make the claim in the document quoted extensively in the text.

47. SS 28, pp. 276-77 from the annals of Paekche is probably the best account of the events and agrees in general outline with the Sillan record, SS 5, pp. 59-63. It was apparently Kim Yu-sin's victory which prevented Paekche from fortifying the mouth of the Paekang and so blocking the passage of the Chinese fleet. The Chinese accounts, for instance TCTC 200, p. 6321, make no mention of the Sillan contribution.

48. SS 28, p. 277. When King Ŭija and the crown prince fled, the king's second son declared himself ruler and invested the capital. His nephew, son of the crown prince, judged this to be usurpation and surrendered to Su Ting-fang with most of the capital residents. On the fall of the city, Uija gave himself up and died of $i 1$ lness shortly thereafter.

49. CTS 199 shang:3616:2 and SS 28, p. 277. Overall authority was vested, however, in a Chinese tu-tu, a post soon given to Liu Jen-yüan.

50. CTS 199 shang:3616:2 and SS 28, p. 277.

51. SS 28, p. 277 specifies that those exiled consisted of "eighty-eight persons of the royal family, great generals and ministers, and 12,807 of the people." We know very little of this resettlement, but the much greater movement of people at the fall of Koguryo has been studied in detail by Hino, "Sho kokuri koku." Hino points out that as early as 643, T'ai-tsung had settled inside the Wall about 3,500 of Korea's best soldiers in order to weaken resistance in the state, providing a precedent for the deportation. Later it was hoped that by removing the leaders of society movements of national liberation could be forestalled. In all likelihood, the same motive was present in 660 and suggests that the Chinese planned to incorporate the peninsula into their empire.

Professor Hatada (Korea, p. 25) is convinced that the Paekcheans were enslaved, but I find no evidence of this. The Koreans, we are told, were later settled in underpopulated areas of the Northwest so that the need for labor was a motive in their placement, but we are also told that they took with them their chariots, horses and cattle, and this seems to suggest quite the opposite of enslavement. Professor Hino makes no suggestion.

52. TCTC 200, pp. 6322-23. In the three areas mentioned there existed nineteen prefectures which had fu-ping units and, according to the figures of $\mathrm{Ku}$ Chi-kuang and Kikuchi, these yielded on paper about 130,000 troops. The fact that only a third of this total was produced by what seems to have been a full levy, and that at least a portion of these were probably conscripts and volunteers, would seem to indicate that the effective strength of the system had been substantially reduced by 660 .

53. With the exception of $\mathrm{Ch}^{\prime} \mathrm{i}-\mathrm{pi} \mathrm{Ho}-\mathrm{li}$, the other three commanders were all 
prominent members of the northeastern hao-chieh. Coupled with the fact that the expedition was launched from Loyang, this suggests a special effort to persuade the Northeast.

54. TCTC 200, p. 6324. The year 660 was that of Kao-tsung's first serious illness. Fitzgerald, Empress Wu, p. 59, speculates on the empress' reasons for opposing her husband's participation, and see also THY 95, p. 1708, for other opposition.

55. SS 28, pp. 278-9 and TCTC 200, pp. 6323-4. Poksin set up as ruler a son of the former king who had been a hostage in Japan. These two, aided by a Buddhist monk called Tochim, managed to rally the people and put the garrison of Li Jen-yüan (HTS 220:4148:4) under severe pressure.

56. $S S 5$, p. 62 and 28 , p. 278 both record engagements in which silla was bested and this may be the real reason it retired. The Sillan king Muyol, who was to die in mid-661, seems to have left state affairs in the hands of his son Munmu and, as will be suggested later, he was playing a double game at the time. Liu Jen-kuei, given the task of relieving the garrison, is said to have remarked that he wanted to pacify once and for all (sco-p'ing) the Eastern "barbarians"-a remark hardly calculated to defuse the situation. TCTC 200, p. 6324.

57. TCTC 200, pp. 6325-27. Su, in fact, was already at the walls of Pyongyang by the seventh month of 661. On Ch'i-pi, see CTS 109:3400:2 and HTS 110: $3932: 2$.

58. On the Uighur rebellion, which in three months had also gained the support of 100,000 Mulguls, see TCTC 200, pp. 6326-29. Five generals were sent against them and, though the heroism of Hsüeh Jen-kuei resolved the incident with relatively little bloodshed, 13,000 Chinese were lost in a fruitless pursuity of the Uighurs. In early 663 two new protectorates were set up in the area.

On Kao-tsung's illness, see TCTC 200, p. 6329, and on the cancellation of the sacrifice, TCTC 201 , p. 6332.

59. TCTC 201, pp. $6336 \mathrm{ff}$. The full text of these instructions is found in CTW 14:3a.

60. SS 6, p. 67. Munmu had been Sillan ambassador to China in 650 .

61. SS 28, p. 279. Jen-kuei was able to do this when the restoration leaders killed each other, leaving Prince P'ung in command. See also Jen-kuei's biography in CTS 84:3346:1 and HTS 108:3928:3, and for the troops, all levied in Ho-pei, TCTC 200 , p. 6330.

62. TCTC 201, p. 6337, dates the decree found in CTW 12:10a in the eighth month of 663 .

63. TCTC 201, pp. 6336-37, SS 28, p. 278 and 6, p. 67. The Sillan source claims that the state had twenty-eight generals in the field and that they were responsible for taking the capital. The only Chinese source to acknowledge Sillan aid is CTS 199 shang:3616:3. I keuchi, Man-Sen shi, v. 2, pp. 72-246, offers the fullest account of the campaign.

The remnants of the Japanese are said to have surrendered, and SS 42, p. 436 preserves a severe reprimand delivered to them by King Munmu.

64. TCTC 201, pp. 6340-42, and a fuller version in CTS 84:3346:3.

65. TCTC 201, p. 6342 and CTS 84:3346:4. Liu had powerful enemies at court of whom Li Ching-hsüan was the most notable. See note 107 below.

66. See SS 6, p. 68, and CTS 199 shang:3616:3 for the text. The pact, which is discussed later in the text, was sealed with the slaughter of a white horse, a ritual seemingly sufficient to guarantee its sacredness. In it Silla is 
praised as a model of "barbarian" submission, and the claim is made that Silla requested the treaty. Munmu was later to claim that it was imposed on him.

67. Munmu's position was that of ta-tu-tu, a post he considered superior to that of Jen-kuei. Hino, "Shō kokuri koku," Shien 61 (1957), p. 32, suggests that it was the practice to have a Chinese tu-tu supervise native rulers even if their ranks were superior. Munmu was also disgruntled because Uija's son had been given the same rank as he. SS 28, p. 279.

68. Liu returned, ostensibly to participate in the feng-shan sacrifices and seems never to have returned to the peninsula. In 668 he was appointed general against Koguryŏ but almost immediately removed for "loitering" in the prosecution of the attack. TCTC 201, p. 6355.

69. TCTC 201, p. 6347. In the fifth month of 666 Y Yn'gae Somun's heir requested aid against a challenge from his younger brothers. The final campaign is described by Ikeuchi, v. 2, pp. 276-418.

70. TCTC 201 , p. 6351.

71. SS 6, pp. 70-71, TCTC 201, pp. $6352 \mathrm{ff.}$, and TFYK 986:9a ff. The biographies of the various commanders also offer details.

TCTC 201, p. 6354 preserves a very interesting conversation between Kaotsung and Chia Yen-chung, a censor who had been attached to the army and was able to explain why this campaign would succeed where the others had failed.

72. TCTC 201, p. 6356 estimates the population at 697,000 households and Hino, pointing out that this is probably a low figure, puts the population at about four million.

73. The siege lasted only two months and the city was betrayed by a monk so that the capital was taken with little bloodshed. The burning seems, therefore, to have been less a reprisal than an expression of Chinese ambition to pacify the country permanently. It should be seen in the context of the exiling of 150,000 Koreans.

74. CTS 199 shang:3616:1. Nishijima, "Tōa," pp. 263-4, suggests some of the implications of the organization, and we might note especially the appointment of King Pojang to the presidency of the Board of Works. Appended to his title was the term ÿ̈an-wai t'ung-cheng which Hu San-hsing (TCTC 201, p. 6356) explains as an auxiliary appointment with all the emoluments of the regular holder of the post. This was essentially a sinecure, awarded only once before and for a much lower post in 654 . It was to become increasingly frequent and, as one of the empress' irregular forms of appointment, was to contribute to the serious economic problems of the end of her reign.

75. CTS 199 shang:3616:1.

76. The major accounts, CTS 199 shang:3616:1 and HTS 220:4148:4 make no mention of sillan participation. The Sillan account suggests that their troops engaged the Koguryons once, in the seventh month of 668 , and reached Py two months later. This was almost twenty months after the campaign was initiated and a few days before the city fell. Munmu on two occasions refused to meet either $\mathrm{Li} C h i$ or Hsüeh Jen-kuei, each time sending a subordinate to represent him.

The attitude of the Chinese in these circumstances seems understandable, and we might note here a remark in CTS 199 shang:3617:1: "In the fifth year of hsien-ch'ing [660]. . . [Paekche was extinguished]. From this time Silla gradually seized the territory of Kogury 8 and Paekche and greatly expanded her borders, in the West even to the sea." Curiously, the other sources have no parallel passage and, if it represents more than the historian's hindsight, it 
could explain, for instance, why Munmu was demoted to tu-tu in 663 and why China determined to incorporate the persinsula.

77. SS 5, pp. 77-81. There exist many lacunae in the early part of the account and a number of errors in the text so that the background is not altogether clear. It seems, however, that in the sixth month of 671 Silla had badly defeated a combined Chinese and Paekchean force, inflicting over 5,000 casualties. The next month it received a severe reprimand from Hsüeh Jen-kuei which gave Munmu two days to decide whether he would repent for his recent "crimes" or face attack by two Chinese armies.

78. There is no Chinese record of any such promise.

79. An event unmentioned in Chinese sources but attested in SS 28, p. 278 and 5, p. 62, the annals both of Paekche and Silla. Neither mentions Munmu's leadership.

80. Unmentioned in any text.

81. SS 5, p. 62 verifies the Sillan defeat which occurred in the fourth month. During the first part of the year, Silla was also meeting an invasion of Koguryŏns and Mulguls and was unable to repel them until mid-year. SS 42, p. 434, the biography of Kim Yu-sin, gives details. I find no other mention of an epidemic, but if Munmu's statement is true, Silla was indeed hard-pressed at the time.

82. The name Te-min, found in Kim Yu-sin's biography, seems to have been a reference to Jen-kuei though it is not mentioned in his biography.

83. The text refers to Jen-yüan as tsung-kuan rather than tu-tu which was his actual rank while heading the garrison.

84. No information is available on Sun.

85. I have not been able to pinpoint the exact location of Ungnyŏng. If, as seems likely, it was near Ungjin and Ungch'ŏn, Silla did quite well in the settlement. See map.

86. SS 6, p. 70, relates that at this time, the tenth month of 667 , Li Chi was two hundred $Z_{i}$ north of Pyongyang. The king sent him a message by fast Khitan cavalry and was told to advance. He had scarcely done so when he heard that $\mathrm{Li}$ Chi had retreated, so he also withdrew.

Chinese sources offer little enlightenment on the matter except to suggest that $\mathrm{Li}$ was busy reprovisioning the fleet which had lost its supplies before effecting a junction with his troops. This, combined with the severe winter, may have prevented him from moving. The next engagement recorded took place in the second month of 668 . It is interesting to note that no sooner had Munmu withdrawn than he received an imperial command, transmitted by Liu Jenyüan, that he "aid in the subjection of Koguryð." Receiving orders from two sources must have caused confusion.

87. I cannot identify the site mentioned.

88. SS 6, p. 71 records a Sillan victory in the seventh month and this is probably the one to which Munmu refers. Coming two months before the fall of Pyongyang, it is difficult to say what effect it had. The Sillan annals, incidentally, make no mention of their cavalry leading the assault on the city, and I suspect exaggeration here.

89. The Chinese sources make no mention of reward to the Sillans, and the Sillan annals detail only the rewards bestowed by their own state. $S S$ 42, p. 433 records that in 660 Su Ting-fang offered Kim Yu-sin and some other generals fiefdoms to be carved from the conquered territory. Kim Yu-sin refused on the grounds that China had rescued his country from peril, but the refusal has a 
ring of insincerity and the text continues, "the T'ang troops had extinguished Paekche. . . and secretly plotted to invade Silla. Our king knew of this and asked his ministers and generals what should be done.. . [preparations were made and] the spies of the Chinese learned we were ready. . . [and the attack was aborted]." There is no confirmation in other sources, but as an explanation for the strained relations which followed, it seems plausible.

SS 43, p. 438 records that in 668 gold and silk were bestowed by the Chinese upon those who had assisted in the campaign and an imperial commendation awarded to Kim Yu-sin. In view of Munmu's claim and in view of the fact that Kim Yu-sin is recorded to have been absent at Pyongyang, this report seems contradictory. The Chinese, furthermore, had never before rewarded the Sillans in this fashion, and $\mathrm{I}$ am inclined to reject the report.

90. There is no record elsewhere that Paekche reinitiated hostilities, and the Sillan annals mention no fighting until early 670.

91. The reference here is to the episode of An Sŭng, discussed on $p .121$ in the text. See $S S 6, \mathrm{p}$. 73. Munmu's version seems reliable since the Sillans had repulsed a large Koguryön invasion only two months earlier and so considered Kogury the greater threat.

92. I am not sure of Munmu's meaning here.

93. SS 7, pp. 77-82.

94. SS 6, p. 67. The text says ta-tu-tu-fu.

95. TCTC 201, pp. 6356-57. An-tung consisted technically only of the nine tu-tu-fu and forty-two chou into which Koguryo had been divided. Both Paekche and Silla were presumably subordinate to the protector-general.

96. Ikeuchi, Man-Sen shi, v. 1, pp. 84-87 provides in tabular form a summation of relations among the peninsular states, and the annals of Paekche and Silla, while often contradictory, at least present a chronicle of aggression and reprisal from which Silla emerges no better than its neighbors.

97. Kim Yu-sin's biography makes no mention of his illness, but SS 6, p. 71 remarks that when Munmu was summoned to join $\mathrm{Li} C h i$ in the sixth month he "remained in the capital because of Yu-sin's illness." Munmu arrived in the ninth month and without Kim Yu-sin. The latter's biography says simply, "Our great king Munmu and the Duke of Ying-kuo [ $\mathrm{Li}$ Chi] defeated Pyongyang." SS 43, p. 438.

98. For instance, Hatada, History of Korea, p. 24 sees the beginning of Sillan ambition only with the fall of Kogury. Han Woo-keun, History of Korea, pp. 7589 offers an interpretation of events very similar to my own though far less detailed.

99. TCTC 201, p. 6359. Every other source gives the figure 28,000 . See, for instance, TFYK 486:12a.

100. See note 51. The deportation of so many Koreans is an indication of the ferocious anti-T'ang feeling which must have been present among the Koreans. Their exile in underpopulated sectors of Northwest China was probably designed to separate them as completely as possible from their homeland since as a group, they were not really farmers and since depopulation was equally serious in the Northeast. Hino, "Shō Kokuri koku," Shien 61 (1957), p. 25 points out that the settlers were taken from every part of the defeated state, and their removal thus caused widespread disturbance.

This measure was perhaps the single most important factor in Silla's later unification of the peninsula. The exiled clans were precisely those who had constituted the greatest opposition to it in previous years, and their removal left Kogury $\gamma$ substantially weakened and her people so angered they either turned on 
China or fled to Silla.

101. SS 6, pp. 73-74 and TCTC 201, pp. 6363-64 where the rebel is incorrectly called An Shun. The uprising was not, in fact, initiated by An Sung who appears as rather an unsuitable leader, killing his colleague and fleeing to silla at the appearance of the Chinese troops. Munmu provided the rebels with supplies early in the rising and in the eighth month of 670 bestowed upon An Sung a patent making him king of Koguryo. The patent, itself a usurpation of imperial prerogative, contained some inflammatory phrases, among them the statement that Koguryo must not be extinguished, its royal line cut off, and its people left leaderless. After their flight, An Sŭng and his followers were given Sillan bone rank and settled in territory seized from Paekche.

102. SS 7, p. 76 .

103. Weems, Hulbert's History of Korea, v. 1, pp. $114 \mathrm{ff}$. contains an account of Silla's aggrandizement in the period. On Munmu's apology, see SS 7, p. 84.

104. SS 7, pp. 82-83.

105. SS 7, pp. 84-85. In 675 Silla claimed eighteen successive victories "large and small" and in an amphibious engagement of $676 \mathrm{claimed}$ to have killed more than 4,000 of Hsüeh's troops. In the second month of 676 Hsüeh was forced to move the seat of the protectorate back to the old city of Liao-tung (THY 73, p. 1318 and TCTC 202, p. 6378). The $k^{\prime}$ ao-i notice, in TCTC 202, p. 6378, reproduces a shih- $Z$ u notice saying the move was made in 670 , but Ssu-ma Kuang rejects this, following the Hui-yao.

106. TCTC 202, p. 6379. A second feng-shan sacrifice in the same reign would have been an unprecedented event.

107. See TCTC 202, p. 6385 and the biography of Li Ching-hsüan, Appendix B, no. 59. The affair reflects badly on Liu Jen-kuei who knew that $L i$ had long been his enemy at court and, knowing also that he had no military ability, recommended him to put down the Tibetans. Li's protests were to no avail since Liu's prestige was so great. The Western Turks were flirting with the Tibetans, and a brief alliance did occur in mid-676. TCTC 202, pp. 6390-91.

108. CTS 199 shang:3616:1, HTS 220:4149:1, TCTC 202, pp. 6382-83, TFYK 710:6a. Hino, "Shō Kokuri koku," Shien 61 (1957), pp. 28 ff. gives a good secondary account.

Sillan successes in the 670 s and the demonstrated unreliability of the Mulguls probably account for the king's return, though the immediate cause was another rising in Kogury 8 in 676 which showed that even the highly praised administration of Hsüeh Jen-kuei could not pacify the area. The hope of the court was that the return of the exiled Koreans would bolster Pojang's authority and perhaps constitute a barrier to further Sillan expansion. The king's betrayal aborted the project, and it seems that most of the Koreans remained in the Liaotung area.

109. Among the several sources cited in the preceding note are a number of contradictions. TCTC is alone in using wang instead of chün-wang, and in the matter of the tu-tu position, CTS 199 shang:3616:1, HTS 220:4149:1, and THY 95, p. 1709 give Liao-tung, TFYK gives Liao-chou, and TCTC gives Liao-tung chou. All term Paekche, Hsiung-chin. The use of Ch'ao-hsien and Tai-fang with its overtones of the Han colonial venture strikes me as rather inept and perhaps reflects the unwillingness of the court to admit the failure of so costly a conquest.

110. The return of Pojang had been accompanied by the movement of the protectorate forward from Liao-tung to Hsin-ch'eng. The latter was an admirable 
defensive position, and when the venture failed the chinese remained there. It is interesting to note that in 676 when the protectorate had been moved back to the Liao, the Chinese had relied principally on Korean officials (TCTC 202, p. 6379), and the same procedure was probably followed at this time. The Chinese awareness of the need for self-government was slow in coming.

After Pojang's death, his position was inherited by his son under whom most of the area between Hsin-ch'eng and the Taedong River became virtually independent and is often termed Lesser Koguryŏ. In 698 the empress ended the fiction of Chinese rule there by creating a much smaller An-tung protectorate. THY 73, p. 1318 points out that most of the Koreans joined the Turks or Mulguls and the royal 1 ine died out.

111. SS 7, p. 86.

112. The relations are outlined in SS 8, pp. 89-100 and 9, pp. 101-109, and THY 95, pp. 1712-13. See also Ikeuchi, Man-Sen shi, v. 1, pp. 325-87.

113. See Pulleyblank, Background, pp. 75-81, and Ku, Fu-ping, pp. 261-70, which emphasizes the strains placed on the system by the Korean wars and the Antung administration. He suggests that the important change there was the melding of conscript and garrison forces.

I am in sympathy with this view but would date the development rather earlier than Professor Ku, possibly from 663 when Kao-tsung lowered to fiftyeight the age when service was ended (TT 6, p. 33). I have tried to point out the initial inadequacy of the northeastern units for the prosecution of the Korean wars and the gradually decreasing reliance of the court upon them. Chapter 9 will attempt to show their inability to cope with the Khitan and Turkish invasions. The argument against this interpretation would point to new units established by the Empress Wu in 690, but my view is precisely that their location was largely a recognition that in Ho-pei the system was no longer viable. Kikuchi, "Tōdai fuhei seido" shows that most of the new units were placed in Ho-nan near the new capital, and the only two Ho-pei locations were Wei-chou and Huai-chou. The first was on the Ho-nan border, and the second adjacent to what was to be the northern capital. It seems fair to assume that had the empress deemed it practicable, she would have taken this opportunity to correct the imbalance between the Northeast and the Northwest which had existed since the inauguration of the system and, particularly with her capital at Loyang, set up units to protect it from the North instead of restricting herself mostly to Ho-nan. The following chapter will point out that the new military dispositions she eventually made in Ho-pei were a pointed denial of the continuing validity of the fu-ping system.

114. TCTC 201, p. 6385. On Chang, see Appendix B, no. 57.

115. T'ang relations with the Tibetans are conveniently summarized in THY 97; CTS 196 shang; HTS 216 shang; and TFYK 970. The best secondary treatment of the years under discussion is Ise, Chügoku, pp. $315 \mathrm{ff}$.

Their first recorded tribute mission to the T'ang arrived in 634 , and by 638 they could send an army estimated at 200,000 to press upon T'ai-tsung their demand for a marriage. In 641 the Wen-ch'eng princess, who may have been an inmate of the harem rather than a daughter of the emperor (HTS 83:3883 and 3884), was married to the Tibetan ruler. She seems to have hastened the process of Sinification in the area and to have played an important role in fostering the harmonious "in-law" relationship of the next decade.

The death of the ruler in 650 and the seizure of power by Lu Tung-tsan brought about a change. Lu and his five sons succeeded not only in strengthening 
the internal power of their people, but also in bringing under their sway many of the surrounding tribes. The most notable of these were the T'u-yü-hun whose 300-year history of independence ended when they became Tibetan vassals in 663 . See CTS 198:3612:3. Tribute to China, often in the form of Buddhist statues and other golden artifacts, continued until 665, but after 667 when many Western Turks joined them, the Tibetans took up a hostile stance and in the summer of 670 , they burst into eighteen prefectures in the Western Regions and seized the Four Garrisons (TCTC 201, p. 6363). Henceforth their raids became an annual threat.

116. TCTC 202, pp. 6385-88. The force sent against the Tibetans, whose power was not at its height, was perhaps the largest of the century. In the spring of 677 an army under twelve commanders was levied from large western prefectures like Feng and Hsing, some of which had no fu-ping units whatsoever. The force must, therefore, have been composed largely of conscripts and volunteers, and two of Kao-tsung's sons were given nominal command. In the twelfth month a statewide call for more troops went out (TCTC 202, p. 6384), and in addition to calling up troops in Shan-nan and Chien-nan where there had never been many fuping units, commissioners were sent through Ho-nan and Ho-pei to "recruit brave soldiers without inquiring into their background and official position." See also CTW 14:5a.

It seems fairly clear from the constitution of this force that the available pool of fu-ping troops was largely exhausted and if $\mathrm{Ku} \mathrm{Chi-kuang}$ is correct in suggesting that exemption from expeditions was granted to all those slated for garrison duty in a given year and that this left a pool of only 100,000 (Fuping, p. 174), this is understandable. The recruitment of the lower classes suggests a certain desperation on the part of the court, and it seems incredible that an attack on Silla could be considered at the same time.

The Tibetan force must have been formidable since it could draw on the resources of an empire which the CTS describes as contiguous to China in the East, touching upon northern India in the South, encompassing the Four Garrisons, and reaching in the North to the territory of the Turks. CTS 196 shang:3604:2.

117. TCTC 202, p. 6396.

118. TCTC 202, p. 6386.

119. On Wei, see Appendix B, no. 121. The memorial is abstracted in TCTC 202, p. 6387.

120. See Ku, Fu-ping, pp. 165-97, and Fonctionnaires, v. 2, pp. 763-69. I simplify greatly here because Ku's treatment is so thorough and because the mechanics of the fu-ping are beyond the scope of this discussion. It is necessary to note, however, the connection between the fu-ping and the lure of empire. The fu-ping made T'ang imperialism possible, but only at the cost of the destruction of the institution itself and ultimately of the centralization it had early promoted so successfully.

121. Chapters 5 and 9 .

122. Ku, Fu-ping, pp. 192-97.

123. See earlier notes and Chapter 9.

124. TCTC 202, p. 6390. On the resurgence of the Western Turks under the khan of the Shih-hsing tribe, see Chavannes, Documents, pp. $74 \mathrm{ff}$.

125. The vagaries of the foundation and control of the Four Garrisons of Kucha (Kuei-tzu), Kashgar (Shu-lo), Tokmak (Sui-yeh) and Khotan (Yü-t'ien) are studied in detail by Ise, Chügoku, pp. $190 \mathrm{ff}$. Chavannes, Documents, pp. 114-28, translates the CTS notice on each. 
126. The Chinese sources refer to the clan as Lun 訽. This is somewhat puzzling since the sounds bear no resemblance to each other, and I am indebted to Professor Henry G. Schwarz for the suggestion that the Tibetan surname nGar よ27よ' is derived from mgar baよयाよ'ロ' "smith" or 'Wheelwright." The Chinese version should therefore be事侖 "wheel," but the sources write the character with an incorrect radical.

127. P'ei was vice-president of the Board of Civil office at the time but, as noted earlier, had had a good deal of experience on the western frontiers. $\mathrm{His}$ discussion centered on the recent defeats by the Tibetans and recommended that since the king of Persia has recently died and his son was a hostage at Ch'ang-an, an embassy should be sent to install him on the throne and, while crossing the territory of the Turks, take the opportunity to detach them from their Tibetan alliance. P'ei was given charge of the affair, and his biography recounts a brave saga of near-starvation on the desert before an ingenious stratagem enabled him to take the khans prisoner and bring them back to the capital, thereby defusing a dangerous situation.

The subsequent administration of the area is best outlined in the biography of Wang Fang-i in CTS 185 shang:3561:1 and HTS 111:3934:1.

128. TCTC 202, pp. 6392-93, CTS 5:3074:3, and THY 94, pp. 1690-91. Ts'en, T'u-chüeh, pp. 289-92 examines the full range of sources. The Turks and their allies advanced to the area of modern Peking before retreating to the Northwest as P'ei's armies advanced. The decisive battle took place at Hei-shan, north of Feng-chou, where the combined Chinese forces are estimated by CTS at 450,000.

129. This is not to say that there was no follow-up to the victory. The great Korean general Hukch'i Sangchi made viable the defenses of the entire Hoyüan area (TCTC 202, p. 6395 and CTS 109:3400:3), and by mid-682 Wang Fang-i could report the final pacification of the Western Turks (TCTC 203, p. 6409). The same year Hsüeh Jen-kuei, recalled from his second disgrace over the Korean debacle, administered another defeat to the restive Turks, taking over 200,000 captives. TCTC 203, p. 6412.

At Kao-tsung's death the Tibetans were recuperating from eight successive defeats at the hands of Lou Shih-te (Appendix B, no. 104), and there were troops in the field pursuing recent Turkish invaders. These returned two months after his burial. The Tibetan campaign was not renewed until 687 .

\section{Chapter 9}

1. The question of ritual abdication is discussed by Carl Leban in a paper titled "The accession of Ssu-man Yen, A.D. 265: Legitimation by ritual replication" (Asilomar, 1975). In the case of the Chou, it is important to note that the annals of the empress in both T'ang histories state simply that she "raised her title" to emperor, and Ssu-ma Kuang records that "the empress-dowager accepted $\left(k^{\prime} O\right)$ the request of the emperor and the ministerial body . . . and elevated her title to sheng-shen huang-ti." TCTC 204, p. 6467. Jui-tsung does not seem to have signed the petition which requested the foundation of the Chou, but rather to have asked simply that his surname be changed from $\mathrm{Li}$ to Wu. TCTC, Zoc cit. In 705 the CTS, HTS, and TCTC use the term ch'uan-wei, "transmit the throne" for Chung-tsung's reassumption of the position of emperor.

2. CTS 6:3076:1, HTS 4:3641:3, and TCTC 204, p. 6467. Jui-tsung's heir was at the same time made huang-sun. 
3. Notes 124 and 139 below.

4. Some of these relationships are outlined in Ch'en, "Hun-yin chi-t'uan," and Fitzgerald, Empress Wu, p. 147. See also TCTC 204, pp. 6466-67 for T'aip'ing's marriage to the empress' nephew and the conferral of the Wu surname on the Ch'ien-chin princess in 690 just prior to the usurpation.

5. TCTC 206, p. 6540 .

6. HTS 4:3641:1 and TCTC 204, p. 6470.

7. Professor Hok-lam Chan has recently pointed out to me that the T'ang did not formally adopt the earth power until 750. Since this is the case, we might assume that the empress had no need to formally choose an element for her dynasty. On the other hand, the tradition of doing so had become well-established in the period of division, and in the early T'ang there were extensive debates on the matter in which Wang Po $(648-75)$ proposed the scheme which was eventually adopted. See Lü Ssu-mien, Liang-Chin, pp. 1469-72.

8. HTS $76: 3869: 2$.

9. See, for instance, Kuo Mo-jo, Wu Tse-t'ien, pp. 135-37 and 154-55 which outline the findings of an academic expedition to the old Li-chou area which discovered epigraphical evidence of her popularity and also the existence of an agricultural festival said to be held in commemoration of her birthday. See also TCTC 208, p. 6587 , for Ts'ui Chiao's secret memorial to Chung-tsung pointing out that the hearts of the people still adhered to the empress.

10. For a recent and succinct discussion of the importance of role in legitimation, see J. D. Langlois Jr., "Ritual and law in the legitimation of the Ming dynasty" (Asilomar, 1975).

11. TCTC 204, pp. 6467-68. Arthur Wright, in his paper on the formal procedures by which Sui Wen-ti sought legitimation, emphasized the importance of the foundation of ancestral temples. For examples of the substitution of "Wu" for "T'ang" in place names, see THY 70, p. 1257 and 71, p. 1261.

12. Chapter 4, n. 92, and Chapter 6; see also Twitchett's remarks in Financial Administration, pp. $84 \mathrm{ff}$. A northern capital was founded in 692, TCTC 205, p. 6487.

13. TCTC 204, p. 6473, TFYK 486:336, THY 84, p. 1553, and CTS 6:3076:1. This occurred in the seventh month of 691 with the households from such chou as Yung, T'ung, and Ch'in where the concentration of fu-ping units was high. There are some source contradictions, with CTS and TCTC saying that those resettled were drawn exclusively from Kuan-nei while the others say Kuan-wai. TCTC limits the number transported to 100,000, and CTS goes on to say that Yung-chou was divided immediately into four parts.

The basic motives, it seems, were to provide a larger base of support for the new capital and the official class concentrated there, and to weaken the old Ch'ang-an area.

14. TCTC 204, p. 6473. Wu Yu-i, in fact, became Ziu-shou prior to the movement of the households.

15. TCTC 205, pp. 6478-79. Li Chao-te (Appendix B, no. 99) was placed in charge of the project.

16. TCTC 205, pp. 6496 and 6502-3. Jao's excellent study, "Tsung-chiao hsinyang" convincingly connects the t'ien-shu with Manicheanism.

17. TCTC 205, p. 6496. Note also Ssu-ma Kuang's comments on p. 6498 suggesting that the treasuries were emptied to pay for the construction of the mingt'ang complex.

18. TCTC 205, p. 6493, which describes these treasures, and also Chapter 4. 
19. THY 35, p. 637.

20. TCTC 204, p. 6471. The petitions appeared in early 691, and the one suggesting the feng-shan sacrifice included 2,800 names.

21. TCTC 205, p. 6503. See also CTS 6:3076:2 and Jao, "Tsung-chiao hsinyang," pp. 402-405. On the forms and purposes of the suburban sacrifice, THY 9 shang, pp. $141 \mathrm{ff}$.

22. TCTC 204, p. 6473. The sons of the former Crown Prince Hsien were given the Wu surname and imprisoned with Jui-tsung's family.

23. TCTC 204, pp. 6473 and 6489.

24. TCTC 204, p. 6472 and CTS 186 shang:3564:4.

25. CTS, Zoc. eit. See also TCTC 205, p. 6485 for Ssu-ma Kuang's estimate of the toll taken by the so-called evil officials.

26. TCTC 205, p. 6485.

27. On Hsü, see Chapter 5, n. 88. His early refusal of office is found in TCTC 204, pp. 6469-70.

28. For examples of the activities of these, see TCTC 205, pp. 6485-86. It is of interest to note that in mid-692 Chu acknowledged in a memorial that "the minds of the people are already made up" (chung-hsin $i$-ting), presumably in favor of the Chou.

29. TCTC 205, p. 6486.

30. Details are found in TCTC 205, pp. 6479 ff. and Fitzgerald, Empress Wu, pp. $138-40$.

31. CTS 183:3553:2 and TCTC 204, pp. 6474-75. See also CTS 87:3352:4.

32. On Li, see Appendix B, no. 99. He is depicted as a courageous official opposing, for instance, the attempt of Lai Chün-ch'en and his cohorts to marry into the T'ai-yüan Wang and Chao-chün Li clans (CTS 87:3352:4), and once having one of the most powerful of the "evil officials" flogged to death, ostensibly for a violation of the sumptuary regulations (TCTC 205, p. 6491). In the matter of the succession, he rapidly showed his position by having Ch'eng-ssu's spokesman beaten to death. TCTC 204 , p. 6475.

33. TCTC 204, p. 6476.

34. TCTC 205, pp. 6483-4. Three others, Ts'ui Shen-chi (Appendix B, no. 97), Yao Shou (no. 100) and Li Yüan-su (no. 101), were all raised to tsai-hsiang status with Chao-te on this occasion and so might be identified as his adherents. All were eventually disgraced or executed.

35. On the posts held by the Wu clan, see CTS 183:3553:1. After 695, with the fall of Hsüeh Huai-i, the use of family and favorites in military posts was very rare, the only exceptions being Wu 1 -tsung and Wu Yu- $i$. This is discussed passim in the text. I do not suggest, however, that members of the Wu clan became a negligible factor in the political equation. The empress used them on subsequent occasions to further her political aims so that, for instance, $\mathrm{Ch}^{\prime} \mathrm{eng}^{-}$ ssu and San-ssu assisted her in the New Year's ceremony of 693 from which Juitsung was barred. (TCTC 205, p. 6488 and HTS 76:3867:4). We may surmise that her aim was to confuse the advocates of a T'ang restoration.

36. See note 32 above.

37. TCTC 205, p. 6496.

38. TCTC 206, p. 6519.

39. Note 35 above.

40. TCTC 205, p. 6488. Hsüan-tsung's mother, the Virtuous Concubine, was the great-granddaughter of Tou $K^{\prime}$ ang (Appendix B, no. 6).

41. CTS 186 shang:3564:3 and TCTC 205, pp. 6489 and 6490. Ssu-ma Kuang remarks that "from that time none of the nobles or ministers were able to see him." 
42. TCTC 205, p. 6490 .

43. See Chapter $5, n .7$ and 8 .

44. Chapter 5, n. 79.

45. See Pulleyblank, Background, pp. $48 \mathrm{ff}$., and more particularly, Chou, Han-T'ang, pp. $373 \mathrm{ff}$.

46. By my calculations, ten men held tsai-hsiang rank in 645 . The totals vary according to source and, although my own are different, I am here following the figures given in THY 1, pp. 3-4. Those for the reign of Kao-tsung, divided to correspond with the expansion of Empress Wu's power, are as follows:

Period

650-659 (4th month)

659-664 (12th month)

664-684

Total
Appointments

$$
\begin{array}{r}
14 \\
4 \\
25 \\
43
\end{array}
$$

Tenure

4.5 years

2.2 years

5.5 years

3.1 years

47. See Appendix B, no. 104, and note TCTC 206, p. 6541), which comments on his remarkable longevity in spite of the terror and the confused politics of the time.

48. While I have made no exact count, I have found that virtually every kind of irregular appointment occurred within the tsai-hsiang group in the Chou. The terms used to designate this type of position are several: chien-chiao "acting," shih 試 "probationary," shou "temporary," and she "provisional." We find also a large number of concurrent (chien 兼) appointments, supervisory duties ( $p^{\prime} a n$ ) and those appointed to one post but designated to fill the function (chih 知) of another. This led not only to uncertainty of tenure among the tsai-hsiang but severely restricted their freedom of action and created an atmosphere of distrust in the highest ranks of officialdom.

49. My calculation. See Appendix B.

50. TCTC 205, p. 6501.

51. On these appointments see, for instance, TCTC 206, p. 6533 and 205, pp. 6496-95 and 6499-6500.

52. See Chapter 1, n. 42, and CTS 6:3077:1.

53. For instance, TCTC 205, P. 6484 and p. 6478, respectively. 6544.

54. See the biography of Chi Hsiu in Appendix B, no. 120 and TCTC 206, p.

55. On the question of the succession as a "household matter," see TCTC 206, p. 6526. Criticism of the Changs brought death in 701 to the son and daughter of Chung-tsung and the son of Wu Ch'eng-ssu. TCTC 207, pp. 6556-57 and CTS 86: $3350: 4$. Other examples of both are cited in the text.

56. Chou, Han-T'ang, pp. $506 \mathrm{ff}$.

57. TCTC 202, p. 6376. Judging by the dates of the literary works for which they were responsible, and by a notice in TFYK 550:2b, the group seems to have existed prior to 674 , perhaps as early as 667 . Most of those whose names are preserved, Liu Wei-chih (Appendix B, no. 72), Fan Li-ping (no. 85), Yüan Wanch'ing (CTS 190 chung:3581:4), Miao Shen-k'o (CTS, Zoc. cit.) and Hu Ch'u-pin (CTS 190 chung:3582:1) received their first capital appointment at about this time. TCTC 204, p. 6447, a notice of 688 , is the last mention of the group.

58. TCTC 203, p. 6417.

59. TCTC 204, p. 6466. On Wan-erh, see CTS 51:3279:4.

60. TCTC 206, p. 6526.

61. TCTC 205, pp. 6477-78. See also THY 67, pp. 1180-81, which says that 132 
appointments were made at this time. The highest posts, acting grand secretaries of the Secretariat, were of the fifth rank, first grade, and the lowest were clerks of the ninth rank, third grade.

62. See TCTC 205, pp. 6500-01 and THY 40, pp. 728-29.

63. See Chapter 7. The bureaucratic expansion in the early Chou seems to have equaled that in the period just prior to the usurpation. Although we are offered no estimates so specific as Wei Yüan-t'ung's statement of 685 that over 1,000 chu-se entered the "current" each year (THY 74, p. 1336), we are told, for instance in 692, that vast numbers had their selection rescinded. THY 74, p. 1345 and T'ai-p'ing kuang-chi 185:5a. It is possible that some of the excess was absorbed in the expansion of military administration: eighty-six new fuping units were created in 690 (WYYH 464:1b), and later new positions were set up in existing units ( $y \ddot{u}-h a i$ 138:4a). As we shall see, the empress had to respond to pressures for bureaucratic reduction toward the end of the Chou.

64. Taking once again our tsai-hsiang sample from the Chou, and excluding those who rose as family or favorites of the empress, we find that of fifty-nine chief ministers, at least thirty-three came from clans which were either aristocratic in background or had a tradition of office holding. Of these, however, only fourteen were from clans specifically regarded as preeminent. This means that less than a quarter of the Chou tsai-hsiang came from the great clans.

65. Pulleyblank, Background, pp. 47-60, and Tonami, "Chūsei," pp. 9 ff.

66. TCTC 205, p. 6478.

67. See, for instance, the case of Tsung Ch'u-k'o (CTS 92:3365:4 and HTS 109: 3930:4) who had not only a marriage connection with the empress, but whose brother had been one of her firmest supporters in the usurpation and is said to have invented her new characters. The Tsungs' first demotion occurred in the tenth month of 690. TCTC 204, p. 6468. A relative of Lai Chün-ch'en lost his position in the Yü-lin Guard in late 692. TCTC 205, p. 6487.

68. THY 85, p. 1555 and TFYK 486:12a.

69. On the decree examinations, see Lin, Sui-T'ang shih, pp. 210-211, and on the Board increases, THY 58, p. 1006, and 59, p. 1030.

70. TCTC 205, p. 6485, from a memorial of 692 .

71. TCTC 205, p. 6489, THY 63, p. 1104, and Yü-hai 48:32a.

72. See, for instance, the list of tributary missions in TFYK 970:17a ff., and the investiture of the Sillan king in TFYK 964:10a.

73. My own calculation. When the Shih-hsing sought refuge in China in 690 , it was after five years of constant attack by the Eastern Turks. Their leader, the Hu-se-lo Khan, was made a general (TCTC 204, p. 6469). THY 98, p. 1756 remarks on the settlement of the Ch'iang, and TCTC 205, p. 6494, that of the Man.

74. On Wang, see CTS $93: 3366: 2$ and HTS $111: 3935: 3$, and on T'ang, CTS 93:3366: 3 and HTS 111:3935:4. Wang had been captured by the Tibetans Hsüeh Jen-kuei's defeat at Ta-fei-ch'uan in 670 and, after living among them for a decade, returned to become China's greatest expert on the Western Regions. T'ang came from a family whose military tradition went back to the Northern Chou, but which had chosen the wrong side at the time of the T'ang foundation so that to establish himself, Shou-ching had taken the ming-ching degree. His early experience was against the Turks.

75. CTS 93:3366:2. The campaign is outlined in the biographies above and discussed in some detail in Ise, Chügoku, pp. $197 \mathrm{ff}$. See also Fitzgerald, Empress Wu, pp. $144-45$.

76. TCTC 205, p. 6493. On Mo-ch'o, see CTS 184:3598:1, HTS 140:4132:1, and 
THY 94, pp. $1691 \mathrm{ff}$. Ts'en, T'u-chüeh, pp. $324 \mathrm{ff}$. outlines Mo-ch'o's raids from 689, even before he became khan. In Western languages, see Giraud, Tures célestes, pp. $49 \mathrm{ff}$, and Grousset, L'empire, pp. $155 \mathrm{ff}$. Mo-ch'o was the brother or half-brother of the Khan Ku-ch'u-lu, usurped the leadership on his death in late 693, and immediately invaded Ling-chou.

77. TCTC 205, p. 6503. The request to submit may have been in response to the fact that Wang Hsiao-chieh had just been sent against him with a large force.

78. Note 63 above and TFYK 532:14a. It is interesting to note also a decree of 694 ( $T H Y 78$, p. 1438) whereby each of the major provincial officials, governors, prefects and garrison commanders were required to leave one son in the capital guard. It seems unlikely that any new posts were created for this but rather that a hostage system was being established.

79. TCTC 205, pp. 6495-96.

80. TCTC 205, p. 6496. It is of interest to note that no protest is recorded.

81. On Li Chiao, see Appendix B, no. 123, and on his memorial, Chapter 5, $n$. 37 and THY 85, pp. 1560-61. The memorial, along with others relating to the problem, is translated by Balazs in "Beiträge."

82. CTS $94: 3368: 2$.

83. See Tonami, "Tō no ritsuryō," and Pulleyblank, Background, pp. 27 ff. On the Tunhuang evidence, see T'ang Ch'ang-ju, "Fo-t'ao-hu."

84. Most notably, the construction of the nine tripods (TCTC 205, p. 6499) on whose Confucian associations, see $T z^{\prime} \dot{u}-y \ddot{u} a n, p .58 a$.

85. TCTC 205, p. 6500 and THY 11 , pp. 278-79.

86. On the reconstruction, see THY 11, pp. 279-80, TFYK 564:7a, and TCTC 205, p. 6505. The new building was called the T'ung-t'ien t'ang and was smaller in all dimensions than the original. On the death of Huai-i, see TCTC 205, p. 6502, CTS 183:3554:4, and note the contradictions pointed out in the $k^{\prime} a 0-i$ notice. The nun who ran a house of ill repute was enslaved with all her followers. TCTC 205, pp. 6499-6500.

87. The hu-ming principle was abolished in the tenth month of 695 . THY 75 , p. 1358. The full decree is found in CTW 96:6a but offers little enlightenment on the reason for ending the practice. The empress acknowledges that she initiated the principle of anonymity so that her officials could be chosen from as many sources as possible, but then goes on to characterize the practice as contrary to principle and calls for its end in the name of efficiency and good government. The reason I suggest for the change is conjectural.

88. TCTC 205, p. 6503.

89. The best account of this campaign is found in the biography of Lou (CTS 93:3366:2, HTS 108:3929:4). See also TFYK 443:5a and TCTC 205, pp. 6504-5. The empress was extremely angry, demoting Wang to commoner's status and Lou to a low provincial post.

90. On the history of Sino-Tibetan relations, see Chapter $8, \mathrm{n} .115$.

91. See CTS 199 hsia:3618:3 and TCTC 198, 6252-3. The details of early Khitan history are extremely sketchy, and since the Sillan annals in the $S S$ make fairly frequent reference to them, the lost annals of Koguryo would probably have been our best source. TCTC 205, p. 6505, $k^{\prime} a 0-i$, gives a brief administrative history of Ying-chou.

92. TCTC 205, p. 6505. The rebel leaders descended from tribal chieftains, and one had won the imperial surname for dynastic service. They were related by marriage and held the positions of governor (tu-tu) and prefect at the time of the rising. 
93. TCTC 205, pp. 6506-7, CTS 199 hsia:3618:4, and HTS 219:4145:4.

94. TCTC 205, p. 6507.

95. The only full description of the empress' actions are contained in a memorial from Ch'en Tzu-ang, abstracted in TCTC, Zoc. cit., and found in full in Ch'en Tzu-ang chi, pp. 178-82.

Ch'en's basic purpose in the memorial was to protest the levy, regarding it as unnecessary, dangerous, and an affront to the national dignity. He took the opportunity, however, to raise a number of other matters, both general and specific. Pointing out that the Khitan ambush was unfortunate and had created a very serious problem, he begged the empress to remain calm and to keep in mind that the Tibetans and Mo-ch'o's Turks posed a more serious threat than the Khitans. To send troops from the northern and western frontiers to meet the latter was folly. Ch'en was critical of the standard of ministerial advice which the empress received, particularly that which permitted the "barbarization" of the armies, and he urged her to seek out the many competent men who had been neglected in appointment to high office. He spoke of self-seeking and timid ministers and conflicts between civil and military officers which the empress should no longer tolerate.

Turning to the situation at hand, he asked that the troops levied from Shan-nan and Huai-nan be given a more reasonable length of time to reach the frontier and not be threatened with the death penalty for tardiness. The diversion of grain to the front, he be! ieved, would not only cause enormous hardship and resentment among the carriers for whom no special reward seems to have been arranged, but would cause a great price rise in the Northeast and general confusion. The actual situation at the front, he pointed out, was not even known! Finally, and perhaps with some regional jealousy, Ch'en pointed out that because the Northeast supplied the armies, its people were not conscripted. He had recently heard that in their arrogance and rudeness, they had claimed that the government could not compel them to serve, and this was being discussed everywhere. Furthermore, the area had recently found itself plagued by a growing number of bands composed of the lawless and unemployed. Central officials should be sent out immediately to conscript them into the forces, thus augmenting the national strength and ensuring that their relatives remain loyal to the state. He ended with a plea that the court be more generous with incentives and rewards for military service lest the task of recruitment become impossible. The common people of the Northeast were exhausted.

From this memorial, submitted less than a month after the defeat, it would seem that the neglect of the military had reached serious proportions. Ho-pei had suffered only two minor invasions since 679, the Turkish raids of 683 and 687 (TCTC 203, p. 6413, and 204, p. 6443), and when Ch'en mentioned the "magnates and roving warriors who have become bandits, the jobless drifters, the wealthy families and strong clans," he was commenting also on the military potential of the area which we noted earlier. This seems to confirm my finding that the fuping declined earliest there, and it might be reasonable to suggest that the dissident elements were deserters or men who might otherwise have found niches within the system.

Two additional facts support this view. In 696 the empress set up in the frontier areas of the Northeast special units called wu-ch'i t'uan-ping, and the next year these were extended throughout Ho-nan and Ho-pei to defend against Moch'o. In these units 150 households provided fifteen soldiers and one horse among them. THY 78, p. 1438 and TCTC 205, p. 6507. See also Hamaguchi, "Fuhei," pp. 
$1466 \mathrm{ff}$. These units were almost certainly the prototypes of the later t'uanchieh, and their creation seems to reflect a concession to regional feeling and an alternative to fu-ping service. Moreover, in Chang Yüeh's report on Wu Itsung's Ho-pei campaign of 697 (WYYH 647:8a) we find the names of those "mentioned in dispatch." Twenty-two men are mentioned, and the origin of their units may be tabulated as follows:

$\begin{array}{llll}\text { Ho-pei } & 7 & \text { Chiang-nan } & 7 \\ \text { Ho-tung } & 5 & \text { Chien-nan } & 1 \\ \text { Kuan-nei } & 4 & \text { Ho-nan } & 1 \\ \text { Lung-yu } & 3 & & \end{array}$

The table suggests that the fu-ping in Ho-pei was weak, especially in view of the fact that of the northeastern units mentioned, only one was among the 86 established in 690 when the empress augmented the forces there. It is difficult to escape the conclusion that these new units were not viable from the start.

We need not, however, read too much into these facts for they seem to say little about the oft-mentioned "separatism" of the area. They suggest more, I think, that because the Northeast had borne the brunt of the T'ang's early imperialism, the inappropriateness of the fu-ping was revealed there first. The response of the area to alternative service and its refusal to respond to Khitan and Turkish calls to dethrone the empress support this view.

96. TCTC 205, pp. 6507-9.

97. On Ch'en's background, see Chapter 5, and on Kuo, CTS 97:3373:2 and HTS 122:3957:1. The latter, a chin-shih graduate of undistinguished lineage, had just returned from personal negotiations with Lun $\mathrm{Ch}^{\prime} \mathrm{in}-\mathrm{ling}$ and seems to have been familiar with the situation among the Tibetans since it was he who conceived the plan adopted by the empress.

98. TCTC 205 , pp. $6508-9$. The $k^{\prime} a 0-i$ reproduces a notice from the yü-shiht'ai chi outlining subsequent events.

99. TCTC 205, pp. 6509-10.

100. TCTC, Zoc. cit.

101. The Khitan call for Chung-tsung's restoration seems to have been made in early 697, and judging from the $k^{\prime} \alpha 0-i$ notices in TCTC 206, pp. 6526-28, the source of the report is the $C^{\prime}$ 'ao-yeh ch'ien-tsai. Corroboration is lacking, but in view of the harmony of Khitan relations with T'ai-tsung and Kao-tsung, it seems perfectly reasonable.

There seems to have been a certain amount of collaboration with the enemy in the area, since we are told that Wu 1 -tsung executed several guilty persons (TCTC 206, p. 6522) before Ti Jen-chieh's pleas for clemency were heeded. Ti's statement (CTS 89:3356:4) mentions both those who were coerced and those who joined the Khitans willingly, but points out that the area suffered from economic depression and the unreasonable demands of harsh officials, so that under the circumstances it had been highly loyal. See also TCTC 206, pp. 6535-36. His remarks were made in late 698 after Mo-ch'o had withdrawn and refer both to Turkish and Khitan invasions.

102. On this affair, see TCTC 206, pp. 6512-13, Fitzgerald, Empress Wu, pp. 152-3, and Chapter 6, n. $70(\mathrm{~g})$.

103. Lai had gone so far as to accuse Chi Hsü, the man who had brought the conspiracy to his notice, of being implicated in it. After Chi had cleared himself he, of course, hated Lai, and the empress used their hatred once again to balance 
her appointments. On Chi Hsü, see Appendix B, no. 120.

104. TCTC 106, p. 6517. These two figures, about whom we would like to know a good deal more, have biographies in CTS 78:3337:1 and HTS 104:3921:4; and for their ancestry, see Appendix B, no. 34. Fitzgerald, Empress Wu, pp. $163 \mathrm{ff}$. , outlines their careers in some detail.

105. See, for instance, Fitzgerald, Empress Wu, p. 163 for his suggestion that the terminology of HTS and TCTC is such as to indicate that both became the empress' lovers. For contemporary evidence, see note 159 to this chapter.

106. TCTC 205, p. 6487. A notice of the ninth month of 692 when the empress grew some new teeth and changed the era name to ch'ang-shou, "long life."

107. TCTC 206, p. 6546 and CTS 78:3337:2. It was for this reason probably that the literary institute, founded in 699 (TCTC 206, p. 6538) to provide a sinecure for the Changs, was called office of the Crane ( $K^{\prime}$ ung-hao $f u$ ). Wang Tzu-ch'in (6th century B.C.), also known as Wang $\mathrm{Ch}^{\prime} \mathrm{iao}$, ascended to the immortals on the back of a white crane and so became a symbol of longevity. See also the remark of Yang Tsai-ssu in TCTC 207, p. 6572, suggesting that Chang Ch'ang-tsung had made an elixir of immortality (shen-tan) for the empress.

108. See preceding note; also TCTC 206, p. 6517 for the account of a man who won lavish rewards from the empress for claiming that he dreamt she would live forever. Jao, "Tsung-chiao hsin-yang," pp. 402-5 discusses the question in some detail.

109. TCTC 206, p. 6514 and CTS $78: 3337: 2$.

110. TCTC, Zoc. cit. See also the biography of Yao Shou (Appendix B, no. 100) who dissuaded the empress from the project. The verses said to be written by the empress for the erection of the tripods are found in CTShih 5:la. These tripods, incidentally, are said to have been cast from 800 tons of bronze.

111. TCTC, Zoc. cit.

112. CTS 185 shang:3560:1 and TCTC 206, pp. 6515-16. In the early 670s, many of the Western Turks and the Tu-yü-hun had submitted to China (TCTC 201, p. 6363, and 202, pp. 6371-72) and had been settled in the six prefectures of Feng, Sheng, Ling, Hsia, Shuo, and Tai.. To send these back to Mo-ch'o would weaken the entire North. Ts'en, T'u-chüeh, pp. 333-39 offers a good examination of the events of this year.

113. On Li Chiao, see Appendix B, no. 123 and on $T^{\prime}$ ien Kuei-tao, CTS 185 shang: 3560:1 and HTS 197:4088:3. Their position was that the Turks were covetous and lacking in good faith and that granting their demands was an invitation to invasion. Their opponents were Yang Tsai-ssu (no. 111) and Yao Shou (no. 100).

114. TCTC 206, p. 6416 and THY 94, p. 1691. The latter remarks "from this Mo-ch'o grew even stronger."

115. On 1-tsung, see CTS 183:3554:1 and HTS 206:4110:1.

116. TCTC 206, pp. 6520-22.

117. On Lai's activities at this time and his fall, see CTS 186 shang:3564:3 and TCTC 206, pp. 6518-19.

118. See CTW 95:8b for the edict of punishment, and TCTC 206, p. 6520.

119. TCTC 206, p. 6523.

120. On Ti, see Appendix B, no. 93, and TCTC 207, pp. 6550-1. Ti was the most famous and perhaps the greatest of the empress' ministers and is the subject of a large secondary literature. A man of uncompromising integrity and infinite subtlety, he won the empress' complete trust and, "although he was fond of arguing with her [in court], she accepted it and followed his advice." She is said to have called him the "old man of the state" (kuo-Zao) and in one incident, 
recounted in TCTC, Zoc. cit., is said to have valued his safety more than that of the crown prince. She was disconsolate on his death in 700 .

It must be acknowledged, however, that $\mathrm{Ti}^{\prime} \mathrm{s}$ power was never total, partly because Wu San-ssu usually occupied a parallel position in the hierarchy and partly because the empress seems to have insisted on the invulnerability of the Changs. Probably because of their relative harmlessness, $\mathrm{Ti}$ never sought a confrontation with them. His biography suggests a different reason for this, pointing out that he recommended "several tens" of T'ang loyalists for high posts, so that these were in a position to carry on his work when he died. Most notable among them were three leaders of the restoration coup, Chang Chien-chih, Huan Yen-fan and Ching Hui. See also TCTC 207, pp. 6551-52. THY 75, p. 1357, says he recommended all five leaders of the coup.

121. TCTC 206, p. 6526.

122. TCTC, Zoc cit. "From this [remonstrance] the empress-dowager had no intention of establishing Ch'eng-ssu or San-ssu."

123. TCTC 206, pp. 6526-27.

124. TCTC 206, p. 6537, and see the lengthy examination of the event in the $k^{\prime} a 0-i$ notice.

125. TCTC 206, p. 6532.

126. TCTC 206, p. 6525. As pointed out earlier, it was Li Chiao who first requested the reduction of ÿ̈an-wai officialdom in the next reign.

127. See Chapter 7. See also TFYK 629:20b-2la for a decree of 696 which recognized that advancement "within the current" had been much too rapid.

128. The full text is in CTW 169:2b, and the memorial is abstracted in THY 73, pp. 1326-27 and TCTC 206, pp. 6524-25.

129. For $\mathrm{Ti}^{\prime} \mathrm{s}$ reference here, see TCTC 195, p. 6148.

130. I cannot identify this figure.

131. TCTC 206, p. 6525.

132. Ch'en Tzu-ang chi, pp. 173-78. In general Ch'en approved of the demobilization but warned the empress that the self-seeking officials in the prefectures of Sung and Mao, deprived of the profit they reaped from the supply of the military, might falsely stir up trouble with the Ch'iang in order to restore their fortunes. He spoke also of 30,000 vagrant households who had fled to the West from the Szechwan region, attributing their migration to the harshness of officials there and requested administrative reform there. Finally, since he saw the necessity for keeping the T'ung-kuei Army stationed in Sung-chou active, he recommended a much less costly and onerous means of keeping them supplied.

Perhaps because he was a westerner, $\mathrm{Ch}$ 'en was more conscious than most of the Tibetan threat. The fact that even he advocated a relatively passive stance toward the foreign neighbors suggests that the attitude was becoming widespread in officialdom.

133. See the preceding note and TCTC 206, p. 6530. Lou Shih-te was appointed commissioner to assess the garrisons in the area.

134. TCTC 206, pp. 6530-31 and CTS 183:3553:4. Yen-hsiu, the second son of Ch'eng-ssu, reached his destination in the eighth month of 698 . He did not return until 704, and in 708 married Princess An-lo.

135. See Appendix B, no. 133 and TCTC 206, p. 6530.

136. TCTC 206, pp. 6530-32, CTS 194 shang:3598:2, TFYK $964: 10 \mathrm{~b}$ and $998: 8 \mathrm{~b}$.

137. TCTC 206, p. 6533; see also Ts'en, T'u-chüeh, pp. 339-50 which offers a full examination of the events of this year, introducing two inscriptions which contradict the standard account. We have no details on the constitution of the 
force, but since the three commanders were designated as tsung-kuan of the eastern, western, and central provinces, it seems likely that the troops were raised throughout the empire.

138. TCTC 206, p. 6534. It is difficult to know whether or not this is true. The dynastic histories reproduce the story only in $\mathrm{Ti}^{\prime} \mathrm{s}$ biography and there as

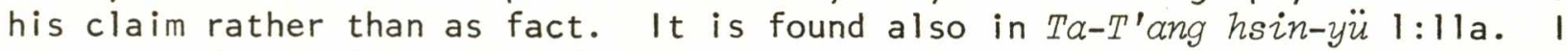
am prepared to believe that Chung-tsung's appointment increased the levies, but the story still seems too contrived to be fully credible.

139. TCTC, Zoc. cit. It is important to note that the new volunteers came from Ho-pei since it is a strong indication that the area was not "separatist" or disloyal to the T'ang. The other possibility, of course, is that Ho-pe $i$ had been alienated by Wu 1-tsung's cruel swoop through the province in 697 to punish those suspected of collaboration with the Khitans. He acted so harshly then that the inhabitants composed a bitter proverb about him. TCTC 206, p. 6522. Undoubtedly the empress' popularity suffered.

140. TCTC, Zoc. cit. It is interesting to note that while Ti Jen-chieh led the new army against Mo-ch'o, the empress placed command of the remaining troops (t'un-ping) at the capital in the hands of Wu 1-tsung and Wu Yu-kuei, the first sign that she was concerned about her security. TCTC 206, p. 6535.

141. CTS 194 shang:3598:2. Ssu-ma Kuang uses the conventional term "over $10,000^{\prime \prime}$ but adds that casualties in the region from Mo-ch'o's five invasions were countless.

142. TCTC 206, p. 6535. See also Grousset, L'empire, pp. $150 \mathrm{ff}$.

143. TCTC, Zoc. cit.

144. TCTC 206, pp. 6539-40 and CTS 196 shang:3604:2.

145. CTS $93: 3366: 3$ and TCTC 207, p. 6549.

146. On Kuo, see CTS 97:3373:2, HTS 122:3957:1, and TCTC 207, pp. 6557-58.

147. CTS 196 shang:3604:2 and TCTC 207, p. 6562.

148. See TCTC 207, p. 6558 and 206, p. 6539; also note 95 above.

149. TCTC 207, p. 6562.

150. TCTC 207, p. 6568. CTS 194 shang:3598:2 says that the empress brought two of her grandsons, Ch'ung-chün and $\mathrm{Ch}^{\prime}$ ung-ming, into the audience hall to show them as prospective bridegrooms to the Turkish envoy. Ch'ung-chün was shortly to be active at court, and no other source mentions that Chung-tsung had a son called Ch'ung-ming. Perhaps Mo-ch'o's new son-in-law was not a prince at all.

151. See TCTC 207, pp. 6562-63. This incident, in fact, involved only the

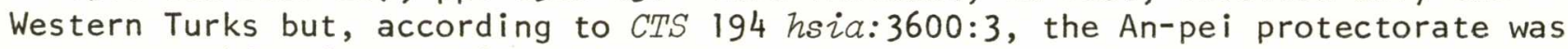
set up at this time at T'ing-chou.

152. CTS 194 shang:3598:2 and Grousset, L'empire, pp. 157-58.

153. TCTC 206, p. 6539 .

154. TCTC 206, p. 6546. The elixir was a costly one and had taken three years to synthesize.

155. TCTC, 20c. cit. and CTS 6:3076:4. In celebration of the event she changed the era name to chiu-shih, "everlasting youth," from the phrase ch'angsheng chiu-shih in the Tao-te ching.

156. TCTC 207, p. 6551 .

157. TCTC 206, p. 6538 and CTS 78:3337:2. Among the best-known scholars appointed to the institute were Li Chiung-hsiu (Appendix B, no. 128), Chi Hsü (no. 120), T'ien Kuei-tao and Yüan Pan-ch'ien. The latter, disgusted at the unprecedented nature of the office and the quality of its incumbents, immediately resigned and was demoted for his presumption. See CTS 190 chung:3582:2.

158. THY 36, p. 657 and TCTC 206, p. 6546. This was the San-chiao chu-ying 
and probably marks the first time Buddhism was officially classified as a teaching equal to Confucianism and Taoism.

159. CTS 78:3337:2. Fitzgerald, Empress Wu, p. 167 seems to put a different interpretation on the matter. The memorial is abstracted in TCTC 206, p. 6546.

160. TCTC 206, p. 6547.

161. TCTC 206, p. 6546 and CTS $78: 3337: 2$.

162. It is difficult to get a complete picture of the Chang clan, but since the principals were referred to as "fifth and sixth master," they must have had several brothers. Two elder and one younger are mentioned in the histories, all of them involved in corruption. On the case of bribery in the hsüan, see TCTC 206 , p. 6547.

163. TCTC 207, p. 6572. Both Li Chiung-hsiu (Appendix B, no. 128) and Chang Hsi (no. 124), who were otherwise reputable officials, seem to have fallen into the same ways.

164. See, for instance, TCTC 207, P. 6563.

165. CTS $78: 3337: 2$.

166. TCTC 207, p. 6556.

167. TCTC 207, pp. 6556-57, and CTS 78:3337:2. Chung-tsung's crown prince was of necessity his son by a concubine, and Empress Wei is said to have been so unhappy with this situation that she sought to have her daughter An-lo replace him. Her actions goaded the Crown Prince Ch'ung-chün into an attempted coup in the summer of 707, initiating a period of unremitting palace intrigue which ceased only with Hsüan-tsung's accession.

168. On Wu San-ssu, see Appendix B, no. 118. He is said at this time to have formed a liaison with Empress Wei in preparation for her husband's succession.

169. TCTC 207, p. 6559. The empress refused, awarding instead dukedoms with revenues of 300 households to both brothers. The TCTC notice is somewhat misleading here since the titles were a reward for literary compilation. CTS 78: $3337: 2$.

170. On Wei, see Appendix B, no. 121 .

171. TCTC 207, pp. 6563-66.

172. See Fitzgerald, Empress Wu, pp. 173-77, which follows closely the TCTC account.

173. TCTC 207, p. 6565.

174. TCTC 207, pp. 6565-66.

175. TFYK 604:4a, TCTC 206, p. 6542, and the full text in CTW 236:3b. On Wei, see Appendix $B$, no. 131 .

176. TCTC, Zoc. cit.

177. CTW $236: 3 \mathrm{~b}$ ff.

178. See, for instance, TCTC 207, p. 6557, on selection. The problem of provincial administration is discussed on $p .151$ in the text.

179. See Chapter 7.

180. Jao, "Tsung-chiao hsin-yang," pp. 403-405.

181. See TCTC 207, pp. 6549-50, and my remarks in Chapter 4.

182. Chapter 4. On the clerical tax, see TCTC 207, p. 6571.

183. TCTC 207, p. 6554 and see the $k^{\prime} a 0-i$ notice.

184. CTS 6:3076:4 and TCTC 207, p. 6557. It may be significant that Jui-tsung was given command of the Yü-lin Guard immediately before the empress' departure.

185. TCTC 207, p. 6556. Su memorialized again on the same subject the next year. See TCTC 207, p. 6559, also TFYK 544:6b.

186. Chapter 7. See Exomens, pp. 36 and 209-212. 
187. TCTC 207, pp. 6560-61. It was not until 704, however, that complete rehabilitation occurred and the road to office was reopened to those whose relatives had been found guilty of crime. TCTC 207, p. 6574 .

188. On the appointments of $\mathrm{Li}$ and Wei to tsai-hsiang rank, see TCTC 207, p. 6571. Wei An-shih (Appendix B, no. 125) was already well-known as an opponent of the Changs. Wei Ssu-li (no. 131) held his position in the university until the twelfth month of 704 and, in view of his concern with education, was probably a successful administrator. On the new censors, see THY 60, p. 1053 and TFYK $512: 6 a$.

189. TFYK 554:17a and THY 63, p. 1094.

190. TCTC 207, p. 6567.

191. The concern perhaps arose from a disturbance in the far South in the eleventh month of 703. TCTC 207, pp. 6568-69. I have been unable to find a definition of the "six categories" of the Han.

192. TCTC 207, p. 6570 and THY 68, pp. 1198-99. Some of the best-known officials assigned to the task were Wei Ssu-li, Hsüeh Ch'ien-kuang and Yang Tsai-ssu. In some cases, at least, the officials retained their current posts and became only acting prefects so that the experiment was perhaps not a wholehearted one.

193. TCTC 207, p. 6571 .

194. Note 9 above.

195. THY 66, p. 1157 and Yü-hai 59:38b.

196. TCTC 207, p. 6578.

197. TFYK 629:22a and THY 75, p. 1359.

198. THY 60, p. 1053 and TFYK 512:6a.

199. TCTC 207, p. 6574.

200. See, for instance, on the palaces, THY 30, p. 557 and TCTC 207, p. 6569.

201. TCTC 207, p. 6575 points out that for several months the empress saw only the Changs, receiving neither chief ministers nor her own sons. The many demotions at the restoration give some idea of the size of the Chang faction.

202. CTS 78:3337:2, TFYK 515:9a, and TCTC 207, pp. 6572-73. Fitzgerald, Empress Wu, p. 182 construes. "meritorious service" as a possible double entendre. 203. TCTC 207, p. 6576.

204. On Huan, see CTS $91: 3360: 4$ and HTS 120:3951:3. He was the scion of an official clan from Huai-nan obtaining his first post through the yin privilege. Much admired by $\mathrm{Ti}$ Jen-chieh, he rose to high positions in the Censorate where he was responsible for the restoration of the political rights of the victims of Lai Chün-ch'en and Chou Hsing. At Ch'ang-tsung's treason trial, his was the strongest call for punishment, and his biography contains the fullest account of the coup.

205. On Chang, see Appendix B, no. 133.

206. TCTC 207, pp. $6574 \mathrm{ff}$. Fitzgerald's account is found in Empress Wu, pp. 184-88.

207. The "tame" judges were Wei Ch'eng-ch'ing (Appendix B, no. 135) and Ts'ui Shen-ch'ing (CTS 77:3335:3 and HTS 109:3930:3).

208. On Sung, see CTS $96: 3372: 1$ and HTS 124:3960:1.

209. See Appendix B, no. 132. Ts'ui was in many ways typical of the northeastern ssu-hsing. After passing the ming-ching, his mother, who was a member of the eminent Lu clan, instructed him on the integrity necessary to an official calling, and it was his incorruptibility while charged with the examination system which brought him to the personal notice of the empress. His biography shows that he was one of the empress' most sincere supporters, never suggesting abdication. 
It was the complete lack of alternatives which finally brought him into the conspiracy.

210. See TCTC 207, p. 6579.

211. CTS 91:3361:3 and HTS 120:3952:2. Ching was one of the "new" officials prominent in the Chou, a member of a family with no tradition of office, a ming-ching graduate and a man whose reputation had been made in the provinces. His opposition to the Wu interests, carried into the next reign, precipitated the destruction of himself and his four co-conspirators by Wu San-ssu.

212. CTS $91: 3362: 3$ and HTS 120:3951:3. Yüan was another of the "new" type of official. A northeasterner, his early career is nowhere documented, and we know only of his capital appointments. He may have had some military experience since during the actual coup, he was in charge of the Southern Guard whose task was to deal with unforeseen resistance.

213. TCTC 207, pp. 6578-79. Li found himself on the losing side in 707 when he joined the crown prince in an attempted coup against Empress Wei.

214. TCTC 207, p. 6579.

215. CTS 78:3337:2. These included Li Chiao, Ts'ui Shen-ch'ing, Ts'ui Jung, Sung Chih-wen, Shen Ch'üan-ch'i and several others who not only held high posts but were among the best-known figures of their time. Their connection with the Changs shows how influential the faction had become.

216. CTS 193:3553:4. Wu Yen-hsiu had returned to the capital in 704 and, although he was not married to Princess An-lo until later, their relationship seems to have existed from this time.

217. TCTC 207, p. 6580. He was persuaded by Li Chan, the son of Li $1-f u$.

218. TCTC 207, pp. 6580-81. The empress had special scorn for Chung-tsung whom she thought perhaps to intimidate, for Li Chan whose father had been her earliest supporter, and for Ts'ui Hsüan-wei who had been her personal and independent choice for high office. Ts'ui, perhaps with some sadness, could attribute his presence only to "Your Majesty's great virtue."

219. CTS 6:3077:1 and TCTC 207, p. 6581.

220. See, for instance, TCTC 208, p. 6587, and 207, p. 6582 for T'ien Kueitao's refusal to cooperate with the conspirators.

221. TCTC 208, p. 6596. 


\section{SELECTED BIBLIOGRAPHY}

Acker, W. R. B. Some T'ang and Pre-T'ang Texts on Chinese Painting. Vol. 1. Leiden, 1954.

Balazs, Étienne. "Beiträge zur Wirtschaftsgeschichte der T'ang-Zeit," MSOS 34 (1931), pp. 1-92; 35 (1932), pp. 1-73; 36 (1933), pp. 1-62. - Le traité juridique du "Souei-chou." Leiden, 1954.

Beasley, W. G. and E. G. Pulleyblank, eds. Historians of China and Japan. London, 1961.

Bingham, Woodbridge. The Founding of the T'ang Dynasty: The Fall of Sui and the Rise of T'ang. Baltimore, 1941.

Chang Ch'ün 章君. "Lun T'ang K'ai-yüan ch'ien ti cheng-chih chi-t'uan,"

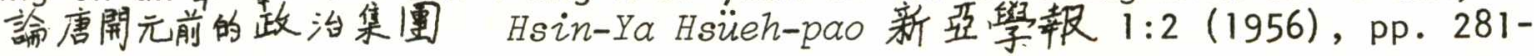
303.

- T'ang-shih 唐史. Hong Kong, 1971.

Chang, G. C. C. The Buddhist Teaching of Totality. College Park: Pennsylvania State University, Press, 1971.

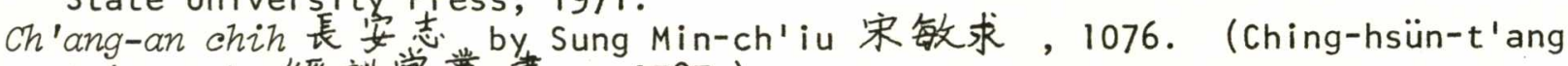
ts'ung-shu經訓堂檔書, 1787.)

Ch'ao-yeh ch'ien-tsai 朝野檢戴 by Chang Cho 钱䉆, 8th century. (Ts'ungshu chi-ch'eng 糔書集成, Shanghai, 1936.)

Chavannes, Edouard. Documents sur les Tou-kiue (Tures) Occidentaux. Paris, 1900.

- Mémoires sur les réligieux eminents. Paris, 1894.

\section{Le T'ai Chan. Paris, 1910.}

Ch'en, Kenneth K. S. Buddhism in China. Princeton, 1964.

The Chinese Transformation of Buddhism. Princeton, 1973.

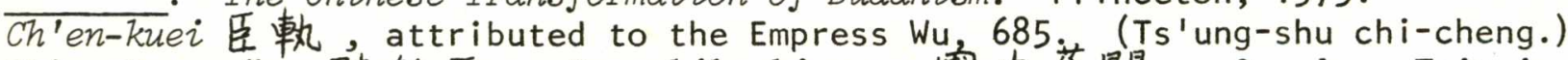

Ch'en Teng-yüan 陳登原. Kuo-shih chiu-wen 國史舊聞. 2 vols. Taipei, 1970.

Ch'en Tzu-ang chi 陳子鼠集. (Shanghai, 1960.)

Ch'en Yin-k'o 陳宙 it各. "Chi T'ang-tai chih Li Wu Wei Yang hun-yin chi-t'uan," 記唐代之季武韋楊婚姻集團, Li-shih Yen-chiu歴史研究, January 1954, pp. 33-51.

'Li-T'ang Wu-Chou hsien-shih shih-chi tsa-k'ao 李唐武周先世事蹟 雜考, CYYY 6:4 (1936), pp. 553-56.

.'Lun Sui-mo T'ang-ch'u so-wei Shan-tung hao-chieh,"論隋末唐初所謂 山東豪傑。 Ling-nan Hsüeh-pao 嶺南學報 12 (1952), pp. 1-14. Sui-T'ang chih-tu yüan-yuan Züeh-Zun kao 隋唐制度㸡源略論稿. Chungking, 1944. T'ang-tai cheng-chih shih shu-Zun kao 唐代政治史述言侖稿. Chungking, 1944 . "Wu Chao yü fo-chiao," 武盟舆佛教 CYYY 5:2 (1935), pp. 137-148. Ch'ien Po-tsan 前伯兟 et al. Chung-kuo Zi-shih kai-yao 中國歴史概要. Peking, 1956 . et al. Concise History of China. Peking, 1964. 
Chin-shih ts'ui-pien 金石萃編 by Wang Ch'ang王水, 1805. (Taipei reprint of 1805 edition.)

[Chiu] T'ang-shu[舊]唐書 by Liu Su劉肃 et al., 985. (Palace edition of 1739; K'ai-ming shu-tien, Shanghai, 1935.)

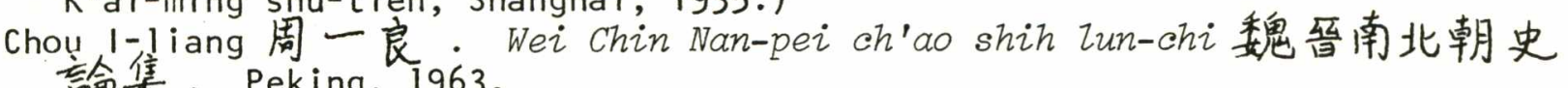
椧集. Peking, 1963.

Chou Tao-chi 周道漓. Han-T'ang tsai-hsiang chih-tu漠唐宰相制度。 Taipei, 1963 .

Chu Hsi-tsu朱希祖. "Po Li-T'ang wei Mu-hsing shuo,"“馬爻李唐为胡姓説 Tung-fang Tsa-chih 東方卒住誌 33:15 (1936), pp. 67-88.

Ch'ü T'ung-tsu. Han Social Stmucture. Seattle, 1972.

Ch'üan Han-sheng 全漢昇. "T'ang Sung shih-tai Yang-chou ching-chi chingk'uang ti fan-jung yu shuai-10,“唐宋時代㛫州㬎濟景況的繁策與哀落 CYYY 11 (1947), pp. 149-176.

Ch'落我 T'ang-shih 全唐詩 by P'eng Ting-ch'iu彭定求 et al., 1705 . Ch'in-

T'ang Sung ti-kuo y ü yün-ho 唐宋帝國與運河. 2nd ed. Shanghai,

th'üan T'ang-wen 全唐文 by Tung Kao 董誥 et al., ca. 1814. Ch'in-ting edition.

de Bary, W. T., et al. Sources of Chinese Tradition. New York, 1964.

Eberhard, Wolfram. Conquerors and Rulers. 2nd ed. Leiden, 1965.

"The leading families of ancient Tun-huang," Sinologica 4:4 (1960),

pp. 209-232.

- Das Toba-Reich Nordchinas. Leiden, 1949.

Elvin, Mark. The Pattern of the Chinese Past. Stanford, 1973.

Fan Wen-lan范文嘱. Chung-kuo t'ung-shih chien-pien中或通史简简扁.

Feng-shih wen-chien chi 封氏聞見記 by Feng Yen封演, ca. 800. (Ts'ungshu chi-ch'eng.)

Fitzgerald, Charles P. The Empress Wu. London, 1961, 1968. - Son of Heaven. Cambridge, 1933.

Forte, Antonino. Political Propaganda and Ideology in China at the End of the Seventh Century. Naples, 1976.

Franke, 0tto. Geschichte des chinesischen Reiches. 5 vols. Berlin, 1930-1952.

Fukushima Shigejirō福鳥繁㳄良. Chügoku nombokuchōshi kenkyu 中国南北朝 史研究. Tokyo, 1963.

Gardner, Charles S. Chinese Traditional Historiography. 2nd ed. Cambridge, Mass., 1961.

Gernet, Jacques. Les aspects économiques du Bouddhisme dans la société chinoise du ve au Xe siecle. Saigon, 1956.

Giles, Lionel. Descriptive Catalogue of the Chinese Manuscripts from Tun-huang in the British Museum. London, 1957.

Gi raud, R. L'empire des tures célestes. Paris, 1960.

Granet, Marcel. La pensée chinoise. Paris, 1968.

Grousset, René. L'empire des steppes. Paris, 1939.

Hamaguchi Shigekuni 洗口重国. "Fuhei seido yori shinheisei e,"府兵制度よ” 新兵制入ShigakuZasshi史学雑誌 41 (1930), pp. 1255-1295, 14301507 . 
Tóōchō no sennin seido 唐王朝の櫻人制度. Kyoto, 1966.

Han, Woo keun ${ }^{\prime}$ The History of Korea. Seoul, 1970.

Hanada Ryōun 花田凌雲, ed. Bukkyō daiji仏教大辞巢. 2nd ed. Kyoto:

Ryōkoku University, 1972.

Hatada Takashi. A History of Korea. W. W. Smith and B. H. Hazard, trs. and eds. Santa Barbara, 1969.

Hayashi Fusao 林房雄. Chügoku senya ichiya中國千㡺一夜. 2 vols. Tokyo, n.d.

Henthorn, William E. A History of Korea. New York, 1971.

Hino Kaisaburo日野開三郎. Shina chüsei no gumbatsu支那中世の軍閥. Tokyo, 1942.

"Shō Kōkuri koku no kenkyū,"小高向麗国の研究Shien史苑 60 (1956), pp. 29-45, and 61 (1957), pp. 19-41.

Hiraoka Takeo 平同武夫, ed. Tódai no gyosei chiri唐代の行政地理.

T'ang Civilization Reference Series, no. 2. Tokyo, 1955.

, and Imai Kiyoshi 今 \#清. Chōan to Rakuyo 長安と洛陽

- T'ang Civilization Reference Series, vols. 5, 6, and 7. Tokyo, 1956.

Hsin T'ang-shu新唐書 by Ou-yang Hsiu區欠陽修 et al., 1060. (Palace edition of 1739; K'ai-ming shu-tien, Shanghai, 1935.)

Hsü Hsiao-t'ien 許啸 天 T'ang-kung erh-shih ch'ao yen-i唐宫二十朝演義。 Shanghai, 1928.

Hu Ju-lei 胡如雷. "Lun Wu-Chou ti she-hui chi-ch'u, "論武周的社會基礎 Li-shih Yen-chiu 歴史研究 1 (1955), pp. 85-96.

Huang Pen-chi 黄本龮. Li-tai chih-kuan piao 歴代職官表. Peking, 1965. Huang Sheng-fy'黄殸緒, T'ang-tai fo-chiao tui cheng-chih chih ying-hsiang 唐代佛教對政治之影䉕. Hong Kong, 1959.

Hung, William. "The T'ang Bureau of Historiography before 708," HJAS 23 (1960) 61), pp. 93-107.

Ikeda On 池间温: "Chūgoku ni okeru ritsuryōhō taikei no seiritsu," 中国!

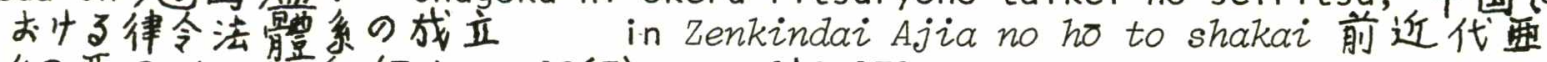
㬎田再の法と社会(Tokyo, 1967), pp. 149-171.

. "Ritsuryo kansei no keisei,"律令官制の形成 in Sekai Rekishi世界 磨史, v. 5 (1970), pp. 277-323.

"'Tōchō shizokushi no ichi kōsatsu," 唐朝氏族志の一考察 Hokkaido Daigaku Bungakubu Kiyo 北海道大学文学部紀要 13:2 (1965), pp. 3-64.

"Tōdai no gumbōhyō,"唐代の郡望表 Toyo Gakuho 東洋学報 42 (195960), pp. 293-331 and 412-430.

Ikeuchi Hiroshi池内宏. Man-Sen shi kenkyu满鮮史研究. 2 vols. Tokyo, 1960.

, ed. Tóyōshi ronsō束洋史論丵. Tokyo, 1925.

Imabori Seiji 今堀誠二. "Tödai shizoku no seikaku sobyō,"唐代士族9性格 素描 Rekishigaku Kenkyū 歴史学研究 9:11 (December 1939), pp. 59-80.

Ise Sentarō伊瀬仙太良. Chügoku seiiki keiei shi kenkyu 中国西域㬎管 史研究. 2nd ed. Tokyo, 1960 .

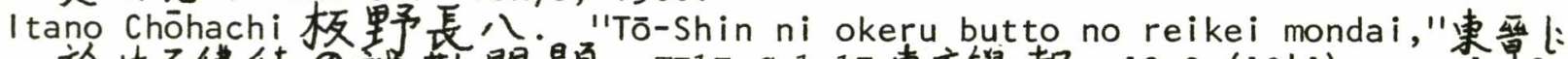

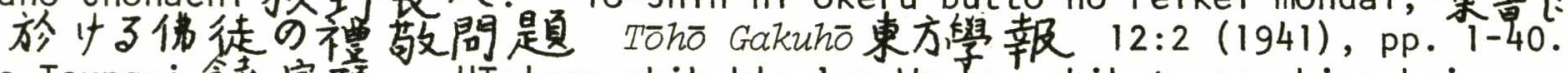
Jao Tsung-i食颂宗臨. "Ts'ung shih-k'o lun Wu-hou chih tsung-chiao hsin-yang," 從石刻論武后之宗教信仰 CYYY 45:3 (1975), pp. 397-413.

Johnson, David G. The Medieval Chinese Oligarchy. Boulder, Colorado, 1977.

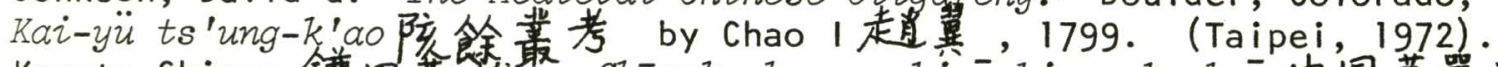
Kamata Shigeo 銉田我雄. Chügoku kegon shisoshi no kenkyu 中国華嚴思想史
の研究. Tokyo, 1965. 
Karlgren, Bernhard. The Book of Odes. Stockholm, 1950.

Kikuchi Hideo 菊池英夫. "Fuhei seido no tenkai,"府兵制度の共開 in Sekai Rekishi 世界歴史，v.5 (1970), pp. 407-439.

"Setsudoshi kenryoku to iwayuru dogōsō,"䈨度使權力といの中る土豪

層 Rekishi Kyöiku 歴史教育 14:5 (1966), pp. 46-58.

"Tō sesshō fu no bumpu mondai ni kan suru ichi kaishaku," 唐折衝

府の分布問题に:關よる一解䆁 Toyoshi Kenkyu束洋史研究 27:2 (1968), pp. 1-37.

"Tōdai fubo no seikaku to meishō to ni tsuite,"唐代府募の性格と名 稗とに゙へし. Shien史㪄 67 (1963), pp. 75-98.

"Tódai fuhei seido ni kan suru ichi gimon," 唐代府兵制度l:㞔引る一 疑阿 Shien史销 63 (1959), pp. 95-115.

$\mathrm{Ku} \mathrm{Chi-kuang}$ 谷霞光 : "An-Shih-luan ch'ien chih Ho-pei tao,"安史慆前之河 北道Yen-ching Hsüeh-pao 燕京學赤 39 (1936), pp. 197-209.

. Fu-ping chih-tu $k^{\prime} a 0-s h i \hbar$ 府兵制度考称。. Shanghai, 1962.

Kubozoe Yoshifumi 崔添麖文. "Gi - Shin Nanbokuchō ni okeru chihōkan no honseki chininyōni tsuite,"魏晋南北朝によける地方官の本籍地任用にんして Shigaku Zasshi史学杂住誌 83:1 (1974), pp.1-41; and 83:2 (1974), pp. 26-56.

Kuo Mo-jo 郭沫若. Wu Tse-t'ien 武埧天. Peking, 1962.

Kuo Pai-kung 郭伯恭. Sung ssu-ta-shu k'ao '宋四大書考. Shanghai, 1940.

Kurihara Masuo 栗原益男. "Fuheiseido no hokai to shinheishu,"府兵制度の崩

壤と新兵種 Shigaku Zasshi史学杂住誌 73:2 (February 1964), pp. 1-26;

and 73:3 (1964), pp. 29-55.

Legge, James. The Chinese Classics. 5 vols. 2nd ed. Hong Kong, 1961.

Leslie, D. D., Colin Mackerras, and Wang Gungwu, eds. Essays on the Sources for Chinese History. Charleston, S.C., 1973.

Levenson, Joseph. Confucian China and its Modern Fate. First combined edition, Berkeley, 1968,

Li Shu-t'yng, 李樹桐. T'ang-shink'ao-pien 唐史考辝. Taipei, 1965.

Li T'ang 李唐林惠祥. Wen-hua jen-iei hsüeh 文化人頪學. Shanghai:

Lin T'ien-wei 林天蔚. Sui-T'ang shih hsin-pien 隋唐史新編 . Hong Kong, 1968.

Lin Ÿ̈-t'ang 林語堂. Lady Wu: A True Story. London, 1957.

Ling-yün Ko-chu淩雲唐主 (pseud.). Li-tai ti-wang hsing-ai mi-wen 歷代帝

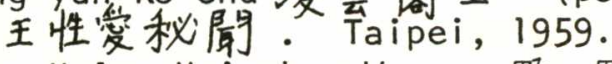

Liu, Helen Hui-chen Wang. The Traditional Chinese Clan Rules. New York, 1959.

Liu P'an-sui 劉盼遂・ 'Li-T' Yen-ching Hsüeh-pao 燕京學報 15 (June 1934), pp 235-242.

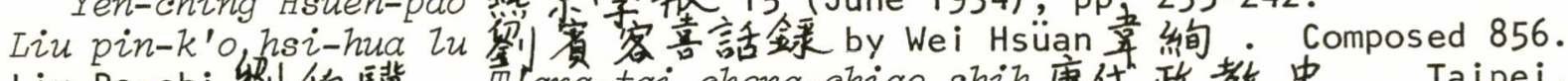

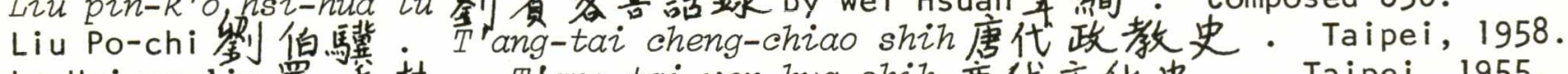

Lo Hsiang-1in 羅香林. T'ang-tai wen-hua shih 卖代文化史. Taipei, 1955.

Lo Lung-chih 睢龍治. 'Lun T'ang-ch'u kung-1i ssu-hsiang yü Wu Chao tai T'ang

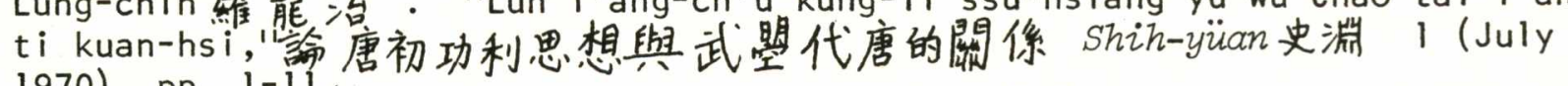

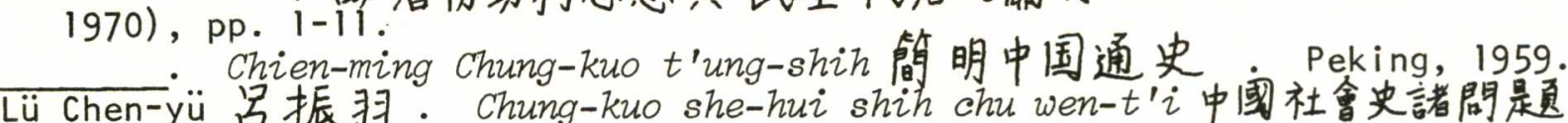

Lü Chen-yü 号振羽. Chung-kuo she-hui shih chu wen-t'i中國社會史諸辟题. Chungking, 1940 .

Lü Ssu-mien 吕思兔. Liang-Chin Nan-pei ch'ao shih雨晉南北朝史. Shanghai, 1948 . 
Sui-T'ang-Wu-tai shih 隋唐五代史。2 vols. Shanghai, 1959. Mahler, Jane G. The Westerners Among the Figurines of the T'ang Dynasty in China. Rome, 1959.

Mao Han-kuang 毛漢光. Liang-Chin Nan-pei-ch'ao shih-tsu cheng-chih chih yenchiu雨晋南北朝主族政治之研究. 2 vols. Taipei, 1966 .

Masumura Hiroshi 增村宏. "Kōhakuseki no shinkenkyū,"“黄白籍の新研究 Toyōshi Kenky $\bar{u}$ 隶洋史研究 $3: 4$ (1947), pp. 30-44.

Maspero, Henri. Les documents chinois de la troisieme expédition de Sir Aurel Stein en Asie Centrale. London, 1953.

- Mélanges posthumes sur les réligions et l'histoire de la Chine. Vol.

2: Le Taoisme. Paris, 1950.

- Le Taoisme. Paris, 1950.

, and Étienne Balazs. Histoire et institutions de la Chine ancienne des origines au XIIe siecle après J.C. Paris, 1967.

Matsui Shüichi 松井秀——. "Sokuten Bukō no yōritsu o megutte,"埧天武后の 擁立をめぐィ\} Hokudai Shigaku 北大史学 11 (1966), pp. 1-18. 誌 71 :9 (1962), pp. 1-37.

Matsunaga Masao 松永雅生. 'Tōdai no 'dōkan' ni tsuite,"庶代の勳官に八い7 Nishi Nippon Shigaku西白本史学 12 (October 1952), pp. 28-47.

Menzel, Johanna M., ed. The Chinese Civil Service: Career Open to Talent?

Michihata Ryōshū 道瑞良秀. Chügoku Bukkyōshi 中国佁教史. Kyoto, 1958.

Mitamura Taisuke. Chinese Eunuchs: The Structure of Intimate Politics. Tokyo, 1970.

Miyakawa Hisashi 宫川尚志. Rikuchōshi kenkyü: Seiji shakai hen 六朝史研究: 政治社会篇? Tokyo, 1956.

Miyakawa Hisayuki. "An outline of the Naitō hypothesis and its effects on Japanese studies of China," Far Eastern Quarterly 14 (1954-55), pp. 533-552.

Miyakawa Ichisada. "The four ages of Chinese history," in J. Meskill, ed., The Pattern of Chinese History (Boston, 1968), pp. 53-56.

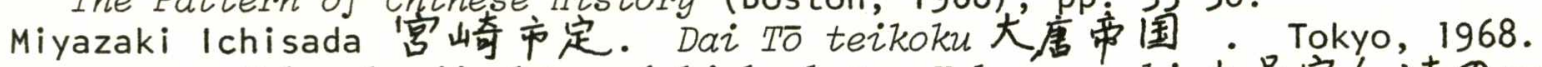

. Kuhon kanjin hō no ichi kenkyü: Kakyo zenshi 九品官人法の一研 究:科舉前类. Kyoto, 1956.

Mori Masao 謢雅夫. "Zui-Tō to Churuku kokka,"隋唐とチュ几俔家Kodaishi Köza

Moriya Mitsuo 守层美都雄。 Rikucho mombatsu no ichi kenkyu六朝門陮の一研究.

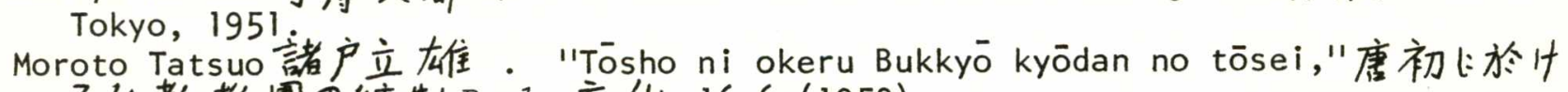
る仏教教通の統制Bunka 文化 16:6 (1952).

Mou Jun-sun 牟潤孫. "Tun-huang T'ang hsieh-pen Hsing-shih Zu ts'an-chüan

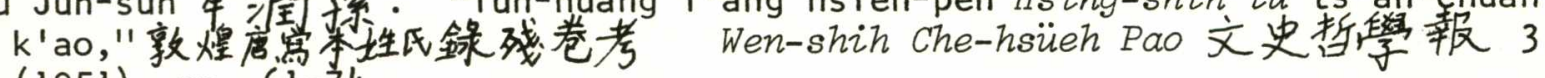

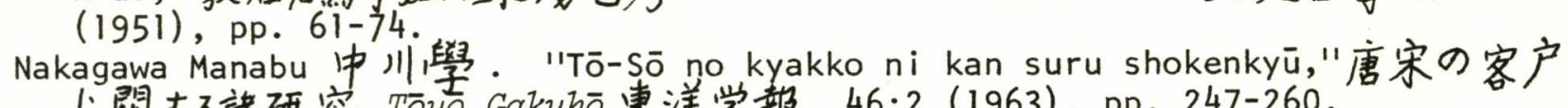

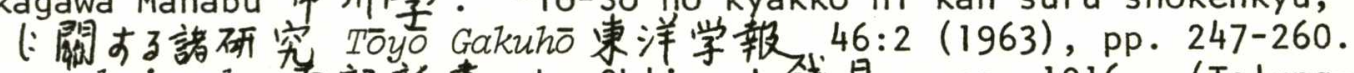

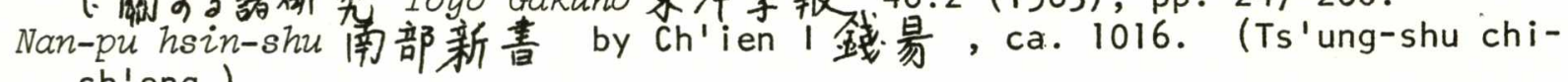
ch'eng.)

Nien-erh-shih cha-chi 世二史符記 by Chao I趙翼，1795. (Taipei, 1961.) Ni ida Noboru 仁井田隌. "Rikuchō yori Tōsho no mibunteki naikonsei," "六朝妙 唐初9身分的内姃制 Rekishigaku Kenkyü 歴史学研究 9:8 (1939), pp. 2-22. Shina mibunhō shi 支那身分法史. Tokyo, 1936. 
- "Stein Tonko hakken no tenka sei bōshizoku fu,"スタイン敦煌発見の 天下姓望氏族譜 in Ishihama sensei koki kinen töyögaku ronso 石潧先生䢬歷 記念東洋学椧丵。Tokyo, 1958.

To-So horrtsu bunsho, no kenkyu唐宋法律文毒の研究. Tokyo, 1937 Tóryo shüi 唐令拾遗. Tokyo, 1933 .

"Tōdai no hōshaku oyobi shokuhōsei,"唐代の封爵及び食封制T Toho Gakuhō東方然郝 10:1 (1939), pp. 1-64.

Nishijima Sadao 西鳥定生. "Roku-hachi seiki no Tōa,"六一八世㬎の東亞 in Nippon rekishi kodai日本歷史講是意 v. 2 (Tokyo: Iwanami, 1962), pp. 230278.

Nunome Chōfū 布目潮湹. Zui-Tōshi kenkyū 䧎唐史研究. Kyoto, 1968. Ochi Shigeaki 越智重明. "Nancho no koseki mondai,"南朝の户籍問题 Shigaku Zasshi史学杂住誌 69:8 (1960), pp. 940-964.

Ogata I samu尾形勇. "Ryosensei no tenkai to sono seikaku,"良賤制の展開と 々の性格 in Sekai Rekishi世界歴史, ‥5 (1970), pp. 325-364.

Okamoto Goichi 周本午-D. "Tödai heizaikō,"唐代聘剘考 in Haneda hakuse jōju kinen toyōshi ronsō羽田博士喜寿記念東洋史詇丵 (Kyoto, 1950), pp. 225-

Ota Yukio, Utsugi Akira, and Hori Toshikazu. History of Ancient China: Oriental Studies in Jopan, Retrospect and Prospect 1963-72. Tokyo, 1974.

ōtani Köshō 大谷光照. Tódai no Bukkyo girei唐代の借教儀福. Tokyo, 1937.

Pan Ku. History of the Former Han Dynasty. H. H. Dubs, tr. 3 vols. Baltimore, 1938-1955.

Pulleyblank, E. G. The Background of the Rebellion of An Lu-shan. London, 1955. "Gentry society: Some remarks on recent work by W. Eberhard," BSOAS

15 (1952), pp. 588-597.

- "Registration of population in China in the Sui and T'ang periods," Joumal of the Economic and Social History of the Orient 4 (1962), pp. 289301 .

- 'The Tzyjyh Tongjiann Kaoyih and the sources for the history of the period 730-763," BSOAS 13 (1950), pp. 448-473.

Reischauer, Edwin 0. Ennin's Travels in T'ang China. New York, 1955.

Rideout, J. K. "The rise of eunuchs during the T'ang dynasty," Asia Major 1 $(1949 / 50)$, pp. 53-73; 3 (1952), pp. 42-58.

des Rotours, Robert. Le traité des excomens. Paris, 1932. 1947. - Traité des fonctionnaires et traité de l'armée. 2 vols. Leiden,

Rutt, Richard. "The flower boys of Silla (Hwarang): Notes on the sources," Transactions of the Korea Branch of the Royal Asiatic Society 38 (1961), pp. $1-66$.

Saiiki bunka kenkyü: Tonko Toroban shakai keizai shiryō西域文化研究: 敦 煌吐急番社会経添资料. Tokyo, 1959-60.

Sconguk Sagi三國史記 by Kim Pusik金富軾，1145. (Tokyo, 1971.)

Scott, Hugh D. The Golden Age of Chinese Art: The Lively T'ang Dynasty. Tokyo, 1967.

Seidel, Anne K. La divinisation de Lao-tseu dans le taoisme des Han. Paris, 1969.

"The image of the perfect ruler in early Taoist messianism," History of Rezigions 9:2-3 (1969-70), pp. 216-248.

Sekai Rekishi世果歷史. v. 5. Kodai古代. Tokyo: I wanami Kōza, 1970.

Shang Yüeh 尚战 et al. Chung-kuo Zi-shih kang-yao中國歴史網要. Peking, 1954. 
Shigematsu Shunshō重松俊章. "Tō-Sōj jidai no Mirokukyo-hi, Fu: Kōsei bukkyō hi"唐宋時代の洂勒教匪, 附:更生佛教匪Shien史苑 3 (1931), pp. 68-103.

Shigenoi Shizuka 㳘野井话. Todai Bukkyoshi ron 唐代仏教史論. Kyoto, 1973. Shih-t'ung 史通 by Liu Chih-chi 拴知幾, 710。 (Shanghai, 1928.)

Soothill, W. E., and L. Hodous. A Dictionary of Chinese Buddhist Terms. Rev. ed. Taipei, 196l.

Sudō Yoshiyuki 周漛吉之. To-so shakai keizaishi kenkyü唐宋社会経济史研 究. Tokyo, 1965.

Sui-shu 陏畫 by Wei Cheng魏微 et al., 629-656. (Shanghai, 1935.)

Sun K'ai-ti孫楷第 Chung-kuo t'ung-su hsiao-shuo shu-mu中国通俗水説書目. Peking, 1957.

Sun Kuo-tung 孫成梀. "'T'ang chen-kuan yung-hui chien tang-cheng ti shih-i,"

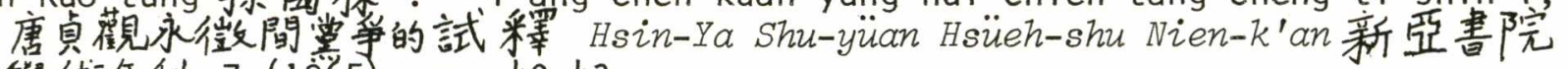
舆訹年利7 (1965), pp. 40-43.

子'T'ang-shu tsai-hsiang piao ch'u-chiao,"唐書宰相表初校 Hsin-Ya Hsüeh-pao 新䌉學報 2 (1956), pp. 307-359.

"T'ang-tai san-sheng-chih chih fa-chan yen-chiu,"唐代三省制之發

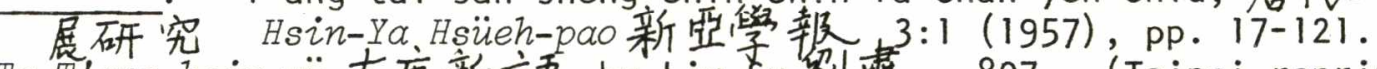

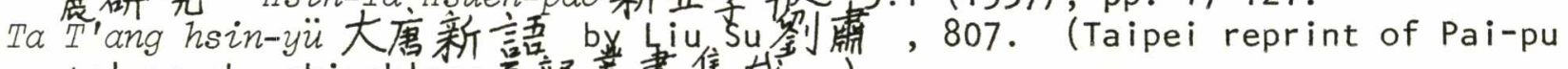
ts'ung-shu chi-ch'eng 百部鼓書集戊 .)

Ta T'ang Ziu-tien大唐六典, attributed to Emperor Hsüan-tsung with commentary of Li Lin-fu季林甫, ca. 739. (Taipei reprint of Ming edition of 1515.)

Taga Akigorō多賀秋五郎. Tödai kyöiku no kenkyu唐代教育の研究 Tokyo,

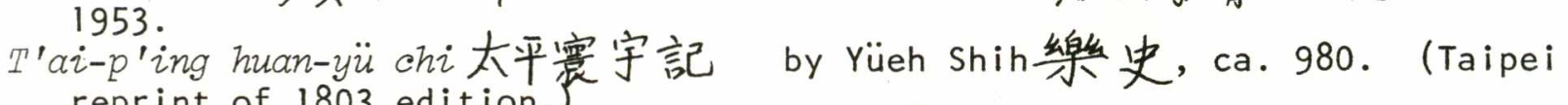
reprint of 1803 edition.) reprint of 1803 edition.
print, 1962.) print, 1962.)
T'ai-p'ing yü-Zan 太平御筧 by Li Fang李昉 et al., 977-983. (Ssu-pu ts'ung-
k'an.)

Taishō shinshu daizōkyō 大正新集大藏出圣, reprint (Tokyo, 1960) in which are found: Fo-tsu Zi-tai t'ung-tsai仍祖歴代通載, v. 49, no. 2036, p. 477.

Fo-tsu t'ung-chi 佛祖方充記, v. 49, no. 2035, p. 129.

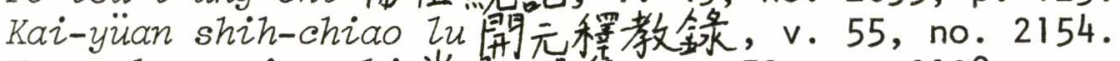

Kuang hung-ming chi光胎明集, v. 52, no. 2108 .

Sung kao-seng chuan 宋高僧傮, v. 50, no. 2061, p. 709.

Ta-fang-teng wu-hsiang ching大方等無想聯, v. 12, no. 387, p. 1077.

Takao Giken 高雄義唚. Chügoku Bukkyo shiron 中国份教史論・ Kyoto, 1952.

Takeda Ryūji 竹田篦兒. "Teikan shizoku shi no hensan ni kansuru ichi

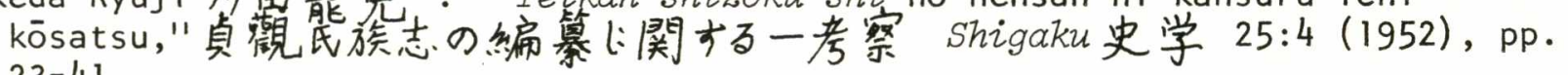
23-41.

史学 24:4 (1951), pp. 26-53.

$$
\text { "Tōdai shijin no gumbō ni tsuite,"唐代士人の郡望にんし、 Shigaku }
$$

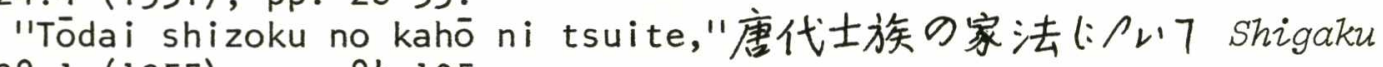
史学 $28: 1$ (1955), pp. 84-105.

T'ang $C_{h}$ 'ang-ju唐晨穤. 'Kuan-yü Wu Tse-t'ien T'ung-chih mo-nien ti fo-t'aohu," 关于武則天統治末年的浮逃户 Li-shih Yen-chiu 歷史研究 6:12 (1961),

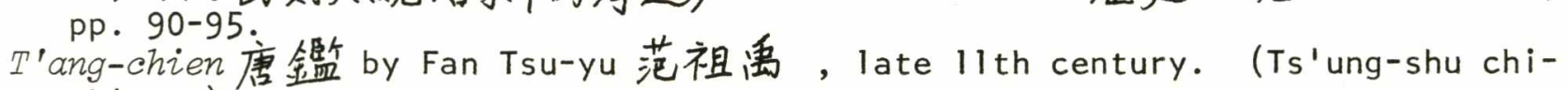
ch'eng.) 
T'ang chih-yen 唐摭言 by Wang Ting-pao王定保, ca.955. (Shanghai, 1957.) T'ang hui-yao 唐畣要 by Wang P'u王簿, 961. (3 vols of reprint with annotations by Yang Chia-10末易家駱, Táipei, 1967.)

T'ang-kuo shih-pu唐國史補by Li Chao 李肇, ca.更825. (Shanghai reprint of 1967 with Yin-hua Iu 因話金录 by Chao Lin越璘.)

T'ang-Zü shu-i 唐律疏義, attributed to Ch'ang-sun Wu-chi晨孫無忌, 653. (Jen-jen wen-k'u 人人文庫 series, Taipei, 1967.)

T'ang-shih Zun-tuan 唐史論所, by Sun Fu 孫甫, 1052. (Ts'ung-shu chi-ch'eng.) T'ang ta chao-ling chi唐大詔令集 by Sung Min-ch'iu宋敏求, 1070. (Taipei, n.d.)

T'ang wen-ts'ui 唐文粹 by Yao Hsüan姚金玄. (Ssu-pu ts'ung-k'an ch'u-pien so-pen 四部最利初編出宿本.)

T'ang y $\ddot{u}$ - Zin 唐語林 by Wang Tang王讜, ca. 1100. (Taipei, 1958.)

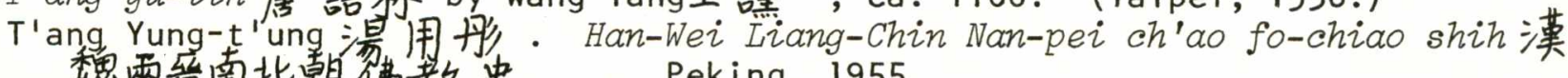
魏兩丝南北朝彿教史・Peking, 1955 .

Tanigawa Michio 谷川道雄. "Shū-Zui kakumei no keii ni tsuite,"周隋革命の 系圣緯し: 几L. Kodai Bunka 古代文化 18:5 (1967).

T'ao Hsi-sheng 陶希聖: Chung-kuo cheng-chih ssu-hsiang shih中國政治思想 史. 4 vols. Taipei, 1964 .

Teng Ssu-yü登嗣禹. Chung-kuo k'ao-shih chih-tu shih中國考試制度史. Taipei, 1966.

Fomily Instructions for the Yen Clan. Leiden, 1966.

Ti-fan 帝範, attributed to T'ang T'ai-tsung, 648. (Ts'ung-shu chi-ch'eng.)

T'ien Han 田漠, "Hsieh Yao-huan 謝瑶環, “Ch ̈

Tokiwa Daijō常盘大定: 'Bu-Shū shinji no ichi kenkyu," 武周新字の一研究in Hattori sensei koki shukuga kinen 月及部先生古稀視賀記念, Toho Gakuho 東方留郝 6 (1936), pp.2-37.

Shina ni okem Bukkyo to Jükyo Dōkyō 支那lおける佛教と儒教道教。 Tokyo, 1930.

Tonami Mamoru 磄波䕶. "Chūsei kizokusei no hōkai to hekishō sei,"中世貴族 制の崩壤、辟召制Tóyoshi Kenkyü東洋史研究 21:3 (1962), pp. 1-26.

"Tón no ritsuryō taisej to U-bun Jung no kakko,"唐の律令體制と宇文 融の括户 Toyo Gakuhōo束洋学報 41:3 (1958), pp.263-288. Gakuhō束洋学報 47:6 (1965), pp. 153-182.

Toyama Gunj i 外山軍治. Sokuten Buko 剘天武后. Tokyo, 1966. et al. Kizoku shakai贵族社会. Osaka, 1969.

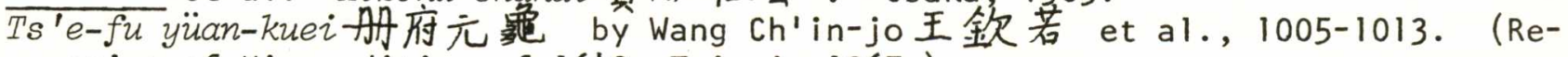
print of Ming edition of 1642, Taipei, 1967.)

Ts'en Chung-mien态仲勉。 Sui-T'得g shih 隋唐史. 2 vols. Peking, 1957. - T'u-chüeh chi-shih 突疱集史. Peking, 1959.

Tsukamoto Zenryū 潒本善隆. "Hokushū no haibutsu ni tsuite," 北周の廃仏

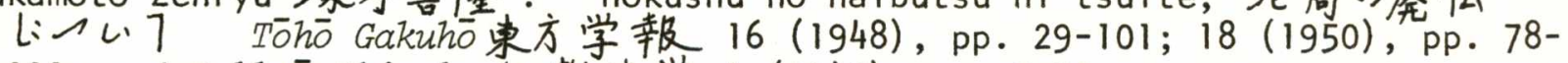
111 ; and Bukkyo Shigaku 仏教史学 1 (1949), pp. 3-31.

. Nisshi Bukkyō kōshōshi no kenky u 日支佛教莫涉史の研究. Tokyo, 1944. Shina Bukkyosshi kenkyü 支那佛教史研究. Tokyo, 1942.

Tsukiyama Chisaburō 策山治三郎. Tódai seiji seido no kenkyū 唐代政治制度 の研究. Osaka, 1967.

T'ung-chih通志 by Cheng Ch'iao㹕樵, ca. 1160. (Shih-t'ung十通 edition, Shanghai, 1936.)

T'ung-tien 通典 by Tu Yu杜佑, 801. (4-volume edition of Kuo-hsüeh chi-pen ts'ung-shu國學基本善春, Taipei, 1965.) 
Twitchett, Denis. "Chinese social history from the seventh to the tenth centuries," Past and Present 35 (December 1966), pp. 28-53.

. Financial Administration under the T'ang Dynasty. Cambridge,

1963

(1956), pp. 322-330.

"The monasteries and China's economy in medieval times," BSOAS 19

(1957), pp. 526-549.

"A note on the Tunhuang fragments of the T'ang regulations (ko),"

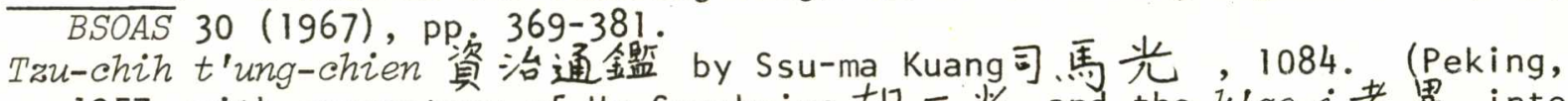
1957, with commentary of Hu San-hsing 胡三省 and the $\dot{k}^{\prime}$ a o - $i$ 考異 inter-

sau-chih t'ung-chien chin-chu資治通鑑今言主. Taipei: Commercial Press, 1965.

Utsunomiyą Kiyoshi 宇都宫清吉. "Tōdai kijin ni tsuite no ichi kōsatsu," 唐代蛽人にノL.7の一考察. Shirin史林 19:3 (1939), pp. 50-106.

Waley, Arthur. The Real Tripitaka. London, 1952.

Wang I-t'ung 主伊同. 'TS'ui Hao kuo-shu-yü shih-i,"崔浩成書狺尤釋疑Ch'inghua Hsüeh-pao 清萃部 $1: 2$ (1957), pp.84-101.

Ware, James R. "Wei Shou on Buddhism," T'oung Pao $30: 1-2$ (1933), pp. 100-180.

250. . "The Wei Shu and the Sui Shu on Taoism," JAOS 3:3 (1933), pp. 215-

Wechsler, Howard J. Mirror to the Son of Heaven: Wei Cheng at the Court of T'ang T'ai-tsung. New Haven, 1974.

Weems, C. N., ed. HuZbert's History of Korea. 2 vols. New York, 1962.

Wen-hsien t'ung-k'do 文㓺通考 by Ma Tuan-1 in 馬端臨, ca. 1319. (Shiht'ung edition Shanghai 1936.)

Wen-yüan ying-hua 文苑英華 by Li Fang 李昉 et al., ca.987. (Taipei, 1965, reprint of Ming edition of 1567.)

Wittfogel, Karl A. "Public office in the Liao dynasty and the Chinese examination system," HJAS 10 (1947), pp. 13-40.

Wright, Arthur F. Buddhism in Chinese History. New York, 1967.

- "The formation of Sui ideology, 581-604," in Chinese Thought and Institutions, J. K. Fairbank, ed. (Chicago, 1957), pp. 71-104.

, and Denis C. Twitchett, eds. Perspectives on the T'ang. New Haven,

Wu Chang-ch'üan 吴章金全. T'ang-tai nung-min wen-t'i yen-chiu 唐代農民政题 研究. Taipei, 1962 .

Wu Tse哭澤. "Kuan-yü Wu Tse-t'ien tsai li-shih chung ti tso-yung wen-t'i," 关于武則天在历史中的作用问题化 Wen-ying Pao 文應报 (December 26, 1959).

- 'Lun T'ang-tai ch'ien-ch'i t'ung-chih chieh-chi nei-pu tou-cheng yü chieh-chi tou-cheng chi,"棆唐代前期然充治阶兹内部斗爭与阶兹斗爭记 Hsin Chien-she新建设 (January 1962), pp. 16-32.

Yabuki Keiki知吹序輝. Sangaikyo no kenkyū 三階教の研究. Tokyo, 1927.

Yamasaki Hiroshi 山崎宏. "Zuichō no Bukkyō fukkō ni tsuite,"隋朝の仏教復

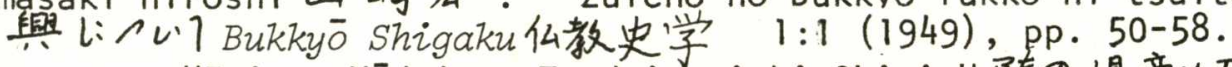

"Zui no Yōdai to Tendai taishi Chigi," 陵の煬帝と天治大師智顗 Toyo Shigaku Ronshū東洋史学論集 (1953), pp. 147-159.

Zui-To Bukkyoshi no kenkyü倩唐仏教史の研究. Tokyo, 1967. 
Yang Chia-lo 楊家謌, ed. T'ang-shih tzu-Ziao cheng-Zi chi-k'an 唐史犋料整 理集利. Taipei, 1969.

Yang Chih-chiu楊志㺵. Sui-T'ang Wu-tai shih kang-yao 隋唐五代史網要. Peking, 1957.

Yang Lien-sheng. Excursions in Sinology. Cambridge, Mass., 1969.

Yang Shu-fan 楊橲蕃. T'ang-tai cheng-chih shih 唐代政治史. Taipei, 1966.

"T'ang-tai tsai-hsiang ti ch'üan-tse yü jen-mien,"唐代宰相的權

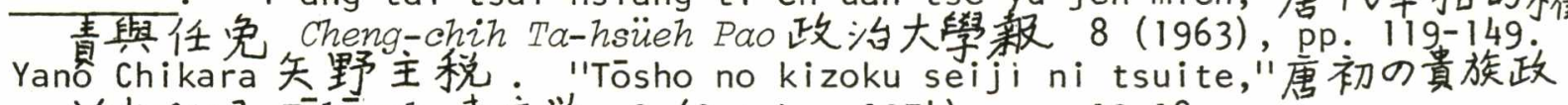
治l: 1 Tohogaku東方学9 (October 1954), pp. 12-18.

Yen Keng-wang 䢃耕望. "Lun T'ang-tai shang-shu-sheng chih chih-ch'üan yü ti-wei,"論唐代尚書省之職權與地位 CYYY 24 (1953), pp.1-68.

1956.
Yokota Shigeru横田滋. 'Bu-Shū seiken seiritsu no zentei,"武周政權成立の
前提 Toyoshi Kenkyu束洋史研究 14:4 (1956), pp. 273-294.

Yü-hai王海 by Wang Ying-1in王應鹿粼, late 13th century. (Che-chiang shuchü, 1883.)

Yüan-ho chün-hsien t'u-chih元和君䅫圆志 by Li Chi-fu李吉甫, 815. (Ch'ifu ts'ung-shu, Taipei, 1965.)

Yūki Reimon 㬎吉域令聞. "Shotō Bukkyō no shisōshi teki mujun to kokka kenryoku to no kōsaku,"“初唐仙教の思想史的矛盾と国家榷力との交錯 Toyo bunka kenkyüjo kiyo 東洋文化研究䘕㬎要 25 (1961), pp. 8-14.

Yün-Zu man-ch'ao 雲麓漫金少 by Chao Yen-wei 趙颜街, f1. 1195. (Shanghai, 1957.)

Zürcher, E. The Buddhist Conquest of China: The Spread and Adaption of Buddhism in Medieval China. 2 vols. Leiden, 1959. 
GLOSSARY

A-shih-na Ho-lu阿史那㖵霉

A-shih-na Hu-se-lo(Hu-se-10 Khan) 阿史那斛瑟羅

A-shih-na Ni-shu-fu阿史那泥熟氞

A-shih-te Wen-fu阿史德温傅

Act of Grace SEE ta-she

Amitayus, Sutra (Wu-Ziang-shou ching) 無量尌㬎

An-hsi 安西

An-10, Princess安㭃留公主

An Lu-shan 安䘵山

An-pei 安北

An Shun 安舜

An Sưng 安幐

An-tung 安束

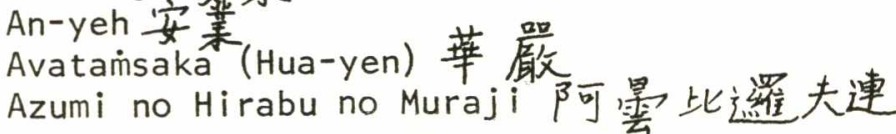

bhadanta (ta-te) 大德

Bodhiruci 菩提流志

bodhisattva ( $\mathrm{p}^{\prime} \mathrm{u}-\mathrm{sa}$ ) 箁应

Buddhapāla 佛陀波利

ćakravartin 輞輪王

ćandraprābha (yueh-kuang wang) 月光王

Chai I翟義

Ch'an 朣

ch'an-wei 瀻䋨

ch'an-yü 厴宇

Chang Ch'ang-i 張昌俄

Chang Ch'ang-tsung 張昌宗

Chang Chao 張昭

chang-chiao 章醮

Chang Chien-chih 張束之

Chang Chiu-ling 張九龄

chang-fu 章符

Chang Hsing-ch'eng 張行成

Chang I-chih 張易之

Chang Jen-wei㲀仁祽

Chang-ku 掌固

Chang Ming-shan 張明善

Chang T'ing-kuei 張廷珪

Chang Wen-kuan 張文琟

Chang Yüeh 張説

ch'ang 唱

Ch'ang-chou 常 州

ch'ang-liu chi yü-nu長流及域奴 


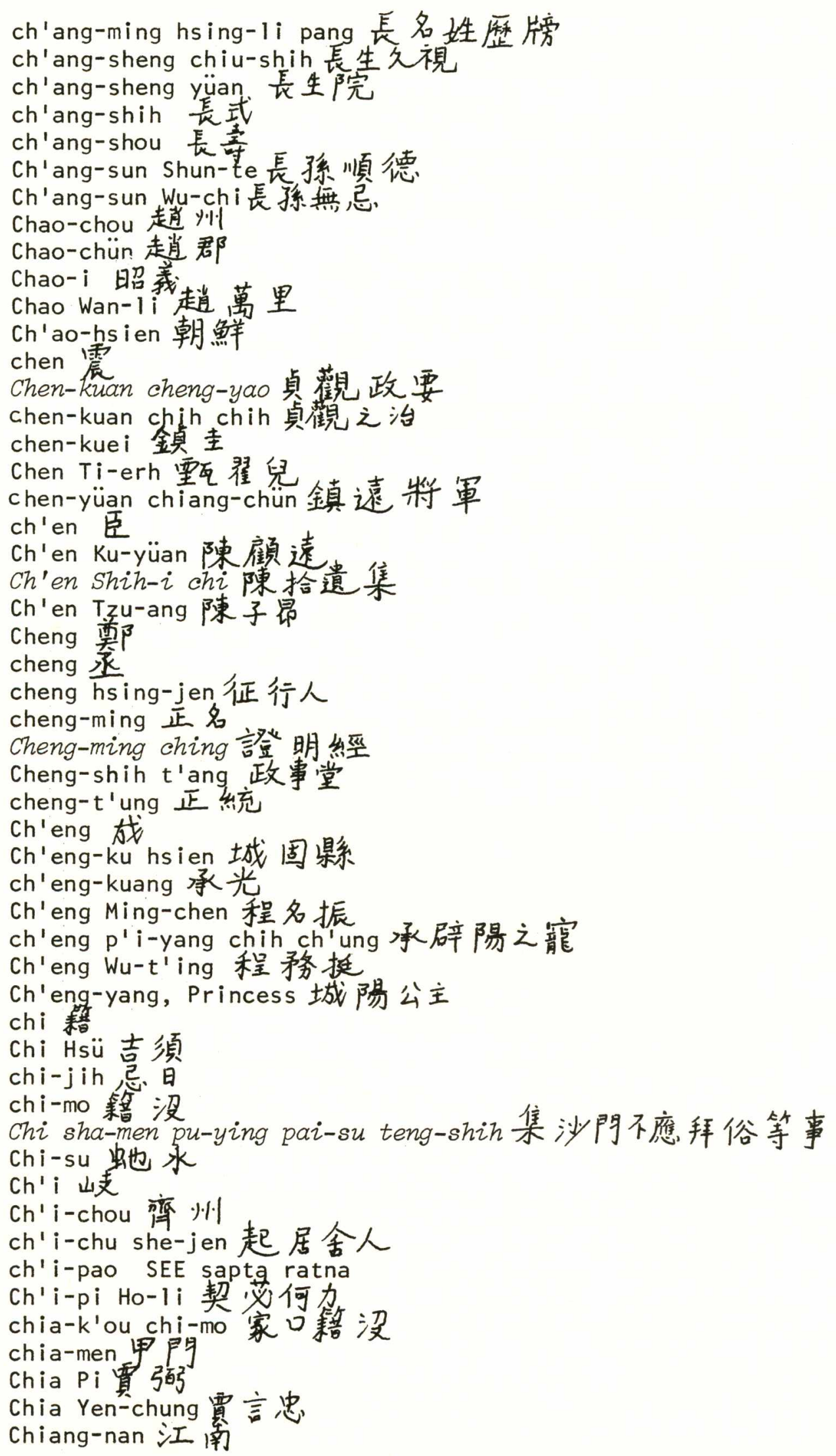




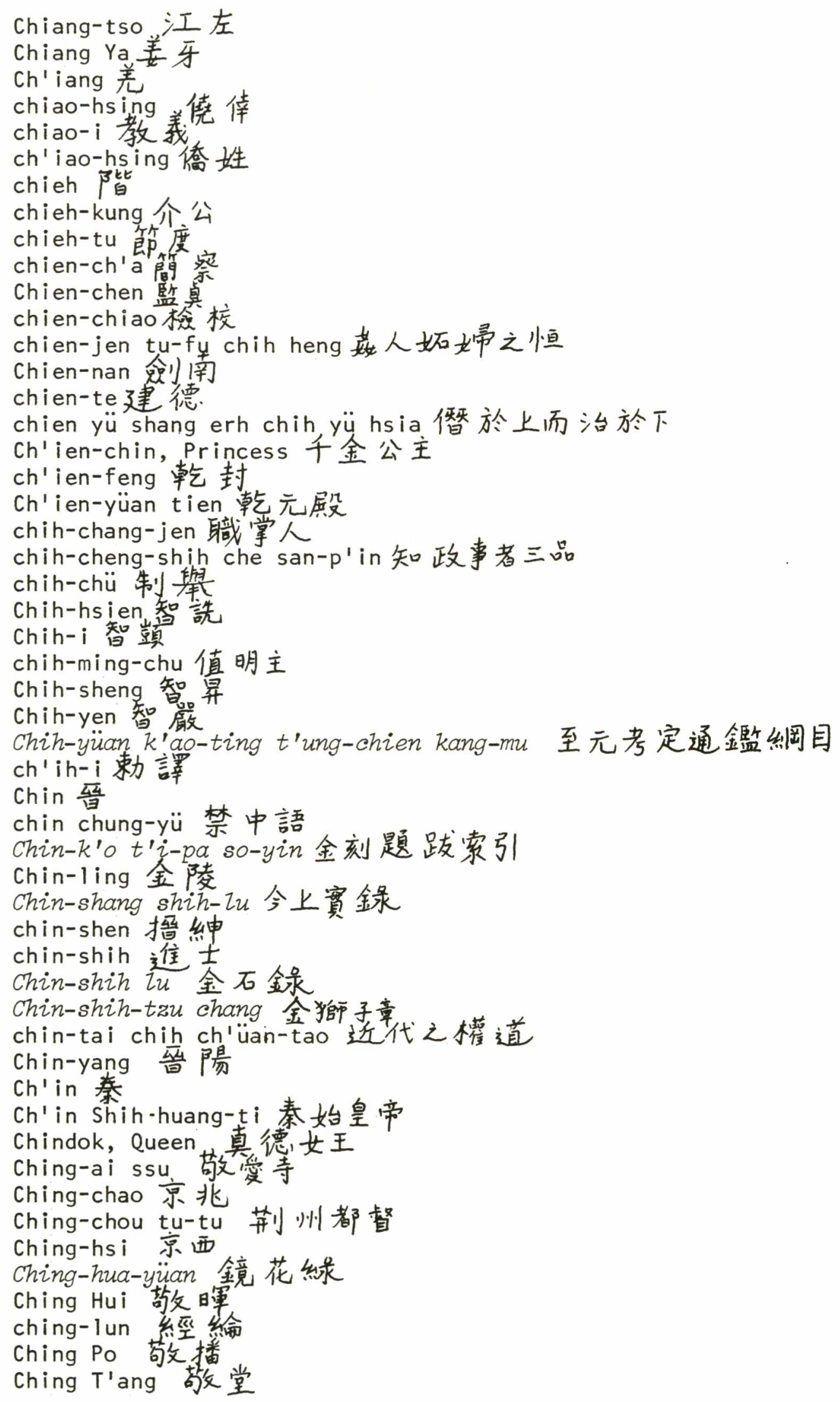




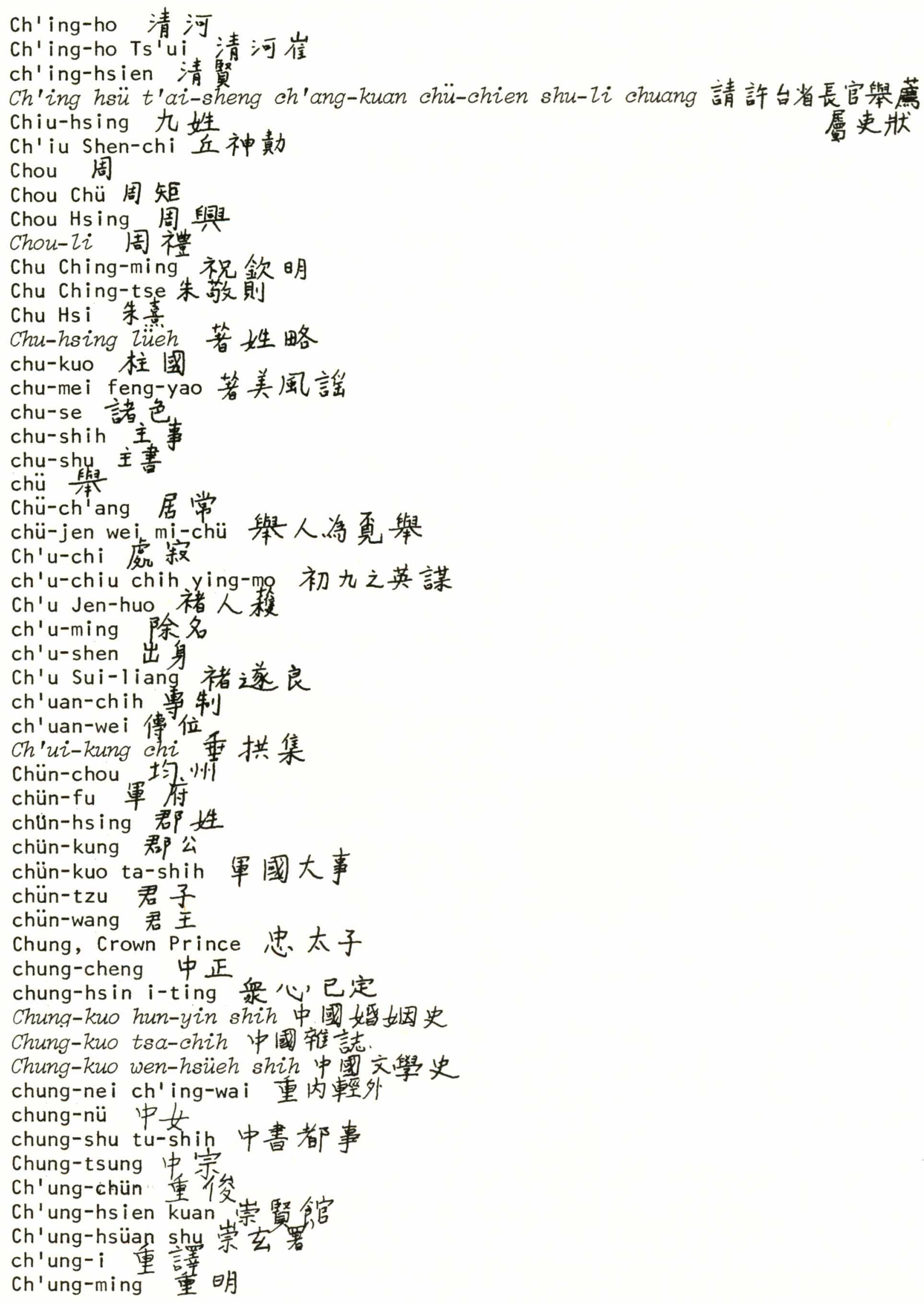


Ch'ung-wen tsung-mu chih-shih lu 崇文總目輯采睪錄

Churyo 周留

Dai karawa jiten 大漢話辞典

Dharmaraksa 曇無蛓

Divākara'日照, “地婆詞羅

en-tu，圏度

Erh-shih-wu-shih pu-pien二十五史補出扁

Fa-hsiang 法相

Fa-min 法敏

Fa-ming 法明

Fa-tsang 法减

fa-tzu 法子

Fa-yüan chu-lin 法苑珠林

fan-chieh chih en 泛階之思。

fan-hu 番户

Fan Tzu-kai 梦子荒

Fan-yang lu 范陽蘆

Fang 房

Fang-chou 房州

Fang Hsiao-ju 方孝, 需

Fang Hsüan-ling 方玄造令

fang-pien 方便

fei-ch'ang ts'ai-yung 非常才用

fei ju-shih 非㩦士

Fen-chin 汾丝

feng-ch'en fu 奉宸府

Feng-chou 辌, 州

Feng HaO 溤浩

feng-ko 鳥 留

feng-ku 風举

feng-nei 封肉

feng-po 封哥爻

feng-shan 封禪

Fo-kuang wang 佛光王

fu-cheng 事甫政

Fu Hsi 伏表路

fu-jui 符瑞

fu-kao 符 告

Fu Kung-shih 車甫 公祏

fu-lu往金等

fu-ma 墨保馬兵

fu-t'ien yü miñ $\mathrm{p}^{\prime} i$ 復乔於明辟

$\mathrm{Fu} \mathrm{Yu-i}$ 傅逰藝

mGar ม口エ

han-chün 㝜 田夋

Han Hsien-tsung 韓彎宗

Han Hsiu 暲休 


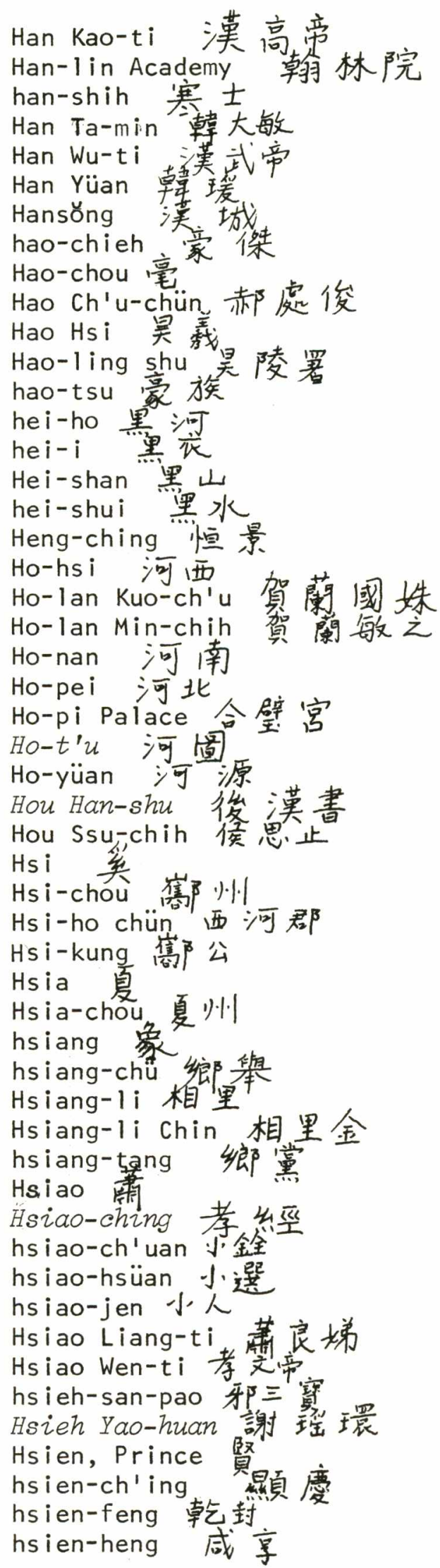


GLossary

307

hsien-ho 㬎臭和

Hsien-hsiang 期享

hsien-kung 版系公

hsien-liang fang-cheng 婜良方正

Hsien-pi 鮮卑

hs ien-shou'

hsien-t'ien t'ai-hou 先天太后

hsien-tz'u 先慈

Hsien-yang 咸陽

hsin 信

Hsin-ch'eng 新城

Hsin-chou 忻州 Hountain 新彗丵山 hsing 女生

Hsing-chou 舆州

hsing-chün 行'軍

hsing-chün ssu-k'ai, 行粱司鎧

Hsing-hsi Zun 姓系論

hsing-1i 姓歴

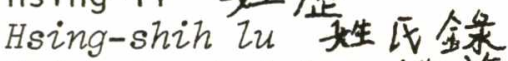

Hsing-tsu-hsi zu 姓族系金录

hsiu-ts'ai 秀才

hsiung 厷住

Hsiung-chin SEE Paekche

Hsü Ching-tsung 許䓪文宗

hsü-li 胥史

Hsü-mi Mountain (Mt. Sumeru) 須雨山

Hsü P'eng-chiao 徐鵬校

hsü-shih 蛋士

Hsü Sung 徐松

$h s u ̈-t ' u$ 零, 徒

Hsü Yen-pai 徐展伯

Hsü Yu-kung 徐有 功

hsüan 選

hsüan-chieh 退解

Hsüan-tsang 玄贸。

Hsüan-tsung 玄宗

Hsüan-t'ung shih-chi, 宣同師記

Hsüan-wu Gate 玄武丽

Hsüeh 薛

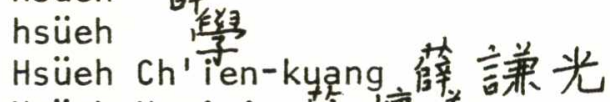

Hsüeh Huai-i 辟懹義

Hsüeh Jen-kuei 藓仁貴

Hsüeh Yüan-ch'ao 䈉元超

hsün 陲

hsün-fu-shih 巡撫使

Hsün-ko 動格

hsün-kuan 恶勳官

hu $p$

Hu Chen-hsiang 胡震享 


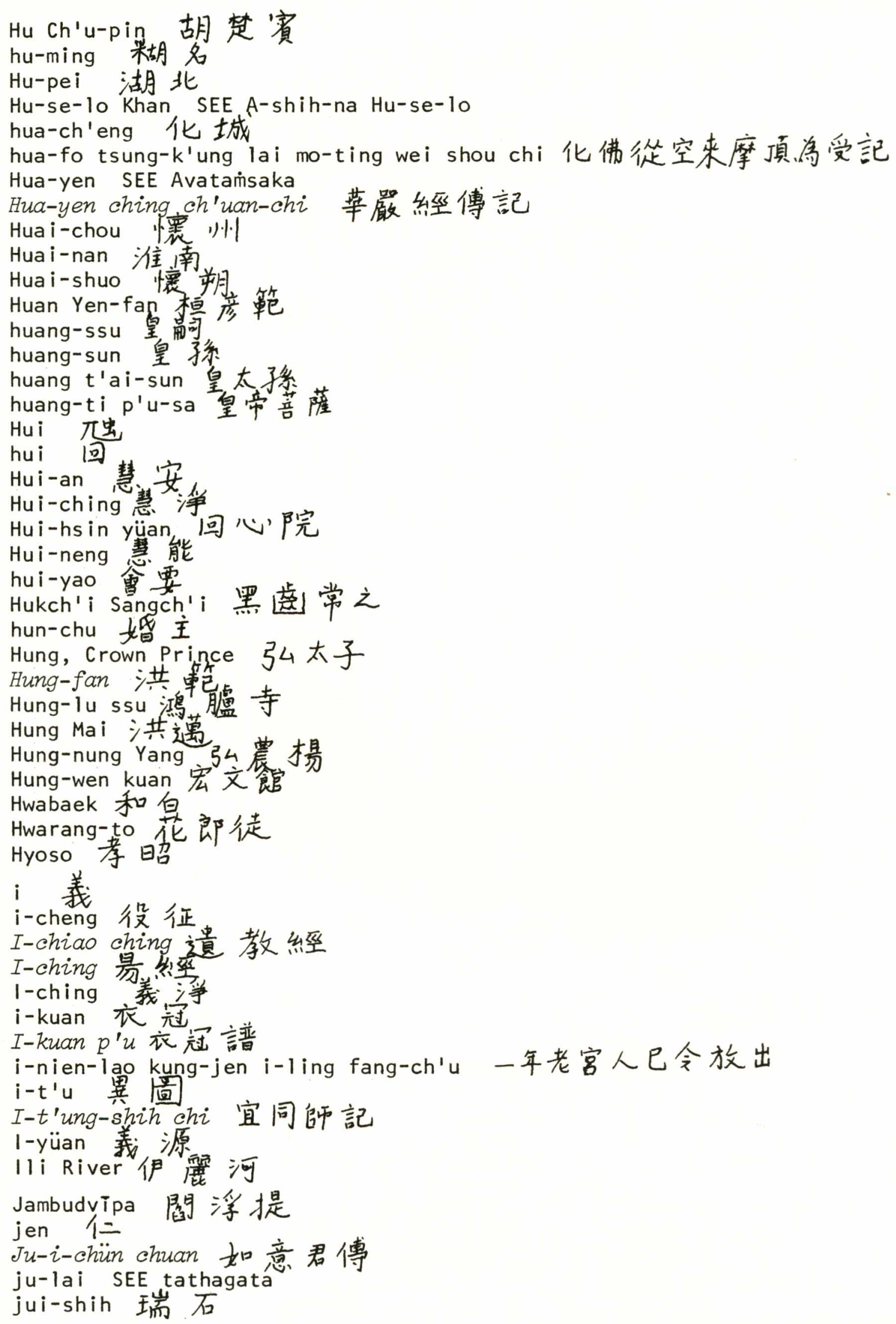




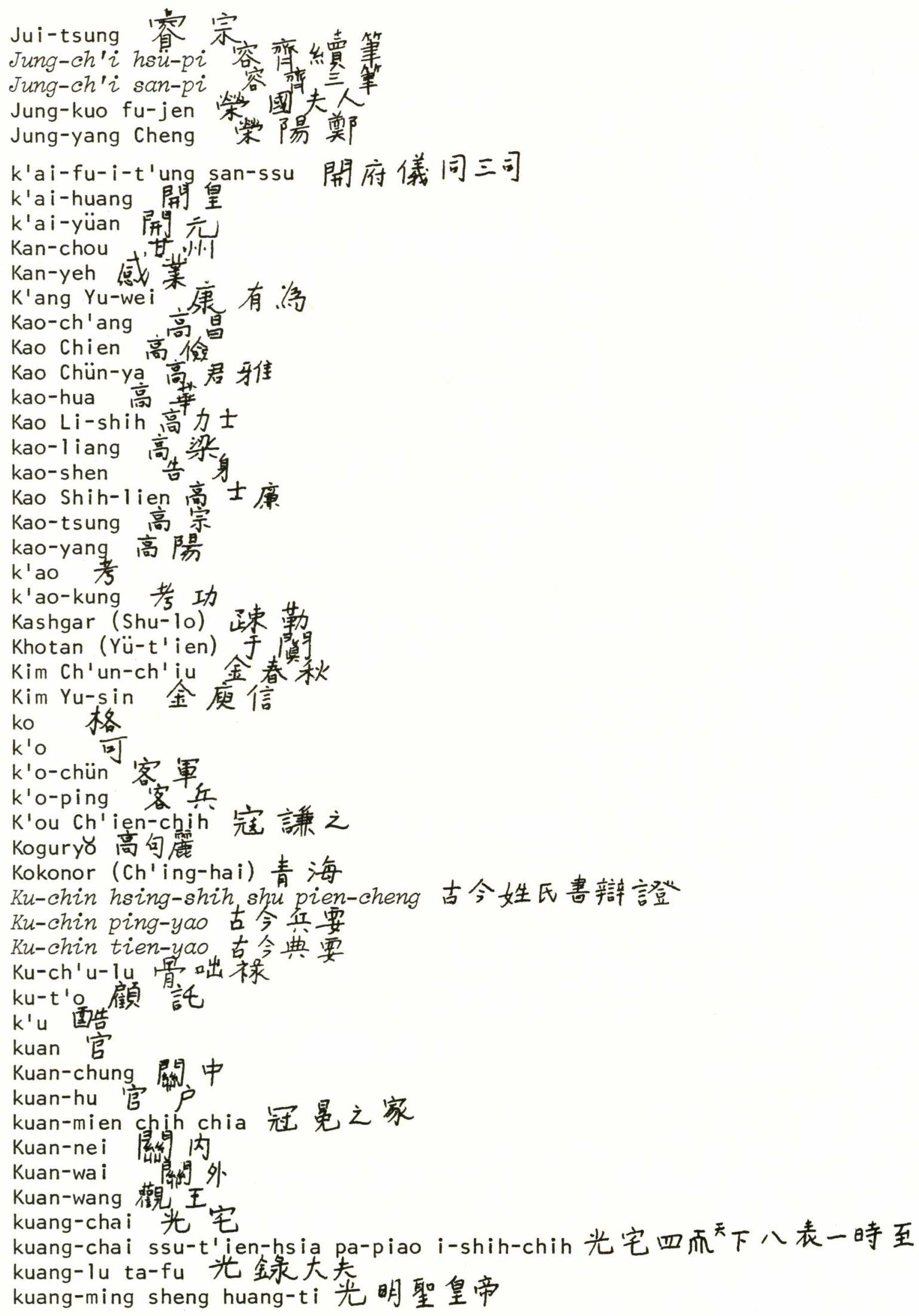




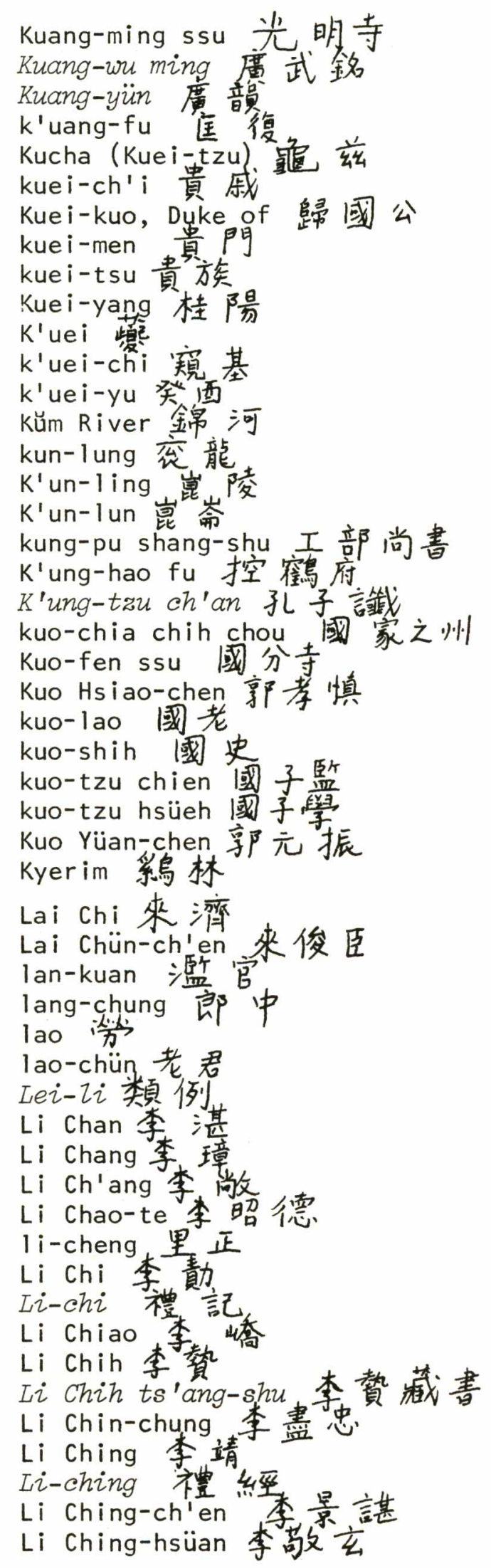


Li Ching-yeh 李䔩業

Li-chou 利帅

Li-chou chiang-t'an tso 利州江潭作

Li Chuan 李鿁

Li Ch'un-feng 李㳯風

Li Ch'ung 李冲

Li Ch'ung-jun 李重渥月

Li Fei 歴 岟

Li Hsiao-ch'ang 李孝常

Li Hsiao-i李孝冕

Li Hsien

Li Hung

Li I-fan

Li I-fu 李

Li I-shan 李

Li Ju-chen

Li Kang 李㬎岡

Li Lung-tzu, 李龍子

$\mathrm{Li} \mathrm{Mi}$

Li 0 本手的

Li Ping 季明丙

Li Shan-kan 李善感

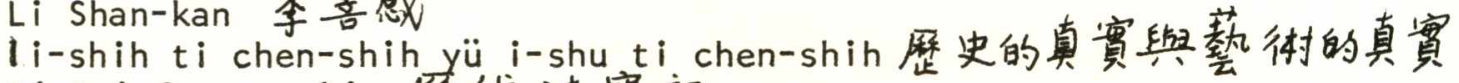

Li-tai fa-pao chi 歴代法賽記

李相國論事集

Li To-tso 李多作

li-ts'un 里禁

Li Yung 李䇼

liang 良

Liang Ch'i-ch'ao 梁啟超

liang-chia 良 家

Liang-Chin Nan-pei ch'ao shih 雨曋南北朝史

Liang-chou 涼州

liang-jen 良人

Liang-kuo, Duke of 梁國公

Liang Wu-ti

Liao River

Liao-tung

lieh-chuan 列傅

Lieh-nü chuan 列女暷

lin-ch'ao ch'eng-chih 臨朝稻制

lin-pao 鄰保

lin-te 鹿数

ling

Ling

梁武帝

Ling of 露

Ling-chou 單 嵪

Ling-hu Te-fen 会狐德篍

Ling-nan 领南

ling-shih 令史

liu 流

Liu Ch'i-hsien 劉弯賢 


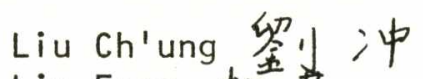

Liu Fang 柳芳

Liu Hsiang一垛o 貿祥道

Liu Hsiao 貿摬

Liu Hung-chi 㔀弘基

Liu Jen-jui 拴仁点

Liu Jen-kuei 贸仁鿂

Liu Jen-yüan 覀仁原面

Liu Liang-pin 柳良奢

LiuMien 鉒河

Liu Mu 柳模

liu-nei 流内

Liu Shih 柳酸

liu-shou shu-tso 留守書佐

liu-shou ssu-ping 留守司兵

Liu Ssu-li 贸思福

liu-t'iao 六條

Liu Tsung-yuian 柳宗元

Liu Tz'u 柳玼

liu-wai 流外

Liu Wei-chih

Liu Wu-chou

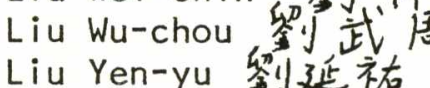

Liu Yün-chi 劉允湾

Lo-chih ching 維 䋨㬎

lo-hsing 虜姓

Lo Kuan-chung 政買中

Lo Pin-wang 駱萆王

Lou Shih-te 婁觇德

Lo-shu 洛書

Lu Ch'eng-ch!ing 盧承膺

Lu Ching-ch'un 路简文㳯

Lu-hsüan-kung ch'光an-chi 陸宣公全集

Lu-ling, Prinçe of 盧陵王

lu-shih 金录事

Lu Tung-tsan 䘵事贊

Lï 点律

Lü-chou 号州

Lü Hsia-ch'ing 号夏很

lï-ling 律令

Lü Ts'ai 号才

luan-t'ai 䜌喜

Lun Ch'in-ling 椧金欠陵

Lung 龍

Lung-ch'eng Zu 龍城镍

Lung-hsi 站西

Lung-men 龍阴

l ung-shuo 龍新

Lung-t'ut'u龍吐圆 


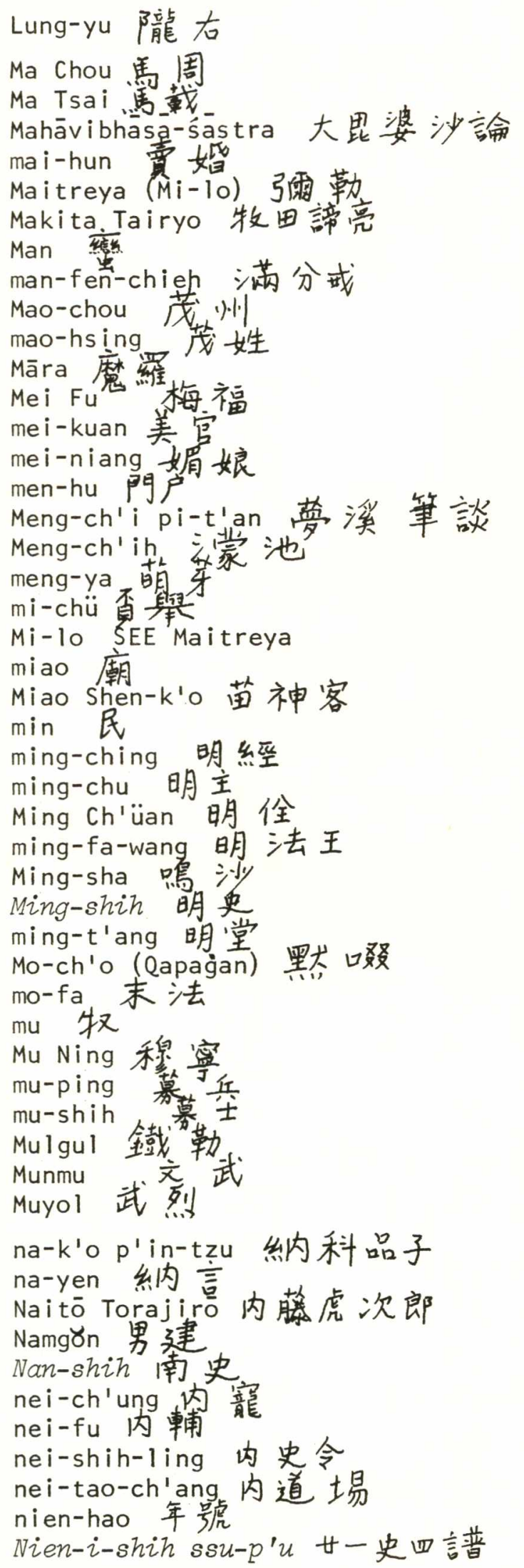


Nü Kua 女㧹

nü-kuan 女 '官

nü-tzu yü hsiao-jen女子與小人

ōda Teizō太田悌藏

Ōtani Shōshin 大谷勝真

Pa-chou 巴州

pa-piao 公表

Paekang 白江

Paekche 百濟

pai 手年

pai-hsing 百姓

p'an 半i

$P^{\prime} a n-$ Zung-t'ai pei 攀龍臺碑

Pañcaveramani (Wu-hsing-fa) 五我法

pao 保

Pao-k'o ts'ung-pien 察刻丵編

Pao Ssu-wei 赛思維

Pao-t'u 害圆

Pao-yü ching 賔雨出垔

parahita 利他

Parhae 渤海

pei-men hsüeh-shih 北阴舆士

Pei-shih 北史

Pei-t'ing tu-hu-fu 北庭都謢府

P'ei Chien 裴兼

P'ei Hsing-chjen 裴行佮

P'ei Yen 裴焱

pen-chi 本紀

pen-kuan 本貫

pen-se 本色

pen-wang 本望

P'eng-lai 逢莱

pi-hsia 陛下

pi-wei 避位

$p^{\prime} i$ 疋

p'i-chao 辟召

p'i-yang chihch'ung 辟陽之窨

pin-k'o 奢 客

p'in-ts'ai 㴔剘

Ping-chou 并州

ping-mu 兵募

Po-chou 博州

Po-ling Ts'ui 博陵崔

Po-shan tien, 博山共

Pojang 察藏

Poksin 福信

pu-ch'üeh 補缺

pu-k'o i chiang 不可以降

pu-shun 不順

$p^{\prime} u$ 譜

p'u-sa SEE bodhisattva 
p'u-sa t'ien-tzu 菩苼天子

$p^{\prime} u-s h e$ 㒒射

$p^{\prime} u-t$ 'ieh 譜諜

P'ung 典

Puyorung 扶食余隆

Rāks̄āsa 羅刹叉奖

Saitō Aiko 涼藤受子

samadhi 三摩地

Scomguk Yusa 三國遺事

san-ch'i ch'ang-shih 散.馬奇常侍

San-chiao chu-ying 三教珠英

san-ch'üan 三铨

san-huang ${ }_{\text {盖 }}$

san-i 三俄

san-kuan 散 官

san-kung 三公

San-kuo chih 三國志

san-lei 三類

san-wei 三得

sanigha (san-kang) 三縲周

sao-p'ing 掃平

sapta ratna (ch'i-pao) 火賽

sari 舍利

Seng-ch'ang 僧長

Seng-ni nieh-hai 僧尼湼海

Seng-shih Züeh 僧史略

Sha-po-lo khan 沙鉢羅可汗

shan 善

Shan-chou陕州

Shan-nan 山南

Shan-tung 山束

Shan-yü 毠于

shang 上

shang-chu-kuo,上柱成

shang-hu $k 户$

Shang-kuan 1 上官義

Shang-kuan Wan-erh 然婉兒

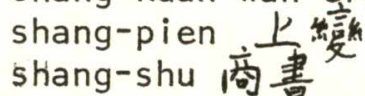

shang-shu tu-shih 尚書都事

shang-t'ien 上天

Shang-yang Palace上陽宫

Shang-yüan 上元

Shao Tzu-wu of P'ing, Prince 平王少子武

she-chih kuo-cheng 㨨知咸政

shen 身

Shen Chi-ch'i 沈玍无黹

Shen Ch'üan-ch'i 沈佺期

shen-hsien 神仙

Shen-hsiu 神秀

Shen-huang wang 神皇王 


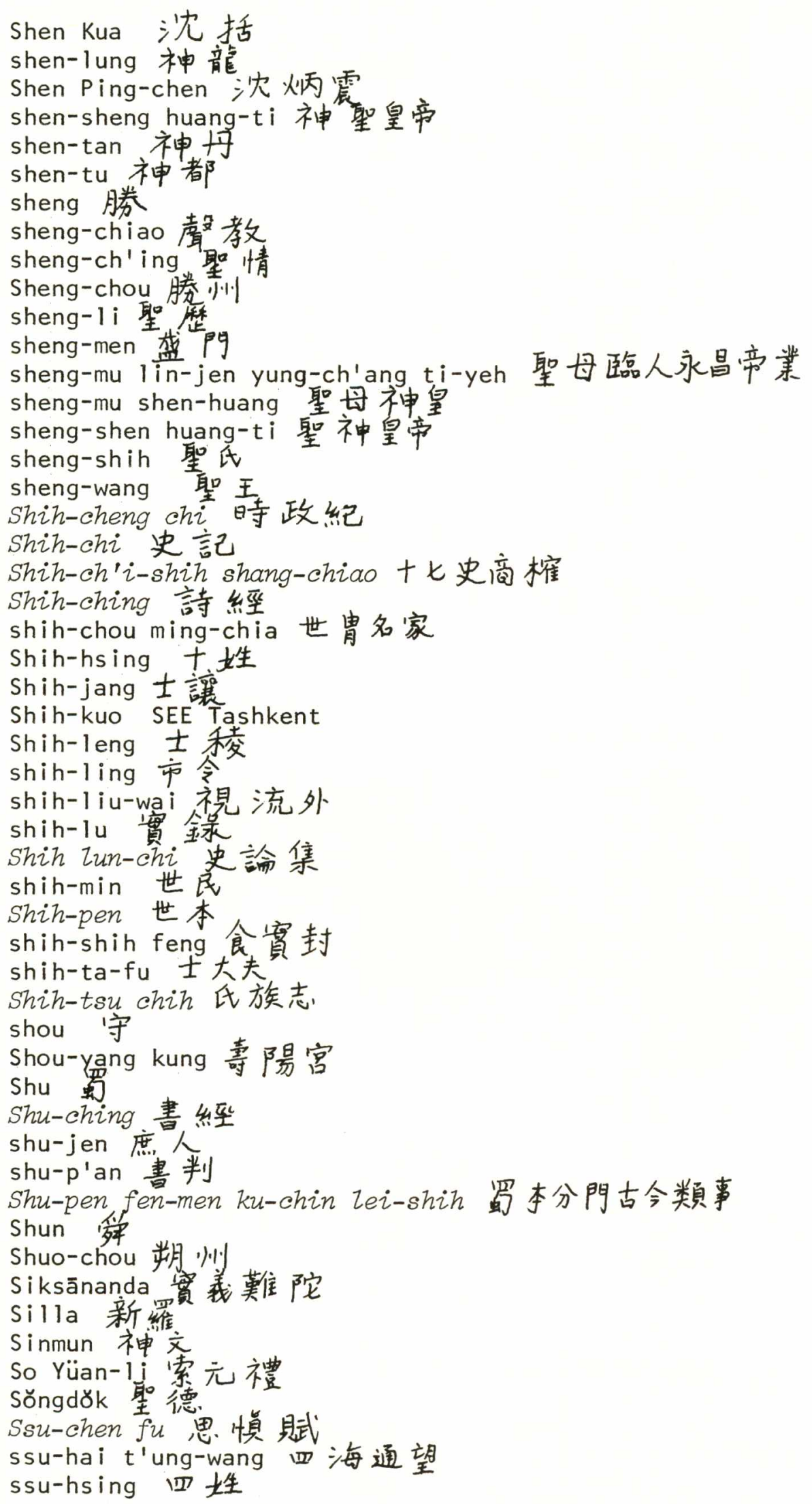


ssu-k'ai ts'an-chün司金豈參軍

ssu-k'ung 司空

ssu-ma 司焉

Ssu-ma Ch'ien 司馬遷

ssu-men hsüeh 四門等

ssu-ta 四大

ssu-t'u同徒

Su An-heng 藮安恒

Su-chou 肃训惊

su-kuan 俗

Su Mien 穌亮

Su Ting-fang 蕉定方

Su-tsung 肃宗

Sui-chou 出妥州

Sui T'ang yen-i 隋唐演義

Sui Wen-ti 隋文帝

Sun Jen-shih 孫仁官币

Sun Wan-jung 孫萬策

Sung 宋

Sung-chou 松州

Sung Chih-wen 宋之辟

sung-shih 米史

ta 達

ta-chen 大臣

ta-ch'eng 大成

ta-chiang-chün fu-k'ai-ts'ao大㭩軍府金崖㤟

Ta Chou k'an-ting chung-ching mu-lu 大周利定奥㬎互目金录

Ta Chou wu-shang hsiao-ming kao huang-hou pei-ming 大周無上孝明高皇后碑銘

Ta-chuang-yen Temple 大裝祳寺

ta-chung-cheng ssu-t'u裝聚正司徒

Ta-fei-ch'uan 大非川

ta-i 大義

ta-kuei 大圭

ta-ni 大逆。

ta-pao 大政

ta-she (Act of Grace)

Ta-sheng hsüan-chi 大聖毀記

ta-te SEE bhadanta

ta-tu-tu 大都督

ta-yeh 大業

Ta-yün ching 大雲出受

Ta-yün mi-tsang 㟥雲密藏

Taedong River 大同江

T'ae-p'yŏng song 太平頌

Tai-chou 垈州

Tai Li ching-yeh t'ao Wu-shih hsi 代李敬美討武代檄

Tai-pej 带 北

t'ai 泰

t'ai-ch'u 太初

T'ai-hang 太行 
t'ai-ho 太和

t'ai-hou 太后

t'ai-hsüeh 太祭

t'ai-huang 太皇

T'ai-p'ing ching 太平出巠

t'ai-shang hsüan-yüan huang-ti 太上玄元皇帝

t'ai-shih 太攴币

t'ai-ssu 台司

t'ai-sun 太㐨

T'ai-tsu hsiao-ming kao huang-ti 太祖孝明高皇帝

T'ai-tsung 太宗

t'ai-tzu 太子

t'ai-tzu san-shih 太子三们

t'ai-wei 太层寸

T'ai-yüan 太原

T'ai-yüan, Prince 太原王

T'ai-yüan chün-kung 太原郡公

T'ai-ÿ̈an shih-chi 太原事跡

T'an-kang 量阙

tang hao-hs i chih 1i-shu 當昊美之歷數

T'ang Chiao 唐皎

T'ang Chih-ch'i 唐之奇

T'ang-hsing hsien 唐興影

T'ang Hsiu-ching 唐休”景

T'ang-jen pa-chia shih 唐人八家詩

T'ang Lin 唐 臨

T'ang p'u-shang ch'eng-lang piao 唐嵄尚丞郎表

T'ang-shih Zun-tuan 唐史論断

T'ang-shu chih-pi 唐害直筆

T'ang-t'ang 唐唐

T'ang Te-tsung 㢆德宗

T'ang t'ung-chi 唐㬎充記

T'ang-wen hsü-shih 唐文綪拾

T'ang-wen shih-i唐文拾遗

T'ang Yin, 唐寅

Tao-an 道

Tao-ch'eng 道伐

Tao-hsüan 道宣

Tao-seng ko 道僧格

tao-shih 道世

Tao-te ching 道德出至

Tao-tsun 道俊

Tashkent (Shih-kuo) 石國

tathāgata (ju-lai) 如来

te 德

te-hsing 僡行

te-mien 德兔

te-ta tzu-tsai 得大自在

Te-tsung 德宗

te-yün 德運

Teng-ch'eng 等乘

Teng-hsia chi 燈下集 
Teng-k'o chi-k'ao 登科記考

Teng-k'0 Zu 登科锒

teng- $\mathrm{t} i$ 等第

ti 地

ti-chu地著

Ti Jen-chieh 狄仁傑

tiao 調

tieh 謀

t'ieh 帖

tien-shih 共齐言式

tien-yeh 典謁

t'ien-hou 天后

t'ien-huang 天㒸

T'ien Kuei-tao 国毁寻道

t'ien-ming wei-kai 天命為改

t'ien-nü 天女

t'ien-nü shou-chi 天女授記

t'ien-pao 天 筫

t'ien-she-nü 国舍

t'ien-shou 天授

T'ien-shou sheng-t'u 天授聖图

t'ien-shu 天樞

T'ien-t'ai 天猿

t'ien-t'ang 天堂

T'ien Te-p'ing 田德平

t'ien-ts'e wan-sui 忝册萬威

t'ien-t'ung-tzu 天童子

Ting 定

Ting-chou 定州

t'ing-ch'ang 亭長

Tódai no koyomi 唐代の曆

Tokchim 道琛

Tokmak (Sui-yeh) 碎業

Tou 蜜

tsa-se-jen 穼住色人

tsa-wen 亲住交

tsai-ch'u載初

tsai-hsiang 宰相

ts'ai $才$

ts'ai-jen

tsan-che 智先者

btsan-po 䎋普

ts'an-chün 突軍

ts'an-tso shih-p'in 參佐視品

Ts'ao 曹

Tse-t'ien shun-sheng huang-hou刞天順聖皇后

Tse-t'ien ta-sheng huang-ti 則天大偟皇帝

Ts'en Wen-pen 芩 文 本

tsou-ch'ü chin-chih 奏取進止

tsu 祖 


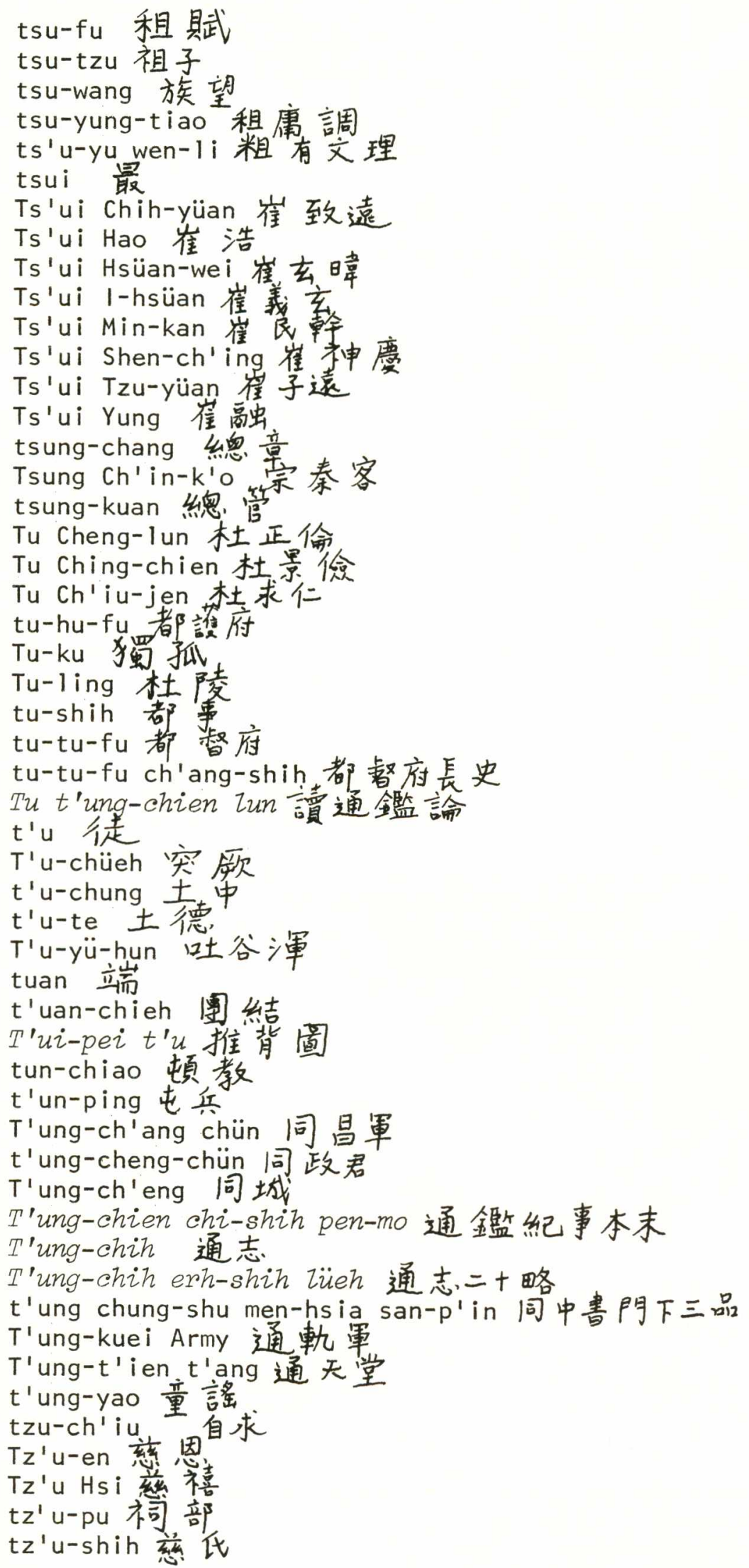


GZossary

321

$T z ' u$-yüan 辤源

Ŭija 義慈

Ungch'袋熊川

Ungj in 熊津

Ungnyŏng 熊領

wai-ch'i 外戚

wan-kuo chih chu, 䓪威之主

wan-sui t'ung-t'ien, 塔歲通天

wang-ch'i 王氣

Wang $\mathrm{Ch}^{\prime}$ i iao 主喬

Wang Ch'iu-li 王求䄈

Wang Fang-i 王方

Wang Fu-chih 王美之。

Wang Fu-sheng 王优勝

Wang Hsiao-chieh 王孝傑

Wang Hung 王弘

Wang Kuei 王珪

wang-ming 主命

Wang Ming-sheng 王鸣盛

Wang Po 王勃

Wang Tzu-chin, 王子䋦

Wang Wei 王威

Wei An-shih 韋安石

Wei, Prince of 魏王

Wei Chao 章超

Wei Chi 韋機

Wei-chin 魏志

Wei-chou 魏州

wei-chuan 佰傅

Wei Hsin-tzu 魏心子

Wei-hsiu 魏秀

Wei Hsüan-chen 章玄真

Wei Hsüan-t'ung 魏玄同

Wei-kuo fu-jen 魏威夫人

Wei Ssu-1i 韋, 思立

Wei Ssu-wen, 魏思温

Wei T'ing 章挺

wei-tsao 傜造

We $\mathrm{i}$ Wen- $\mathrm{ti}$ 魏文帝

Wei Yüan-chung 魏元忠

wen 文

Wen-ch'eng, Princess 文戊公主

wen-lii 文律

wen-ming 文明

Wen of Chou, Prince 周文王

Wen-shui 文 水

Wu 武

WU 武

Wu-ch'ang hsien 武昌影

wu-che-hui 無遮會 


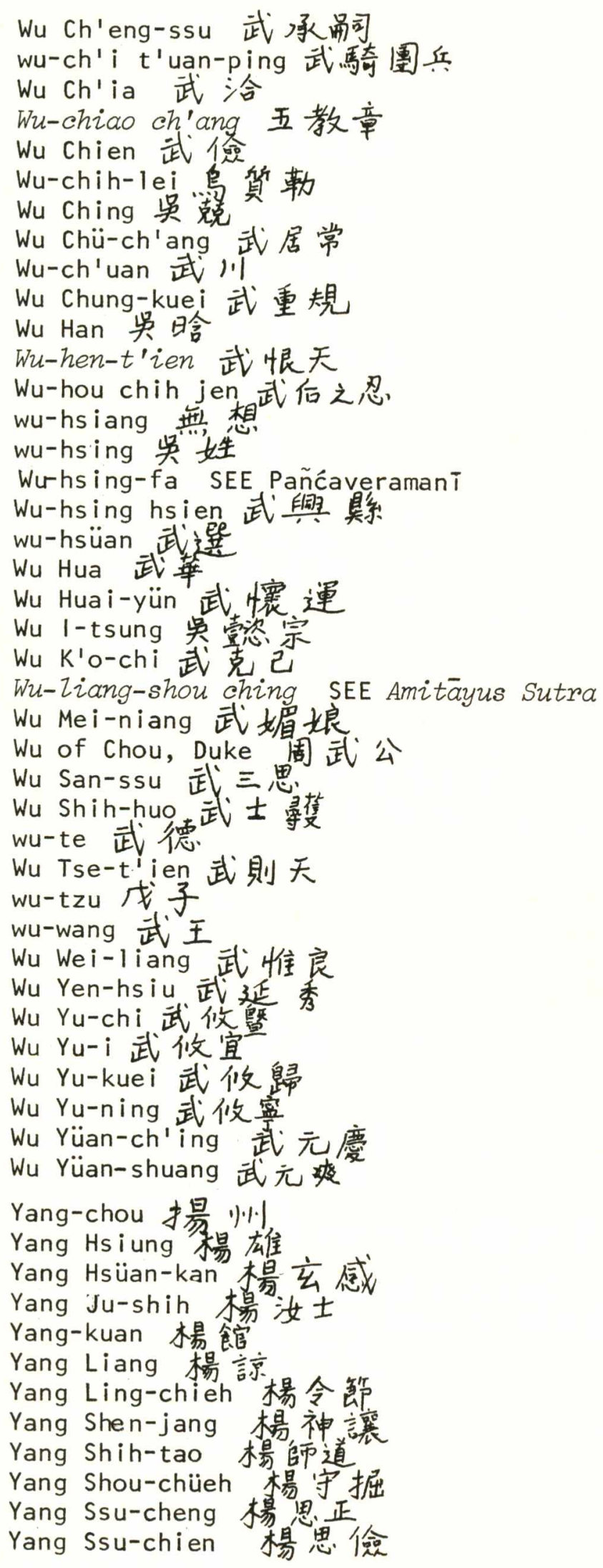




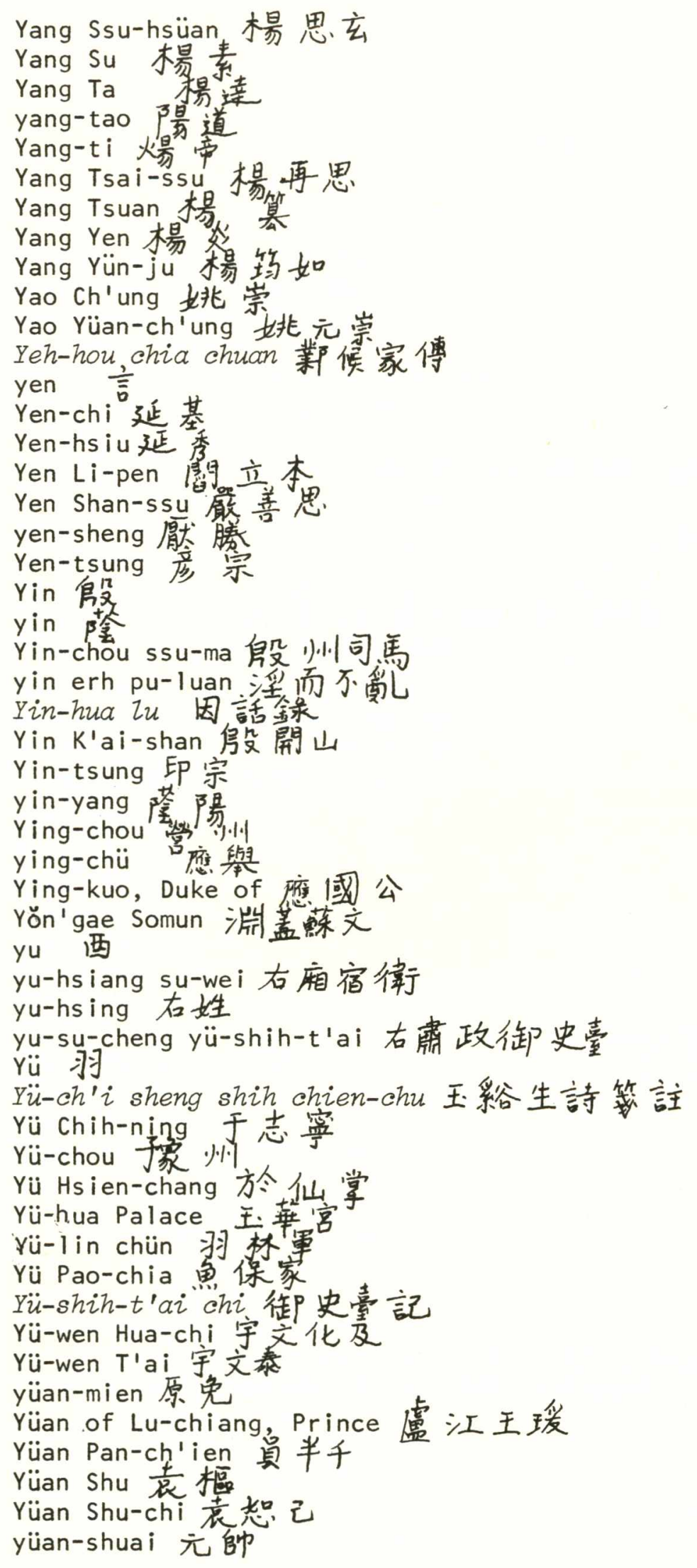


Yüan-sung ch'an 元高菲伐

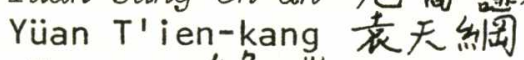

yüan-tso 慈条坐

yüan-wai 尊外

yüan-wai-lang 总外郎

yüan-wai t'ung-cheng, 員外同正

Yüan Wan-ch'ing 元嶅㴪

yüeh-kuang wang SEE ćandraprābha

yüeh-wang ch'ang-shih越王長史

Yung 䔨

yung-ch'ang, 永昌

Yung-chou 雍州

yung-hui 永得了

yung-lung 永 隆

yung-shih 永式

Yung-t'ai, Princess 永泰公主 
INDEX

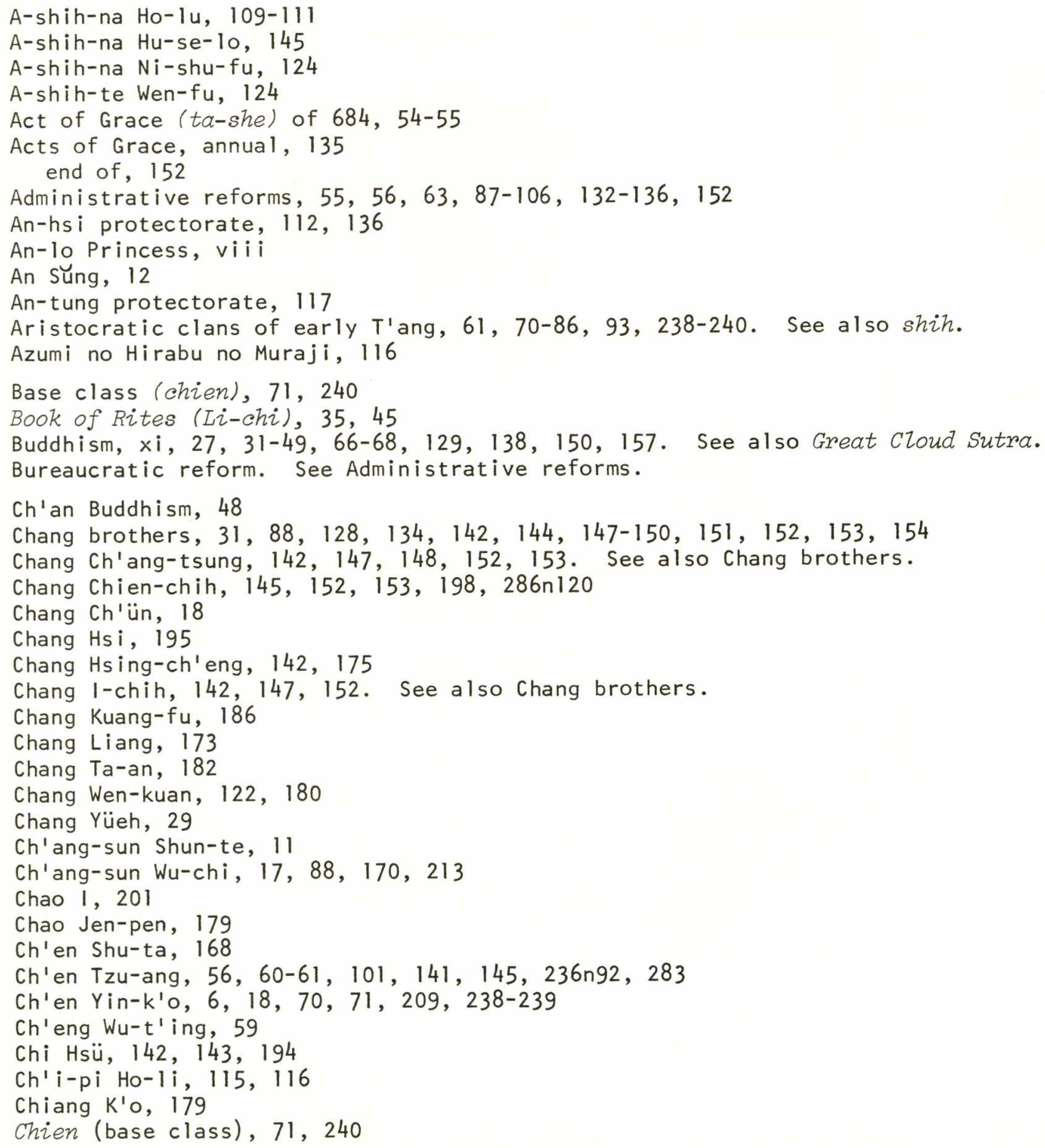


Ch'ien-chin, Princess, 36

Ch'ien Wei-tao, 185

Chih-hsien, 48

Chih-sheng, 45

Chih-yen, 48

Ching-hua ÿ̈аn (Flowers in the Mirror), 158, 199

Ching Hui, 153, 286n120

Chiu T'ang Shu, see Old T'ang History

Chou Chü, 130

Chou, dynasty founded by Empress Wu, 2, 126-154

stages leading up to, 54,62, 64-65

rationale for its founding, 156-157

founding of, 66, 68

and Buddhism, 46-47

and examination system, 101-106

rituals and state ideology of, 35, 49

stages of, 128

Chou Hsing, 60, 88, 104-105, 130, 151

Chou Yün-yüan, 193

Chu Ching-tse, 130, 197

Chu Hsi, 3

Ch'u Sui-liang, 17, 18, 174, 233

Ch'üan T'ang-wen, 33

Chung-tsung, Emperor, viii, 2, 24, 51-52, 55, 65, 80, 101, 126, 132, 141, 143, $144,145-146,148,153,154$

Ch'ung-hsien kuan, 28

Comprehensive Mirror For And in Government, 3, 5, 8, 20, 52, 61, 62, 63, 66, $121,130,145,149$. See also Ssu-ma Kuang.

Confucianism as legitimizing ideology, 28-30, 53, 127, 129-130, 138, 144, 149150

Cosmic hall, see Ming-t'ang

Discussion of Surnomes and Lineages (Hsing-hsi Zun), 71-74

Divăkara, 48

Economic affairs, $64,96,137-138,158-159$

Education, 28, 90, 95, 149-150. See al so Examination system.

Examination system, $x i, 28,66,70,81,89-103,132-136,138,149-150,151,158$

Fa-hsiang school, 47, 48

Fa-ming, 36

Fa-tsang, 48

Fan Li-ping, 187

Fang Hsiao-ju, 5

Fang Hsüan-ling, 170-171

Fang Jung, 198

Female rulers in Chinese history, vii, 3-4, 50, 54, 87, 199

Feminism, vii, viii, 3-4, 5, 50,61, 63-64, 67, 144, 149, 155, 157, 199, $20 \ln 36$. See also Legitimation.

Feng-shan ceremony, 2, 20-21, 25, 28-29, 53, 104, 105, 116, 121, 129

Feng $\mathrm{Te}-\mathrm{i}, 169$

Fiefs of maintenance (shih-shih feng), 88, 253-254 
Fiscal problems, 64, 137-138. See also Economic affairs.

Flowers in the Mirror (Ching-hua-yüan), 158, 199

Foreign policy, 107-125, 136-137, 138-144, 145-147

Fu Kung-shih, 15

Fu-ping (militia), x, 25, 55, 56, 70, 109, 111, 122, 123-124, 125, 129, 137, $232-233,266$ n10, 276n116, 283-284

Fu Yu-i, 187-188

Great Cloud Sutra (Mahōmegha), xi, 36, 37-46, 66-68, 129, 157, 158

Han Yüan, 18, 162, 175, 213

Hao-chieh (magnate clans), 71, 76, 240. See also Aristocratic clans, Shih.

Hao Ch'u-chün, 23, 181

Heng-ching, 48

Hereditary privilege $(y i n), 91$

Ho-lan Kuo-ch'u, 21

Ho-lan Min-chih, 21,34

Hou Chün-chi, 172

Hsiao Liang-ti, 17, 18, 23, 28

Hsiao Yü, 167

Hsien, Crown Prince, 23-24, 41, 44, 54, 58

Hs in Mao-chiang, 177

Hsin T'ang Shu, see New T'ang History

Hsing-hsi Zun (Discussion of Sumames and Lineages), 71-74

Hsing-shih $\mathrm{Zu}, 77-79,80,81,93,103,110$

Hsing Wen-we i, 187

Hsü Ching-tsung, 9-10, 18, 89, 163-164, 177, 212

Hsü Sung, 95

Hsü Yu-kung, 62, 130, 136

Hsü Yü-shih, 177

Hsüan-tsang, 19, 35, 47, 48

Hsüan-tsung, Emperor, 57, 88, 132, 133, 137

Hsüeh Huai-i, 35-36, 46, 62-63, 66, 88, 138, 147

Hsüeh Jen-kuei, $116,117-120,121$

Hsüeh Yüan-ch'ao, 181

Hu San-hsing, 98

Hua-yen sect, 48, 49

Huan Yen-fan, 152, 153, 286n120

Hui-neng, 48

Hung, Crown Prince, 23

Hung Mai, 202

Hyoso, King of Silla, 122

I-cheng (volunteers), 111

I-ching, 48

Ideology, state, development of, 26-50

during Han, 26

Empress Wu and, 49-50, 126-127, 129

Japan, 116

Jen Chih-ku, 188

Jen Ya-hsiang, 177

Jui-tsung, Emperor, 2, 40, 52, 63, 68, 101, 126, 130, 131, 132, 143, 145, 146, 148,153 


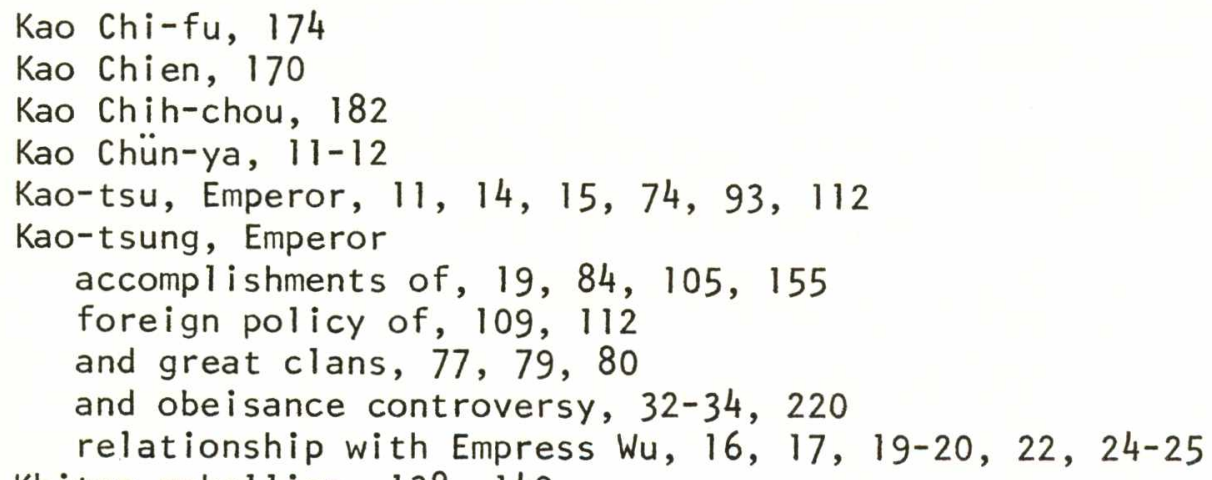

Khitan rebellion, 138, 142

Kim Yu-sin, 114, 117, 120-121, 273n89

Ko Fu-yüan, 188

Kogury $, 19,110,112-122,145$

Korea, wars with, 55, 79, 105, 109, 110, 112-122.

See also Kogury 8, Paekche, Silla.

Ku Ts'ung, 196

Kuang-chai Temple, 35

Kuang-ming sheng Emperor's rebellion, 35

Kuo Cheng-i, 183

Kuo-fen temples, 34

Kuo Mo-jo, 6, 159, 210

Kuo Yüan-chen, 141, 146

Lai Chi, 162, 176, 213

Lai Chün-ch'en, 60,61, 88, 130, 131, 141-142, 143, 151

Lai Heng, 182

Lao Tzu, 22, 30, 66. See also Taoism.

Legal system of $T^{\prime}$ ang, $6,85,126$

Legitimation, political issue of, x, 1, 2, 3, 24, 26-50, 52-53, 66-67, 68-69, $104,126,128,144,149,200 n 5,6,7$

Li An-ch'i, 180

Li Chan, 154

Li Ch'ang, 44

Li Chao-te, 131, 133, 136, 143, 189-190

Li Chen, 65, 66

Li-chi (Book of Rites), 35, 45

$\mathrm{Li}$ Chi, 18, 57, 107, 116, 119, 123, 173, 213

Li Chiang, 201

Li Chiao, 12, 55, 137, 144, 151, 195, 205-206, 236n96

Li Chih, 202

Li Chin-chung, 138, 141

Li Ching, 171

Li Ching-ch'en, 184

Li Ching-hsüan, 84, 94, 96, 181

Li Ching-yeh, 57-59, 64, 65, 156, 250-251

Li Ch'iung-hsiu, 196

Li Chuan, 65-66

Li Ch'ung, 65

Li clan, 42, 44, 66, 74, 126, 132, 154, 157 
Li Hsiao-ch'ang, 15

Li Hsien, 32

Li Huai-yüan, 196

Li $1-f u, 18,89,90,93,94,176$

Li I-yen, 182

Li Lin-fu, 88

Li Mi, 14

Li Shu-t'ung, 211-212

Li Tao-kuang, 193

Li Yu-tao, 189

Li Yüan-chi, 169-170

Li Yüan-su, 190

Liang Wu-ti, 46, 67

Ling-hu Te-fen, 33

Liu Chih-chi, 8-9, 10, 104, 133, 135

Liu Fang, $71-74,76$

Liu Hsiang-tao, 89-91, 93, 94, 101, 102, 103

Liu Hsiao, 98

Liu Hung-chi, 11

Liu Jen-kuei, 54, 115, 116, 123, 179

Liu Jen-yüan, $115,118,119$

Liu Po, 172-173

Liu Shih, 175

Liu Ssu-1i, 61, 96, 97, 141

Liu-wai ("outside the current") officials, 103-104, 263-264

Liu Wei-chih, 61, 133, 134, 184

Liu Wen-ching, 167

Liu Wu-chou, 43

Lo Lung-chih, 18

Lo Pin-wang, 13, 58

Lou Shih-te, 133, 138, 191

Loyang, $80,128-129,247$

Lu Ch'eng-ch'ing, 111-112, 177-178

Lu Chih, 201

Lu Yüan-fang, 191

Lü, Empress, of Han, 4, 54, 87

Lï Hsia-ch'ing, 3

Lü-ling system, 6 . See also Legal system.

Lü Ssu-mien, 6

Lun $C^{\prime}$ in-ling, 138, 141, 146

Lungmen Buddhist temples, 31, 35, 46, 59

Ma Chou, 93, 173-174

Mahāmegha, see Great Cloud Sutra

Maitreya Buddha, 35-45, 67

Matsui Shüichi, 18

Military examination, 102,151

Military organizations, see Fu-ping (militia)

Ming-t'ang (cosmic hali), 35, 42, 46, 63, 65,88, 126, 129, 134, 138 Mo-ch'o (Qapaġan), 136-137, 141, 142, 143, 145, 146-147, 151

Mu-ping (conscripts), 111 . See also Fu-ping. 
Munmu, King of Silla, 115, 116, 117-120, 121, 122

Muyol, King of Silla, 114

Naitō Toraji rō, 70

New T'ang History, 3, 5, 8, 20, 22, 23, 59, 91, 94, 96, 127, 160-165

North Gate Scholars (pei-men hsüeh-shih), 134

Obeisance controversy of $662,31-34,66$

OZd T'ang History, 3, 5, 14, 17, 20, 76, 147, 148, 160-165

Ou-yang Hsiu, 3. See also New T'ang History.

Ou-yang T'ung, 188-189

"Outside the current" ( $2 i u$-wai) officials, 103-104, 263-264

Paekche, 19, 110, 112-122. See also Korea.

Pai controversy, see obeisance controversy of 662 .

$P^{\prime}$ an-Zung-t'ai pei, $x i, 12-16$

Pao-t'u, 65

Pei-men hsüeh-shih (North Gate Scholars), 134

P'ei Chi, 167

P'ei Chien, 44

P'ei Chü, 169

P'ei Chü-tao, 185-186

$P^{\prime}$ 'ei Hsing-chien, 94, 96, 107, 124

P'ei Hsing-pen, 189

$P^{\prime}$ ei Yen, 51-2, 54, 59-60, 132-133, 134, 156, 183, 229, 230n8

Pojang, King of Kogury , 121-122

Poksin, 115, 117, 118

Princes' Rebellion, 65

Punishments of officials, 235n80. See also Terror.

Pure Land sect, 48

Puyorung, King of Paekche, 121-122

Qapag̉an (Mo-ch'o), 136-137, 141, 142, 143, 145, 146-147, 151

Recommendation, as method of appointing officials, 55-56, 233

Rites of Chou (Chou- $2 i), 35,54,64$

Samguk Sagi, xi, 117-120

Sha-po-lo khan, 109, 111

Shang-kuan 1, 19-20,89, 116, 178

Shang-kuan Wan-erh, 134

Shen Chi-ch'i, 2-3

Shen Chün-liang, 184-185

Shen-hsiu, 48

Shih, 71, 73, 79, 81, 82-86, 239-240, 241-242. See also Aristocratic clans.

Shih-pen, 71

Shih-shih feng (fiefs of maintenance), 88, 253-254

Shih-tsu chih, 76, 77-79, 80, 81, 93

Shih Wu-tzu, 187

Shu (commoners), 71, 73, 79, 81, 239

Siksānanda, 48

Silla, 112-122, 136. See also Korea.

Sinmun, King of Silla, 122

Sogdiana, 111,115 
Sŏngdŏk, King of Silla, 122

Ssu-ma Kuang, 3, 9, 10, 16, 18, 22, 23, 28, 60, 77, 104, 123, 134, 136, 143, $151,160,165$. See also Comprehensive Mirror For Aid in Goverment.

Su An-heng, 150

Su Liang-ssu, 186

Su Mien, 74

Su Ting-fang, 107, 110-111, 112-122, 123

Su Wei-tao, 192

Sui-T'ang yen-i, 199

Sui Wen-ti, 13, 27, 224n127

Sui Yang-ti, 14, 20, 31

Sun Ch'u-yao, 179

Sun Jen-shih, 118

Sun Wan-jung, 138, 143

Sun Yüan-heng, 193

Sung Ching, 153

Sung kao-seng chuan, 47

Ta-she (Act of Grace) of 684, 54-55

Tai Chih-te, 180

Tai Chou, 172

T'ai-p'ing kuang-chi, 13

T'ai-p'ing Princess, viii, 2, 21, 30, 134, 142, 143, 148, 218

T'ai-tsung, Emperor,

and Buddhism, 32, 34, 36, 41

foreign policy of, 109, 117

and great clans, 74-75, 76-77, 79, 88, 93, 132

and Wu Shih-huo, 15

and Empress Wu, 16

T'ai-yüan Temple, 48

T'ang History, see New T'ang History and old T'ang History

T'ang Hsiu-ching, 136, 146, 151, 152, 197

T'ang Lin, 93

Tao-an, 35

Tao-hsüan, 32, 33

Tao-te ching, 22, 30, 32

Taoism, as legitimizing ideology, 27, 30-31, 147, 150, 157

Teng-k'o chi-k'ao, 95

Terror during Empress Wu's reign, 60-63, 130, 143-144, 250-252

Ti Jen-chieh, 88, 128, 133, 134, 136, 143, 144-145, 146, 147, 148, 151, 157, $188,256 n 33,285-286$

Tibet, 109, 121, 122-123, 124, 128, 136, 138-144, 145-147

T'ien-shou sheng-t'u, 41

T'ien-t'ai Buddhism, 47, 48

T'ien Te-p'ing, 12

Tou K'ang, 168

Tou-lu Ch'in-wang, 191-192

Tou Te-hsüan, 178

Tou Wei, 168

Tripitaka, 48

Tsai-hsiang, analys is of membership in, 88, 93, 165-198, 248-249 and examination system, 91, 105, 106 
prerogatives of, $89,132-136$

Ts'e-fu ÿ̈аn-kuei, 15

Ts'en Ch'ang-ch'ien, 183

Ts'en Chung-mien, 6

Ts'en Wen-pen, 173

Ts'ui Chih-wen, 182-183

Ts'ui Hsüan-wei, 153, 197, 289n209

Ts'ui Jen-shih, 174

Ts'ui [Min-]-kan, 75

Ts'ui Shen-chi, 189

Ts'ui Tun-li, 176

Ts'ui Tzu, 185

Ts'ui Yüan-tsung, 190

Tsung Ch'in-k'o, 9, 221

Tsung Ch'u-k'o, 194

Tu Cheng-lun, 176

Tu Ching-ch'uan, 194

Tu Ju-hui, 171

Tu Yen, 170

T'ui-pei t'u, 44

Tunhuang genealogical manuscripts, 82

Turks, Eastern, 136-137, 141, 142, 143, 145, 146-147, 151

Turks, Western, 19, 63, 109, 111, 121, 124, 136, 236 n92

Tzu-chih t'ung-chien, see Comprehensive Mirror For Aid in Govermment

Tz'u-en, 47

Tz'u-pu, 45

yighurs, 109, 111,115

Uija, King of Paekche, 114

Wang, Empress, 16-17, 18, 28, 212-213

Wang Chi-shan, 193-194

Wang Fang-ching, 193

Wang Fu-chih, 5

Wang Hsiao-chieh, 136, 138, 142, 192

Wang Hsüan, 190-191

Wang Kuei, 171

Wang Mang, 54, 64

Wang Pen-1i, 186-187

Wang Tzu-chin, 142, 147, 148

Wang Wei, $11-12$

Weber, Max, 52, 53. See also Legitimation.

Wei, Empress, 51, 230

Wei An-shih, 151, 152, 196

Wei Cheng, 4, 61, 171

Wei Ch'eng-ch'ing, 198

Wei Chü-yüan, 191

Wei Fang-chih, 185

Wei-hsiu, 32

Wei Hsüan-chen, 51

Wei Hsüan-t'ung, 100-101, 183-184

Wei Hung-min, 184 
Wei Ssu-ch'ien, 185

Wei Ssu-1i, 102, 149-150, 151, 197

Wei Tai-chia, 186

Wei T'ing, 93

Wei Yüan-chung, $62,96,123,136,148-149,151,195$

Wen-hsien t'ung-k'ao, 95

Wen Yen-po, 171-172

Women, claims by, to political authority in China, see Female rulers, Feminism Wright, Arthur, 26

Wu, Empress, antecedents and ealry life of, 11-16; birth

of, 160, 210; enters T'ai-tsung's harem, 160-161; enters convent, 211-212;

becomes empress, 17-18, 162-163; and Kao-tsung, 19-20, 22, 24-25; as

regent, 51-69, 156; usurpation by, 65, 156-157, 158; 705; coup against

and its antecedents, 128, 150, 152, 153-154; death of, 154

alleged murders by, 17, 21, 23, 24, 58, 96

and Buddhism, 27, 34, 35-49

and Chou dynasty, 126-154

and the economy, $64,96,137-138$

and the examination system, 92, 94,95, 98,99, 102, 104, 105-106

in fiction and drama, 199

foreign policy of, 107-125, 136-137, 138-144, 145-147

historians' judgments on, 5-7, 70, 87, 124, 155

historiographic sources concerning, 8-11, 160-164

legitimacy of her position, 1, 5, 26-50, 52-54, 63-64, 68-69, 104, 144, 147, 149

and Li clan, 42, 44, 66, 74, 126, 132, 155

as literary figure, 35, 66, 99, 131, 221-222, 262n86

and military affairs, 110 . See also Fu-ping.

motives of, viii, 155-158

and position of women, 5, 61. See also Feminism.

as a reformer, 56-57, 77, 81, 92, 94-95, 98, 99, 102, 105-106, 133-136

and state ideology, 49-50. See also Confucianism, Taoism, Buddhism,

Legitimation.

and the Terror, 60-63, 84, 130, 143-144, 156

and the tsai-hsiang, 89, 91, 105, 106, 132-136

Wu-che-hui ("no-barrier" rites), 46

Wu Ch'eng-ssu, 21, 65, 88, 131, 143, 145, 184, 226n157

Wu Chien, 206

Wu Ching, 8-9

Wu Chung-kuei, 146

Wu Chü-ch'ang, 206

Wu clan, 21, 54,87-88, 126, 130, 131, 150, 154, 157, 206-207

Wu Han, 6

Wu Hsia-shih, 207

Wu Hua, 13, 206

Wu Huai-yün, 21

Wu I-tsung, 141, 142-143

Wu K'o-chi, 206

Wu San-ssu, 9, 21, 88, 134, 143, 144, 148, 151, 152, 154, 194

Wu Shih-fang, 192 


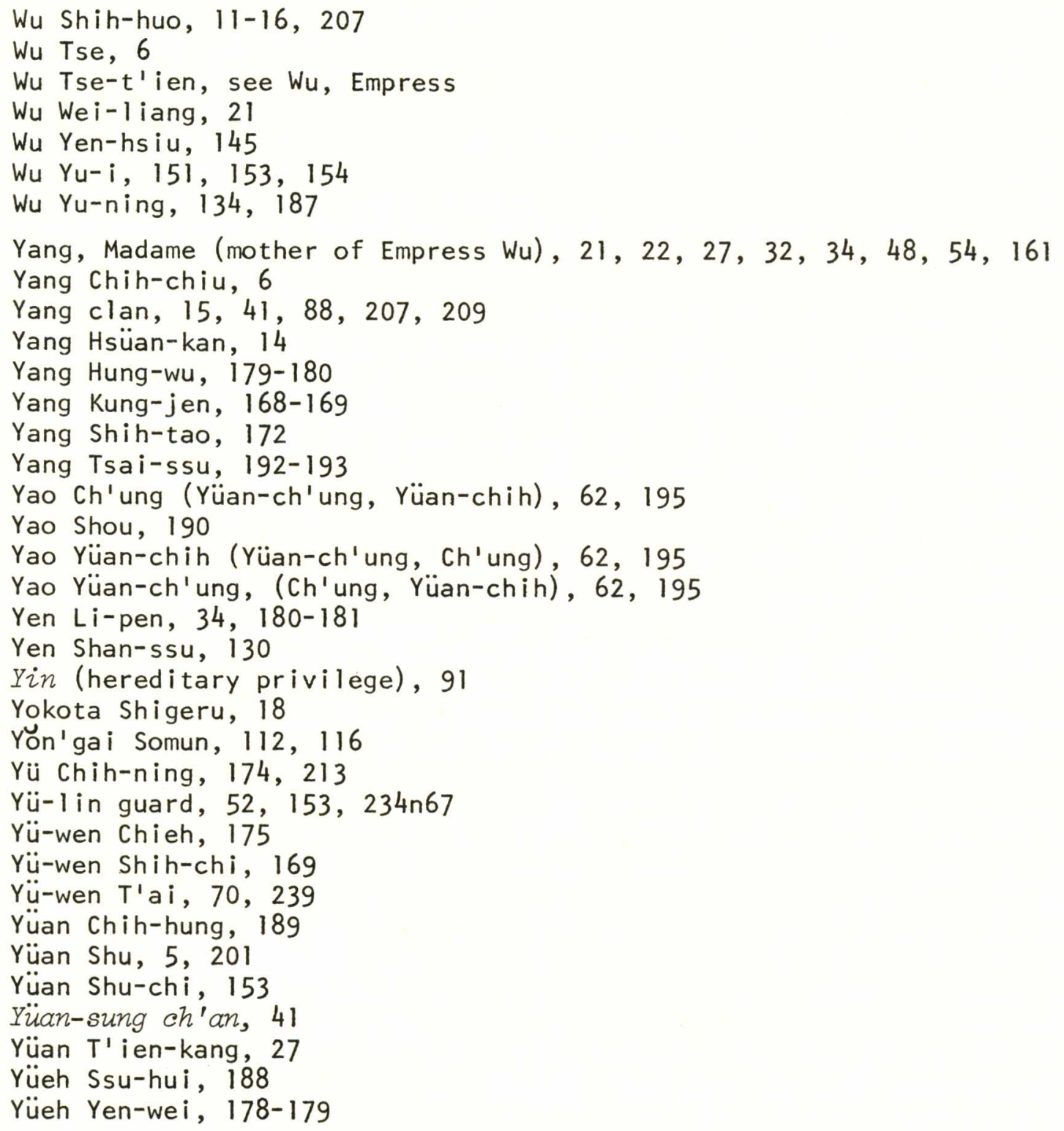


R. W. L. Guisso was born in 1943 in Galt, Ontario. He received his B.A. in Honors History at the University of Toronto in 1966. A Rhodes scholarship enabled him to spend the years 1966-68 at Wadham College, 0xford where, after a year of doing research at the University of Kyoto, he received his doctorate in Oriental Studies. He is presently teaching at the University of Toronto. 


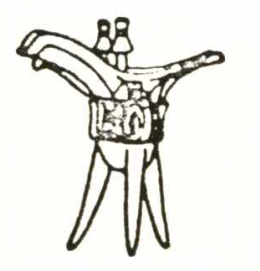

WESTERN WASHINGTON UNI
PROGRAM IN EAST ASIAN
General Editor
Henry G. Schwarz

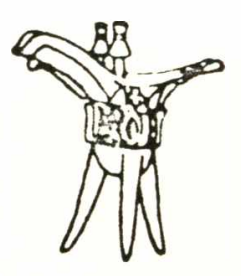

Occasional Papers

1. MAXIMS FOR THE WELL-GOVERNED HOUSEHOLD by Chu Yung-ch'un, translated and with a preface by Edward H. Kaplan. 1971. 10 pp. ISBN 0-914584-01-4. Out of print.

2. CHINESE POLICIES TOWARDS MINORITIES: AN ESSAY AND DOCUMENTS by Henry G. Schwarz. 1971. $200 \mathrm{pp}$. ISBN 0-914584-02-2. Out of print.

3. THE LOVE OF NATURE: HSÜ HSIA-K'O AND HIS EARLY TRAVELS by Li Chi. 1971.134 pp. ISBN 0-914584-03-0. Out of print.

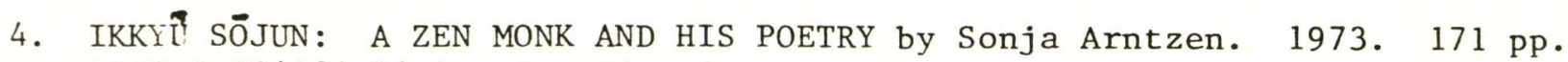
ISBN 0-914584-04-9. Out of print.

5. TEN GREAT YEARS: STATISTICS OF THE ECONOMIC AND CULTURAL ACHIEVEMENTS OF THE PEOPLE'S REPUBLIC OF CHINA by the State Statistical Bureau, Peking (originally published in 1960). Introduction by Feng-hwa Mah. 1974. xi, 154 pp. \$4.00. ISBN 0-914584-05-7.

6. WORKERS AND COMMISSARS: TRADE UNION POLICY IN THE PEOPLE'S REPUBLIC OF CHINA by Merton Don Fletcher. 1974. vi, 148 pp. \$4.00. ISBN 0-914584-06-5.

7. AN ECONOMIC HISTORY OF CHINA by Chou Chin-sheng, translated in précis and with an introduction by Edward H. Kaplan. 1974. ix, 273 pp. \$5.50. ISBN 0-91458407-3.

8. MONGOLIAN SHORT STORIES edited and with an introductory chapter by Henry $G$. Schwarz. 1974. xxv, $179 \mathrm{pp}$. \$5.00. ISBN 0-914584-08-1.

9. HAN RIVER CHULMUNTOGI: A STUDY OF EARLY NEOLITHIC KOREA by Sarah M. Nelson. 1975. 176 pp. \$5.00. ISBN 0-914584-09-X.

10. A DISCOURSE ON GOVERNMENT: NAKAE CHŌMIN AND HIS SANSUIJIN KEIRIN MONDŌ by Margaret B. Dardess. 1977. 109 pp. \$4.00. ISBN 0-914584-10-3.

11. WU TSE-T'IEN AND THE POLITICS OF LEGITIMATION IN T'ANG CHINA by R.W.L. Guisso. 1978. xii, 335 pp. Hardback, \$16.00. ISBN 0-914584-11-1.

12. BIBLIOTHECA MONGOLICA. PART I: WORKS IN ENGLISH, FRENCH, AND GERMAN, compiled by Henry G. Schwarz. In preparation. 
PLEASE NOTE

We accept standing orders. We will send each new title, along with an invoice, to our standing order customers. All other orders must be accompanied by prepayment in U.S. funds. Add the equivalent of US\$1.50 to payments in other currencies to cover bank charges.

A free examination copy of any title in print will be sent upon receipt of a prepaid order of at least 10 copies from a university bookstore.

There is no discount for orders of up to 9 copies per volume. We do, however, pay the book-rate charges to all domestic and foreign destinations. In addition, we offer the following discounts for bulk orders:

$$
\begin{aligned}
& \text { copies per volume: 10-19 10\% } \\
& 20-29 \quad 20 \% \\
& 30 \text { and over } 30 \%
\end{aligned}
$$

All sales are final.

Prices are subject to change without prior notice. 